Base de Conhecimentos Gerados na Engenharia Ambiental e Sanitáña 
Base de Conhecimentos Gerados na Engenharia Ambiental e Sanitánia 


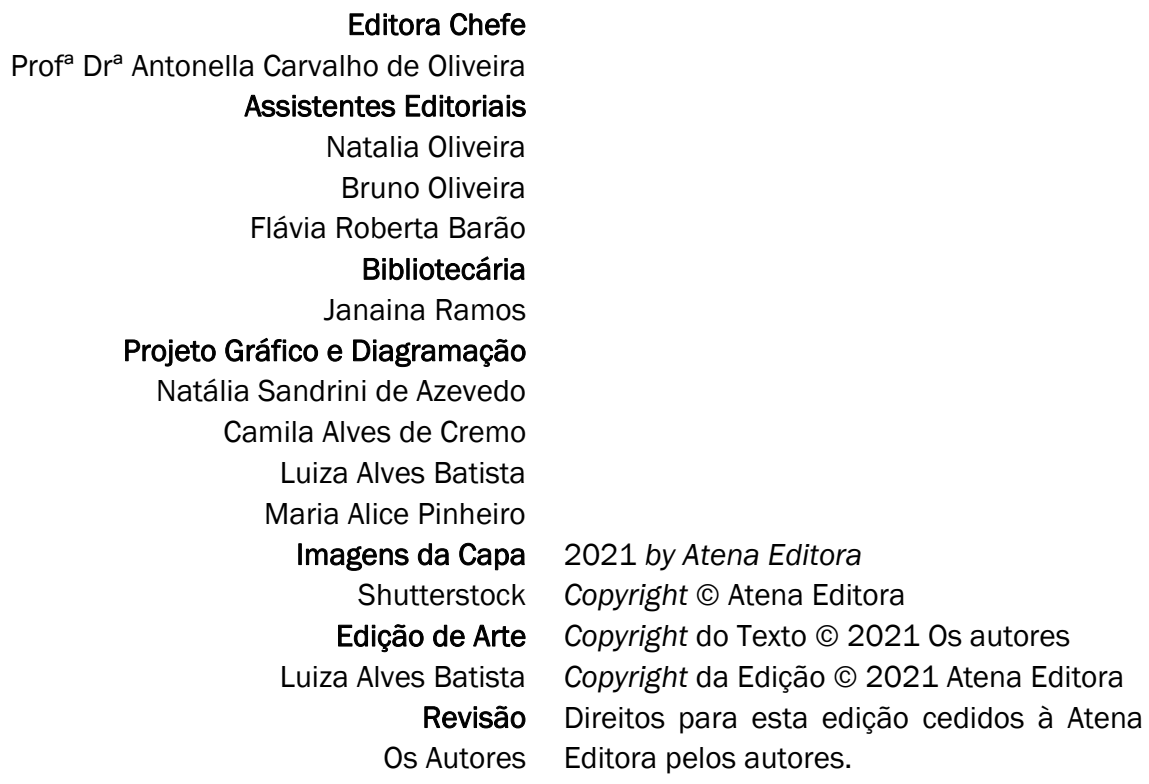

Todo o conteúdo deste livro está licenciado sob uma Licença de Atribuição Creative Commons. Atribuição-Não-ComercialNãoDerivativos 4.0 Internacional (CC BY-NC-ND 4.0).

O conteúdo dos artigos e seus dados em sua forma, correção e confiabilidade são de responsabilidade exclusiva dos autores, inclusive não representam necessariamente a posição oficial da Atena Editora. Permitido o download da obra e o compartilhamento desde que sejam atribuídos créditos aos autores, mas sem a possibilidade de alterá-la de nenhuma forma ou utilizá-la para fins comerciais.

Todos os manuscritos foram previamente submetidos à avaliação cega pelos pares, membros do Conselho Editorial desta Editora, tendo sido aprovados para a publicação com base em critérios de neutralidade e imparcialidade acadêmica.

A Atena Editora é comprometida em garantir a integridade editorial em todas as etapas do processo de publicação, evitando plágio, dados ou resultados fraudulentos e impedindo que interesses financeiros comprometam os padrões éticos da publicação. Situações suspeitas de má conduta científica serão investigadas sob o mais alto padrão de rigor acadêmico e ético.

\section{Conselho Editorial}

\section{Ciências Humanas e Sociais Aplicadas}

Prof. Dr. Alexandre Jose Schumacher - Instituto Federal de Educação, Ciência e Tecnologia do Paraná

Prof. Dr. Américo Junior Nunes da Silva - Universidade do Estado da Bahia

Prof. Dr. Antonio Carlos Frasson - Universidade Tecnológica Federal do Paraná

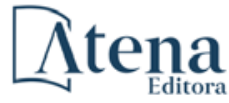


Prof. Dr. Antonio Gasparetto Júnior - Instituto Federal do Sudeste de Minas Gerais

Prof. Dr. Antonio Isidro-Filho - Universidade de Brasília

Prof. Dr. Carlos Antonio de Souza Moraes - Universidade Federal Fluminense

Prof. Dr. Crisóstomo Lima do Nascimento - Universidade Federal Fluminense

Prof ${ }^{\mathrm{a}} \mathrm{Dr}^{\mathrm{a}}$ Cristina Gaio - Universidade de Lisboa

Prof. Dr. Daniel Richard Sant'Ana - Universidade de Brasília

Prof. Dr. Deyvison de Lima Oliveira - Universidade Federal de Rondônia

Prof $^{\mathrm{a}}$ Dr $^{\mathrm{a}}$ Dilma Antunes Silva - Universidade Federal de São Paulo

Prof. Dr. Edvaldo Antunes de Farias - Universidade Estácio de Sá

Prof. Dr. Elson Ferreira Costa - Universidade do Estado do Pará

Prof. Dr. Eloi Martins Senhora - Universidade Federal de Roraima

Prof. Dr. Gustavo Henrique Cepolini Ferreira - Universidade Estadual de Montes Claros

Prof $^{\mathrm{a}} \mathrm{Dr}^{\mathrm{a}}$ Ivone Goulart Lopes - Istituto Internazionele delle Figlie de Maria Ausiliatrice

Prof. Dr. Jadson Correia de Oliveira - Universidade Católica do Salvador

Prof. Dr. Julio Candido de Meirelles Junior - Universidade Federal Fluminense

Prof $^{a}$ Dr $^{a}$ Lina Maria Gonçalves - Universidade Federal do Tocantins

Prof. Dr. Luis Ricardo Fernandes da Costa - Universidade Estadual de Montes Claros

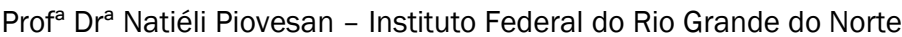

Prof. Dr. Marcelo Pereira da Silva - Pontifícia Universidade Católica de Campinas

Prof $^{a}$ Dr $^{a}$ Maria Luzia da Silva Santana - Universidade Federal de Mato Grosso do Sul

Prof $^{a}$ Dr $^{\mathrm{a}}$ Paola Andressa Scortegagna - Universidade Estadual de Ponta Grossa

Prof $^{a}$ Dr $^{\mathrm{a}}$ Rita de Cássia da Silva Oliveira - Universidade Estadual de Ponta Grossa

Prof. Dr. Rui Maia Diamantino - Universidade Salvador

Prof. Dr. Urandi João Rodrigues Junior - Universidade Federal do Oeste do Pará

Prof $^{a}$ Dr $^{a}$ Vanessa Bordin Viera - Universidade Federal de Campina Grande

Prof. Dr. William Cleber Domingues Silva - Universidade Federal Rural do Rio de Janeiro

Prof. Dr. Willian Douglas Guilherme - Universidade Federal do Tocantins

\section{Ciências Agrárias e Multidisciplinar}

Prof. Dr. Alexandre Igor Azevedo Pereira - Instituto Federal Goiano

Prof $^{a}$ Dr $^{a}$ Carla Cristina Bauermann Brasil - Universidade Federal de Santa Maria

Prof. Dr. Antonio Pasqualetto - Pontifícia Universidade Católica de Goiás

Prof. Dr. Cleberton Correia Santos - Universidade Federal da Grande Dourados

Prof $^{a}$ Dr $^{\mathrm{a}}$ Daiane Garabeli Trojan - Universidade Norte do Paraná

Prof ${ }^{a}$ Dr $^{a}$ Diocléa Almeida Seabra Silva - Universidade Federal Rural da Amazônia

Prof. Dr. Écio Souza Diniz - Universidade Federal de Viçosa

Prof. Dr. Fábio Steiner - Universidade Estadual de Mato Grosso do Sul

Prof. Dr. Fágner Cavalcante Patrocínio dos Santos - Universidade Federal do Ceará

Prof ${ }^{a}$ Dr $^{a}$ Girlene Santos de Souza - Universidade Federal do Recôncavo da Bahia

Prof. Dr. Jael Soares Batista - Universidade Federal Rural do Semi-Árido

Prof. Dr. Júlio César Ribeiro - Universidade Federal Rural do Rio de Janeiro

Prof $^{a}$ Dr $^{a}$ Lina Raquel Santos Araújo - Universidade Estadual do Ceará

Prof. Dr. Pedro Manuel Villa - Universidade Federal de Viçosa

Prof $^{a}$ Dr $^{a}$ Raissa Rachel Salustriano da Silva Matos - Universidade Federal do Maranhão

Prof. Dr. Ronilson Freitas de Souza - Universidade do Estado do Pará

Prof $^{\mathrm{a}} \mathrm{Dr}^{\mathrm{a}}$ Talita de Santos Matos - Universidade Federal Rural do Rio de Janeiro

Prof. Dr. Tiago da Silva Teófilo - Universidade Federal Rural do Semi-Árido

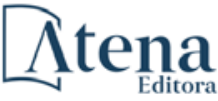

Ano 2021 
Prof. Dr. Valdemar Antonio Paffaro Junior - Universidade Federal de Alfenas

\section{Ciências Biológicas e da Saúde}

Prof. Dr. André Ribeiro da Silva - Universidade de Brasília

Prof $^{\mathrm{a}} \mathrm{Dr}^{\mathrm{a}}$ Anelise Levay Murari - Universidade Federal de Pelotas

Prof. Dr. Benedito Rodrigues da Silva Neto - Universidade Federal de Goiás

Prof $^{a}$ Dr $^{a}$ Débora Luana Ribeiro Pessoa - Universidade Federal do Maranhão

Prof. Dr. Douglas Siqueira de Almeida Chaves - Universidade Federal Rural do Rio de Janeiro

Prof. Dr. Edson da Silva - Universidade Federal dos Vales do Jequitinhonha e Mucuri

Prof $^{\mathrm{a}}$ Dr $^{\mathrm{a}}$ Elizabeth Cordeiro Fernandes - Faculdade Integrada Medicina

Prof $^{a}$ Dr $^{a}$ Eleuza Rodrigues Machado - Faculdade Anhanguera de Brasília

Prof $^{\mathrm{a}} \mathrm{Dr}^{\mathrm{a}}$ Elane Schwinden Prudêncio - Universidade Federal de Santa Catarina

Prof $^{a}$ Dr $^{a}$ Eysler Gonçalves Maia Brasil - Universidade da Integração Internacional da Lusofonia

Afro-Brasileira

Prof. Dr. Ferlando Lima Santos - Universidade Federal do Recôncavo da Bahia

Prof. Dr. Fernando Mendes - Instituto Politécnico de Coimbra - Escola Superior de Saúde de Coimbra

Prof $^{a}$ Dr $^{a}$ Gabriela Vieira do Amaral - Universidade de Vassouras

Prof. Dr. Gianfábio Pimentel Franco - Universidade Federal de Santa Maria

Prof. Dr. Helio Franklin Rodrigues de Almeida - Universidade Federal de Rondônia

Prof $^{a}$ Dr $^{a}$ lara Lúcia Tescarollo - Universidade São Francisco

Prof. Dr. Igor Luiz Vieira de Lima Santos - Universidade Federal de Campina Grande

Prof. Dr. Jefferson Thiago Souza - Universidade Estadual do Ceará

Prof. Dr. Jesus Rodrigues Lemos - Universidade Federal do Piauí

Prof. Dr. Jônatas de França Barros - Universidade Federal do Rio Grande do Norte

Prof. Dr. José Max Barbosa de Oliveira Junior - Universidade Federal do Oeste do Pará

Prof. Dr. Luís Paulo Souza e Souza - Universidade Federal do Amazonas

Prof $^{a}$ Dr $^{a}$ Magnólia de Araújo Campos - Universidade Federal de Campina Grande

Prof. Dr. Marcus Fernando da Silva Praxedes - Universidade Federal do Recôncavo da Bahia

Prof $^{a}$ Dr $^{a}$ Maria Tatiane Gonçalves Sá - Universidade do Estado do Pará

Prof $^{\mathrm{a}} \mathrm{Dr}^{\mathrm{a}}$ Mylena Andréa Oliveira Torres - Universidade Ceuma

Prof ${ }^{a}$ Dr $^{a}$ Natiéli Piovesan - Instituto Federacl do Rio Grande do Norte

Prof. Dr. Paulo Inada - Universidade Estadual de Maringá

Prof. Dr. Rafael Henrique Silva - Hospital Universitário da Universidade Federal da Grande Dourados

Prof $^{a}$ Dr $^{\mathrm{a}}$ Regiane Luz Carvalho - Centro Universitário das Faculdades Associadas de Ensino

Prof $^{\mathrm{a}} \mathrm{Dr}^{\mathrm{a}}$ Renata Mendes de Freitas - Universidade Federal de Juiz de Fora

Prof $^{a}$ Dr $^{\text {a }}$ Vanessa Lima Gonçalves - Universidade Estadual de Ponta Grossa

Prof $^{a}$ Dr $^{a}$ Vanessa Bordin Viera - Universidade Federal de Campina Grande

\section{Ciências Exatas e da Terra e Engenharias}

Prof. Dr. Adélio Alcino Sampaio Castro Machado - Universidade do Porto

Prof. Dr. Carlos Eduardo Sanches de Andrade - Universidade Federal de Goiás

Prof $^{a}$ Dr $^{\text {a }}$ Carmen Lúcia Voigt - Universidade Norte do Paraná

Prof. Dr. Cleiseano Emanuel da Silva Paniagua - Instituto Federal de Educação, Ciência e Tecnologia de Goiás

Prof. Dr. Douglas Gonçalves da Silva - Universidade Estadual do Sudoeste da Bahia

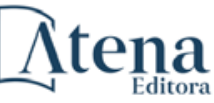


Prof. Dr. Eloi Rufato Junior - Universidade Tecnológica Federal do Paraná

Prof $^{\mathrm{a}} \mathrm{Dr}^{\mathrm{a}}$ Érica de Melo Azevedo - Instituto Federal do Rio de Janeiro

Prof. Dr. Fabrício Menezes Ramos - Instituto Federal do Pará

Prof $^{a}$ Dra. Jéssica Verger Nardeli - Universidade Estadual Paulista Júlio de Mesquita Filho

Prof. Dr. Juliano Carlo Rufino de Freitas - Universidade Federal de Campina Grande

Prof $^{a}$ Dr $^{a}$ Luciana do Nascimento Mendes - Instituto Federal de Educação, Ciência e Tecnologia do Rio Grande do Norte

Prof. Dr. Marcelo Marques - Universidade Estadual de Maringá

Prof. Dr. Marco Aurélio Kistemann Junior - Universidade Federal de Juiz de Fora

Prof $^{a}$ Dr $^{a}$ Neiva Maria de Almeida - Universidade Federal da Paraíba

Prof $^{a}$ Dr $^{\mathrm{a}}$ Natiéli Piovesan - Instituto Federal do Rio Grande do Norte

Prof ${ }^{a}$ Dr $^{a}$ Priscila Tessmer Scaglioni - Universidade Federal de Pelotas

Prof. Dr. Takeshy Tachizawa - Faculdade de Campo Limpo Paulista

\section{Linguística, Letras e Artes}

Prof $^{a}$ Dr $^{a}$ Adriana Demite Stephani - Universidade Federal do Tocantins

Prof $^{\mathrm{a}} \mathrm{Dr}^{\mathrm{a}}$ Angeli Rose do Nascimento - Universidade Federal do Estado do Rio de Janeiro

Prof $^{\mathrm{a}} \mathrm{Dr}^{\mathrm{a}}$ Carolina Fernandes da Silva Mandaji - Universidade Tecnológica Federal do Paraná

Prof $^{a}$ Dr $^{\mathrm{a}}$ Denise Rocha - Universidade Federal do Ceará

Prof. Dr. Fabiano Tadeu Grazioli - Universidade Regional Integrada do Alto Uruguai e das Missões

Prof. Dr. Gilmei Fleck - Universidade Estadual do Oeste do Paraná

Prof $^{a}$ Dr $^{a}$ Keyla Christina Almeida Portela - Instituto Federal de Educação, Ciência e Tecnologia do Paraná

Prof $^{a}$ Dra $^{a}$ Miranilde Oliveira Neves - Instituto de Educação, Ciência e Tecnologia do Pará

Prof $^{a}$ Dr $^{a}$ Sandra Regina Gardacho Pietrobon - Universidade Estadual do Centro-Oeste

Prof $^{a}$ Dr $^{\text {a }}$ Sheila Marta Carregosa Rocha - Universidade do Estado da Bahia

\section{Conselho Técnico Científico}

Prof. Me. Abrãao Carvalho Nogueira - Universidade Federal do Espírito Santo

Prof. Me. Adalberto Zorzo - Centro Estadual de Educação Tecnológica Paula Souza

Prof. Dr. Adaylson Wagner Sousa de Vasconcelos - Ordem dos Advogados do Brasil/Seccional Paraíba

Prof. Dr. Adilson Tadeu Basquerote Silva - Universidade para o Desenvolvimento do Alto Vale do Itajaí

Prof. Dr. Alex Luis dos Santos - Universidade Federal de Minas Gerais

Prof. Me. Alexsandro Teixeira Ribeiro - Centro Universitário Internacional

Prof ${ }^{a}$ Ma. Aline Ferreira Antunes - Universidade Federal de Goiás

Prof. Me. André Flávio Gonçalves Silva - Universidade Federal do Maranhão

Prof $^{a}$ Ma. Andréa Cristina Marques de Araújo - Universidade Fernando Pessoa

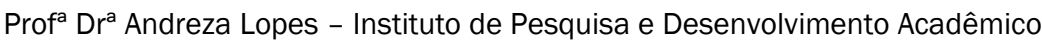

Prof ${ }^{a}$ Dra $^{a}$ Andrezza Miguel da Silva - Faculdade da Amazônia

Prof ${ }^{a}$ Ma. Anelisa Mota Gregoleti - Universidade Estadual de Maringá

Prof ${ }^{a}$ Ma. Anne Karynne da Silva Barbosa - Universidade Federal do Maranhão

Prof. Dr. Antonio Hot Pereira de Faria - Polícia Militar de Minas Gerais

Prof. Me. Armando Dias Duarte - Universidade Federal de Pernambuco

Prof ${ }^{a}$ Ma. Bianca Camargo Martins - UniCesumar

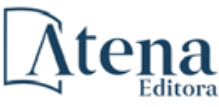


Prof $^{a}$ Ma. Carolina Shimomura Nanya - Universidade Federal de São Carlos

Prof. Me. Carlos Antônio dos Santos - Universidade Federal Rural do Rio de Janeiro

Prof. Me. Christopher Smith Bignardi Neves - Universidade Federal do Paraná

Prof. Ma. Cláudia de Araújo Marques - Faculdade de Música do Espírito Santo

Prof $^{a}$ Dra $^{a}$ Cláudia Taís Siqueira Cagliari - Centro Universitário Dinâmica das Cataratas

Prof. Me. Clécio Danilo Dias da Silva - Universidade Federal do Rio Grande do Norte

Prof. Me. Daniel da Silva Miranda - Universidade Federal do Pará

Prof $^{a}$ Ma. Daniela da Silva Rodrigues - Universidade de Brasília

Prof $^{a}$ Ma. Daniela Remião de Macedo - Universidade de Lisboa

Prof ${ }^{a}$ Ma. Dayane de Melo Barros - Universidade Federal de Pernambuco

Prof. Me. Douglas Santos Mezacas - Universidade Estadual de Goiás

Prof. Me. Edevaldo de Castro Monteiro - Embrapa Agrobiologia

Prof. Me. Eduardo Gomes de Oliveira - Faculdades Unificadas Doctum de Cataguases

Prof. Me. Eduardo Henrique Ferreira - Faculdade Pitágoras de Londrina

Prof. Dr. Edwaldo Costa - Marinha do Brasil

Prof. Me. Eliel Constantino da Silva - Universidade Estadual Paulista Júlio de Mesquita

Prof. Me. Ernane Rosa Martins - Instituto Federal de Educação, Ciência e Tecnologia de Goiás

Prof. Me. Euvaldo de Sousa Costa Junior - Prefeitura Municipal de São João do Piauí

Prof. Dr. Everaldo dos Santos Mendes - Instituto Edith Theresa Hedwing Stein

Prof. Me. Ezequiel Martins Ferreira - Universidade Federal de Goiás

Prof $^{a}$ Ma. Fabiana Coelho Couto Rocha Corrêa - Centro Universitário Estácio Juiz de Fora

Prof. Me. Fabiano Eloy Atílio Batista - Universidade Federal de Viçosa

Prof. Me. Felipe da Costa Negrão - Universidade Federal do Amazonas

Prof. Me. Francisco Odécio Sales - Instituto Federal do Ceará

Prof $^{a}$ Dr $^{a}$ Germana Ponce de Leon Ramírez - Centro Universitário Adventista de São Paulo

Prof. Me. Gevair Campos - Instituto Mineiro de Agropecuária

Prof. Me. Givanildo de Oliveira Santos - Secretaria da Educação de Goiás

Prof. Dr. Guilherme Renato Gomes - Universidade Norte do Paraná

Prof. Me. Gustavo Krahl - Universidade do Oeste de Santa Catarina

Prof. Me. Helton Rangel Coutinho Junior - Tribunal de Justiça do Estado do Rio de Janeiro

Prof $^{a}$ Ma. Isabelle Cerqueira Sousa - Universidade de Fortaleza

Prof $^{a}$ Ma. Jaqueline Oliveira Rezende - Universidade Federal de Uberlândia

Prof. Me. Javier Antonio Albornoz - University of Miami and Miami Dade College

Prof. Me. Jhonatan da Silva Lima - Universidade Federal do Pará

Prof. Dr. José Carlos da Silva Mendes - Instituto de Psicologia Cognitiva, Desenvolvimento Humano e Social

Prof. Me. Jose Elyton Batista dos Santos - Universidade Federal de Sergipe

Prof. Me. José Luiz Leonardo de Araujo Pimenta - Instituto Nacional de Investigación Agropecuaria Uruguay

Prof. Me. José Messias Ribeiro Júnior - Instituto Federal de Educação Tecnológica de Pernambuco

Prof ${ }^{a}$ Dr $^{a}$ Juliana Santana de Curcio - Universidade Federal de Goiás

Prof ${ }^{a}$ Ma. Juliana Thaisa Rodrigues Pacheco - Universidade Estadual de Ponta Grossa

Prof $^{a}$ Dr $^{a}$ Kamilly Souza do Vale - Núcleo de Pesquisas Fenomenológicas/UFPA

Prof. Dr. Kárpio Márcio de Siqueira - Universidade do Estado da Bahia

Prof $^{a}$ Dr $^{a}$ Karina de Araújo Dias - Prefeitura Municipal de Florianópolis

Prof. Dr. Lázaro Castro Silva Nascimento - Laboratório de Fenomenologia \& Subjetividade/UFPR

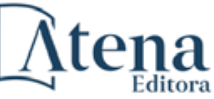


Prof. Me. Leonardo Tullio - Universidade Estadual de Ponta Grossa

Prof $^{a}$ Ma. Lilian Coelho de Freitas - Instituto Federal do Pará

Prof $^{a}$ Ma. Liliani Aparecida Sereno Fontes de Medeiros - Consórcio CEDERJ

Prof $^{a}$ Dr $^{a}$ Lívia do Carmo Silva - Universidade Federal de Goiás

Prof. Dr. Lucio Marques Vieira Souza - Secretaria de Estado da Educação, do Esporte e da Cultura de Sergipe

Prof. Dr. Luan Vinicius Bernardelli - Universidade Estadual do Paraná

Prof $^{a}$ Ma. Luana Ferreira dos Santos - Universidade Estadual de Santa Cruz

Prof $^{\mathrm{a}}$ Ma. Luana Vieira Toledo - Universidade Federal de Viçosa

Prof. Me. Luis Henrique Almeida Castro - Universidade Federal da Grande Dourados

Prof $^{a}$ Ma. Luma Sarai de Oliveira - Universidade Estadual de Campinas

Prof. Dr. Michel da Costa - Universidade Metropolitana de Santos

Prof. Me. Marcelo da Fonseca Ferreira da Silva - Governo do Estado do Espírito Santo

Prof. Dr. Marcelo Máximo Purificação - Fundação Integrada Municipal de Ensino Superior

Prof. Me. Marcos Aurelio Alves e Silva - Instituto Federal de Educação, Ciência e Tecnologia de São Paulo

Prof ${ }^{a}$ Ma. Maria Elanny Damasceno Silva - Universidade Federal do Ceará

Prof $^{a}$ Ma. Marileila Marques Toledo - Universidade Federal dos Vales do Jequitinhonha e Mucuri

Prof. Me. Pedro Panhoca da Silva - Universidade Presbiteriana Mackenzie

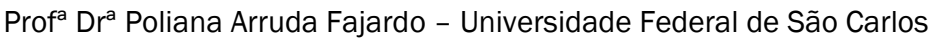

Prof. Me. Ricardo Sérgio da Silva - Universidade Federal de Pernambuco

Prof. Me. Renato Faria da Gama - Instituto Gama - Medicina Personalizada e Integrativa

Prof $^{a}$ Ma. Renata Luciane Polsaque Young Blood - UniSecal

Prof. Me. Robson Lucas Soares da Silva - Universidade Federal da Paraíba

Prof. Me. Sebastião André Barbosa Junior - Universidade Federal Rural de Pernambuco

Prof $^{a}$ Ma. Silene Ribeiro Miranda Barbosa - Consultoria Brasileira de Ensino, Pesquisa e

Extensão

Prof $^{a}$ Ma. Solange Aparecida de Souza Monteiro - Instituto Federal de São Paulo

Prof $^{a}$ Ma. Taiane Aparecida Ribeiro Nepomoceno - Universidade Estadual do Oeste do Paraná

Prof. Me. Tallys Newton Fernandes de Matos - Faculdade Regional Jaguaribana

Prof $^{\mathrm{a}}$ Ma. Thatianny Jasmine Castro Martins de Carvalho - Universidade Federal do Piauí

Prof. Me. Tiago Silvio Dedoné - Colégio ECEL Positivo

Prof. Dr. Welleson Feitosa Gazel - Universidade Paulista 
Editora Chefe: Prof $^{a} \operatorname{Dr}^{\mathrm{a}}$ Antonella Carvalho de Oliveira

Bibliotecária: Janaina Ramos

Diagramação: Camila Alves de Cremo

Correção: Mariane Aparecida Freitas

Edição de Arte: Luiza Alves Batista

Revisão: Os Autores

Organizador: Daniel Sant'Ana

Dados Internacionais de Catalogação na Publicação (CIP)

B299 Base de conhecimentos gerados na engenharia ambiental e sanitária / Organizador Daniel Sant'Ana. - Ponta Grossa - PR: Atena, 2021.

\section{Formato: PDF}

Requisitos de sistema: Adobe Acrobat Reader Modo de acesso: World Wide Web

Inclui bibliografia

ISBN 978-65-5706-744-4

DOI 10.22533/at.ed.444211901

1. Engenharia. 2. Conhecimento. I. Sant'Ana, Daniel (Organizador). II. Título.

Elaborado por Bibliotecária Janaina Ramos - CRB-8/9166

Atena Editora

Ponta Grossa - Paraná - Brasil Telefone: +55 (42) 3323-5493 www.atenaeditora.com.br contato@atenaeditora.com.br

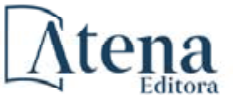




\section{DECLARAÇÃO DOS AUTORES}

Os autores desta obra: 1. Atestam não possuir qualquer interesse comercial que constitua um conflito de interesses em relação ao artigo científico publicado; 2. Declaram que participaram ativamente da construção dos respectivos manuscritos, preferencialmente na: a) Concepção do estudo, e/ou aquisição de dados, e/ou análise e interpretação de dados; b) Elaboração do artigo ou revisão com vistas a tornar o material intelectualmente relevante; c) Aprovação final do manuscrito para submissão.; 3. Certificam que os artigos científicos publicados estão completamente isentos de dados e/ou resultados fraudulentos; 4. Confirmam a citação e a referência correta de todos os dados e de interpretações de dados de outras pesquisas; 5 . Reconhecem terem informado todas as fontes de financiamento recebidas para a consecução da pesquisa. 


\section{APRESENTAÇÃO}

A coleção "Base de Conhecimentos Gerados na Engenharia Ambiental e Sanitária" tem como objetivo disseminar o estado atual do conhecimento das diferentes áreas das ciências ambientais e sanitárias, apresentando a evolução do campo científico por meio de diferentes tipos de trabalhos que abordam os aspectos tecnológicos, políticos, econômicos, sociais e ambientais desta disciplina.

Com o crescimento desordenado das cidades brasileiras, observamos, cada vez mais, os impactos de ocupações urbanas sobre o meio ambiente. Com isso, os primeiros capítulos deste livro debatem sobre a importância da legislação no controle do crescimento desordenado das cidades e na proteção ambiental de bacias hidrográficas, seja pela proteção e a recuperação de matas ciliares ou pela gestão sustentável de águas pluviais urbanas.

E na medida em que as cidades crescem, a demanda por água potável aumenta. Com isso, torna-se crucial promover o controle da demanda urbana de água por meio de medidas que estimulem o uso racional de água, seja por meio de uma revisão tarifária (Capítulo 5) ou pela otimização das redes de distribuição de água (Capítulos 6 e 7).

O uso de fontes alternativas de água, como o aproveitamento de águas pluviais em usos não potáveis, é capaz de promover reduções significativas no consumo de água potável em edificações (Capítulo 8). Porém, para garantir a saúde e o bem-estar de usuários, toda água deve passar por um processo de tratamento capaz de atingir os padrões de qualidade estabelecidos em legislação ou instrumentos normativos (Capítulos 9 e 10).

Evidentemente, para qualquer tomada de ação, é necessário um diagnóstico preliminar para avaliar as condições das águas. Os Capítulos 11 e 12 realizam diagnósticos da qualidade de águas subterrâneas, enquanto os capítulos subsequentes apresentam resultados de análises da qualidade de água do Rio Piabinha (Capítulo 13), Córrego Mirasol (Capítulo 14) e do Rio Chumbao, Peru (Capítulo 15).

A evolução da inovação tecnológica vem auxiliando tomadores de decisão na gestão de recursos hídricos (Capítulos 16 e 17) para garantir a segurança hídrica no abastecimento de água e na preservação ambiental. Os capítulos finais deste volume discorrem a importância de promover a conscientização da população e a educação ambiental para reduzir os impactos ambientais causados pelas ações do ser humano.

Este primeiro volume contou com a contribuição de pesquisadores de diferentes partes do país, Argentina e Peru, trazendo de forma interdisciplinar, um amplo espectro de trabalhos acadêmicos relativos à legislação, abastecimento de água, diagnóstico de qualidade das águas, inovação tecnológica e educação ambiental. Por fim, desejo que esta obra, fruto do esforço de muitos, seja seminal para todos que vierem a utilizá-la. 


\section{SUMÁRIO}

CAPÍTULO 1

ANÁLISE DOS INSTRUMENTOS JURÍDICOS QUE NORTEIAM O DESENVOLVIMENTO TERRITORIAL, DAS OBRAS DE HABITAÇÃO, INFRAESTRUTURA E SANEAMENTO DA BACIA HIDROGRÁFICA DO RIO PONTE GRANDE, EM LAGES-SC

Mayara Rafaeli Lemos
Daniely Neckel Rosini
Valter Antonio Becegato
Vitor Rodolfo Becegato
Alexandre Tadeu Paulino

DOI 10.22533/at.ed.4442119011

CAPÍTULO 2

CONSEQUÊNCIAS AMBIENTAIS DA APLICAÇÃO DO DECRETO ESTADUAL No 42.356/2010 NA DELIMITAÇÃO DE FAIXA MA̧RGINAL DE PROTEÇÃO EM ÁREA URBANA CONSOLIDADA. ESTUDO DE CASO: RIO PIABANHA/RJ - TRECHO 4

Jorge Chaves Junior

Ana Cristina Malheiros Gonçalves Carvalho

Rafaela dos Santos Facchetti Vinhaes Assumpção

DOI 10.22533/at.ed.4442119012

CAPÍTULO 3

AVALIAÇÃO AMBIENTAL ESTRATÉGICA: POSSÍVEIS CONTRIBUIÇÕES PARA O PLANO DIRETOR DO MUNICÍPIO DE GOIÂNIA, NO ESTADO DE GOIÁS

Raquel Santarém de Souza Costa

Aldo Muro Junior

Flávio Roldão de Carvalho Lélis

DOI 10.22533/at.ed.4442119013

CAPÍTULO 4 47

LEVANTAMENTO E ANÁLISE DO ORDENAMENTO JURÍDICO ACERCA DA CAPTAÇÃO DE ÁGUAS PLUVIAIS NO BRASIL COM FOCO NAS REGIÕES SUDESTE E SUL

Jordana dos Anjos Xavier

Emili Louise Diconcili Schutz

Nicole Martins Pessoa

Daniely Neckel Rosini

Débora Cristina Correia Cardoso

Valter Antonio Becegato

Vitor Rodolfo Becegato

Alexandre Tadeu Paulino

Natália Martins Vieira

DOI 10.22533/at.ed.4442119014

CAPÍTULO 5

INDICADOR ECONÔMICO FINANCEIRO PARA AVALIAÇÃO DA NECESSIDADE DE REVISÃO TARIFÁRIA EM CONCESSÕES DE ABASTECIMENTO DE ÁGUA E ESGOTAMENTO SANITÁRIO NOS MUNICÍPIOS CATARINENSES

Daniel Antonio Narzetti 
Willian Carlos Narzetti

Ricardo Motta Martins

Ciro Loureiro Rocha

Diego Pavam Ferreira

DOI 10.22533/at.ed.4442119015

CAPÍTULO 6

INFLUÊNCIA DAS EQUAÇÕES EXPLÍCITAS DE FATOR DE ATRITO NO DIMENSIONAMENTO DE REDES DE DISTRIBUIÇÃO

Renata Shirley de Andrade Araújo

Alessandro de Araújo Bezerra

Bruno Duarte Moura

Mauro César de Brito Sousa

DOI 10.22533/at.ed.4442119016

CAPÍTULO 7 88

QUANTIFICANDO PERDAS HÍDRICAS EM CIDADES PARAIBANAS

Ayuri Medeiros da Silva

Carolina Coeli Rodrigues Batista de Araújo

Flaubert Ruan Nobelino de Araujo

Mikaele de Oliveira Candeia

Francisca Rozângela Lopes de Sousa

DOI 10.22533/at.ed.4442119017

CAPÍTULO 8

PROJETO DE CAPTAÇÃO DE ÁGUA PLUVIAL PARA APROVEITAMENTO NO LABORATÓRIO DE ENGENHARIA CIVIL DO CAMPUS ALTO PARAOPEBA - UFSJ

Deysiane Antunes Barroso Damasceno

Isabela Carvalho Pinheiro

Emmanuel Kennedy da Costa Teixeira

DOI 10.22533/at.ed.4442119018

CAPÍTULO 9 109

SEGUIMIENTO FÍSICO, QUÍMICO Y BACTERIOLÓGICO DEL AGUA EN LA LOCALIDAD DE AGUARAY - SALTA

Claudia Silvana Soledad Cequeira

Cecilia Hebe Noemi Orphèe

Maria Ines Mercado

Rosa Magdalena Cruz

DOI 10.22533/at.ed.4442119019

CAPÍTULO 10

OTIMIZAÇÃO DA CAPACIDADE DE FLOCULAÇÃO DE COAGULANTES NATURAIS NO TRATAMENTO DE ÁGUA

David Choque-Quispe

Yudith Choque Quispe

Betsy Suri Ramos Pacheco

Aydeé Marilú Solano Reynoso 
Lourdes Magaly Zamalloa Puma

Carlos Alberto Ligarda Samanez

Fredy Taipe Pardo

Miriam Calla Flórez

Miluska Marina Zamalloa Puma

Jhunior Felix Alonzo Lanado

Yadyra Quispe Quispe

DOI 10.22533/at.ed.44421190110

CAPÍTULO 11

APLICAÇÃO DO MÉTODO GOD PARA AVALIAÇÃO DA VULNERABILIDADE AMBIENTAL DOS POÇOS DE CAPTAÇÃO DE ÁGUA DA CIDADE DE ABATETUBA - PARÁ

Gabriel Pereira Colares da Silva

Éverton Costa Dias

Giovanni Chaves Penner

Adria Lorena de Moraes Cordeiro

Cleyanne Kelly Barbosa Souto

DOI 10.22533/at.ed.44421190111

CAPÍTULO 12

MODELAGEM DO FLUXO DE CONTAMINANTES NAS ÁGUAS SUBTERRÂNEAS DO CEMITÉRIO AREIAS, TERESINA, BRASIL

Mauro César de Brito Sousa

Bruna de Freitas Iwata

DOI 10.22533/at.ed.44421190112

CAPÍTULO 13 148

ANÁLISE DO SANEAMENTO E DA QUALIDADE DE ÁGUA NA BACIA HIDROGRÁFICA DO RIO PIABANHA

Luis Carlos Soares da Silva Junior

José Paulo Soares de Azevedo

Ana Silvia Pereira Santos

Verônica Silveira de Andrade

Marília Carvalho de Melo

DOI 10.22533/at.ed.44421190113

CAPÍTULO 14

PHYSICO-CHEMICAL DIAGNOSIS OF WATER QUALITY IN THE MIRASSOL STREAM, CITY OF SÃO PAULO, BRAZIL

André Contri Dionizio

Marta Ângela Marcondes

Raul Neiva Bertulucci

DOI 10.22533/at.ed.44421190114

CAPÍTULO 15

ACTIVIDADES ANTRÓPICAS Y CONTAMINANTES EMERGENTES, PROPIEDADES FISICOQUÍMICAS Y MICROBIOLÓGICAS DEL RIO CHUMBAO, PERÚ

Carlos Alberto Ligarda Samanez 
David Choque Quispe

Betsy Suri Ramos Pacheco

DOI 10.22533/at.ed.44421190115

CAPÍTULO 16 185

SISTEMA EM PLATAFORMA WEB PARA IMPLANTAÇÃO DE PLANO DE SEGURANÇA DA ÁGUA (PSA) EM SISTEMAS DE ABASTECIMENTO DE ÁGUA

Nolan Ribeiro Bezerra

Isabela Moura Chagas

Geraldo Alves Pereira Júnior

DOI 10.22533/at.ed.44421190116

CAPÍTULO 17 198

SISTEMA WEB PARA ESTIMATIVA DE EVAPOTRANSPIRAÇÃO POTENCIAL POR DIFERENTES MÉTODOS

Lucas Moraes dos Santos

Taison Anderson Bortolin

Adriano Gomes da Silva

Vania Elisabete Schneider

DOI 10.22533/at.ed.44421190117

CAPÍTULO 18 217

UM CENÁRIO DA EDUCAÇÃO AMBIENTAL EM RESÍDUOS SÓLIDOS NO MUNICÍPIO SANTARÉM - PA: ESTUDO DE CASO - RESIDENCIAL SALVAÇÃO

Jarlison Sarmento Lopes

Andressa Rodrigues de Sousa

Antônia Liliane Ferreira de Oliveira

Claudiane da Silva Rosa

Ewellyn Cristina Santos de Sousa

Kairo Silva de Oliveira

Elton Raniere da Silva Moura

Maria Francisca de Miranda Adad

DOI 10.22533/at.ed.44421190118

CAPÍTULO 19 233

EDUCAÇÃO AMBIENTAL COM ESTUDANTES DO ENSINO MÉDIO DURANTE A PANDEMIA DO CORONAVÍRUS EM ESCOLAS RURAIS DE LAGES-SC

Daniely Neckel Rosini

Débora Cristina Correia Cardoso

Jordana dos Anjos Xavier

Valter Antonio Becegato

Vitor Rodolfo Becegato

Alexandre Tadeu Paulino

DOI 10.22533/at.ed.44421190119

SOBRE O ORGANIZADOR. 245

ÍNDICE REMISSIVO 


\section{CAPÍTULO 1}

\section{ANÁLISE DOS INSTRUMENTOS JURÍDICOS QUE NORTEIAM O DESENVOLVIMENTO TERRITORIAL, DAS OBRAS DE HABITAÇÃO, INFRAESTRUTURA E SANEAMENTO DA BACIA HIDROGRÁFICA DO RIO PONTE GRANDE, EM LAGES-SC}

Data de aceite: 04/01/2021

Mayara Rafaeli Lemos

Universidade do Estado de Santa Catarina (UDESC)

Lages - SC

http://lattes.cnpq.br/7642263124693032

Daniely Neckel Rosini

Universidade do Estado de Santa Catarina

(UDESC)

Lages - SC

http://lattes.cnpq.br/1290138248832119

Valter Antonio Becegato

Universidade do Estado de Santa Catarina

(UDESC)

Lages - SC

http://lattes.cnpq.br/3196823526572670

Vitor Rodolfo Becegato

Universidade do Estado de Santa Catarina

(UDESC)

Lages - SC

http://lattes.cnpq.br/7642634231071974

Alexandre Tadeu Paulino

Universidade do Estado de Santa Catarina

(UDESC)

Pinhalzinho - SC

http://lattes.cnpq.br/8957379372810063

RESUMO: O desenvolvimento territorial da maioria das cidades brasileiras se deu de forma desordenada, em razão da carência de instrumentos jurídicos que norteassem a ocupação urbana. A urbanização sem planejamento também é realidade no município de Lages, que possui uma demanda de moradias maior do que a oferta em bairros com infraestrutura, e isso acarreta o surgimento de ocupações irregulares, pois os bairros planejados e com infraestrutura são inacessíveis pela população carente. Assim, objetivando compreender o surgimento das normativas que explanam sobre o avanço na ocupação urbana, realizou-se análise das legislações em nível municipal, estadual e nacional quanto as prerrogativas de uso do solo, com enfoque no desenvolvimento da bacia hidrográfica do Rio Ponte Grande, em Lages-SC. Para tanto, fez-se análise bibliográfica, com enfoque qualitativo, com o objetivo de verificar a aplicabilidade das leis que balizam o desenvolvimento territorial da bacia hidrográfica do rio Ponte Grande, em Lages, e após correlacionar o desenvolvimento territorial desordenado com a qualidade de vida da população. A área objeto do estudo foi ocupada de forma desordenada, com precariedade nas edificações, ao acesso de bens e serviços e com alto impacto ambiental. Diante de tais impasses, a Prefeitura Municipal de Lages protocolou junto ao Governo Federal - Ministério das Cidades, um projeto de habitação, infraestrutura e de saneamento na bacia hidrográfica em questão. Para a realização do estudo sobre as obras e serviços do Complexo Ponte Grande, realizou-se análise a partir de contratos, documentos, fotos e projeto de execução fornecidos pela Prefeitura Municipal de Lages. Foi possível observar que a obra Complexo Ponte Grande é de extrema importância para a melhoria da qualidade de vida da população lageana. Porém, foram 
encontradas diversas falhas nos procedimentos da obra, a mesma precisa ser executada de forma correta, pois está acarretando problemas para a qualidade de vida da população.

PALAVRAS-CHAVE: Bacia hidrográfica; empreendimento; infraestrutura; saneamento; Complexo Ponte Grande.

\section{ANALYSIS OF LEGAL INSTRUMENTS THAT GUIDE TERRITORIAL DEVELOPMENT, HOUSING, INFRASTRUCTURE AND SANITATION WORKS IN THE HYDROGRAPHIC BASIN OF RIO PONTE GRANDE, IN LAGES-SC}

ABSTRACT: The territorial development of most Brazilian cities has taken place in a disorganized way, due to the lack of legal instruments that guide urban occupation. Urbanization without planning is also a reality in the municipality of Lages, which has a demand for housing greater than the supply in neighborhoods with infrastructure, and this leads to the emergence of irregular occupations, because planned neighborhoods with infrastructure are inaccessible to the needy population. Thus, aiming to understand the emergence of the norms that explain the advance in urban occupation, an analysis of the legislation at the municipal, state and national levels was carried out as to the prerogatives of land use, focusing on the development of the Ponte Grande River basin, in Lages-SC. For this, a bibliographic analysis was carried out, with a qualitative focus, aiming to verify the applicability of the laws that guide the territorial development of the Ponte Grande River basin, in Lages, and after correlating the disordered territorial development with the quality of life of the population. The area object of the study was occupied in a disordered way, with precarious buildings and access to goods and services, as well as high environmental impacts. Faced with such impasses, the Lages City Government filed a housing, infrastructure and sanitation project in the basin along the Federal Government - Ministry of Cities. For the study on the works and services of the Ponte Grande Complex, an analysis was made based on contracts, documents, photos and execution project provided by the Lages City Hall. It was possible to observe that the project of the Ponte Grande Complex is extremely important for the improvement of the quality of life of the city population. However, several flaws were found in the work procedures; it needs to be performed correctly, since it is causing problems for the quality of life of the population.

KEYWORDS: Hydrographic basin; undertaking; infrastructure; sanitation; Ponte Grande Complex.

\section{I INTRODUÇÃO}

Em meados do século $X X$, iniciou-se um crescimento exponencial das cidades brasileiras, não atuando mais apenas como centro administrativo e coordenador das atividades agrícolas, mas sim como alternativa de novas oportunidades e crescimento (BARBOSA, 2012). Porém, as cidades não possuíam infraestrutura e o aporte necessário para acolher a população advinda do campo, gerando um crescimento desordenado. $O$ Estado carece de políticas públicas para ordenar o desenvolvimento e promover o acesso a moradias adequadas para os indivíduos, estando a maioria desses em situação de vulnerabilidade social e econômica (MATOS; BRAGA, 2013). 
O planejamento inicial das cidades brasileiras era díspar, voltado à questão econômica, privilegiando regiões centrais e nobres, as classes detentoras de capital. Suprimiu-se o amparo aos vulneráveis economicamente, que não detinham de condições para adquirir terrenos em áreas com serviços básicos estabelecidos. Por carência de uma condição econômica satisfatória, moradias começaram a surgir em espaços precários, impróprios para a ocupação humana, com risco ambiental e insalubres (MATTIA; SANTIN, 2014).

Os problemas em razão da crescente urbanização começaram a assombrar as cidades, como a precariedade no acesso a bens e serviços, infraestrutura urbana inadequada, uso e ocupação do solo imprópria, segregação de espaços urbanos e construção de moradias em áreas de risco (KAUFFMANN; DA SILVA, 2013). A origem do problema não é o crescimento populacional, mas sim a exposição dos munícipes aos riscos da transformação do ambiente. O fator demográfico assume um caráter dúplice: o homem influenciando o meio, mas também sofrendo forte influência desse (MARANDOLA JR; HOGAN, 2009).

O desenvolvimento se deu, na maioria das vezes, em áreas sem a infraestrutura mínima, sem saneamento, refletindo diretamente na degradação socioambiental. A projeção da desigualdade nos municípios é a demonstração de como o espaço é constituído de forma incongruente (CARLOS, 2009). É importante avaliar o ambiente das cidades, no que diz respeito ao uso da terra e as transformações decorrentes da antropização, para assim mapear fragilidades e planejar adequações. Para isso, utiliza-se a bacia hidrográfica como unidade de planejamento, tendo essa aceitação mundial e efetivação na gestão ambiental (TORRES; MACHADO, 2012).

Fica a cargo do Poder Público Municipal a competência de desenvolvimento urbano e ordenamento das funções sociais da cidade, conforme exposto nos artigos 182 e 183 da Constituição Federal (BRASIL, 1988). Isso significa que o município, sendo representante legal do Sistema Nacional do Meio Ambiente - SISNAMA, é o ente que deve gerenciar os recursos hídricos, principalmente no que diz respeito à preservação e ao uso e ocupação da terra. O planejamento das cidades deve se dar a curto, médio e longo prazo ao mesmo tempo, pelo instrumento denominado Plano Diretor. Esse delineamento busca projetar a ocupação nos próximos 10, 20 e 50 anos, estabelecendo regras, delimitações de áreas específicas para cada atividade afim (IPUF, 2003).

Verifica-se, então, que a legislação urbanística se deu a partir de demandas sociais, onde a área urbana deixava de ser suporte e passada a ser insumo de grande importância. Assim, o Estatuto da Cidade chega com um século de mora no que diz respeito ao uso de instrumentos que norteiem a ocupação, para regular socialmente o mercado imobiliário. Diante disso, obras e serviços começaram a ser executados pelas prefeituras municipais a fim de levar à toda extensão territorial infraestrutura urbana, saneamento e condições de habitabilidade. Porém, a crescente urbanização faz com que o poder público municipal 
padeça de obras de melhoria e, muitas das vezes, não consiga suprir a demanda populacional.

Serviços de infraestrutura em geral e de saneamento em particular requerem projetos de alto teor técnico, multidisciplinares e complexos. Para que essa cadeia produtiva seja efetiva é necessário que se tenham projetos elaborados, práticas inovadoras de gestão econômica e financeira, um ambiente regrado, que opere com transparência e com regramento consolidado. Projetos de infraestrutura e saneamento não se esgotam na iminência da obtenção do recurso, mas sim na execução de obras com impactos socioeconômicos e ambientais (VASCONCELLOS; TUROLLA, 2016).

A carência de serviços de saneamento básico está diretamente relacionada com a saúde pública e o aviltamento do meio ambiente, pois contribuem para a disseminação de doenças de veiculação hídrica, como infecções gastrointestinais de origem infecciosa presumível, acarretando impactos negativos em campos como educação, economia, trabalho, biodiversidade e outros (FERREIRA; GARCIA, 2017).

No município de Lages, o panorama era semelhante ao vivenciado no restante do país, com uma urbanização desmedida e desregrada. Essa característica de desenvolvimento ocasiona adversidades ambientais de grande impacto, como perdas da biodiversidade da fauna e da flora, contaminação de corpos hídricos, inundação, desertificação do solo e movimentação de encostas (SUERTEGARAY, 2000).

Assim, objetivou-se com o presente estudo realizar uma análise temporal dos instrumentos jurídicos que norteiam a ocupação do município de Lages e da compatibilidade da legislação local com as normativas federais. Além disso, o estudo traz um enfoque na análise dos contratos vinculados às obras do Complexo Ponte Grande, sendo esse composto por obras de infraestrutura, saneamento, habitação e revitalização da Avenida Ponte Grande, verificando o que fora ou não executado. Tal estudo é de grande valia aos administradores públicos para que se verifique a empregabilidade do dinheiro público, a aplicabilidade das normativas federais, estaduais e municipais e dos direitos fundamentais da população, para que se concertem possíveis falhas e, com exatidão, cumpram com as prerrogativas legais.

\section{I MATERIAL E MÉTODOS}

O presente estudo foi realizado baseando-se em revisão bibliográfica compilada. Analisaram-se as legislações territoriais e ambientais desde o surgimento até a atualidade, em âmbito nacional, estadual e local. Comparou-se a ocupação do solo na área de estudo, verificando a aplicabilidade das normativas.

Para discorrer sobre as obras de infraestrutura, saneamento e habitação fez-se análise dos contratos, documentos, fotos e projeto de execução fornecidos pela Prefeitura Municipal de Lages. Assim, efetuou-se uma revisão bibliográfica, de forma qualitativa, 
construtiva, para verificar os métodos de execução das obras concernentes ao Complexo Ponte Grande e, ao final, verificou-se a interferência das obras na qualidade de vida da população local.

O estudo remete-se à bacia hidrográfica do rio Ponte Grande, pertencente ao município de Lages, estado de Santa Catarina, sul do Brasil (Figura 1), com área total de 2.722,35 ha. (OLIVEIRA, 2015).
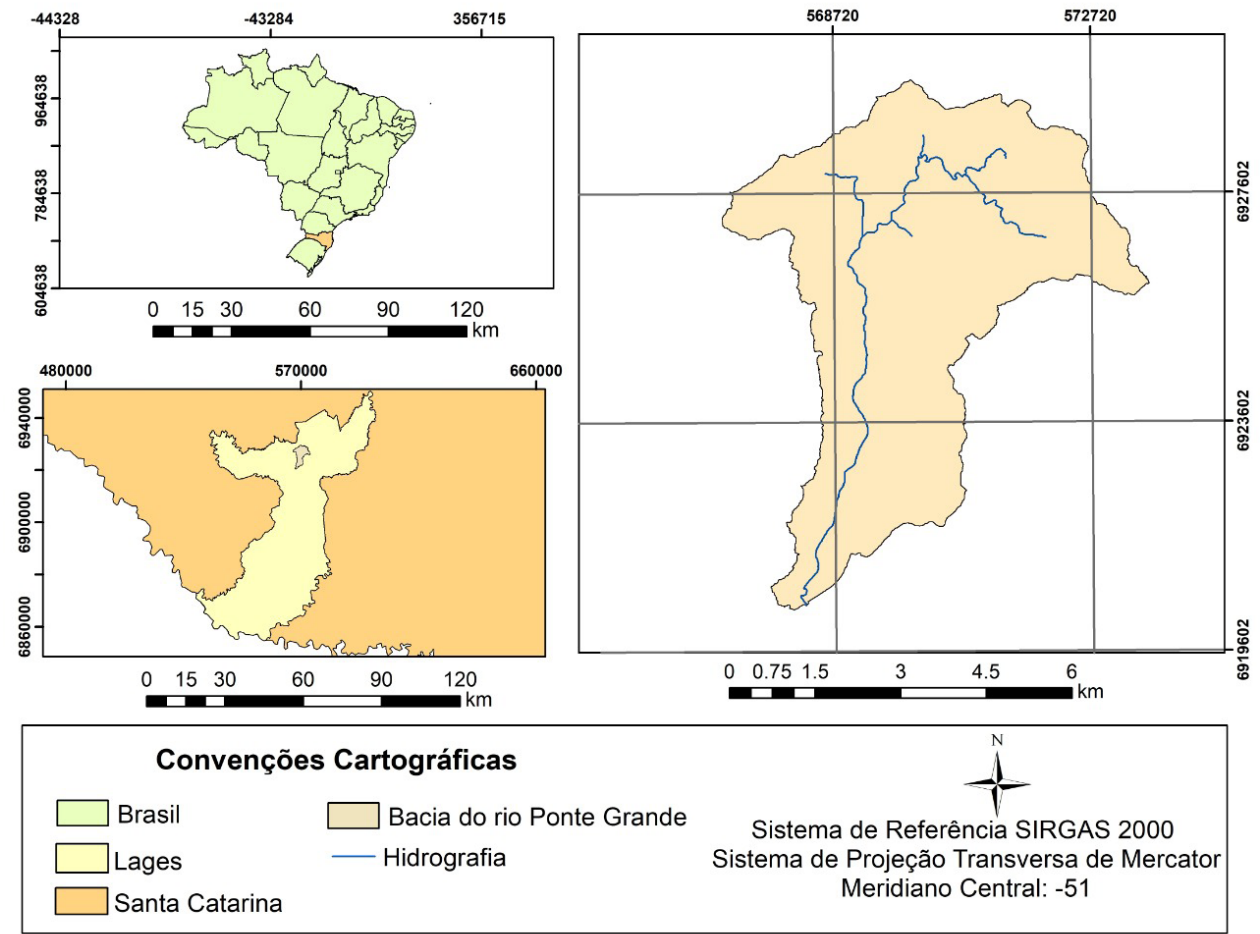

Figura 1 - Mapa de localização nacional, estadual e municipal da bacia hidrográfica do rio Ponte Grande

\section{I RESULTADOS E DISCUSSÃO}

\subsection{Análise das legislações que tratam sobre o desenvolvimento territorial}

A região do atual planalto catarinense era habitada por indígenas da etnia Kaingang até que iniciou sua colonização, no início do século XVIII, por bandeirantes e tropeiros, que comercializavam muares da região da Platina até Sorocaba, popularmente conhecido por "Caminho das tropas" (MACHADO, 2004). O campo das Lages possuía o correspondente a $72.000 \mathrm{~km}^{2}$, com mata de araucária e campos de pastagens como principais formas de vegetação. Mas, com o passar dos anos, esses foram substituídos por área urbana 
consolidada (COSTA, 1982).

O processo de ocupação, assim como em todo o território nacional, foi caracterizado por desordem e falta de normativas que norteassem o desenvolvimento urbano. 0 acesso restrito aos serviços públicos e à moradia agravaram a desigualdade social e, por hipossuficiência, muitos ocupavam locais sem infraestrutura necessária, sendo na maioria áreas de risco, culminando a vulnerabilidade físico-ambiental e social (CIDADE, 2013).

Foi então, que através de pressão popular, surgiu a normativa que iria estabelecer normas de ordem pública e interesse social, regulando o uso da propriedade urbana, visando o bem coletivo, a segurança, o equilíbrio ambiental e o bem-estar dos citadinos, denominado Estatuto da Cidade, através da Lei n 10.257/2001 (BRASIL, 2001). Para se ter a regularização da ocupação da terra, o município deve desenvolver normativas, utilizando-se do Plano Diretor, conforme expresso no Estatuto da Cidade. Tem-se que em $87 \%$ dos municípios brasileiros com mais de vinte mil habitantes havia Plano Diretor vigente, aprovado em plenária municipal, até o ano de 2009 (OLIVEIRA, 2013).

Em Lages, no ano de 1986, foi aprovada a primeira normativa falando sobre o parcelamento do solo, sendo essa a Lei $n^{\circ}$ 1.052. Nela, são expostas as áreas permitidas para utilização da expansão urbana, excetuando aquelas do parágrafo $1^{\circ}$ do artigo 34 e as do artigo 35, sendo florestas e demais formas de vegetação natural, áreas de preservação permanente e áreas consideradas de risco, conforme preconizado pelo Código Florestal em vigor na época, Lei $n^{\circ} 4.771 / 1965$.

O primeiro Plano Diretor fora aprovado em 1988, mediante a Lei $n^{\circ} 1.362$. No presente documento, em seu artigo 18, estão expostas as unidades territoriais, para fins de uso e ocupação do solo, nas zonas urbanas e de expansão urbana. Porém, as Áreas de Interesse Especial (AIE) das unidades territoriais não estão ali apresentadas, dizendo que essas devem estar contidas em legislação específica, porém não há legislação adjacente a isso. Áreas de Interesse Especial são aquelas das quais deve haver preservação dos valores culturais e paisagísticos ou recursos naturais (LAGES, 1988).

Assim como preconizado no Estatuto da Cidade, o Plano Diretor municipal deve ser revisto a cada 10 anos, para que seus zoneamentos e áreas estejam de acordo com a realidade local, apresentando áreas urbanizadas, áreas a serem ocupadas por indústria, áreas destinadas a comércio e a preservação. Em 21 de dezembro de 2007 foi aprovado o segundo Plano Diretor de Lages por meio da Lei n 30 (LAGES, 2007), com princípios e objetivos da política de desenvolvimento territorial, para se ter o ordenamento da ocupação da terra. Em 22 de agosto de 2018, teve-se a aprovação do atual plano, utilizado para normatizar a urbanização e utilização do solo. No documento, contendo atualizações do antigo plano de 2007, são estabelecidos os zoneamentos da cidade, esses com características singulares, para ordenar o uso do solo.

As áreas que possuem algum empecilho de serem edificadas são apresentadas como Áreas Especiais de Amortecimento Ambiental - AEAA; Áreas Especiais de Interesse 
Ambiental - AEIA, Área de Preservação Permanente - APP e áreas verdes (LAGES, 2018). Essas, devem ser resguardadas, não devendo haver urbanização, para que se mantenham preservadas características ambientais e sociais. Muitas residências estão irregulares, inseridas em áreas de resguardo e, consequentemente, em áreas de risco. Apesar de existir impedimento legal quanto a ocupação dessas áreas, é possível visualizar grande parte dessas já condensadas e essa sistemática já fora objeto de estudo em nível local, regional, estadual e até nacional, dos quais demonstram o crescimento exponencial de residências instaladas em áreas de preservação ou áreas de risco (PINTO, 2007; RIBEIRO; MENDES, 2012; LOPES et al., 2013; MAZZOLLI; EHRHARDT-BROCARDO, 2013; SILVA, 2013).

Com o passar dos anos, as normativas foram sendo atualizadas, contabilizando as áreas já consolidadas, urbanizadas. Porém, verifica-se a incompatibilidade dessas com a realidade da ocupação do solo, mesmo atualizadas, em razão de o crescimento das cidades se dar de forma rápida e estar em constante avanço.

Em 2012, o Código Florestal Brasileiro fora atualizado, mediante a aprovação da Lei n 12.651 (BRASIL, 2012), trazendo em seu escopo áreas de proteção e como resguardálas. Mas, no interim de sua aprovação, já se verifica a ineficácia quanto a algumas regiões do município, pois são áreas demarcadas como de resguardo e já estão consolidadas pela ocupação, com diversas edificações em áreas impróprias. No Brasil, cerca de 84,36\% da população reside na área urbana, sendo que $50 \%$ dessa têm suas moradias em aglomerados subnormais. No tocante a essas áreas, mais de $66 \%$ das residências estão localizadas em unidades de conservação ou em margem de corpos hídricos (IBGE, 2011).

Segundo Censo Demográfico feito pelo IBGE (2018), a área territorial de Lages corresponde a 2.637,66 km², com população de 157.544 habitantes. Tem-se na área urbana 48.403 residências, contrastado a 920 na área rural. Porém, apenas $26,7 \%$ dos domicílios urbanos apresentam infraestrutura adequada, como pavimentação, meio fio, calçada e bueiro (IBGE, 2011). Tais dados demonstram como a municipalidade não consegue dispor da infraestrutura necessária para atender a todos os indivíduos residentes em áreas periféricas. Apesar da crescente urbanização, muitos ainda vão em busca de locais impróprios para residir, eludir da especulação imobiliária, em razão da carência financeira para a aquisição de melhores locais para morar.

Mas, não apenas há carência de infraestrutura, pois inúmeros são os problemas relacionados ao meio ambiente causados pela ação antrópica, como exemplo a extinção de espécies da flora e da fauna, mudanças climáticas, redução das áreas de preservação e poluição (Figura 2), onde residências foram construídas em área de preservação permanente, com despejo irregular de esgoto no corpo hídrico. 


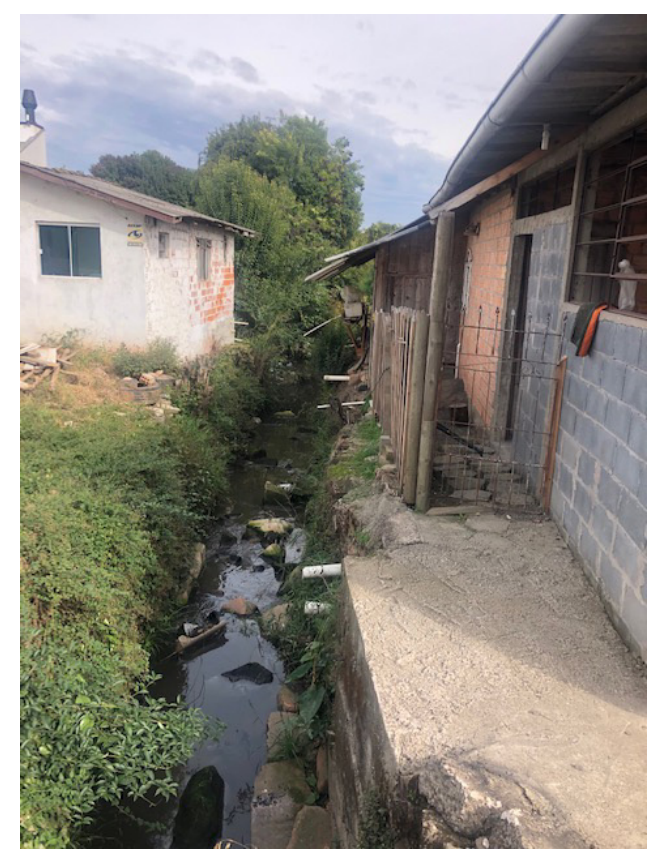

Figura 2 - Ocupação consolidada em área de resguardo.

A ocupação irregular já é uma realidade nas cidades brasileiras, conforme descrito em estudos de Mesquita et al. (2017), Gomes et al. (2019) e Soares et al. (2019) e em Lages não é diferente. Na bacia hidrográfica do rio Ponte Grande muitas são as áreas sensíveis ocupadas de forma irregular. Em estudo realizado pelo CPRM - Serviço Geológico do Brasil no município de Lages em 2018, foi demonstrada a fragilidade da bacia hidrográfica do rio Ponte Grande, pois muitas são as áreas consideradas de alto e muito alto risco ao fenômeno de inundação em sua extensão, totalizando 1313 edificações.

Conforme a Figura 3, a área urbanizada, exposta na cor cinza, se alastrou pela extensão da bacia, ocupadas margens de corpos hídricos e a planície topográfica de inundação. A bacia é densamente povoada, contabilizando 30.548 edificações. Verificase a ocupação das APP's, em sua maioria, havendo preservação apenas de áreas de cabeceiras e aquelas cuja declividade seja acentuada, como em topos de morro. 


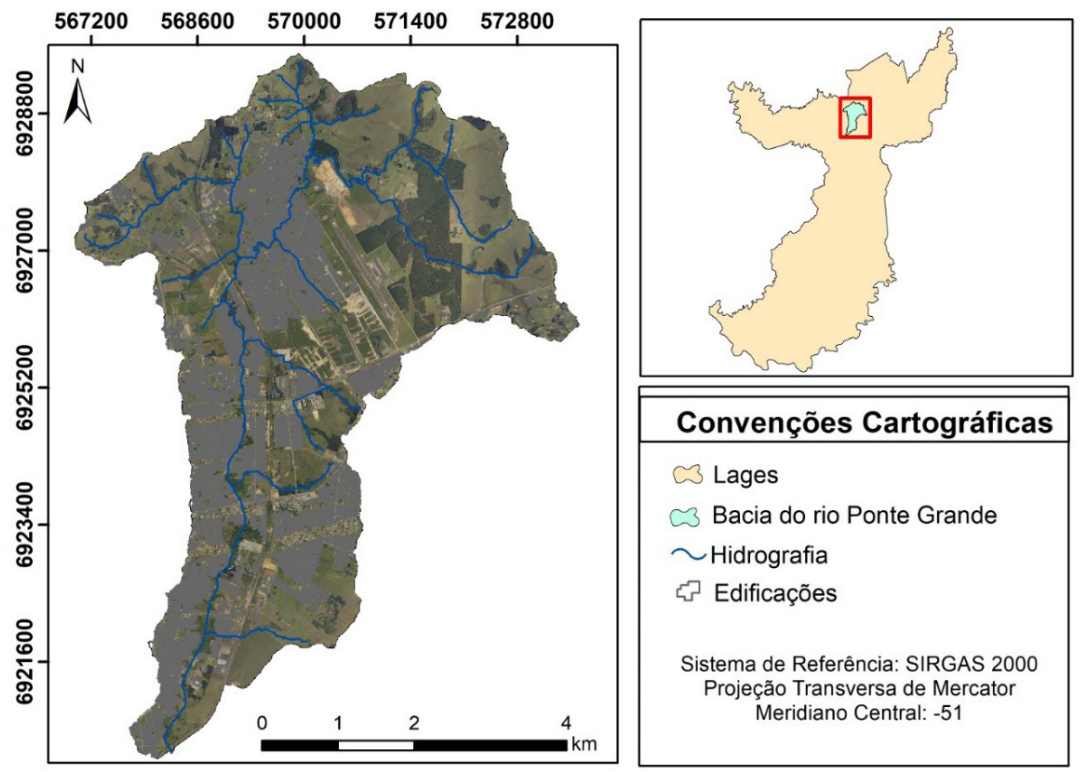

Figura 3 - Recorte da bacia hidrográfica do rio Ponte Grande, demostradas as edificações e os corpos hídricos.

\subsection{Complexo Ponte Grande}

O complexo Ponte Grande é composto por obras de habitação, infraestrutura, como a pavimentação da Avenida Ribeirão Ponte Grande, ciclovia, faixa exclusiva para ônibus, pela macro e micro drenagem da avenida, relocação de aproximadamente 170 famílias, desapropriações de terrenos, pela construção da rede de coleta e estação de tratamento de efluentes.

A importância dos serviços de distribuição de água e esgotamento sanitário é reconhecida na Assembleia Geral da Organização das Nações Unidas (2010) por meio da resolução n 64/292, em que cita o direito a água potável e limpa e ao saneamento como essenciais para uma adequada qualidade de vida.

Do ponto de vista ambiental, o saneamento qualifica o solo urbano, com efeito sobre as atividades nele desenvolvidas, isso porque o saneamento valoriza as construções existentes e possibilita edificações de maior valor agregado, o que implica no aumento do capital imobiliário das cidades (TOMÉ, 2017). De acordo com a UNESCO, em países em desenvolvimento, a cada US\$1 investido em saneamento pode gerar um retorno entre US\$ 5 e US $\$ 28$ para a economia (PIMENTAL; CAPANEMA, 2018).

A obra é executada pela Secretaria Municipal de Planejamento e Obras e pela Secretaria Municipal de Águas e Saneamento, fazendo parte do PAC - Programa de Aceleração do Crescimento, implementado pelo Governo Federal, que perpassará por 13 bairros. Na Figura 4, é possível observar parte dessas obras. Para a realização da obra 
foi feito convênio com o Governo Federal mais contrapartida da prefeitura, totalizando um aporte de 81 milhões de reais, sendo que desses: 57 milhões serão para a estruturação da avenida (verba ministerial), 12 milhões para construção do conjunto habitacional (verba ministerial e contrapartida municipal de 8\%), 10 milhões para indenizar as desapropriações (município), 2 milhões para aluguel social e infraestrutura de vias de conexão (município).

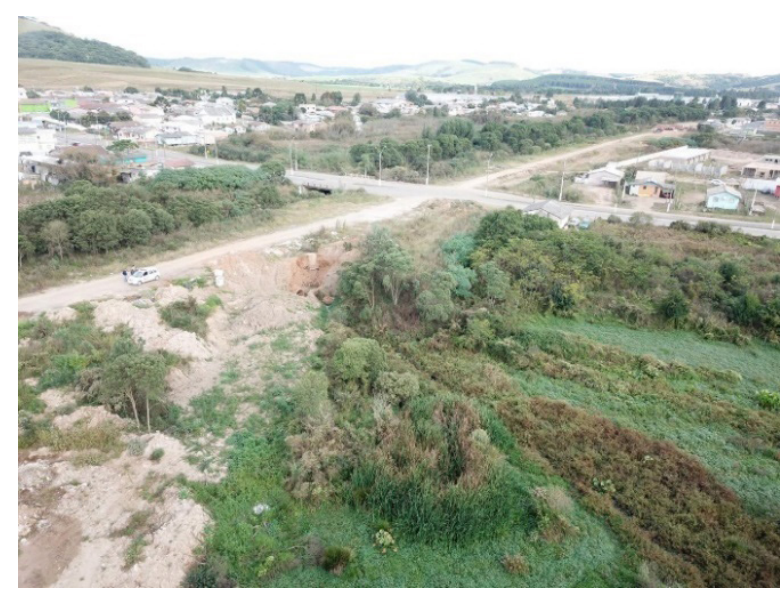

Figura 4- Imagem aérea da Avenida Ponte Grande em trecho onde já foi feita a instalação da rede de esgoto e o traçado da rua está pronto.

Fonte: Coordenadoria Municipal de Proteção e Defesa Civil de Lages (2019).

\subsubsection{Condomínio Ponte Grande}

Para que fossem iniciadas as obras de infraestrutura e saneamento, necessitavase que diversas residências fossem desocupadas, pois encanamentos e equipamentos precisavam do local ora ocupado por essas. Porém a grande maioria dessas edificações foram construídas em áreas impróprias, sendo áreas de preservação permanente, institucionais e/ou de risco, tornando-se essencial a realocação dessas famílias, para o bom andamento dos trabalhos.

A dificuldade de acesso à terra urbanizada, em particular, pode ser considerada o núcleo do problema da habitação de baixa renda no Brasil e em outros países da América Latina. Tal dificuldade leva à ocupação e à degradação de áreas ambientalmente vulneráveis, como áreas de preservação permanente e/ou áreas de risco, mesmo que elas estejam protegidas pela legislação ambiental e urbanística (GONDIM, 2012).

Nas áreas de preservação permanente (APP's), em tese, não deveria haver ocupação, pois estes são locais ambientalmente sensíveis e que podem sofrer danos irreversíveis em razão de ocupações humanas irregulares (VIEIRA, JÚNIOR, 2017). As APP's têm sofrido com o descaso quando de sua proteção em função da escassa consciência ambiental da 
sociedade e do Estado. Haja vista a proteção ambiental ter sido consagrada no artigo 225 da Carta Magna e imposta ao Poder Público e à coletividade é fato que ambos também colaboram para sua degradação (PAIANO, 2014).

Assim, foi adquirido pelo Poder Público Municipal terreno com 71 mil metros quadrados, para que fossem construídas 200 casas geminadas, com aproximadamente 240 metros quadrados de terreno e 46 metros quadrados de área construída cada, com dois quartos, um banheiro, sala e cozinha conjugada. As obras iniciaram em 2013. Mas seguiu a passos curtos e apenas em 2017 pode-se vislumbrar a obra em etapas finais.

As 200 residências foram fabricadas para abrigar as 170 famílias que moravam nas margens do rio Ponte Grande e para famílias atingidas por eventos hídricos de inundação, enxurrada, enchente e/ou alagamento.

No primeiro semestre de 2017 as casas estavam concluídas, mas não se pode fazer a entrega aos beneficiários por não ter sido concluída a rede de saneamento e a via de acesso para o condomínio. Em junho de 2017, tempestade local/convectiva - chuvas intensas (COBRADE 13.214) assolou o município de Lages, atingindo grande parte da bacia hidrográfica do rio Ponte Grande, inclusive as casas do Condomínio Ponte Grande. As residências ainda não haviam sido entregues aos moradores, mas fortes discussões a respeito iniciaram, pois se questionava a efetividade em retirar 180 famílias de áreas de risco, margens de córrego, para realocarem em outra área com suscetibilidade a inundação. Na Figura 5 é apresentado um registro da inundação no condomínio, onde mostra as casas parcialmente cobertas pela água.

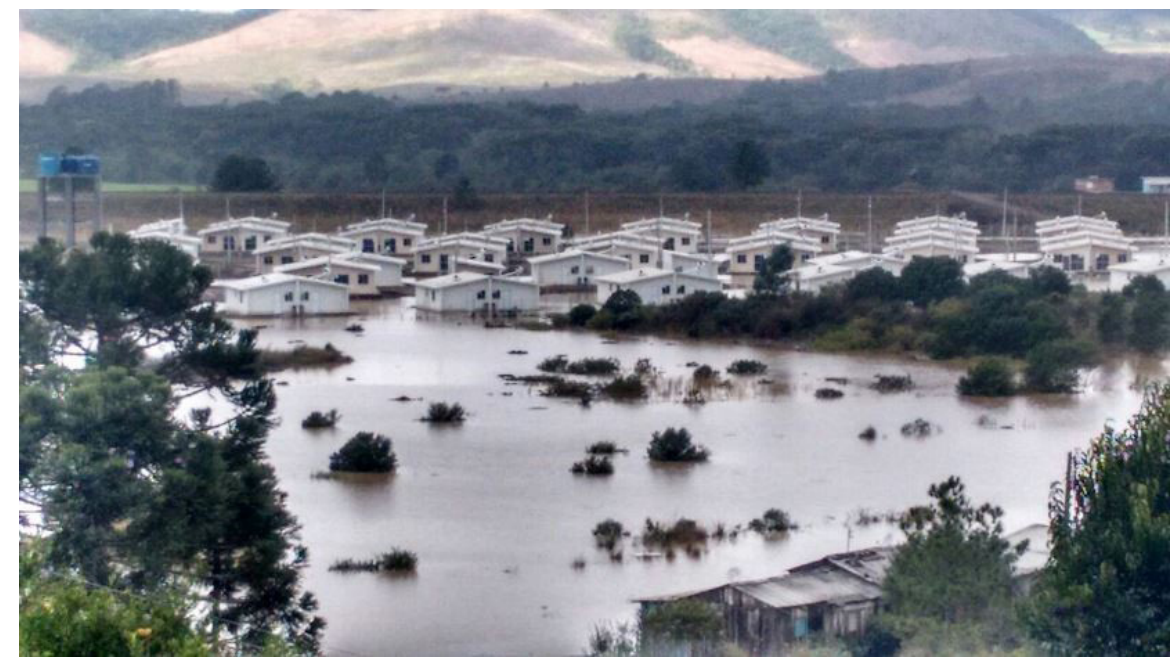

Figura 5 - Registro do fenômeno inundação no Condomínio Ponte Grande, em tempestade ocorrida em junho de 2017.

Fonte: Coordenadoria Municipal de Proteção e Defesa Civil de Lages (2017). 
Conforme exposto por Vieira e Cunha (2010), as enchentes e as inundações urbanas impactam a sociedade e são ocasionadas por fatores como o aumento da precipitação, vazão dos picos de cheia e estrangulamento das seções transversais, oriundo de obras de canalização, assoreamento, aterro e acúmulo de resíduos sólidos. Inundação é o fenômeno caracterizado pelo transbordo do canal principal, fora dos limites normais de um curso d'água, devido à ocorrência de enchentes em que a água em excesso atinge a planície topográfica de inundação (CEMADEN, 2016; BITAR, 2017). Planície de inundação é aquela região ao longo do curso d'água que ocorre naturalmente o processo de inundação e está associada com as condições climáticas e hidrológicas da bacia hidrográfica (LEOPOLD et al. 1964).

Apenas em maio de 2018 houve o sorteio para definir qual casa será ocupada por cada beneficiário, sendo que 150 famílias participaram da ocasião. Tal número fora reduzido em razão de 50 famílias não terem aceitado sair do seu local de origem para se destinarem ao condomínio e ajuizaram demanda judicial, pois entendem ser merecedores de indenização. Os favorecidos passaram por acompanhamento técnico social, que perdurou aproximadamente seis meses, para conscientização e acompanhamento desses, pela mudança de moradia, por não terem tido contato com moradia em condomínio, auxiliando no bom convívio entre todos. A obra iniciada em maio de 2013, que em cronograma contava com a conclusão em 18 meses, fora findada e entregue aos novos proprietários em agosto de 2018.

\subsubsection{Infraestrutura e saneamento}

Concernente ao denominado Complexo Ponte Grande tem-se as obras da avenida que interligará 13 bairros, desde o Guarujá até o Caça e Tiro, micro e macrodrenagem, ciclovia, rede de coleta e estação para tratamento de efluentes. Para tanto sinalizouse o recebimento de 57 milhões de reais por parte do Ministério das Cidades, em 2011. Assim, em 2012 iniciaram-se os procedimentos licitatórios, as contratações das empresas especializadas para a execução do mesmo e em fevereiro de 2013 assinou-se a Ordem de Serviço referente à maior obra pública de Lages.

Assim, firmou-se contrato com as empresas, formando um consórcio para gerenciamento, supervisão, fiscalização, supervisão ambiental e desenvolvimento dos projetos executivos, bem como as built, readequações e estudos complementares, relativos ao Plano de Saneamento Integrado - canalização do ribeirão Ponte Grande, construção da Avenida Ponte Grande, implantação e ampliação do sistema de esgotamento sanitário no município de Lages (LAGES, 2013). Outra empresa foi contratada para a realização dos serviços de ampliação do sistema de esgotamento sanitário, redes coletoras, ligações de macro e microdrenagem, urbanização da Avenida Ponte Grande e do sistema integrado (LAGES, 2012). 
Paralelo a isso, fora adquirido pela municipalidade terreno no bairro Ponte Grande, para a construção de 200 casas populares para realocação de aproximadamente 180 famílias residentes nas margens do rio. As obras do denominado Condomínio Ponte Grande iniciaram em meados de 2014. O recurso advindo do Ministério das Cidades é repassado a Caixa Econômica Federal, que após aprovação dos projetos feitos pelas empresas e com aval da Secretaria de Planejamento de Obras, repassa o montante executado para liquidação. Porém, o andar das obras não foi tão simples e nem ágil. Após a emissão da Ordem de Serviço, o canteiro de obras começou a ser ocupado e máquinas iniciaram os trabalhos. Mas, alguns meses depois tudo estava abandonado, porque o licenciamento ambiental não havia sido realizado.

De acordo com a Confederação Nacional da Indústria (2018) o Brasil sofre com entraves ao investimento público em infraestrutura. Segundo a mesma fonte, entre as causas apontadas como responsáveis pela paralisação das obras de saneamento, encontra-se a má qualidade dos projetos, principalmente por eles não levarem em conta os riscos ambientais, de desapropriação e de contestações judiciais. Além disso, a capacidade de elaboração e execução de projetos é ruim, principalmente no caso das Prefeituras Municipais.

Questões como revisão de projeto, reajustes de valores e prorrogação de prazos foram situações que causaram entraves, atrasando a obra e ocasionaram o abandono das empresas. Porém, tais alterações justificaram-se em razão de as medições terem sido feitas antes de as casas e famílias desocupassem a área. Então, em 2015 fora feita novo procedimento licitatório para a contratação de empresa de engenharia para assessoria técnica e estudos complementares referente ao Projeto Ponte Grande.

As obras que haviam sido paralisadas em agosto de 2014 , foram retomadas apenas na segunda quinzena de janeiro de 2015. Em julho de 2015 nova paralização nas obras, pelo projeto estar inapropriado, não condizente com a realidade. O Ministério das Cidades (2017) coloca que durante a execução de obras públicas surgem diversas situações inesperadas que precisam de solução, seja devido ao meio ambiente, seja por conta dos deslocamentos involuntários - desapropriações ou remoção de famílias - seja ainda por questões relacionadas com o patrimônio histórico, o que provoca a paralisação das mesmas.

Em 2016, em novo certame, contratou-se uma empresa para a execução das obras de implantação da rede de esgoto sanitário do Projeto Ponte Grande (LAGES, 2015; 2016). Outra empresa foi contratada para a realização dos serviços de terraplanagem, pavimentação asfáltica, drenagem, obras de arte correntes, obras complementares, sinalização definitiva e de obra do trecho correspondente aos bairros da Várzea, Popular e Ferrovia, até o acesso ao condomínio de casas populares.

Diante de tantos impasses e déficit financeiro, o projeto não mais contará com a pavimentação de ambos os lados do corpo hídrico, e sim apenas com o lado direito, sentido 
o rio Caveiras. Então, resolveu-se por dividir o projeto em duas partes: saneamento e infraestrutura e em cinco etapas, cada uma com aproximadamente 1,6 quilômetros. $O$ saneamento executa-se primeiro e após findado, realiza-se a pavimentação.

Assim, a etapa zero é correspondente à entrega das casas do condomínio popular, a construção da ponte de acesso às moradias e a pavimentação entre a ponte e a Rua Cirilo Vieira Ramos, finalizada no mês de abril de 2019. Acontecendo em paralelo ao asfaltamento da etapa zero, executa-se o saneamento do trecho desde a ponte de acesso ao condomínio até a Avenida Castelo Branco, correlato a etapa um, já concluído.

Ao iniciar a pavimentação da etapa um, a equipe que fará a implementação da rede de esgoto da etapa dois iniciará suas atividades. A referida refere-se ao trecho desde a Avenida Castelo Branco até a Avenida Presidente Vargas. O mesmo acontecerá com a etapa três, demarcada entre a Avenida Presidente Vargas até a BR 282, sendo então o trecho mais complexo, por haver grande número de desapropriações a serem feitas. $O$ trecho entre a BR 282 e o bairro Guarujá é a etapa quatro, porém essa não está contida no projeto enviado e aprovado pelo Ministério das Cidades. Apresenta-se o mapa do traçado da obra, aprovado em projeto inicial, na Figura 6.

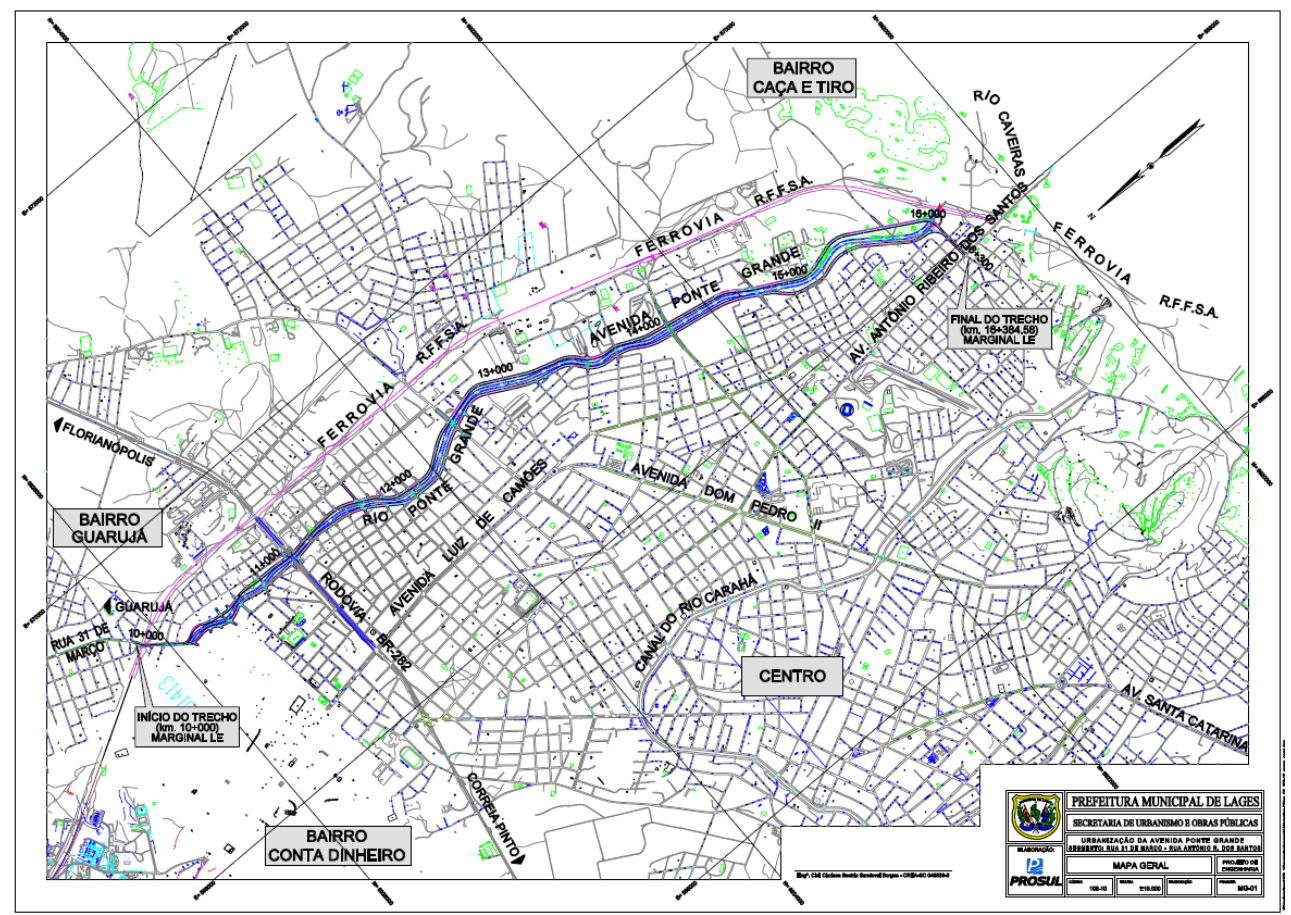

Figura 6 - Mapa do projeto aprovado para execução com localização e traçado da avenida. Fonte: LAGES (2012). 
As obras de infraestrutura que foram realizadas e findadas até o momento dizem respeito ao trecho da Rua Cirilo Vieira Ramos até a ponte de acesso ao condomínio, perpassando pela Rua Antônio Ribeiro dos Santos. Após muitas tratativas com o Ministério das Cidades e com a Caixa Econômica Federal, em razão de a verba disponibilizada em 2012 não ser mais suficiente para a execução de todas as obras contidas no projeto inicial, decidiu-se por dar seguimento apenas ao saneamento, tendo esse um caráter essencial e primordial.

O contrato com a empresa executora da parte de infraestrutura, foi findado em fevereiro de 2020 e rescindido, devendo ser aberta nova licitação para que as obras de drenagem e pavimentação sejam feitas nas demais etapas. O saneamento tinha como prazo para entrega da rede até a BR 282 - etapa três - o término de 2019. Porém, verificase o não cumprimento do disposto e o aditamento no prazo contratual até janeiro de 2021. A falta de eficiência em obras de saneamento se inicia na lentidão das licitações e, consequentemente, na desatualização dos projetos de saneamento, que ao iniciarem já estão ultrapassados, uma vez que as licitações somente ocorrem anos após a elaboração do projeto, os quais abrangem principalmente áreas de intenso adensamento e ocupação urbana (LUIZ, 2014).

Analisando o exposto, vislumbra-se que diversos são os problemas vivenciados em razão das obras inclusas ao projeto Complexo Ponte Grande, desde ambientais, sociais, até de saúde e de gestão. É possível vislumbrar o não cumprimento do projeto inicial, tendo sido esse reavaliado e alterado de acordo com as possibilidades de execução. Atualmente apenas a faixa da direita será contemplada por infraestrutura e o saneamento é o primordial, devendo ser executado primeiro com verba ministerial. Do aporte de 57 milhões de reais, pouco mais de 20 milhões já fora repassado pela execução dos serviços.

É nítida a mora das empresas, os problemas referentes a projetos e execução. Além disso, verifica-se a insatisfação da população residente na área diretamente afetada, pois convive com poeira e movimentação de maquinários durante sete anos consecutivos. Além de muitos se mostrarem descontentes com as residências, pois já apresentam problemas estruturais e estão em área sujeita a inundação.

Segundo Ribeiro (2012), a falta de fiscalização e a corrupção crônica, um verdadeiro câncer da chamada "cultura política brasileira", caracterizada pela busca do proveito pessoal em detrimento do interesse público, que resvala para o nepotismo, o empreguismo, a ineficiência, leva necessariamente ao superfaturamento de qualquer obra pública deste país.

Quanto às desapropriações, essas são feitas das áreas particulares, ocupadas por residência ou empreendimento que estejam dentro do traçado da avenida e da rede de coleta e tratamento de esgoto. Até novembro de 2019 registraram-se 28 decretos de utilidade pública dessas áreas, mas ainda são necessários mais procedimentos e alguns encontram-se em esfera judicial (LAGES, 2019). 
Analisando o projeto num todo, contabiliza-se um total de 298 imóveis atingidos, sendo que 72 desses são particulares com alguma edificação, 77 são glebas/ lotes baldios e 147 famílias foram realocadas. Desses 298 imóveis, 204 são residenciais, 13 são comerciais, 3 são templos religiosos e 2 estabelecimentos de ensino. Dos 11.300 metros de extensão de rede de esgoto, a maioria já foi finalizada, restando parte do trecho próxima a BR 282. Acredita-se que o saneamento será executado até o término do contrato, janeiro de 2021. Porém, não há previsão para a conclusão da infraestrutura do complexo.

\section{I CONSIDERAÇÕES FINAIS}

Observa-se falhas procedimentais desde a projeção até a execução das etapas, com diversas interrupções por falta de documentação, burocracia ou pressão popular, em razão das áreas desapropriadas. Verificou-se desagrado por parte dos residentes nas áreas de influência direta à obra, pois além dos transtornos e movimentações de máquinas e trabalhadores, há acúmulo de poeira, deterioração de calçadas e vias das adjacências, problemas respiratórios.

O valor ora disponibilizado pelo ministério não será totalmente utilizado e isso demonstra a ineficácia do Poder Público Municipal em gerir e administrar tamanho projeto. A ligação da rede coletora até a estação de tratamento foi concluída, necessitando os moradores ligarem sua tubulação na nova rede. Mas, grande parte dos munícipes da região são de baixa renda, residindo em edificações precárias e sem condições de arcar com os custos da implantação de seu esgoto na rede coletora. Nada se questiona quanto a melhoria na qualidade de vida dos residentes na área de abrangência do Complexo Ponte Grande caso a obra tivesse sido concluída. No entanto a realidade é diversa, estando as obras inacabadas e sem previsão de fim.

Conclui-se que a projeção da referida obra é vultuosa, tendo essa que se adequar a realidade local, sendo reduzida e, mesmo assim, não conseguirá cumprir com o que fora acordado, devendo o Poder Público Municipal, na negativa de prorrogação ministerial, arcar com os custos para continuação das obras até a conclusão dessas, não deixando à mercê a população que a oito anos aguarda por melhoria em sua comunidade.

\section{REFERÊNCIAS}

BARBOSA, L. G. C. C. A tutela do Direito à moradia como forma de promover a dignidade da pessoa humana em face do Direito ambiental brasileiro. Revista Brasileira de Direito Ambiental, São Paulo: Editora Fiuza, v. 32, 2012.

BITAR, O. Y. Cartas de suscetibilidade a movimentos gravitacionais de massa e inundações 1:25.000: nota técnica explicativa. São Paulo: IPT, 2017. 124p.

BRASIL. Constituição de 1988. Constituição da República Federativa do Brasil de 1988. Diário Oficial [da] União, de 05 de outubro de 1988, Seção 1. 
BRASIL. Lei n ${ }^{\circ} 12.651$, de 25 de maio de 2012. Institui o novo Código Florestal Brasileiro. Diário Oficial [da] República Federativa do Brasil, Brasília, DF, 24 mai. 2012.

BRASIL. Estatuto da Cidade: Lei 10.257/2001 que estabelece diretrizes gerais de política urbana. Brasília: Câmara dos Deputados, 2001.

CARLOS, A.F.A. A Cidade. 8. ed. Contexto, São Paulo. 2009.

CONFEDERAÇÃO NACIONAL DA INDÚSTRIA. Grandes Obras Paradas: como enfrentar o problema? Confederação Nacional da Indústria. Brasília: CNI, 2018.

Centro Nacional de Monitoramento e Alertas de Desastres Naturais - CEMADEN. Inundação. 2016. Disponível em: <http://www.cemaden.gov.br/inundacao>.

CIDADE, L. C. F. Urbanização, ambiente, risco e vulnerabilidade: em busca de uma construção interdisciplinar. Cadernos Metrópole, v. 15, n. 29, p. 171-191, 2013.

Coordenadoria Municipal de Proteção e Defesa Civil de Lages. Relatório de inundação 2017. Lages SC, 2017.

Coordenadoria Municipal de Proteção e Defesa Civil de Lages. Relatório limpeza e desassoreamento rio Ponte Grande. Lages - SC, 2019

COSTA, L. O continente das lagens: sua história e influência no sertão da terra firme. Florianópolis: Fundação Catarinense de Cultura, 1982. 4v. p. 729.

FERREIRA, M. P.; GARCIA, M. S. D. Saneamento básico: meio ambiente e dignidade humana. Dignidade Re-Vista, v. 2, n. 3, july 2017.

GOMES, M. L et al Mapeamento da cobertura vegetal do município de Currais Novos-RN, BRASIL. v. 21, n. 2, p. 293-302, 30 set. 2019.

GONDIM, L. M. P. Meio ambiente urbano e questão social: habitação popular em áreas de preservação ambiental. Caderno CRH, Salvador, v. 25, n. 64, 2012.

KAUFFMANN, M. O.; DA SILVA, L. P. Taxa de impermeabilização do solo: um recurso para a implementação da bacia hidrográfica como unidade de planejamento urbano integrado à gestão dos recursos hídricos. Anais: Encontros Nacionais da ANPUR, v. 11, 2013.

INSTITUTO BRASILEIRO DE GEOGRAFIA E ESTATÍSTICA - IBGE. Base de informações do Censo Demográfico 2010: Resultados do Universo por setor censitário. 2011.

INSTITUTO BRASILEIRO DE GEOGRAFIA E ESTATÍSTICA - IBGE. IBGE Cidades -Lages SC, 2018.

IPUF. Instituto de Planejamento Urbano de Florianópolis. Disponível em:<http.www.ipuf.sc.gov.br> Acesso em: 10 abr.2019.

LAGES. Lei $n^{\circ}$ 1362/1988: Estabelece diretrizes, normas e critérios para o uso e ocupação do solo urbano no município. Lages, 1988. 
LAGES, P. D. D. T. Lei n 306/ 2007: Institui o Plano Diretor de Desenvolvimento Territorial de

Lages. LAGES, P. D. D. T., 2007.

LAGES, P. D. D. T. Lei $n^{\circ}$ 523/ 2018: Institui o Plano Diretor de Desenvolvimento Territorial de

Lages. LAGES, P. D. D. T., 2018.

LAGES. Portal Transparência Municipal. 2012, 2013, 2014, 2015, 2016, 2017, 2018 e 2019.

Disponível em: <http://www.lages.sc.gov.br>.

LEOPOLD, L. B.; WOLMAN, M. G.; MILLER, J. P. Fluvial processes in geomorphology. San Francisco: Freedman, 1964. p. 319.

LOPES, A. R. S et al. Uma análise histórica e ambiental do desplacamento da "pedra" do Morro da Mariquinha-Florianópolis (SC). Revista Latino-Americana de História. v. 2, n. 8, p. 115-125, 2013.

LUIZ, R. G. S. Análise de desempenho da obra de saneamento básico e seus impactos locais na região metropolitana de São Paulo - terceira etapa do projeto Tietê. 64 p. Monografia (PósGraduação em Economia e Meio Ambiente). Universidade Federal do Paraná, Curitiba, 2014.

MACHADO, P. P. Lideranças do Contestado. Campinas, SP: Editora da Unicamp, 2004. p. 60.

MARANDOLA JR., E.; HOGAN, D. J. Vulnerabilidade do lugar vs. vulnerabilidade sociodemográfica: implicações metodológicas de uma velha questão. Revista Brasileira de Estudos de População. v. 26, n. 2, p. 161-181, 2009.

MATOS, R.; BRAGA, F. Urbanização no Brasil contemporâneo, população e a rede de localidades centrais em evolução. Anais: Encontros Nacionais da ANPUR, v. 11, 2013.

MATTIA, R. Q.; SANTIN. J. R. Direito urbanístico e estatuto das cidades, Revista dos tribunais, 2014.

MAZZOLLI, M.; EHRHARDT-BROCARDO, N. C. M. Ocupação irregular em áreas de recarga do Aquífero Guarani e vegetação ripária em Lages-SC. Geosul, v. 28, n. 55, p. 164-180, 2013.

MESQUITA, F. N. M.; SILVESTRE, K. S.; STEINKE, V.A. Urbanização e degradação ambiental: Análise da ocupação irregular em áreas de proteção permanente na região administrativa de Vicente Pires, DF, utilizando imagens aéreas do ano de 2016. Revista Brasileira de Geografia Física, v. 10, n.03, 2017.

MINISTÉRIO DAS CIDADES. Relatório de Obras Paralisadas do FGTS. 2017.

OLIVEIRA, F. L. Elaboração e aprovação de planos diretores brasileiros no século XXI. Anais:

Encontros Nacionais da ANPUR, v. 15, 2013.

OLIVEIRA, J. C. de. Caracterização ambiental da bacia hidrográfica do Rio Ponte Grande no município de Lages-SC. Dissertação (mestrado) - Universidade do Estado de Santa Catarina, Centro de Ciências Agroveterinárias, Programa de Pós-Graduação em Produção Vegetal, Lages, 2015.

ONU. Resolução da Assembleia Geral da ONU. Resolução A/RES/64/292. 2010. 
PAIANO, D. B. A proteção constitucional do meio ambiente: uma perspectiva do desenvolvimento econômico. Saarbrucken: Novas Edições Acadêmicas, 2014.

PIMENTEL, L. B.; CAPANEMA, L. X. L. Água e esgoto. In: PUGA, Fernando Pimentel; CASTRO, Lavínia Barros de (Org.). Visão 2035: Brasil, país desenvolvido: agendas setoriais para alcance da meta. 1. ed. Rio de Janeiro: Banco Nacional de Desenvolvimento Econômico e Social, 2018.

PINTO, V. C. Ocupação irregular do solo e infra-estrutura urbana: o caso da energia elétrica. 2007.

RIBEIRO, R. A Lenta Evolução da Gestão de Obras Públicas no Brasil. E-legis. n. 8. p: 82-103, 2012.

RIBEIRO, B. M. G.; MENDES, C. A. B. Índice de Qualidade Ambiental Urbano: uma proposta metodológica aplicada a áreas urbanas de ocupação irregular, 2012.

SILVA, G. D. V. Avaliação de uma ocupação irregular em fase de regularização fundiária em Curitiba, utilizando indicadores da qualidade ambiental urbana-IQAU. 2013.

SOARES, I. A.; SILVA, W. G.; OLIVEIRA, J. E. L. Planejamento, gestão e sustentabilidade da Área de Proteção Ambiental de Jenipabu, Rio Grande do Norte, Brasil. Geosul, Florianópolis, v. 34, n. 73, p. 193-216, dez. 2019.

SUERTEGARAY, D. M. A. Ambiente e Lugar no Urbano. A Grande Porto Alegre. Porto Alegre: Ed. Universidade/UFRGS, 2000. 61p.

TOMÉ, L. M. Infraestrututra de saneamento na região nordeste: situação atual e perspectivas. Banco do Nordeste, n. 10, 2017.

TORRES, F.T.P.; MACHADO, P.J.O. Introdução à Hidrogeografia. Cengaga Learning, São Paulo. 2012.

VASCONCELLOS, L. F. R.; TUROLLA, F. A. Saneamento em obras: os entraves para a expansão. Conjuntura da Construção. 2016.

VIEIRA, V.T., CUNHA, S.B., 2010. Mudanças na rede de drenagem urbana de Teresópolis (Rio de Janeiro), in: Vieira, V.T., Cunha, S.B., Guerra, A.J.T. (Org.), Impactos Ambientais Urbanos no Brasil. 6. ed. Bertrand Brasil, Rio de Janeiro, p. 111-142.

VIEIRA, E. G.; JUNIOR, O. C. R. A regularização fundiária urbana de interesse social em áreas de preservação permanente à luz do direito fundamental ao meio ambiente ecologicamente equilibrado no Brasil. Revista Síntese Direito Imobiliário, v.6, n.37, 2017. 


\section{CONSEQUÊNCIAS AMBIENTAIS DA APLICAÇÃO DO DECRETO ESTADUAL N ${ }^{\circ} 42.356 / 2010$ NA DELIMITAÇÃO DE FAIXA MARGINAL DE PROTEÇÃO EM ÁREA URBANA CONSOLIDADA. ESTUDO DE CASO: RIO PIABANHA/RJ - TRECHO 4}

Data de aceite: 04/01/2021

\section{Jorge Chaves Junior}

Discente do Mestrado Profissional em Engenharia Urbana e Ambiental - PUC-Rio

Rio de Janeiro/RJ

http://lattes.cnpq.br/9256170556403928

\section{Ana Cristina Malheiros Gonçalves Carvalho}

Docente do Mestrado Profissional em

Engenharia Urbana e Ambiental - PUC-Rio

Rio de Janeiro/RJ

http://lattes.cnpq.br/8239160174236523

\section{Rafaela dos Santos Facchetti Vinhaes Assumpção}

Analista de Gestão em Saúde - Escola Nacional de Saúde Pública Sergio Arouca FIOCRUZ/RJ

Rio de Janeiro/RJ http://lattes.cnpq.br/8458350924239277

RESUMO: No Brasil, o Rio de Janeiro é o único Estado com atribuição legal para demarcação de faixas marginais de proteção, amparado pelo Decreto Estadual n. ${ }^{\circ}$ 42.356/10 que para áreas urbanas consolidadas permite aplicar limites inferiores ao do Código Florestal Brasileiro. As alterações das margens do rio Piabanha são relevantes, devido à sua importância para melhoria da qualidade das águas do rio Paraíba do Sul que abastece $80 \%$ do Estado do Rio de Janeiro. Por meio do sensoriamento remoto via satélites, foi possível identificar que, entre o ano de 2006 e de 2019, o desmatamento foi crescente nas áreas que deixaram de integrar as faixas marginais de proteção do rio Piabanha/ RJ. Pode-se concluir que a revisão do Decreto Estadual n. ${ }^{\circ} 42.356 / 10$ é necessária, o qual não deveria ter sido editado sem previsão de aplicação de instrumentos urbanísticos que considerasse a regeneração e a recuperação das áreas das margens dos corpos hídricos e sem que houvesse um planejamento urbano com alternativas locacionais voltadas às questões das ocupações irregulares e ocupações futuras.

PALAVRAS-CHAVE: Rio Piabanha; Decreto 42.356/2010.

\section{ENVIRONMENTAL CONSEQUENCES OF THE APPLICATION OF STATE DECREE 42,356/2010 IN THE DELIMITATION OF THE PROTECTION MARGINAL STRIP IN A CONSOLIDATED URBAN AREA. CASE STUDY: PIABANHA/RJ RIVER - SECTION 4}

ABSTRACT: In Brazil, Rio de Janeiro is the only state with legal attribution for the demarcation of protection marginal strips, supported by State Decree 42.356/10 which allows for lower limits to be applied to consolidated urban areas than the Brazilian Forest Code. The changes in the banks of the Piabanha River are relevant, due to their importance for improving the quality of the waters of the Paraíba do Sul River, which supplies $80 \%$ of the State of Rio de Janeiro. Through remote sensing via satellites, it was possible to identify that, between 2006 and 2019, deforestation was increasing in areas that ceased to integrate the protection marginal strips of the Piabanha/RJ river. It can be concluded that the revision of State Decree $42.356 / 10$ is necessary, which should not have been edited without the application of urban 
planning instruments that would consider the regeneration and recovery of the areas along the banks of water bodies and without there was an urban planning with locational alternatives focused on the issues of future and irregular occupations.

KEYWORDS: Piabanha River; Decree 42,356/2010.

\section{I INTRODUÇÃO}

As áreas às margens dos corpos hídricos, em função de suas características hidrológicas, geológicas e ecológicas, necessitam estar legalmente e adequadamente demarcadas para serem monitoradas e protegidas das ações do homem. Nesse contexto, as faixas marginais de proteção (FMPs) são de grande importância e discussões a respeito de normativas que visem à proteção das matas ciliares em áreas urbanas tornamse relevantes, pois muitas cidades surgem e crescem ao longo dos cursos d'água sem observar os regramentos de uso e ocupação do solo.

No Estado do Rio de Janeiro, o Instituto Estadual do Ambiente (INEA) utiliza para demarcação das FMPs dos corpos hídricos critérios de dimensões mínimas estabelecidos pelo Decreto Estadual n. ${ }^{\circ} 42.356 / 2010$ que admite, para as áreas urbanas consolidadas, larguras de FMPs menores que aquelas estabelecidas pela Lei Federal n. ${ }^{\circ}$ 4.771/1965, vigente a época da edição do Decreto Estadual, como também menores que aquelas estabelecidas pela atual Lei Federal n. ${ }^{\circ}$ 12.651/2012, também conhecida como Novo Código Florestal Brasileiro.

O rio Piabanha é afluente do principal manancial do Estado do Rio de Janeiro, o rio Paraíba do Sul. Com sua nascente em Petrópolis/RJ, possui grande parte da sua extensão na Região Serrana do Estado, onde são frequentes os eventos de inundação, tendo sua foz em Três Rios/RJ. Por isso, a identificação de remoção de proteção natural por desmatamento e por ocupações antrópicas nas áreas que deixaram de integrar as FMPs, devido a edição do Decreto Estadual n. ${ }^{\circ} 42.356 / 2010$, são importantes para discutir a pertinência deste normativo estadual.

Para o desenvolvimento do trabalho, foi realizada revisão da bibliografia e da legislação sobre o tema e, posteriormente, mediante uma pesquisa aplicada e exploratória foram identificadas alterações na cobertura do solo nas áreas que deixaram de integrar as FMPs do Trecho 4 do rio Piabanha/RJ devido a aplicação do Decreto Estadual n. ${ }^{\circ}$ 42.356/2010 naquele trecho. Sendo assim, em primeiro momento executou-se uma análise quantitativa de dados coletados de imagens capturadas via satélites orbitais e, por conseguinte, de forma mais subjetiva, foi feita uma análise qualitativa desses dados a respeito das consequências ambientais da promulgação do Decreto Estadual para a cobertura do solo daquelas áreas e avaliando a necessidade de sua revisão com inclusão de instrumentos legais urbanísticos que considerarem a regeneração e a recuperação das áreas das margens dos corpos hídricos. 


\section{I REVISÃO BIBLIOGRÁFICA}

\subsection{Faixas Marginais de Proteção e o Decreto Estadual $N^{\circ}$ 42.356/2010}

A vegetação das margens fluviais, denominada 'mata ciliar', proporciona efeitos positivos para a qualidade da água, a mitigação de enchentes, a preservação da biodiversidade e outros fatores que apontam para a necessidade de proteção das áreas ribeirinhas. Devido a sua relevância, a legislação brasileira classificou as margens dos cursos d'água como Áreas de Preservação Permanente (APPs) atribuindo-Ihes a destinação florestal, sendo assim, essas áreas são consideradas como não edificantes e deverão estar livres de ocupações. A Constituição Estadual do Rio de Janeiro, Art. 268, caput, inciso III, equipara as FMPs às APPs.

Entretanto, essa equiparação gerou impasse na demarcação de FMPs em áreas cujas características naturais já não mais existisse e, no ano de 2007, a Procuradoria Jurídica da então FEEMA/RJ, agora extinta, emitiu o Parecer RD n. ${ }^{\circ}$ 04/2007 que versava, entre outros temas, sobre as APPs que apresentassem perda de sua função ecológica, admitindo que, em casos excepcionais, as FMPs poderiam ter limite mínimo de 10 ou 15 metros, desde que atendessem os seguintes requisitos: a) longa e consolidada ocupação urbana; b) a perda da função ecológica da área de preservação permanente a ser desconsiderada, ou seja, a ausência do cumprimento das funções descritas no art. 1 $1^{\circ}$, II, do Código Florestal, tais como: a preservação dos recursos hídricos, da paisagem, da estabilidade geológica, da biodiversidade, do fluxo gênico da fauna e flora, da proteção do solo, e do bem-estar das populações humanas; c) a recuperação da área como um todo seja inviável sem custos manifestamente excessivos (custos não necessariamente financeiros).

O Parecer RD n. ${ }^{\circ}$ 04/2007 foi o embrião do Decreto n. ${ }^{\circ} 42.356 / 2010$ ao admitir que nos processos de licenciamento e de emissão de autorizações ambientais nas áreas de zona urbana de municípios, com limitações incidentes sobre as margens dos corpos hídricos, em caso concreto, pudessem reduzir os limites mínimos fixados abstratamente pelo Código Florestal. Assim, em 16 de março de 2010, foi editado o Decreto Estadual $n^{\circ} 42.356$ que trata de forma unificada as FMPs e as APPs, prevendo que no Estado do Rio de Janeiro os limites do Código Florestal pudessem ser excepcionalizados diante das seguintes características: 1) área antropizada; 2) longa e consolidada ocupação urbana; 3) inexistência de função ecológica; e 4) inviabilidade econômica de recuperação.

Segundo Carvalho (2019), o Rio de Janeiro é o único Estado do Brasil com atribuição para demarcação de FMPs e, pelo Decreto Estadual n 42.356/2010, permite redução das suas larguras para 15 metros em áreas urbanas consolidadas, enquanto que pelo Código Florestal possuiriam 50 metros, no mínimo. De Moraes (2012) adverte que essa redução de larguras pela simples atestação dos pré-requisitos por 03 (três) servidores do INEA revestiu a demarcação de FMPs de subjetivismo e tornou-a carente de parâmetros técnicos e impessoais que fundamentasse os respectivos atestados. 
Coelho Junior (2010), Procurador da República no Município de São GonçaloRJ, reconheceu a possiblidade de afastamento da aplicação do Código Florestal em casos concretos, entretanto, concluiu pela inconstitucionalidade do Decreto Estadual $n .^{\circ}$ 42.356/2010, pois, segundo o Excelentíssimo Sr. Procurador que também é Especialista em Direito Ambiental pela PUC-Rio e Mestre em Direito Constitucional pela Universidade de Sevilha - Espanha, somente lei federal poderia estabelecer normas com este conteúdo. A AGU (2007) também já se pronunciou sobre o tema e, para aquela Advocacia Geral da União, nas áreas onde a ocupação urbana é consolidada, deve ser ponderado, de forma razoável, qual a melhor solução para o meio ambiente e para os cidadãos.

Logo, apesar de toda a controvérsia que envolve o Decreto Estadual n. ${ }^{\circ}$ 42.356/2010, ele segue como base legal para demarcação de FMPs no Rio de Janeiro, tendo completado 10 anos de vigência em 16 de março de 2020.

\subsection{A Bacia Hidrográfica do Rio Piabanha}

A Bacia Hidrográfica do Rio Piabanha é composta por áreas dispostas em 7 municípios fluminenses - Areal, Petrópolis, Teresópolis e São José do Vale do Rio Preto, Paty do Alferes, Paraíba do Sul e Três Rios, população estimada em 674.258 habitantes no ano de 2019, segundo IBGE (2020). O principal curso d'água é o rio Piabanha, com aproximadamente $80 \mathrm{~km}$ de extensão. Segundo a COPPETEC (2013), a Bacia Hidrográfica do Rio Piabanha apresenta a maior cobertura florestal dentre as grandes sub-bacias afluentes do rio Paraíba do Sul com cerca de $20 \%$ de Mata Atlântica.

Tendo em vista a sua relevância para a qualidade das águas do rio Paraíba do Sul, oxigenando e contribuindo para aumento de sua vazão deste manancial que abastece $80 \%$ do Estado do Rio de Janeiro, é importante que sejam identificadas as alterações das margens do rio Piabanha ocorridas após a edição do Decreto Estadual n. ${ }^{\circ}$ 42.356/2010, gerando informações que permitem embasar possíveis estudos e discussões sobre a pertinência ambiental do referido normativo estadual.

\subsection{Sensoriamento Remoto}

A busca por alternativas para transpor as limitações técnicas e econômicas dos métodos tradicionais tem encontrado importante apoio na evolução e acessibilidade das geotecnologias.

De acordo com INPE (2019), dentre as tecnologias do geoprocessamento, é crescente a utilização do sensoriamento remoto nas áreas de: controle e proteção da biodiversidade; degradação de florestas; urbanização; poluição; uso e qualidade da água; entre outras.

Segundo CARVALHO e LEITE (2009), sensoriamento remoto é uma técnica que obtém informações sobre uma área ou um objeto através de instrumentos que não estejam em contato físico com o objeto ou a área em questão.

No sensoriamento remoto a obtenção de informações se dá pela captação da 
energia eletromagnética refletida ou emitida por um alvo na superfície da Terra, por meio de levantamentos fotográficos aéreos ou por imagens capturadas via satélites orbitais.

\section{I MATERIAIS E MÉTODOS APLICADOS}

\subsection{A Demarcação da FMP do Rio Piabanha}

No Estado do Rio de Janeiro as Faixas Marginais de Proteção dos corpos hídricos são demarcadas pelo Instituto Estadual do Ambiente (INEA). Sendo assim, no Processo Administrativo E-07/00.07317/2017 consta demarcação das FMPs do rio Piabanha, desde sua nascente no município de Petrópolis, abrangendo áreas urbanas e rurais, até a sua foz no município Três Rios, dividindo o rio Piabanha em 05 (cinco) trechos ao considerar a 'aplicação' ou a 'não-aplicação' do Decreto Estadual n. ${ }^{\circ} 42.356 / 2010$, conforme as características do seu entorno imediato, sendo elas: o grau de ocupação e a antropização observados nas suas margens, conforme discriminado a seguir na Tabela 1:

\begin{tabular}{|c|c|c|c|c|}
\hline \multicolumn{5}{|c|}{ Trecho 1 - Não Aplica o D.E. 42.356/2010 } \\
\hline Seção & Início & Término & Largura (m) & Geometria \\
\hline Nascente - 1 & Cabeceiras & $\begin{array}{c}22^{\circ} 28^{\prime} 57.566^{\prime \prime} \mathrm{S} / \\
43^{\circ} 12^{\prime} 33.84^{\prime \prime} \mathrm{O}\end{array}$ & 2.4 & Natural \\
\hline $1.1-1.2$ & $\begin{array}{c}22^{\circ} 28^{\prime} 57.566^{\prime \prime} \mathrm{S} / \\
43^{\circ} 12^{\prime} 33.84^{\prime \prime} \mathrm{O}\end{array}$ & $\begin{array}{c}22^{\circ} 29^{\prime} 37.366^{\prime \prime} \mathrm{S} / \\
43^{\circ} 13^{\prime} 15.10^{\prime \prime} \mathrm{O} \\
\end{array}$ & 7.0 & Trapezoidal \\
\hline \multicolumn{5}{|c|}{ Trecho 2 - Aplica o D.E. 42.356/2010 } \\
\hline Seção & Início & Término & Largura (m) & Geometria \\
\hline \multirow{2}{*}{$2.1-2.2$} & $\begin{array}{l}22^{\circ} 29^{\prime} 37.36 \text { "S / } \\
43^{\circ} 13^{\prime} 15.10^{\prime \prime} \mathrm{C} \\
\end{array}$ & $\begin{array}{l}22^{\circ} 30^{\prime} 13.71 \text { "S / } \\
43^{\circ} 10^{\prime} 55.94^{\prime \prime} \mathrm{O}\end{array}$ & 12 & Trapezoidal \\
\hline & $\begin{array}{c}22^{\circ} 30 \text { '39.17"S / } \\
43^{\circ} 12^{\prime} 44.69 " \mathrm{O}\end{array}$ & $\begin{array}{c}22^{\circ} 30^{\prime} 13.71 " \mathrm{~s} / \\
43^{\circ} 10^{\prime} 55.94^{\prime \prime O}\end{array}$ & $\begin{array}{l}\text { Margens como } \\
\text { referência }\end{array}$ & $\begin{array}{l}\text { Retangular } \\
\text { (Canalizado) }\end{array}$ \\
\hline \multirow{2}{*}{$2.2-2.3$} & $\begin{array}{l}22^{\circ} 30^{\prime} 13.71 \text { "S / } \\
43^{\circ} 10^{\prime} 55.94^{\prime \prime} \mathrm{O} \\
\end{array}$ & $\begin{array}{c}22^{\circ} 28^{\prime} 30.88^{\prime \prime} \mathrm{S} / \\
43^{\circ} 09^{\prime} 13.26^{\prime \prime} \mathrm{O}\end{array}$ & 23 & Natural \\
\hline & $\begin{array}{c}22^{\circ} 28^{\prime} 29.56^{\prime \prime} \mathrm{S} / \\
43^{\circ} 09^{\prime} 48.46^{\prime \prime} \mathrm{O}\end{array}$ & $\begin{array}{c}22^{\circ} 28^{\prime} 30.88^{\prime \prime} \mathrm{S} / \\
43^{\circ} 09^{\prime} 13.26^{\prime \prime} \mathrm{O}\end{array}$ & $\begin{array}{l}\text { Margens como } \\
\text { referência }\end{array}$ & $\begin{array}{c}\text { Natural (Seção } \\
\text { variável) }\end{array}$ \\
\hline $2.3-2.4$ & $\begin{array}{c}22^{\circ} 28^{\prime} 30.88^{\prime \prime} \mathrm{S} / \\
43^{\circ} 09^{\prime} 13.26^{\prime \prime} \mathrm{O}\end{array}$ & $\begin{array}{c}22^{\circ} 24^{\prime} 55.59^{\prime \prime} \mathrm{S} / \\
43^{\circ} 08^{\prime} 19.75^{\prime \prime O}\end{array}$ & 28 & Natural \\
\hline $2.4-2.5$ & $\begin{array}{c}22^{\circ} 24^{\prime} 55.59^{\prime \prime} \mathrm{S} / \\
43^{\circ} 08^{\prime} 19.75^{\prime \prime} \mathrm{O}\end{array}$ & $\begin{array}{c}22^{\circ} 23^{\prime} 09.79^{\prime \prime} \mathrm{S} / \\
43^{\circ} 08^{\prime} 04.43^{\prime \prime O}\end{array}$ & 29 & Natural \\
\hline $2.5-2.6$ & $\begin{array}{c}22^{\circ} 23^{\prime} 09.79 \text { "S / } \\
43^{\circ} 08^{\prime} 04.43^{\prime \prime O}\end{array}$ & $\begin{array}{c}22^{\circ} 19^{\prime} 51.61 " \mathrm{~S} / \\
43^{\circ} 07^{\prime} 54.75^{\prime \prime O}\end{array}$ & 31 & Natural \\
\hline \multicolumn{5}{|c|}{ Trecho 3 - Não Aplica o D.E. 42.356/2010 } \\
\hline Seção & Início & Término & Largura (m) & Geometria \\
\hline \multirow{2}{*}{ Todo Trecho } & $\begin{array}{l}22^{\circ} 19^{\prime} 51.61 " \mathrm{~s} / \\
43^{\circ} 07^{\prime} 54.75^{\prime \prime} \mathrm{O}\end{array}$ & $\begin{array}{l}22^{\circ} 16^{\prime} 20.21^{\prime \prime S} / \\
43^{\circ} 05^{\prime} 12.68^{\prime \prime O}\end{array}$ & 33 & Natural \\
\hline & $\begin{array}{l}22^{\circ} 17^{\prime} 19.95^{\prime \prime} \mathrm{S} / \\
43^{\circ} 07^{\prime} 22.86^{\prime \prime O}\end{array}$ & $\begin{array}{l}22^{\circ} 16^{\prime} 20.21^{\prime \prime} \mathrm{S} / \\
43^{\circ} 05^{\prime} 12.68^{\prime \prime} \mathrm{O}\end{array}$ & $\begin{array}{l}\text { Margens como } \\
\text { referência }\end{array}$ & Natural \\
\hline
\end{tabular}


Trecho 4 - Aplica o D.E. 42.356/2010

\begin{tabular}{|c|c|c|c|c|}
\hline Seção & Início & Término & Largura (m) & Geometria \\
\hline Todo Trecho & $\begin{array}{l}22^{\circ} 16^{\prime} 20.21^{\prime \prime S} / \\
43^{\circ} 05^{\prime} 12.68^{\prime \prime O}\end{array}$ & $\begin{array}{c}22^{\circ} 13^{\prime} 58.41^{\prime \prime S} / \\
43^{\circ} 06^{\prime} 21.89^{\prime \prime} \mathrm{O}\end{array}$ & $\begin{array}{l}\text { Margens como } \\
\text { referência }\left(L_{\text {min }}\right. \\
\quad-42)\end{array}$ & Natural \\
\hline \multicolumn{5}{|c|}{ Trecho 5 - Não Aplica o D.E. 42.356/2010 } \\
\hline Seção & Início & Término & Largura (m) & Geometria \\
\hline Todo Trecho & $\begin{array}{l}22^{\circ} 13^{\prime} 58.41^{\prime \prime} \mathrm{S} / \\
43^{\circ} 06^{\prime} 21.89^{\prime \prime} \mathrm{O}\end{array}$ & $\begin{array}{c}22^{\circ} 06^{\prime} 38.85^{\prime \prime} \mathrm{S} / \\
43^{\circ} 08^{\prime} 15.05^{\prime \prime} \mathrm{O}\end{array}$ & $\begin{array}{l}\text { Margens como } \\
\text { referência }\left(L_{\text {min }}\right. \\
\quad-59)\end{array}$ & Natural \\
\hline
\end{tabular}

Tabela 1 - Demarcação de FMP do Rio Piabanha

\subsection{Delimitação da Área de Estudo - Trecho 4 do Rio Piabanha}

O Trecho 4 do rio Piabanha possui cerca de 8,34 km de extensão e largura mínima de $42 \mathrm{~m}$, conforme Tabela 1. Para delimitação da área excluída da FMP devido a aplicação do Decreto Estadual n. ${ }^{\circ}$ 42.356/2010, considerou-se largura mínima prevista pelos parâmetros normativos estabelecidos pelo Código Florestal Brasileiro (50 metros) e posteriormente foi subtraída a largura demarcada pelo Decreto Estadual n. ${ }^{\circ} 42.356 / 2010$ (15 metros). Esse processo foi executado no programa Autocad, acrescentando 35 metros a partir do limite da largura da FMP demarcada no Processo Administrativo E-07/00.07317/2017 - Demarcação de FMP do rio Piabanha, resultando em 594.562,00 $\mathrm{m}^{2}$ área excluída da FMP do Trecho 4 do rio Piabanha, conforme ilustram as figuras a seguir: 


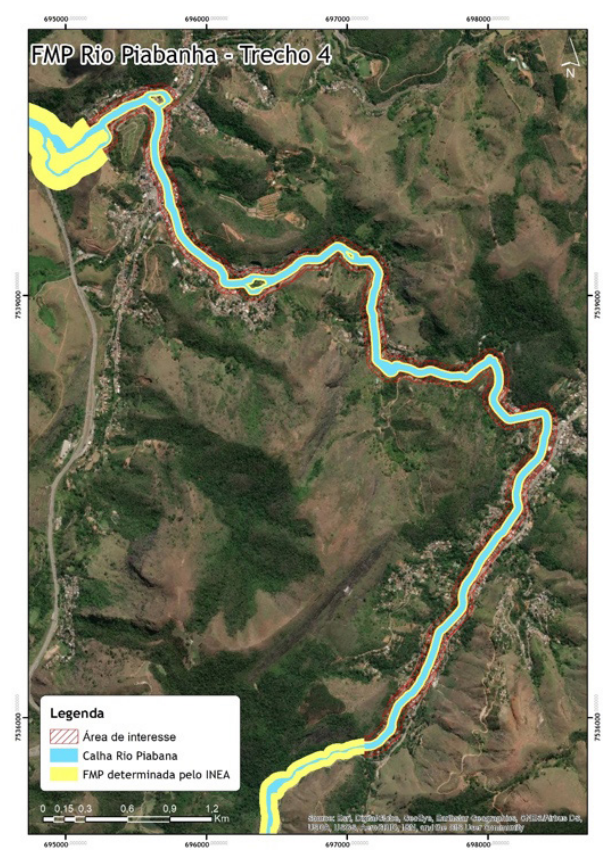

Figura 1 - Área Excluída da FMP Trecho 4 - Rio Piabanha

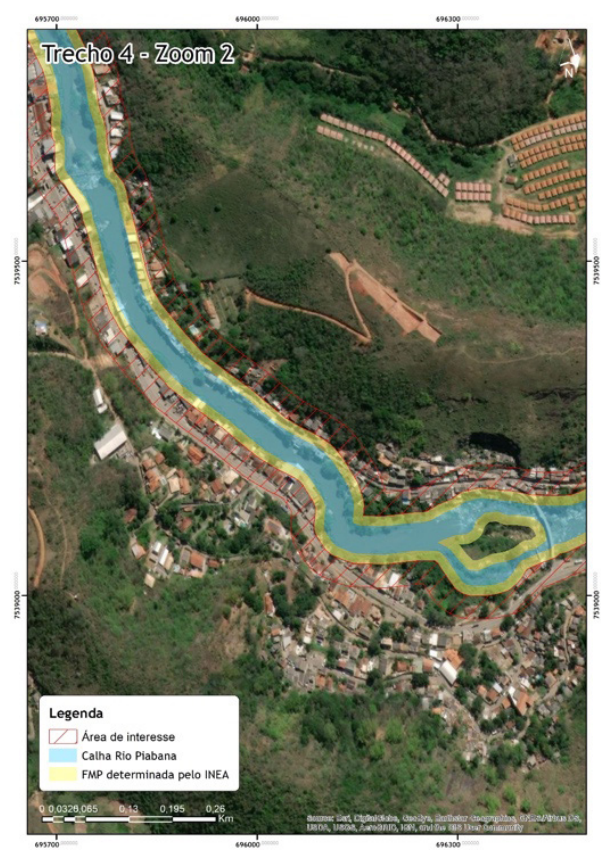

Figura 2 - Área Excluída da FMP Detalhe

\subsection{Obtenção das Imagens}

Para gerar as informações do uso e cobertura do solo, visando identificar alterações ocorridas nas áreas que deixaram de integrar as Faixas Marginais de Proteção do Trecho 4 do rio Piabanha/RJ, após a edição do Decreto Estadual n. ${ }^{4} 42.356 / 2010$, buscou-se imagens de satélite que demonstrassem a realidade do território em momentos distintos, antes da edição do decreto e as mais recentes disponíveis. As imagens utilizadas foram fornecidas pela Secretaria Estadual do Ambiente e Sustentabilidade do Estado do Rio de Janeiro (SEAS/RJ), geradas no Projeto de Mapeamento da Cobertura da Terra e de Detecção de Mudanças na Cobertura Florestal do Estado do Rio de Janeiro.

\subsection{Tratamento e Agrupamento das Imagens}

As imagens recentes selecionadas datam de 17/11/2019. Já as imagens anteriores à edição do Decreto Estadual n. ${ }^{\circ}$ 42.356, de 16 de março de 2010, tendo em vista à interferência de nuvens na região, tal busca se apresentou mais difícil e trabalhosa, então, as imagens do ano de 2006 foram consideradas como mais adequadas. Posteriormente, por meio de mosaicos construídos no software ArcGis, foi feito comparativo entre as datas estudadas identificando alterações na cobertura do solo.

Foram observados 5 (cinco) tipos de alterações: (I) De Vegetação (2006) para Campo (2019); (II) De Vegetação (2006) para Construção (2019); (III) De Campo (2006) 
para Construção (2019); (IV) De Campo (2006) para Vegetação (2019); (V) De Construção (2006) para Vegetação (2019).

\subsection{Análise das Imagens}

Não foram identificadas alterações do uso e cobertura do solo na área objeto do estudo do tipo ' $D$ e Construção (2006) para Campo (2019)'. O gráfico a seguir ilustra os valores em $\left(\mathrm{m}^{2}\right)$ das alterações identificadas para o uso e cobertura do solo do ano de 2006 para o ano de 2019:

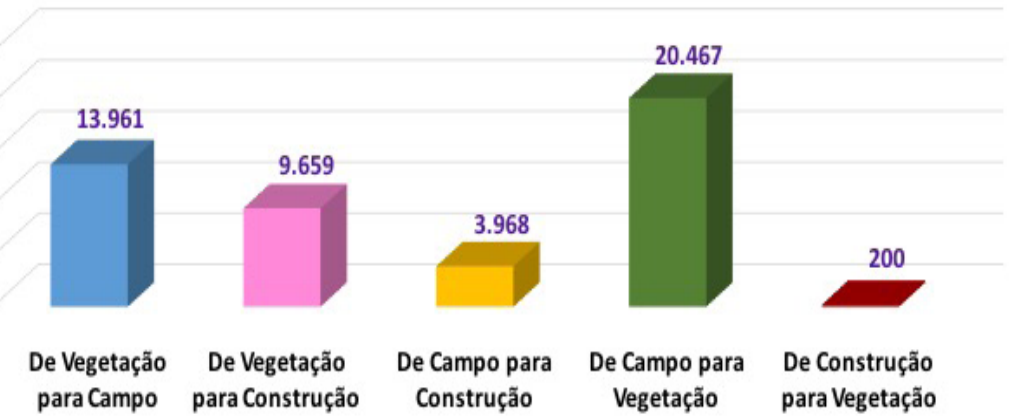

Figura 3 - Alterações Identificadas $\left(\mathrm{m}^{2}\right)$ - Trecho 4 do Rio Piabanha - 2006/2019

Comparando as alterações encontradas com a área total estudada estudo, foram identificados $20.467 \mathrm{~m}^{2}$ da alteração 'De Campo para Vegetação' (Figura 4), representando regeneração de 3,46\% na vegetação inserida na área excluída da FMP do Trecho 4 do rio Piabanha (Figura 1).

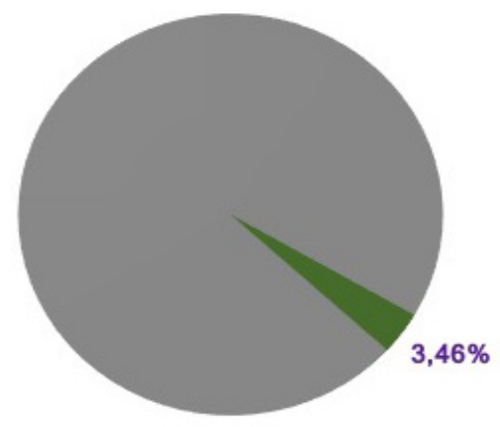

" De Campo para Vegetação \# Área do Estudo

Figura 4 - Cobertura do Solo - 2006/2019 - 'De Campo para Vegetação' 
Entretanto, foi identificado $13.961 \mathrm{~m}^{2}$ da alteração 'De Vegetação para Campo' (Figura 5) e $9.659 \mathrm{~m}^{2}$ da alteração 'De Vegetação para Construção' (Figura 6), representando, respectivamente, 2,36\% e 1,63\% de desmatamento na área excluída da FMP do Trecho 4 do rio Piabanha (Figura 1).

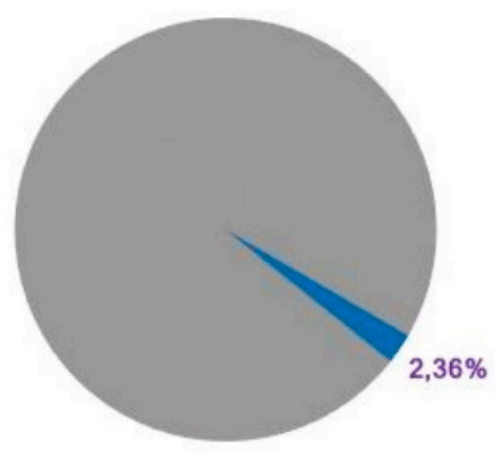

- De Vegetação para Campo \#́rea do Estudo

Figura 5 - Cobertura do Solo - 2006/2019 'De Vegetação para Campo'

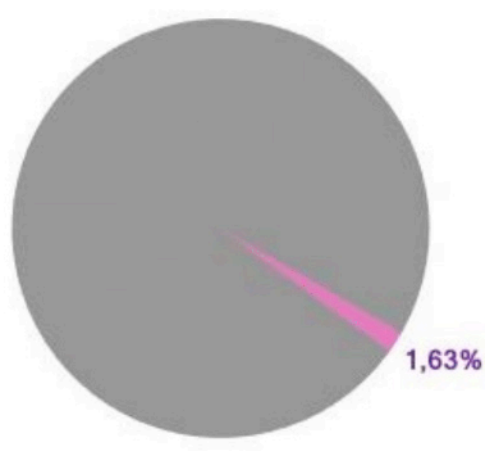

We Vegetação para Construção = Área do Estudo

Figura 6 - Cobertura do Solo - 2006/2019 'De Vegetação para Construção'

Considera-se como negativa a alteração de $3.968 \mathrm{~m}^{2}$ 'De Campo para Construção' (Figura 7) que representa $0,67 \%$ de áreas excluídas da FMP que poderiam ter recebido iniciativas de recuperação ou, simplesmente, terem sido protegidas e monitoradas para que houvesse regeneração natural da vegetação. Já a alteração do tipo 'De Construção para Vegetação', identificada com o total de $200 \mathrm{~m}^{2}$ (Figura 8), pode ser considerada como pouco relevante, por representar apenas 0,03\%.

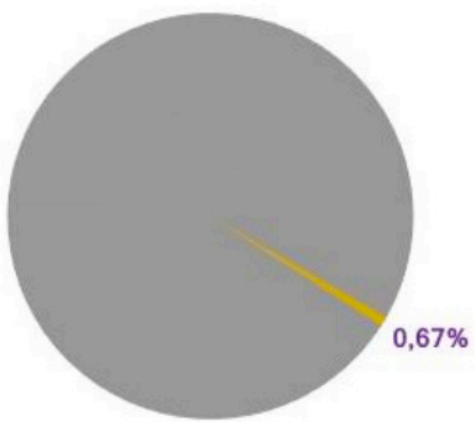

De Campo para Construção = Área do Estudo

Figura 7 - Cobertura do Solo - 2006/2019 'De Campo para Construção'

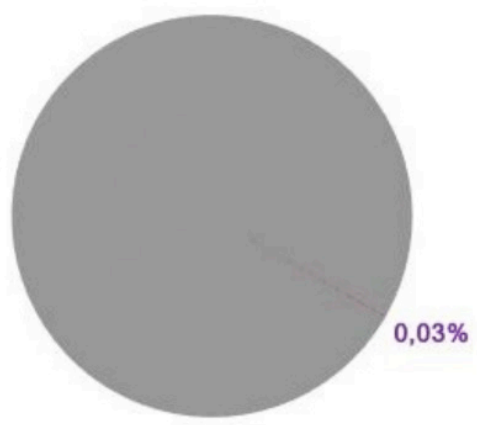

ne Construção para Vegetação \# Área do Estudo

Figura 8 - Cobertura do Solo - 2006/2019 'De Construção para Vegetação' 


\section{I CONCLUSÃO}

As FMPs são áreas protegidas, ainda que não estejam cobertas por vegetação, mesmo quando inseridas em áreas urbanas consolidadas, logo, deveriam ter como primeira alternativa a sua desocupação para proteger os corpos hídricos, ou ao menos que cada caso fosse analisado individualmente, mediante critérios técnicos rigorosamente definidos e mensuráveis, para que somente aquelas que não mais gozassem de sua função ecológica e sem possibilidade de recuperação, ou que não estejam em áreas de risco de inundação, fossem então submetidas à regulação fundiária, contudo, ressalvando a proibição de expansão da ocupações horizontais e verticais.

Entretanto, pelas alterações identificadas na cobertura do solo nas áreas excluídas das FMPs do Trecho 4 do rio Piabanha, nota-se que o desmatamento na região foi crescente, pois foram identificados $27.588 \mathrm{~m}^{2}$ de área degradada ou que poderia ter sido recuperada contrapondo com $20.667 \mathrm{~m}^{2}$ de área regenerada, ou seja, no período analisado, de ano de 2006 a 2019, para cada $1 \mathrm{~m}^{2}$ de área regenerada há cerca de 1,35 $\mathrm{m}^{2}$ de área degradada ou que poderia ter sido recuperada.

Assim, infere-se que o Decreto Estadual n. ${ }^{\circ} 42.356 / 2010$ traduz o reconhecimento da ineficiência dos entes públicos e seus órgãos de fiscalização, ao reduzir os limites das larguras das faixas marginais de proteção em áreas urbanas consolidadas, no caso do Trecho 4 do rio Piabanha de 50 para 15 metros em cada margem do rio, tendo sido desconsideradas questões sobre ilícitos de ocupações em área de preservação permanente, como também proibição de novas intervenções, o que, novamente, vai de encontro ao que seria correto e desejável.

Ora, ao promulgar o Decreto Estadual n. ${ }^{\circ} 42.356 / 2010$ foi relevado todo passado de transgressão ao Código Florestal de 1965, então vigente à época, sem que houvesse qualquer tipo de garantia que no decorrer dos anos outras anistias não seriam ofertadas aos degradadores.

A preservação das FMPs é imperiosa e clama pela revogação ou revisão do decreto, tendo em vista que o normativo implica em graves danos ambientais. Logo, os dispositivos estaduais deverão prever aplicação de instrumentos legais urbanísticos que considerarem a regeneração e a recuperação das áreas das margens dos corpos hídricos, viabilizando estratégias de gestão integradas e inclusivas, pois, mesmo quando oriundas de processos democráticos, as normativas serão inanes se não contribuírem para um planejamento urbano com alternativas locacionais voltadas às questões das ocupações irregulares e ocupações futuras.

\section{REFERÊNCIAS}

1. AGU, 2007. Procuradoria Federal Especializada junto ao IBAMA. Processo Administrativo n. ${ }^{\circ}$

02022.000671/2006 - Aplicação do Art. $2^{\circ}$ do Código Florestal em Área Urbana, pág. 32. 
2. BRASIL, 1965. Lei $\mathbf{n} .^{\circ} \mathbf{4 . 7 7 1}$, de 15 de setembro de 1965. Institui o novo Código Florestal.

Disponível em: <http://www.planalto.gov.br/ccivil_03/leis/14771.htm>. Acesso em: 1 jul. 2020.

3. BRASIL, 2012. Lei $\mathbf{n}$. $^{\circ} \mathbf{1 2 . 6 5 1}$ de 25 de maio de 2012. Dispõe sobre a Proteção da Vegetação Nativa. Disponível em: <http://www.planalto.gov.br/ccivil_03/_ato2011-2014/2012/lei/l12651.htm>. Acesso em: 1 jul. 2020.

4. CARVALHO, Germana, 2019. Faixa Marginal de Proteção no Rio Piabanha - Petrópolis (RJ), Revisão da Legislação e Demarcação. Trabalho de Conclusão do Curso de Engenharia de Recursos Hídricos e do Meio Ambiente. Universidade Federal Fluminense - UFF. Niterói/RJ.

5. CARVALHO, Grazielle Anjos; LEITE, Débora Veridiana Brier; 2009. Geoprocessamento na Gestão Urbana Municipal - A Experiência dos Municípios Mineiros Sabará e Nova Lima. Anais do XIV Simpósio Brasileiro de Sensoriamento Remoto, Natal, Brasil, 25-30 abril 2009.

6. CHAVES JUNIOR, Jorge, 2020. Consequências ambientais da aplicação do Decreto Estadual n. ${ }^{\circ}$ 42.356/2010 na delimitação de Faixa Marginal de Proteção em Área Urbana Consolidada. Estudo de Caso: Rio Piabanha/RJ - Trecho 4. Dissertação de Mestrado. Programa de PósGraduação em Engenharia Urbana e Ambiental. Pontifícia Universidade Católica do Rio de Janeiro PUC-Rio. Rio de Janeiro/RJ.

7. COELHO JUNIOR, Lauro, 2010. Intervenções nas Áreas de Preservação Permanente em Zona Urbana: Uma Discussão Crítica Acerca das Possibilidades de Regularização. Revista Custos Legis, Revista Eletrônica do Ministério Público Federal. V ENCONTRO ASSOÇIAÇÃO NACIONAL DE PÓS GRADUAÇÃO E PESQUISA EM AMBIENTE E SOCIEDADE 4 a 7 de outubro de 2010 - UFSC. Florianópolis/SC.

8. COPPETEC, 2013. Plano de Recursos Hídricos da Bacia do Rio Paraíba do Sul. Caderno de Ações - Área do Piabanha. Laboratório de Hidrologia e Estudos de Meio Ambiente. Disponível em: $<$ http://www.ceivap.org.br/downloads/cadernos/PIABANHA.pdf>. Acesso: 15 jun. 2020.

9. DE MORAES, Tatiana Vieira, 2012. Ocupação Urbana de Faixas Marginais de Proteção de Cursos D'água no Estado do Rio de Janeiro: Exame da Legislação e o Exemplo do Projeto Iguaçu. Dissertação de Mestrado. Área de Concentração: Estudos de Processos Socioambientais. Universidade Federal Fluminense - UFF. Niterói/RJ.

10. FEEMA, 2007. Parecer RD n. ${ }^{\circ}$ 04/2007 - Processo E-07/203.472/2006. Rio de Janeiro/RJ.

11. INEA, 2017. Demarcação da Faixa Marginal de Proteção Contínua do Rio Piabanha - Processo E-07/00.07317/2017. Rio de Janeiro/RJ.

12. INPE, 2019. Simpósio Brasileiro de Sensoriamento Remoto acontece em Santos. Disponível em: <http://www.inpe.br/noticias/noticia.php?Cod_Noticia=5075>. Acesso em: 15 jun. 2020.

13. RIO DE JANEIRO. Constituição (1989). Constituição do Estado do Rio de Janeiro. Disponível em: <http://www2.alerj.rj.gov.br/biblioteca/assets/documentos/pdf>. Acesso em: 1 jul. 2020.

14. RIO DE JANEIRO (Estado). Decreto Estadual n. ${ }^{\circ}$ 42.356, de 16 de março de 2010. Dispõe sobre o tratamento e a demarcação das faixas marginais de proteção nos processos de licenciamento ambiental e de emissões de autorizações ambientais no Estado do Rio de Janeiro e dá outras providências. Diário Oficial do Estado do Rio de Janeiro, 17 de mar. 2010.

15. SILVA, Aline Neves, 2019. A Expansão Urbana como Agente de Transformações Ambientais no Município de Paripueira-AL. Dissertação de Mestrado. Pós-Graduação em Ciểncias Geodésicas e Tecnologias da Geoinformação. Universidade Federal de Pernambuco - UFP. Recife/PE. 
Data de aceite: 04/01/2021

Data de submissão: 25/11/2020

Raquel Santarém de Souza Costa Engenheira Ambiental e Sanitarista, pelo Instituto Federal de Goiás Goiânia - GO http://lattes.cnpq.br/0415555731128786

Aldo Muro Junior

Professor Titular da Coordenação de Engenharia Ambiental e Sanitária - IFG Goiânia - GO http://lattes.cnpq.br/4399910242348015

Flávio Roldão de Carvalho Lélis

Professor Titular da Coordenação de Engenharia Ambiental e Sanitária - IFG Goiânia - GO http://lattes.cnpq.br/7287069183620494

RESUMO: A Avaliação Ambiental Estratégica (AAE) surge da necessidade de uma ferramenta específica para planejamento e auxílio na elaboração de políticas, planos e programas (PPPs). Diferentemente da Avaliação de Impactos Ambientais (AIA), instrumento utilizado por entidades públicas e privadas, a $\mathrm{AAE}$, comumente, tem seu uso restringido à elaboração de PPPs governamentais. O objetivo deste trabalho foi o de identificar as possíveis contribuições da AAE para o planejamento de uso e ocupação do solo, utilizando como objeto o Plano Diretor de Goiânia, no Estado de Goiás. Os resultados foram cotejados com os obtidos em trabalho semelhante cujo recorte geográfico foi a cidade de São Carlos, no Estado de São Paulo, e seu respectivo Plano Diretor. Por meio da identificação das etapas de elaboração do Plano Diretor Municipal de Goiânia (PDMG), e de sua sistematização com os elementos da AAE, observou-se a contribuição da ferramenta para o incremento da variável ambiental no Plano Diretor de ambas as cidades, cujo resultado demonstrou divergências no grau de inserção. Em Goiânia, foi observada a presença da variável ambiental na elaboração de seu plano diretor, diferentemente do ocorrido em São Carlos. O trabalho indicou a relevância da avaliação ser democratizada e seu uso regulamentado no Brasil. Concluiu-se que a $A A E$ constitui um importante mecanismo de auxílio na elaboração da legislação que regulamenta os Planos Diretores Municipais (PDMs), para mitigação dos impactos ambientais decorrentes do crescimento urbano.

PALAVRAS-CHAVE: Uso e ocupação do solo, desenvolvimento urbano, sustentabilidade, meio ambiente.

STRATEGIC ENVIRONMENTAL ASSESSMENT: POSSIBLE CONTRIBUTIONS TO THE GOIÂNIA'S MUNICIPAL MASTER PLAN, IN THE STATE OF GOIÁS

ABSTRACT: Strategic Environmental Assessment (SEA) arises from the need for a specific tool for planning and assisting in the development of policies, plans and programs (PPPs). Unlike Environmental Impact Assessment (EIA), a tool used by public and private entities, SEA is commonly restricted to the development of 
government PPPs. The objective of this work was to identify the possible contributions of SEA to land use and occupation planning, using the Master Plan of Goiânia, in the State of Goiás as its object. The results were compared with those obtained in similar work whose geographic cutout was the city of São Carlos, in the State of São Paulo, and its respective Master Plan. The stages identification and systematisation of the Goiânia's Master Plan (GMP) using SEA results in the importance of the tool for the variable environmental increment in the city law of both cities, whose work showed divergences. In Goiânia, it was observed the presence of the environmental variable in the elaboration of its Master Plan, differently from what happened in São Carlos. The work indicated the relevance of the evaluation to be democratised and its use regulated in Brazil. It was concluded that SEA is an important mechanism to assist in the preparation of legislation that governs Municipal Master Plans (MMPs), for mitigation of environmental impacts resulting from urban growth.

KEYWORDS: Land use and occupation planning, urban development, sustainability, environment.

\section{I INTRODUÇÃO}

Com o incremento da preocupação ambiental ocorrido após os movimentos hippies, passou a vigorar, nos Estados Unidos, a Lei de Política Ambiental Nacional naquele país. Denominada originariamente National Environmental Policy Act (NEPA), teve como objetivo incentivar uma harmonia produtiva e agradável entre o homem e o meio ambiente (NEPA, 2019; CORREIA, 2009).

A NEPA foi a responsável pela criação de uma ferramenta que viria a ser a precursora da Avaliação Ambiental Estratégica (AAE) e o Estudo de Impacto Ambiental (EIA), instrumento desenvolvido para realizar avaliação prévia dos impactos das ações governamentais de interação com o meio ambiente, norteando as políticas, planos e programas de licenciamentos para as ações capazes de afetar potencialmente a higidez e a qualidade do meio ambiente (MUNK, 2015).

O tema Avaliação Ambiental Estratégica tem suscitado atenção do meio científico, especificamente sua aplicação em planos de saneamento básico, avaliação para o planejamento de transportes e políticas de mudanças climáticas, incluindo os procedimento de avaliação da efetividade de suas ferramentas (MALVESTIO, 2017; OPPERMANN, 2017; FELIX, 2016; BASTOS, 2015; TEIXEIRA, 2014; REBELO, 2012).

O Brasil volveu-se para a necessidade da extensão conceitual da AAE, após a realização da ECO-92 (GARCIA \& GARCIA, 2014), por meio de proposições do Ministério do Meio Ambiente (MMA), em adotar procedimento sistemático e contínuo relacionável à avaliação da qualidade do meio ambiente e análise das consequências ambientais resultantes de diferentes alternativas de desenvolvimento associadas às políticas, planos e programas públicos, correlacionando a inserção da variável ambiental com aspectos econômicos, sociais e políticos, para a tomada de decisão das políticas e instrumentos de definição discricionários ambientais (FABBRO NETO, 2010; ALMEIDA et al, 2015). 
Em relação à elaboração de uma $\mathrm{AAE}$ estudiosos apontam que esta apoia-se sobre seis pilares, devendo ser integrada, orientada pela sustentabilidade, focada, verificável, participativa e interativa (RIZZO, GALLARDO E MORETTO, 2017; CORREIA, 2009).

O Conselho Nacional do Meio Ambiente (CONAMA) ainda não regulamentou a AAE como instrumento da Política Nacional do Meio Ambiente (PNMA). Contudo, o MMA analisa esta regulamentação, reconhecendo sua aplicabilidade e relevância (MANSUR, 2006). Nesta linha, Sánchez (2017) propõe resposta quanto ao porquê a AAE não avança no cenário brasileiro, explicitando que para que isto ocorra será necessário apresentar aos tomadores de decisões as vantagens deste mecanismo, de forma que os agentes políticos vejam a transparência exigida pela $A A E$ como um aliado às gestões da coisa pública e incremento à tutela ambiental.

Mesmo sem a regulamentação, a AAE é objeto de estudo em pesquisas referentes à sua aplicação em PPPs nacionais (MACHADO et al., 2019). Torres, Pina e Oliveira (2018), Piérola e Almeida (2015), Ferreira (2013), Cezare, Malheiros e Philippi Jr. (2007), Schweigert (2007) abordaram acerca da sustentabilidade como tema importante a ser discutido na elaboração dos Planos Diretores dos municípios pátrios, reconhecendo a necessidade do equilíbrio entre ambiente construído e ambiente natural dentro dos perímetros urbanos.

O Plano Diretor de um município é um instrumento de planejamento urbano e de gestão de municípios, no qual a presença da variável ambiental é preponderante (FERREIRA, 2013; REZENDE \& ULTRAMARI, 2007).

Gasparini (2002), apud Rodovalho (2008), afirma que o Plano Diretor corresponde a um conjunto de normas legais e diretrizes técnicas referentes ao desenvolvimento contínuo do município, sob os aspectos físico, social, econômico e administrativo, no qual são estabelecidos objetivos, prazos e responsáveis.

A Carta da República Federativa do Brasil (BRASIL, 1998), em grau hierárquico nomológica superior e o Estatuto da Cidade (BRASIL, 2001) oferecem diretrizes para a composição deste instrumento, isto é, o PDM é abordado quando do traçado da política de desenvolvimento e de ordenamento da expansão urbana (PASQUALETO \& RODOVALHO, 2012; REZENDE \& ULTRAMARI, 2007).

O $\S 1^{\circ}$ do artigo 182 da Constituição Federal Brasileira (BRASIL, 2016), instituiu como obrigatórios os Planos Diretores para municípios que apresentam população acima de 20.000 habitantes, em termos de conceituação, o Guia de Implementação do Estatuto da Cidade, elaborado pela Câmara dos Deputados da União definiu o Plano Diretor como um complexo de princípios e regras que determinam o desenvolvimento e uso do espaço urbano (BRASIL, 2002).

No que se refere aos objetivos do PDM, Ferreira (2013) afirma que este instrumento de planejamento urbano objetiva, em suma, a análise e reflexão quanto à realidade urbana, a fim de que o ordenamento territorial seja melhor projetado, por meio da definição de ações e diretrizes, assim sendo, o alcance desses objetivos se dá por meio de estratégias 
de intervenções imediatas, à medida que o PDM define poucos e claros princípios de ação para o conjunto dos agentes envolvidos na construção da cidade.

Um importante conteúdo abordado no PDM refere-se ao uso e ocupação do solo, um mecanismo de planejamento urbano que tem como finalidade a organização do território municipal (TAKEDA, 2013), em zonas urbana ou rural, levando em consideração os aspectos sociais, econômicos e ambientais, buscando garantir equilíbrio e sustentabilidade ao desenvolvimento destas áreas.

Em 2010, Francisco Fabbro Neto (FABBRO NETO, 2010), em sua dissertação vinculada ao Programa de Pós Graduação da Escola de Engenharia de São Carlos, da Universidade de São Paulo, no Estado de São Paulo, sistematizou a aplicação da AAE nas etapas de elaboração e revisão do Plano Diretor Municipal de São Carlos (PDMSC), definido pela Lei Municipal de São Carlos n 13.691, de 25 de novembro 2005, (SÃO PAULO, 2005), a fim de verificar as contribuições da aplicação da ferramenta para o planejamento de uso e ocupação do solo daquele município.

A metodologia de aplicação da AAE utilizada por Fabbro Neto (2010) teve como suporte referencial as disposições da Diretiva Europeia 2001/42/EC (EU, 2001). Este documento da Comunidade Europeia, destaca-se como instrumento formulado para o auxílio na aplicação da AAE, cuja utilização deve ser adaptada para aplicação em cada cidade, porém norteia a metodologia a ser utilizada (FABBRO NETO, 2010).

A partir desta Diretiva (EU, 2001) podem ser identificadas as etapas de inserção da variável ambiental quando da elaboração de PPPs, descritas no Quadro 1.

\begin{tabular}{|c|c|}
\hline $1^{\text {a }}$ ETAPA: & $\begin{array}{l}\text { Identificar os objetivos e indicadores de AAE e incluir questões ambientais e de } \\
\text { sustentabilidade. Nesta etapa verifica-se a necessidade da aplicação da AAE, } \\
\text { observando a forma como será executada e a existência de conflitos entre seus } \\
\text { interesses e o de outros PPPs }\end{array}$ \\
\hline $2^{\text {a }}$ ETAPA: & $\begin{array}{l}\text { Descrever a base de referência ambiental. É realizada identificação dos setores onde } \\
\text { a inserção da variável ambiental se faz mais necessária e das conexões com outras } \\
\text { ações estratégicas, onde é verificada a contribuição de outros PPPs }\end{array}$ \\
\hline $3^{\text {a }}$ ETAPA: & $\begin{array}{l}\text { Identificar as alternativas mais sustentáveis. São identificadas alternativas de diversas } \\
\text { naturezas (de investimento, localização de ações e projetos, emprego de tecnologia) } \\
\text { para a PPP em análise, verificando-se as opções mais sustentáveis }\end{array}$ \\
\hline $4^{\text {a }}$ ETAPA: & $\begin{array}{l}\text { Estabelecer o conteúdo a ser considerado para a avaliação. São definidos os dados } \\
\text { e informações que deverão ser levantados, assim como os indicadores passíveis de } \\
\text { serem selecionados, com decisões apoiadas pela população }\end{array}$ \\
\hline $5^{\text {a }}$ ETAPA: & $\begin{array}{l}\text { Prever e avaliar os possíveis impactos causados pelas alternativas escolhidas. } \\
\text { São identificados os tipos e magnitudes dos impactos ambientais esperados para a } \\
\text { implementação dos objetivos, a partir da análise das bases de referência }\end{array}$ \\
\hline $6^{\text {a }}$ ETAPA: & $\begin{array}{l}\text { Identificar as técnicas de mitigação destes impactos, assim como a documentação } \\
\text { destas. Nesta etapa são sugeridas medidas mitigadoras para os impactos ambientais } \\
\text { identificados na etapa anterior }\end{array}$ \\
\hline
\end{tabular}




\begin{tabular}{|l|l|}
\hline $7^{\text {a }}$ ETAPA: & $\begin{array}{l}\text { Incluir a participação pública nos momentos de decisões. Esta etapa corresponde } \\
\text { à realização de consultas, debates e audiências públicas, que corroboram para as } \\
\text { etapas subsequentes, uma vez que a população passa a conhecer os PPPs }\end{array}$ \\
\hline $\mathbf{8}^{\text {a }}$ ETAPA: & $\begin{array}{l}\text { Finalizar o relatório de AAE e estabelecer as diretrizes de implementação da ação } \\
\text { estratégica avaliada. São apresentadas aos responsáveis políticos as formas como se } \\
\text { pretende implementar a AAE para que seja aprovada }\end{array}$ \\
\hline $9^{\text {a ETAPA: }}$ & $\begin{array}{l}\text { Monitorar os impactos das ações. A última etapa corresponde à aplicação do modelo } \\
\text { de monitoramento proposto pelos elaboradores da AAE, com o qual os impactos da } \\
\text { estratégia poderão ser testados contra as previsões e as bases de referência serão } \\
\text { atualizadas para ações futuras }\end{array}$ \\
\hline
\end{tabular}

Quadro 1. Inserção da variável ambiental em PPPs

Fonte: Adaptado de EU (2001)

Utilizando as etapas apresentadas pela Diretiva Europeia 42/2001/EC (EU, 2001), associadas às disposições ambientais contidas na Constituição Federal Brasileira (BRASIL, 1988) e no Estatuto das Cidades (BRASIL, 2001), pode-se aplicar a AAE a um Plano Diretor em qualquer município brasileiro, contribuindo para o desenvolvimento sustentável da cidade onde se almeja fazer viger o plano diretor.

O presente trabalho teve como objetivo a identificação das possíveis contribuições da aplicação da AAE para o planejamento de uso e ocupação do solo, utilizando-se o Plano Diretor de Goiânia (PDMG) como objeto de estudo e, como referência, foram cotejados os resultados obtidos por Fabbro Neto (2010), no Plano Diretor de São Carlos (PDMSC), que realizou estudo semelhante.

\section{I PROCEDIMENTO EXPERIMENTAL}

Segundo seus objetivos, esta pesquisa caracteriza-se como descritiva, uma vez que busca, primordialmente, o estabelecimento de relações entre variáveis (GIL, 2007), neste caso, apresentando as contribuições da aplicação da AAE sobre o PDMG, no que se refere à natureza, é uma pesquisa aplicada, considerando que sua realização tem como propósito a geração de aprendizado para aplicações reais (GERHARDT e SILVEIRA, 2009).

Quanto à abordagem do problema, a pesquisa classifica-se como qualitativa, à medida que visa interpretar resultados que não podem ser quantificados. Os procedimentos utilizados para o alcance dos objetivos foram a pesquisa bibliográfica, descrita por Lima e Mioto (2007), como uma forma ordenada de busca por resultados pertinentes ao objeto de estudo, e o uso de estudo de caso.

A revisão bibliográfica foi realizada em teses, dissertações, artigos publicados em periódicos nacionais, legislações e regulamentações da política nacional. O levantamento desta revisão fundamentou-se nas bases de dados digitais, como as plataformas Capes, Scielo, Google Acadêmico e sites da Prefeitura Municipal de Goiânia. As palavras-chave pesquisadas foram: Avaliação Ambiental Estratégica, Desenvolvimento Urbano e Plano 
Diretor Municipal.

O objeto de estudo escolhido para este trabalho foi o Plano Diretor Municipal de Goiânia (PDMG), instituído pela Lei Complementar $N^{\circ} 171$, de 29 de maio de 2007, (GOIÂNIA, 2007), sendo tal decisão pautada por conveniência dos pesquisadores. Na Figura 1 ilustra-se a localização do município-alvo em relação ao país e ao Estado.

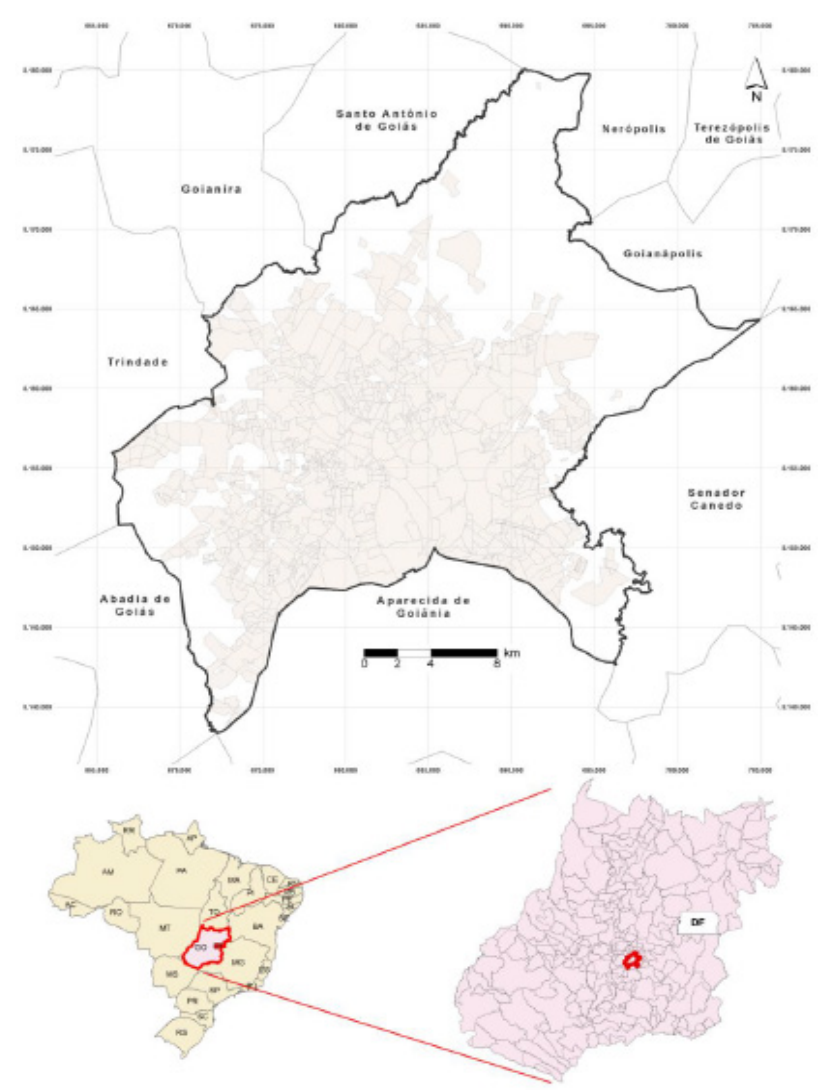

Figura 1. Localização de Goiânia em relação à Goiás e ao Brasil Fonte: Adaptado de Abdala (2013)

Foram definidas duas etapas para que o objetivo da pesquisa fosse alcançado. Inicialmente verificou-se as contribuições da aplicação da AAE sobre o PDMG, por meio da análise do cruzamento entre as etapas de elaboração do PDMG e as diretrizes da AAE, definidas pela Diretiva Europeia 42/2001/EC (EU, 2001). Posteriormente, à título de comparação, foram confrontados os resultados encontrados para o PDMG e os resultados obtidos por Fabbro Neto (2010), ao realizar pesquisa semelhante para o PDMSC.

As variáveis utilizadas para fundamentar a identificação das contribuições da 
aplicação da AAE no PDMG foram extraídas das etapas que constituem a Diretiva Europeia 42/2001/EC (EU, 2001), adotada como modelo de análise nesta pesquisa. Ao todo são identificadas nove variáveis, cada qual com sua intencionalidade ao ser aplicada ao PDMG.

A primeira variável aborda os "objetivos e indicadores", a partir dela é verificado se no Plano Diretor há objetivos e indicadores definidos em relação às questões ambientais e de sustentabilidade, a "base de referência ambiental", segunda variável, é usada para identificar onde se faz mais necessária a inserção da variável ambiental no PDMG, analisando possíveis conexões com outras ações estratégicas.

Posteriormente são exploradas "alternativas sustentáveis", "conteúdo a ser considerado", "impactos das alternativas" e "mitigação das alternativas", respectivamente terceira, quarta, quinta e sexta variável, que possuem como intencionalidade identificar alternativas de diversas naturezas que auxiliem na execução do PDMG, definir os dados e informações que deverão ser coletados para compor a AAE aplicada ao Plano Diretor, categorizar e avaliar os possíveis impactos causados decorrentes das alternativas selecionadas e verificar quanto da identificação e documentação das técnicas de mitigação dos impactos avaliados propostas na implementação do PDMG.

A sétima variável, "participação pública”, busca verificar, no PDMG, se é considerada a participação pública nos momentos de decisões, como forma corroborativa, o "relatório de AAE", oitava variável, é usado para definir as diretrizes de implementação da AAE para o Plano Diretor, e, por fim, a nona variável, "monitoramento", tem como intencionalidade verificar se há propostas de monitoramento dos impactos, estabelecidas pelo PDMG.

O que se pretendeu com esta pesquisa foi apresentar as possíveis contribuições da AAE quando da elaboração de um Plano Diretor Municipal, em termos de inserção da questão ambiental às diretrizes desta PPP, por meio da sistematização entre etapas de planejamento urbano e desenvolvimento sustentável.

Goiânia, também conhecida como "capital verde", está entre as cidades brasileiras com melhor índice de qualidade de vida do país, (SILVA, 2010). De acordo com o Ministério do Turismo (BRASIL, 2014), dentro do país, Goiânia é o município com maior área verde por habitante $\left(94 \mathrm{~m}^{2}\right)$. A cidade, capital de Goiás, destaca-se por implementar um modelo de desenvolvimento urbano aliado à consistente política de responsabilidade ambiental.

O município de Goiânia, foi fundado em 24 de outubro de 1933, com o objetivo de abrigar a capital do Estado de Goiás (SEDI, 2016), sua criação foi prevista na política de interiorização nacional, do governo de Getúlio Vargas (BORGES, BARREIRA e COSTA, 2017). A cidade foi planejada para uma população de 50.000 habitantes, porém, no ano de 2010 este número ultrapassava um milhão e trezentos (IBGE, 2019). Com isso, pode ser observada uma expansão urbana desenfreada, que acarreta consequências para o controle de uso e ocupação do solo no município.

O Plano Diretor não é uma ferramenta nova na história do município de Goiânia. Desde sua fundação, em 1933, o uso deste instrumento para guiar o desenvolvimento da 
cidade é estudado por arquitetos e urbanistas. Ao todo foram elaborados quatro Planos Diretores, datados de 1938, 1962 (não oficializado, em decorrência do Golpe de 1964), 1979 e 1994, e a Lei Complementar de 2007, lei esta que previa o início do processo de revisão do Plano Diretor no ano de 2017 (RODOVALHO, 2008).

Na Figura 2 ilustra-se a evolução da série histórica dos Planos Diretores de Goiânia.

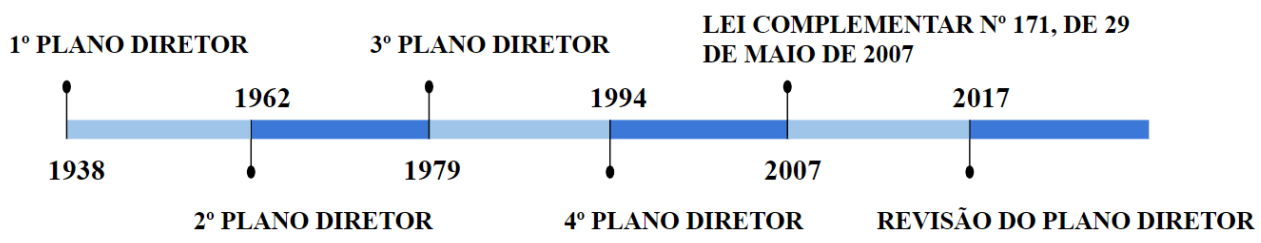

Figura 2. Planos Diretores de Goiânia ao longo do tempo.

O conteúdo discutido no PDMG é trabalhado em títulos e capítulos compreendidos na divisão de quatro partes principais (Tabela 1)

\begin{tabular}{|c|c|c|c|}
\hline PARTE I & PARTE II & PARTE III & PARTE IV \\
\hline $\begin{array}{c}\text { Dispõe dos princípios } \\
\text { e objetivos da Política } \\
\text { Urbana, assim como } \\
\text { das Estratégias de } \\
\text { Desenvolvimento } \\
\text { Urbano, entre elas, } \\
\text { aquela que se refere } \\
\text { à sustentabilidade } \\
\text { socioambiental }\end{array}$ & $\begin{array}{l}\text { Trata do Modelo } \\
\text { Espacial, dos } \\
\text { Elementos Estruturais } \\
\text { que o definem e } \\
\text { dos Instrumentos } \\
\text { Urbanísticos de } \\
\text { regulação para } \\
\text { intervenção no solo, } \\
\text { contemplando normas } \\
\text { e instrumentos }\end{array}$ & $\begin{array}{c}\text { Refere-se } \\
\text { ao processo de } \\
\text { planejamento } \\
\text { municipal, apresenta } \\
\text { os princípios do } \\
\text { sistema municipal de } \\
\text { planejamento e dos } \\
\text { objetivos do sistema } \\
\text { de informações } \\
\text { urbanas }\end{array}$ & $\begin{array}{c}\text { Remete à } \\
\text { apresentação das } \\
\text { disposições gerais e } \\
\text { transitórias do Plano } \\
\text { Diretor, instituindo } \\
\text { a adequação da } \\
\text { legislação às diretrizes } \\
\text { e normas propostas } \\
\text { pela ferramenta }\end{array}$ \\
\hline
\end{tabular}

Tabela 1. PDMG de acordo com divisão em partes

\section{Identificação das etapas do Plano Diretor Municipal}

A partir da análise e interpretação da Lei Complementar $n^{\circ} 171$, de 29 de maio de 2007 (GOIÂNIA, 2007) que institui o PDMG foram identificadas nove etapas que compuseram a elaboração deste instrumento.

$1^{\text {a }}$ etapa: Definir as estratégias de desenvolvimento urbano.

$2^{a}$ etapa: Definir o modelo espacial.

$3^{a}$ etapa: Definir o perímetro urbano.

$4^{\mathrm{a}}$ etapa: Instituir as macrozonas urbanas e rurais. 
$5^{\mathrm{a}}$ etapa: Definir os elementos estruturadores do modelo espacial.

$6^{\circ}$ etapa: Definir os instrumentos urbanísticos de regulação para intervenção no solo. $7^{\text {a }}$ etapa: Realizar audiências públicas.

$8^{a}$ etapa: Submeter o projeto ao Poder Legislativo, para transformação em lei.

$9^{a}$ etapa: Implementar a Lei, destacando revisão a ser feita a cada 10 anos.

É possível verificar a questão ambiental sendo contemplada no corpo do PDMG, uma vez que é definido pelo Art. $4^{\circ}$ da Lei Complementar $n^{\circ} 171$, de 29 de maio de 2007 :

O Plano Diretor, instrumento da Política Urbana, incorpora o enfoque ambiental de planejamento na definição do modelo de desenvolvimento do Município, devendo compatibilizar-se com os planos regionais e setoriais complementares.

O aparecimento da variável ambiental no PDMG decorre também da definição do Eixo Estratégico de Sustentabilidade Socioambiental, ferramenta responsável por priorizar o desenvolvimento local de forma sustentável para todo o município, composto por diretrizes gerais e propostas de programas socioambientais a serem implementados.

\section{Cruzamento entre as etapas de elaboração do PDMG e as diretrizes da AAE}

Apesar de não apresentar um Relatório de AAE (GOIÂNIA, 2019), o PDMG aborda a questão ambiental ao longo de seu texto. Havendo também a inserção da variável ambiental às etapas de elaboração do PDMG tornaria estas, muitas vezes, mais completas, de forma a contemplar os objetivos da aplicação da AAE.

Realizando o cruzamento entre as variáveis da $A A E$, identificadas para o auxílio da inserção da variável ambiental em PPPs, e as etapas de elaboração identificadas no PDMG, foi possível visualizar as possíveis contribuições provenientes da aplicação da ferramenta de avaliação, quanto às suas finalidades:

\section{(1) Objetivos e indicadores}

Ao analisar o PDMG quanto à identificação dos objetivos e indicadores definidos em relação às questões ambientais e de sustentabilidade, observa-se no Art. $2^{\circ}$, sobre a Política Urbana do Município, que se sustentaria, dentre outros princípios, pelo princípio da igualdade (Parágrafo único, inciso I), que ressalta o saneamento ambiental. Foram definidas estratégias de desenvolvimento urbano, tais como a de ordenamento territorial, uso e ocupação do solo, que colabora com a estratégia de sustentabilidade socioambiental.

(2) Base de referência ambiental

Uma questão importante no desenvolvimento do município de Goiânia refere-se ao seu crescimento desordenado, observado há tempo, por meio do número de habitantes da cidade e o respectivo adensamento populacional. Em razão dessa expansão urbana tem- 
se grande preocupação quanto ao uso e ocupação do solo no município, sendo necessária uma orientação sustentável quanto ao zoneamento do município.

O PDMG conta com o auxílio de documentos como a Carta de Risco, definido pelo Art. 166 como "instrumento definidor das ações e medida de promoção, proteção e recuperação da qualidade ambiental do espaço físico-territorial, segundo suas características ambientais".

Ainda do corpo do Plano Diretor, são apresentadas diversas propostas de programas que abrangem os aspectos ambiental, social e econômico de forma integrada. A implementação destas ações, de cunho público ou privada, e a realização de relatórios referentes às mesmas fortaleceriam a coleta de informações para composição das bases de referência.

\section{(3) Alternativas sustentáveis}

Entre os Instrumentos Complementares de Gestão Urbana, definidos no Art. 71, são descritas PPP's que auxiliam na execução do PDMG, por exemplo, os Planos Regionais dispostos no inciso I, do referido artigo que correspondem à políticas, programas, entre outras ações, que visam promover o desenvolvimento sustentável de cada uma das Regiões Administrativas do Município, adequando-se às propostas do PDMG para esta finalidade (GOIÂNIA, 2007).

Quanto aos Planos Setoriais ou Intersetoriais (inciso II), estes "consistem na definição de políticas, diretrizes, programas, ações e normas setoriais ou intersetoriais para as áreas transversais ao físico-territorial, como meio ambiente" (GOIÂNIA, 2007, n.p.).

E os Planos de Manejo das Sub-Bacias Hidrográficas, descritos no inciso III propõem compatibilizar o uso e ocupação do solo nas áreas de sub-bacias hidrográficas, preservar, conservar e recuperar os recursos ambientais e naturais desses territórios, principalmente os recursos hídricos e a biodiversidade (GOIÂNIA, 2007).

\section{(4) Conteúdo a ser considerado}

Para compor a AAE, seriam utilizados dados que definem os elementos estruturadores do modelo espacial, abordando elementos naturais e construídos, áreas especiais de interesse ambiental, social, urbanístico e institucional, bem como os Eixos de Desenvolvimento, integrados ao uso do solo. Com o debate referente à estes elementos tornar-se-ia possível prever e avaliar os impactos decorrentes de suas implementações.

\section{(5) Impactos das alternativas}

Quanto à categorização e avaliação dos impactos causados pelo desenvolvimento das PPP's, o PDMG dispõe sobre a ferramenta de AIA, no inciso XXVIII, ao tratar, no Capítulo IV, dos Instrumentos de Política Urbana, apresentando, dos Instrumentos Gerais. 
(6) Mitigação dos impactos

Com a definição dos elementos estruturadores do modelo espacial seriam então definidos os instrumentos urbanísticos de regulação e também das políticas urbana e rural, de modo que estes seriam responsáveis por mitigar os impactos causados pelos elementos que compõem o PDMG, anteriormente previstos e avaliados.

$\mathrm{Na}$ atual leitura do PDMG não é feita alusão à medidas mitigadoras como forma de reparação ao ambiente que sofre ações de impactos ambientais.

\section{(7) Participação Pública}

A necessidade da participação da comunidade para efeito do desenvolvimento urbano do município de Goiânia é apresentada algumas vezes ao longo do PDMG, o tema é disposto e instituído em itens dos Art. 69, Art. 70, Art. 134 e Art. 174, que abordam sobre as estratégias de gestão urbana e como a participação pública é compreendida como objetivo do planejamento urbano e, desta forma, tem sua realização garantida em momentos de aprovação do uso de instrumentos de gestão pública, sempre que estes dependerem de dispêndios de recursos por parte do Poder Público Municipal (GOIÂNIA, 2007).

(8) Relatório de $A A E$

Com a definição das diretrizes de implementação do PDMG e a elaboração de um relatório da aplicação da $\mathrm{AAE}$, a aprovação da estrutura elaborada para o Plano Diretor e a transformação deste em lei municipal se apoiariam nas etapas já executadas.

\section{(9) Monitoramento}

O Art. 184 da Lei Complementar de Goiânia n 171, de 29 de maio de 2007 (GOIÂNIA, 2007), criou um Sistema Municipal de Planejamento, que tem como um de seus objetivos instrumentalizar o processo de planejamento municipal e controlar planos, programas e projetos.

Ressalta-se que, a etapa proposta pela $A A E$, referente ao monitoramento, sendo realizada de forma frequente, contribuiria para a atualização das informações referentes à elaboração do Plano Diretor, otimizando seu processo de revisão. O monitoramento da base de referência ambiental, faria com que as PPPs propostas ao longo do Plano Diretor fossem de fato implementadas, e aquelas em execução gerassem relatórios periódicos, de consulta livre à população.

\section{PDMSC x PDMG}

Antes de comparar a aplicação da AAE nos Planos Diretores dos municípios de Goiânia (GO) e São Carlos (SP) foi realizado um levantamento de acordo com dados do IBGE quanto à alguns aspectos territoriais e ambientais das cidades (Figura 3), como forma 


\section{Aspectos Ambientais}

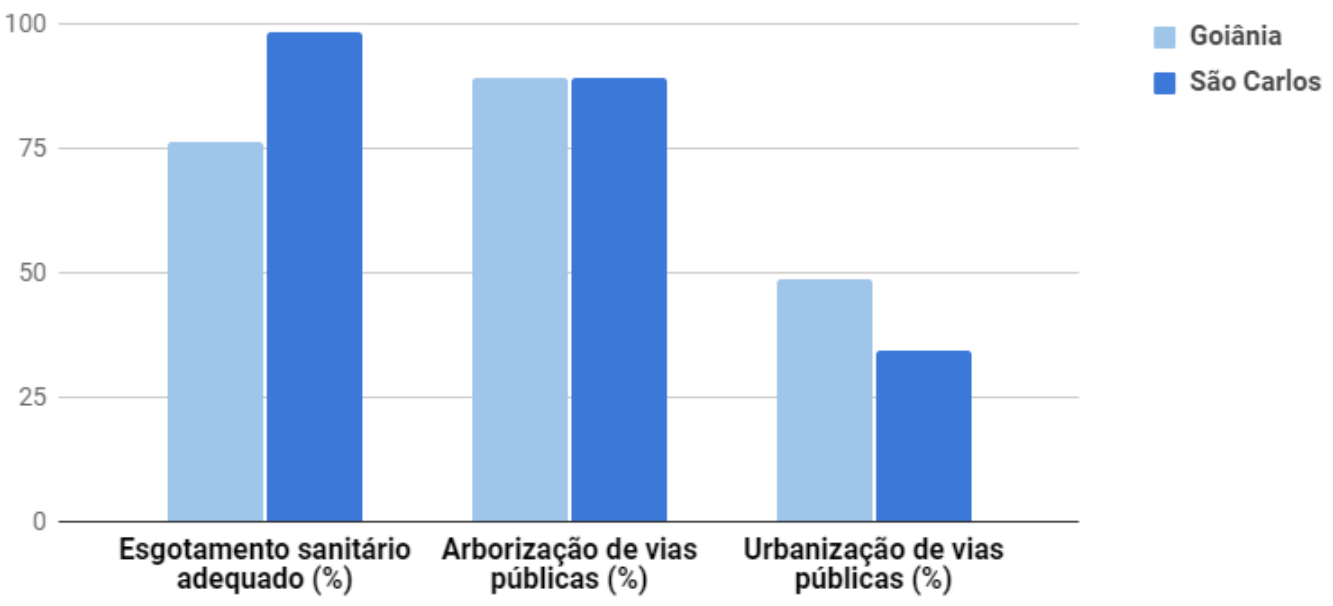

Figura 3. Aspectos ambientais - Goiânia e São Carlos

Fonte: elaboração própria, adaptado de IBGE (2019).

Quanto aos aspectos territoriais, o município de Goiânia possui 728,841 km² de área da unidade territorial, o que torna a cidade a $1856^{a}$ maior dentre os 5570 municípios do Brasil, e a $132^{\mathrm{a}}$ em relação aos 246 municípios do estado de Goiás. Enquanto isso, a cidade de São Carlos possui 1.136,907 km² de área da unidade territorial, fazendo deste o $1286^{\circ}$ maior município do país, e $25^{\circ}$ em relação aos 645 municípios do estado de São Paulo.

A respeito da análise da sistematização dos instrumentos ambientais aplicados para o planejamento de uso e ocupação do solo nos municípios de Goiânia (GO) e São Carlos (SP) é observada maior contribuição da $A A E$, no que se refere ao incremento da variável ambiental, no PDMSC. Isso decorre da existência de um enfoque ambiental no PDMG, desde as suas primeiras etapas de elaboração, ao apresentar eixos estratégicos para o planejamento utilizando desta variável integrada à outras.

Mesmo sendo considerada maior necessidade de incremento da variável ambiental ao PDMSC, ainda é observada a importância da AAE para estruturação do PDMG, uma vez que sua aplicação sistematiza os instrumentos necessários para a elaboração do Plano Diretor, de forma semelhante à que faz com o PDMSC.

Ressalta-se que a aplicação da AAE nos dois Planos Diretores, de diferentes formas, seria contemplada ao todo, sendo analisadas as nove etapas de implementação definidas 
pela Diretiva Europeia, que corroboram com o alcance dos objetivos de sustentabilidades previstos pelo Estatuto da Cidade.

No PDMG é observada maior contribuição da aplicação da AAE sobre sua elaboração em razão de algumas de suas variáveis. Primeiramente, quanto da identificação de objetivos e indicadores que atendam às questões ambientais e de sustentabilidade, de forma que seriam abordados mais destes. No que diz respeito aos impactos ambientais e à mitigação destes, a AAE colaboraria de forma que houvesse maior registro quanto a informações sobre as variáveis.

No que se refere ao Relatório de AAE, a elaboração deste, quanto ao PDMG, contribuiria para o ordenamento das diretrizes a serem seguidas, em prol do desenvolvimento sustentável. A participação pública, nos momentos de revisão do Plano Diretor, bem como de outros momentos de decisão, contaria com maior disponibilidade de informações.

Outra contribuição vale-se da verificação das propostas de monitoramento, institucionalizadas pela Lei Complementar $n^{\circ}$ 171, de 29 de maio de 2007, (GOIÂNIA, 2007). O acompanhamento das diretrizes dos projetos de planejamento, assim como o controle das PPPs associadas ao PDMG colaboraria com a construção de maiores bases de dados de referência e a otimização da revisão periódica do Plano Diretor.

Quanto ao PDMSC, desde a identificação das etapas de sua elaboração, Fabbro Neto, (2010), observa a "caracterização de um processo decisório desvinculado da incorporação da variável ambiental", possibilitando, quando da aplicação da AAE, a implementação da variável ambiental prevista em todas as etapas, diferentemente do que ocorre quando da sistematização entre AAE e PDMG, sendo muitas das variáveis observadas já no corpo do Plano Diretor.

\section{I CONCLUSÕES}

A AAE pode ser utilizada em diferentes PPPs e em suas diferentes etapas. A pesquisa mostrou que a aplicação da AAE sobre Planos Diretores é útil para o incremento da variável ambiental no momento de suas elaborações e revisões. Podendo estar presente em todas as etapas ou potencializando aquilo que já foi realizado, a AAE contribui para a concretização do que foi apresentado.

É notável a necessidade de inserção da variável ambiental em etapas de elaboração de Planos Diretores. Destaca-se que, independente da atuação da aplicação da AAE, seja esta com intuito de inserir a variável ambiental à PPP, como observado no caso do PDMSC, ou corroborar com aquilo que já foi previsto, por exemplo, quando a aplicação ocorre em momentos de revisão, como no caso do PDMG, a AAE contribui para a elaboração da PPP para qual for proposta.

A aplicação da AAE de forma convergente aos objetivos do Estatuto da Cidade mostra que a sustentabilidade do uso e ocupação do solo pode ter seu gerenciamento 
encorajado através da identificação de objetivos e indicadores coerentes, da integração dos atores envolvidos nas tomadas de decisão, bem como do monitoramento das ações.

Durante a revisão da Lei Complementar $n^{\circ}$ 171, de 29 de Maio de 2007, que teve seu processo iniciado em novembro de 2017, e até a presente data encontra-se em discussão, a aplicação efetiva da AAE, prevista como Instrumento de Gestão Ambiental, no Art. 171 do próprio PDMG, pelos tomadores de decisão poderia contribuir para a real implementação de PPPs que visam o desenvolvimento sustentável no município.

Por fim, considera-se importante a democratização da AAE e a regulamentação de seu uso no Brasil, sendo compreendida pelo governo como instrumento de apoio e promoção da sustentabilidade, podendo ter sua aplicação proposta à PPPs de diversos setores, ao longo de todo território nacional, visando amparar o desenvolvimento sustentável do país.

\section{REFERÊNCIAS}

ABDALA, I. M. de R. Aplicação do índice de mobilidade urbana sustentável (IMUS) em Goiânia. Dissertação de mestrado. PUC/GO. Programa de Pós-graduação de Desenvolvimento e Planejamento Territorial. Goiânia, 2013. 82 p., il. color. Disponível em: http://tede2.pucgoias.edu.br:8080/handle/ tede/2805. Acesso em 18 nov. 2019.

ALMEIDA, R. E. et al. Análise da Proposta Federal de Implementação da Avaliação Ambiental Estratégica no Brasil. Revista de Gestão Ambiental e Sustentabilidade - GeAS, São Paulo, Brasil, v. 4, n. 2, p. 18-32, ago/2015. Disponível em: http://www.revistageas.org.br/ojs/index.php/geas/article/ viewFile/292/153. Acesso em 13 ago. 2019.

BRASIL. [Constituição (1988)]. Constituição da República Federativa do Brasil de 1988. Brasília, DF: Presidência da República, [2016]. Disponível em: http://www.planalto.gov.br/ccivil_03/constituicao/ constituicaocompilado.htm. Acesso em: 19 ago. 2019.

BRASIL. Estatuto da Cidade: Guia para implementação pelos municípios e cidades. 2. ed. Brasília: Câmara dos Deputados, Coordenação de Publicações, 2002. Disponível em http://planodiretor. saolourenco.sc.gov.br/leis/Estatuto\%20das\%20Cidades.pdf. Acesso em 6 out. 2019.

BRASIL. Lei $n^{\circ}$ 10.257, de 10 de julho de 2001. Regulamenta os arts. 182 e 183 da Constituição Federal, estabelece diretrizes gerais da política urbana e dá outras providências. Brasília [2001]. Disponível em: http://www.planalto.gov.br/ccivil_03/leis/leis_2001//10257.htm. Acesso em 20 set 2019.

BORGES, E. M.; BARREIRA, C. C. M. A.; DA COSTA, E. P. V. S. M.; Habitação Social e Desenvolvimento Urbano Sustentável: o caso da região metropolitana de Goiânia. Geo UERJ, Rio de Janeiro, n. 30, p. 122-144, 2017. Disponível em: https://www.e-publicacoes.uerj.br/index.php/geouerj/ article/viewFile/28323/21163. Acesso em: 10 nov. 2019.

CORREIA, M. M. M. Avaliação Ambiental Estratégica - Aplicação aos Planos Municipais de Ordenamento do Território. 2009. Dissertação (Mestrado em Ordenamento do Território e Planeamento Ambiental). Faculdade de Ciências e Tecnologia, Universidade Nova de Lisboa, Lisboa. Disponível em: https://run.unl.pt/bitstream/10362/4974/1/Correia_2010.pdf. Acesso em 7 out. 2019. 
EUROPEAN UNION. The European Parliament - Directive 2001/42/EC of the European Parliament and the Council on the assessment of the effects ou certain plans and programmes on the environment. Disponível em: http://www.environ.ie/en/publications/environment/miscellaneous/ filedownload,1805,en.pdf. Acesso em: 17 out. 2019.

FABBRO NETO, Francisco. A avaliação ambiental estratégica para planos de uso e ocupação do solo: um estudo sobre o plano diretor municipal. 2010. Dissertação (Mestrado em Ciências da Engenharia Ambiental) - Escola de Engenharia de São Carlos, University of São Paulo, São Carlos, 2010. Disponível em: http://www.teses.usp.br/teses/disponiveis/18/18139/tde-31032010-111208/publico/ Dissertaca oFranciscoFabbroNeto.pdf. Acesso em: 10 set. 2019.

FERREIRA, L.C.G. Uma reflexão sobre a expansão e mobilidade em Goiânia: uma análise do plano diretor de Goiânia - GO. OBSERVATORIUM: Revista Eletrônica de Geografia, v.5, n.15, p. 62-86, dez. 2013. Disponível em: http://www.seer.ufu.br/index.php/Observatorium/article/download/45759/24496. Acesso em 10 out. 2019.

GARCIA, H. S.; GARCIA, D. S. S. Importância da aplicação da Avaliação Ambiental Estratégica (AAE) no ordenamento jurídico brasileiro. Universitas JUS, v. 25, n. 2, p. 45-57, 2014. Disponível em: https:// www.cienciasaude.uniceub.br/jus/article/view/2469. Acesso em: 17 ago. 2019.

GERHARDT TE, SILVEIRA DT. Métodos de pesquisa. Universidade Aberta do Brasil - UAB/UFRGS. Porto Alegre: Editora da UFRGS; 2009. A pesquisa científica; p.120. Disponível em: http://www.ufrgs.br/ cursopgdr/downloadsSerie/derad005.pdf. Acesso em: 27 nov. 2019.

GIL, A. C. Como elaborar projetos de pesquisa. 4. ed. São Paulo: Atlas, 2007. Disponível em: http:// www.urca.br/itec/images/pdfs/modulo\%20v\%20-\%20como_elaborar_projeto_de_pesqu isa_-_antonio_ carlos_gil.pdf. Acesso em: 27 nov. 2019.

GOIÂNIA: a cidade verde completa 81 anos. Ministério do Turismo, 2014. Disponível em: http://www. turismo.gov.br/\%C3\%BAltimas-not\%C3\%ADcias/708-goiania--a-cidade-verde-c ompleta-81-anos.html. Acesso em: 26 nov. 2019.

GOIÂNIA. Lei Complementar n $^{\circ}$ 171, de 29 de maio de 2007. Dispõe sobre o Plano Diretor e o processo de planejamento urbano do Município de Goiânia e dá outras providências. Disponível em: http://www.goiania.go.gov.br/download/legislacao/PLANO_DIRETOR_DO_MUNICI

PIO_D E_GOIANIA_2007.pdf. Acesso em: 2 set. 2019. INSTITUTO BRASILEIRO DE GEOGRAFIA E ESTATÍSTICA. IBGE Cidades. Disponível em: https://cidades.ibge.gov.br/. Acesso em: 18 nov. 2019.

LIMA, Telma CS; MIOTO, Regina Célia Tamaso. Procedimentos metodológicos na construção do conhecimento científico: a pesquisa bibliográfica. Revista Katálysis, v. 10, n. 1, p. 37-45, 2007. Disponível em: http://www.scielo.br/pdf/rk/v10nspe/a0410spe. Acesso em: 26 nov. 2019.

MANSUR, de M. S. C.; SANTOS, G. F.; LIMA, G. S. Vulnerabilidade natural: método para uma das etapas da avaliação ambiental estratégica, com aplicação do sig no bairro Fidélis (Blumenau, SC). In: VI SIMPÓSIO NACIONAL DE

\section{GEOMORFOLOGIA. Geomorfologia}

Tropical e Subtropical: processos, métodos e técnicas. Goiânia: set. 2006. Anais. Disponível em: http:// Isie.unb.br/ugb/sinageo/6/9/399.pdf. Acesso em: 20 set. 2019. 
MUNK, N. Inclusão dos Serviços Ecossistêmicos na Avaliação Ambiental Estratégica.

Dissertação (Mestrado). Programa de Pós Graduação em Planejamento Energético, Universidade Federal do Rio de Janeiro. Rio de Janeiro. 2015. 179p. Disponível em: http://www.ppe.ufrj.br/images/ publica\%C3\%A7\%C3\%B5es/mestrado/Nicole_Munk.pdf. Acesso em 30 set 2019.

NATIONAL Environmental Policy Act. NEPA.GOV, 2019. Disponível em https://ceq.doe.gov/. Acesso em: 02 out. 2019.

PASQUALETTO, Antônio; RODOVALHO, Márcia. Eficácia e efetividade no Plano Diretor de Goiânia. In: Estudos. Goiânia, v. 39, n. 1, p. 45-60, jan./mar. 2012. Disponível em http://revistas.pucgoias.edu. br/index.php/estudos/article/download/2364/1453. Acesso em: 13 set. 2019. PLANO Diretor - O Estado de Goiás: Indicadores Sociais, Econômicos e Culturais. Secretaria de Estado e Desenvolvimento e Inovação, 2013. Disponível em: http://www.desenvolvimento.go.gov.br/ciencia-tecnologia-e-inovacao/ bolsas/72-area-de-atua cao/educacao-superior-e/2468-plano-diretor--o-estado-de-goias--indicadoressociais-economi cos-e-culturais.html. Acesso em: 18 nov. 2019.

REZENDE, D. A.; ULTRAMARI, C. Plano diretor e planejamento estratégico municipal: introdução teórico-conceitual. Rev. Adm. Pública, v. 41, n. 2, 2007. Disponível em http://www.scielo.br/scielo. php?script=sci_arttext\&pid=S0034-76122007000200005\&lng=en \&nrm=iso. Acesso em: 18 set. 2019.

RIZZO, H. B.; GALLARDO, A. L. C. F.; MORETTO, E. M.. Avaliação ambiental estratégica e planejamento do setor de transportes paulista. Engenharia Sanitária e Ambiental, v. 22, n. 6, p. 1085-1094, 2017. Disponível em: http://www.scielo.br/scielo.php?script=sci_abstract\&pid=S141341522017000601085\&lng=e n\&nrm=iso\&tlng=pt. Acesso em 15 out. 2019.

RODOVALHO, M. O. Análise do Planejamento Urbano e Efetividade dos Planos Diretores de Goiânia. 2008. 75f. Dissertação (Mestrado em Desenvolvimento e Planejamento Territorial) Universidade Católica de Goiás, Goiânia, 2008.Disponível em: http://tede2.pucgoias.edu.br:8080/ handle/tede/2859. Acesso em: 14 set. 2019.

SÁNCHEZ, Luis Enrique. Por que não avança a avaliação ambiental estratégica no Brasil? Estud. av., São Paulo, v. 31, n. 89, p. 167-183, Abr. 2017. Disponível em http://www.scielo.br/scielo.php?script=sci_ arttext\&pid=S0103-40142017000100167\&lng=en \&nrm=iso. Acesso em: 10 out. 2019.

SILVA, Clarinda Aparecida da; ALMEIDA, Maria Geralda de. Goiânia (s): Uma discussão sobre representações sociais e identidades conferidas à capital goiana. 2010. Disponível em: https:// repositorio.bc.ufg.br/xmlui/handle/ri/199. Acesso em: 27 nov. 2019.

TAKEDA, Tatiana. Uso e ocupação do solo urbano. JurisWay, 2013. Disponível em: https://www. jurisway.org.br/v2/dhall.asp?id_dh=12363. Acesso em: 27 set. 2019. 


\section{CAPÍTULO 4}

\section{LEVANTAMENTO E ANÁLISE DO ORDENAMENTO JURÍDICO ACERCA DA CAPTACCÃO DE ÁGUAS PLUVIAIS NO BRASIL COM FOCO NAS REGIÕES SUDESTE E SUL}

Data de aceite: 04/01/2021

Jordana dos Anjos Xavier

Universidade do Estado de Santa Catarina

(UDESC)

Lages - SC

http://lattes.cnpq.br/1562975042294996

Emili Louise Diconcili Schutz

Universidade do Estado de Santa Catarina

(UDESC)

Lages - SC

http://lattes.cnpq.br/9885898209240091

Nicole Martins Pessoa

Universidade do Estado de Santa Catarina

(UDESC)

Lages - SC

http://lattes.cnpq.br/9072929403521441

Daniely Neckel Rosini

Universidade do Estado de Santa Catarina

(UDESC)

Lages - SC

http://lattes.cnpq.br/1290138248832119

Débora Cristina Correia Cardoso

Universidade do Estado de Santa Catarina

(UDESC)

Lages - SC

http://lattes.cnpq.br/2767570871721905

Valter Antonio Becegato

Universidade do Estado de Santa Catarina

(UDESC)

Lages - SC

http://lattes.cnpq.br/3196823526572670
Vitor Rodolfo Becegato

Universidade do Estado de Santa Catarina

(UDESC)

Lages - SC

http://lattes.cnpq.br/7642634231071974

Alexandre Tadeu Paulino

Universidade do Estado de Santa Catarina

(UDESC)

Pinhalzinho - SC

http://lattes.cnpq.br/8957379372810063

Natália Martins Vieira

Universidade do Planalto Catarinense

(UNIPLAC)

Lages - SC

RESUMO: Estima-se que mais da metade da população mundial reside em área urbana, porém a ocupação realizada sem planejamento ou fiscalização é responsável por danos ao meio ambiente e à população. No Brasil, o processo de antropização nas cidades se dá de forma acelerada e sem acompanhamento adequado, o que resulta na ocorrência de catástrofes naturais, pois a impermeabilização do solo influencia na hidrologia local, culminando em inundações e alagamentos. Dessa forma, a adoção de um planejamento aliado a técnicas sustentáveis de drenagem urbana é capaz de reduzir os impactos promovidos pela impermeabilização do solo, juntamente com a fiscalização. Além disso, a utilização de sistemas individuais, como a captação da água da chuva, consiste em uma prática bastante incentivada em vista da capacidade de retardar a chegada dos volumes 
provenientes das precipitações até os corpos hídricos. Nesse sentido, o presente trabalho objetivou analisar as legislações federais, estaduais e municipais acerca da captação pluvial, com foco nas regiões sudeste e sul Brasil. Observou-se que o ordenamento jurídico no Brasil a respeito do desenvolvimento das cidades com aplicação de medidas compensatórias acontece de maneira corretiva e não preventiva, isto é, cidades como Curitiba, São Paulo, Rio de Janeiro implantaram as técnicas compensatórias após sofrerem os efeitos da urbanização, e municípios menores que sofrem constantemente com inundações também carecem de legislação para mitigar os impactos da impermeabilização desordenada. Constata-se assim, a falta de especificidade das legislações, principalmente de uma normativa que sirva como base às legislações estaduais e municipais, e a importância da presença de um agente especializado no assunto para elaboração das leis.

PALAVRAS-CHAVE: Drenagem urbana. Legislações. Captação pluvial. Urbanização. Inundações.

ABSTRACT: It is estimated that more than half of the world population resides in urban areas, but the occupation carried out without planning or inspection is responsible for damage to the environment and the population. In Brazil, the anthropization process in cities takes place in an accelerated manner and without adequate monitoring, resulting in the occurrence of natural disasters, as the impermeabilization of the soil influences local hydrology, culminating in floods. Thus, the adoption of a planning allied to sustainable urban drainage techniques is capable of reducing the impacts caused by soil impermeabilization, along with fiscalization. In addition, the use of individual systems, such as rainwater harvesting, is a highly encouraged practice due to the ability of delaying the arrival of volumes from rainfalls into water bodies. In this sense, the objective was to evaluate the laws regarding issues related to rainwater harvesting. It was observed that the legal system in Brazil regarding the development of cities with the application of compensatory measures happens in a corrective and non-preventive way, that is, cities like Curitiba, São Paulo and Rio de Janeiro implemented the compensatory techniques after suffering the consequences of urbanization, and smaller municipalities that constantly suffer from floods also have no laws to mitigate the impacts of disordered impermeabilization. Thus, there is a lack of specificity in legislation, especially of a regulation that serves as a basis for state and municipal laws, and the importance of the presence of an agent specialized in the subject in the drafting of laws.

KEYWORDS: Urban drainage. Legislation. Rainwater harvesting. Urbanization. Floods.

\section{I INTRODUÇÃO}

As áreas urbanas surgiram a partir do povoamento em zonas próximas aos rios, pela necessidade de utilização dos corpos d'água para fins alimentícios, de higiene e transporte (CANHOLI, 2014). De acordo com o Centro Regional de Informações das Nações Unidas (UNRIC) (2019) estimou-se que 55\% da população mundial reside em área urbana, e ainda se prevê que no ano de 2050 a população urbana seja correspondente a $70 \%$ da população mundial.

No entanto, a ocupação do solo urbano, quando realizada sem planejamento ou fiscalização, é responsável pelos danos causados ao meio ambiente e principalmente 
responsável pelos prejuízos causados à população, uma vez que a apropriação de áreas de risco ou inadequadas para moradia é a maior causadora de males visíveis aos habitantes (GRANDE et al., 2014). Ainda, tem-se observado que o acelerado processo de antropização das cidades brasileiras não é acompanhado de um planejamento ambiental adequado, visto que é constante a ocorrência de catástrofes naturais, como as enchentes, que podem estar associadas a problemas preliminares de uso inadequado do solo urbano (BRASIL, 2016).

A impermeabilização do solo exerce influência direta na hidrologia local, já que através dela ocorre a redução da infiltração das vazões provenientes da precipitação. Como consequência têm-se o aumento dos picos de vazão de cheia, a diminuição no tempo de concentração e o aumento do volume de escoamento superficial, culminando então em inundações e alagamentos (ARAGÃO, 2012). Contudo, as cidades são construídas a partir de processos sociais e econômicos, que caminham em paralelo com as transformações espaciais ao longo do tempo. Assim, o aumento da urbanização levou a um aumento das áreas impermeabilizadas, e como consequência, o ciclo hidrológico natural sofreu alterações significativas (GONÇALVES, BAPTISTA, RIBEIRO, 2016).

O planejamento do sistema urbano atual adotado pela maioria das cidades cria unidades artificiais de relevo, e as alterações na composição do material e das propriedades de superfícies são apontadas como os principais fatores influenciadores nas funções de retenção de água, desencadeando a ocorrência das inundações urbanas (SHI et al., 2016). A adoção dessa abordagem no planejamento das cidades resulta em um distanciamento do desenvolvimento sustentável dos sistemas de drenagem urbanos, pois os cursos d'água na ocupação do espaço foram ignorados, ocasionando os problemas de alagamentos e inundações atuais (SOUZA, 2013).

Entretanto, Gonçalves, Baptista e Ribeiro (2016) afirmam que a maneira de reduzir os impactos promovidos pela impermeabilização do solo é a adoção de um planejamento aliado a técnicas sustentáveis de drenagem urbana, que estimulem a permanência de áreas com cobertura vegetal a fim de possibilitar o escoamento natural das águas. Assim sendo, a captação da água da chuva, alternativa já implantada em muitos países, é uma prática bastante incentivada em vista da capacidade de retardar a chegada dos volumes provenientes das precipitações até os corpos hídricos evitando a ocorrência de extravasamentos dos rios e ainda aumentando o tempo de concentração que fora diminuído durante o processo de urbanização (ZAHMATKESH et al. 2015; ZAVALA; PRIETO; ROJAS, 2018; MOLAEl et al., 2018). Segundo os autores, este armazenamento pode ocorrer em variadas configurações, como por exemplo cisternas, pavimentos permeáveis e dispositivos com camadas filtrantes e de vegetação conhecidos como jardins de chuva, entretanto, tais sistemas precisam ser adotados de acordo com a funcionalidade pretendida e se adequarem às características do local a serem implantados.

Diante do exposto, percebe-se a importância da fiscalização através de políticas 
públicas que estabeleçam parâmetros de forma a nortear os habitantes a respeito do uso adequado do solo (XAVIER et al., 2020). Dessa forma, o presente trabalho tem como objetivo analisar as legislações federais, estaduais e municipais, das regiões sudeste e sul do Brasil, com foco maior em municípios da região sul, que permeiam questões relacionadas a captação da água da chuva.

\section{I RESULTADOS E DISCUSSÃO}

\subsection{Ordenamento jurídico federal}

No Brasil, não há lei federal com diretrizes para captação pluvial, apenas projetos de leis. Em vista disso, tal atividade é pungida por legislações municipais que visam atenuar problemas de escassez e a ocorrência de enchentes e inundações, como no caso da região semiárida e do centro-oeste e sul do país. No entanto, em abril de 2012 foi instituída a lei federal $n^{\circ}$ 12.608, que trata da criação da Política Nacional de Proteção e Defesa Civil (PNPDEC), a qual delineia basicamente a redução dos riscos de desastres, prestação de assistência às populações atingidas por desastres, estimulação ao ordenamento da ocupação do solo urbano e rural, entre outras questões (BRASIL, 2012a). Entretanto, a lei não aborda as medidas propriamente ditas para sanar tais pontos por eles mesmos levantados, isto é, a lei dita responsabilidade que cabe ao Município, Estado e à União no sentido de instituir normas, promover estudos e realizar monitoramentos e não impõe de fato que os órgãos públicos devem criar legislações efetivas e rígidas que atuem nos originadores dos transtornos.

Em junho de 2012 foi apresentado o projeto de lei $n^{\circ} 4.109$ que pretende instituir o programa nacional de conservação, uso racional e reaproveitamento das águas no qual prevê em seu capítulo III as ações de reaproveitamento das águas que essencialmente trata da captação, o armazenamento e a utilização de águas servidas e águas das chuvas. Contudo o documento não regulamenta os parâmetros e procedimentos para dimensionamento ou ainda se as medidas estabelecidas devem ser adotadas por toda e qualquer nova edificação (BRASIL, 2012b). O projeto de lei ainda se encontra em tramitação, aguardando apreciação pelo Senado Federal.

Ainda tratando de projetos de leis apresentados pelos deputados federais, foi apresentado em 2014 pelo deputado Geraldo Resende o projeto de lei $\mathrm{n}^{\circ}$ 7.818, que objetiva estabelecer a política de captação, armazenamento e aproveitamento de águas pluviais, no qual determina no artigo quinto a obrigatoriedade para implantar o sistema de captação e aproveitamento de águas das chuvas nos seguintes casos:

I - Os empreendimentos, cuja construção e manutenção provoquem a impermeabilização do solo em área superior a mil metros quadrados e os empreendimentos que envolvam parcelamento do solo para fins urbanos e os 
a) município com mais de 100 (cem) mil habitantes;

b) município com histórico de problemas de enchentes associadas à excessiva impermeabilização do solo, comprovados por Avaliação de Danos da Defesa Civil;

c) municípios que integrem região metropolitana ou aglomeração urbana, instituídas por lei complementar estadual;

d) município com histórico de seca, comprovados por Avaliação de Danos da Defesa Civil;

II - As edificações que tenham consumo de volume igual ou superior a 20.000 (vinte mil) litros de água por dia;

III - os edifícios e os empreendimentos públicos (BRASIL, 2014).

O projeto de lei $n^{\circ} 7.818$ ainda dispõe que os municípios com população maior de cem mil habitantes devem necessariamente produzir plano de manejo e drenagem de águas pluviais, e determina que o plano citado deve estar em harmonia com os planos de recursos hídricos das bacias hidrográficas, o qual deve compreender a caracterização do índice pluviométrico da área ou região, mapeamento do lençol freático, avaliação da capacidade de escoamento, identificação de locais passíveis de constituírem como reservatórios, entre outros (BRASIL, 2014). O projeto em questão aguarda o parecer do Relator na Comissão de Desenvolvimento Urbano.

O projeto de lei $n^{\circ} 324$ que está em tramitação desde 2015, pretende instituir que toda nova construção independente da sua destinação, ou seja, comercial, residencial, industrial, público ou privada, deve conter no projeto técnico da obra o item referente a captação e aproveitamento de águas pluviais assim como a destinação do recurso para fins não consuntivos. O documento traz como justificativa para implantação do até então projeto de lei, entre outros dados, a estatística de que cerca de $40 \%$ da população do planeta Terra viva hoje algum tipo de estresse hídrico, e vai além quando divulga que segundo o relatório das Nações Unidas publicado em 2015 as reservas hídricas do mundo podem ter seu volume reduzido em $40 \%$ até 2030 e com isso argumenta a necessidade da gestão deste recurso (BRASIL, 2015).

O Plano Nacional de Recursos Hídricos (PNRH), estabelecido pela lei $n^{\circ}$ 9.433, de 8 de janeiro de 1997, é um dos instrumentos que orienta a gestão integrada das águas no Brasil. Quando se trata de água da chuva, nele consta o programa "Um milhão de Cisternas e "Uma Terra, duas águas", os quais visam incentivar a captação e armazenamento de 
água da chuva para fins agrícolas, complementando o abastecimento para fins de consumo humano (BRASIL, 1997; MENDONÇA, 2006). Apesar de estimular o uso da água pluvial e de áreas urbanas com cobertura vegetal a fim de evitar enchentes, o plano não conta com metas para promover tais ações. (TESTON et al, 2018).

Para o dimensionamento dos sistemas de captação de água da chuva, a Associação Brasileira de Normas Técnicas detém algumas normas que, apesar de não serem consideradas um instrumento legal, são utilizadas como referência aos projetos, como é o caso das NBR's n's: 10.844/1989, 5.626/1998, 15.527/2007 e 5.688/2010, as quais dispõem sobre os requisitos para aproveitamento pluvial de coberturas em áreas urbanas para fins não potáveis, dos requisitos para tubos e conexões de sistemas prediais de água pluvial, esgoto sanitário e ventilação, da instalações prediais de águas pluviais e da instalação Predial de água fria, respectivamente (ASSOCIAÇÃO BRASILEIRA DE NORMAS TÉCNICAS, 1989, 1998, 2007, 2010).

Segundo Silva e Borja (2017), tecnicamente a NBR n 15.527/2007 demonstra algumas incoerências com a literatura, como a não obrigatoriedade de instalação de um desvio automático dos primeiros milímetros de chuva e o quesito de 0,5mg/L a 3,0mg/L de cloro residual livre em casos de desinfecção, sendo que a Portaria do Ministério da Saúde (MS) $\mathrm{n}^{\circ} 2.914 / 11$ recomenda que o teor máximo de cloro residual livre seja de $2 \mathrm{mg} / \mathrm{L}$ (BRASIL, 2011). Ainda, não especifica quais são os usos restritivos quando se trata ao destes usos não potáveis (ASSOCIAÇÃO BRASILEIRA DE NORMAS TÉCNICAS, 2007).

\subsection{Ordenamento jurídico estadual e municipal}

\subsubsection{Região sudeste do Brasil}

Quando se trata das legislações municipais, a primeira referente ao tema é datada de 2002, no município de São Paulo, cuja prefeitura municipal sancionou a lei $n^{\circ} 13.276$, de 05 de janeiro de 2002, obrigando a execução de reservatório para captação de águas coletadas por área impermeabilizada superior a $500 \mathrm{~m}^{2}$, ou seja, telhados, coberturas, calçadas, etc., nos lotes edificados ou não. Tal medida busca evitar o escoamento instantâneo das águas pluviais para a rede coletora, isso porque a canalização diminui substancialmente o tempo de concentração e transfere o problema das inundações a jusante (SÃO PAULO, 2002a).

Cinco anos após a implantação da lei municipal, o estado de São Paulo sancionou a lei $n^{\circ}$ 12.526, de 02 de janeiro de 2007, a qual estabelece normas para a contenção de enchentes e destinação de águas pluviais. Os objetivos desta lei consistem na redução da velocidade do escoamento destas águas para as bacias hidrográficas, no controle das ocorrências de inundações e na contribuição para a redução do consumo e o uso adequado da água potável tratada (SÃO PAULO, 2007). Ressalta-se as semelhanças entre as diretrizes da lei do estado de São Paulo com a lei municipal, a qual possivelmente serviu como norma balizadora. 
Entre as medidas ordenadas pela lei $\mathrm{n}^{\circ} 12.526 / 07$, o artigo primeiro estabelece a implantação de sistema para a captação e retenção de águas pluviais em locais com áreas impermeabilizadas superiores a $500 \mathrm{~m}^{2}$, edificados ou não. Este tipo de medida se caracteriza como uma maneira elementar e eficiente no controle de problemas oriundos de uma má drenagem urbana e alta vazão pluvial, visto que a conscientização pela população ocorrerá com o tempo, propiciando o aceite a obras e projetos com a ideia da permeabilidade intrínseca (SÃO PAULO, 2007).

Em 2015, o município de São Paulo estabeleceu ainda a lei $n^{\circ} 16.174$, de 22 de abril, a qual estabeleceu a prioridade quanto ao reuso de águas pluviais em aplicações urbanas que não requeiram água potável, e em obras e serviços executados com mão de obra própria ou contratados, como lavagem de ruas, calçadas, praças públicas, monumentos, túneis, pátios e estacionamentos de próprios municipais e outros logradouros, desobstrução/ limpeza de galerias de águas pluviais, bueiros, bocas de lobo e piscinões, operações de rescaldo após incêndios realizadas por bombeiros, entre outros (SÃO PAULO, 2015).

Ainda no estado de São Paulo, a prefeitura de Mauá em 29 de outubro de 2002 estabeleceu a lei $n^{\circ} 3.528$, a qual impõe como pré-requisito para obtenção do alvará e/ou habite-se que toda edificação de obras ou ampliações as quais impermeabilizem área igual ou superior a $500 \mathrm{~m}^{2}$ detenham obrigatoriamente reservatório para acumulação das águas pluviais. A lei estabelece ainda o método de cálculo que deve ser utilizado para determinar a capacidade mínima que o reservatório deve possuir. É sugerido que a água contida pelo reservatório preferencialmente seja conduzida para infiltrar-se no solo, mas tal proposta cabe ao proprietário da edificação a decisão, assim como a escolha da utilização da água para fins não potáveis (SÃO PAULO, 2002b).

De acordo com este mesmo viés, o estado do Rio de Janeiro sancionou a lei $n^{\circ}$ 4.393, em 16 de setembro de 2004, a qual determina a obrigatoriedade às empresas de construção civil e projetistas a adoção de edificações, tanto para fins residenciais quanto comerciais, com dispositivos para captação de água da chuva. É imprescindível relatar que tal medida cabe apenas para empreendimentos comerciais com área construída superior a $50 \mathrm{~m}^{2}$ e empreendimentos residenciais que abriguem mais de cinquenta famílias. A lei determina que os empreendimentos que se enquadrem nas especificações citadas disponham de coletores, caixa de armazenamento e distribuidores do recurso captado, porém, não fica estabelecido pela lei o método de cálculo que deve ser seguido para o dimensionamento dos dispositivos (RIO DE JANEIRO, 2004).

\subsubsection{Região sul do Brasil}

Abordando mais especificamente a região sul do país, Curitiba-PR, que assim como a grande maioria das metrópoles do Brasil, sofre com problemas de inundações, criou em 18 de setembro de 2003 a lei $n^{\circ} 10.785$, que instituiu o Programa de Conservação e Uso 
Racional da Água nas Edificações (PURAE). O objetivo principal do programa consiste na preservação da água, porém de maneira indireta interfere nas razões das inundações já que a mesma dita o uso de cisternas para o armazenamento da água da chuva e sua utilização para fins que não requeiram o uso de água tratada, como rega de jardins e hortas, lavagem de roupa, lavagem de calçadas, veículos, etc., e induz as novas edificações à utilização de fontes alternativas para captação de água bem como a conscientização dos usuários sobre a importância da conservação desta (CURITIBA, 2003).

Visando uma maior efetividade na contenção de inundações, o município em questão publicou o decreto $n^{\circ} 293$, de 22 de março de 2006, que regulamentou a lei $n^{\circ} 10.785 / 03$ sobre os parâmetros da conservação e uso racional da água nas edificações. A partir desse decreto, tornou-se obrigatório a apresentação junto aos órgãos responsáveis municipais, para a obtenção do licenciamento de construção, nos projetos de instalações hidráulicas, toda a estrutura necessária para a implantação do sistema de captação das águas pluviais nas coberturas das edificações, e estabeleceu ainda a exigência do armazenamento para posterior uso das águas em fins que não exijam água tratada (CURITIBA, 2006).

A cidade de Porto Alegre no Estado do Rio Grande do Sul, instituiu em 05 de agosto de 2008 a lei $n^{\circ} 10.506$, que estabelece o programa de conservação, uso racional e reaproveitamento das águas, e determinou a obrigatoriedade de novas edificações possuírem um sistema de captação e reaproveitamento das águas provenientes das chuvas e das águas servidas. A lei vai além e aborda também a conservação e uso racional da água em que exige, dentre outras medidas o controle da ocupação urbana, o controle da poluição de córregos, rios e lagos, e educação ambiental para evitar a poluição e o desperdício (PORTO ALEGRE, 2008).

É sabido que Santa Catarina sofre severamente com inundações e a partir disso estabeleceu-se o decreto estadual nº 099 em 01 de março de 2007, o qual tornou obrigatório todas as construções novas e reformas de edificações públicas dispor de sistema de captação de águas pluviais, coletadas por pavimentos descobertos, terraços, coberturas e telhados. Tal medida também enquadra todas as construções privadas que usufruíram ou usufruem de incentivos ou financiamentos de órgãos do governo do Estado. O decreto estabelece ainda que é incumbência da Fundação de apoio à Pesquisa Científica e Tecnologia do Estado de Santa Catarina (FAPESC), estimular e apoiar pesquisas que objetivem a busca de soluções de prospecção, preservação e conservação de fontes de águas superficiais e subterrâneas (SANTA CATARINA, 2007).

$\mathrm{Na}$ capital do Estado de Santa Catarina, Florianópolis, em 02 de junho de 2016 entrou em vigor a lei complementar $n^{\circ} 561$, que incluiu no código de obras do município a obrigatoriedade para novas edificações com área superior a $200 \mathrm{~m}^{2}$, a apresentação do projeto de sistema de captação, armazenamento e utilização das águas das chuvas, apresentando ainda instrução de que o recurso captado deve ser submetido a tratamento sanitário para que possa ser utilizado para finalidades não potáveis. Contudo, a legislação 
não trata de que modo deve ser dimensionado o sistema bem como os materiais a serem empregados e afins (FLORIANÓPOLIS, 2016).

Em 07 de abril de 2008 criou-se, no município de São José-SC, localizado na Grande Florianópolis, a lei $n^{\circ} 4.625$ que criou o sistema de reuso de água de chuva para utilização não potável. Tal medida cabe à edificações públicas, clubes, conjuntos habitacionais, condomínios, imóveis residenciais, comerciais e industriais com áreas acima de $200 \mathrm{~m}^{2}$, visando a contenção de enchentes, redução de consumo de água pública, redução do consumo de água potável para fins onde a utilização poderia ser substituída para águas oriundas da captação pluvial, entre outros. A lei preconiza ainda que o sistema de captação deve coletar água provinda dos telhados, terraços, coberturas e pavimentos descobertos (SÃO JOSÉ, 2008).

A mais recente lei $n^{\circ} 4.631$ de 2018,em vigor dessa natureza em Palhoça-SC, que de maneira vaga e superficial estabelece a política municipal de captação, armazenamento e aproveitamento de águas pluviais, com o intuito de melhor utilizar as águas no município. Em 2019 acrescentou-se um dispositivo à lei, o qual, em seu Art. 5º, determina que a implantação de sistema de captação e armazenamento de água pluvial para o reuso, na edificação vertical ou horizontal, construída com área superior a $1000 \mathrm{~m}^{2}$ é obrigatória, e cuja comprovação da eficiência do funcionamento é requisito para a expedição do habitese (PALHOÇA, 2018).

No município de Criciúma-SC a lei $n^{\circ} 7.160$ de 2018, criou o Programa de Conservação e Uso Racional da Água nas Edificações Públicas e Privadas do município. A lei estabelece que as entidades da administração pública devem dispor de coletores, caixas de armazenamento e distribuidores para os recursos pluviais em todas as construções e projetos de edificações públicas. Uma particularidade interessante é que seu artigo oitavo regulamenta os casos de locação de imóveis pela prefeitura municipal, onde trata que deve ser priorizado edificações que estejam de acordo com as normas definidas na lei (CRICIÚMA, 2018).

Em alguns casos a legislação é mais rígida, como exemplo a lei $n^{\circ} 324$ de 2008 do município de Chapecó-SC, que dispõe sobre a obrigatoriedade da instalação de sistema para captação pluvial e valas de infiltração. A lei determina que toda edificação unifamiliar superior a $150 \mathrm{~m}^{2}$ deve obrigatoriamente construir mecanismos para coleta, reserva e infiltração de águas pluviais a que tem posse, bem como as edificações multifamiliares ou comerciais de qualquer área. A lei não somente preconiza sobre a captação pluvial, como também delineia diretrizes para destinação de áreas para infiltração das águas captadas se não forem utilizadas pelo cidadão, como cita o trecho:

É obrigatório o destino de uma área igual a 30\% da diferença entre a área do terreno e a área resultante da taxa de ocupação, para a infiltração das águas pluviais. Para atender o percentual indicado acima podem ser utilizados os seguintes meios: canteiro de infiltração; pátios gramados ou 
britados e/ou outros meios, desde que permita a percolação das águas das chuvas. Deve-se adotar os coeficientes de percolação do solo utilizados nos dimensionamentos de unidades de infiltração (CHAPECÓ, 2008).

O município de Blumenau-SC localizado na mesorregião do Vale do Itajaí do estado de Santa Catarina aprovou a lei complementar $n^{\circ} 691$ de 2008, que concebeu o programa de conservação e uso racional de água. Esta determina que as novas edificações de uso não residencial com área construída superior a $750 \mathrm{~m}^{2}$ devem conter bacias sanitárias com volume reduzido de descarga, torneiras equipadas com arejadores, lavatórios e chuveiros com volumes fixos de disparo e sistema de captação pluvial (BLUMENAU, 2008). Baseandose em legislações desse mesmo sentido considera-se a medida branda e pouco efetiva, já que é conhecido que o município de Blumenau sofre com inundações em sua maioria motivados pelo transbordamento do rio Itajaí-açu, principal rio que corta a cidade.

Em Lages-SC o projeto de lei $n^{\circ} 064$ de 2017, que preconizava a fundação do programa de captação e aproveitamento de água de chuva para fins não potáveis. Destacase o Art. $5^{\circ}$, o qual prevê:

A captação de água de chuva será obrigatória em todas as edificações, inferiores a três andares sejam elas residenciais, comerciais, industriais e públicas, inclusive quando se tratar de edificações de interesse social, com área total construída igual ou superior a $300 \mathrm{~m}^{2}$ (LAGES, 2017).

No entanto o projeto foi arquivado em setembro de 2017 conforme consta no site da câmara de vereadores de Lages-SC (LAGES, 2017). O município ainda não aprovou nenhuma legislação que vise minimizar os efeitos da impermeabilização descontrolada que a cidade sofre. É incontestável que o projeto de lei $n^{\circ} 064$ tem seus objetivos pautados acerca da conservação, qualidade ambiental e estímulo do reuso do recurso, e não visando propriamente o controle dos problemas que o sistema de drenagem existente é capaz de suprir. Entretanto, um fator é intrínseco a outro, e se tratando de crescimento urbano e do cenário em que o município se encontra, Lages carece de medidas que venham, de maneira ordenada, regulamentar e educar a população sobre os ônus decorrentes de atitudes ambientalmente inadequadas.

O município de Lages conta com leis e decretos que atuam no auxílio e reabilitação da população e não propriamente na causa que a origina. A exemplo disso a lei $n^{\circ} 428$ de 2013, que institui a Coordenadoria Municipal de Proteção e Defesa Civil (COMPDECLAGES). Esta consiste em um órgão integrante do Sistema Nacional da Defesa Civil e traz como seus objetivos a prevenção dos desastres, preparação e mitigação para emergências e desastres, respostas aos desastres e a reconstrução e recuperação (LAGES, 2013). Observa-se que a lei possui foco especialmente voltado ao restabelecimento da parte afetada e não a sua origem.

Têm-se ainda em Lages a lei $n^{\circ} 4.149$ de 2016, que concede isenção do Imposto Predial e Territorial Urbano (IPTU) aos proprietários de imóveis localizados em áreas que 
foram atingidas pelos alagamentos, enchentes e enxurradas ocasionadas pelas chuvas ocorridas a partir de 2015 (LAGES, 2016). Sendo assim, com tais medidas criadas pela Prefeitura Municipal de Lages, a cidade mantém-se nesse processo de recuperação a cada novo desastre que, para os parâmetros atuais, é considerada uma metodologia retrógrada e ímpio para com a população diretamente afetada.

\section{3। CONCLUSÃO}

O ordenamento jurídico no Brasil a respeito do desenvolvimento das cidades com aplicação de medidas compensatórias acontece de maneira corretiva e não preventiva, isto é, cidades como Curitiba, São Paulo e Rio de Janeiro implantaram as técnicas compensatórias após sofrerem os efeitos da urbanização.

Alegislação brasileira acerca da captação pluvial é recente e carece de especificidade em muitos casos. A ausência de uma legislação balizadora com diretrizes e critérios bem definidos acarreta em leis municipais distintas, algumas mais rígidas enquanto outras são mais permissíveis e superficiais.

Constata-se também, a importância do auxílio de uma equipe com pessoal especializado em temas de drenagem urbana, hidrografia, engenharia e afins para a definição de leis íntegras, que contemplem todas as informações essenciais à implantação dos projetos de captação pluvial.

\section{AGRADECIMENTOS}

À UNIEDU (Programa de Bolsas Universitárias de Santa Catarina) e à CAPES (Coordenação de Aperfeiçoamento de Pessoal de Nível Superior) pela concessão das bolsas de estudos.

\section{REFERÊNCIAS}

ARAGÃO, R. Análise da influência da mata ciliar na bacia do rio Japaratuba-mirim, Sergipe, sobre o escoamento superficial e produção de sedimentos simulados com o modelo Swat. In: Embrapa Tabuleiros Costeiros-Artigo em anais de congresso (ALICE). SIMPÓSIO BRASILEIRO DE RECURSOS HÍDRICOS, 20., 2013, Bento Gonçalves. Água desenvolvimento econômico e socioambiental: anais. Bento Gonçalves, RS: ABRH, 2013., 2012.

ASSOCIAÇÃO BRASILEIRA DE NORMAS TÉCNICAS. NBR 10.844: Instalações prediais de águas pluviais. Rio de Janeiro. 1989.

ASSOCIAÇÃO BRASILEIRA DE NORMAS TÉCNICAS. NBR 5.626: Instalação predial de água fria. Rio de Janeiro. 1998.

ASSOCIAÇÃO BRASILEIRA DE NORMAS TÉCNICAS. NBR 15.527: Água de chuva -Aproveitamento de coberturas em áreas urbanas para fins não potáveis - Requisitos. Rio de Janeiro. 2007. 
ASSOCIAÇÃO BRASILEIRA DE NORMAS TÉCNICAS. NBR 5.688: Tubos e conexões de PVC-U, para sistemas prediais de água pluvial, esgoto sanitário e ventilação - Requisitos. Rio de Janeiro. 2010.

BLUMENAU (Município). Lei Complementar $n^{\circ} 691$, de 29 de setembro de 2008. Institui o programa de conservação e uso racional de água no município de Blumenau. Blumenau, SC.

BRASIL. Lei $\mathbf{n}^{\circ}$ 9.433, de 08 de janeiro de 1997. Institui a Política Nacional de Recursos Hídricos, cria o Sistema Nacional de Gerenciamento de Recursos Hídricos, regulamenta o inciso XIX do art. 21 da Constituição Federal, e altera o art. $1^{\circ}$ da Lei $n^{\circ} 8.001$, de 13 de março de 1990 , que modificou a Lei $n^{\circ}$ 7.990, de 28 de dezembro de 1989. Diário Oficial [da] União, de 09 de janeiro de 1997.

BRASIL. Ministério da Saúde. Gabinete do Ministro. Portaria n 2.914, de 12 de dezembro de 2011. Brasília, 2011.

BRASIL. Lei $\mathbf{n}^{\circ} \mathbf{1 2 . 6 0 8}$, de 10 de abril de 2012a. Institui a política nacional de proteção e defesa civilPNPDEC; dispõe sobre o sistema nacional de proteção e defesa civil-SINPDEC e o Conselho Nacional de Proteção e Defesa Civil-CONPDEC; autoriza a criação de sistema de informações e monitoramento de desastres; altera as Leis nos 12.340 , de $1^{\circ}$ de dezembro de 2010, 10.257, de 10 de julho de 2001 , 6.766, de 19 de dezembro de 1979, 8.239, de 4 de outubro de 1991, e 9.394, de 20 de dezembro de 1996; e dá outras ... Diário Oficial [da] União, v. 70, 2012.

BRASIL. Congresso. Câmara dos Deputados. Projeto de Lei n $^{\circ}$ 4.109, de 26 de junho de 2012b. Institui o Programa Nacional de Conservação, Uso Racional e Reaproveitamento das Águas. Brasília, DF.

BRASIL. Congresso. Câmara dos Deputados. Projeto de Lei $\mathbf{n}^{\circ} \mathbf{7 . 8 1 8}$, de 16 de julho de 2014 . Estabelece a Política Nacional de Captação, Armazenamento e Aproveitamento de Águas Pluviais e define normas gerais para sua promoção. Brasília, DF.

BRASIL. Congresso. Senado. Projeto de Lei ${ }^{\circ}$ 324, de 02 de junho de 2015. Institui obrigatoriedade para as novas construções, residenciais, comerciais, e industriais, público ou privado, a inclusão no projeto técnico da obra, item referente a captação de água da chuva e seu reuso não potável e dá outras providências. Brasília, DF.

BRASIL, J. Contribuições da geomorfologia aplicada no planejamento da drenagem urbana: Estudo de caso no município de Goiânia, Goiás, Brasil. Entre-Lugar, Dourados, v. 7, n. 13, p. 50-64, 2016.

CANHOLI, A. P. Drenagem urbana e controle de enchentes. São Paulo: Oficina de Textos, 2014. 302 p.

CHAPECÓ (Município). Lei $\mathbf{n}^{\circ}$ 324, de 10 de março de 2008. Dispõe sobre a obrigatoriedade de instalação de reservatórios e valas de infiltração para aproveitamento da água da chuva em edificações e dá outras providências, 2012.Chapecó, SC.

CRICIÚMA. Câmara dos Vereadores. Projeto de Lei $\mathbf{n}^{\circ} \mathbf{7 . 1 6 0}$, de 5 de janeiro de 2018. Cria O Programa de Conservação e Uso Racional da Água nas Edificações Públicas e Privadas do Município de Criciúma/SC. Criciúma, SC.

CURITIBA (Município). Decreto $\mathrm{n}^{\circ}$ 293, de 22 de março de 2006. Regulamenta A Lei $\mathrm{N}^{\circ}$ 10.785/03 e dispõe Sobre Os critérios do Uso e conservação Racional da Água nas edificações e DÁ Outras providências. Curitiba, PR. 
CURITIBA (Município). Lei $\mathbf{n}^{\circ} \mathbf{1 0 7 8 5}$, de 18 de setembro de 2003. Ria no município de Curitiba, O Programa de conservação e Uso Racional da Água nas edificações - Purae. Curitiba, PR.

FLORIANÓPOLIS (Município). Lei Complementar $n^{\circ} 561$, de 02 de junho de 2016. Inclui Inciso Ao Art. 25 da Lei Complementar № 60, de 2000 (Código De Obras E Edificações De Florianópolis). Florianópolis, SC.

GONÇALVES, L. M. BAPTISTA, L. F. da S. RIBEIRO, R. A. O uso de técnicas compensatórias de drenagem para controle dos impactos da urbanização. Fórum Ambiental da Alta Paulista, v. 12, n. 1, p. 92-106, 2016.

GRANDE, M. GALVÃO, C. MIRANDA, L. Rufino, I. Environmental equity as a criterion for water management, Proceedings of the International Association of Hydrological Sciences, 364 , 519-525, https://doi.org/10.5194/piahs-364-519-2014, 2014.

LAGES (Município). Lei Complementar $n^{\circ}$ 428, de 27 de novembro de 2013. Institui a coordenadoria municipal de proteção e defesa civil - compdec-lages, o fundo municipal de proteção e defesa civil e conselho municipal de proteção e defesa civil e dá outras providências. Lages, SC.

LAGES (Município). Lei $\mathbf{n}^{\circ}$ 4.149, de 13 de março de 2016. Concede isenção do pagamento do imposto predial e territorial urbano (IPTU), aos proprietários de imóveis localizados em áreas que foram atingidas pelos alagamentos, enchentes e enxurradas ocasionadas pelas chuvas ocorridas a partir do ano de 2015. Lages, SC.

LAGES (Município). Projeto de Lei $\mathbf{n}^{\circ}$ 064, de 11 de julho de 2017. Cria o Programa de Captação e Aproveitamento de Água de Chuva para fins não potáveis e institui sua obrigatoriedade nas edificações localizadas no município de Lages. Lages, SC.

MENDONÇA, M.C. Plano Nacional de Recursos Hídricos. Ministério do Meio Ambiente, Secretaria de Recursos Hídricos: Brasília, 2006.

MOLAEI, O.; KOUCHAKZADEH, M.; FASHI, F. H. Evaluation of rainwater harvesting performance for water supply in cities with cold and semi-arid climate. Water Supply, [S.L.], v. 19, n. 5, p. 1322-1329, 21 dez. 2018. IWA Publishing.

PALHOÇA (Município). Lei $\mathbf{n}^{\circ}$ 4.631, de 27 de junho de 2018. Estabelece A Política Municipal de Captação, Armazenamento e Aproveitamento de águas Pluviais. Palhoça, SC.

PORTO ALEGRE (Município). Lei $\mathbf{n}^{\circ}$ 10506, de 05 de agosto de 2008. Institui o programa de conservação, uso racional e reaproveitamento das águas. Porto Alegre, RS.

RIO DE JANEIRO (Estado). Lei ${ }^{\circ}$ 4393, de 16 de setembro de 2004. Dispõe sobre a obrigatoriedade das empresas projetistas e de construção civil a prover os imóveis residenciais e comerciais de dispositivo para captação de águas da chuva e dá outras providências. Rio de Janeiro, RJ.

SANTA CATARINA (Estado). Decreto n 099, de 01 de março de 2007. Obriga Todas As Obras Públicas,e As Privadas, Financiadas Ou Incentivadas Pelo Governo do Estado de Santa Catarina, Implantar Sistema de Captação e Retenção de águas Pluviais e Estabelece Outras Providências.. Florianópolis, SC. 
SÃO JOSÉ (Município). Lei $\mathbf{n}^{\circ}$ 4.625, de 07 de abril de 20018. Cria o sistema do reuso de água de chuva do município de São José para utilização não potável em edificações públicas, condomínios, clubes, entidades, conjuntos habitacionais e demais imóveis residenciais, industriais e comerciais. São José, SC.

SÃO PAULO (Município). Lei n 13.276, de 04 de janeiro de 2002a. Torna obrigatória a execução de reservatório para as águas coletadas por coberturas e pavimentos nos lotes, edificados ou não, que tenham área impermeabilizada superior a 500m. São Paulo.

SÃO PAULO (Estado). Lei $\mathbf{n}^{\circ} \mathbf{3 . 5 2 8}$, de 29 de outubro de 2002b. Dispõe sobre a obrigatoriedade da execução de reservatório para as águas pluviais coletadas em áreas impermeabilizadas superiores a $500 \mathrm{~m}^{2}$ para novas edificações e dá outras providências. Mauá, SP.

SÃO PAULO (Estado). Lei $\mathbf{n}^{\circ}$ 12.526, de 02 de janeiro de 2007. Estabelece normas para a contenção de enchentes e destinação de águas pluviais. São Paulo, SP.

SÃO PAULO (Município). Lei $\mathbf{n}^{\circ}$ 16.174, de 22 de abril de 2015. Estabelece regramento e medidas para fomento ao reúso de água para aplicações não potáveis, oriundas do polimento do efluente final do tratamento de esgoto, de recuperação de água de chuva, da drenagem de recintos subterrâneos e de rebaixamento de lençol freático e revoga a Lei Municipal $n^{\circ}$ 13.309/2002, no âmbito do Município de São Paulo e dá outras providências. São Paulo.

SHI, D. WENLONG, W. JIANG, G. PENG, X. YU, Y. LI, X. DING, W. Effects of disturbed landforms on the soil water retention function during urbanization process in the Three Gorges Reservoir Region, China. Catena, n. 144, p. 84-93, 2016.

SILVA, A. R; BORJA, P. C. V-152 - Aproveitamento de água de chuva no brasil: avanços e limitações dos aspectos legais. In: Congresso ABES - FENASAN, 2017, São Paulo.

SOUZA, V. C. B. Gestão da drenagem urbana no Brasil: Desafios para a sustentabilidade. Revista Eletrônica de Gestão e Tecnologias Ambientais, v. 1, n. 1, p. 57-72, 2013.

\author{
TESTON, A.; GERALDI, M.S.; COLASIO, B.M.; GHISI, E. Rainwater Harvesting in Buildings in \\ Brazil: A Literature Review. Water, v. 10, n. 471, 2018.
}

UNRIC. Centro Regional de Informação das Nações Unidas. Relatório da ONU mostra população mundial cada vez mais urbanizada, mais de metade vive em zonas urbanizadas ao que se podem juntar 2,5 mil milhões em 2050. 2019. Disponível em: < https://news.un.org/pt/story/2019/02/1660701 >. Acesso em: 21 de outubro de 2020.

XAVIER, J. A. et al. A consolidação das políticas públicas ambientais como uma ferramenta de controle e mitigação dos efeitos causados pela poluição atmosférica no Brasil e no mundo. In: XAVIER, Jordana dos Anjos. Engenharia Sanitária e Ambiental: tecnologias para a sustentabilidade. 5. ed. Ponta Grossa: Atena Editora, 2020. Cap. 1. p. 1-14. Organizador Helenton Carlos da Silva.

ZAVALA, M. A. L.; PRIETO, M. J. C.; ROJAS, C. A. Rainwater harvesting as an alternative for water supply in regions with high water stress. Water Supply, [S.L.], v. 18, n. 6, p. 1946-1955, 24 jan. 2018. IWA Publishing.

ZAHMATKESH, Z.; BURIAN, S. J.; KARAMOUZ, M.; TAVAKOL-DAVANI, H.; GOHARIAN, E. LowImpact Development Practices to Mitigate Climate Change Effects on Urban Stormwater Runoff: case study of new york city. Journal Of Irrigation And Drainage Engineering, [S.L.], v. 141, n. 1, jan. 2015. American Society of Civil Engineers (ASCE). 


\section{INDICADOR ECONÔMICO FINANCEIRO PARA AVALIAÇÃO DA NECESSIDADE DE REVISÃO TARIFÁRIA EM CONCESSÕES DE ABASTECIMENTO DE ÁGUA E ESGOTAMENTO SANITÁRIO NOS MUNICÍPIOS CATARINENSES}

Data de aceite: 04/01/2021

Data de submissão: 08/12/2020

\section{Daniel Antonio Narzetti}

Doutorando no Instituto Superior Técnico Universidade de Lisboa, Economista pela UFSC, Sócio Consultor da Facilita Assessoria Econômica e Projetos. Florianópolis, Santa Catarina http://lattes.cnpq.br/2819501208330837

Willian Carlos Narzetti

Doutorando na UDESC, Economista pela UFSC, Sócio Consultor da Facilita Assessoria

Econômica e Projetos

Florianópolis, Santa Catarina

http://lattes.cnpq.br/9563331051062998

Ricardo Motta Martins

Engenheiro Sanitarista-Ambiental pela UFSC e Sócio Consultor na Motta Martins Engenharia Florianópolis, Santa Catarina http://lattes.cnpq.br/8102234601969227

\section{Ciro Loureiro Rocha}

Engenheiro Civil e Sanitarista pela Escola de Engenharia da Universidade Federal (RS)

Florianópolis, Santa Catarina http://lattes.cnpq.br/6368602699066461

\section{Diego Pavam Ferreira}

Graduando de Economia na UFSC, Foi estagiário de Regulação da ARIS

Florianópolis, Santa Catarina

RESUMO: Neste artigo foram desenvolvidas as formulações necessárias para obter os resultados esperados para análise e a indicação dos fatores preponderantes para o estabelecimento de prioridades quanto a estruturação de modelagens para a tomada de decisão envolvendo a aplicação de critérios de avaliação da sustentabilidade econômico financeira da prestação de serviços em saneamento básico.

PALAVRAS-CHAVE: Regulação econômica financeira, Indicador de revisão tarifária, Custos, Desempenho.

FINANCIAL ECONOMIC INDICATOR FOR EVALUATING THE NEED FOR FARE REVISION IN WATER SUPPLY AND SANITARY SEWAGE CONCESSIONS IN THE MUNICIPALITIES OF THE STATE OF SANTA CATARINA

ABSTRACT: In this article, the necessary formulations were developed to obtain the expected results for analysis and the indication of the predominant factors for the establishment of priorities regarding the structuring of models for decision making involving the application of criteria for assessing the financial and economic sustainability of service provision in water and sanitation services.

KEYWORDS: Economic and financial regulation, Tariff review indicator, Costs, Performance.

\section{INTRODUÇÃO}

Para atender às suas demandas como regulador, as Agências Reguladoras desenvolvem ferramentas de apoio à tomada de decisão, contemplando questões técnicas de 
engenharia, como acompanhamento de metas físicas dos Planos Municipais de Saneamento Básico - PMSB e metas econômico-financeiras necessárias para a sustentabilidade da operação e dos investimentos previstos. Estas ferramentas possibilitam acompanhar as eficiências técnico-operacionais da prestação dos serviços de saneamento básico ao mesmo tempo em que permitem uma adequação das estruturas tarifárias necessárias, que podem apontar eventual desequilíbrio econômico-financeiro.

A Lei Federal 11.445/2007, conhecida como Lei do Saneamento, traz em seus Artigos 29 a 39, definições e diretrizes para que os serviços de saneamento básico tenham a sustentabilidade econômico-financeira assegurada, sempre que possível, mediante remuneração pela cobrança destes serviços. Evidencia-se a função social do saneamento e a necessidade que estes serviços tenham assegurado sua sustentabilidade econômica para garantir a eficiente prestação dos serviços públicos e a aplicação de tarifas módicas.

Tendo como referência informações obtidas no Sistema Nacional de Informações sobre Saneamento - SNIS, foi desenvolvida uma matriz de análise técnica e econômicofinanceira, que organiza as informações referentes aos custos, despesas, receitas e dados técnicos operacionais por município catarinense, aplicou-se a metodologia apresentada para calcular o indicador de equilíbrio econômico financeiro da prestação de serviço de saneamento básico.

\section{MATERIAIS E MÉTODOS}

A metodologia apresenta uma avaliação econômico-financeira com base nos resultados anuais e por ciclos de revisão tarifária dos serviços de saneamento básico prestados nos municípios. Identifica, através de indicadores, desequilíbrios que apontem, em percentual, a relação da receita total com o custo total, indicando a necessidade de uma revisão da tarifa praticada. Desta forma, têm-se uma ferramenta de uso rápido e dinâmico em que se pode realizar um diagnóstico da real situação da concessão de saneamento quanto à sua sustentabilidade econômico-financeira através das informações disponibilizadas no Sistema Nacional de Informações sobre Saneamento- SNIS.

A despesa anual de serviço é definida através da variável Despesa Total dos Serviços - DTS, pois demonstra o valor dispendido com a manutenção e operação do sistema de saneamento. Por definição, acumula todas as despesas que compõe a prestação do serviço.

O custo total considera, além da DTS, a remuneração dos investimentos realizados com recursos próprios e de terceiros, incluindo a depreciação. Os investimentos não onerosos ou a "fundo perdido" não deverão ser considerados na composição do custo total, mesmo que este componente esteja presente no arranjo que estima a tarifa.

O custo do capital está contemplado na despesa total dos serviços, sendo que para a taxa de remuneração dos investimentos toma-se como base o definido pelo Decreto 
Estadual $N^{\circ} 1.035 / \mathrm{SC}$ de 25 de janeiro de 2008, onde, entre outras deliberações, instituiu a faixa de remuneração sobre os investimentos reconhecidos em até $12 \%$. Neste sentido, a taxa de remuneração do capital quando não estiver definida em contrato ou em Lei específica, deve ser definida com base em indicadores macroeconômicos.

A metodologia tem como referência conceitos consagrados nas bibliografias do setor, bem como as determinações da legislação vigente, disposta na Lei 11.445/2007. Precisamente, em seu Artigo 38, onde define os regramentos para a revisão tarifária.

Com base nos custos, receitas, produtividade e investimentos, devem ser projetados custos futuros de operação e manutenções dos serviços prestados, assim como as receitas tarifárias. Esta última, bem como os investimentos, deve ter como base as projeções já definidas no Plano Municipal de Saneamento básico - PMSB.

Ainda, deve-se ter uma base de dados quanto ao mercado consumidor, ou seja, em saneamento básico é preciso se atentar aos histogramas de consumo por faixas e categorias, conforme a tabela tarifária em vigor. Neste mercado consumidor, é possível trabalhar com as despesas e receitas por metro cúbico produzido, $\mathrm{m}^{3}$ faturado, $\mathrm{m}^{3}$ micromedido ou $\mathrm{m}^{3}$ macromedido, a fim de apresentar parâmetros e indicadores de sustentabilidade financeira, correlacionados à realidade local e com os distintos consumidores. Ainda, as informações utilizadas e os resultados, devem ser confrontadas com os dados levantados nas fiscalizações realizadas pelas agências reguladoras, certificando assim as premissas consideradas.

A partir das informações disponíveis na base de dados do SNIS, pode-se avaliar para o período desejado o equilíbrio econômico-financeiro por município, que na metodologia apresentada é dado pela relação entre a receita total e o custo total ocorrido no período de referência.

Para atingir os resultados almejados, a seguir são apresentadas as definições e equações necessárias.

$$
R T=A T
$$

Onde:

RT: Receita Total (R\$ano)

AT: Arrecadação Total - Valor anual efetivamente arrecadado de todas as receitas operacionais, diretamente nos caixas do prestador de serviços ou por meio de terceiros autorizados (bancos e outros), (R\$/ano).

$$
C T=D T S+R C l
$$

Onde:

CT: Custo Total (R\$/ano) 
DTS: Despesas Totais com os Serviços (DTS): Valor anual total do conjunto das despesas realizadas para a prestação dos serviços, compreendendo Despesas de Exploração (DEX), Despesas com Juros e Encargos das Dívidas (incluindo as despesas decorrentes de variações monetárias e cambiais), Despesas com Depreciação, Amortização do Ativo Diferido e Provisão para Devedores Duvidosos, Despesas Fiscais ou Tributárias não Computadas na DEX, mas que compõem a DTS, além de Outras Despesas com os Serviços (R\$/ano).

RCI: Remuneração do Capital Investido (R\$/ano).

A revisão tarifária avalia os resultados acumulados, em uma série de anos, determinado por ciclos. Sendo assim, um ciclo deve apresentar sustentabilidade no funcionamento (índices de eficiência e de qualidade), no fluxo de caixa (índices econômicos e financeiros) e na ampliação do atendimento (capacidade de desenvolvimento e manutenção).

Para aferir o equilíbrio econômico e financeiro, deve-se, a partir de uma avaliação crítica de produtividade, determinar as relações das receitas com as despesas mais a remuneração do capital investido - $\mathrm{RCl}$. A taxa de remuneração de capital é dada por um coeficiente aqui denominado, Coeficiente de Remuneração de Capital Investido - CRCl. Adota-se, para fins de cálculo nesse estudo, uma taxa de remuneração de $12 \%$ ao ano, sendo a equação de cálculo da remuneração do capital investido apresentada a seguir:

$$
R C I=C R C I \times(C I P+C 01)
$$

Onde:

RCI: Remuneração do Capital Investido (R\$/ano)

CRCI: Coeficiente de Remuneração do Capital Investido (\%/ano)

CIP: Capital Investido pelo Prestador (R\$/ano)

COI: Capital Oneroso Investido (R\$/ano)

A taxa de equilíbrio financeiro no ano se dá pela relação entre a receita total e a soma das despesas totais com a remuneração do capital, uma vez que os valores de depreciação dos ativos já estão computados nas despesas totais. Para avaliar se a tarifa praticada no ano de referência proporciona equilíbrio ao fluxo de caixa, a equação geral de cálculo de equilíbrio econômico-financeiro no ano é apresentada a seguir.

$$
T_{x E \text { quilibrio }}=\left(\frac{R_{\text {Total }}}{\text { DTS }+R C I}\right)-1
$$

Onde:

TxEquilíbrio= Taxa de Equilíbrio financeiro (\%)

RTotal= Receita Total (R\$/ano)

DTS = Despesa Total do Serviço (R\$/ano) 
RCI: Remuneração do capital investido (R\$/ano)

O resultado obtido através do cálculo de avaliação da taxa de equilíbrio econômico financeiro demonstra percentualmente a relação do custo total com a receita total, indicando superávit, equilíbrio ou déficit.

Para avaliar a taxa de equilíbrio em um ciclo, utiliza-se a equação 5, que representa o somatório dos resultados de caixa do ano um até o ano n. Deve-se entender que essa avaliação permite determinar o somatório dos resultados de cada exercício financeiro, não sendo recomendado sua aplicação para períodos maiores que quatro anos.

$$
T_{x \text { Equilibrion }}=\sum_{t \rightarrow 1, n}\left(\left(\frac{R_{\text {Total } t}}{D T S_{t}+R C I_{t}}\right)\right)-1
$$

Essa metodologia foi aplicada para avaliar os últimos quatro anos de concessão dos municípios catarinenses com base nas informações disponibilizadas pelo SNIS (2011-2014). Os resultados anuais serão apresentados a seguir, bem como os resultados acumulados no período denominado ciclo.

\section{PRIMEIRA ETAPA: CLASSIFICAÇÃO E AVALIAÇÃO DOS RESULTADOS HISTÓRICOS}

As informações do sistema de abastecimento de água e de esgotamento sanitário são classificadas por município, por ano, por prestador de serviço, por natureza jurídica, por tipo de serviço, entre outras categorias. Ressalta-se a classificação por tipo de serviço: água, esgoto e água e esgoto, pois pode ter mais de um tipo de serviço por município, fato que ocorre quando há mais de um prestador no mesmo município. Sendo assim, os valores foram calculados em cada município, segmentados por tipo de serviço.

\section{RESULTADOS DA PRIMEIRA ETAPA}

Santa Catarina possui 295 municípios cadastrados no IBGE e, destes, 293 foram analisados neste estudo por possuírem informações cadastradas no SNIS. Os resultados foram calculados para os anos de 2008 a 2014, considerando o tipo de serviço prestado. No ano de 2014, dos 246 municípios que oferecem o serviço de água, apenas 86 deles foram superavitários, enquanto 160 apresentaram déficit financeiro naquele ano. Essa situação também ocorre no serviço de esgoto, no qual dos nove municípios que ofereciam tal serviço isolado, apenas dois eram superavitários. Na prestação de serviço conjunta de água e esgoto, a situação se mostra diferente, sendo que dos 40 municípios analisados, 25 são superavitários enquanto 15 são deficitários, como demonstrado na Tabela 1. 


\begin{tabular}{|l|c|c|c|}
\hline $\begin{array}{c}\text { Taxa de equilibrio } \\
\text { financeiro }\end{array}$ & Água e Esgoto & Água & Esgoto \\
\hline Maior que 0 & 25 & 86 & 2 \\
\hline Menor que 0 & 15 & 160 & 7 \\
\hline Não se aplica & 253 & 47 & 284 \\
\hline
\end{tabular}

Tabela 1: Relação de Municípios por taxa de equilíbrio financeiro em 2014.

Cada município apresenta uma realidade financeira distinta e a Figura 01 ilustra o gráfico de dispersão da taxa de equilíbrio de cada município catarinense em 2014. Pode ser observado também a relação dos três tipos de serviços. Cada ponto representa, por tipo de serviço, um município.

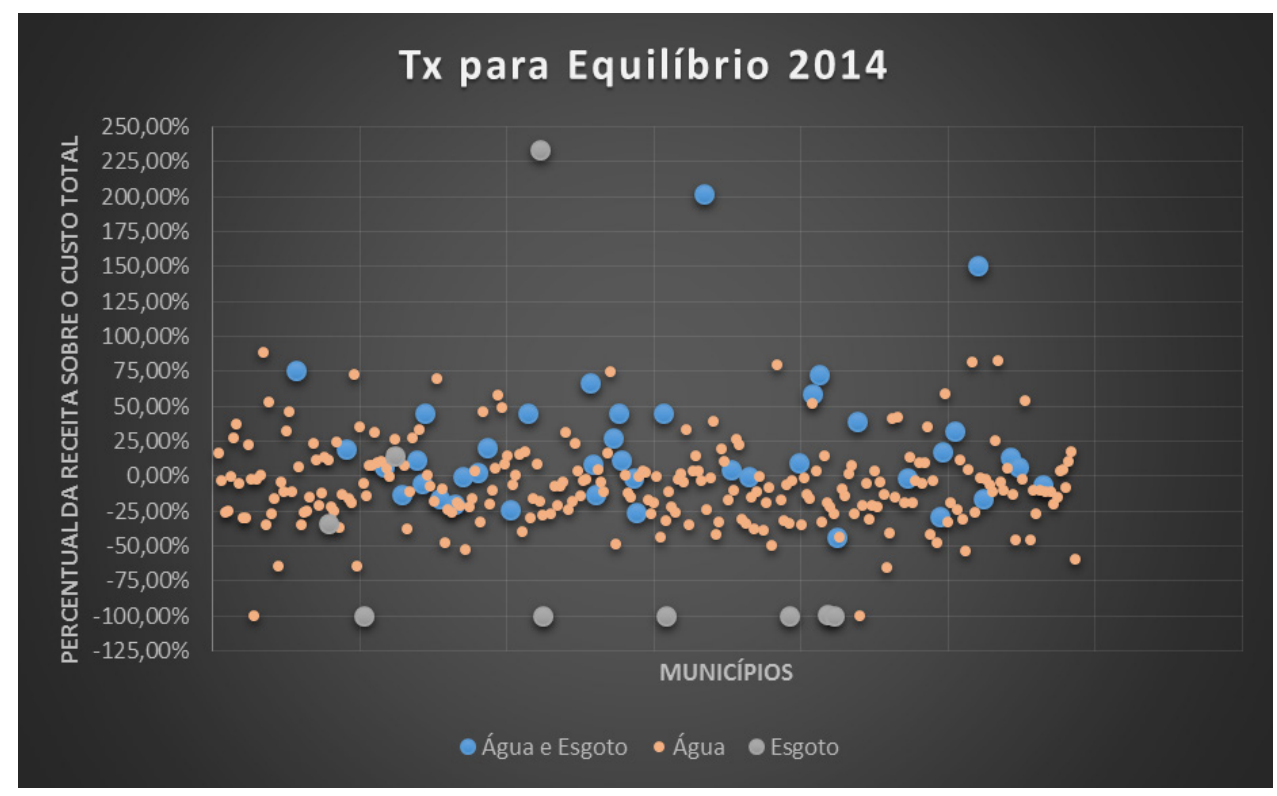

Figura 01 - Taxa de equilíbrio Econômico e Financeiro dos Municípios de Santa Catarina.

Resultados com base nos dados SNIS 2014.

Observa-se na Figura 01 o dimensionamento das informações apresentadas na Tabela 1. A relação entre a receita total e o custo total demonstra o resultado financeiro anual do serviço de saneamento prestado. O resultado deve sempre tender ao equilíbrio, sendo a tarifa o meio de correção da taxa de equilíbrio financeiro.

A situação financeira precisa ser avaliada por períodos, denomindos ciclos. Essa abordagem permite compensar ganhos e perdas exógenos, ou seja, mesmo que em um ano específico o resultado da taxa de equilíbrio seja negativo, quando considerado um ciclo 
composto por um conjunto de anos, a média dos resultados poderá ser positiva.

O período (ciclo) definido e utilizado nesse estudo, para avaliar a média da taxa de equilíbrio, foi de quatro anos, considerando os resultados ocorridos em 2011 a 2014. A prestação de serviço de abastecimento de água, classificado no SNIS como tipo do serviço "água", atende a maioria dos munícipios catarinense. Em menor proporção o atendimento com o serviço conjugado de "água e esgoto" e, em número reduzido, a prestação do serviço apenas de "esgoto".

No período definido, o serviço de água apresenta resultados bastante variados no Estado, onde se identificam 138 municípios deficitários com receita menor que o custo, variando entre $-5 \%$ a $-100 \%$, ou seja, há municípios onde o custo total é o dobro da receita arrecada. Considerando a faixa entre $-4 \%$ e $5 \%$, denominada faixa de equilíbrio, encontramse 36 municípios. Na faixa variando de $6 \%$ a $100 \%$ de receita maior que os custos, somamse 79 municípios, considerados superavitários. A Figura 02, apresenta o mapa do Estado com a distribuição da taxa de equilíbrio de acordo com a situação de cada município no período definido.

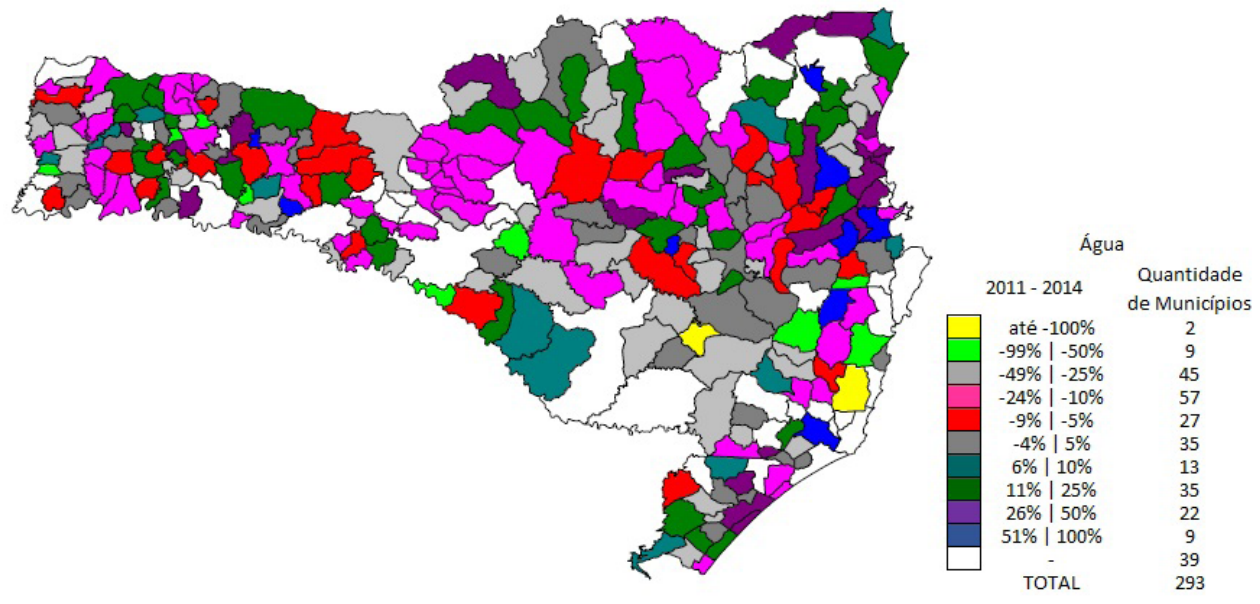

Figura 02 -Taxa de equilíbrio Econômico e Financeiro dos Municípios de Santa Catarina, atendidos pelo serviço de água. Resultados com base nos dados do SNIS (2011 - 2014)

De um total de 46 os municípios atendidos pelo serviço de "água e esgoto" no Estado, 17 apresentam-se deficitários, com receita menor que o custo, variando entre -5\% a $-100 \%$. Considerando a faixa entre $-4 \%$ e $5 \%$, encontram-se apenas 4 municípios. Já os municípios superavitários somam 25 , com resultados variando de $6 \%$ a $138 \%$ de receita maior que os custos. A distribuição geográfica pode ser observada na Figura 03. 


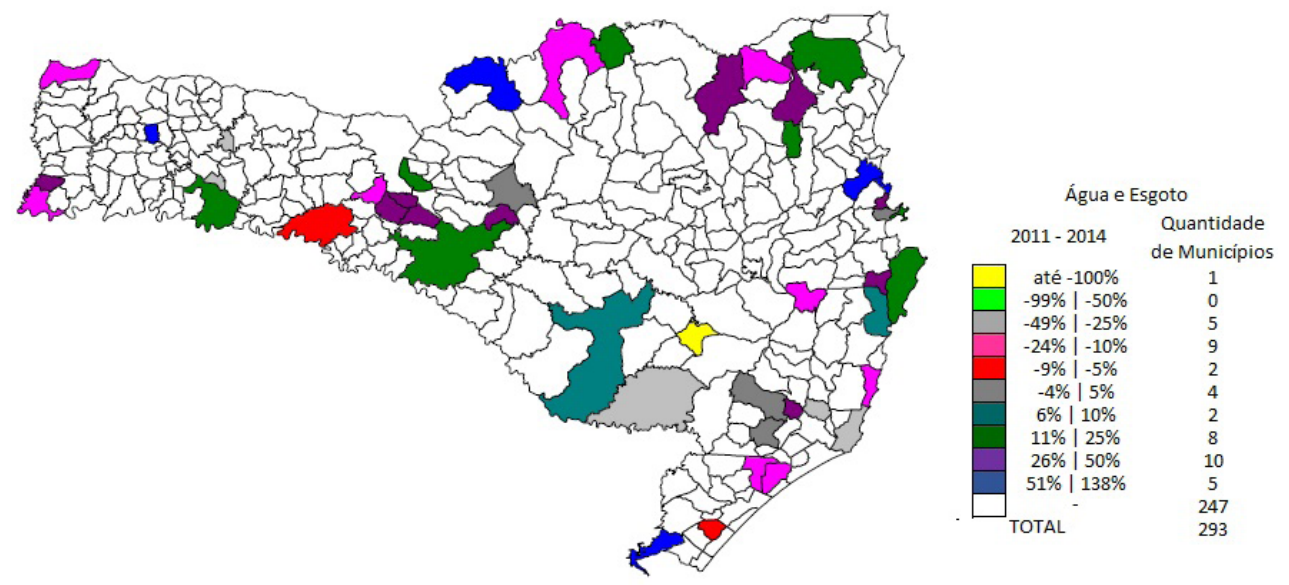

Figura 03 - Taxa de equilíbrio Econômico e Financeiro dos Municípios de Santa Catarina, atendidos pelo serviço de água e de esgoto. Resultados com base nos dados SNIS (2011 2014)

Os municípios atendidos pelo serviço individual de esgoto no Estado somam apenas 18 , sendo 16 deficitários com receita menor que o custo variando entre $-5 \%$ a $-100 \%$. Não há municípios na faixa entre $-4 \%$ e $5 \%$, denominada faixa de equilíbrio e os municípios superavitários são apenas dois, variando de $6 \%$ a $233,15 \%$ de receita maior que os custos. A distribuição geográfica é apresentada na Figura 04.

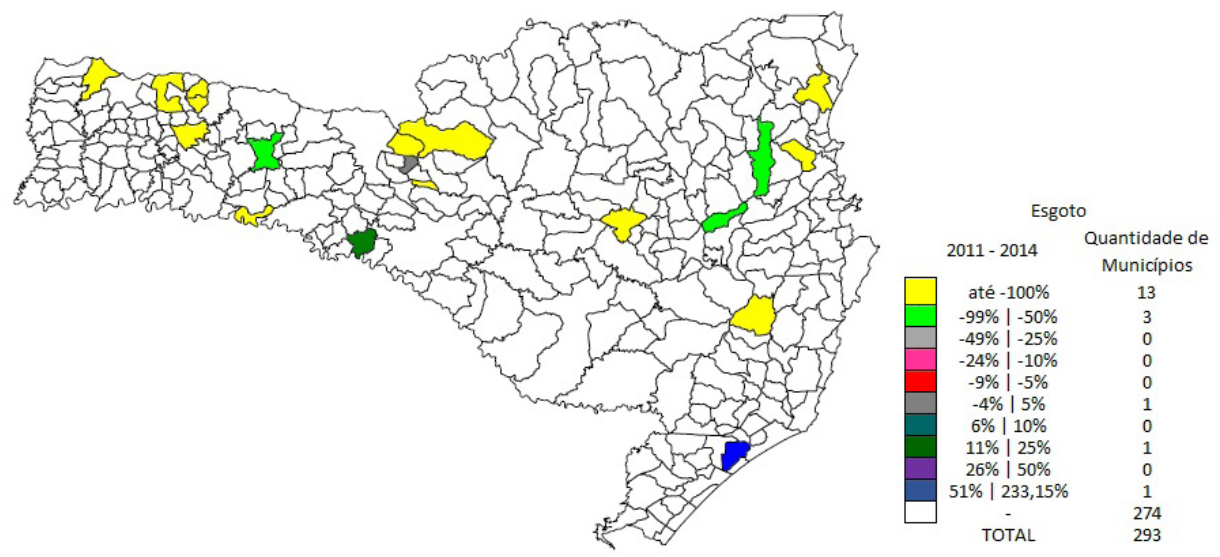

Figura 04 -Taxa de equilíbrio Econômico e Financeiro dos Municípios de Santa Catarina, atendidos pelo serviço de esgoto. Resultados com base nos dados SNIS (2011 - 2014) 
A fim de identificar a tendência da taxa de equilíbrio financeiro nos municípios, podese comparar o resultado ocorrido no ciclo $(2011$ - 2014) com o último resultado disponível (2014). Esta comparação permite avaliar se o ano analisado apresenta uma tendência positiva (recuperação) ou negativa (degeneração) da taxa de equilíbrio financeira. As tendências dos municípios catarinenses são apresentadas na Figura 05.
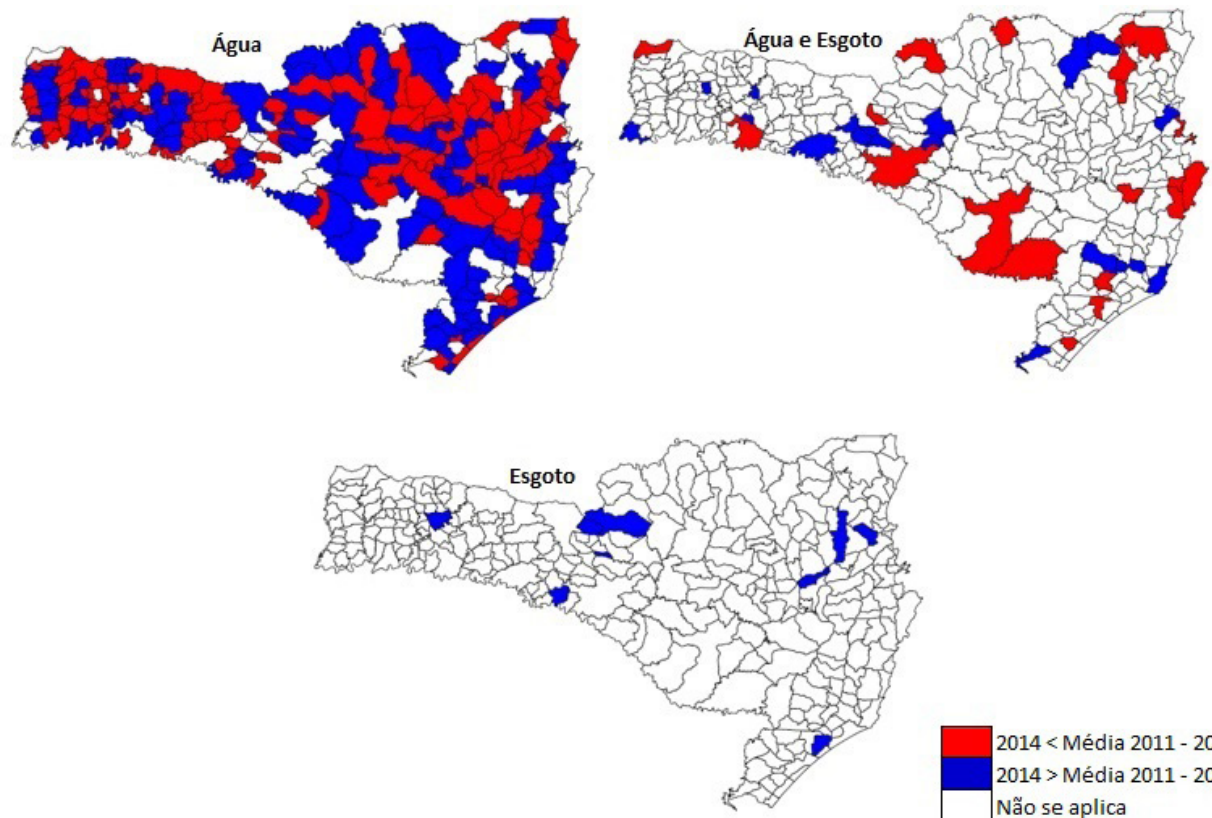

2014 < Média 2011 - 2014 2014 > Média 2011 - 2014 Não se aplica

Figura 05 - Representação Espacial da Tendência da Taxa de equilíbrio Econômico e Financeiro dos Municípios de Santa Catarina. Resultados com base nos dados SNIS (2011 2014 e 2014)

\section{SEGUNDA ETAPA: DEFAZAGEM REAL DA TARIFA PRATICADA}

A tarifa praticada nos municípios catarinense são anualmente reajustas por índices inflacionários diversos, por exemplo: Índice Nacional de Preços ao Consumidor Amplo (IPCA); Índice Nacional de Preços ao Consumidor (INPC); Índice Geral de Preços Mercado (IGP-M); entre outros. Muitas vezes, não são avaliados critérios de sustentabilidade nem de previsão, acarretando demandas extraordinárias que afetam diretamente a qualidade do serviço, o atendimento e sustentabilidade do sistema. A segunda etapa desse trabalho busca identificar potencias caminhos para o desenvolvimento e sustentabilidade dos sistemas de saneamento básico (água e esgoto) nos municípios.

O serviço de saneamento é de responsabilidade pública, sendo a prestação concedida a empresas públicas (Estadual ou Municipal) ou privadas, por períodos de concessão 
relativamente longos (30 anos), prazo esse que justifica os investimentos necessários e o tempo para recuperá-los. Nesse contexto, o sistema de saneamento básico é dinâmico, passando por constante ampliação e manutenção de seus ativos. A remuneração de todos os custos inerentes à provisão destes serviços se dá primordialmente através de tarifas, cobrada sobre o consumo de cada unidade consumidora.

O controle da produtividade é de extrema importância, assim como o monitoramento dos histogramas de consumo, que nos dias de hoje já podem ser observados por cada economia consumidora. Sendo assim, pode-se determinar a tarifa praticada por cada faixa de consumo e projetar as receitas de acordo com o histórico de consumo. As informações sobre os histogramas de consumo, via de regra, não são dados de domínio público, entretanto, as informações sobre a produção são divulgadas, assim como as tarifas médias praticadas em cada município. Dessa maneira, pode-se identificar as taxas de reajuste ocorridas no período analisado. Assim, a partir da média das tarifas praticadas no período e da taxa de equilíbrio calculada, será apresentado o valor de tarifa necessária para alcançar o equilíbrio do sistema, ou seja, a tarifa que cobre os custos ocorridos.

\section{RESULTADOS DA SEGUNDA ETAPA}

A equação apresentada na Figura 06 para calcular a tarifa média praticada, atende as três modalidades de serviços de maneira equivalente, uma vez que só haverá soma de receitas e volumes quando o sistema for conjunto (água e esgoto).

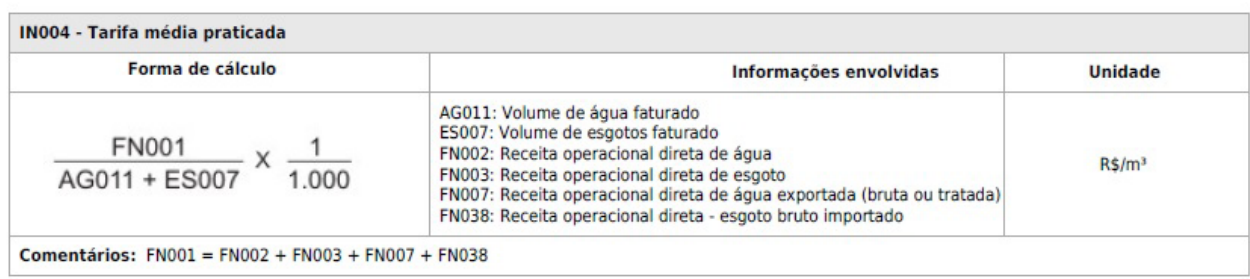

Figura 06: Equação para Cálculo da Tarifa Média Praticada

A partir das tarifas médias praticadas no ano de 2014, foi aplicada a correção do valor pela taxa de equilíbrio obtida na análise do ciclo 2011-2014. O resultado dessa interação está apresentado espacialmente na Figura 07 para o serviço de água e na Figura 08 para o serviço de água e esgoto. Com relação a aplicação para o sistema que compreende apenas esgoto, os resultados estão apresentados na Tabela 02. 


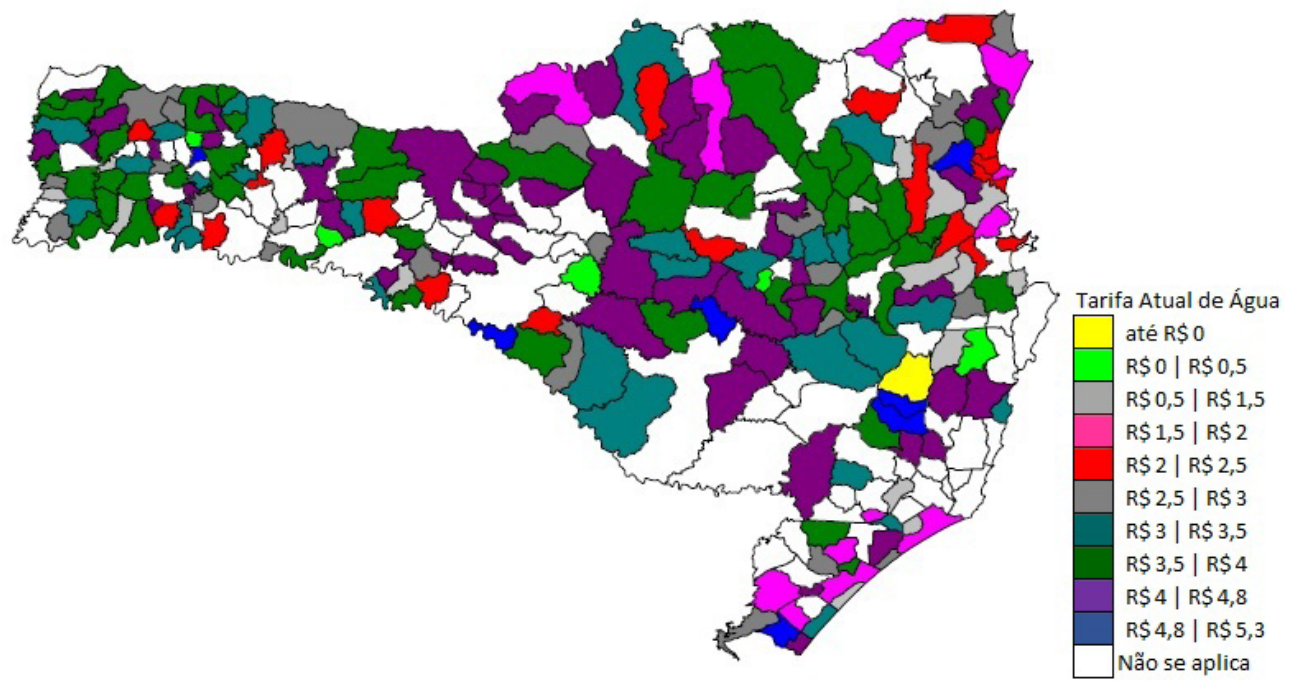

Figura 07 - Atualização Tarifária Sistema de Água dos Municípios de Santa Catarina.

Resultados com base nos dados SNIS (2011-2014)

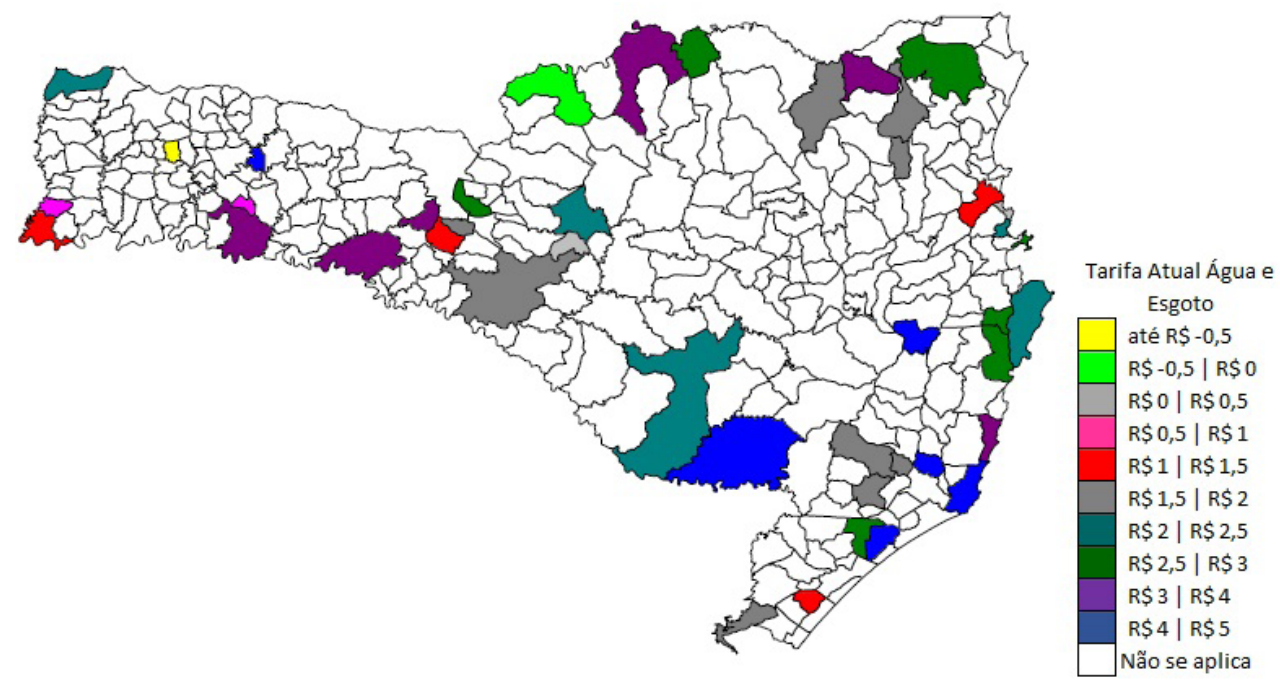

Figura 08 - Atualização Tarifária Sistema de Água e Esgoto dos Municípios de Santa Catarina.

Resultados com base nos dados SNIS (2011 - 2014)

\begin{tabular}{|l|c|cc|cc|}
\hline Municípios & $\begin{array}{c}\text { Tx de } \\
\text { Equlíbrio }\end{array}$ & \multicolumn{2}{|c|}{$\begin{array}{c}\text { Média Tarifa } \\
\text { Praticada }\end{array}$} & \multicolumn{2}{|c|}{$\begin{array}{c}\text { Atualização } \\
\text { da Tarifa }\end{array}$} \\
\hline Blumenau & $-54 \%$ & $\mathrm{R} \$$ & 3,04 & $\mathrm{R} \$$ & 4,69 \\
\hline Capinzal & $15 \%$ & $\mathrm{R} \$$ & 3,36 & $\mathrm{R} \$$ & 2,87 \\
\hline
\end{tabular}

Tabela 2: Atualização Tarifária Sistema de Esgoto. 


\section{CONCLUSÕES}

Analisando os resultados obtidos, podemos afirmar que a metodologia desenvolvida apresenta resultados satisfatórios frente a necessidade de garantir a sustentabilidade das tarifas de saneamento básico, devendo-se atentar para o fato que se trata de um indicador de avaliação de equilíbrio econômico-financeiro. Como já comentado ao longo do trabalho, a análise destes resultados obtidos não permite definir valores para revisão tarifária, apenas indica a necessidade de tal revisão de modo que a tarifa consiga suprir os custos envolvidos na provisão dos serviços. O processo de revisão tarifária deverá contar ainda com outros mecanismos de avaliação, tais como: fator de eficiência, plano de investimentos e amortizações, avaliação de ativos na definição do valor de depreciação, entre outros. Essa análise pode ser auxiliada pela ferramenta de avaliação de desempenho dos indicadores de qualidade, produtividade e atendimento da prestação do serviço.

\section{REFERÊNCIAS}

ARIS - AGÊNCIA REGULADORA INTERMUNICIPAL DE SANEAMENTO - SC. Estudo para elaboração de revisões tarifárias em Samaes. Estudo de caso para o Samae de Jaraguá do Sul, 2014.

ARIS - AGÊNCIA REGULADORA INTERMUNICIPAL DE SANEAMENTO - SC. O papel do ente regulador e mecanismos para avaliação e controle da implementação de Planos Municipais de Saneamento Básico (PMSB) em Santa Catarina. ABAR, VIII CONGRESSO BRASILEIRO DE REGULAÇÃO, Fortaleza, 2013.

ARIS - AGÊNCIA REGULADORA INTERMUNICIPAL DE SANEAMENTO - SC. Resoluções Normativas. Florianópolis, 2011. Disponível em: www.aris.sc.gov.br.

ARIS - AGÊNCIA REGULADORA INTERMUNICIPAL DE SANEAMENTO - SC. O papel do ente regulador na transformação de dados sobre o saneamento básico em informações para o usuário. ABAR, VIII CONGRESSO BRASILEIRO DE REGULAÇÃO, Fortaleza, 2013.

BRASIL, MINISTÉRIO DAS CIDADES, Sistema Nacional de Informações de sobre Saneamento, 2016. Informações disponível - www.snis.gov.br

BRASIL. Lei n 11.445, de 05 de janeiro de 2007. Estabelece a Política Federal de Saneamento Básico.

MARTINS, R. NARZETTI, D.A. ROCHA, C.L. Matriz tarifária para serviços prestados por instituições Municipais. ABAR, IX CONGRESSO BRASILEIRO DE REGULAÇÃO, Brasília, 2015.

NARZETTI, D.A. ROCHA, C.L. MARTINS, R. MOHEDANO, S. M. H. CARAMORI, M. Ferramenta de análise de índices operacionais, financeiros e de qualidade em saneamento básico para formulação de indicadores de apoio à regulação. ABAR, IX CONGRESSO BRASILEIRO DE REGULAÇÃO, Brasília, 2015.

SANDRIN, C.C. MARTINS, R. ROCHA, C.L. NARZETTI, D.A. Metodologia para avaliação de indicadores de desempenho de prestadores de serviços. ABAR, IX CONGRESSO BRASILEIRO DE REGULAÇÃO, Brasília, 2015.

SANTA CATARINA (Estado). Informações gerais sobre a ARIS. Agência Reguladora Intermunicipal de Saneamento Básico. Disponível em: www.aris.sc.gov.br. 


\section{INFLUÊNCIA DAS EQUAÇÕES EXPLÍCITAS DE FATOR DE ATRITO NO DIMENSIONAMENTO DE REDES DE DISTRIBUIÇÃO}

Data de aceite: 04/01/2021

Data de submissão: 03/11/2020

\section{Renata Shirley de Andrade Araújo}

Professora da Universidade Federal do Piauí, Departamento de Recursos Hídricos,

Geotecnia e Saneamento Ambiental

Teresina - PI

http://lattes.cnpq.br/6959135851581992

Alessandro de Araújo Bezerra

Professor da Universidade Federal do Piauí, Departamento de Recursos Hídricos,

Geotecnia e Saneamento Ambiental

Teresina - PI

http://lattes.cnpq.br/1375170517742002

\section{Bruno Duarte Moura}

Graduado em Engenharia Civil pela Universidade Federal do Piauí (UFPI)

Teresina - PI

http://lattes.cnpq.br/3201285287514596

Mauro César de Brito Sousa

Professor do Instituto Federal do Piauí

Teresina - PI

http://lattes.cnpq.br/2049460389729603

RESUMO: Este trabalho tem o objetivo de analisar a influência de equações explícitas para o fator de atrito $f$ da equação universal da perda de carga de Darcy-Weisbach no dimensionamento de redes de distribuição e identificar as equações que mais se aproximam da fórmula de Colebrook-White. A indicação preferencial do uso da equação Darcy-
Weisbach para o cálculo da perda de carga no dimensionamento de redes, que, por sua vez, necessita da obtenção do fator de atrito f para o cálculo em cada trecho. A fórmula do fator de atrito de Colebrook-White é a equação mais representativa para a realidade da tubulação, mas é implícita para f. As equações explícitas são aproximações que tentam contornar este problema, mas, muitas vezes, são equações extensas e apresentam erros, o que as tornam opções pouco confiáveis. A análise da situação no dimensionamento de uma rede ramificada e uma rede malhada a partir de cada uma das metodologias de fator de atrito selecionadas apresentaram resultados que permitiram avaliar quais as melhores opções alternativas de equações explícitas para a fórmula implícita de Colebrook-White, de acordo com os valores obtidos do fator $f$, da perda de carga total das redes e das pressões disponíveis nos nós. Os resultados exibidos indicam que as equações de Sousa-Cunha-Marques e de Zigrang-Silvester apresentam uma maior aproximação a fórmula de Colebrook-White, enquanto que a equação de Swamee-Jain apresenta valores que mais se distancia das outras equações e, apesar disso, a diferença consiste na terceira e quarta casa decimal, o que não a torna inviável para utilização.

PALAVRAS-CHAVE: Fator de Atrito. Equações Explícitas. Redes de Distribuição. 


\section{INFLUENCE OF EXPLICIT FRICTION FACTOR EQUATIONS ON THE SIZING OF DISTRIBUTION NETWORKS}

ABSTRACT: This work aims to analyze the influence of explicit equations for the friction factor $f$ of the Darcy-Weisbach universal head loss equation in the design of distribution networks and to identify the equations that most closely match the Colebrook-White equation. The preferred indication of the use of the Darcy-Weisbach equation for the calculation of the head loss in the dimensioning of networks, which, in turn, needs to obtain the friction factor f for the calculation in each stretch. The Colebrook-White friction factor is the most representative equation for the pipe reality, but it is implicit for $\mathrm{f}$. Explicit equations are approximations that try to circumvent this problem, but they are often extensive equations and have errors, which make them unreliable options. The analysis of the situation in the dimensioning of a branched network and a meshed network based on each of the selected friction factor methodologies presented results that allowed us to evaluate which are the best alternative options of explicit equations for the Colebrook-White implicit formula, according with the values obtained from the factor $f$, the total pressure drop of the networks and the pressures available at the nodes. The results shown indicate that the Sousa-Cunha-Marques and Zigrang-Silvester equations present a greater approximation to the Colebrook-White formula, while the Swamee-Jain equation presents values that are more distant from the other equations and, despite that , the difference consists of the third and fourth decimal place, which does not make it unfeasible for use.

KEYWORDS: Friction Factor. Explicit Equations. Distribution Networks.

\section{I INTRODUÇÃO}

As equações do fator de atrito são utilizadas para obtenção do fator $f$ da fórmula de Darcy-Weisbach, também conhecida como a "fórmula Universal" aplicada ao cálculo da perda de carga em tubulações (equação 1) Porto (2006). Em 1938, Colebrook e White desenvolveram uma fórmula que relaciona o fator de atrito, o número de Reynolds e a rugosidade relativa do conduto, sendo até hoje considerada a equação mais representativa no cálculo da resistência ao escoamento (equação 2). Com sua aplicabilidade demonstrada, então, se tornou a fórmula padrão para cálculo do fator de atrito. Entretanto, sua forma implícita anula uma rápida estimativa do fator de atrito em cálculos manuais (GENIĆ et al., 2011), uma vez que o fator f, sendo implícito, deve ser obtido através de iterações.

$$
\mathrm{h}_{\mathrm{f}}=f \frac{\mathrm{Lv}^{2}}{\mathrm{D} 2 \mathrm{~g}}
$$

em que: $h_{f}=$ perda de carga $(m) ; f=$ fator de atrito (adimensional); $L=$ comprimento da tubulação $(\mathrm{m}) ; \mathrm{v}=$ velocidade do fluido $(\mathrm{m} / \mathrm{s}) ; \mathrm{D}=$ diâmetro do tubo $(\mathrm{m})$ e $\mathrm{g}=$ aceleração da gravidade $\left(\mathrm{m} / \mathrm{s}^{2}\right)$. 
$\frac{1}{\sqrt{f}}=-2 \cdot \log \left[\frac{\varepsilon}{3,7 \mathrm{D}}+\frac{2,51}{\operatorname{Re} \sqrt{f}}\right]$

em que: $f=$ fator de atrito (adimensional); Re = número de Reynolds (adimensional) e $\varepsilon=$ rugosidade absoluta $(\mathrm{m})$.

Segundo Sousa e Neto (2014), após vários anos de pesquisas para equações do fator de atrito em regimes turbulentos, a partir de 1960 elas já apresentavam técnicas de soluções explícitas, mas que sempre possuem limitações ou são expressões longas. Isso gera a necessidade de aprimoramentos que simplifiquem o cálculo e ampliem a sua faixa de abrangência. Mesmo frente às suas limitações, conforme Silva (2014), quando comparadas aos cálculos da fórmula universal, uma grande quantidade de projetistas prefere utilizar fórmulas práticas e empíricas, pois "as mesmas foram criadas para facilitar o desenvolvimento do projeto".

Estudiosos da área tentaram desde então encontrar uma fórmula explícita em que os resultados possuiriam os menores erros em relação à fórmula de Colebrook-White. Dentre as várias obtidas ao longo desses anos, este trabalho irá propor verificar a influência de diversas equações de fator de atrito apresentadas na literatura no dimensionamento de redes de distribuição de água. Para tanto, serão dimensionadas redes de distribuição utilizando a equação universal de Darcy-Weisbach, sendo identificadas aquelas com os menores erros em comparação à fórmula de Colebrook-White.

Dessa maneira, o objetivo desse trabalho é verificar a influência de diversas equações de fator de atrito apresentadas na literatura no dimensionamento de redes de distribuição de água. Além disso, identificar as equações que apresentaram as menores diferenças de perdas de carga em relação à apresentada pela fórmula de Colebrook-White.

\section{I METODOLOGIA}

A seleção das equações deveu-se a alguns aspectos, foram consideradas as mais relevantes de acordo com sua importância na prática de dimensionamentos de redes, como também algumas das mais atuais sem um uso mais amplo. O escoamento em redes de distribuição é caracterizado, geralmente, como turbulento hidraulicamente de transição. Entretanto, utilizou-se também duas equações, que, apesar de serem destinadas ao cálculo em escoamento turbulento hidraulicamente lisos, devido a sua simplicidade, resolveu-se comparar os resultados gerados, são as equações de: Blasius (1913) e Sousa-Neto (2014).

As equações explícitas selecionadas para o desenvolvimento do estudo de seus efeitos no dimensionamento nas redes de distribuição escolhidas estão disponíveis em Genić et al. (2011) e Camargo (2001), sendo as seguintes:

a. Equação de Moody (1947) [Abrangência: $R e=4000$ a 5x10; e = 0 a 0,01], em que: $e=\varepsilon / D=$ rugosidade relativa (adimensional): 
$f=0,0055\left[1+\left(\frac{2000 \varepsilon}{\mathrm{D}}+\frac{10^{6}}{\mathrm{Re}}\right)^{\frac{1}{3}}\right]$

b. Equação de Swamee-Jain (1976) [Abrangência: $R e=5000$ a 108; $; e=0,000001$ a 0,05]:

$f=\left[-2 \log \left(\frac{\varepsilon}{3,7 \mathrm{D}}+\frac{7}{\operatorname{Re}^{0,9}}\right)\right]^{-2}$

c. Equação de Haaland (1983) [Abrangência: $R e=4000$ a 108; e = 0,000001 a $0,05]$ :

$f=\left\{-1,8 \log \left[\left(\frac{\varepsilon}{3,7 \mathrm{D}}\right)^{1,11}+\frac{6,9}{\operatorname{Re}}\right]\right\}^{-2}$

d. Equação de Zigrang-Silvester (1982) [Abrangência: $R e=4000$ a $10^{8} ; \mathrm{e}=$ 0,000001 a 0,05]:

$f=\left\{-2 \log \left[\frac{\varepsilon}{3,7 \mathrm{D}}-\frac{5,02}{\mathrm{Re}} \log \left(\frac{\varepsilon}{\mathrm{D}}-\frac{5,02}{\mathrm{Re}} \log \left(\frac{\varepsilon}{3,7 \mathrm{D}}+\frac{13}{\mathrm{Re}}\right)\right)\right]\right\}^{-2}$

e. Equação de Brkić (1) (2011) [Abrangência: Não Especificada]:

$$
f=\left[-2 \log \left(\frac{1}{10^{0,4343 \beta}}+\frac{\varepsilon}{3,71 \mathrm{D}}\right)\right]^{-2}, \beta=\ln \frac{\operatorname{Re}}{1,816 \ln \left(\frac{1,1 \mathrm{Re}}{\ln (1+1,1 \mathrm{Re})}\right)}
$$

f. Equação de Brkić (2) (2011) [Abrangência: Não Especificada]:

$$
f=\left[-2 \log \left(\frac{2,18 \beta}{\operatorname{Re}}+\frac{\varepsilon}{3,71 \mathrm{D}}\right)\right]^{-2}, \beta=\ln \frac{\mathrm{Re}}{1,816 \ln \left(\frac{1,1 \mathrm{Re}}{\ln (1+1,1 \mathrm{Re})}\right)}
$$

g. Equação de Sousa-Cunha-Marques (1999) [Abrangência: Não Especificada]:

$$
\frac{1}{\sqrt{f}}=-2 \log \left[\frac{\varepsilon}{3,7 \mathrm{D}}-\frac{5,16}{\operatorname{Re}} \log \left(\frac{\varepsilon}{3,7 \mathrm{D}}+\frac{5,09}{\mathrm{Re}^{0,87}}\right)\right]
$$


h. Equação de Blasius (1913) [Abrangência: $R e=4000$ a 1066]:

$f=0,345 \cdot \operatorname{Re}^{-0,25}$

i. Equação de Sousa-Neto (2014) [Abrangência: $R e=4000$ a 106].

$$
f=0,1114 \cdot \mathrm{D}^{-0,2333} \cdot \operatorname{Re}^{-\left(0,1638 \cdot \mathrm{D}^{-0,0964)}\right.}
$$

$\mathrm{Na}$ abordagem deste trabalho foram utilizadas duas redes fictícias retiradas do sistema UFC, elaborado pelo Laboratório de Hidráulica Computacional - LAHC, pertencente à Universidade Federal do Ceará - UFC. Uma rede possui o traçado ramificado e a outra rede tem o seu formato em malha. Todas as fórmulas de dimensionamento, coeficientes de rede, constantes numéricas da água e de materiais adotados no trabalho encontram-se em Porto (2006), Azevedo Netto et al. (1998), Munson et al. (2002) e Tsutiya (2006), tão bem como em literaturas correlatas, seguindo os critérios determinados pela NBR 12211 (ABNT, 1992) e NBR 12218 (ABNT, 1994).

Os parâmetros para cálculo da vazão de distribuição de ambas as redes foram os seguintes:

a. Coeficiente do dia de maior consumo (k1): Adotou-se o valor 1,2;

b. Coeficiente da hora de maior consumo (k2): Adotou-se o valor 1,5;

c. População final $(P)$ : Estimado de acordo com a planta baixa da área de distribuição estabelecida para cada rede;

d. Consumo per capita (q): Para a rede ramificada, adotou-se $q=200$ L/hab.dia. Para a rede malhada, adotou-se $\mathrm{q}=150 \mathrm{~L} / \mathrm{hab}$.dia;

e. Extensão total de distribuição (L): Soma total de todas as extensões de tubulações em cada uma das redes, em metros, excetuando-se a tubulação ligada diretamente ao reservatório (sem distribuição).

Para o material das tubulações da rede de distribuição, adotou-se o PVC, cuja rugosidade absoluta foi estabelecida como $\varepsilon=0,0015 \mathrm{~mm}$. Para os cálculos do número de Reynolds e perda de carga, a constante viscosidade cinemática da água foi estabelecida como $\mathrm{u}=0,00000101 \mathrm{~m}^{2} / \mathrm{s}$, e a constante aceleração da gravidade como $\mathrm{g}=9,80665 \mathrm{~m} / \mathrm{s}^{2}$.

Na planta de situação original obtiveram-se as curvas de nível, as ruas por onde deverá preferencialmente passar as redes, as áreas residenciais a serem abastecidas, a identificação dos nós e suas respectivas cotas e o comprimento de cada trecho. A figura 1 mostra a representação da rede ramificada adotada no trabalho, enquanto a figura 20 traçado da rede malhada utilizada. 


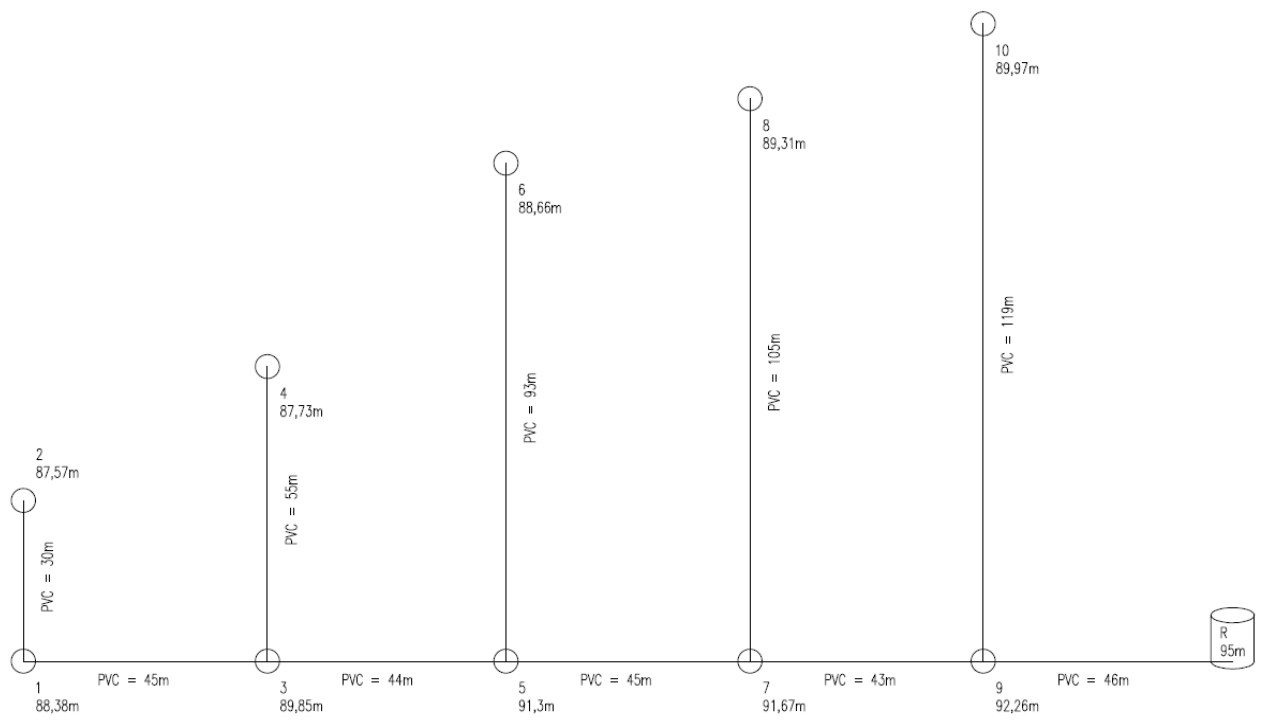

Figura 1: Rede ramificada.

A estimativa populacional para a área em ambas as redes foi feita com base em 3 parâmetros relacionados a seguir:

a. Em cada lote, 1 prédio de apartamentos;

b. Em cada prédio, 5 apartamentos (1 por andar);

C. Em cada apartamento, 5 pessoas.

Para a rede ramificada, contou-se 90 lotes, o que resultou em 90 prédios, 450 apartamentos e 2.250 pessoas atendidas pelo sistema. Para a rede malhada, contou-se 136 lotes, o que resultou em 136 prédios, 680 apartamentos e 3400 pessoas. 


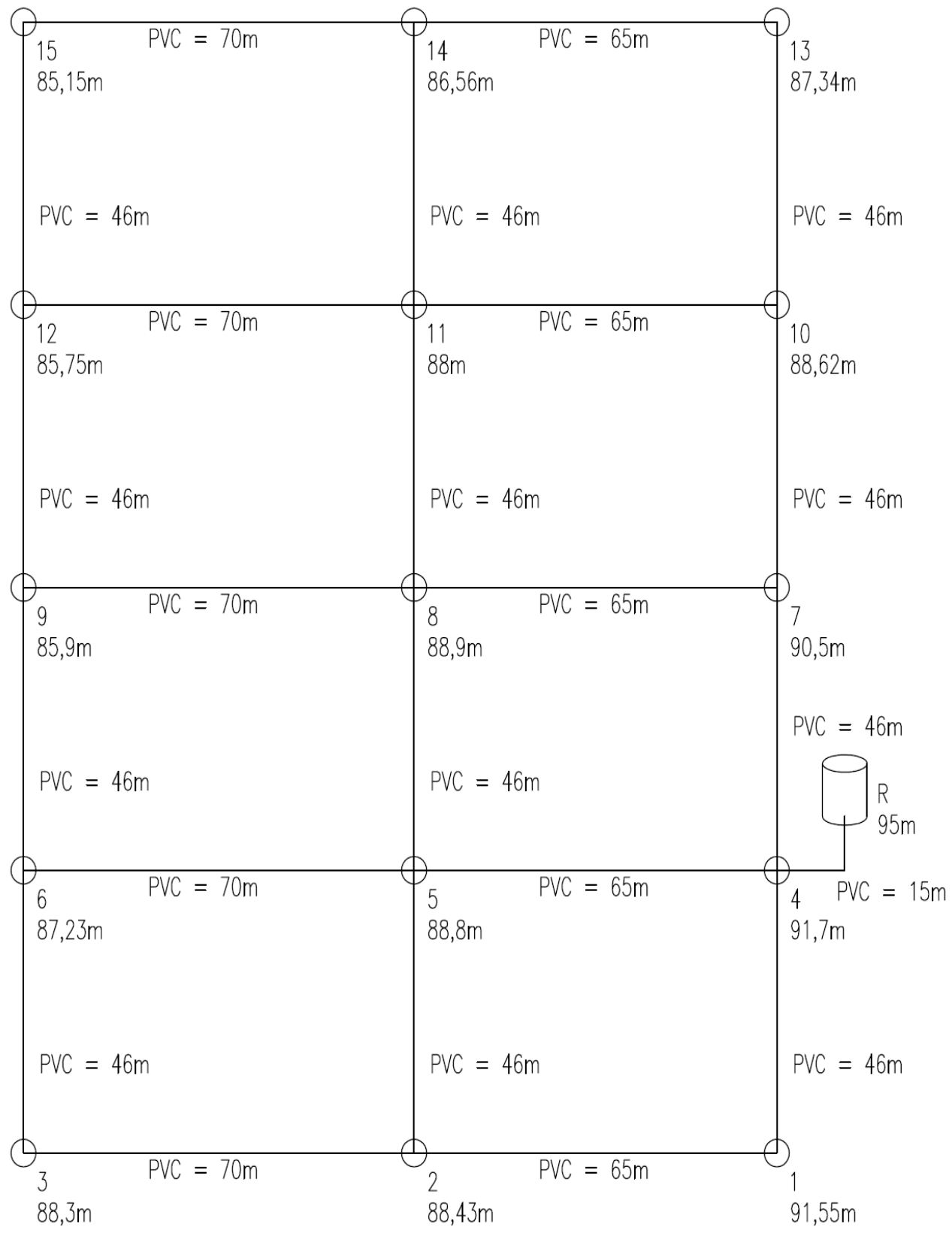

Figura 2: Rede malhada.

\section{I RESULTADOS}

A rede ramificada, constituída de 10 nós, 10 trechos e 1 reservatório, teve seu dimensionamento realizado dez vezes. Um dimensionamento comparativo através da 
fórmula de Colebrook-White, e nove outros através das equações explícitas para o fator de atrito selecionadas. Os resultados dos valores de fator de atrito e suas perdas de carga em cada um dos trechos e as pressões disponíveis em cada um dos nós foram compilados nas tabelas 1 e 2 respectivamente.

\begin{tabular}{ccccccccccc}
\hline Trecho & $\begin{array}{c}\text { Colebrook- } \\
\text { White } \\
\mathbf{( 1 9 3 9 )}\end{array}$ & $\begin{array}{c}\text { Brkic' (1) } \\
\mathbf{( 2 0 1 1 )}\end{array}$ & $\begin{array}{c}\text { Brkic' (2) }_{\mathbf{( 2 0 1 1 )}} \\
\end{array}$ & $\begin{array}{c}\text { Sousa- } \\
\text { Cunha- } \\
\text { Marques } \\
\mathbf{( 1 9 9 9 )}\end{array}$ & $\begin{array}{c}\text { Zigrang- } \\
\text { Silvester } \\
\mathbf{( 1 9 8 2 )}\end{array}$ & $\begin{array}{c}\text { Haaland } \\
\mathbf{( 1 9 8 3 )}\end{array}$ & $\begin{array}{c}\text { Swamee- } \\
\text { Jain } \\
\mathbf{( 1 9 7 6 )}\end{array}$ & $\begin{array}{c}\text { Moody } \\
\mathbf{( 1 9 4 7 )}\end{array}$ & $\begin{array}{c}\text { Blasius } \\
\mathbf{( 1 9 1 3 )}\end{array}$ & $\begin{array}{c}\text { Sousa- } \\
\text { Neto } \\
\mathbf{( 2 0 1 4 )}\end{array}$ \\
\hline $1 \sim 2$ & 0,033950 & 0,032861 & 0,034134 & 0,033954 & 0,033918 & 0,034069 & 0,036471 & 0,034154 & 0,037618 & 0,032263 \\
$3 \sim 1$ & 0,025514 & 0,024767 & 0,025630 & 0,025542 & 0,025462 & 0,025348 & 0,026890 & 0,025305 & 0,028510 & 0,025317 \\
$3 \sim 4$ & 0,028910 & 0,028027 & 0,029051 & 0,028933 & 0,028863 & 0,028825 & 0,030692 & 0,028915 & 0,032329 & 0,028259 \\
$5 \sim 3$ & 0,020825 & 0,020259 & 0,020909 & 0,020850 & 0,020771 & 0,020618 & 0,021753 & 0,020273 & 0,022875 & 0,020858 \\
$5 \sim 6$ & 0,025377 & 0,024635 & 0,025491 & 0,025405 & 0,025324 & 0,025208 & 0,026738 & 0,025158 & 0,028350 & 0,025193 \\
$7 \sim 5$ & 0,019010 & 0,018510 & 0,019082 & 0,019031 & 0,018959 & 0,018809 & 0,019799 & 0,018341 & 0,020590 & 0,019044 \\
$7 \sim 8$ & 0,024651 & 0,023938 & 0,024760 & 0,024679 & 0,024597 & 0,024470 & 0,025934 & 0,024379 & 0,027503 & 0,024533 \\
$9 \sim 7$ & 0,018487 & 0,018002 & 0,018554 & 0,018507 & 0,018442 & 0,018294 & 0,019241 & 0,017804 & 0,019943 & 0,018511 \\
$9 \sim 10$ & 0,023934 & 0,023250 & 0,024039 & 0,023962 & 0,023880 & 0,023744 & 0,025145 & 0,023609 & 0,026656 & 0,023871 \\
$R \sim 9$ & 0,017466 & 0,017019 & 0,017528 & 0,017484 & 0,017419 & 0,017280 & 0,018151 & 0,016719 & 0,018605 & 0,017488 \\
\hline
\end{tabular}

Tabela 1 - Fatores de atrito nos trechos da rede ramificada.

\begin{tabular}{|c|c|c|c|c|c|c|c|c|c|c|}
\hline Trecho & $\begin{array}{l}\text { Colebrook- } \\
\text { White } \\
\text { (1939) }\end{array}$ & $\begin{array}{l}\text { Brkic }^{\prime} \\
(1) \\
(2011)\end{array}$ & $\begin{array}{l}\text { Brkic } \\
(2) \\
(2011)\end{array}$ & $\begin{array}{c}\text { Sousa- } \\
\text { Cunha- } \\
\text { Marques } \\
\text { (1999) }\end{array}$ & $\begin{array}{c}\text { Zigrang- } \\
\text { Silvester } \\
\text { (1982) }\end{array}$ & $\begin{array}{c}\text { Haaland } \\
\text { (1983) }\end{array}$ & $\begin{array}{c}\text { Swamee- } \\
\text { Jain } \\
(1976)\end{array}$ & $\begin{array}{l}\text { Moody } \\
\text { (1947) }\end{array}$ & $\begin{array}{c}\text { Blasius } \\
\text { (1913) }\end{array}$ & $\begin{array}{l}\text { Sousa- } \\
\text { Neto } \\
(2014)\end{array}$ \\
\hline $1 \sim 2$ & 0,021211 & 0,02053 & 0,02132 & 0,021214 & 0,02119 & 0,02128 & 0,022786 & 0,02133 & 0,02350 & 0,02015 \\
\hline $3 \sim 1$ & 0,219668 & 0,21323 & 0,22066 & 0,219909 & 0,21922 & 0,21823 & 0,231515 & 0,21786 & 0,24546 & 0,21797 \\
\hline $3 \sim 4$ & 0,111282 & 0,10788 & 0,11182 & 0,111371 & 0,11110 & 0,11095 & 0,118142 & 0,11130 & 0,12444 & 0,10877 \\
\hline $5 \sim 3$ & 0,590571 & 0,57452 & 0,59295 & 0,591280 & 0,58904 & 0,58470 & 0,616888 & 0,57491 & 0,64870 & 0,59150 \\
\hline $5 \sim 6$ & 0,472270 & 0,45846 & 0,47439 & 0,472791 & 0,47128 & 0,46912 & 0,497598 & 0,46819 & 0,52759 & 0,46884 \\
\hline $7 \sim 5$ & 0,655372 & 0,63813 & 0,65785 & 0,656096 & 0,65361 & 0,64844 & 0,682573 & 0,63230 & 0,70984 & 0,65654 \\
\hline $7 \sim 8$ & 0,660322 & 0,64122 & 0,66324 & 0,661072 & 0,65887 & 0,65547 & 0,694690 & 0,65303 & 0,73671 & 0,65716 \\
\hline $9 \sim 7$ & 0,331568 & 0,32286 & 0,33277 & 0,331927 & 0,33076 & 0,32810 & 0,345091 & 0,31931 & 0,35768 & 0,33199 \\
\hline $9 \sim 10$ & 0,933207 & 0,90653 & 0,93730 & 0,934298 & 0,93110 & 0,92579 & 0,980425 & 0,92053 & 1,03934 & 0,93075 \\
\hline $\mathrm{R} \sim 9$ & 0,584259 & 0,56930 & 0,58633 & 0,584861 & 0,58268 & 0,57803 & 0,607173 & 0,55927 & 0,62236 & 0,58499 \\
\hline Somatório & 4,579730 & 4,45270 & 4,59866 & 4,584819 & 4,56887 & 4,54016 & 4,796881 & 4,47809 & 5,03565 & 4,56870 \\
\hline $\begin{array}{l}\text { Diferença } \\
\text { para } \\
\text { Colebrook- } \\
\text { White }\end{array}$ & - & 0,12703 & $-0,01893$ & $-0,00509$ & 0,01086 & 0,03957 & $-0,21715$ & 0,10164 & $-0,45593$ & 0,01102 \\
\hline
\end{tabular}

Tabela 2 - Perdas de carga, em $\mathrm{m}$, nos trechos da rede ramificada para cada uma das equações de fator de atrito.

Em relação ao valor obtido pelas várias equações de fator de atrito da tabela 1 , 
os resultados da tabela 2 permitem inferir que as equações de Sousa-Cunha-Marques, Zigrang-Silvester e Sousa-Neto deram os resultados para o fator $f$ mais próximos do obtido pela fórmula de Colebrook-White, como evidencia a tabela 3.

\begin{tabular}{cc|cc|cc|cc}
\hline Trecho & $\begin{array}{c}\text { Colebrook- } \\
\text { White } \\
\mathbf{( 1 9 3 9 )}\end{array}$ & $\begin{array}{c}\text { Sousa- } \\
\text { Cunha- } \\
\text { Marques } \\
\mathbf{( 1 9 9 9 )}\end{array}$ & $\begin{array}{c}\text { Diferença } \\
\text { para } \\
\text { Colebrook- } \\
\text { White }\end{array}$ & $\begin{array}{c}\text { Zigrang- } \\
\text { Silvester } \\
\mathbf{( 1 9 8 2 )}\end{array}$ & $\begin{array}{c}\text { Diferença } \\
\text { para } \\
\text { Colebrook- } \\
\text { White }\end{array}$ & $\begin{array}{c}\text { Sousa- } \\
\text { Neto } \\
\text { (2014) }\end{array}$ & $\begin{array}{c}\text { Diferença } \\
\text { para } \\
\text { Colebrook- } \\
\text { White }\end{array}$ \\
\hline $1 \sim 2$ & 0,033950 & 0,033954 & $-4 \mathrm{E}-06$ & 0,033918 & $3,2 \mathrm{E}-05$ & 0,032263 & 0,001687 \\
$3 \sim 1$ & 0,025514 & 0,025542 & $-2,8 \mathrm{E}-05$ & 0,025462 & 0,000052 & 0,025317 & 0,000197 \\
$3 \sim 4$ & 0,028910 & 0,028933 & $-2,3 \mathrm{E}-05$ & 0,028863 & $4,7 \mathrm{E}-05$ & 0,028259 & 0,000651 \\
$5 \sim 3$ & 0,020825 & 0,020850 & $-2,5 \mathrm{E}-05$ & 0,020771 & $5,4 \mathrm{E}-05$ & 0,020858 & $-3,3 \mathrm{E}-05$ \\
$5 \sim 6$ & 0,025377 & 0,025405 & $-2,8 \mathrm{E}-05$ & 0,025324 & $5,3 \mathrm{E}-05$ & 0,025193 & 0,000184 \\
$7 \sim 5$ & 0,019010 & 0,019031 & $-2,1 \mathrm{E}-05$ & 0,018959 & $5,1 \mathrm{E}-05$ & 0,019044 & $-3,4 \mathrm{E}-05$ \\
$7 \sim 8$ & 0,024651 & 0,024679 & $-2,8 \mathrm{E}-05$ & 0,024597 & $5,4 \mathrm{E}-05$ & 0,024533 & 0,000118 \\
$9 \sim 7$ & 0,018487 & 0,018507 & $-2 \mathrm{E}-05$ & 0,018442 & $4,5 \mathrm{E}-05$ & 0,018511 & $-2,4 \mathrm{E}-05$ \\
$9 \sim 10$ & 0,023934 & 0,023962 & $-2,8 \mathrm{E}-05$ & 0,023880 & $5,4 \mathrm{E}-05$ & 0,023871 & $6,3 \mathrm{E}-05$ \\
$\mathrm{R} \sim 9$ & 0,017465 & 0,017484 & $-1,9 \mathrm{E}-05$ & 0,017419 & $4,6 \mathrm{E}-05$ & 0,017488 & $-2,3 \mathrm{E}-05$ \\
\hline
\end{tabular}

Tabela 3 - Menores diferenças em relação aos resultados de fator de atrito de Colebrook-White para a rede ramificada.

Analisando de maneira global a rede ramificada e a perda de carga total da rede, as equações também apresentaram esse mesmo comportamento de variação. Algumas tiveram uma perda de carga maior que a apresentada utilizando a fórmula de ColebrookWhite, enquanto outras tiveram seus valores reduzidos. A figura 3 a seguir, mostra um gráfico que demonstra o comportamento dessa variação.

O desenho do gráfico apresentado na figura 3 para a perda de carga total da rede ramificada foi praticamente o mesmo apresentado pelas perdas de carga em cada um dos trechos da rede, variando-se apenas os valores para a perda de carga em cada situação. As equações explícitas cujos resultados mais se aproximaram da perda de carga apresentada pela fórmula de Colebrook-White foram as de Sousa-Cunha-Marques (1999), Sousa-Neto (2014) e Zigrang-Silvester (1982). A equação de Sousa-Cunha-Marques apresentou uma perda de carga total apenas 0,005122 m maior que a fórmula usual. 
— Perda de carga da rede pelo Fator de Atrito de Colebrook-White

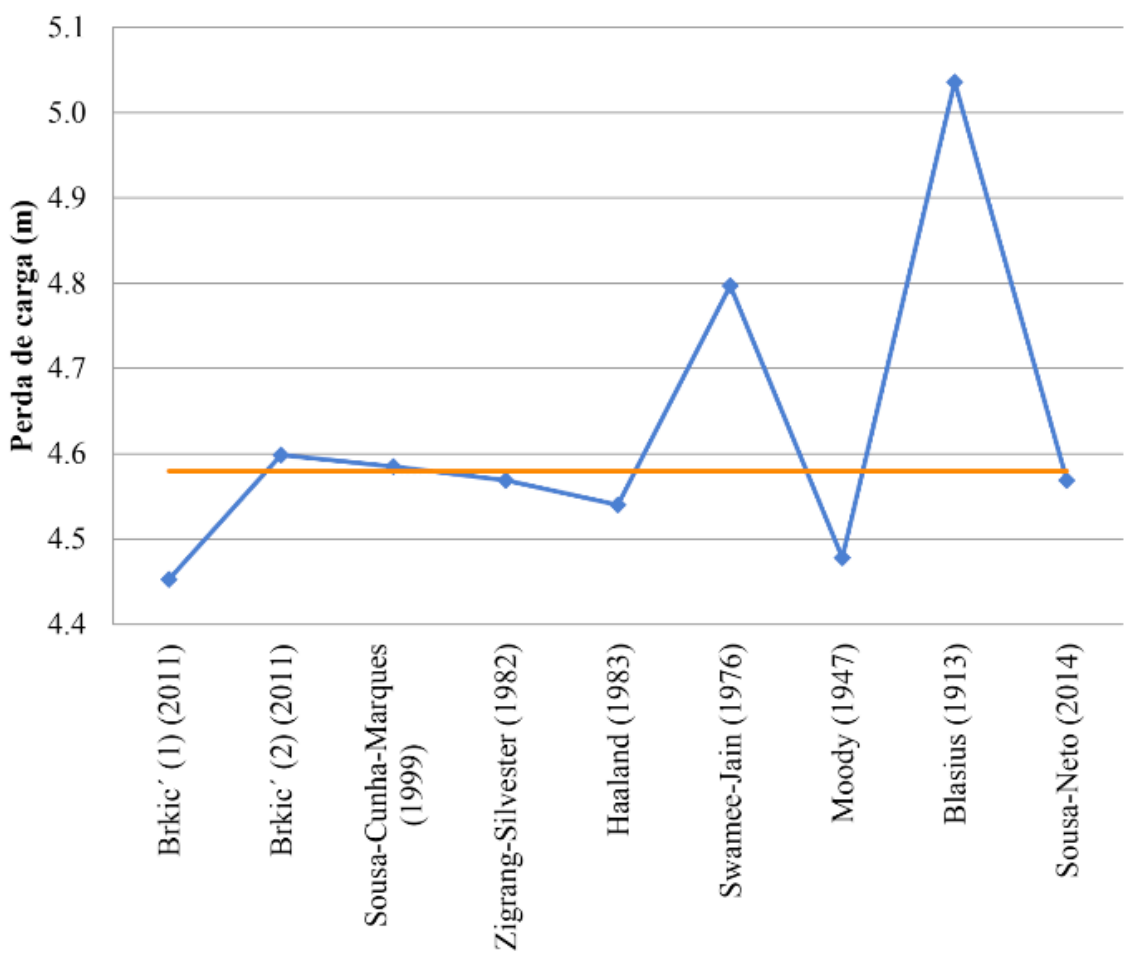

Figura 3 - Gráfico da perda de carga total da rede ramificada.

A curta e mais atual equação de Sousa-Neto, mesmo dependendo apenas do diâmetro e do número de Reynolds para obter o resultado do fator de atrito, conseguiu resultados mais satisfatórios. Por ter menos termos e ser mais próxima de Colebrook-White em relação a cada uma das perdas de carga nos trechos a tornam uma boa alternativa entre as equações explícitas selecionadas, no caso do material ser o PVC com rugosidade absoluta de 0,0015 $\mathrm{mm}$.

A rede malhada, constituída de 15 nós, 1 reservatório, 23 trechos e 8 anéis, seu dimensionamento foi realizado dez vezes, assim como o teve a rede ramificada. A obtenção da vazão correta nos trechos da rede malhada se deu através do método iterativo de HardyCross, e executou-se esse método para cada tipo de equação do fator de atrito.

Seguindo os procedimentos feitos na rede ramificada, a fim de comparação, compilaram-se em tabelas os resultados do fator de atrito de cada um dos trechos da rede malhada, por cada uma das metodologias (tabela 4), seguido de suas respectivas perdas de carga (tabela 5). 


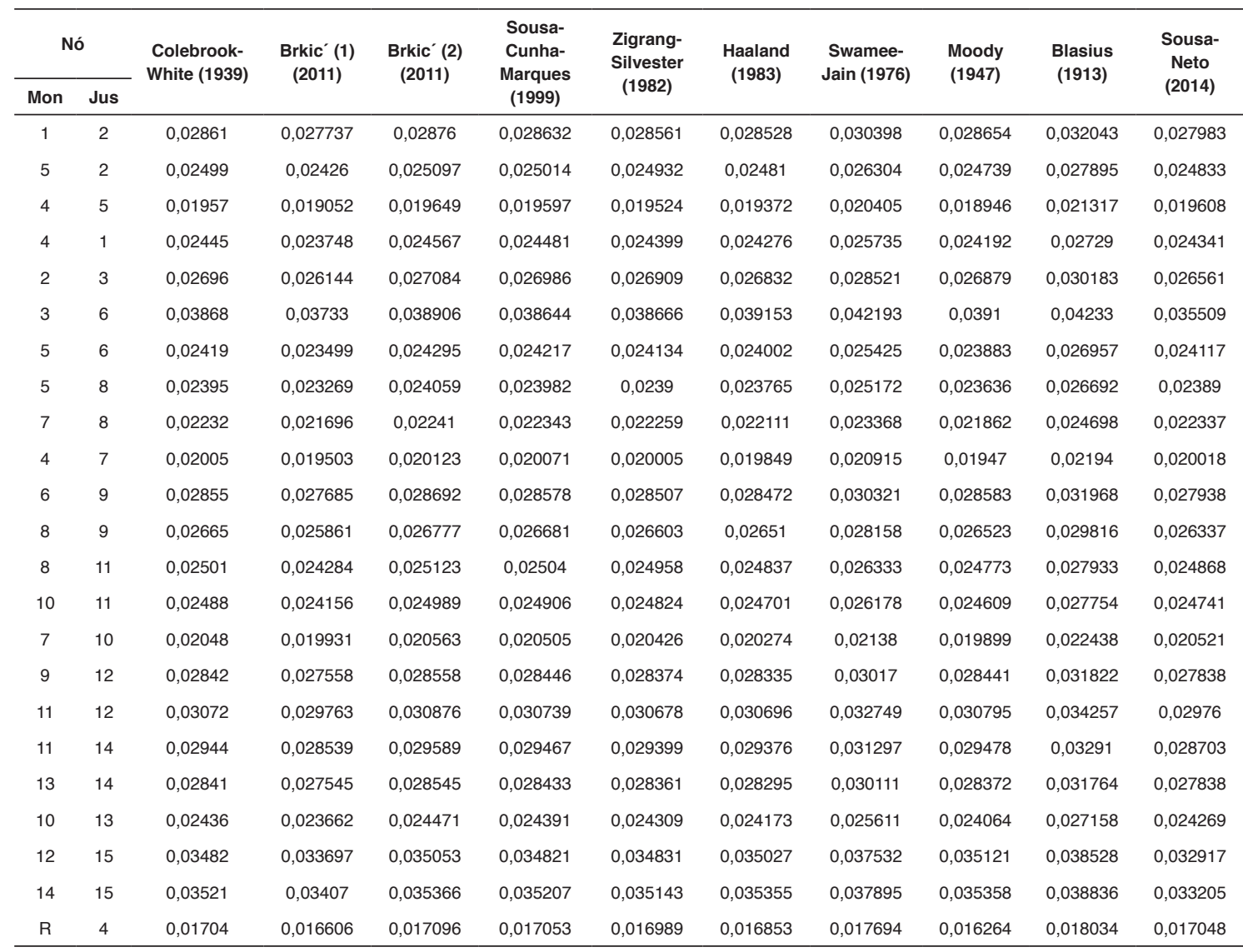

Tabela 4 - Fatores de atrito nos trechos da rede malhada

Uma visualização dos resultados apresentados pela tabela 4, acerca das diferenças entre as perdas de carga totais da rede permite inferir que essas 3 equações teriam de fato resultados mais próximos aos obtidos pela fórmula de Colebrook-White.

Assim como apresentou os resultados da rede ramificada, a perda de carga apresentada pelas equações explícitas do fator de atrito na rede malhada variou para mais ou para menos de acordo com o trecho em questão, de um modo parecido com o do fator de atrito. 


\begin{tabular}{|c|c|c|c|c|c|c|c|c|c|c|c|}
\hline & & \multirow{2}{*}{$\begin{array}{l}\text { Colebrook- } \\
\text { White (1939) }\end{array}$} & \multirow{2}{*}{$\begin{array}{c}\text { Brkic }^{\prime}(1) \\
(2011)\end{array}$} & \multirow{2}{*}{$\begin{array}{c}\text { Brkic }^{\prime}(2) \\
(2011)\end{array}$} & \multirow{2}{*}{$\begin{array}{c}\text { Sousa- } \\
\text { Cunha- } \\
\text { Marques } \\
\text { (1999) }\end{array}$} & \multirow{2}{*}{$\begin{array}{c}\text { Zigrang- } \\
\text { Silvester } \\
\text { (1982) }\end{array}$} & \multirow{2}{*}{$\begin{array}{l}\text { Haaland } \\
(1983)\end{array}$} & \multirow{2}{*}{$\begin{array}{c}\text { Swamee- } \\
\text { Jain } \\
(1976)\end{array}$} & \multirow{2}{*}{$\begin{array}{c}\text { Moody } \\
\text { (1947) }\end{array}$} & \multirow{2}{*}{$\begin{array}{c}\text { Blasius } \\
\text { (1913) }\end{array}$} & \multirow{2}{*}{$\begin{array}{l}\text { Sousa- } \\
\text { Neto } \\
(2014)\end{array}$} \\
\hline Mon & Jus & & & & & & & & & & \\
\hline 1 & 2 & 0,14131 & 0,136998 & 0,14152 & 0,141418 & 0,141068 & 0,140379 & 0,148463 & 0,13943 & 0,156497 & 0,139248 \\
\hline 5 & 2 & 0,261846 & 0,254197 & 0,262967 & 0,262097 & 0,261238 & 0,25996 & 0,275614 & 0,259216 & 0,292285 & 0,260763 \\
\hline 4 & 5 & 0,738625 & 0,719075 & 0,741607 & 0,739644 & 0,736889 & 0,731152 & 0,77014 & 0,715074 & 0,804179 & 0,739707 \\
\hline 4 & 1 & 0,307069 & 0,298253 & 0,307942 & 0,307458 & 0,306429 & 0,304295 & 0,321311 & 0,30145 & 0,340726 & 0,306906 \\
\hline 2 & 3 & 0,23013 & 0,223823 & 0,231188 & 0,230351 & 0,229694 & 0,228362 & 0,24202 & 0,227412 & 0,256123 & 0,229407 \\
\hline 3 & 6 & 0,014745 & 0,014389 & 0,014832 & 0,014732 & 0,01474 & 0,014757 & 0,015723 & 0,014404 & 0,015774 & 0,014153 \\
\hline 5 & 6 & 0,507032 & 0,491622 & 0,509233 & 0,507598 & 0,505858 & 0,503092 & 0,532918 & 0,500597 & 0,56503 & 0,503601 \\
\hline 5 & 8 & 0,358383 & 0,348193 & 0,360014 & 0,358862 & 0,357635 & 0,355615 & 0,375989 & 0,353046 & 0,397972 & 0,357485 \\
\hline 7 & 8 & 0,873793 & 0,849364 & 0,877316 & 0,874693 & 0,871405 & 0,865611 & 0,916035 & 0,856999 & 0,968172 & 0,873298 \\
\hline 4 & 7 & 0,179022 & 0,174138 & 0,179749 & 0,179209 & 0,17862 & 0,177302 & 0,186903 & 0,174131 & 0,196221 & 0,178661 \\
\hline 6 & 9 & 0,101291 & 0,098222 & 0,101795 & 0,101391 & 0,101139 & 0,10064 & 0,106778 & 0,100283 & 0,112578 & 0,099857 \\
\hline 8 & 9 & 0,249434 & 0,242049 & 0,250623 & 0,249724 & 0,248994 & 0,248124 & 0,263548 & 0,248245 & 0,279067 & 0,245811 \\
\hline 8 & 11 & 0,259798 & 0,252257 & 0,260972 & 0,26011 & 0,259258 & 0,258001 & 0,273541 & 0,256779 & 0,289533 & 0,257764 \\
\hline 10 & 11 & 0,381978 & 0,370863 & 0,383652 & 0,382377 & 0,381119 & 0,37923 & 0,402758 & 0,379421 & 0,42791 & 0,379844 \\
\hline 7 & 10 & 0,707482 & 0,68799 & 0,710349 & 0,708346 & 0,705617 & 0,700366 & 0,739123 & 0,688436 & 0,776276 & 0,707828 \\
\hline 9 & 12 & 0,104597 & 0,101424 & 0,105105 & 0,104693 & 0,104428 & 0,103905 & 0,11023 & 0,103534 & 0,116266 & 0,102828 \\
\hline 11 & 12 & 0,094214 & 0,091279 & 0,094692 & 0,094272 & 0,094085 & 0,09414 & 0,100436 & 0,094909 & 0,105579 & 0,090821 \\
\hline 11 & 14 & 0,082182 & 0,079667 & 0,082598 & 0,082257 & 0,082068 & 0,082003 & 0,087366 & 0,082288 & 0,091869 & 0,080125 \\
\hline 13 & 14 & 0,148286 & 0,143771 & 0,148991 & 0,148406 & 0,148031 & 0,148223 & 0,157737 & 0,148627 & 0,166396 & 0,145301 \\
\hline 10 & 13 & 0,315652 & 0,306608 & 0,31709 & 0,316054 & 0,314991 & 0,313837 & 0,332507 & 0,312422 & 0,352591 & 0,314473 \\
\hline 12 & 15 & 0,027764 & 0,026869 & 0,027732 & 0,027765 & 0,027556 & 0,027711 & 0,029693 & 0,027568 & 0,030481 & 0,026247 \\
\hline 14 & 15 & 0,039453 & 0,038175 & 0,039951 & 0,039449 & 0,039699 & 0,039938 & 0,042808 & 0,040266 & 0,043871 & 0,037206 \\
\hline $\mathrm{R}$ & 4 & 0,238501 & 0,232427 & 0,239285 & 0,238683 & 0,237787 & 0,235884 & 0,247655 & 0,22764 & 0,252414 & 0,238613 \\
\hline Som & ório & 6,362587 & 6,181653 & 6,389203 & 6,369589 & 6,348348 & 6,312527 & 6,679296 & 6,252177 & 7,03781 & 6,329947 \\
\hline \multicolumn{2}{|c|}{$\begin{array}{c}\text { para } \\
\text { Colebrook- } \\
\text { White }\end{array}$} & & 0,18093 & $-0,02662$ & $-0,00700$ & 0,01424 & 0,05006 & $-0,316709$ & 0,11041 & $-0,67522$ & 0,03264 \\
\hline
\end{tabular}

Tabela 5 - Perdas de carga, em m, nos trechos da rede malhada para cada uma das equações de fator de atrito.

Em relação ao fator de atrito, a equação de Sousa-Cunha-Marques e de ZigrangSilvester obtiveram em todos os trechos valores bastante semelhantes aos apresentados pela fórmula de Colebrook-White, com erros menores que 0,0001. Próximo disso esteve os resultados da Segunda equação explícita de Brkić, cujos erros foram menores que 0,001, mas bem próximos de 0,0001, como mostra a tabela 6 .

Segundo a perda de carga total da rede, as equações também apresentaram esse mesmo comportamento de variação linear. Algumas tiveram uma perda de carga maior que a apresentada utilizando a fórmula de Colebrook-White, enquanto outras tiveram seus valores reduzidos. 


\begin{tabular}{|c|c|c|c|c|c|c|c|c|}
\hline \multicolumn{2}{|c|}{ Nó } & \multirow{2}{*}{$\begin{array}{c}\text { Colebrook- } \\
\text { White (1939) }\end{array}$} & \multirow{2}{*}{$\begin{array}{c}\text { Sousa- } \\
\text { Cunha- } \\
\text { Marques } \\
(1999)\end{array}$} & \multirow{2}{*}{$\begin{array}{c}\text { Diferença } \\
\text { para } \\
\text { Colebrook- } \\
\text { White }\end{array}$} & \multirow{2}{*}{$\begin{array}{c}\text { Zigrang- } \\
\text { Silvester } \\
\text { (1982) }\end{array}$} & \multirow{2}{*}{$\begin{array}{c}\text { Diferença } \\
\text { para } \\
\text { Colebrook- } \\
\text { White }\end{array}$} & \multirow{2}{*}{$\begin{array}{l}\text { Brkic' (2) }^{\prime} \\
(2011)\end{array}$} & \multirow{2}{*}{$\begin{array}{c}\text { Diferença } \\
\text { para } \\
\text { Colebrook- } \\
\text { White }\end{array}$} \\
\hline Mon & Jus & & & & & & & \\
\hline 1 & 2 & 0,02861 & 0,028632 & $-2,2 \mathrm{E}-05$ & 0,028561 & 4,9E-05 & 0,02876 & $-0,00015$ \\
\hline 5 & 2 & 0,02499 & 0,025014 & $-2,4 \mathrm{E}-05$ & 0,024932 & 5,8E-05 & 0,025097 & $-0,000107$ \\
\hline 4 & 5 & 0,01957 & 0,019597 & $-2,7 \mathrm{E}-05$ & 0,019524 & 4,6E-05 & 0,019649 & $-7,9 \mathrm{E}-05$ \\
\hline 4 & 1 & 0,02445 & 0,024481 & $-3,1 \mathrm{E}-05$ & 0,024399 & 5,1E-05 & 0,024567 & $-0,000117$ \\
\hline 2 & 3 & 0,02696 & 0,026986 & $-2,6 \mathrm{E}-05$ & 0,026909 & 5,1E-05 & 0,027084 & $-0,000124$ \\
\hline 3 & 6 & 0,03868 & 0,038644 & 3,6E-05 & 0,038666 & $1,4 \mathrm{E}-05$ & 0,038906 & $-0,000226$ \\
\hline 5 & 6 & 0,02419 & 0,024217 & $-2,7 \mathrm{E}-05$ & 0,024134 & 5,6E-05 & 0,024295 & $-0,000105$ \\
\hline 5 & 8 & 0,02395 & 0,023982 & $-3,2 \mathrm{E}-05$ & 0,0239 & $5 \mathrm{E}-05$ & 0,024059 & $-0,000109$ \\
\hline 7 & 8 & 0,02232 & 0,022343 & $-2,3 \mathrm{E}-05$ & 0,022259 & 6,1E-05 & 0,02241 & $-9 \mathrm{E}-05$ \\
\hline 4 & 7 & 0,02005 & 0,020071 & $-2,1 \mathrm{E}-05$ & 0,020005 & 4,5E-05 & 0,020123 & $-7,3 \mathrm{E}-05$ \\
\hline 6 & 9 & 0,02855 & 0,028578 & $-2,8 \mathrm{E}-05$ & 0,028507 & 4,3E-05 & 0,028692 & $-0,000142$ \\
\hline 8 & 9 & 0,02665 & 0,026681 & $-3,1 \mathrm{E}-05$ & 0,026603 & 4,7E-05 & 0,026777 & $-0,000127$ \\
\hline 8 & 11 & 0,02501 & 0,02504 & $-3 E-05$ & 0,024958 & 0,000052 & 0,025123 & $-0,000113$ \\
\hline 10 & 11 & 0,02488 & 0,024906 & $-2,6 \mathrm{E}-05$ & 0,024824 & 5,6E-05 & 0,024989 & $-0,000109$ \\
\hline 7 & 10 & 0,02048 & 0,020505 & $-2,5 \mathrm{E}-05$ & 0,020426 & 5,4E-05 & 0,020563 & $-8,3 E-05$ \\
\hline 9 & 12 & 0,02842 & 0,028446 & $-2,6 \mathrm{E}-05$ & 0,028374 & 4,6E-05 & 0,028558 & $-0,000138$ \\
\hline 11 & 12 & 0,03072 & 0,030739 & $-1,9 \mathrm{E}-05$ & 0,030678 & 4,2E-05 & 0,030876 & $-0,000156$ \\
\hline 11 & 14 & 0,02944 & 0,029467 & $-2,7 \mathrm{E}-05$ & 0,029399 & 4,1E-05 & 0,029589 & $-0,000149$ \\
\hline 13 & 14 & 0,02841 & 0,028433 & $-2,3 \mathrm{E}-05$ & 0,028361 & 4,9E-05 & 0,028545 & $-0,000135$ \\
\hline 10 & 13 & 0,02436 & 0,024391 & $-3,1 \mathrm{E}-05$ & 0,024309 & 5,1E-05 & 0,024471 & $-0,000111$ \\
\hline 12 & 15 & 0,03482 & 0,034821 & $-1 E-06$ & 0,034831 & $-1,1 \mathrm{E}-05$ & 0,035053 & $-0,000233$ \\
\hline 14 & 15 & 0,03521 & 0,035207 & $3 E-06$ & 0,035143 & 6,7E-05 & 0,035366 & $-0,000156$ \\
\hline $\mathrm{R}$ & 4 & 0,01704 & 0,017053 & $-1,3 \mathrm{E}-05$ & 0,016989 & 5,1E-05 & 0,017096 & $-5,6 \mathrm{E}-05$ \\
\hline
\end{tabular}

Tabela 6 - Menores diferenças em relação aos resultados de fator de atrito de Colebrook-White para a rede malhada.

As equações explícitas cujos resultados mais se aproximaram da perda de carga apresentada pela fórmula de Colebrook-White foram as de Sousa-Cunha-Marques (1999), Zigrang-Silvester (1982), a Segunda equação de Brkić (2011) e a de Sousa-Neto (2014). A equação de Sousa-Cunha-Marques novamente apresentou uma perda de carga total pouco diferente da apresentada pela fórmula de Colebrook-White, apenas 0,007002 m maior.

\section{4 | CONCLUSÕES}

Para o cálculo do fator de atrito f da equação universal da perda de carga de DarcyWeisbach, a fórmula implícita de Colebrook-White, segundo a literatura, ainda é a equação que melhor representa a resistência ao escoamento em uma tubulação, mesmo com o 
problema evidente do fator $f$ ser implícito. As aproximações explícitas existentes ainda encontram problemas quanto à extensão de seus termos, tornando-as cansativas para o uso e, como se verificou, seus resultados podem mostrar-se um pouco distantes do encontrado pela fórmula implícita.

Em vista dos resultados apresentados pela fórmula de Colebrook-White e pelas equações explícitas de fator de atrito selecionadas, observando as duas redes analisadas, recomenda-se o uso das equações de Sousa-Cunha-Marques (1999) e Zigrang-Silvester (1982) como boas aproximações explícitas para o fator de atrito de Darcy-Weisbach. A equação de Sousa-Neto (2014) deve ser utilizada com cautela, pois, nesse trabalho, não foram analisadas rugosidades absolutas do PVC diferentes de 0,0015 mm, e assim os resultados gerados podem não ser satisfatórios. O mesmo vale para valores de número de Reynolds abaixo de 12.000, aproximadamente. A Segunda equação de Brkić (2011), mesmo em vista dos bons resultados, é uma equação bastante extensa para ser utilizada.

Em contrapartida, as equações de Blasius (1913) e de Swamee-Jain (1976) apresentaram valores um pouco mais altos para perda de carga e pressões em relação a todas as outras equações em estudo. Da mesma forma, a equação de Moody (1947) e a Primeira equação de Brkić (2011) exibiram tais valores abaixo dos obtidos pela fórmula de Colebrook-White. Apesar disso, a diferença de seus fatores de atrito para o da equação de Colebrook-White é bem pequena, situando-se na terceira ou quarta casa decimal.

\section{REFERÊNCIAS}

1. ABNT - ASSOCIAÇÃO BRASILEIRA DE NORMAS TÉCNICAS. NBR 12211: Estudos de concepção de sistemas públicos de abastecimento de água. Rio de Janeiro: ABNT, 1992.

2. ABNT - ASSOCIAÇÃO BRASILEIRA DE NORMAS TÉCNICAS. NBR 12218: Projeto de rede de distribuição de água para abastecimento público. Rio de Janeiro, ABNT, 1994.

3. AZEVEDO NETTO, José Martiniano de; FERNANDEZ Y FERNANDEZ, Miguel; ARAUJO, Roberto de; ITO, Acácio Eiji. Manual de hidráulica. $8^{a}$ ed. São Paulo: Ed. Edgard Blücher, 1998. 670p.

4. CAMARGO, L. A. Equações Explícitas para o Fator de Atrito de Darcy-Weisbach. Hidrotec

Calculator, 2001. Sitio <www.hidrotec.xpg.com.br/EquExpli.htm> acessado em: 25/04/2014.

5. GENIĆ, S. et al. A Review of Explicit Approximations of Colebrook's Equation. Faculty of Mechanical Engineering Transactions, Belgrado, v.39, n.2, p.67-71, 2011.

6. MUNSON, B. R.; YOUNG, D. F.; OKIISHI, T. H. Fundamentos da Mecânica dos Fluidos. $4^{\mathrm{a}}$ ed. São Paulo: Ed. Edgard Blücher, 2004. 572p.

7. PORTO, R. M. Hidráulica básica. 4. Ed. São Carlos: EESC-USP, 2006. 540 p.

8. SILVA, A. M. F. da C e. Determinação de perda de carga em tubulações de sistemas de abastecimento. XII Simpósio Ítalo-Brasileiro de Engenharia Sanitária e Ambiental, Natal, 2014. 16p. 
9. SOUSA, J. S. C. de; NETO, J. D. Equação Explícita para Cálculo do Fator de Atrito de DarcyWeisbach em Projetos de Irrigação Pressurizada. Irriga, Botucatu, v.19, n.1, p.137-148, jan./mar. 2014.

10. TSUTIYA, Milton Tomoyuki. Abastecimento de Água. $3^{\mathrm{a}}$ ed. São Paulo: Departamento de Engenharia Hidráulica e Sanitária da Escola Politécnica da Universidade de São Paulo, 2006. 643p. 


\section{QUANTIFICANDO PERDAS HÍDRICAS EM CIDADES PARAIBANAS}

Data de aceite: 04/01/2021

Data de submissão: 06/11/2020

\section{Ayuri Medeiros da Silva}

Universidade Estadual da Paraíba

Patos - Paraíba

http://lattes.cnpq.br/4568769342186618

Carolina Coeli Rodrigues Batista de Araújo

Universidade Estadual da Paraíba

Patos - Paraíba

http://lattes.cnpq.br/6382078287933543

Flaubert Ruan Nobelino de Araujo

Universidade Estadual da Paraíba

Patos - Paraíba

Mikaele de Oliveira Candeia

Universidade Estadual da Paraíba

Patos - Paraíba

Francisca Rozângela Lopes de Sousa

Universidade Estadual da Paraíba

Patos - Paraíba

http://lattes.cnpq.br/7564029475757969

RESUMO: No último século tem-se debatido bastante sobre recursos hídricos e o seu desperdício, tendo em vista a necessidade de controle de perdas e conscientização por parte da população no tocante ao uso desses recursos. Desse modo, o presente artigo consiste em um estudo de caso, com análise quantitativa sobre as perdas físicas de água que ocorrem na companhia responsável pela distribuição de água no estado da Paraíba (CAGEPA). A pesquisa teve como objetivo analisar as perdas de água, ocorridas no processo de distribuição, nas cidades que compõem a regional do Espinharas no intervalo temporal de 2015 a 2017. Para tanto, fez-se necessária a obtenção dos dados, cedidos pela própria CAGEPA, para então calcular a quantidade anual de água produzida e água perdida da região. Para seleção dos dados utilizou-se um critério de enfoque nas cidades que têm perdas próximas da metade da quantia de água produzida ou maior que essa quantidade. Dentre os resultados alcançados, pode-se considerar que, de todas as cidades abastecidas na regional do Espinharas, sete se destacaram com os maiores índices de perdas, uma vez que são de pequeno porte, seja por sua área territorial ou sua população relativa. Vale ressaltar que o combate a perdas de recursos hídricos é um processo lento, que precisa de investimentos, mas que traz benefícios seja para a distribuidora e a população.

PALAVRAS-CHAVE: Recursos Hídricos; Perdas de água; Distribuição de água; Paraíba.

\section{QUANTIFYING WATER LOSSES IN PARAIBA CITIES}

ABSTRACT: In the last century there has been a lot of debate regarding water resources and it's waste, keeping in mind the need to control losses and raise public awareness about the use of such resources. Thus, this article consists of a case study, with quantitative analysis on the physical losses of water that occur with the company responsible for water distribution in the state of Paraiba; CAGEPA. The research had as it's objective to analyze the losses of water, occurred 
in it's distribution process, on the cities that compose the Espinharas region in the time interval of 2015 to 2017. For such project, it was necessary to obtain data, provided by CAGEPA itself, to then calculate the annual quantity of water produced and water wasted in the region. For the data selection, a criteria of focus was utilized in the cities with losses nearing half the amount of water produced or bigger. Among the results archived, it can be considered that, of all cities supplied in the Espinharas region, seven stood out with the highest amounts of waste, since they are small cities, either because of their territorial area or their relative populace. It's worth noting that the combat against the wasting of water resources is a slow process, that needs investment, but one that brings benefits for both the distributor and the populace.

KEYWORDS: Water resources; Water losses; Water distribution; Environmental Management; Paraíba.

\section{I INTRODUÇÃO}

Nas últimas quatro décadas o mundo se viu diversas vezes à frente de discussões, tanto empírica quanto cientificamente, em relação à escassez de recursos hídricos existentes no planeta e como preservá-los. Considerando o quão escassos são tais recursos, esses debates - muito bem vindos, por sinal - evocam uma questão bastante urgente: quão grave é o desperdício?

O desperdício da água é um problema socioambiental que acontece em múltiplos setores da sociedade, visto que o ser humano, assim as outras formas de vida no planeta, é totalmente dependente da água, que, além do consumo, usa para muitas outras tarefas do dia a dia. No entanto, o problema vem a se tornar ainda mais extravagante quando se trata da agricultura, das grandes indústrias e dos sistemas de abastecimento, sendo este último o enfoque do presente artigo.

No Brasil, o tratamento e a distribuição de água potável, na maioria das cidades, são realizados por meio de sistemas de abastecimento. A partir de Brasil (2018), junto da Go Associados e Instituto Trata Brasil, apontam que em 2016 foi desperdiçado 38\% da água potável tratada e distribuída, o que significou quase 7 piscinas olímpicas de água potável perdidas todos os dias e um prejuízo financeiro acima dos $\mathrm{R} \$ 10$ bilhões/ano, onde, considerando a crise financeira que se sucede no Brasil, não é um valor a ser desprezado.

Nesse contexto, o artigo a seguir tem como objetivo analisar, quantitativamente, as perdas físicas em algumas cidades da região através de dados cedidos pela CAGEPA (Companhia de Água e Esgotos da Paraíba), além de realizar um estudo comparativo, para que, assim, usando da estatística para a construção de gráficos e tabelas e as comparações, seja possível ter uma melhor visualização e entendimento por parte do público. 


\section{I FUNDAMENTAÇÃO TEÓRICA}

\subsection{Recursos hídricos}

Um dos recursos mais abundantes da Terra é a água, considerada também como um recurso natural renovável, isto é, um recurso que ao decorrer do tempo se repõe. A maior porcentagem dessa água é inadequada para o consumo humano, neste caso são águas salgadas. Quando o assunto é a água doce disponível os números são bem menores, essa é representada por apenas $2,5 \%$ de toda a água disponível, desta quantidade de água doce $68,7 \%$ está armazenada nas calotas polares e nas geleiras e apenas 0,27\% está localizada nos rios e lagos (LIMA, 2001). A distribuição por país ou região também é pouco igualitária, alguns países possuem percentuais elevados de água enquanto outros sofrem com insuficiência, e são vários os fatores que influenciam nessa divisão.

As crescentes demandas para os mais diferentes usos da água, sobretudo nos grandes centros urbanos, o uso desenfreado dos mananciais superficiais e subterrâneos; a exploração excessiva, aos poucos está desencadeando a sua degradação e escassez, ao passo que também é oneroso o processo de captação de águas em mananciais distantes, fato cada vez mais comum nessa crise hídrica (COSTA, 2013).

Segundo Pereira Júnior (2004), a escassez pode ser resultado de variações climáticas, poluição de mananciais, grande concentração populacional, atividades econômicas, entre outros impasses. O Brasil é um país com índices bastante consideráveis de água doce, em contrapartida suas taxas de escassez em algumas de suas regiões são também elevadas.

Um dos fatores que sucedem neste país é a desvantajosa distribuição hídrica em suas regiões. Geralmente ocorre quando o volume de água disponível não é condizente com o tamanho da população local. A região Nordeste, por exemplo, enfrenta dificuldades em relação à escassez, seja causada por essa má distribuição ou até mesmo por questões climáticas e ações humanas.

Partindo desse pressuposto, Rosa e Ribeiro (2014) mencionam que o problema da escassez de água afeta inúmeros usuários, tais como o abastecimento urbano, industrial, agricultura, aquicultura, navegação dentre outros, podendo prejudicar inúmeros seres, comprometendo inclusive, o desenvolvimento nacional. Nessa perspectiva, a crise hídrica não se limita apenas a sua escassez, envolve questões como a falta de conscientização e a negligência por parte dos usuários que poluem os mananciais, o que prejudica ainda mais a disponibilidade de água em padrões de qualidade desejáveis.

A Lei $n^{\circ}$ 9.433/1997, que institui a Política Nacional de Recursos Hídricos (PNRH), cria o Sistema Nacional de Gerenciamento de Recursos Hídricos (SINGREH), regulamenta de forma geral a gestão brasileira de recursos hídricos, desse modo, Viana (2011) acrescenta que a aprovação da referida Lei, trata-se de um marco regulatório da gestão dos recursos hídricos do país. A lei menciona a água como um bem de domínio público, de valor 
econômico e escasso, e por sua vez deve ter sua gestão descentralizada e participativa. Tendo ainda como objetivos, assegurar a disponibilidade de água para as gerações atuais e futuras, propondo inclusive a utilização racional e integrada deste recurso.

\subsection{Perdas e desperdício de recursos hídricos}

O desperdício não é um problema recente enfrentado pela sociedade, o uso irresponsável e desenfreado, o aumento da população do planeta nos últimos 50 anos tem aumentado gradativamente e com isso a possibilidade de um colapso hídrico mundial se torna cada vez maior.

Tendo em vista que o aumento populacional provocou a adoção e a ampliação de diversas atividades nas quais é necessário o uso da água, a carência de uma melhor administração e reaproveitamento dela têm induzido a uma série de consequências às massas, especialmente as mais pobres, tornando o acesso à água potável muitas vezes incerto. Segundo dados retirados do Instituto Trata Brasil, aproximadamente 633 milhões de pessoas no mundo continuam sem acesso à uma fonte de água potável mesmo que $90 \%$ da água usada pela população mundial não seja coletada e nem tratada, sendo $70 \%$ do total usada na agricultura, já que é preciso, em média, 1000 toneladas de água para produzir 1 tonelada de grãos, sendo este o setor que mais consome água doce (BRASIL, 2018).

De acordo com o estudo do Grupo de Trabalho Sobre Recursos Hídricos (2016, p.16), "As indústrias precisam se tornar mais independentes do fornecimento de água para os seus processos de produção, bem como aumentar a eficiência no uso do recurso". Isso remete a uma realidade enfrentada hoje pelos órgãos encarregados da distribuição de água potável para a população em seus sistemas de abastecimento. As perdas hídricas por sua vez, são causadas pelos sistemas de abastecimento de água responsáveis pela retirada, tratamento, transporte e fornecimento à população, ocorrem com frequência.

No Brasil a situação não é diferente, de acordo com o Estudo Fundace (2013), no setor de abastecimento brasileiro, a pouca atenção dada aos investimentos da manutenção e modernização no serviço de abastecimento de água, resultou numa série de ineficiências na produção, dentre as quais, podem ser destacadas as elevadas perdas de água, tanto fisicamente quanto financeiramente. Ainda que seja praticamente impossível eliminar definitivamente a perda de água nos sistemas de abastecimento é fundamental procurar soluções, aplicar métodos e ferramentas de regularização cada vez mais precisas e efetivas para combater as perdas abundantes de água, sobretudo por se tratar de um bem tão essencial para a sobrevivência.

As perdas nos sistemas de abastecimento são identificadas e classificadas, segundo a International water situation (AUGUSTO et al., 2012), de acordo com sua natureza, categorizando-as em físicas ou aparentes, como mostrado no Quadro 1. 


\begin{tabular}{|c|c|c|c|}
\hline \multirow{5}{*}{ Perdas de Água } & \multirow{2}{*}{$\begin{array}{l}\text { Perdas Aparentes } \\
\text { (Não Físicas) }\end{array}$} & Consumo não autorizado & \multirow{5}{*}{ Água não faturada } \\
\hline & & Erro de medição & \\
\hline & \multirow{3}{*}{$\begin{array}{l}\text { Perdas Reais } \\
\text { (Físicas) }\end{array}$} & $\begin{array}{c}\text { Vazamentos e extravasamentos } \\
\text { em reservatórios }\end{array}$ & \\
\hline & & Vazamentos em adutoras e redes & \\
\hline & & $\begin{array}{l}\text { Vazamentos em ramais até o } \\
\text { ponto de medição do cliente }\end{array}$ & \\
\hline
\end{tabular}

QUADRO 1: Balanço de Água

FONTE: AUGUSTO et al. (2012).

As perdas aparentes (Não físicas), como mostrado no quadro acima, ocorrem por diversos fatores como ligações clandestinas, hidrômetros danificados ou parados, erros de manuseio (leituras e faturamento) entre outros. Nessas condições a água é consumida, porém não é faturada pela empresa de saneamento, gerando assim impactos financeiros sobre os provedores.

As perdas reais (físicas), por outro lado, são as que ocorrem em todas as etapas de produção e transporte da água desde o logradouro até o consumidor por causa de vazamentos nas adutoras, redes de distribuição e reservatórios, extravasamentos em reservatórios e procedimentos operacionais. Neste tipo de perda, tanto os recursos hídricos quanto os custos do tratamento da água sofrem um impacto, por vezes crítico. Ela também é o objeto de estudo do presente artigo.

\section{I METODOLOGIA}

O presente artigo trata-se de um estudo de caso quantitativo sobre as consequências das perdas físicas no abastecimento de água que compõem a Regional das Espinharas, a qual é composta pelas seguintes cidades: Patos, Água Branca, Igaracy, Condado, Itaporanga, Malta, Princesa Isabel, Piancó, Santa Luzia, São Mamede, Tavares, Taperoá, Teixeira, Santana dos Garrotes, Desterro, Olho D’água, Catingueira, Juru, Nova Olinda, Manaíra, São José do Bonfim, Imaculada, São do Sabugi, Várzea, Emas, São José de Espinharas, Santa Terezinha, Passagem, Quixaba, Salgadinho, São Bentinho, Maturèia, Areia de Baraúnas, Cacimbas, Vista Serrana, Cacimba de Areia, Cajazeirinhas, Santa Gertrudes, Assunção, Coremas, Junco do Seridó e Pedra Branca (CAGEPA, 2019).

De acordo com Gil (2002, p. 54), o estudo de caso "Consiste no estudo profundo e exaustivo de um ou poucos objetos, de maneira que permita seu amplo e detalhado conhecimento, tarefa praticamente impossível mediante outros delineamentos já considerados". Levando em conta que este método é muito utilizado para "explorar 
situações da vida real cujos limites não estão claramente definidos” (GIL, 2002, pg. 54). Quanto à abordagem quantitativa, Fonseca (2002, p. 20) afirma que é a mesma "[...] se centra na objetividade. Influenciada pelo positivismo, considera que a realidade só pode ser compreendida com base na análise de dados brutos, recolhidos com o auxílio de instrumentos padronizados e neutros.".

De acordo com a finalidade deste artigo, pode-se afirmar ainda que se trata de uma pesquisa descritiva que segundo Vergara (2004, p. 47) "expõe características de determinada população ou de determinado fenômeno. Pode também estabelecer correlações entre variáveis e definir sua natureza. Não tem compromisso em explicar os fenômenos que descreve, embora sirva de base para tal explicação".

Para a obtenção dos dados, foi protocolado na CAGEPA uma solicitação das tabelas que continham os dados de produção e macromedição da regional das Espinharas, do período de 2015 a 2017, que por sua vez, é redigida mensalmente para análise dos municípios que a CAGEPA provêm o abastecimento de água e esgoto, sendo arquivada na empresa ao término do mês. A partir desses dados, tomando as tabelas de 2015 e começou-se a analisar as tabelas mês a mês, contabilizando as perdas anuais da seguinte forma: com a vazão nominal $\left(\mathrm{m}^{3} / \mathrm{h}\right)$, multiplica-se pelas horas de um dia e pela quantidade de dias do respectivo mês, assim, sendo possível adquirir a quantidade de água enviada pela CAGEPA (Companhia de Água e Esgotos da Paraíba) no mês. Logo após, foi feita a diferença do resultado obtido - quantidade de água enviada no mês - pela macromedição estimada total do mês, obtendo os valores numéricos de perdas mensais. Em seguida, tomando dos dados dos 12 meses foi realizada a média de perdas no ano (analogamente para 2016 e 2017).

\section{I RESULTADOS}

A partir da análise dos índices de perdas em todas as cidades que compõem a Regional das Espinharas, foi estabelecido um parâmetro para separar as cidades, que foi: as cidades que se destacaram com índices de perdas maior ou igual à média total de água produzida no seu respectivo ano. Dessa forma, obtemos às cidades: São José do Sabugi, Areias de Baraúnas, Princesa Isabel, Cacimbas, São José de Espinharas, Teixeira e Passagem, conforme o Quadro 2 e a Figura 2. 


\begin{tabular}{|c|c|c|c|c|c|c|}
\hline & \multicolumn{2}{|c|}{2015} & \multicolumn{2}{c|}{2016} & \multicolumn{2}{c|}{2017} \\
\hline CIDADES & $\begin{array}{c}\text { MÉDIA } \\
\text { DE ÁGUA } \\
\text { PRODUZIDA } \\
\left(\mathrm{m}^{3}\right)\end{array}$ & $\begin{array}{c}\text { MÉDIA DE } \\
\text { PERDAS } \\
2015\left(\mathrm{~m}^{3}\right)\end{array}$ & $\begin{array}{c}\text { MÉDIA } \\
\text { DE ÁGUA } \\
\text { PRODUZIDA } \\
\left(\mathrm{m}^{3}\right)\end{array}$ & $\begin{array}{c}\text { MÉDIA DE } \\
\text { PERDAS } \\
2016\left(\mathrm{~m}^{3}\right)\end{array}$ & $\begin{array}{c}\text { MÉDIA } \\
\text { DE ÁGUA } \\
\text { PRODUZIDA } \\
\left(\mathrm{m}^{3}\right)\end{array}$ & $\begin{array}{c}\text { MÉDIA DE } \\
\text { PERDAS } \\
2017\left(\mathrm{~m}^{3}\right)\end{array}$ \\
\hline $\begin{array}{c}\text { PRINCESA } \\
\text { ISABEL }\end{array}$ & 85.786 & $61.323,08$ & 86.376 & 86.376 & 40.852 & $22.991,3$ \\
\hline TEIXEIRA & 34.074 & $13.653,17$ & 40.774 & 20.672 & 43.800 & 43.800 \\
\hline $\begin{array}{c}\text { SJ DO } \\
\text { SABUGI }\end{array}$ & 17.050 & 6.213 & 22.692 & $12.652,7$ & 22.630 & $14.825,3$ \\
\hline $\begin{array}{c}\text { SJ DE } \\
\text { ESPINHARAS }\end{array}$ & 30.050 & $18.595,92$ & 30.980 & 18.494 & 29.930 & $18.087,8$ \\
\hline PASSAGEM & 9.490 & 4.940 & 9.516 & $6.283,3$ & 9.490 & $6.246,5$ \\
\hline CACIMBAS & 14.834 & $14.370,08$ & 9.516 & $6.203,2$ & 9.490 & $6.093,8$ \\
\hline $\begin{array}{c}\text { AREIA DE } \\
\text { BARAÚNAS }\end{array}$ & 9.984 & $4.883,42$ & 12.072 & $9.398,9$ & 10.950 & $4.587,7$ \\
\hline
\end{tabular}

QUADRO 2 - Médias Anuais de Produção e Perdas de Água.

FONTE: Dados da pesquisa (2019).

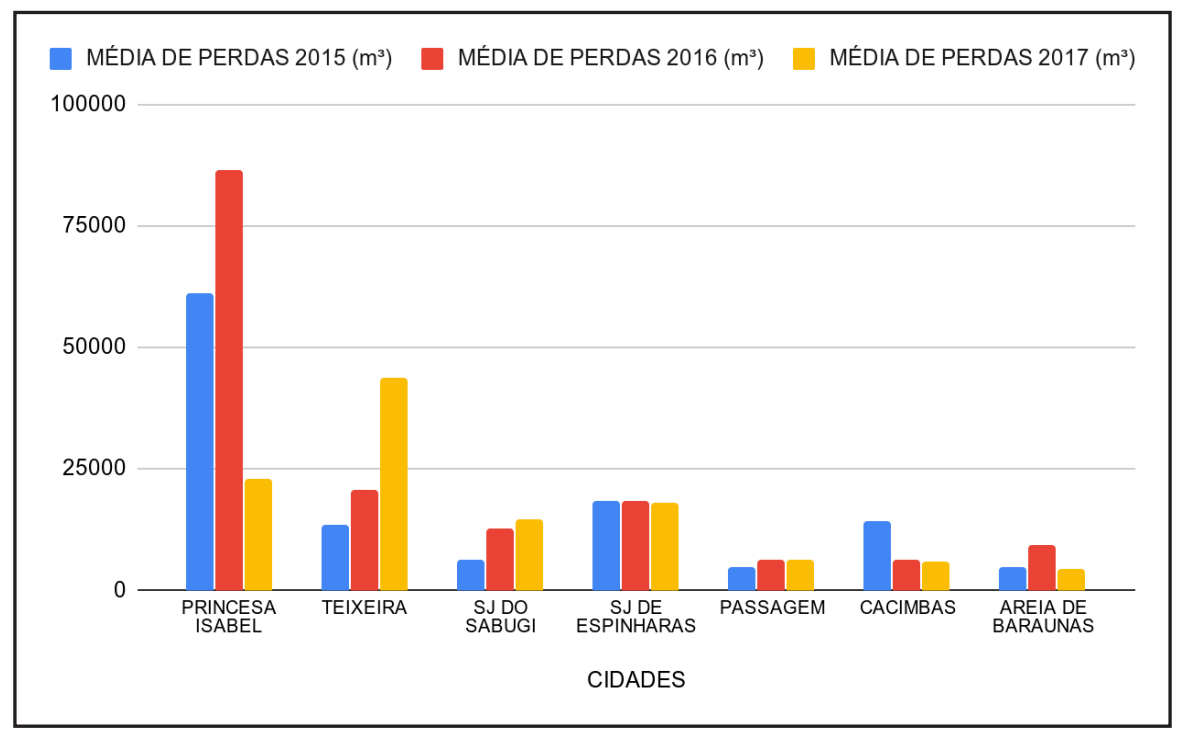

FIGURA 1: Cidades com maiores índices de perdas de água na Regional das Espinharas.

FONTE: Dados da pesquisa (2019).

No Quadro 2 é apresentada uma relação da média de água produzida e água perdida nos anos 2015, 2016 e 2017. Note que os dados estão em m³ , ou seja, para cada $1 \mathrm{~m}^{3}$ falado, este equivale a 1000 litros de água. As perdas reveladas pelos dados são 
assustadores, levando em conta as estiagens e o clima da região em questão.

Já na Figura 1, os anos de 2015, 2016 e 2017, em sua maioria, não apresentaram uma notável melhoria na média de perda, exceto por Cacimbas. No caso de Cacimbas, a mesma perdeu em média anual 14370,08, 9398,9 e 4587,7 entre 2015 e 2017, que, por sua vez, vem a ser uma situação calamitosa dada a condição hídrica pobre dessas cidades. Já em contraste, tem-se Teixeira que à medida que os anos passaram o sistema piorou drasticamente, chegando ao ponto de não haver água para a população, devido ao sistema estar em colapso, ou seja, toda a água foi perdida. Outro caso semelhante, é o de São José do Sabugi, que perdeu em média anual $6213 \mathrm{~m}^{3}, 12652,7 \mathrm{~m}^{3}$ e 14825,3 $\mathrm{m}^{3}$ de água nos anos de 2015, 2016 e 2017, respectivamente.

No Quadro 3 fica bem claro o quão grave vem a ser a situação, pois, tomado como referência a média de capacidade de um caminhão pipa, que é de 10 mil litros, as cidades teriam perdido nos respectivos anos:

\begin{tabular}{|c|c|c|c|}
\hline & \multicolumn{3}{|c|}{ QUANTIDADE DE CAMINHÕES PIPA } \\
\hline CIDADES & 2015 & 2016 & 2017 \\
\hline PRINCESA ISABEL & 6132 & 8638 & 2299 \\
\hline TEIXEIRA & 1365 & 2067 & 4380 \\
\hline SJ DO SABUGI & 621 & 1265 & 1483 \\
\hline SJ DE ESPINHARAS & 1860 & 1849 & 1809 \\
\hline PASSAGEM & 494 & 628 & 625 \\
\hline CACIMBAS & 1437 & 620 & 609 \\
\hline AREIA DE BARAÚNAS & 488 & 940 & 459 \\
\hline TOTAL & 12398 & 16008 & 11663 \\
\hline
\end{tabular}

QUADRO 3 - Quantidade de Caminhões Pipa por Ano em litros FONTE: Dados da pesquisa (2019).

Diante do exposto, a fim de melhor dimensionar essas perdas, durante estes 3 anos seria possível abastecer 40.069 caminhões pipa de 10.000 litros, que por sua vez poderia abastecer muitas cidades da própria região que vivem em racionamento ou da água que chega por caminhões pipa, sem contar as pequenas fazendas que poderiam usar essa água para irrigação de sua lavoura ou para matar a sede de seus animais. 


\section{I CONSIDERAÇÕES FINAIS}

Nesse sentido, respondendo ao objetivo da pesquisa em analisar, de modo quantitativo, as perdas físicas em algumas cidades que são abastecidas pela CAGEPA e realizando uma comparação com as perdas, levando em consideração os aspectos já apresentados, os danos sociais e econômicos causados pelas perdas de água são espantosos, já que, as sete cidades com os maiores índices de perdas são de pequeno porte, seja por sua área territorial ou sua população relativa, sendo que este fato passa despercebido pela população.

Segundo documento elaborado pela ABES (2015), o combate às perdas é uma atividade operacional contínua e das mais importantes das operadoras de saneamento. Nesse caso, o combate às perdas deve ser tratado como um esforço consecutivo, pois as perdas de água tem uma tendência natural de aumento, ou seja, se nada for feito, a infraestrutura envelhece, surgem novos vazamentos, hidrômetros perdem a precisão e outras irregularidades aumentam. É preciso um nível de esforço e aplicação de recursos para evitar o aumento das perdas e outro para que elas comecem a diminuir (SABESP, 2014).

Celeste (2006) em contrapartida, menciona que a solução para o problema da escassez não se restringe apenas a construção de reservatórios, é primordial a implementação de políticas operacionais do uso das águas em tais reservatórios, refletido principalmente nas avaliações e análises de desempenho do sistema hídrico, inclusive em períodos críticos de seca, possibilitando a análise de possíveis cenários.

Por fim, fica sugestão que tanto a população quanto a própria empresa dê mais atenção para o problema de perdas de recursos hídricos, já que tratou-se de uma região semiárida com poucas chuvas no inverno e que apresenta dados bastante alarmantes. E assim, com dedicação e investimento no setor que combate as perdas, ao longo do tempo, essa situação possa mudar.

\section{REFERÊNCIAS}

ABES. Associação Brasileira de Engenharia Sanitária e Ambiental. Controle e redução de perdas nos sistemas públicos de abastecimento de água, 2015. Disponível em: <http://abes-dn.org.br/ pdf/28Cbesa/Perdas_Abes.pdf> Acesso em: 14 set. 2019.

AUGUSTO, L. G. da S. et al (Org.). O contexto global e nacional frente aos desafios do acesso adequado à água para consumo humano. Ciênc. Saúde Coletiva, [s.l.], v. 17, n. 6, p.1511-1522, jun. 2012. FapUNIFESP (SciELO). Disponível em: <http://www.scielo.br/pdf/csc/v17n6/v17n6a5.pdf>. Acesso: 16 set. 2019.

BRASIL. Lei de Águas: Lei nº 9.433, de 08 de janeiro de 1997. Brasília - DF, 1997.

CELESTE, A. B.; Determinação e análise de indicadores de desempenho e de sustentabilidade de seis açudes na bacia do rio Piancó - PB e de suas potenciais demandas. 2006. 119 f. Dissertação (Mestrado em Engenharia Civil e Ambiental) - Universidade Federal de Campina Grande, Campina Grande - PB, 2006. 
COSTA, M. A. M.; Os fluxos da água na metrópole - usos múltiplos e gestão participativa na Baía de Guanabara (RJ). 217 f. Tese de Doutorado (Planejamento Urbano e Regional) - Universidade Federal do Rio de Janeiro, UFRJ, Rio de Janeiro. 2013.

FONSECA, J. J. S. Metodologia da pesquisa científica. Fortaleza: UEC, 2002. Apostila. Disponível em: <http://www.cesadufs.com.br/ORBI/public/uploadCatalago/09520520042012Pratica_de_ Pesquisa_I_Aula_2.pdf>. Acesso em: 23 set. 2019.

FUNDACE. ESTUDO FUNDACE: PERDAS DE ÁGUA: ENTRAVES AO AVANÇO DO SANEAMENTO BÁSICO E RISCOS DE AGRAVAMENTO À ESCASSEZ HÍDRICA NO BRASIL. 2013. 52 f. Monografia (Especialização) - Curso de Administração, Fundação Para Pesquisa e Desenvolvimento da Administração, Contabilidade e Economia, Ribeirão Preto, 2013. Disponível em: <http://www.tratabrasil. org.br/datafiles/uploads/perdas-de-agua/estudo-completo.pdf>. Acesso em: 17 set. 2019.

GIL, Antônio Carlos. Como elaborar projetos de pesquisa. São Paulo: Atlas, 2002. 176 p. Disponível em: <http://www.urca.br/itec/images/pdfs/modulo\%20v\%20-\%20como_elaborar_projeto_de_. pesquisa_-_antonio_carlos_gil.pdf>. Acesso em: 12 out. 2019.

GRUPO DE TRABALHO SOBRE RECURSOS HÍDRICOS. Manual de gestão eficiente de recursos hídricos. São Paulo: Abiquim, 2016. Disponível em: <https://www.abiquim.org.br/uploads/guias estudos/Manual_Recursos_Hidricos_Vs8_WEB_FINAL.pdf>. Acesso em: 14 set. 2019.

LIMA, Jorge Enoch Furquim Werneck. Recursos hídricos no Brasil e no mundo. Embrapa CerradosDocumentos (INFOTECA-E), 2001.

BRASIL, Instituto Trata. PERDAS DE ÁGUA 2018 (SNIS 2016): DESAFIOS PARA DISPONIBILIDADE HÍDRICA E AVANÇO DA EFICIÊNCIA DO SANEAMENTO BÁSICO. São Paulo: Instituto Trata Brasil, 2018. Disponível em: <http://www.tratabrasil.org.br/images/estudos/itb/perdas-2018/estudo-completo. pdf $>$. Acesso em: 18 set. 2019.

PEREIRA JÚNIOR, J. de S. Recursos Hídricos - conceituação, disponibilidade e usos. Biblioteca digital da câmara dos deputados, p. 04-05, abril, 2004.

ROSA. B. P.; RIBEIRO. J. C. J.; A cobrança pelo uso da água como mecanismo de sustentabilidade. Revista do Mestrado em Direito da Universidade Católica de Brasília: Escola de Direito. Brasília - DF, v. 9, n² 2, p. 59-90, jul./ Dez, 2014.

SABESP. Companhia de Saneamento Básico do Estado de São Paulo. Controle de perdas. 2014. São Paulo. Disponível em: <http://site.sabesp.com.br/site/interna/Default.aspx?secaold=37> Acesso em: 13 set. 2019.

VERGARA, S. C. Projetos e relatórios de pesquisa em administração. 5. ed. São Paulo: Atlas, 2004.

VIANA, L. F. G. Proposta de modelo de cobrança de água bruta no estado do Ceará: Uma revisão do modelo atual. 2011. 85 p. Dissertação (Mestrado em Economia Rural) - Universidade Federal do Ceará, Fortaleza - CE, 2011.

WERDINE, Demarcus. PERDAS DE ÁGUA EM SISTEMAS DE ABASTECIMENTO. 2002. $129 \mathrm{f}$. Dissertação (Mestrado) - Curso de Engenharia da Energia, Pró-diretoria de Pesquisa e Pós-graduação Engenharia da Energia, Universidade Federal de Itajubá, Itajubá, 2002. Disponível em: <http://saturno. unifei.edu.br/bim/0031253.pdf>. Acesso em: 16 set. 2019. 


\section{CAPÍTULO 8}

\section{PROJETO DE CAPTAÇÃO DE ÁGUA PLUVIAL PARA APROVEITAMENTO NO LABORATÓRIO DE ENGENHARIA CIVIL DO CAMPUS ALTO PARAOPEBA - UFS $J$}

Data de aceite: 04/01/2021

Data de submissão: 14/11/2020

Deysiane Antunes Barroso Damasceno Centro Universitário Presidente Antônio Carlos UNIPAC Barbarcena

Barbacena-MG http://lattes.cnpq.br/3346750236308165

Isabela Carvalho Pinheiro Universidade Federal de São João Del Rei UFSJ/CAP

São João Del Rei-MG http://lattes.cnpq.br/3103246914806704

Emmanuel Kennedy da Costa Teixeira Universidade Federal de São João Del Rei UFSJ/CAP

Ouro Branco-MG http://lattes.cnpq.br/1331927563540337

RESUMO: A captação e uso de água da chuva é uma prática muito utilizada para diferentes fins, como diminuir o número de enchentes em determinados lugares, minimizar os gastos financeiros, abastecer regiões que sofrem com falta de água e, principalmente, diminuir o uso de água potável para fins menos nobres. Diante desses fatores, esse trabalho tem como finalidade apresentar os componentes que integram um sistema de captação e armazenamento de água de chuva e a metodologia de dimensionamento desses componentes. Essa metodologia foi então aplicada no dimensionamento de um sistema de captação de água da chuva para utilização no laboratório de Engenharia Civil do
Campus Alto Paraopeba da Universidade Federal de São João Del-Rei. Para isso, levantaram-se os dados pluviométricos da região onde está localizado o laboratório e sua demanda de água para consumo não potável. O dimensionamento do sistema incluiu a determinação da área da cobertura que contribuirá para a coleta da água precipitada, o dimensionamento dos condutores verticais, horizontais, calhas, reservatório de acumulação e de descarte da primeira chuva.

PALAVRAS-CHAVE: Chuva. Água pluvial. Sustentabilidade. Aproveitamento de água de chuva. Recursos hídricos.

\section{RAINWATER HARVESTING PROJECT}

FOR USE IN THE CIVIL ENGINEERING LABORATORY OF CAMPUS ALTO PARAOPEBA - UFSJ

ABSTRACT: The capture and use of rainwater has been widely used for different purposes, such as reducing floods, minimizing taxes, supplying regions that suffer from water shortages and reducing the use of drinking water in some situations. Given these factors, this work aims to present the components of the rainwater collection system and the dimensioning methodology for these components. This methodology was applied in the design of a rainwater catchment system of the Civil Engineering laboratory of the Alto Paraopeba Campus of the Federal University of São João Del-Rei. For this, the region rainfall data and the laboratory's demand for water for non-potable consumption were collected. The dimensioning of the system included the determination of the coverage area that will contribute to the collection of precipitated water, 
the dimensioning of the vertical, horizontal conductors, gutters, accumulation and disposal reservoir of the first rain.

KEYWORDS: Rain. Rainwater. Sustainability. Use of Rainwater. Water resources.

\section{I INTRODUÇÃO}

Cerca de 2/3 da superfície do planeta Terra são ocupados pelos oceanos. O volume total de água na Terra é estimado em torno de 1,35 milhões de quilômetros cúbicos, sendo que $97,5 \%$ deste volume é de água salgada, encontrada em mares e oceanos. Já $2,5 \%$ é de água doce, porém localizada em regiões de difícil acesso, como aquíferos (águas subterrâneas) e geleiras. Apenas $0,007 \%$ da água doce se encontram em locais de fácil acesso para o consumo humano, como lagos, rios e na atmosfera (UNIÁGUA, 2006 apud MARTINS et al, 2019).

O Brasil é um dos países que possui o maior volume acumulado de água, porém essas reservas encontram-se mal distribuídas. As regiões brasileiras com maior concentração da população apresentam menor disponibilidade de água, por exemplo o Sudeste e Nordeste do país. Ao contrário do que acontece nessas regiões, o Norte do país possui menor população e a maior parte dos recursos hídricos encontroados no Brasil (GHISI, 2006 apud MARINOSKI, 2007).

A ideia de desenvolvimento sustentável, o dispêndio com tratamento de água e a necessidade de garantir às futuras gerações acesso aos recursos hídricos impulsionam a busca por alternativas para reduzir o desperdício e consumo de água potável para usos menos nobres. Nesse cenário, a utilização da água da chuva tem se tornado uma ótima opção, principalmente para o Brasil, onde o volume de chuva anual é considerável.

No Laboratório de Engenharia Civil (LEC), do Campus Alto Paraopeba da Universidade Federal de São João Del-Rei (CAP-UFSJ), há um elevado consumo de água tratada em destiladores e bacias sanitárias. Dessa forma, a captação da água de chuva pode ser uma excelente alternativa para reduzir a parcela de água potável destinada a estes fins.

\section{I OBJETIVO}

Este trabalho tem como finalidade dimensionar um sistema de captação e aproveitamento de água de chuva para utilização nas bacias sanitárias e destiladores do LEC do CAP-UFSJ, para isso, esse estudo foi dividido nas seguintes etapas: levantamento da área de captação da água de chuva, dimensionamento das calhas, condutos verticais e horizontais; dimensionamento do reservatório de armazenamento por diferentes métodos; e dimensionamento do reservatório de descarte. 


\section{I FUNDAMENTAÇÃO TEÓRICA}

\section{1 Águas pluviais como recurso hídrico}

Fontes alternativas de abastecimento de água têm sido cada vez mais difundidas pelo mundo na tentativa de suprir a demanda deste bem, uma vez que a escassez deste recurso, associada à ineficácia dos sistemas de tratamento de água e esgoto, e a crescente poluição que atinge em larga escala a qualidade dos mananciais tornam cada vez mais difícil e oneroso obter água por métodos convencionais (GONÇALVES et al., 2006).

O aproveitamento de águas de chuvas para consumo é uma prática antiga realizada por várias civilizações passadas, possuindo relatos de sistemas de coleta e armazenamento de águas pluviais no Oriente Médio, Europa e pelos Incas, Maias e Astecas na América Latina, há cerca de 2000 anos. Com o passar do tempo e com o aparecimento de novas técnicas de obtenção de água, este método foi deixando de ser praticado (GONÇALVES et al., 2006).

Atualmente, no Brasil, a utilização de técnicas que utilizam águas de chuvas não acompanha o crescimento do país, assim como não tem se desenvolvido na mesma proporção que surgem os problemas com escassez de água (GONÇALVES et al., 2006). Os deflúvios superficiais provenientes de águas de chuvas representam fontes alternativas de água para consumos menos exigentes, além de se caracterizarem como alternativa socioambiental e economicamente viável (RIGHETTO et al., 2009).

\subsection{Qualidade das águas pluviais}

Vários fatores influenciam na qualidade das águas de chuvas. O posicionamento geográfico, o clima, a presença de indústrias na região, o índice de poluição etc., são fatores que estão intimamente ligados à qualidade das águas pluviais. Quando há precipitação, a chuva limpa a atmosfera incorporando suas impurezas, o que reduz sua qualidade. Outra forma de contaminação das águas de chuvas é na própria superfície que a coleta. Os materiais destas superfícies não devem conter impurezas que interfiram na qualidade da água, assim como devem preferencialmente não reter sujeiras. Os reservatórios de armazenamento destas águas devem também ser projetados de forma a não contaminála. Uma medida para garantir a eliminação de impurezas incorporadas na captação e reservação é eliminar o primeiro milímetro de água captada (GONÇALVES et al., 2006).

O padrão de qualidade da água é função do uso a que ela se destina. De maneira geral, estas águas são destinadas a fins não potáveis como: rega de jardins, lavagem de roupas e pisos, descargas sanitárias etc. Quando as águas pluviais se destinam a outros fins, como o consumo direto humano, é necessário que ela passe por um processo de desinfecção (GONÇALVES et al., 2006). 


\subsection{Sistema de aproveitamento de água de chuva}

Convencionalmente, as instalações de águas pluviais têm por objetivo coletar as águas de chuvas vindas de superfícies impermeabilizadas e conduzi-las à rede pública de drenagem pluvial. Porém, com a implantação de sistemas de aproveitamento de águas de chuvas, estas não são mais direcionadas a rede pública de coleta, mas sim a dispositivos que as retêm e posteriormente as distribui para o consumo não potável (BAPTISTA e LARA, 2010).

A configuração básica de um sistema de aproveitamento de água de chuva constitui de superfície de captação, dos dispositivos de condução, eventualmente de unidades de filtração e tratamento - a depender do fim a que se destina a água e de sua qualidade e, por fim, do elemento de acumulação. Há casos ainda que seja necessário sistema de recalque, o que acontece quando não existe a possibilidade da condução da água ser feita por gravidade até o reservatório ou não há pressões mínimas necessárias para sua distribuição. Sendo assim, nestes casos, geralmente usam-se dois reservatórios, sendo um inferior e outro superior, e a unidade de recalque (SANTOS, 2002).

\subsection{Intensidade pluviométrica}

A intensidade pluviométrica (I) é a razão entre a altura pluviométrica precipitada e a duração da precipitação. O dimensionamento dos componentes de um sistema de aproveitamentos de águas pluviais depende de análises estatísticas das chuvas mais intensas registradas na região ao longo do tempo, as quais permitem relacionar intensidade, duração e frequência das chuvas (BAPTISTA e LARA, 2010). Um parâmetro importante para a determinação da intensidade pluviométrica é o período de retorno $(T)$, que corresponde ao intervalo de tempo que a intensidade de determinada chuva leva para ser superada ou igualada.

Outro parâmetro fundamental para se determinar a intensidade pluviométrica de determinada região é o tempo de duração da chuva (t), que segundo a NBR 10844/1989 deve ser fixado em 5 minutos para o dimensionamento de sistemas de coleta de águas pluviais.

Por fim, a equação que relaciona intensidade, duração e frequência da chuva para diferentes localidades é dada na Equação 1;

$$
\mathrm{I}=\frac{\mathrm{kT}^{\mathrm{m}}}{\left(\mathrm{t}+\mathrm{t}_{0}\right)^{\mathrm{n}}} \quad \text { Equação 1 }
$$

Onde os parâmetros $K, m, n$ e $t_{0}$ variam de acordo com a localidade e podem ser obtidos pelas estações pluviométricas que monitoram as ocorrências de chuvas. A NBR 10844/1989 ressalta que para construções de até $100 \mathrm{~m}^{2}$ de área de projeção horizontal, salvo casos especiais, pode-se adotar / igual a $150 \mathrm{~mm} / \mathrm{h}$. 


\section{5 Área de coleta}

A área de contribuição $(A)$ é definida como a área plana onde a chuva incide. Devese também considerar a inclinação da cobertura e caso existam paredes e platibandas que também interceptam a chuva, estas devem ser consideradas.

O cálculo destas áreas pode ser feito conforme a NBR 10844/1989 que estabelece critérios de dimensionamento da área de contribuição para diferentes tipos de cobertura.

\subsection{Coeficiente de deflúvio}

Nem todo volume de água que incide na área de coleta pode ser captado, parcela da água precipitada infiltra, evapora e/ou fica retida na superfície de coleta. O grau de impermeabilização desta superfície pode ser obtido pelo coeficiente de deflúvio $(C)$, também conhecido como coeficiente de Runoff, que é a relação entre a vazão que escoa na superfície e a vazão precipitada, para telhados esse coeficiente pode variar de 0,75 a 1 (BAPTISTA e LARA, 2010).

\subsection{Vazão de dimensionamento}

A vazão de água pluvial $Q(L / m i n)$ que será coletada é função da intensidade pluviométrica $I(\mathrm{~mm} / \mathrm{h})$, do coeficiente de deflúvio $C$ e da área de coleta $A\left(\mathrm{~m}^{2}\right)$, e pode ser calculada pela Equação 2.

$$
Q=\frac{\text { CIA }}{60} \quad \text { Equação } 2
$$

\subsection{Dimensionamento das calhas}

As calhas são componentes responsáveis por receber a água coletada e encaminhála até o reservatório de armazenamento. Elas funcionam em regime de escoamento livre, por isso podem ser dimensionadas segundo a equação de Manning-Strickler, conforme também sugere a NBR 10844/1989. As calhas podem ser fabricadas em diversos materiais, como plástico, fibrocimento, aço, metais não ferrosos, concreto, alvenaria etc., assim como em diversos formatos, retangulares, semicirculares, trapezoidais entre outros (BAPTISTA e LARA, 2010).

A NBR 10844/1989 sugere a Equação 3 para o dimensionamento das calhas.

$$
Q=\frac{D^{\frac{10}{3}}}{8^{\frac{5}{3}}}(\theta-\operatorname{sen} \theta)^{\frac{5}{3}} \sqrt{I} /\left(\frac{\theta D}{2}\right)^{2 / 3} n \quad \text { Equação } 3
$$

Onde: $Q$ é vazão de projeto, em $\mathrm{m}^{3} / \mathrm{s} ; \theta=2 \cos ^{-1}\left(1-\frac{2 y}{D}\right)$, em rad; $\frac{Y}{D}=66 \%$ é a lâmina d'água; $D$ é o diâmetro da calha, em $\mathrm{mm}$; e $n$ é o coeficiente de rugosidade de Manning, este coeficiente varia de acordo com o material do componente.

A NBR 10844/1989 ainda sugere que a inclinação das calhas de beiral e platibanda devem ser uniformes, com valor mínimo de 0,5\%, e quando a saída da calha estiver a 
menos de $4 \mathrm{~m}$ de uma mudança de direção, a vazão de projeto deve ser multiplicada pelos coeficientes 1,2 e 1,1 para curvas de canto reto a menos de $2 \mathrm{~m}$ e entre $2 \mathrm{~m}$ e $4 \mathrm{~m}$ da saída da calha, respectivamente, e, pelos coeficientes 1,1 e 1,05 para curvas de canto arredondado a essas mesmas distâncias.

\subsection{Dimensionamento dos condutores verticais e horizontais}

O dimensionamento dos condutores verticais não se dá de forma direta, uma vez que seu escoamento pode ser livre e/ou forçado, a depender das condições de entrada e saída da água na canalização (BAPTISTA e LARA, 2010). Por isso, a NBR 10844/1989 sugere ábacos que permitem o dimensionamento destas tubulações em função da vazão de projeto, lâmina líquida nas calhas e comprimento dos condutores verticais.

A NBR 10844 recomenda também que o diâmetro mínimo adotado seja de 70 mm, e que os condutores sejam preferencialmente projetados em uma única prumada. Quando isto não é possível, devem-se utilizar curvas de 45 ou $90^{\circ}$ e projetar pontos de inspeção.

Condutores horizontais devem, assim como as calhas, serem projetados como condutos livres, ou seja, seu dimensionamento também se dá pela Equação 3. Deve-se adotar uma declividade mínima de 0,5\% para estas tubulações e quando se tratar de tubos circulares a lâmina de água não deve ultrapassar 2/3 do diâmetro adotado.

\subsection{Dimensionamento do reservatório}

Para o dimensionamento dos reservatórios deve-se levar em conta as séries históricas das precipitações médias mensais, sendo recomendado séries que contenham dados de pelo menos dez anos (TOMAZ, 2010).

Os reservatórios devem ser projetados como aqueles que armazenam água potável, levando-se em conta todas as precauções no que se refere à preservação da qualidade da água. Os reservatórios podem ser elevados, apoiados, semienterrados ou enterrados. Podem ser em materiais como concreto, alvenaria armada, materiais plásticos como polietileno, PVC, fibra de vidro e aço inox (TOMAZ, 2010).

A NBR 15527/2007 sugere alguns métodos de dimensionamento de reservatórios de acumulação de água pluvial, os quais serão discutidos a seguir.

\subsubsection{Método de Rippl}

Este método também é conhecido como método do diagrama de massas, originalmente desenvolvido para regularização de vazões de grandes reservatórios, fornece volumes elevados que garantem água tanto em períodos chuvosos como em períodos secos. Para aplicação deste método é necessário o uso de séries históricas de precipitações médias mensais ou diárias. Pode-se estimar o volume de reservatórios de demanda constante ou variável. Este método permite que o volume seja determinado analiticamente ou através de gráficos e tabelas (COUTO, 2012). 
No gráfico da Figura 1, a curva em azul representa a variação do volume de água disponível em função do tempo, enquanto a curva rosa cheia representa a demanda. A distância entre as duas linhas paralelas que tangenciam os pontos máximo e mínimo da curva azul, fornece o volume que deve ser reservado para garantir água no período de estiagem.

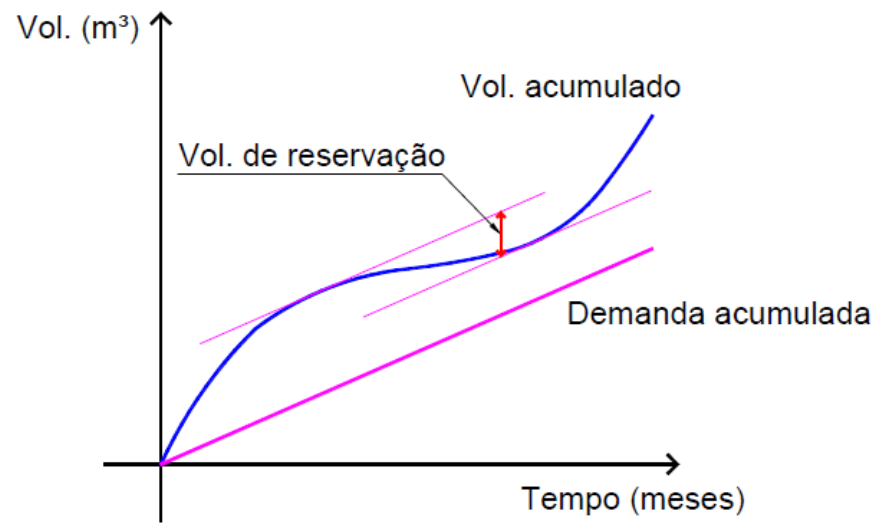

Figura 1: Esquema gráfico do Método de Rippl Fonte: Couto, 2012.

\subsubsection{Método da simulação}

Neste método um determinado volume é arbitrado e verifica-se se ocorre excesso de reservação (overflow) ou falta. Varia-se o volume arbitrado do reservatório de forma a atender o interesse do construtor, caso não se deseja usar água de fonte externa, deve-se aumentar as dimensões do reservatório, caso contrário, diminui-se o reservatório, mas criase a necessidade do uso de suprimento nos períodos de seca (COUTO, 2012).

\subsubsection{Método Azevedo Neto}

Também conhecido como Método Prático Brasileiro, este método utiliza uma série de precipitação anual relacionando-a com a quantidade de meses com pouca chuva ou seca.

O volume $(L)$ do reservatório é ideal quando for cerca de $4,2 \%$ do produto entre a precipitação média anual em $\mathrm{mm}$, a área do telhado em $\mathrm{m}^{2} \mathrm{e}$ o número de meses de pouca chuva (COUTO, 2012).

\subsubsection{Método prático alemão}

Trata-se de um método empírico onde o volume adotado é o menor valor entre 6\% 
do volume anual de consumo ou $6 \%$ do volume anual de precipitação aproveitável.

3.10.5 Método prático inglês

Segundo Fontanela et al (2012 apud COUTO, 2012) este método considera apenas que o volume a reservar deve ser $5 \%$ do produto entre a precipitação média anual $P$, em $\mathrm{mm}$ e a área de coleta $A$, em $\mathrm{m}^{2}$, sem levar em consideração variáveis como demanda, impermeabilização etc.

\subsubsection{Método prático australiano}

Este método utiliza séries históricas mensais de precipitação. O cálculo faz uma análise entre a chuva total do mês e a demanda mensal. Fazem-se estimativas de valores do volume do reservatório até que o volume adotado reserve água suficiente para suprir a demanda nos meses de estiagem.

\subsection{Dimensionamento do reservatório de descarte}

Vários estudos sugerem que a primeira água de chuva que cai sobre a superfície de coleta é a mais poluída, uma vez que ela limpa a superfície. É recomendado então, que se descarte certo volume de água antes que se comece o armazenamento de fato. Tomaz (2010) ressalta que o first flush, que é o primeiro volume de chuva que será descartado, varia de $0,4 \mathrm{~L} / \mathrm{m}^{2}$ a $8 \mathrm{~L} / \mathrm{m}^{2}$ de telhado, conforme o local, e que na falta de dados locais sugere-se o uso do first flush no valor de $2 \mathrm{~L} / \mathrm{m}^{2}$ de área de telhado.

\section{I DIMENSIONAMENTO DO SISTEMA DE CAPTAÇÃO DE ÁGUA DE CHUVAS DO LEC- UFSJ/CAP}

\subsection{Metodologia}

O sistema de captação e aproveitamento da água de chuva no Laboratório de Engenharia Civil do Campus Alto Paraopeba - UFSJ - foi dimensionado considerando as seguintes etapas: Levantamento de dados pluviométricos da região onde está localizado o laboratório; levantamento quantitativo do consumo de água não potável; determinação da área da cobertura que contribuirá para a coleta; dimensionamento dos condutores verticais, horizontais, calhas, reservatório de acumulação e de descarte da primeira chuva.

\subsection{Resultados e discussões}

O consumo de água nas bacias sanitárias do LEC foi estimado a partir do limite máximo de utilização de água para limpeza de bacias sanitárias, estabelecido em 6 L/ descarga, e pelo número estimado de descargas diárias no laboratório. Considerando o número de pessoas que frequentam diariamente o Laboratório de Engenharia Civil, cerca 20 pessoas, e o número de vezes que cada uma utiliza os sanitários, em média duas vezes por dia, tem-se um total de 40 descargas por dia. Porém, o dimensionamento foi feito de 
maneira conservadora considerando 50 descargas por dia, gerando uma vazão de $300 \mathrm{~L} /$ dia. Já o consumo de água nos destiladores foi determinado através da medição da vazão nos dois aparelhos, encontrando-se 654,35 L/d em cada um. Assim, o consumo mensal é $48,26 \mathrm{~m}^{3}$.

A vazão de projeto de $1936,86 \mathrm{~L} / \mathrm{min}$ foi obtida em função da intensidade de precipitação da região $\mathrm{I}=146 \mathrm{~mm} / \mathrm{h}$, da área de coleta $A=795,97 \mathrm{~m}^{2}$ e do coeficiente de Runoff $\mathrm{C}=1$. Esta vazão foi utilizada para o dimensionamento das calhas e condutores verticais, encontrando-se os diâmetros mínimos necessários iguais a $180 \mathrm{~mm}$ e 91,72 mm, respectivamente. Foram adotados os diâmetros comerciais de $200 \mathrm{~mm}$ e $100 \mathrm{~mm}$, nessa ordem.

O dimensionamento do reservatório de acumulação foi realizado conforme os seis métodos apresentados. O Método de Rippl forneceu um volume de 146,58 $\mathrm{m}^{3}$, este volume significa o volume de chuva que deve ser acumulado durante os períodos chuvosos para que não se falte água durante os períodos de seca e não seja necessário o uso de suprimentos extras.

O Método da simulação permite que se adote um volume do reservatório e se analise a variação do seu volume. Foi estipulado, então, um volume próximo ao valor de demanda, de 50,00 $\mathrm{m}^{3}$. Tal volume se mostrou suficiente para abastecer a edificação durante a maioria dos meses, exceto nos meses de junho a setembro, os quais precisariam de suprimento de água.

O Método de Azevedo Neto forneceu um valor elevado para o volume do reservatório, 236,14 $\mathrm{m}^{3}$, ao se adotar este volume, um reservatório de grandes dimensões seria necessário, o que oneraria muito os custos com implantação do sistema. Por outro lado, o Método alemão estabeleceu um volume igual 34,70 $\mathrm{m}^{3}$, inferior ao volume de demanda mensal. Dessa forma, seria obrigatoriamente necessário o uso de suprimento de água de outras fontes em todos os meses, por outro lado, as dimensões do reservatório seriam diminuídas, reduzindo-se o custo de implantação do sistema.

O Método Prático Inglês forneceu um valor moderado para o volume do reservatório, $56,22 \mathrm{~m}^{3}$, enquanto o Método Australiano apontou que o reservatório de acumulação deve ter no mínimo $154,57 \mathrm{~m}^{3}$ para garantir água durante o período de estiagem.

O reservatório de descarte foi dimensionado considerando first flush de $2 \mathrm{~L} / \mathrm{m}^{2}$. Dessa maneira, seu volume necessário seria de 1591,94 L.

\section{I CONCLUSÃO}

Sistemas de captação e armazenamento de águas de chuva para consumo não potável mostram-se alternativas sustentáveis e de grande potencial econômico.

No dimensionamento do sistema para o LEC UFSJ-CAP pôde-se notar que o volume do reservatório de acumulação e a demanda de suprimento de água de fontes extras são os 
fatores de maior impacto na viabilidade econômica do projeto. Isso porque os reservatórios de acumulação de grandes dimensões implicam em altos custos de implantação, enquanto aqueles de menor capacidade exigem suprimento de água do sistema de abastecimento externo, que por sua vez, é taxado. Sugerindo a necessidade de uma análise mais detalhada a respeito dos custos e efetividade do sistema.

Apesar disso, é inegável a contribuição que esse sistema promove ao meio ambiente: redução do consumo de água potável e deflúvio superficial, por exemplo. Somados ao exposto estão o elevado consumo de água em edificações e a alta incidência de chuva na região durante alguns meses do ano, que juntos reforçam a necessidade de implantação de sistemas de captação de água alternativos.

\section{REFERÊNCIAS}

ABNT - Associação Brasileira de Normas Técnicas. NBR 10844: Instalações Prediais de Águas Pluviais. Rio de Janeiro, 1989.

ABNT - Associação Brasileira de Normas Técnicas. NBR 15527: Água de Chuva- Aproveitamento de Coberturas em Áreas Urbanas para Fins Não Potáveis. Rio de Janeiro, 2007.

BAPTISTA, Márcio; LARA, Márcia. Fundamentos de Engenharia Hidráulica. 3ed. Belo Horizonte: UFMG, 2010.

COUTO, Vanessa. Projeto de Aproveitamento da Água da Chuva Para o Ginásio de Esporte da Universidade do Estado de Santa Catarina (UDESC) em Joinville. Trabalho de Conclusão de Curso - Universidade do Estado de Santa Catarina, Joinville-SC, 2012.

FONTANELA, Leonarodo; MENDES, João Paulo; BACK, Álvoro José; VARGAS, Alexandre. Avaliação de metodologias para dimensionamento de reservatórios de água pluvial. Hydro, São Paulo, n.65, p.50-58, mar. 2012.

GHISI, E.; TRÉS, A. C. R. Netuno: aproveitamento de águas pluviais no setor residencial. Disponível em < http://www.labeee.ufsc.br/software/netuno.html>. Programa computacional, 2004. Acesso em 15 out. 2015a.

GONÇALVES, Ricardo (Coord.) Uso Racional da Água em Edificações.1 ed. Rio de Janeiro: ABES, 2006.

MARINOSKI, Ana. Aproveitamento de Água Pluvial para Fins Não Potáveis em Instituição de Ensino: Estudo de Caso em Florianópolis-SC. Trabalho de Conclusão de Curso - Universidade do Estado de Santa Catarina, Florianópolis-SC, 2007.

MARTINS, J. V.; COSTA, E. S.; MOTA, K. R. R.; MATSUOKA, J. V. Aproveitamento de água pluvial para fins não potáveis: estudo de caso na Fundação Carmelitana Mário Palmério, Monte CarmeloMG. GETEC, v. 8, n. 20, p.184-203/2019. 
TOMAZ, Plínio. Livro Digital - Água: Pague Menos, capítulo 03 - Aproveitamento de água de chuva de cobertura em área urbana para fins não potáveis, 2010. Disponível em: http://pliniotomaz.com.br/ downloads/livros/livro_pague_menos/capitulo03.pdf>. Acesso em 15 out. 2015a.

RIGHETTO, Antônio (Coord.) Manejo de Águas Pluviais Urbanas. 1 ed. Rio de Janeiro: ABES, 2009.

SANTOS, Daniel. Os Sistemas Prediais e a Promoção da Sustentabilidade Ambiental. Porto Alegre, v.2, n.4, p.7-18, out./dez. 2002. Associação Nacional de Tecnologia do Ambiente Construído.

UNIÁGUA. Universidade da água. Água no Planeta. 2006. Disponível em: . Acesso em: 25 mar 2018. 
Data de aceite: 04/01/2021

Data de submissão: 09/10/2020

\section{Claudia Silvana Soledad Cequeira}

Cátedra Salud Pública, Facultad de Bioquímica, Química y Farmacia

Universidad Nacional de Tucumán

San Miguel de Tucumán -Tucumán https://orcid.org/0000-0002-7957-3420

\section{Cecilia Hebe Noemi Orphèe}

Cátedra Salud Pública, Facultad de Bioquímica, Química y Farmacia

Universidad Nacional de Tucumán

San Miguel de Tucumán -Tucumán https://orcid.org/0000-0001-75569558

Maria Ines Mercado

Laboratorio Morfología Vegetal -Instituto Miguel

Lillo

Universidad Nacional de Tucumán

San Miguel de Tucumán -Tucumán https://orcid.org/0000-0002-81283377

Rosa Magdalena Cruz

Cátedra Salud Pública, Facultad de Bioquímica, Química y Farmacia

Universidad Nacional de Tucumán

San Miguel de Tucumán -Tucumán https://orcid.org/0000-0002-57271819 los meses de Septiembre y Febrero se observa en la superficie del agua algas, cuya presencia causa turbidez. Motivo por el cual, se realizó el seguimiento durante los años 2015 -2018, de parámetros físicos, químicos, y bacteriológicos del agua, además se caracterizó la ficoflora presente. Se tomaron muestras de agua en cinco lugares: Embalse El Limoncito, Rio Carapary, grifo de un Hospital, grifo y purificador de un hogar particular. El pH vario entre 6,00 y 6,50; sulfato y cloruros resultaron positivas, amoniaco, nitritos y nitratos fueron negativos. La dureza del agua fue de 13,65; 33,33; 31,60; 34,33 y 33,90 ( $\left.{ }^{\circ} \mathrm{F}\right)$ Estos valores indicarían aguas duras de acuerdo a la norma establecida por la Organización Mundial de la Salud (O.M.S.) y el Código alimentario argentino (C.A.A.). Los análisis bacteriológicos (Método de Wilson), resultaron positivos en las muestras del Embalse y del Río, el resto negativo. Con la técnica de Petri- Film sólo dio positivo la muestra del Río. Los resultados en los análisis físico-químicos y bacteriológicos del agua de los distintos puntos de muestreo, estuvieron dentro de los permitidos por CAA, con una dureza moderada según la OMS por lo tanto se concluyó que el agua era apta para consumo humano. La especie de alga encontrada es una macrofita del genero Chara sp.

PALABRAS CLAVES:Agua, chara, bacteriología, Salta, ficoflora.
RESUMEN: En la localidad de Aguaray-Salta se encuentra la Planta Potabilizadora Itiyuro, en el paraje Carapary, que abastece de Agua Potable a dicha localidad, la misma recibe agua del Rio Itiyuro y del embalse natural El Limoncito. Entre 


\section{PHYSICAL, CHEMICAL AND BACTERIOLOGICAL MONITORING OF WATER IN THE TOWN OF AGUARAY - SALTA}

ABSTRACT: In the town of Aguaray-Salta there is the Itiyuro Water Treatment Plant, in the Carapary area, which supplies Potable Water to said town, it receives water from the Itiyuro River and the El Limoncito natural reservoir. Between the months of September and February, algae are observed on the surface of the water, whose presence causes turbidity. Reason for which, during the years $2015-2018$, the physical, chemical, and bacteriological parameters of the water were monitored, and the phycoflora present was characterized. Water samples were taken in five places: El Limoncito Reservoir, Rio Carapary, tap from a Hospital, tap and purifier from a private home. The pH varied between 6.00 and 6.50; sulfate and chlorides were positive, ammonia, nitrites and nitrates were negative. The hardness of the water was 13.65; 33.33; $31.60 ; 34.33$ and $33.90\left({ }^{\circ} \mathrm{F}\right)$ These values would indicate hard water according to the standard established by the World Health Organization (O.M.S.) and the Argentine Food Code (C.A.A.). Bacteriological analyzes (Wilson's method) were positive in the samples from the Reservoir and the River, the rest negative. With the Petri- Film technique, only the Rio sample was positive. The results in the physical-chemical and bacteriological analyzes of the water from the different sampling points were within those allowed by CAA, with a moderate hardness according to the WHO, therefore it was concluded that the water was suitable for human consumption. The species of algae found is a macrophyte of the genus Chara sp.

KEYWORDS: Water, chara, bacteriology, Salta, phycoflora.

\section{INTRODUCCIÓN}

En la localidad de Aguaray, al norte de la provincia de Salta (paraje Carapary) se encuentra la Planta Potabilizadora Itiyuro (figura $\mathrm{N}^{\circ} 1$ y foto $\mathrm{N}^{\circ} 1$ ) que abastece de agua potable a dicha localidad; recibe agua del Rio Carapary y del embalse El Limoncito (foto $\mathrm{N}^{\circ} 2$ ). En la década del 70 se construyó el dique Itiyuro aguas arriba al noroeste de la ruta nacional 34, entre las localidades de Aguaray y Profesor Salvador Mazza, a 540 m.s.n.m.. La desestabilización de la cuenca de aporte ocasionó graves problemas de erosión colmatando el vaso del dique en un corto periodo de tiempo (1979-1982). Como respuesta a los problemas con el agua, la planta potabilizadora creó un acueducto entre el embalse natural de El Limoncito y la toma del dique Itiyuro. Asimismo la alimentación del río y del embalse es de origen pluvial lo que hace que su régimen sea muy irregular, recorre un área de escasa pendiente y el transporte de material en suspensión no se manifiesta durante el estiaje momento en que sus aguas son claras. El clima del lugar es tropical (el trópico de capricornio cruza la cuenca en su parte media); con estación seca, tiene como característica temperaturas elevadas y precipitaciones abundantes aunque presenta un período seco durante el invierno y entre los meses de Septiembre y Febrero se observa turbidez en la superficie del agua, debido a la presencia de algas. 

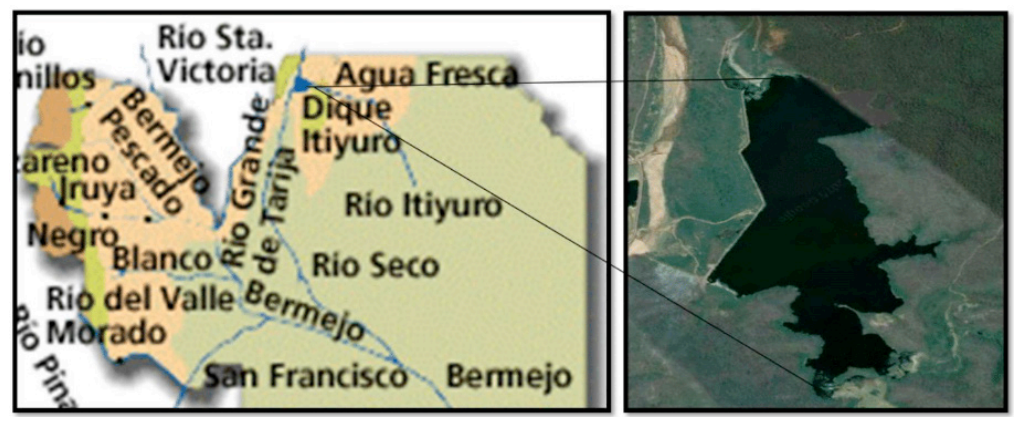

Figura $N^{\circ} 1$.- Dique Itiyuro. Ubicación geográfica

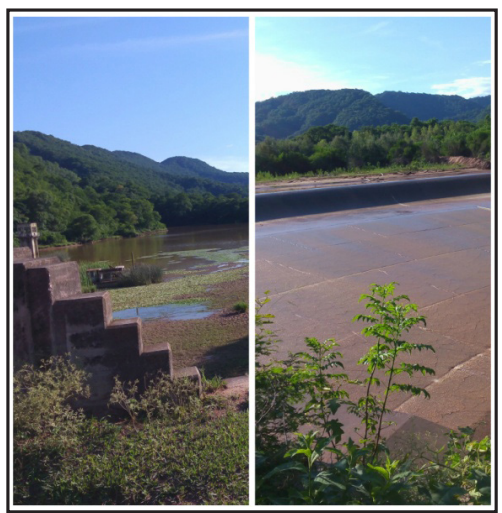

Foto $\mathrm{N}^{\circ} 1 .-$ Dique Itiyuro

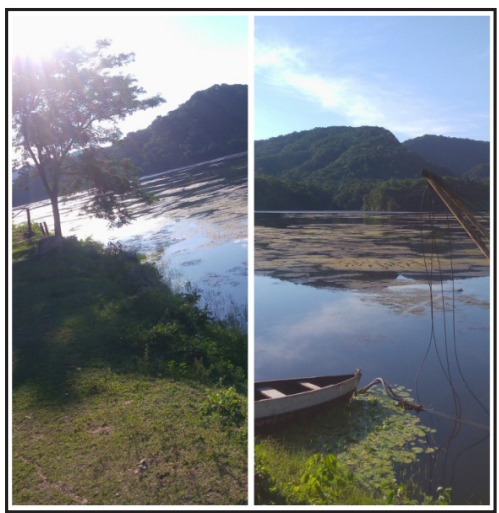

Foto N².- Embalse El Limoncito

\section{OBJETIVO}

Realizar el seguimiento de los parámetros físicos, químicos y bacteriológicos del agua recolectada de la Localidad de Aguaray - Salta y caracterizar la ficoflora presente en el Embalse natural El Limoncito durante el periodo 2015-2018.

\section{MATERIALES Y MÉTODOS}

Para el desarrollo de este trabajo se recolectaron muestras de agua y muestras del alga dominante del Embalse. Se tomaron muestras de agua en cinco puntos diferentes: del Embalse "El Limoncito" (M1), del río Carapary (M2), agua potable del Hospital Dr. Luis Adolfo Güemes en Aguaray (M3), de un domicilio particular (de la localidad de Aguaray - Salta) (M4) y del purificador Psa-S-1000 del mismo (M5). Se utilizaron métodos estandarizados para el análisis de aguas potables (APHA, AWWA, WPCF,1992).

En el análisis bacteriológico se emplearon recipientes estériles y se estudió la presencia de bacterias coliformes por el método de S.G. Wilson y mediante Petri Film la determinación de E. coli. 
Para el estudio de la ficoflora se emplearon frascos de vidrio de $250 \mathrm{~mL}$ estériles conteniendo $3 \mathrm{~mL}$ de cloroformo al 10\%, para caracterizar la misma por observación en microscopio estereoscópico.

Las muestras recolectadas se rotularon de la siguiente manera (Foto $\mathrm{N}^{\circ} 3$ ):

$$
\begin{aligned}
& M_{1} \equiv \text { Agua del Embalse el Limoncito } \\
& M_{2} \equiv \text { Agua del Río Carapary } \\
& M_{3} \equiv \text { Agua del Hospital de Aguaray } \\
& M_{4} \equiv \text { Agua de una casa particular } \\
& M_{5} \equiv \text { Agua del purificador Psa-S-1000 }
\end{aligned}
$$

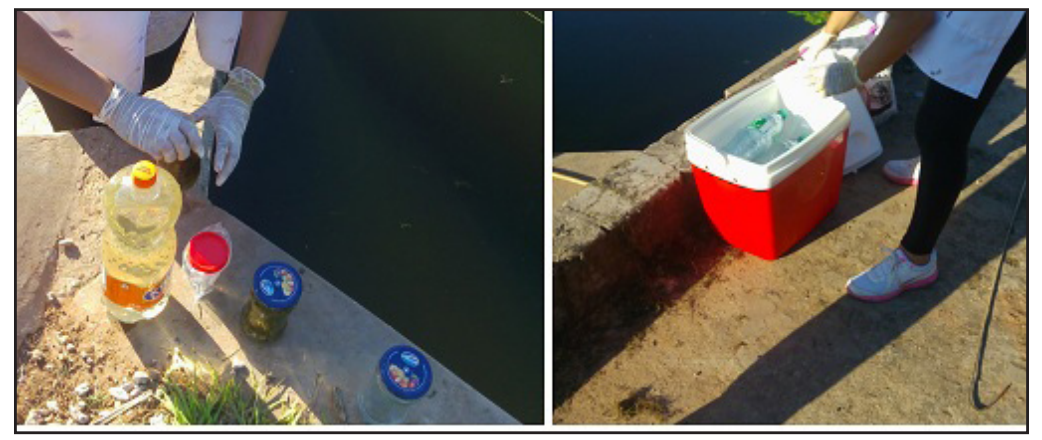

Foto $\mathrm{N}^{\circ}$ 3.- Toma de muestras del embalse El Limoncito

\section{RESULTADOS}

Los resultados obtenidos fueron los siguientes:

- El pH para las muestras $M_{1}$ y $M_{2}$ fue 6,5 y $\mathrm{pH} 6$ para las muestras $M_{3}, M_{4}$ y $M_{5}$. (Tabla $\mathrm{N}^{\circ} 2$ )

- En todas las muestras los análisis químicos de cloruro y sulfato dieron positivo, mientas que amoniaco, nitrito y nitrato fueron negativos. (Tabla $\mathrm{N}^{\circ} 2$ )

- Los valores de la alcalinidad están representados por el contenido de bicarbonatos, $M_{1}: 153,25 ; M_{2}: 210,50 ; M_{3}: 158,00 ; M_{4}: 171,50$ y $M_{5}: 169,50 \mathrm{mg} \mathrm{CaCO}_{3} / L$. (Tabla $\mathrm{N}^{\circ} 2$ ).

- La dureza del agua fue de 13,65;33,33; 31,60; 34,33 y 33,90 Grados Franceses $\left({ }^{\circ} \mathrm{F}\right)$ para las muestras $\mathrm{M}_{1}, \mathrm{M}_{2}, \mathrm{M}_{3}, \mathrm{M}_{4}$ y $\mathrm{M}_{5}$ respectivamente (Tabla $\mathrm{N}^{\circ} 2$ ). Estos valores indicarían aguas duras de acuerdo a la norma establecida por la Organización Mundial de la Salud (O.M.S.) y el Código alimentario argentino (C.A.A.) (Tabla $N^{\circ} 1$ ). 


\begin{tabular}{|c|c|}
\hline $\begin{array}{c}\text { Concentración de mg } \\
\mathrm{CaCO}_{3} / \mathrm{L}\end{array}$ & Tipo \\
\hline $0-60$ & Blanda \\
\hline $61-120$ & Moderadamente dura \\
\hline $120-180$ & Dura \\
\hline$>180$ & Muy dura \\
\hline
\end{tabular}

Tabla N 1. Clasificación de la Dureza por $\mathrm{CaCO}_{3} / \mathrm{L}$ en el agua, según O.M.S.

- Los resultados bacteriológico por el método de Wilson, el NMP/100 mL de agua fue de 300 y >a 300 para las muestras $M_{1}$ y $M_{2}$ respectivamente, siendo las restantes muestras negativas (Tabla $\mathrm{N}^{\circ} 2$ ).

En el Recuento de E.coli/Coliformes (Placa Petrifilm), $M_{1}$ dio 54 UFC/mL y en $M_{2} 220$ $\mathrm{UFC} / \mathrm{mL}$, resultando las demás muestras negativas (Tabla $\mathrm{N}^{\circ} 2$ ).
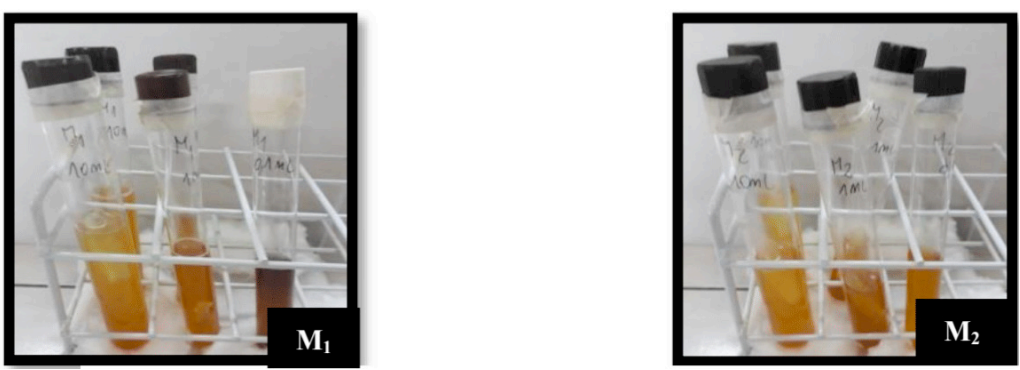

Figura 2: Muestras $\mathrm{M}_{1}$ y $\mathrm{M}_{2}$.

Resultados positivos con método de Wilson.

Fotografía: C. Cequeira
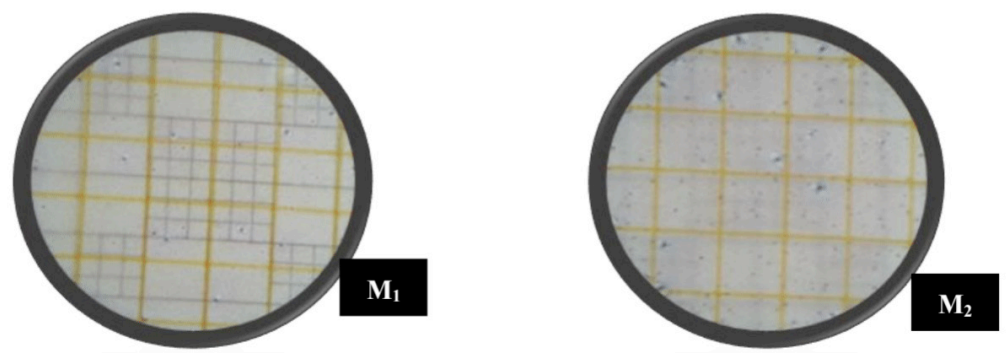

Figura 3: Muestras $M_{1}$ y $M_{2}$.

Resultados positivos con placas Petrifilm.

Fotografía: C. Cequeira 
- $\quad$ Los valores de D.B.O. para la muestra $\mathrm{M}_{1}$ (Embalse) y $\mathrm{M}_{2}$ (Río) fueron de 8,9 $\mathrm{mgO}_{2}$ / L y $3,3 \mathrm{mgO}_{2} / \mathrm{L}$ respectivamente; este último podría deberse a contaminación bacteriana relacionada con desechos humanos y animales (Tabla $\mathrm{N}^{\circ} 2$ )

\begin{tabular}{|c|c|c|c|c|c|}
\hline MUESTRAS & $\begin{array}{c}M_{1} \\
\text { EMBLASE EL } \\
\text { LIMONCITO }\end{array}$ & $\begin{array}{c}\mathrm{M}_{2} \\
\text { RÍO } \\
\text { CARAPARY }\end{array}$ & $\begin{array}{c}M_{3} \\
\text { HOSPITAL } \\
\text { DE } \\
\text { AGUARAY }\end{array}$ & $\begin{array}{c}\mathrm{M}_{4} \\
\text { CASA } \\
\text { PARTICULAR }\end{array}$ & $\begin{array}{c}M_{5} \\
\text { PURIFICADOR } \\
\text { PSa -1000 }\end{array}$ \\
\hline Temperatura & 22 & 22 & 22 & 22 & 22 \\
\hline Turbidez & Lig. Turbio & Turbio & Límpido & Límpido & Límpido \\
\hline Sedimento & - & Escaso & - & - & - \\
\hline Olor & Pescado & Tierra & Inodoro & inodoro & Inodoro \\
\hline $\mathrm{pH}$ & 6,5 & 6,5 & 6 & 6 & 6 \\
\hline Cloruro & + & + & + & + & + \\
\hline Sulfato & + & + & + & + & + \\
\hline Amoniaco & - & - & - & - & - \\
\hline Nitrito & - & - & - & - & - \\
\hline Nitrato & - & - & - & - & - \\
\hline $\begin{array}{l}\text { Alcalinidad } \\
\mathrm{mg} \mathrm{HCO} / \mathrm{L}\end{array}$ & 153,25 & 210,50 & 158,00 & 171,50 & 169,50 \\
\hline Dureza $\left({ }^{\circ} \mathrm{F}\right)$ & 13,65 & 33,33 & 31,60 & 34,33 & 33,90 \\
\hline $\begin{array}{c}\text { Wilson } \\
\text { N.M.P./ 100mL }\end{array}$ & 300 & $>300$ & - & - & - \\
\hline $\begin{array}{l}\text { Petrifilm } \\
\text { U.F.C/mL }\end{array}$ & 54 & 220 & - & - & - \\
\hline $\begin{array}{c}\text { D.B.O. } \\
\left(\mathrm{mg} \mathrm{O}_{2} / \mathrm{L}\right)\end{array}$ & 8,9 & 3,3 & & & \\
\hline
\end{tabular}

Tabla № 2.- Determinación Química

- La especie dominante de este grupo fue identificada y caracterizada taxonómicamente como Chara sp. Tabla Nㅜ․ Es un género de algas verdes de agua dulce con distribución cosmopolita, crecen sumergidas principalmente en ambientes lóticos y lénticos, cumpliendo varias funciones importantes en los ecosistemas de agua dulce (Coops, 2002). Adicionalmente, se las considera un buen indicador de la calidad del agua debido a que son muy sensibles a la contaminación (Van Dijk\& Van Vierssen; Coops; Cirujano y col. 1991). 


\begin{tabular}{|c|c|}
\hline Clase & Charophyta \\
\hline Orden & Charales \\
\hline Familia & Characeae o Charophiceae \\
\hline Género & Chara \\
\hline
\end{tabular}

Tabla N⒊ Identificación Taxonómica de Chara

\section{CONCLUSIONES}

Según los resultados obtenidos, las muestras de agua de grifo (M4) y purificador de la casa particular (M5), como también la del Hospital (M3) en los análisis físico-químicos y bacteriológicos del agua, estuvieron dentro de los permitidos por CAA (Código Alimentario Argentino) Los valores de dureza obtenidos en los análisis de las muestras de agua del Embalse natural El Limoncito y del Rio Itiyuro, podrían estar relacionados con el crecimiento del alga en época estival, momento en el cual se realizó el muestreo. No obstante se requieren continuidad de estas determinaciones para obtener datos concluyentes que evidencien algún impacto negativo en la salud, debido a la presencia de dicha alga. Además sería importante conocer la existencia río arriba de algún emprendimiento que vierta sus desechos al Rio Itiyuro y al Embalse el Limoncito que pudieran ser responsables de la dureza del agua como de la presencia del alga en la superficie.

\section{AGRADECIMIENTO}

A mis Padres que son la inspiración de lucha, paciencia y ansias de superación. A mis profesoras Magui y Ceci que son las impulsoras de mi trabajo con gran dedicación, constancia y contención incondicional. Mis compañeras y amigas Celeste, Marta, Gisel, Susana, Flor y Graciela que siempre me apoyaron y alentaron. A Dios que escucho siempre mis oraciones.

\section{REFERENCIAS}

-APHA-AWA-WPCF. (1992). Métodos Normalizados para el Análisis de Aguas Potables y

Residuales. Díaz de Santo

-C.A.A. Código Alimentario Argentino (2012). Capítulo XII bebidas hídricas, agua y agua gasificada. Artículo 982 - (Resolución Conjunta SPRyRS y SAGP y A N 68/2007 y N 196/2007)

-Coops, H. (2002). Ecology of charophytes: An introduction.Editorial Elsevier. Volume 72, Issues 3-4, April 2002, Pages 205-208

-Evaluación de los Recursos Naturales de la Argentina (1962). Tomo IV,volumen. Recursos Hidráulicos Superficiales. Consejo Federal de Inversiones. Buenos Aires 
-Fair- Geyer- Okun (1997). Purificación de Agua, Tratamiento y Remoción de Agua Residuales. Limusa

-Las Regiones Naturales de la Argentina: Caracterización y Diagnóstico. (1994). En "El Sistema Nacional de Áreas Naturales Protegidas de la Argentina. Diagnóstico de su Patrimonio y su Desarrollo Institucional". Daniele, C. y Natenzon, C. Buenos Aires. Argentina

-Organización Mundial para la Salud, (OPS) (1993). Consideraciones sobre el programa medio ambiente y salud en el Istmo Centroamericano San José, CR. 50p.

-Pastrana,C.F.(2009). No son aptas para consumo humano las aguas que abastecen a Tartagal. LA NACION. http://www.lanacion.com.ar/1182484-no-son-aptas-para-consumo-humano-las-aguas-queabastecen-a-tartagal.

-Paoli,H., Elena H.,Mosciaro J., Ledesma F., Noé Y. - EEA Salta (2011).Características de las cuencas hídricas de las provincias de Salta y Jujuy: Cuenca "sin aportes significativos - Noreste de Salta".

-Rodier, J. (1981). Análisis de Agua. Omega

-Rojas, R. A. (1976). Epidemiología Básica: Vol.I.y II. Interamericana

-V. Mazzafero y col (1987).Medicina en Salud Pública. El Ateneo

-Wais de Badgen I. (1998).Ecología de la Contaminación Ambiental - Universo 


\section{OTIMIZACCÃO DA CAPACIDADE DE FLOCULAÇÃO DE COAGULANTES NATURAIS NO TRATAMENTO DE ÁGUA}

Data de aceite: 04/01/2021

Data de submissão: 03/11/2020

David Choque-Quispe

Escuela Profesional de Ingeniería

Agroindustrial - UNAJMA

Andahuaylas - Perú

ORCID: 0000-0003-4002-7526

Yudith Choque Quispe

Universidad Tecnológica de los Andes

Cusco - Perú

ORCID: 0000-0002-3690-7267

Betsy Suri Ramos Pacheco

Escuela Profesional de Ingeniería

Agroindustrial - UNAJMA

Andahuaylas - Perú

ORCID: 0000-0002-0286-0632

Aydeé Marilú Solano Reynoso

Escuela Profesional de Ingeniería Ambiental,

UTEA

Andahuaylas - Perú

ORCID: 0000-0002-1835-2210

Lourdes Magaly Zamalloa Puma

Escuela Profesional de Ingeniería

Agroindustrial - UNSAAC

Curso - Perú

ORCID: 0000-0001-9866-1939

\section{Carlos Alberto Ligarda Samanez}

Escuela Profesional de Ingeniería

Agroindustrial - UNAJMA

Andahuaylas - Perú

ORCID: 0000-0001-7519-8355

\section{Fredy Taipe Pardo}

Escuela Profesional de Ingeniería Agroindustrial - UNAJMA

Andahuaylas - Perú

ORCID: 0000-0002-8234-7643

Miriam Calla Flórez

Escuela Profesional de Ingeniería

Agroindustrial - UNSAAC

Curso - Perú

ORCID: 0000-0003-0592-6454

Miluska Marina Zamalloa Puma

Escuela Profesional de Física - UNSAAC

Curso - Perú

ORCID: 0000-0002-1334-1627

Jhunior Felix Alonzo Lanado

Programa de posgrado - UNSAAC

Curso - Perú

ORCID: 0000-0001-7888-860X

Yadyra Quispe Quispe

Programa de posgrado - UAC

Cusco - Perú

ORCID: 0000-0002-5232-693X

RESUMO: O objetivo do trabalho foi otimizar a capacidade de floculação de três variedades de Cactaceae Echinopsis pachanoi (San Pedro), Neoraimondia arequipensis (Ulluquite) e Opuntia ficus (Atum) no tratamento de águas residuárias artificiais. Foram aplicadas as doses de 1\%, 2\% e $3 \%$ de coagulante das três variedades de cactos extraídos com etanol 96\%, avaliada a atividade floculante (AF) e a porcentagem de remoção (\% $R$ ), observando-se aumento significativo ( $p$-valor 
$<0,05)$ com doses crescentes de coagulantes. A otimização foi realizada considerando como função objetivo o \% R sujeito às restrições para $\mathrm{AF}, \mathrm{pH}$, Dureza, Alcalinidade e $\mathrm{DBO}_{5}$ da água tratada, reportando valores de 99,09\% R para a variedade San Pedro, 92,42\% R para a variedade Ulluquite e $98,98 \% \mathrm{R}$ para a variedade Atum, para doses de $0,207 \%, 0,246 \%$ e $0,754 \%$ de coagulante respectivamente.

PALAVRAS CHAVE: água residual artificial, atividade floculante, porcentagem de remoção.

\title{
OPTIMIZATION OF THE FLOCCULATING CAPACITY OF NATURAL COAGULANTS IN WATER TREATMENT
}

\begin{abstract}
The aim was optimize the flocculating capacity of three varities of cacti Echinopsis pachanoi (San Pedro), Neoraimondia arequipenses (Ulluquite) and Opuntia ficus (Tuna) in the artificial wastewater treatment. They were applied $1 \%, 2 \%$ and $3 \%$ coagulant doses of the three varieties of cactaceae extracted with $96 \%$ ethanol. It was evaluated the flocculating activity (FA) and removal percentage (\%R); a significant increase was observed ( $p$-value < 0.05 ) with the increase in the coagulant dose. The optimization was carried out considering as objective function the $\% \mathrm{R}$ which were subjected to $\mathrm{FA}, \mathrm{pH}$, hardness, alkalinity and $\mathrm{BOD}_{5}$ of water treatment. Which were reported values of $99.09 \% \mathrm{R}$ for San Pedro variety, $92.42 \% \mathrm{R}$ for Ulluquite variety and $98.98 \% \mathrm{R}$ for tuna variety, for doses of $0.207 \%, 0.246 \%$ and $0.754 \%$ of coagulant respectively.
\end{abstract}

KEYWORDS: artificial wastewater, flocculating activity, removal percentage.

\section{I INTRODUCTION}

Cacti are one of the most abundant botanical families in Peru, being found in all altitudinal floors, in a large number of varieties. Thus, since ancient times cacti have been important and linked to a large number of Latin American cultures and peoples in many parts of the world. Cacti are used in very different ways and applications such as water clarification or as a natural polymer.

These polymers are complex in their chemical composition and are constituted mainly by several types of polysaccharides and proteins. Some of them have coagulant or flocculating properties and in many places, they are used empirically to clarify turbid water with satisfactory results (CHOQUE-QUISPE et al., 2018).

One of the cactaceae that has been widely used in coagulation is the genus Opuntia (family of cactaceae) which was characterized by the hydrocolloid production. It is known as mucilage, it forms molecular networks that retain large amounts of water (DESHMUKH et al., 2018). Besides, it is a complex polymeric compound of glucidic nature with a highly branched structure (MATSUHIRO et al., 2006). Mucilage contains variable proportions of L-arabinose, D-galactose, L-rhamnose and D-xylose, as well as galacturonic acid in different proportions (VILLABONA et al., 2013).

Another cactus that has coagulant properties is the Echinopsis pachanoi, which calls "San Pedro" as a common name in some areas of Peru. As well as the Neoraimondia 
arequipensis which receives the common name of Ulluquite. It is not really known whether it is related to the well-known Puyas de Raimondi, which grow in different parts of Peru including the Peruvian-Bolivian highlands.

Drinking water for human consumption must have quality characteristics such as free of turbidity, color and perceptible taste and other parameters regulated according to the regulations of the countries. Usually natural waters do not have satisfactory quality for human consumption or industrial use and generally should be treated (MUMBI et al., 2018), as well as wastewater according to their use.

Coagulation consists in the addition of chemical substances in order to mix the particles and some dissolved pollutants that can be agglutinated in larger particles and then being removed through solids removal processes or by sedimentation (ABIDIN et al., 2013). Coagulation as a physicochemical process destabilizes colloidal particles, precipitating and grouping suspended solids. This supplies their extraction by means of the flocs formation in water (RAMÍREZ et al., 2015), reducing turbidity, color and to a lesser extent bacteria (GARCÍA 2005).

For coagulation, conventional chemical substances are used. However, there are disadvantages associated with the use of these coagulants such as high acquisition costs, large production volumes of sludge and the fact that they significantly affect the $\mathrm{pH}$ of the treated water (YIN, 2010; HAAROFF et al., 1988). Also, in some cases adverse neurological effects, such as the manifestation of Alzheimer's disease (VARA, 2012; MATILAINEN et al., 2010). Therefore, it is necessary to carry out optimization processes to minimize the use of additives and chemical substances, and to maximize the parameters of water quality.

\section{I MATERIALS AND METHODS}

\subsection{Raw material}

The Echinopsis pachanoi (San Pedro), Neoraimondia arequipensis (Ulluquite) and Opuntia ficus (Tuna) cacti varieties were obtained from wild crops located in Santa Rosa area from Talavera district at 3000 meters above sea level. At latitude $13^{\circ} 36^{\prime} 07.89^{\prime \prime S}$, length $73^{\circ} 16^{\prime} 33.13^{\prime \prime} \mathrm{W}$. Andahuaylas province, Peru has an average temperature of $13^{\circ} \mathrm{C}$ and an average annual rainfall of $930 \mathrm{~mm}$.

The cactaceae collection criteria were physiological maturity, morphology (external appearance and apparent color), size (length and width or diameter) and weight.

\subsection{Preparation of artificial water}

In order to simulate suspended particles in the artificial wastewater for its subsequent flocculation and coagulation. A stock solution was prepared by dissolving $25 \mathrm{~g}$ of kaolin $\left(2 \mathrm{SiO}_{2} \cdot \mathrm{Al}_{2} \mathrm{O}_{3} \cdot 2 \mathrm{H}_{2} \mathrm{O}\right)$ in $500 \mathrm{~mL}$ of distilled water that was homogenized for 30 minutes manually. The solution was allowed to stand for 24 hours. Finally, 6 liters of drinking water 
was taken and $30 \mathrm{ml}$ of kaolin stock solution was added to the solution.

\subsection{Extraction of natural coagulant}

The method proposed by Dujardin et al. (1975) was modified. The thorns were completely eliminated from the cacti samples, then they were cut into small pieces and liquefied at high speed with distilled water in a 1:1 ratio. Afterward, the fine grinding was sifted in a 1000 micron mesh in order to eliminate the fiber and obtain only the mucilage (filtered juice). After that, a liquid - liquid extraction from the filtered juice was carried out by means of a solvent ( $96 \%$ Ethanol) in relation to 1 of juice:2 of solvent. Subsequently, as many changes of solvent as necessary were made until the color was eliminated and later the precipitate was dried at room temperature. After drying, the sample was finely ground and then sieved in a 300 micron mesh. A fine and crystallized coagulant powder was obtained.

\subsection{Flocculant activity - FA}

The methodology by Sánchez and Untiveros (2004) was adapted. $0.25 \mathrm{~mL}$ at $1 \%$ natural coagulant solution, $4.50 \mathrm{~mL}$ of kaolin suspension and $0.25 \mathrm{~mL}$ at $1 \%$ iron (III) solution were poured into a test tube. Which was homogenized for 15 seconds with a Vortex and then left for $5 \mathrm{~min}$. $2.5 \mathrm{~mL}$ of the supernatant was carefully removed from the top of the test tube with a pipette and the absorbance was measured at $550 \mathrm{~nm}(\mathrm{~A})$ and a control (B). The flocculant activity was calculated using eq. (1). The test was repeated with $2 \%$ and $3 \%$ of natural coagulant.

$$
F A=\frac{1}{A}+\frac{1}{B}
$$

\subsection{Evaluation of the removal percentage}

The process efficiency was determined by the percentage of turbidity removal (\% $R$ ), according to eq. (2) (Yagual, 2012). For which the initial turbidity $\left(T_{0}\right)$ and final turbidity $\left(T_{f}\right)$ were determined with an Orbeco turbidimeter model TB300-IR from 0.01 to 1100 NTU range.

$$
\% R=\frac{T_{0}-T_{f}}{T_{0}} * 100
$$

\subsection{Evaluation of physicochemical characteristics}

The characterization of the treated water quality parameters was carried out, such as $\mathrm{pH}$, total alkalinity, total hardness and BOD (APHA, 2012).

\subsection{Optimization of flocculant capacity}

The objective function for the optimization was the removal percentage of turbidity for each treatment. Which was evaluated through linear regression and nonlinear regression 
and taking as a convergence criterion the correlation coefficient $R^{2}$. It was considered restrictions to the limits established by the Peruvian technical standards and WHO for the parameters evaluated in the treated water. For the optimization, the Excel Solver utility was used.

\subsection{Statistical analysis}

Analysis of variance and Tukey's multiple comparison means test were performed at a significance level of $5 \%$. The data were processed with the statistical package Statgraphics Centurion XV.

\section{I RESULTS AND DISCUSSION}

In Table 1, it can see that the AF is in the range from 28 to 48; Ferreira et al. (2014) reported similar results. It is also observed that the removal percentages are greater than 92\%; similar results showed Jiménez et al. (2012) when treating artificial wastewater with a mixture of coagulants based on Opuntia cochenillifera although with doses of the order of 20 ppm likewise Arismendi (2016) using modified tannins. Sánchez and Untiveros (2004) used pectin with concentration of $30 \mathrm{ppm}(0.003 \%)$ in artificial wastewater formulated with kaolin and iron (III). Yagual (2012) found removal percentages between 95\% to $99.6 \%$ for river water samples when using coagulants such as aluminum sulphate, floater praestol 650 TR and artisanal chemical flocculant. Quirós et al. (2010) found a solids removal of $83 \%$ with coagulant extracted from Moringa at $400 \mathrm{ppm}$.

\begin{tabular}{|c|c|c|c|c|c|c|c|c|c|c|c|c|c|c|c|c|}
\hline \multirow[t]{2}{*}{ Variety } & \multirow{2}{*}{$\begin{array}{l}\text { Coagulant } \\
\text { solution } \\
(\%)\end{array}$} & \multicolumn{3}{|c|}{ Flocculant activity } & \multicolumn{3}{|c|}{$\begin{array}{c}\text { Removal } \\
\text { percentage }\end{array}$} & \multicolumn{3}{|c|}{$\mathrm{pH}$} & \multicolumn{3}{|c|}{$\begin{array}{l}\text { Hardness (ppm } \\
\left.\mathrm{CaCO}_{3}\right)\end{array}$} & \multicolumn{3}{|c|}{$\mathrm{BOD}\left(\mathrm{mg} \mathrm{O}_{2} / \mathrm{L}\right)$} \\
\hline & & $\overline{\mathrm{x}}$ & \pm & $\mathrm{s}$ & $\overline{\mathrm{x}}$ & \pm & $\mathrm{s}$ & $\overline{\mathrm{x}}$ & \pm & $\mathrm{s}$ & $\overline{\mathrm{x}}$ & \pm & $\mathrm{s}$ & $\overline{\mathrm{x}}$ & \pm & $s$ \\
\hline \multirow{3}{*}{ E.P. } & 1 & $47.39^{a}$ & \pm & 0.46 & $99.21^{a}$ & \pm & 0.06 & 6.98 & \pm & 0.04 & 266.3 & \pm & 1.5 & 2.41 & \pm & 0.1 \\
\hline & 2 & $48.39^{b}$ & \pm & 0.19 & $99.31^{a}$ & \pm & 0.06 & 7.25 & \pm & 0.02 & 268 & \pm & 1.0 & 2.65 & \pm & 0.04 \\
\hline & 3 & $48.58^{b}$ & \pm & 0.06 & $99.44^{\mathrm{b}}$ & \pm & 0.06 & 7.28 & \pm & 0.01 & 269 & \pm & 1.0 & 2.72 & \pm & 0.04 \\
\hline \multirow{3}{*}{ N. A. } & 1 & $28.41^{\mathrm{a}}$ & \pm & 0.94 & $92.64^{\mathrm{a}}$ & \pm & 0.33 & 6.75 & \pm & 0.03 & 262 & \pm & 1.0 & 3.08 & \pm & 0.02 \\
\hline & 2 & $30.36^{\mathrm{b}}$ & \pm & 0.11 & $92.79^{\mathrm{a}}$ & \pm & 0.18 & 6.93 & \pm & 0.04 & 263.7 & \pm & 0.6 & 3.32 & \pm & 0.02 \\
\hline & 3 & $30.38^{\mathrm{b}}$ & \pm & 0.11 & $92.78^{a}$ & \pm & 0.09 & 7.02 & \pm & 0.01 & 263.7 & \pm & 1.5 & 3.34 & \pm & 0.03 \\
\hline \multirow{3}{*}{$O . F$} & 1 & $46.13^{a}$ & \pm & 0.39 & $99.02^{\mathrm{a}}$ & \pm & 0.15 & 6.68 & \pm & 0.03 & 269.3 & \pm & 1.2 & 3.35 & \pm & 0.11 \\
\hline & 2 & $46.41^{a}$ & \pm & 0.11 & $99.11^{\mathrm{a}}$ & \pm & 0.18 & 6.9 & \pm & 0.02 & 270.7 & \pm & 0.6 & 3.64 & \pm & 0.11 \\
\hline & 3 & $46.48^{a}$ & \pm & 0.22 & $99.15^{\mathrm{a}}$ & \pm & 0.06 & 6.96 & \pm & 0.02 & 271 & \pm & 1.0 & 3.66 & \pm & 0.05 \\
\hline \multicolumn{2}{|c|}{ Initial value } & \multicolumn{3}{|c|}{--- } & \multicolumn{3}{|c|}{--- } & \multicolumn{3}{|c|}{6.61} & \multicolumn{3}{|c|}{260} & \multicolumn{3}{|c|}{0.57} \\
\hline
\end{tabular}

Where: E.P. is Echinopsis pachanoi; N.A. is Neoraimondia arequipensis; O.F. is Opuntia ficus; $\overline{\mathrm{x}}$ is the average; $s$ is the standard deviation.

* Equal letters mean that there is no significant difference evaluated through the Tukey test, with $\alpha=5 \%$

Table 1. Parameters of water treated with natural coagulants 
On the other hand, slight variation of the $\mathrm{pH}$ in the treated water is observed for all the cases with basic tendencies. Solís et al. (2012) showed that the $\mathrm{pH}$ of the water treated with mixtures of cassava starch coagulants and aluminum sulfate did not vary significantly presenting less acidic tendencies up to 6.7 from an initial value of untreated water of 6.9. In addition, the hardness shows a slight increase compared to its initial value of untreated water a similar behavior was reported by Mgombezi et al. (2017). However, Miranda et al. (2012) showed a slight increase when adding cal and kollpa coagulants (Alum from Altiplano).

The coagulant addition increases significantly the $\mathrm{BOD}_{5}$ of the artificial water due to the tests were realized in solution with the coagulant, which showed that its composition is made up by proteins and carbohydrates.

The objective function to optimize the flocculant capacity was the removal percentage of solids in artificial treated water for three coagulant varieties of cacti, thus, mathematical models or equations were determined, which are shown in Table 2, which show $R^{2}>0.9$.

Table 3, shows the results for coagulant Echinopsis pachanoi (San Pedro) variety with its respective restrictions. It is observed that optimum removal percentage is $99.092 \%$ for an application percentage of $0.27 \%$ coagulant at $1 \%$ in the solution. Thus, achieving values of the flocculant activity of $46.01 \%, \mathrm{pH}$ of 6.6 , Hardness of $264.536 \mathrm{ppm}$ of $\mathrm{CaCO}_{3}$, Alkalinity 30.00 ppm of $\mathrm{CaCO}_{3}$ and BOD of $2.097 \mathrm{mg} \mathrm{O} 2 / \mathrm{L}$.

\begin{tabular}{|c|c|c|}
\hline & Model & $\mathrm{R}^{2}$ \\
\hline \multicolumn{3}{|c|}{ Echinopsis pachanoi (San Pedro) variety } \\
\hline$\% R$ & $\% R=0.108 * \operatorname{LnC}+99.218$ & 0.97 \\
\hline AF & $\% F A=1.119 * \operatorname{LnC}+47.456$ & 0.95 \\
\hline $\mathrm{pH}$ & $p H=0.282 * \operatorname{LnC}+6.999$ & 0.92 \\
\hline D & $D=2.425 * \operatorname{LnC}+266.33$ & 1.00 \\
\hline A & $A=30.113 * \exp (0.0055 * C)$ & 0.80 \\
\hline BOD & $B O D=0.293 * \operatorname{LnC}+6.415$ & 0.98 \\
\hline \multicolumn{3}{|c|}{ Neoraimondia arequipensis (Ulluqiute) variety } \\
\hline$\% R$ & $\% R=0.138 * \operatorname{LnC}+92.65$ & 0.83 \\
\hline $\mathrm{AF}$ & $\% F A=1.907 * \operatorname{LnC}+28.576$ & 0.87 \\
\hline $\mathrm{pH}$ & $p H=0.247 * L n C+6.756$ & 0.99 \\
\hline $\mathrm{D}$ & $D=1.613 * \operatorname{LnC}+262.15$ & 0.87 \\
\hline A & $A=1.561 * \operatorname{Ln} C+31.734$ & 0.97 \\
\hline BOD & $B O D=0.249 * \operatorname{LnC}+3.098$ & 0.91 \\
\hline \multicolumn{3}{|c|}{ Opuntia ficus (Tuna) variety } \\
\hline$\% R$ & $\% R=0.117 * L n C+99.024$ & 0.98 \\
\hline $\mathrm{AF}$ & $\% F A=0.324 * \operatorname{LnC}+46.143$ & 0.96 \\
\hline $\mathrm{pH}$ & $p H=0.265 * \operatorname{LnC}+6.691$ & 0.97 \\
\hline $\mathrm{D}$ & $D=1.561 * \operatorname{LnC}+269.40$ & 0.97 \\
\hline A & $A=2.206 * \operatorname{Ln} C+36.46$ & 0.94 \\
\hline BOD & $B O D=0.302 * \operatorname{LnC}+3.368$ & 0.90 \\
\hline
\end{tabular}

Where: \%R, Removal percentage; AF, flocculant activity; D, Hardness; A, Alkalinity, BOD, Biochemical Oxygen Demand; $C$ is the percentage of coagulant application; $R^{2}$ is correlation coefficient.

Table 2. Models for parameters in treated water. 
On the other hand, the coagulant from Neoraimondia arequipensis variety shows a $92.42 \%$ of removal percentage, it must be applied $0.246 \%$ of coagulant at $1 \%$ in solution. Being that, under this condition the flocculant activity will be $25.667 \%$, pH of 6.558 , hardness of $259.641 \mathrm{ppm}$ of $\mathrm{CaCO}_{3}$, alkalinity $30.0 \mathrm{ppm}$ of $\mathrm{CaCO}_{3}$ and $\mathrm{BOD}$ of $2.754 \mathrm{mg}$ of $\mathrm{O}_{2} / \mathrm{L}$. While the optimum removal percentage was $98.988 \%$, for an application of $0.754 \%$ coagulant of the Opuntia ficus variety (1\%) in solution. The $\mathrm{pH}$ was 7.2 , hardness of $268.852 \mathrm{ppm}$ of $\mathrm{CaCO}_{3}$, alkalinity of $25.58625 .586 \mathrm{ppm}$ of $\mathrm{CaCO}_{3}$ and $\mathrm{BOD}$ of $3.230 \mathrm{mg} \mathrm{O} / \mathrm{L}$.

\begin{tabular}{|c|c|c|c|c|}
\hline & Properties & Minimum & Maximum & Optimum \\
\hline \multicolumn{5}{|c|}{ Echinopsis pachanoi (San Pedro) variety } \\
\hline Objective function & Removal percentage & --- & 100 & 99.092 \\
\hline \multirow{6}{*}{ Restrictions } & Flocculant activity (\%) & --- & 50 & 46.011 \\
\hline & $\mathrm{pH}$ & 6.6 & 7.2 & 6.600 \\
\hline & Hardness $\left.(\mathrm{ppm} \mathrm{CaCO})_{3}\right)$ & 200 & 300 & 264.536 \\
\hline & Alkalinity $\left(\mathrm{ppm} \mathrm{CaCO}_{3}\right)$ & 20 & 30 & 30.00 \\
\hline & $\mathrm{BOD}\left(\mathrm{mg} \mathrm{O}_{2} / \mathrm{L}\right)$ & -- & 15 & 2.097 \\
\hline & Coagulant dose percentage ( $1 \%$ in sol) & 0.1 & 3.0 & 0.207 \\
\hline \multicolumn{5}{|c|}{ Neoraimondia arequipensis (Ulluquite) variety } \\
\hline Objective function & Removal percentage & -- & 100 & 92.419 \\
\hline \multirow{6}{*}{ Restrictions } & Flocculant activity (\%) & -- & 50 & 25.667 \\
\hline & $\mathrm{pH}$ & 6.6 & 7.2 & 6.558 \\
\hline & Hardness $\left(\mathrm{ppm} \mathrm{CaCO}{ }_{3}\right)$ & 200 & 300 & 259.641 \\
\hline & Alkalinity $\left.(\mathrm{ppm} \mathrm{CaCO})_{3}\right)$ & 20 & 30 & 30.000 \\
\hline & $\mathrm{BOD}\left(\mathrm{mg} \mathrm{O}_{2} / \mathrm{L}\right)$ & --- & 15 & 2.754 \\
\hline & Coagulant dose percentage ( $1 \%$ in sol) & 0.1 & 3.0 & 0.246 \\
\hline \multicolumn{5}{|c|}{ Opuntia ficus (Tuna) variety } \\
\hline Objective function & Removal percentage & -- & 100 & 98.988 \\
\hline \multirow{6}{*}{ Restrictions } & Flocculant activity (\%) & --- & 50 & 46.026 \\
\hline & $\mathrm{pH}$ & 6.6 & 7.2 & 6.600 \\
\hline & Hardness $\left(\mathrm{ppm} \mathrm{CaCO}_{3}\right)$ & 200 & 300 & 268.852 \\
\hline & Alkalinity $\left(\mathrm{ppm} \mathrm{CaCO}_{3}\right)$ & 20 & 30 & 25.586 \\
\hline & $\mathrm{BOD}\left(\mathrm{mg} \mathrm{O}_{2} / \mathrm{L}\right)$ & -- & 15 & 3.230 \\
\hline & Coagulant dose percentage ( $1 \%$ in sol) & 0.1 & 3.0 & 0.754 \\
\hline
\end{tabular}

Table 3. Optimum values and their restrictions for the coagulant behavior

\section{I CONCLUSIONS}

The optimization of the flocculant capacity of three natural coagulants in the artificial treated water evaluated through the removal percentage shows values of $99.09 \%$ for Echinopsis pachanoi (San pedro) variety, 92.419\% for Neoraimondia arequipensis 
(Ulluquite) varierty and $98.98 \%$ for Opuntia ficus (Tuna) variety. For dosages of $0.207 \%$, $0.246 \%$ and $0.754 \%$ respectively in coagulant solution at $1 \%$.

\section{REFERENCES}

ABIDIN, Z.Z., SHAMSUDIN, N.S.M., MADEHI, N., SOBRI, S. Optimization of a method to extract the active coagulant agent from Jatropha curcas seeds for use in turbidity removal. Industrial Crops and Products, 41, p. 319-323, 2013. DOI: 10.1016/j.indcrop.2012.05.003

APHA, Standard methods for the examination of water and wastewater, 22nd ed.. Washington, DC, USA: American Public Health Association (APHA), American Water Works Association (AWWA) and Water Environment Federation (WEF), 2012.

ARISMENDI, W.A. Evaluación y comparación de la capacidad floculante de taninos modificados (quebracho, acacia, castaño) y su aplicación en el tratamiento de aguas residuales, Tesis (Maestría en Ciencias Biológicas), Bogotá, Colombia, Pontificia Universidad Javeriana, 2016, 110 p.

CHOQUE-QUISPE, D., CHOQUE-QUISPE, Y., SOLANO-REYNOSO, A.M., RAMOS-PACHECO, B.S. Capacidad floculante de coagulantes naturales en el tratamiento de agua. Tecnología Química, 38(2), p. 298-309, 2018.

DESHMUKH, S., HEDAOO, M.N. Wastewater Treatment using Bio-Coagulant as Cactus Opuntia Ficus Indica - A Review. IJSRD, 6(10), p. 711-717, 2018. DOI: 10.13140/RG.2.2.28932.99202

DUJARDIN, E., LASZIO, P., SACKS, D. The chlorophylls. An experiment in bio-inorganic chemistry. Journal of Chemical Education, 52(11), p. 742-748, 1975. DOI: 10.1021/ed052p742

FERREIRA, M.T., AMBROSIO, E., ANDRADE, C., FORMICOLI, T.K., BRIOLA, L., CINQUE, V., GARCIA, J.C. The use of a natural coagulant (Opuntia ficus-indica) in the removal for organic materials of textile effluents. Environ Monit Assess., 186(8), p. 5261-5271, 2014. DOI: 10.1007/s10661-014$3775-9$

GARCÍA, S.A., Estudio de la eficiencia de eliminación de radionúclidos naturales en procesos compatibles con el de potabilización de aguas, tesis (Doctorado en Ciencias Físicas), España, Universidad de Extremadura, 2005, 246 p.

HAAROFF, J., CLEASBY, J. Comparing aluminum and iron coagulants for in line filtration of cold waters. J. Am. Water Works Assoc,, 80(4), p. 168-175, 1988. DOI: 10.1002/j.1551-8833.1988.tb03022.x

JIMÉNEZ, J., VARGAS, M., QUIRÓS, N. Evaluación de la tuna (Opuntia cochenillifera) para la remoción del color en agua potable. Tecnología en Marcha, 25(4), p. 55-62, 2012. DOI: 10.18845/tm.v25i4.619

MATILAINEN, A., VEPSÄLÄINEN, M., SILLANPÄÄ, M. Natural Organic Matter Removal by Coagulation during Drinking Water Treatment: A Review. Adv. Colloid Interface Sci., 159(2), p. 189-197, 2010. DOI: 10.1016/j.cis.2010.06.007

MATSUHIRO B., LILLO, L., SÁENZ, C., URZÚA, C., ZÁRATE O. Chemical characterization of the mucilage from fruits of Opuntia ficus indica. Carbohydrate Polymer, 63(2), p. 263-267, 2006. DOI: 10.1016/j.carbpol.2005.08.062 
MGOMBEZI, D., MAHESWARA, V., HAMAD, S., SINGH, S. An Investigation On Effectiveness Of Cactus Materials (Opuntia Spp.) As Adsorbentsfor Hard Water Treatment. International Journal of Scientific \& Technology Research, 6(10), p. 239-244, 2017.

MIRANDA, R., TTITO, S., PALACIOS, R., ALVAREZ, A. Tratamiento de aguas residuales minero metalúrgico por floculación y sedimentación con uso de floculantes naturales mejorados, Tesis de licenciatura, Universidad Nacional del Altiplano, Puno, Perú, 2012, 160 p.

MUMBI, W., FENGTING, L., KARANJA, A. Sustainable treatment of drinking water using natural coagulants indeveloping countries: A case of informal settlements in Kenya. Water Utility Journal, 18, p. 1-11, 2018. DOI: 10.13140/RG.2.2.21105.94563

QUIRÓS, N., VARGAS, M., JIMÉNEZ J. Desarrollo de coagulantes y floculantes para la remoción del color en aguas de consumo humano; el rio Humo, reserva forestal rio Macho [en línea], Costa Rica: Instituto tecnológico de Costa Rica, Centro de Investigación en protección ambiental; 2010 [Consulta 22 diciembre de 2018]. Available at: https://repositoriotec.tec.ac.cr/handle/2238/2930

RAMÍREZ, H., JARAMILLO, J. Agentes naturales como alternativa para el tratamiento del agua. Revista Facultad de Ciencias Básicas. 11(2), p. 136-153, 2015. DOI: 10.18359/rfcb.1303

SÁNCHEZ, S., UNTIVEROS, G. Determinación de la actividad floculante de la pectina en soluciones de hierro (III) y cromo (III). Rev. Soc. Quím. Perú, 70(4), p. 201-208, 2004.

SOLÍS, R., LAINES, J. Y HERNÁNDEZ J.R. Mezclas con potencial coagulante para clarificar aguas superficiales. Revista internacional de contaminación ambiental, 28(3), p. 229-236, 2012.

VARA, S. Screening and evaluation of innate coagulants for water treatment: a sustainable approach. International Journal of Energy and Environmental Engineering, 3(1), p. 2-11, 2012. DOI: 10.1186/2251-6832-3-29

VILLABONA, Á., PAZ, I.C. Y MARTíNEZ, J. Caracterización de la Opuntia ficus-indica para su uso como coagulante natural. Revista Colombiana de Biotecnología, 15(1), p. 137-144, 2013.

YAGUAL, M.G. Análisis comparativo del proceso de floculación-coagulación en la potabilización de agua de río, usando como fuente de captación el Río Daule y el Río Babahoyo en la Provincia del Guayas, Tesis (Licenciatura en Ingeniería Química), Ecuador, Instituto de Ciencias Químicas y Ambientales, 2012, $159 \mathrm{p}$.

YIN C.Y. Emering usage of plant-based coagulants for water and wastewater treatment. Process Biochem., 45(9), p. 437-1444, 2010. DOI: 10.1016/j.procbio.2010.05.030 


\section{CAPÍTULO 11}

\section{APLICAÇÃO DO MÉTODO GOD PARA AVALIAÇÃO DA VULNERABILIDADE AMBIENTAL DOS POÇOS DE CAPTAÇÃO DE ÁGUA DA CIDADE DE ABATETUBA - PARÁ}

Data de aceite: 04/01/2021

Data de submissão: 06/11/2020

Gabriel Pereira Colares da Silva Mestrando do Programa de Pós-graduação de Engenharia Civil - UFPA

Belém/PA

http://lattes.cnpq.br/7898937588351056

\section{Éverton Costa Dias}

Mestrando do Programa de Pós-graduação de Engenharia Civil - UFPA

Belém/PA

http://lattes.cnpq.br/0095216956895722

\section{Giovanni Chaves Penner}

Doutor em Engenharia Hidráulica e Saneamento pela Escola de Engenharia de São Carlos (EESC/USP). Professor Adjunto do curso de Engenharia Sanitária e Ambiental da Universidade Federal do Pará Belém/PA

http://lattes.cnpq.br/3110276957027781

Adria Lorena de Moraes Cordeiro Mestranda do Programa de Pós-graduação de Engenharia Civil - UFPA

Belém/PA http://lattes.cnpq.br/6247501976648612

\section{Cleyanne Kelly Barbosa Souto}

Engenheira Sanitarista e Ambiental pela Universidade Federal do Pará - UFPA

Belém/PA http://lattes.cnpq.br/6930934174398196
RESUMO: Os recursos hídricos possuem importância vital para os seres vivos, principalmente a água doce de origem subterrâneas. No entanto, com o uso e ocupação do solo, uso e gestão das águas estão sendo administrados de modo inadequado, sendo assim, busca-se estudos para desenvolver conhecimento sobre a avaliação da vulnerabilidade natural dos aquíferos. Nesse contexto, o trabalho objetiva, principalmente, verificar a vulnerabilidade dos mananciais que abastecem a cidade de Abaetetuba/PA, por intermédio do método GOD, o qual foi desenvolvido em 1988 por Foster e Hirata. Esse método utiliza dados de litologia, informações sobre as camadas rochosas que envolvem os aquíferos, que relaciona a profundidade e o grau de confinamento. $O$ índice da escala GOD varia entre 0 e 1 sendo o mínimo qualificado como vulnerabilidade insignificante e o máximo como vulnerabilidade extrema. $\mathrm{Na}$ cidade, utilizaram-se nove pontos de captação de água subterrânea, localizados na área urbana de Abaetetuba, sendo que os dados foram obtidos pelo Sistema de Informações de Águas Subterrâneas (SIAGAS - CPRM) e por meio de pesquisas bibliográficas. Os resultados indicaram que os poços possuem uma vulnerabilidade natural insignificante. Isso pode ocorrer devido o sistema seja confinado, ou seja, havendo uma baixa possibilidade de penetração de agentes contaminantes externos, mostrando um resultado favorável as finalidades desses aquíferos. Por fim, o estudo da vulnerabilidade dos aquíferos é de grande importância para avaliação e controle da qualidade dos recursos hídricos subterrâneos. PALAVRAS-CHAVE: Água Subterrânea, Método 


\title{
APPLICATION OF THE GOD METHOD FOR ASSESSMENT THE ENVIRONMENTAL VULNERABILITY OF THE WATER COLLECTION WELLS IN THE CITY OF ABATETUBA - PARÁ
}

\begin{abstract}
Water resources are vitally important for living beings, specially fresh groundwater. However, with the land use and occupation, the water use and management are being inadequately administered, therefore, studies are sought to advance knowledge about the assessment of aquifers natural vulnerability. In this sense, the work aims, mainly, to verify the vulnerability of the springs that supply the city of Abaetetuba / PA, through the GOD method, which was developed in 1988 by Foster and Hirata. This method uses lithology data, information about the rock layers that surround the aquifers, which relates the depth and the confinement degree. The index of the GOD scale varies between 0 and 1 with the minimum qualified as insignificant vulnerability and the maximum as extreme vulnerability. In the city, nine groundwater collection points were used, located in the urban area of Abaetetuba, and the data were obtained by the Groundwater Information System (SIAGAS - CPRM) and through bibliographic research. The results indicated that the wells have an insignificant natural vulnerability. This can occur because the system is confined, in other words, there is a low possibility of external contaminants penetration, showing a favorable result for the purposes of these aquifers. Finally, the study of aquifers vulnerability is of great importance for assessing and controlling the quality of groundwater resources.
\end{abstract}

KEYWORDS: Groundwater, GOD Method, Environmental Vulnerability.

\section{I INTRODUÇÃO}

A demanda por água, especificamente a doce, em um cenário mundial aumenta na mesma proporção do crescimento populacional. Dessa forma, a água subterrânea é uma fonte abundante e bastante valiosa no fornecimento de água doce de qualidade para os setores da sociedade como industrial, consumo humano e de irrigação (SILVA, PARANHOS, MARTINS, 2017). Deste modo, sabe-se que com a exploração excessiva dos recursos hídricos subterrâneos, em conjunto com a ocupação irregular do solo e o descumprimento da legislação, colocam em risco a qualidade natural dos recursos hídricos subterrâneos.

Isto ocorre tendo em vista que, os diversos poluentes lançados na superfície detêm um potencial favorável de percolação através das camadas subterrâneas e, com isso, podem atingir os aquíferos (principalmente os não confinados). Além disso, a drenagem superficial contribui com a qualidade do manancial (RIBEIRO et al, 2011).

Diante disso, é evidente que um dos os principais responsáveis pela poluição dos aquíferos subterrâneos são atividades antrópicas. Por isso, em 2017, a Agência Nacional de Águas (ANA) indicou a necessidade da incorporação de estudos de vulnerabilidade e proteção de aquíferos para realizar a melhor gestão possível da água subterrânea em todo território nacional. 
De acordo com Ribeira (2004), a vulnerabilidade pode ser definida como sendo uma série de atributos ou características de determinado meio, o qual pode ser o solo, a zona não saturada, os parâmetros hidráulicos do aquífero e a recarga, características estas que controlam a habilidade do meio de resistir a determinado impacto e sua capacidade de auto-restauração.

Segundo Ribeiro et al (2011), a vulnerabilidade também pode ser representada, de uma forma mais didática, como mapas. Dessa forma, permite aos órgãos gestores, uma maior facilidade no momento de avaliação das propostas de desenvolvimento aliada ao controle da poluição e monitoramento da qualidade da água subterrânea.

\section{I OBJETIVOS}

O objetivo do trabalho é avaliar a vulnerabilidade à contaminação dos poços tubulares profundos de captação de água para o abastecimento da cidade de Abaetetuba - PA, visando ampliar o conhecimento sobre a sua situação atual e sua proteção, através do método GOD.

\section{I MATERIAIS E MÉTODOS}

\section{1 Área de estudo}

O município de Abaetetuba fica localizado a $60 \mathrm{~km}$ a sudoeste da capital paraense (Belém) e possuía uma população de aproximadamente 141.100 habitantes, em 2010, sendo que destes 82.998 são residentes da área urbana, a qual é a área de interesse deste estudo, e 58.102 estão alocados na área rural do município. Sua área de unidade territorial é de aproximadamente 1.610,6 km2. Localizado na mesorregião do nordeste paraense o município limita-se ao norte com Barcarena e o Rio Pará; ao sul com Igarapé-Miri; a leste com Moju e a Oeste com Limoeiro do Ajuru e a Baia de Marapatá (IBGE, 2010).

Vale ressaltar que, como não há captação de água superficial para abastecimento público na cidade de Abaetetuba, tal serviço ocorre através da explotação de água subterrânea utilizando poços tubulares profundos, operados pela Companhia de Saneamento do Pará (COSANPA). Por isso, os poços aqui analisados serão os quais abastecem a região.

\subsection{Obtenção dos dados}

Inicialmente, foram realizadas pesquisas para obtenção de dados sobre poços de captação de água (aspectos gerais, construtivos, geológicos, hidrogeológicos, entre outros, os quais são gratuitamente fornecidos pelo Sistema de Informações de Águas Subterrâneas (SIAGAS - CPRM). Além disso, foram utilizadas outras pesquisas encontradas em revistas, livros e sites ligadas à esta temática, para que se pudesse ter um embasamento técnico 
mais aprofundado. Na Figura 1 indica-se a delimitação dos setores de abastecimento e os pontos de localização dos poços.

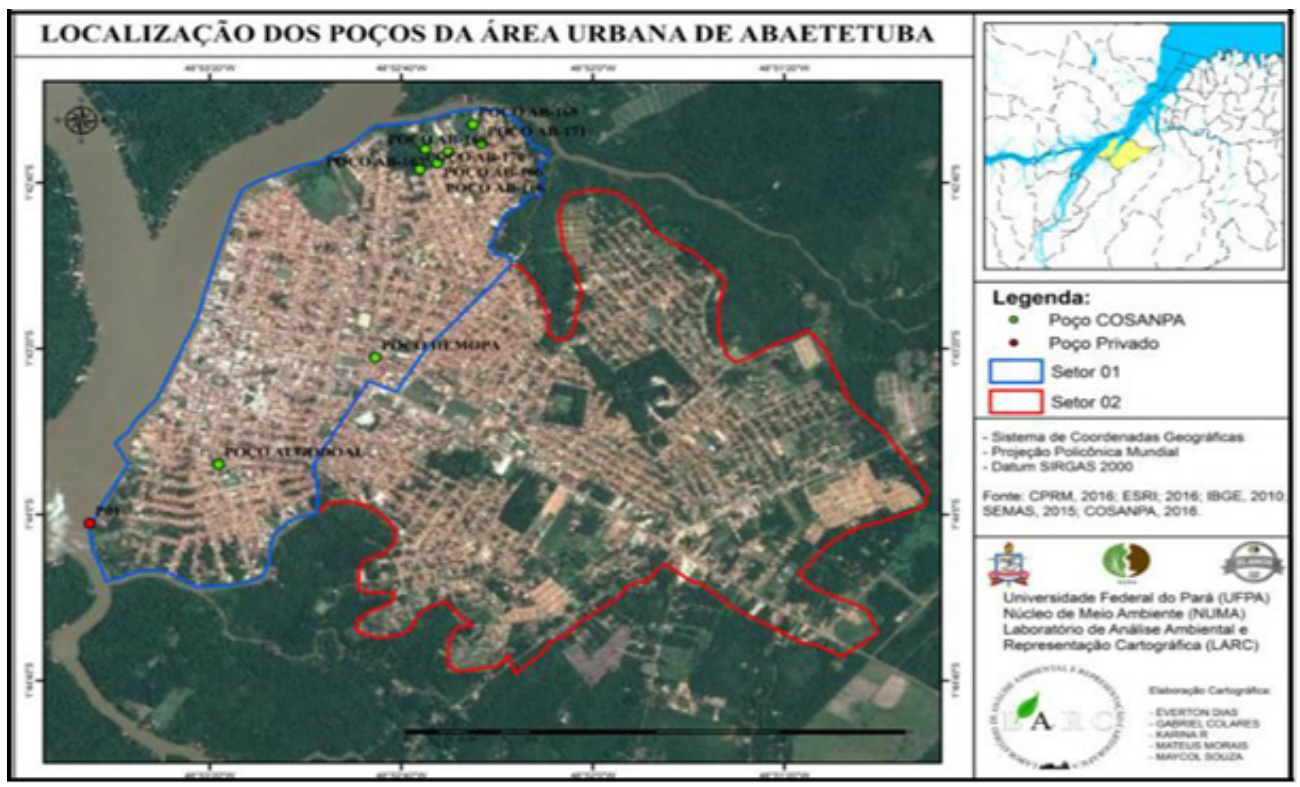

Figura 1: Mapa de localização dos poços e dos setores de distribuição de água.

Fonte: Autores, 2017.

Além disso, fora realizada uma visita à cidade de Abaetetuba, para fazer um reconhecimento geral da área de trabalho, assim como entender o funcionamento e a operação do seu sistema de abastecimento de água. Para isso foram visitados os poços de abastecimento da cidade assim também como a Estação de Tratamento de Água - ETA - a qual possui etapas de aeração, filtração e desinfecção; e alguns pontos de distribuição na rede.

Durante a pesquisa realizada no banco de dados do Serviço Geológico do Brasil, através do Sistema de Informações de Águas Subterrâneas (SIAGAS), encontrou-se um total de 33 poços perfurados cadastrados nos sistemas existentes no município de Abaetetuba. Desse total, 9 são de propriedade da COSANPA e os outros 24 pertencem a propriedades particulares.

Porém, dos 9 poços pertencentes à companhia, apenas 7 ainda se encontram em operação. Além dos 7 poços cadastrados no SIAGAS, há um que não está no sistema, mas foi construído no bairro de Algodoal e está em operação, atualmente, contabilizando 8 poços em funcionamento sob responsabilidade da COSANPA.

Do total de poços cadastrados no SIAGAS, apenas 11 fazem parte da área urbana 
do município. Destes, como já mencionado, 10 são de propriedade da COSANPA e um é de propriedade privada. A Figura 3 identifica os poços de propriedade da COSANPA em Abaetetuba que estão em operação.

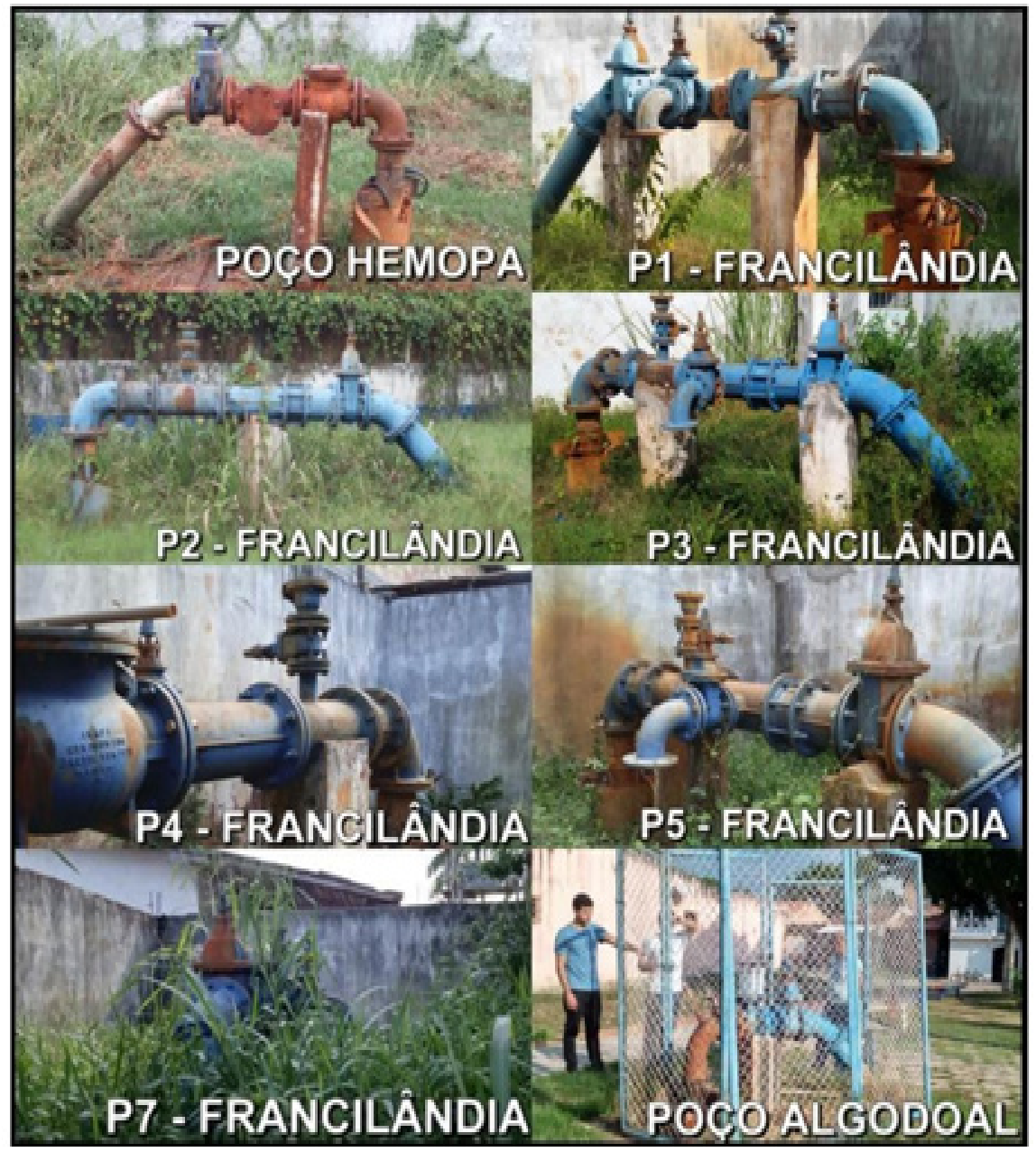

Figura 2: Poços operantes do município de Abaetetuba.

Fonte: Autores, 2017.

Após a reunião e organização dos dados sobre os poços, iniciou-se o processo de análise da vulnerabilidade de cada um deles, utilizando o método GOD, o qual será detalhado adiante.

\subsection{Método GOD}

No presente estudo, para realização da análise da vulnerabilidade natural de 
aquífero, foi empregada a metodologia GOD (Groundwater occurrence, Overall lithology of the unsaturated zone, Depth to the water table), proposta por Foster e Hirata (1988), que leva em consideração a avaliação de três parâmetros:

a. Ocorrência do aquífero (livre, confinado, semiconfinado): podendo admitir valores de 0 a 1.

b. Litologia da zona vadosa e camadas confinantes: o solo e a litologia situada acima da zona saturada do aquífero condicionam o tempo de deslocamento de contaminantes e vários processos de sua atenuação. Cada tipo de solo tem sua capacidade de atenuação. A ocorrência de estratos litológicos pode ter valores de 0,3 a 1.

c. Profundidade do aquífero (espessura da zona vadosa): pode ser definida como a distância que o contaminante terá de percorrer para alcançar a zona saturada do aquífero. A Profundidade ou nível estático pode assumir valores de 0,4 a 1 .

Ressalta-se que todos os parâmetros possuem o mesmo nível de importância. Sendo assim, o índice de vulnerabilidade natural é dado pela multiplicação desses três parâmetros, logo, para fins de classificação dos resultados deve-se considerar vulnerabilidade insignificante valores de 0 a 0,1; baixa valores de 0,1 a 0,3; média valores de 0,3 a 0,5; alta valores de 0,5 a 0,7; e por fim, extrema valores de 0,7 a 1,0. (FOSTER \& HIRATA, 1988).'

A finalidade de aplicação desse método é para avaliação da vulnerabilidade do aquífero livre da região do munícipio, pois possui fácil aplicabilidade em virtude da exigência mínima de parâmetros, logo, viabiliza a utilização do método em situações de escassez de informações disponíveis.

Abaixo, a Figura 3 identifica o esquema e os valores de cada parâmetro, utilizado no cálculo da vulnerabilidade pela metodologia GOD. Para a aplicação da metodologia, os dados de grau de confinamento, litologia no perfil do nível estático e a distância até o lençol freático foram obtidos na plataforma do Sistemas de Informações de Águas Subterrâneas (SIAGAS). 


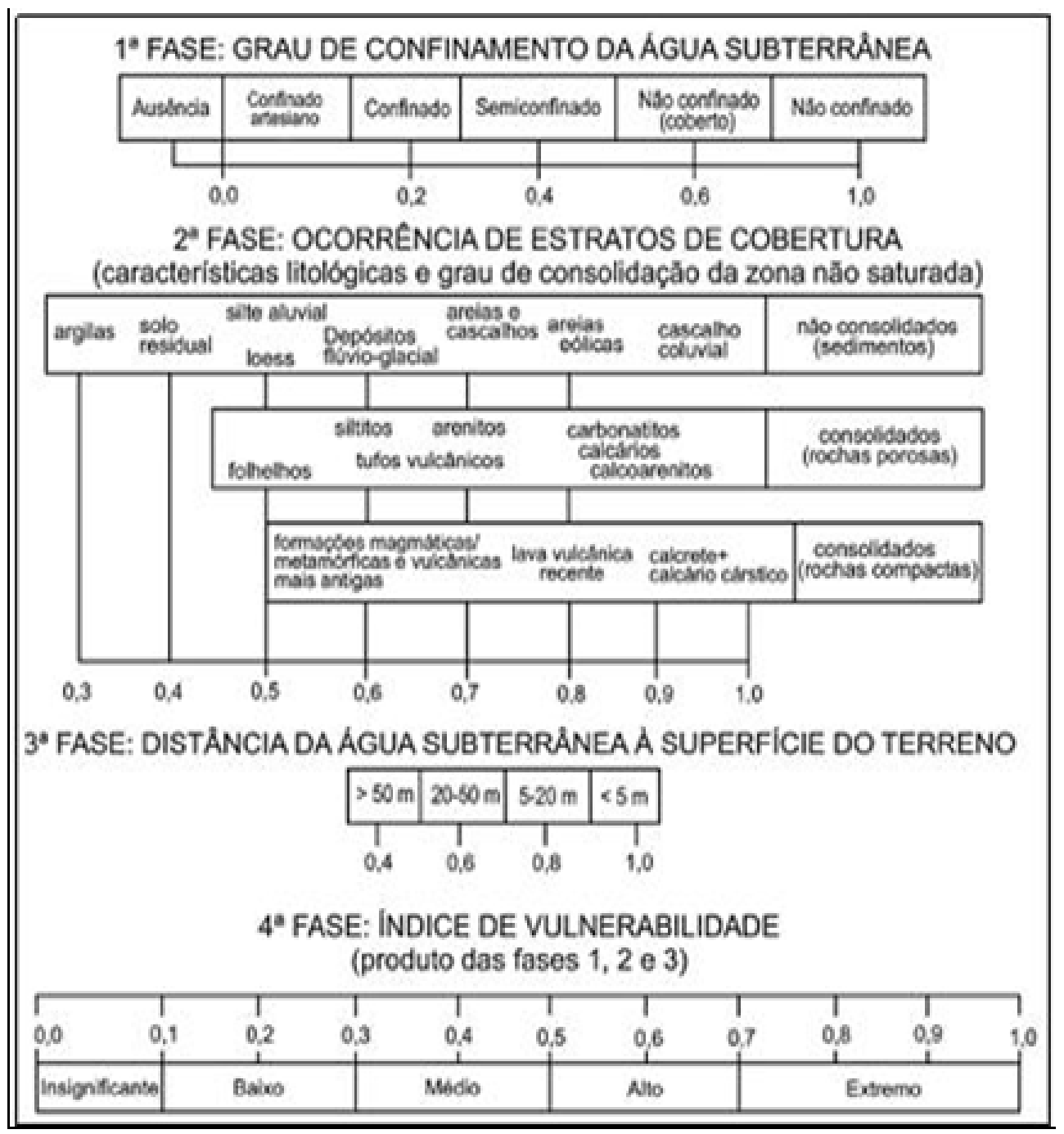

Figura 3: Critérios avaliativos do método GOD.

Fonte: Adaptado de FOSTER et al, 2006 apud TAVARES et al, 2009).

\section{I RESULTADOS}

$\mathrm{Na}$ cidade de Abaetetuba, ainda hoje, há um problema muito comum para quem recebe água através da rede de distribuição da COSANPA, que é a falta deste recurso e a interrupção da sua distribuição durante a noite. Estes problemas são causados visto que a captação de água atual dos poços operantes no município já não atendem mais as demandas atuais de abastecimento. Uma das principais causas para que dificultam a captação de água e suprimento das demandas é a ausência de manutenção preventiva nos poços subterrâneos e nas bombas utilizadas para explotação de água (DIAS et al, 2017). 
Porém, quando houve a visita aos locais onde se encontram os referidos poços, percebeu-se que não apenas as bombas de captação carecem de manutenção preventiva, mas também há um grande problema de "abandono" desses locais. Isto ocorre pois fora verificado que, na maioria das áreas em que os poços estão inseridos, principalmente aqueles presentes no bairro da Francilândia, a vegetação encontrava-se elevada, a ponto de quase cobrir as instalações dos poços (Figura 4). Tal fato dificultou até mesmo a entrada nesses locais. Esta situação torna a manutenção das bombas e poços uma atividade ainda menos provável de acontecer.

Além da vegetação verificou-se também que na maioria dos poços, a área onde estes estão alocados encontrava-se repleta de resíduos sólidos, principalmente nos poços que ficam rodeados por moradias, sendo que tais resíduos são despejados, muitas vezes, pelos próprios moradores que, infelizmente, não entendem que esses resíduos podem ser prejudiciais para a qualidade da água captada. Devido à presença destes materiais, há também o risco de perfuro cortantes encobertos pela vegetação.

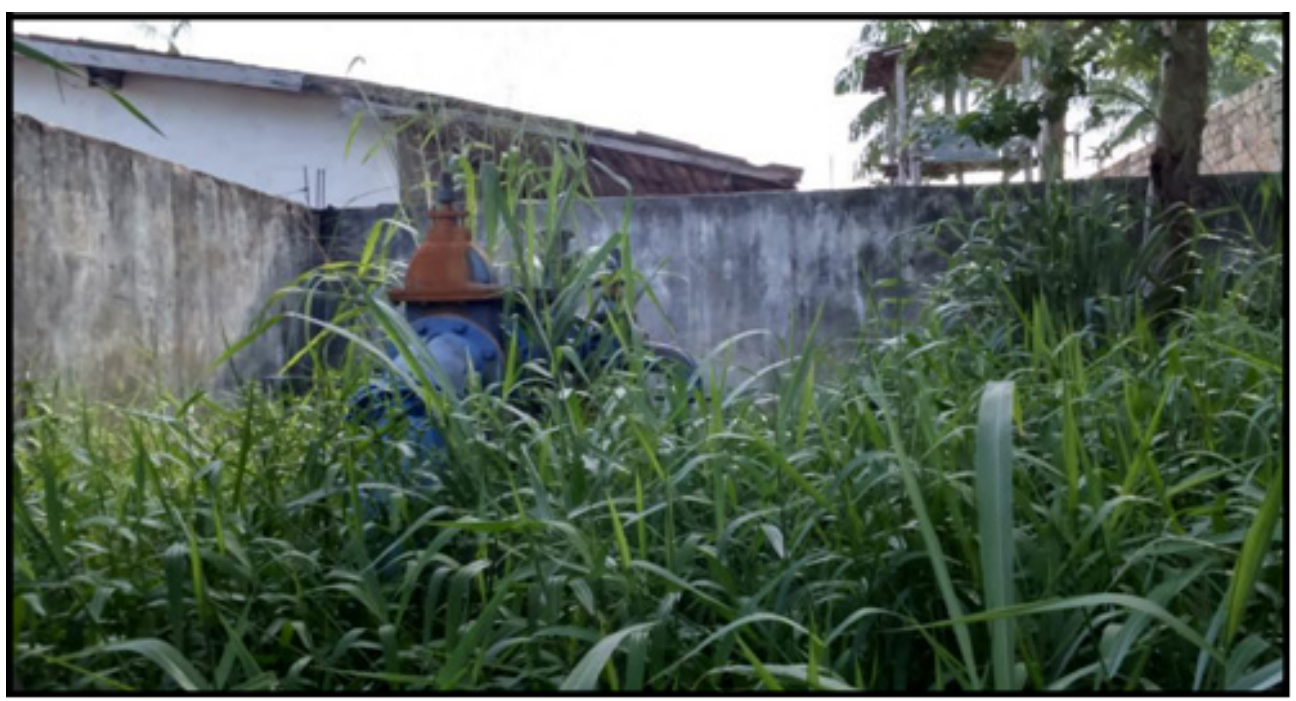

Figura 4: Condição da área do poço 7.

Fonte: Autores, 2017.

Para aplicação do método GOD, fez-se uso da plataforma SIAGAS, ondee foram obtidos dados que possibilitassem a análise dos poços, os quais foram as coordenadas geográficas, tipo de aquífero, litologia e profundidade do nível estático. A partir destes dados, com exceção das coordenadas geográficas, foram atribuídos, em outra tabela, os valores referentes a cada característica, de acordo com a metodologia utilizada, a fim de se obter os índices de vulnerabilidade para cada poço. 
Porém, como não foi possível encontrar no referido sistema de informações, em dois poços operantes, o nível estático da água (aspecto primordial para que fosse realizada a análise adequada dos poços) estes foram retirados do estudo, restando assim apenas 6 poços subterrâneos. A seguir serão apresentados na Tabela 1 as características dos poços analisados neste estudo.

\begin{tabular}{c|c|c|c|c|c}
\hline \multirow{2}{*}{ Poço } & \multicolumn{2}{|c|}{ Coordenadas Geográficas } & \multirow{2}{*}{ Tipo de Aquífero (G) } & $\begin{array}{c}\text { Litologia } \\
\text { (O) }\end{array}$ & $\begin{array}{c}\text { Nível } \\
\text { Estático (D) }\end{array}$ \\
\cline { 2 - 5 } & $\mathbf{X}$ & $\mathbf{Y}$ & Confinado & Argila & 11,05 \\
\hline P1 & 14234 & 485230 & Confinado & Argila & 10,15 \\
\hline P2 & 14235 & 485235 & Arenoso & 9,4 \\
\hline P3 & 14230 & 485233 & Semiconfinado & Argila & 10,31 \\
\hline P4 & 14231 & 485228 & Confinado & Argila & 9,4 \\
\hline P5 & 14235 & 485225 & Confinado & Arenoso & 9,15 \\
\hline P6 & 014229 & 485222 & Semiconfinado & & \\
\hline
\end{tabular}

Tabela 1: Características dos poços subterrâneos analisados.

Para a variável "Tipo de Aquífero" constatou-se que 4 deles estão na condição de confinado, devido satisfazerem a condição descrita pelo Serviço Geológico do Brasil (CPRM) que diz que o aquífero confinado é "aquele onde a pressão da água em seu topo é maior do que a pressão atmosférica. Em função das camadas limítrofes pode ser definido como: confinado não drenante e confinado drenante." Tal característica permite definir um índice 0,2 para a variável G. Por outro lado, dois poços (P3 e P6) estão na condição de semiconfinados devido terem apenas uma camada limítrofe. Tal característica permite definir um índice 0,4 para a mesma variável.

Passando para as características da zona não saturada, relacionadas ao tipo de solo que constitui esta zona, pode-se observar que 4 poços possuem solo predominantemente argiloso, característica obtida por meio dos perfis construtivos. Sendo assim, para estes poços atribuiu-se um valor de 0,3 para a variável O. Porém, os poços P3 e P6 possuem solo predominantemente arenoso e por isso recebem o valor de 0,7 para a variável 0 .

Em relação à profundidade do nível estático, os dados obtidos dos poços de captação de água indicaram que estes variam de 9,40m em P3 e P5, até 11,05m em P1. Este fato garante definir um valor 0,8 todos os poços analisados, para a variável D.

Vale ressaltar que o nível estático da água do poço é um fator que influencia também a caracterização litológica da zona não saturada, visto que o solo analisado deve ser aquele presente até onde se encontra o nível estático de cada poço.

Na Tabela 2 são apresentados os resultados obtidos após a submissão dos valores de cada característica constante na Tabela 1 à metodologia GOD. 


\begin{tabular}{|c|c|c|c|c|c|}
\hline \multirow{2}{*}{ Poço } & \multicolumn{3}{|c|}{ Resultados } & Índice & \multirow{2}{*}{ Vulnerabilidade } \\
\cline { 2 - 5 } & G & O & D & G x O x D & \\
\hline P1 & 0,2 & 0,3 & 0,8 & 0,048 & Insignificante \\
\hline P2 & 0,2 & 0,3 & 0,8 & 0,048 & Insignificante \\
\hline P3 & 0,4 & 0,7 & 0,8 & 0,224 & Baixa \\
\hline P4 & 0,2 & 0,3 & 0,8 & 0,048 & Insignificante \\
\hline P5 & 0,2 & 0,3 & 0,8 & 0,048 & Insignificante \\
\hline P6 & 0,4 & 0,7 & 0,8 & 0,224 & Baixa \\
\hline
\end{tabular}

Tabela 2: Aplicação da metodologia GOD.

Portanto, analisando os resultados calculados dos índices de vulnerabilidade foi possível observar que os poços analisados apresentam um nível de vulnerabilidade natural que varia entre insignificante à baixo. Isto mostra que há um alto grau de resistência natural à penetração de contaminantes no solo. Tal característica deve-se, principalmente ao fato deles estarem presentes em aquíferos confinados e semiconfinados, associado às características litológicas da zona não saturada. A Tabela 2 indica as principais definições para cada classe de vulnerabilidade assim como seus respectivos índices.

\section{I CONCLUSÕES}

Por meio do cálculo da vulnerabilidade natural através do método GOD, podese observar que o sistema aquífero que abastece o Município de Abaetetuba no Estado do Pará, possui uma vulnerabilidade natural classificada de insignificante a baixa. Isto se dá principalmente pelo fato de apresentar na ocorrência da água subterrânea, um sistema confinado ou semiconfinado, havendo uma baixa possibilidade de penetração de agentes contaminantes externos, mostrando um resultado favorável as finalidades desses aquíferos, como o abastecimento municipal de água. Todavia, apesar do resultado mostrarse positivo, os poços devem conter laje de proteção, devem estar cercados (de forma a impedir a entrada de pessoas não autorizadas e de animais), em conjunto com manutenção regular, etc, diminuindo, potencialmente, a possibilidade de contaminação dos mesmos.

Desse modo, confirma-se a importância de conhecimento das características hidrogeológicas de uma determinada região, pois, torna-se fundamental para a execução de diagnósticos da qualidade da água em áreas urbanas, especialmente quando a finalidade desses recursos é voltada para o abastecimento público humano, como a área de estudo do trabalho. Sendo que nessas áreas urbanas situam-se as principais fontes potenciais de poluição dos recursos naturais, visto que existe diversas atividades antrópicas implantadas. Dessa maneira, a vulnerabilidades dos aquíferos é de grande importância para avaliação e controle da qualidade dos recursos hídricos subterrâneos. 


\section{REFERÊNCIAS}

ANA (Agência Nacional de Águas). Conjuntura dos Recursos Hídricos no Brasil - Capítulo 04 sobre a Gestão da água. 2017. Disponível em: <http://conjuntura.ana.gov.br/static/media/gestao_ agua.20ba2c97.pdf>. Acesso em: 27 Abr. 2018.

CRUZ, W.T; CASSIMIRO, C.D; PAES, G.F; ANDRADE, N.L.R. Vulnerabilidade dos aquíferos do município de cacoal/RO: uma aplicação do método GOD. In: XIV ENEEAmb, II Fórum Latino e I SBEA - Centro-Oeste, 2016.

DIAS, E. C; SILVA, G. P. C. DA; MORAIS, M. S.; SOUZA, M. W. M.; FERNANDES, L. L. Proposta de aperfeiçoamento do sistema de abastecimento de água do município de Abaetetuba - PA. In: $3^{\circ}$ Congresso Internacional RESAG, Belo Horizonte, 2017.

FOSTER, S.; HIRATA, R.; GOMES, D.; D'ELIA, M.; PARIS, M. Proteção da Qualidade da Água Subterrânea. Um guia para empresas de abastecimento de água, órgãos municipais e agencias ambientais. Banco Mundial, Washington, D.C. 2006.

FOSTER, S. S. D. e HIRATA, R. C. A. Groundwater pollution risk assessment: a methodology using available data. WHO-PAHO/HPE-CEPIS Technical Manual, Lima, Peru. 81pp, 1988.

RIBEIRA, F. Calidad. Contaminación y protection de acuíferos. In III Curso Hispanoamericano de Hidrologia Subterránea. Montevideo-UY, 2004.

RIBEIRO, D. M.; ROCHA, W. F.; GARCIA, A. J. V. 2011. Vulnerabilidade natural à contaminação dos aquíferos da sub-bacia do rio Siriri, Sergipe. Águas Subterrâneas, p 25.1: 91-102.

SERVIÇO GEOLÓGICO DO BRASIL - CPRM. Aquíferos. Disponível em: < http://www.cprm.gov.br/ publique/Redes-Institucionais/Rede-de-Bibliotecas---Rede-Ametista/Canal-Escola/Aquiferos-1377. html >. Acesso em 20 fev. 2018.

SILVA, A. S. C. S; PARANHOS, P. F; MARTINS, J. B. Avaliação da vulnerabilidade dos aquíferos da região oeste do município de Barcarena-PA através da aplicação do método G.O.D. In: I Congresso Brasil Norte de Engenharia Sanitária e Ambiental, 2017.

TAVARES, P. R L; Castro, C. T. F; SILVEIRA, J. das G. P; ALMEIDA JÚNIOR, F. J. B. de. 2009. Mapeamento da vulnerabilidade à contaminação das águas subterrâneas localizadas na Bacia Sedimentar do Araripe, Estado do Ceará, Brasil. Rem: Rev. Esc. Minas [online]. vol.62, n.2, pp.227236. ISSN 0370-4467. http://dx.doi.org/10.1590/S0370-44672009000200015.

TERRA, L.G., LÖBER, C.A., SILVA, J.L.S, ERTEL, T. Análise dos recursos hídricos subterrâneos do município de Santiago-RS, como ferramenta de gestão. In: XIX Simpósio Brasileiro de Recursos Hídricos, 
Data de aceite: 04/01/2021

Data de submissão: 23/10/2020

\section{Mauro César de Brito Sousa}

Instituto Federal do Piauí

Teresina, PI, Brasil

http://lattes.cnpq.br/2049460389729603 https://orcid.org/0000-0002-0650-6577

\section{Bruna de Freitas Iwata \\ Instituto Federal do Piauí \\ Teresina, PI, Brasil}

http://lattes.cnpq.br/3036032785449787

https://orcid.org/0000-0002-6465-9731

RESUMO: O impacto de cemitérios na qualidade das águas subterrâneas foi observado em vários países do mundo. Em Teresina, Brasil, o cemitério Areias é um típico exemplo deste tipo de impacto ambiental, pois oferece riscos à comunidade local pela possibilidade de contaminação das águas superficiais e subterrâneas da região. Este estudo utilizou a simulação do fluxo subterrâneo para avaliar o transporte de contaminantes via águas subterrâneas e analisar a extensão de uma possível pluma de contaminação oriunda do cemitério. Os resultados apontados pela simulação computacional indicaram pequena probabilidade de avanço da contaminação para além dos limites da necrópole. Assim, o método proposto neste artigo oferece uma importante contribuição para melhorar o diagnóstico ambiental na área do cemitério Areias.

PALAVRAS-CHAVE: Águas subterrâneas, modelagem computacional, necrópoles.

\section{MODELLING OF CONTAMINANTS FLOW IN GROUNDWATER IN THE AREIAS CEMETERY, TERESINA, BRAZIL}

ABSTRACT: The impact of cemeteries on groundwater quality was observed in many countries all over the world. The Areias cemetery in Teresina, Brazil, is a typical example of that kind of environmental impact, because it presents risks to local people by the possibility of contamination in superficial water and groundwater. This case study used groundwater flow simulation to evaluate contaminants transport on the water and analyze the extension of a possible contamination from the cemetery. The results showed by computational simulator indicated small probability of the contamination drive exceed the necropolis limits. Thus, the proposed method in this article offers an important contribution to improve environmental diagnosis in the Areias cemetery area.

KEYWORDS: Groundwater, computational modelling, cemeteries.

\section{1। INTRODUÇÃO}

Se inadequadamente localizados ou insuficientemente protegidas, as necrópoles representam um problema de saúde pública comumente negligenciado, com considerável risco de contaminação de solos e aquíferos (Żychowski, 2012).

Segundo boletim técnico da ABAS (2001), no Brasil, praticamente a totalidade 
dos cemitérios municipais apresentam algum problema de cunho ambiental ou sanitário. Além disso, é comum que a comunidade de baixa renda, localizada nas imediações dos cemitérios, utilize as águas dos aquíferos freáticos sem o conhecimento dos perigos de contaminação.

O lixiviado gerado na decomposição da matéria orgânica enterrada na subsuperfície de necrópoles pode adentrar os espaços intragranulares do solo e encontrar o lençol freático, tornando-o poluído pelo aumento da concentração natural de substâncias orgânicas e inorgânicas (Bouwer 1978, Üçisik e Rushbrook 1998, Environment Agency 2002, Environment Agency 2004, Martins et al. 1991, Pacheco 2000, Matos 2001, Dent 2005).

De forma geral, em águas subterrâneas, o impacto está associado com o aumento das concentrações de microrganismos (Dent e Knight 1998, Matos 2001), de íons (Knight e Dent 1995, Pacheco et al. 2000, Üçisik e Rushbrook 1998) e vários elementos químicos nos solos (Spongberg e Becks, 2000). Segundo a Environment Agency (2002), observando dados disponíveis e comparando-os com padrões de qualidade aceitos mundialmente, verifica-se que o nitrogênio amoniacal é o parâmetro mais suscetível de ser ultrapassado.

Em Teresina, capital do Piauí, Brasil, o caso do cemitério Areias, chama a atenção pela peculiaridade da situação. Localizado às margens do Rio Parnaíba, principal manancial de água para abastecimento e à montante do ponto de captação da concessionária de abastecimento da cidade, o cemitério oferece riscos à comunidade local pela possibilidade de contaminação das águas subterrâneas e superficiais da região.

Sousa et. al (2015) realizou uma ampla campanha de amostragens da qualidade das águas subterrâneas na localidade, donde a partir dos resultados das amostras coletadas, determinou-se a baixa ocorrência de indicadores de contaminação no aquífero livre do cemitério em estudo.

Apesar dos dados apresentados, foi perceptível a necessidade de aprofundamento de outras frentes de pesquisa para dirimir dúvidas da comunidade, que continuava propensa a acreditar na possível contaminação advinda dos limites do cemitério. Assim, utilizou-se a modelagem computacional do aquífero local para propiciar maiores subsídios ao diagnóstico da contaminação apresentado por Sousa et. al (2015).

A presente investigação propôs, portanto, a modelagem computacional do aquífero freático em questão, com o objetivo de estabelecer a velocidade do fluxo subterrâneo e deliberar sobre a possibilidade de propagação de uma pluma de contaminação composta por formas de nitrogênio e microrganismos patogênicos. 


\section{I MATERIAIS E MÉTODO}

\subsection{Caracterização da área de estudo}

O cemitério Areias está situado na margem direita do Rio Parnaíba, em zona urbana, na região sul da cidade de Teresina e a montante do ponto de captação de água superficial para abastecimento público.

A base geológica do município de Teresina pertence à uma estrutura geológica de dimensões regionais conhecida por Bacia Sedimentar do Piaúi-Maranhão. Entre as unidades de solo, destaca-se o Latossolo Vermelho-Amarelo, situado em uma faixa paralela ao rio Parnaíba, com uma largura média de $10 \mathrm{~km}$, ocorrendo com grande profundidade. A média anual da precipitação acumulada é de $1332 \mathrm{~mm}$, com regime pluviométrico concentrandose com $75,6 \%$ da chuva nos primeiros quatro meses do ano e $24,4 \%$ restantes nos oitos meses subsequentes (Teresina, 2002).

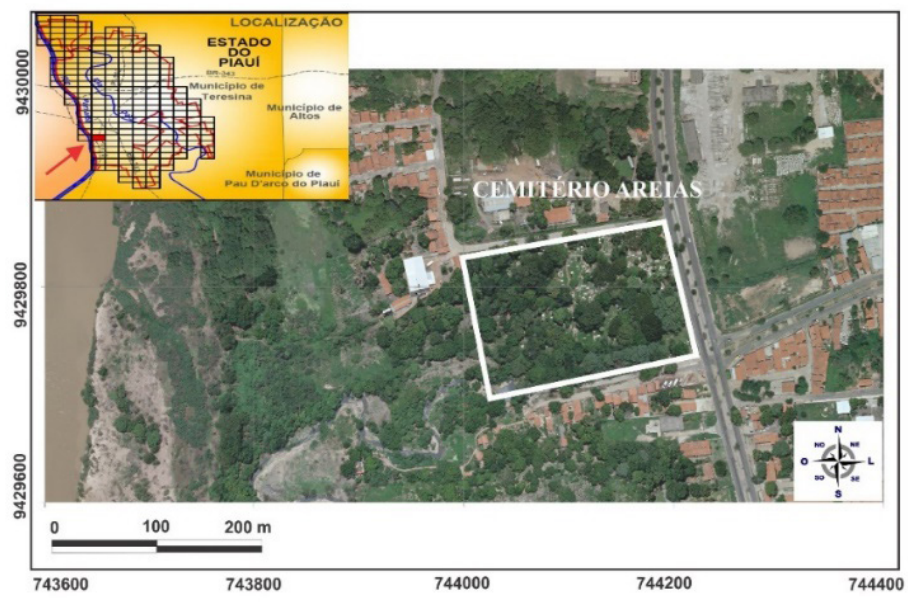

Figura 1. Localização do Cemitério Areias na Zona UTM 23, Teresina, Piauí, Brasil. Fonte: Sousa et. al (2015).

\section{2 modelo computacional}

Dentre os modelos numéricos computacionais disponíveis, utilizou-se nessa pesquisa o PMWIN PRO®, desenvolvido por Chiang (2005), que oferece interface para simulação do fluxo da água subterrânea no pacote MODFLOW ${ }^{\circledast}$ (Mcdonald e Harbaugh, 1988) e simulação do transporte advectivo de partículas no pacote PMPATH® (Chiang e Kinzelbach, 1994).

Para calibração do modelo, onde é realizada o ajuste dos parâmetros para produzir as cargas hidráulicas e fluxo medidos no campo, foi utilizado o procedimento desenvolvido 
por Schuster (2004), denominado de Método Iterativo de Gradiente Hidráulico Alternativo ou MIGHA.

A Figura 2 apresenta o fluxograma do processo de modelagem computacional aplicado na região do cemitério Areias e os itens subsequentes descrevem como foram obtidos cada um dos dados requeridos.

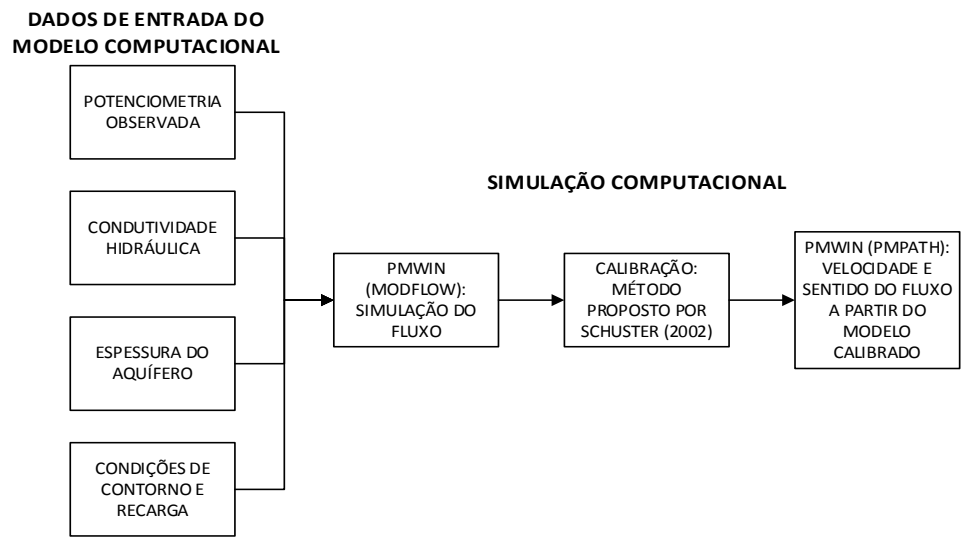

Figura 2. Simulação do fluxo e velocidade da água subterrânea

\subsubsection{Potenciometria observada}

Foram executados 4 poços de monitoramento para coleta de amostras da água subterrânea na localidade e determinação da profundidade do nível estático no período de observação do estudo. O monitoramento da variação do nível estático ocorreu durante o período de novembro de 2012 a outubro de 2013 (Sousa et. al, 2015).

O nível estático no mês de maio de 2013 foi considerado para estimativa da potenciometria inicial. Essa escolha é justificada pela maior proximidade do aquífero ao topo do terreno, o que levaria a maiores riscos de contaminação. A Figura 3 apresenta os pontos de monitoramento na área de estudo. 


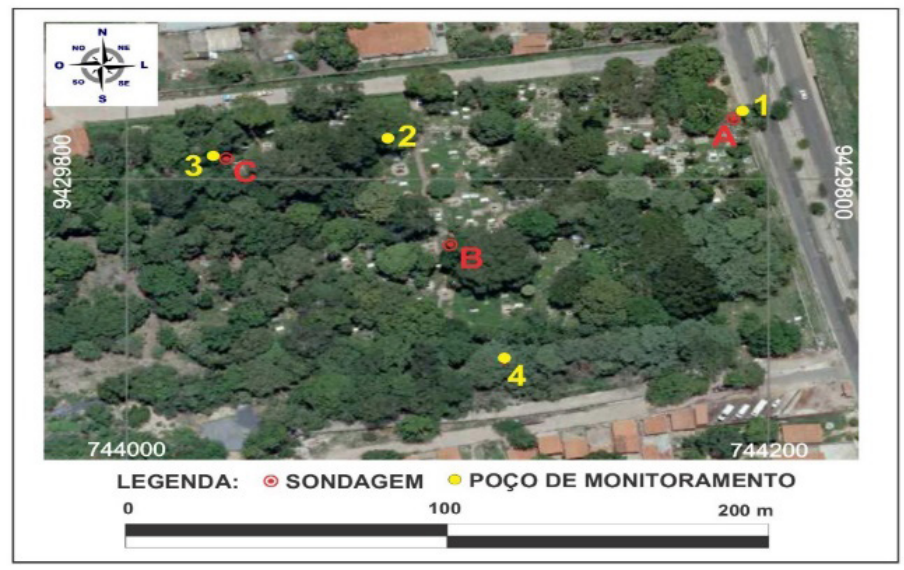

Figura 3. Localização dos pontos de sondagem

\subsubsection{Estimativa inicial da condutividade hidráulica na área}

Foram perfurados $28,35 \mathrm{~m}$ do regolito interno aos limites do cemitério, a partir de três furos de sondagem identificados na Figura 3. Segundo dados constantes nas sondagens, areias com granulometrias mais finas são uma tendência nos perfis amostrados (Sousa et. al, 2015).

Assim, foi proposto que o aquífero freático teria condutividade de $10-5 \mathrm{~m} / \mathrm{s}$, característico de areias finas, segundo valores de expressos em Todd (1980).

\subsubsection{Determinação da espessura do aquífero}

Considerou-se a camada de argila que passa a $7 \mathrm{~m}$ de profundidade no ponto de sondagem C - segundo estudo de Sousa et. al (2015) - como representativa do topo da camada considerada impermeável para toda a área modelada. Assim, o modelo conceitual do aquífero freático tem espessura de $7 \mathrm{~m}$ de profundidade.

\subsubsection{Recarga do aquífero}

O método de Flutuação da Superfície Piezométrica (WTF - Water Table Fluctuation) foi utilizado para a determinação da recarga do aquífero. Aplicável a aquíferos livres (não confinados), a recarga é calculada em função do rendimento específico do aquífero e das variações nos níveis de água ao longo do tempo (Maziero e Wendland, 2005). O resultado encontrado equivale a uma recarga de 103,66 mm/ano ou 3,28E-09 m/s.

\subsubsection{Porosidade}

Nessa pesquisa, a porosidade considerada foi de $43 \%$, segundo valores indicados por Todd (1980) para a predominância de areia fina no substrato do aquífero. 


\subsubsection{Condições de contorno}

Considerou-se uma condição de contorno fixa (carga hidráulica especificada na fronteira de entrada de fluxo) e condição de contorno fixa no limite de saída de fluxo e jusante do cemitério. Aos dois outros limites laterais, partindo-se do princípio que existam linhas de corrente que tornam o fluxo nulo na direção perpendicular a essas fronteiras, admitiu-se contornos sem fluxo. Vide representações na Figura 4.

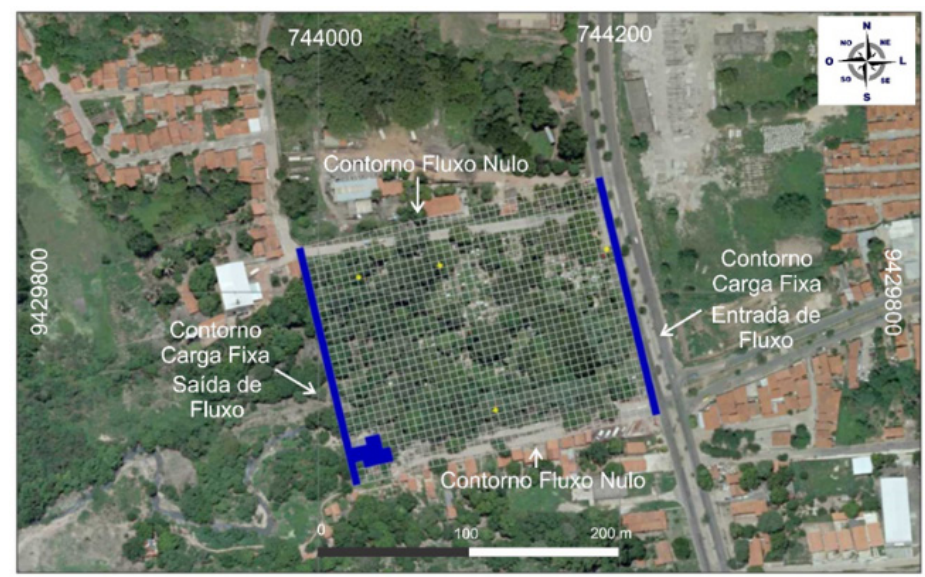

FIGURA 4. Condições de contorno

\subsubsection{Discretização da malha e seleção do modelo numérico}

O domínio do modelo compreende uma área de $34650 \mathrm{~m}^{2}$ e foi discretizado em uma malha de diferenças finitas de dimensões $210 \mathrm{~m}$ ao longo da direção x e $165 \mathrm{~m}$ ao longo da direção y, com células de dimensões $5 \times 5 \mathrm{~m}$ (Figura 13). Sendo considerada uma camada não confinada de espessura média de $7 \mathrm{~m}$ e recarga de $3,28 \mathrm{E}-09 \mathrm{~m} / \mathrm{s}$.

Os modelos numéricos utilizados foram o MODFLOW ${ }^{\circledR}$ (Mcdonald e Harbaugh, 1988), responsável pela simulação do fluxo de água subterrânea e o PMPATH $^{\circledR}$ (Chiang e Kinzelbach, 1994), responsável pela simulação do transporte advectivo de partículas e determinação da velocidade de fluxo.

\subsubsection{Calibração}

Foi utilizado o método de calibração MIGHA (Schuster, 2004), que consiste em um processo iterativo que tem início com a estimativa da condutividade hidráulica, com a definição da potenciometria observada (com posterior cálculo do gradiente observado) e com a tomada da potenciometria calculada no MODFLOW (com cálculo posterior do gradiente calculado). A cada nova iteração no processo, o valor da condutividade é ajustado 
e as cargas hidráulicas calculadas aproximam-se dos valores observados em campo.

Os ângulos $(\phi)$ formados pelos vetores do gradiente hidráulico observado e calculado, e o erro quadrático médio das cargas hidráulicas são utilizados como critério de convergência. Segundo esse critério, a modelagem é encerrada quando se atinge um valor mínimo predefinido tido por satisfatório.

\section{I RESULTADOS E DISCUSSÃO}

A partir do cenário modelado calibrado, foi possível abstrair o indicativo de velocidade de fluxo subterrâneo, importante para as conclusões deste estudo. A Figura 5 (à esquerda) indica o processo final de calibração do modelo computacional, onde encontrou-se o menor erro quadrático médio (RMSH) entre as cargas observadas e as cargas hidráulicas calculadas ao final da calibração, $0.0328 \mathrm{~m}$. A divergência máxima encontrada na soma dos ângulos $(\phi)$ formados pelos vetores do gradiente hidráulico observado e calculado foi de apenas $5,35^{\circ}$, demonstrando o sucesso da calibração. O modelo foi calibrado com 12 iterações pelo processo proposto por Schuster (2004).

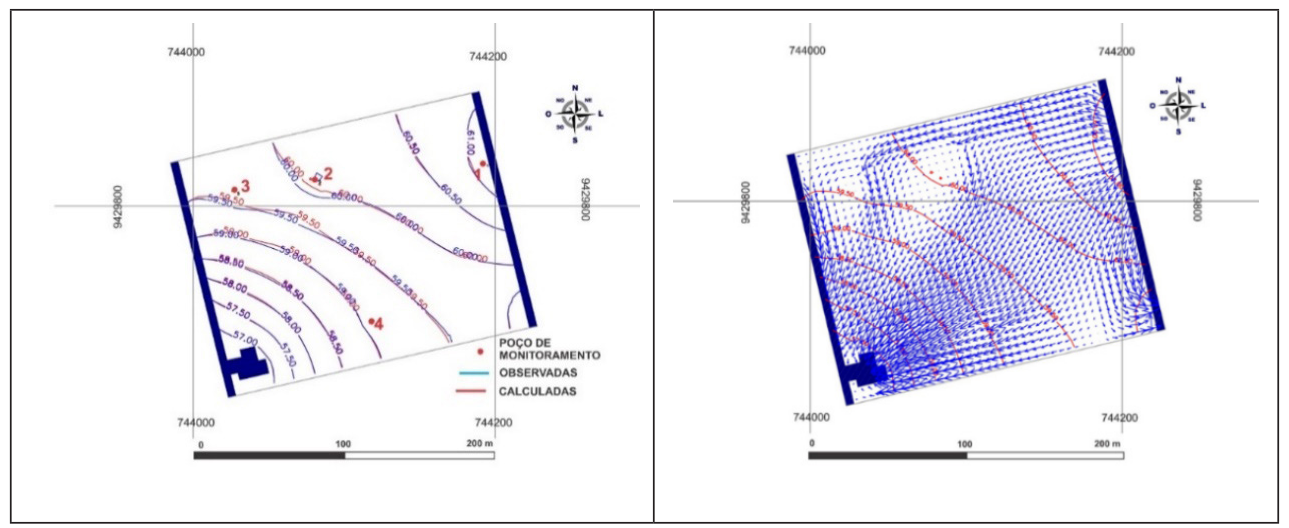

Figura 5. Cargas hidráulicas observadas $x$ cargas hidráulicas calculadas após processo de calibração (à esquerda) e Sentido do fluxo subterrâneo (à direita)

O produto da calibração apresenta a condutividade hidráulica para a área de estudo e apresentou valores médios da ordem de $9.07 \mathrm{E}-05 \mathrm{~m} / \mathrm{s}$, condizentes com a condutividade características de areias finas encontradas no aquífero freático local. A velocidade média linear do fluxo subterrâneo foi determinada em 0.0304 m/dia (11.10 m/ano) após simulação do fluxo calibrado no pacote PMPATH ${ }^{\circledR}$. A Figura 5 (à direita) apresenta o sentido do fluxo subterrâneo modelado para a área do cemitério Areias.

Segundo Hirata (1994), existem dois mecanismos que descrevem o transporte de contaminantes associados ao fluxo no aquífero: a advecção e a dispersão. A advecção é 
um processo hidráulico pelo qual o soluto é carreado pelo fluxo das superfícies igualandose à velocidade linear média das águas subterrâneas. No caso de contaminantes nãodegradáveis os efeitos podem ser maiores, pois por serem conservativos, a maior velocidade acaba resultando em maiores plumas, com maiores áreas atingidas.

A dispersão hidrodinâmica é um fenômeno em que um soluto, durante seu movimento em subsuperfície, se mistura com águas não-contaminadas, causando a redução na concentração original. A dispersão hidrodinâmica é uma função da heterogeneidade do meio, que induz a uma variação e uma estratificação da velocidade das águas subterrâneas, e em menor proporção, da difusão molecular (Hirata, 1994).

No caso do cemitério Areias, dois contaminantes foram estudados como representativos da contaminação. O primeiro, microbiológico, extremamente sensível às condições ambientais exteriores ao hospedeiro e, portanto, altamente degradável. O segundo, o nitrato, mais persistente e móvel, capaz de transpor grandes distâncias dependendo da sua concentração inicial.

Comumente, ao se proteger fontes de abastecimento, o primeiro passo é definir a zona de proteção microbiológica. Esta zona baseia-se na distância equivalente a um tempo de trânsito horizontal na zona saturada, servindo como barreira de atenuação contra atividades que infiltram vírus, bactérias e parasitas patogênicos (Foster et al., 2006).

Evidências empíricas mostram que estimar tempos de percursos entre 25 e 50 dias, é suficiente para reduzir concentrações de coliforme fecal a um nível de detecção improvável nas amostras de qualidade da água (ARGOSS, 2001). Dessa forma, convencionou-se que 50 dias é uma estimativa razoável para se definir a zona de proteção microbiológica, o que está em conformidade com a prática de muitos países de alta e baixa renda per capita (ARGOSS 2001, Taylor 2004).

Neste estudo, após simulação do fluxo calibrado no pacote PMPATH, a velocidade média linear do fluxo subterrâneo no cemitério Areias foi determinada em 0,0304 m/dia (11,10 m/ano). Com essa velocidade de fluxo subterrâneo, o limite de contaminação em 50 dias de trânsito na zona saturada seria de $1,52 \mathrm{~m}$ a jusante do cemitério, obedecendo a orientação do sentido de fluxo presente na Figura 5. Tal perspectiva, descredencia a probabilidade de uma possível contaminação microbiológica impactando o rio Parnaíba, devido à distância média de 400 metros entre o rio e a necrópole.

A contaminação do rio Parnaíba por uma pluma de nitrato oriunda do cemitério Areias, também pode ser desconsiderada devido às concentrações iniciais diminutas amplamente relatadas no estudo de Sousa et. al (2015). Além disso, as baixas velocidades envolvidas no fluxo subterrâneo do Areias, a distância do cemitério ao rio Parnaíba e a dispersão hidrodinâmica que pode acontecer na zona saturada, desempenham um importante papel na atenuação da pequena concentração de nitrato ainda existente. 


\section{I CONCLUSÃO}

A modelagem computacional do fluxo subterrâneo tem desempenhado importante papel como dispositivo de subsídio para previsão e controle de contaminação em aquíferos. Atualmente, o gerenciamento de recursos hídricos, seja na delimitação de zonas de proteção de poços, avaliação de transporte de contaminantes ou remediação de sítios contaminados, tem sido facilitada pelo aporte de dados gerados por estes modelos.

Nesta pesquisa, a modelagem computacional forneceu estimativas da velocidade de fluxo subterrâneo como meio para delimitação da faixa máxima de impacto de uma pluma de microrganismo patogênicos e formas de dissolvidas de nitrogênio oriundas do cemitério Areias. A partir da velocidade média linear do fluxo subterrâneo, determinada em 0.0304 $\mathrm{m} /$ dia ( $11.10 \mathrm{~m} / \mathrm{ano}$ ), foi possível admitir que a faixa máxima de impacto de uma possível pluma de contaminação microbiológica não ultrapassaria 1,52 $\mathrm{m}$ a jusante do cemitério. Ademais, as baixas concentrações de formas dissolvidas de nitrogênio aliadas às baixas velocidades de fluxo subterrâneo descredenciam um possível impacto desse parâmetro químico em mananciais a jusante da necrópole.

\section{REFERÊNCIAS}

ABAS - ASSOCIAÇÃO BRASILEIRA DE ÁGUAS SUBTERRÂNEAS. (2001). Cemitérios: risco potencial às águas subterrâneas. Boletim Informativo, n. 111, fev.

ARGOSS. (2001). Guidelines for assessing the risk to groundwater from on-site sanitation. British Geological Survey Commissioned Report CR/01/142. BGS keyworth, England. 104 p.

Bouwer, H. (1978). Groundwater hydrology. New York: McGraw-Hill Book, 480 p.

Chiang, W. H. (2005). 3D - Groundwater modeling with PMWIN: a simulation system for modeling groundwater flow and transport processes. 2. ed. New York: Springer Berlin Heidelberg. 397 p.

Chiang, W. H; Kinzelbach, W. (1994). PMPATH for Windows: User's manual. Washington, DC: Scientific Software Group.

Dent, B. B.; Knight, M. J. (1998). Cemeteries: a special kind of landfill. In: International Association Of Hydrogeologists Sustainable Solutions Conference, February 1998, Melbourne. Proceedings... Kenilworth: IAH.

Dent, B. B. (2005). Vulnerability and the unsaturated zone: the case for cemeteries. In: Joint Conference, New Zealand Hydrological Society, International Association of Hydrogeologists (Australian Chapter) and New Zealand Soil Science Society, 5., Nov. 30 - Dec. 2 2005, Auckland. Proceedings: where waters meet. Auckland: IAH.

Environment Agency. (2002). Pollution potential of cemeteries - Draft Guidance. R\&D Technical Report P223, 71. 
Environment Agency. (2004). Assessing the groundwater pollution potential of cemetery developments. $20 \mathrm{p}$.

Foster, S. S. D.; Hirata, R.; Gomes, D.; D’elia, M. Paris, M. (2006). Proteção da qualidade da água subterrânea: um guia para empresas de abastecimento de água, órgãos Municipais e agências ambientais. Tradução Silvana Vieira. Revisão Técnica Ricardo Hirata. São Paulo: Servmar - Serviços Técnicos Ambientais Ltda.

Hirata, R. (1994). Fundamentos e estratégias de proteção e controle da qualidade das águas subterrâneas: estudo de casos no estado de São Paulo. 1994. Tese (Doutorado em Recursos Minerais e Hidrogeologia) - Instituto de Geociências, Universidade de São Paulo, São Paulo, 1994.

Knight, M.J.; Dent, B.B. (1995). A watery grave - the role of hydrogeology in cemetery Practice. Australian Cemeteries \& Crematoria Association National Conference - Sydney, 8-12 October, ACCA News, Summer, pp. 19-22.

Manoel Filho, J.; Feitosa, F. A. C. (2000). Hidrogeologia: conceitos e aplicações. $2^{a}$ Edição. Fortaleza: CPRM - Serviço Geológico do Brasil; LABHID - Laboratório de Hidrogeologia da UFPE, 391 p ISBN.

Martins, T.; Pellizari, V. H.; Pacheco, A.; Myaki, D. M.; Adams, C.; Bossolan, N. R. S. et al. (1991). Qualidade bacteriológica de águas subterrâneas em cemitérios. Revista Saúde Pública, São Paulo, v. 25, n. 1, p. 47-52.

Matos, B. A. (2001). Avaliação da ocorrência e do transporte de microrganismo no aquífero freático do cemitério de Vila Nova Cachoeirinha, município de São Paulo. 2001. 161f. Tese (Doutorado em Recursos Minerais e Hidrogeologia) - Instituto de Geociências, Universidade de São Paulo, São Paulo.

Maziero, T. A.; Wendland, E. (2005). Avaliação da recarga subterrânea de bacias urbanas no município de São Carlos-SP. In: XIV Encontro Nacional de Perfuradores de Poços e II Simpósio de Hidrogeologia do Sudeste, Ribeirão Preto. Anais do XIV Encontro Nacional de Perfuradores de Poços e II Simpósio de Hidrogeologia do Sudeste. São Paulo - SP: ABAS - Associação Brasileira de Águas Subterrâneas, v. 1. p. 1-18.

Mcdonald, M. G.; Harbaugh, A. W. (1988). MODFLOW: a modular three-dimensional finite difference ground-water flow model. Washington: United States Government Printing Office. U. S. Geological Survey, Open-file report 83-875, Chapter A1. 523 p.

Pacheco, A. Cemitérios e meio ambiente. (2000). 102f. Tese (Livre Docência) - Universidade de São Paulo, São Paulo.

Schuster, H. D. M. (2002). Modelagem Matemática do Uso Conjunto das Águas Superficiais e Subterrâneas da Sub-Bacia do Rio das Fêmeas-Bahia. Projeto de Gerenciamento Integrado das Atividades na Bacia do São Francisco - ANA/GEF/PNUMA/OEA, Salvador-BA, 59 p.

Sousa, M. C. B., Castro, M. A. H, Monteiro, C. A. B., Pessoa, G. P., Souza, C. D. (2015). Estudo da contaminação do aquífero próximo ao cemitério Areias, Teresina/PI, Brasil. Brazilian Geographical Journal: Geosciences and Humanities research medium, Ituiutaba, v. 6, n. 1, p. 41-57, jan./jun. 
Spongberg, A.L.; Becks, P. (2000). Organic Contamination in Soils Associated with Cemeteries. Journal of Soil Contamination 9 (2), 87-97.

Taylor, R.; Cronin, A.; Pedley, S.; Barker, J.; Atkinson, T. (2004). The implications of groundwater velocity variations on microbial transport and wellhead protection - review of field evidence. FEMS Microbiol. Ecology, v. 49, n. 1, p. 17-26.

TERESINA. (2002). Prefeitura Municipal. Secretaria Municipal de Planejamento e Coordenação Geral. Teresina: Agenda 2015 - Plano de Desenvolvimento Sustentável. Teresina.

Todd, D. K. (1980). Groundwater hydrology. 2. ed. New York: John Wiley \& Sons, 537 p.

Üçisik, A. S.; Rushbrook, (1998). P. The impact of cemeteries on the environment and public health: an introductory briefing. Copenhagen: WHO, 15p.

Żychowski, Józef. (2012). Impact of cemeteries on groundwater chemistry: A review. Catena, v. 93, p. 29-37, 2012. 


\section{ANÁLISE DO SANEAMENTO E DA QUALIDADE DE ÁGUA NA BACIA HIDROGRÁFICA DO RIO PIABANHA}

Data de aceite: 04/01/2021

Data de submissão: 06/11/2020

Luis Carlos Soares da Silva Junior Universidade Federal do Rio de Janeiro, Programa de Engenharia Civil - COPPE Rio de Janeiro, RJ http://lattes.cnpq.br/0940732667062068

\section{José Paulo Soares de Azevedo}

Universidade Federal do Rio de Janeiro, Programa de Engenharia Civil - COPPE Rio de Janeiro, RJ http://lattes.cnpq.br/5270317603423573

\section{Ana Silvia Pereira Santos}

Universidade do Estado do Rio de Janeiro, Departamento de Engenharia Sanitária e

Ambiental

Rio de Janeiro, RJ

http://orcid.org/0000-0001-7823-9837

Verônica Silveira de Andrade

Universidade Federal do Rio de Janeiro, Programa de Engenharia Civil - COPPE Rio de Janeiro, RJ

http://lattes.cnpq.br/1888369104165501

\section{Marília Carvalho de Melo}

Universidade Vale do Rio Verde e Secretaria de Estado de Meio Ambiente e Desenvolvimento

Sustentável

Belo Horizonte, MG http://orcid.org/0000-0002-9789-2169 degradação ambiental. Para observar essa relação na sub-bacia do rio Piabanha, o presente trabalho visa diagnosticar os serviços de esgotamento sanitário através do cruzamento de dados oficiais de saneamento com campanhas de medições de qualidade da água realizadas neste rio. Inicialmente, foi caracterizado o atendimento dos serviços de esgotamento sanitário na região através de dados oficiais, seguido da análise dos dados de monitoramento da qualidade do rio. Através da caracterização e georreferenciamento dos índices de esgotamento, adensamento populacional e do índice de qualidade de água fuzzy para ambientes lóticos (IQAFAL) foi possível explicar a relação entre saneamento da região com a qualidade de água no rio Piabanha. Concluiu-se que as divergências das informações nas bases de dados oficiais são preocupantes para a informação da população e tomada de decisão por gestores. Além de chegar à conclusão de que, apesar dos bons índices de coleta e tratamento da cidade de Petrópolis, esta é a principal responsável pela degradação ambiental do rio Piabanha. No entanto, ressaltase a importância da modelagem das fontes de lançamento pontuais como as das indústrias, além das fontes difusas para garantir uma melhor representação da situação do rio e promover prognósticos.

PALAVRAS-CHAVE: Esgotamento sanitário; Qualidade de água; Carga orgânica; Bacia hidrográfica; Rio Piabanha.

RESUMO: O crescimento populacional acrescido da falta de infraestrutura de saneamento provoca 


\section{ANALYSIS OF SANITATION AND WATER QUALITY IN THE PIABANHA RIVER BASIN}

ABSTRACT: The increased population growth coupled with lack of sanitation infrastructure promotes environmental degradation. To analyze this relationship in the Piabanha River watershed, the present paper diagnosed the sewage services by crossing governmental sanitation datum with water quality sampling analysis from Piabanha River. First, the wastewater transport and treatment facilities in the cities within the basin were identified and compared between the available databases. This information was compared with the monitoring river quality data, according to the fuzzy water quality index for lotic environments (IQAFAL). After characterizing and georeferencing all data, we observed that cities' low sanitation indexes and population densification proved to be main causes of the poor water quality in the Piabanha River. Moreover, the divergence of information in the official databases is of concern for the correct information of the population and decision-making by managers. Besides, despite the good collection and treatment rates in Petrópolis, this city is the main responsible for the environmental degradation of the Piabanha River. However, we indicate that it is important to develop a water quality model to understand pollution dynamics of the effluents discharges and diffuse sources to ensure a better representation of the situation of the river and provide a prognosis.

KEYWORDS: Wastewater facilities; Water quality; Organic load; Watershed; Piabanha River.

\section{I INTRODUÇÃO}

O território do Estado do Rio de Janeiro (RJ) é dividido em nove Regiões Hidrográficas (RHs) para fins de gestão de Recursos Hídricos (CERHI-RJ, 2013). Uma das bacias hidrográficas de maior relevância dentro da RH IV é a bacia do rio Piabanha. Com área de drenagem de $2.058 \mathrm{~km}^{2}$, é uma das menores sub-bacias que drenam para o Paraíba do Sul e abrange os municípios de Areal e Teresópolis e parte dos municípios de Petrópolis, São José do Vale do Rio Preto, Paraíba do Sul, Paty do Alferes e Três Rios, onde habitam cerca de 625 mil pessoas, conforme Figura 1. (DE PAULA, 2011; COPPE, 2010). 


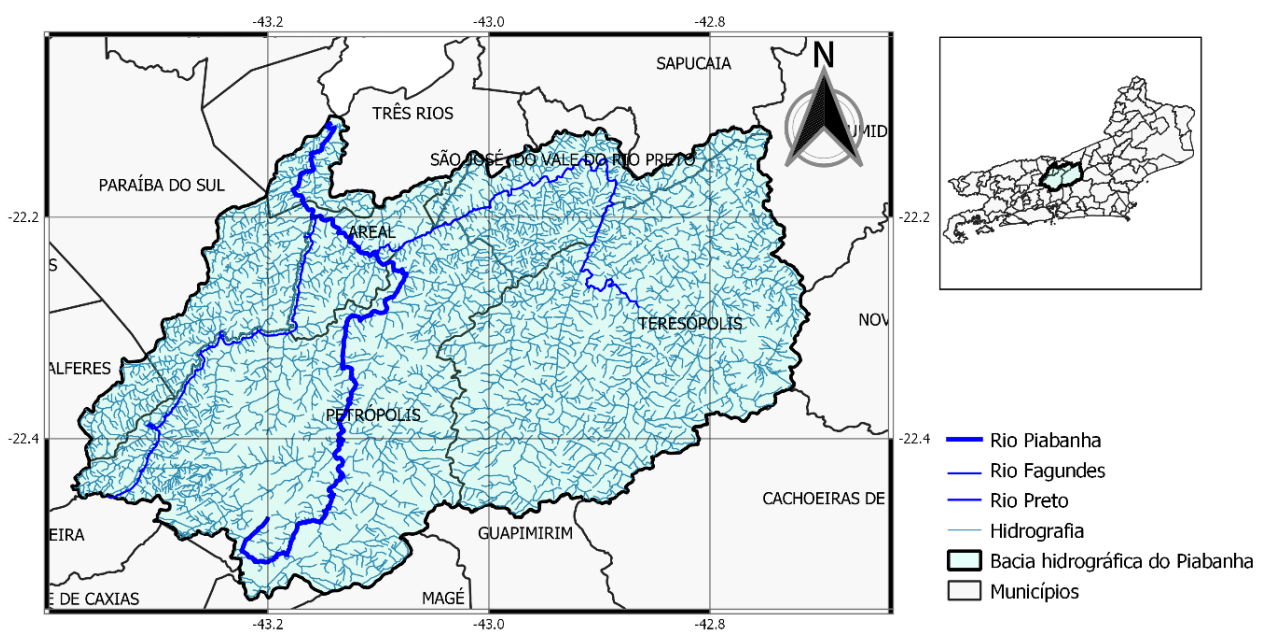

Figura 1 - Bacia Hidrográfica do Rio Piabanha, destacando municípios, população e hidrografia

Entre as sub-bacias do Paraíba do Sul, a bacia do Piabanha é a que possui maior número de indústrias, cerca de 57 industrias, que totalizam 95\% da carga de Demanda Bioquímica de Oxigênio (DBO) outorgada por ano para os rios da bacia. Segundo o Plano de Recursos Hídricos da bacia do rio Paraíba do Sul, estas indústrias são responsáveis pelo lançamento de 1,4 toneladas de DBO/dia em toda a bacia do rio Piabanha. (AGEVAP, 2006)

Os municípios de Petrópolis e Teresópolis possuem forte influência socioeconômica da Região Metropolitana do Rio de Janeiro. Ambas as cidades, bem como todas as demais áreas urbanas da bacia hidrográfica, se estabeleceram às margens dos rios da bacia e não dispõem de tratamento adequado de esgotos, o que contribui para o comprometimento da qualidade das águas dos rios da bacia. O rio Piabanha, corpo hídrico que dá nome à bacia, nasce na Serra do Mar a 1.546 metros de altitude em Petrópolis e drena para o médio vale do rio Paraíba do Sul, a 263 metros de altitude, em Três Rios. O rio possui comprimento de 80 km, percorre Petrópolis, Areal e Três Rios e tem como principais afluentes os rios Preto e Fagundes (INEA, 2014; DE PAULA, 2011).

O crescimento populacional do país, propulsor da ocupação dos vazios urbanos, não foi acompanhado da implementação da infraestrutura urbana, inclusive de saneamento, adequada para atender às necessidades de saúde da população e dos rios. Portanto, a gestão eficiente do saneamento é vital para o equilíbrio socioambiental. O déficit de oferta de serviços de saneamento está diretamente ligado ao aumento dos riscos à saúde através de doenças de veiculação hídrica e do desequilíbrio ambiental. Essa situação reflete na insalubridade de regiões que não são atendidas por serviços de saneamento básico (MARCHI, 2015; ALBUQUERQUE \& DALTRO FILHO, 2015).

O presente trabalho, que foi publicado nos anais do $30^{\circ}$ Congresso Brasileiro de 
Engenharia Sanitária e Ambiental da ABES em 2019, visa diagnosticar os serviços de esgotamento sanitário na bacia do rio Piabanha através do cruzamento de dados oficiais de saneamento com dados obtidos em campanhas de medições de qualidade da água realizadas no rio. Para tal, foram discutidas informações de serviços de esgotamento sanitário nos municípios que drenam para o rio Piabanha e seus afluentes de forma a obter um mapa de correlação entre qualidade da água monitorada nas estações e os dados de lançamento de carga orgânica provenientes de esgoto no principal rio da bacia. Essas informações servem como bases para aplicação de ferramenta de suporte à gestão.

\section{I METODOLOGIA}

A primeira etapa da metodologia busca a caracterização do atendimento e informações dos sistemas de esgotamento sanitário na bacia do rio Piabanha dos municípios drenantes para rio homônimo da bacia. Essa análise foi embasada na evolução temporal apresentada pelo Sistema Nacional de Informações sobre Saneamento (SNIS, 2019) e no Atlas de Esgotos: Despoluição das bacias hidrográficas (ANA, 2017).

Em seguida, foram analisados dados de monitoramento da qualidade da água no rio Piabanha obtidos através de monitoramentos qualiquantitativos da rede HIDROECO (2018), que deram continuidade ao monitoramento do projeto EIBEX em parceria da COPPE/UFRJ com a CPRM. Dados disponíveis forneceram o índice do Índice Fuzzy de Qualidade de Água para Ambientes Lóticos (IQA ${ }_{\mathrm{FAL}}$ ) para avaliação dos trechos monitorados pela rede.

De posse do diagnóstico dos índices de atendimento por esgotamento sanitário na bacia, bem como da carga orgânica lançada pelos municípios e a análise qualiquantitativa da água, gerou-se um mapa que correlaciona as regiões com maiores impactos na qualidade da água dos rios com as condições de esgotamento sanitário.

\section{I RESULTADOS}

Os municípios analisados foram os que são banhados pelo rio Piabanha: Petrópolis, Três Rios e Areal, cujas realidades diferem bastante uns dos outros. No entanto, foram analisadas informações de toda a bacia do rio Piabanha, devido à importância dos contribuintes rio Fagundes e Preto. Na Tabela 1 pode-se comparar os aspectos envolvidos na prestação de serviços de esgotamento sanitário, como população urbana, prestador, vazão, carga gerada, carga lançada e número de Estações de Tratamento de Esgotos (ETEs) de cada um dos municípios e o total da sub-bacia.

Através de dados disponibilizados pelo SNIS (2018), foi possível levantar dados históricos sobre o saneamento nos municípios na região de estudo. A Figura 2 ilustra a série temporal da implementação do serviço de esgotamento sanitário (índice ES001 População total atendida com esgotamento sanitário) nos municípios banhados pelo rio Piabanha. Os municípios de Areal, Paraíba do Sul, Paty dos Alferes, São José do Vale 
do Rio Preto (SJVRP) e Teresópolis não foram incluídos pois não possuem informações consistentes disponibilizadas no SNIS sobre esgotamento sanitário.

\begin{tabular}{ccccccc}
\hline Município & $\begin{array}{c}\text { População } \\
\text { Urbana }\end{array}$ & $\begin{array}{c}\text { Prestador de } \\
\text { serviços }\end{array}$ & $\begin{array}{c}\text { Vazão } \\
\text { Total }\end{array}$ & Carga Gerada & Carga Lançada & ETEs \\
\hline habitantes & & I.s $^{-1}$ & kg DBO.d $^{-1}$ & kg DBO.d $^{-1}$ & Unid. \\
\hline Areal & 10.237 & SAAE & 15,5 & 552.8 & 510,6 & 0 \\
Paraíba do Sul & 36.920 & PM & 66,8 & $1.993,7$ & $1.964,3$ & 0 \\
Paty do Alferes & 18.823 & PM & 30,0 & $1.016,4$ & 890,7 & 0 \\
Petrópolis & 283.160 & Águas do & 764,8 & $15.189,4$ & $4.952,8$ & 17 \\
SJVRP & 9.208 & PMerador & 9,9 & 497,2 & 437,9 & 0 \\
Teresópolis & 151.656 & PM & 284,7 & $7.854,2$ & $6.305,3$ & 0 \\
Três Rios & 76.418 & SAAE & 33,9 & $4.058,9$ & $3.512,2$ & 1 \\
\hline Total & $\mathbf{3 6 9 . 8 1 5}$ & - & $\mathbf{8 1 4 , 2}$ & $\mathbf{1 9 . 8 0 1 , 1}$ & $\mathbf{8 . 9 7 6 , 3}$ & $\mathbf{1 8}$ \\
\hline
\end{tabular}

Tabela 1 - Informações da prestação de serviço de esgotamento sanitário Fonte: ANA, 2017.

Observação: SAAE - Serviço Autônomo de Água e Esgoto; PM - Prefeitura Municipal
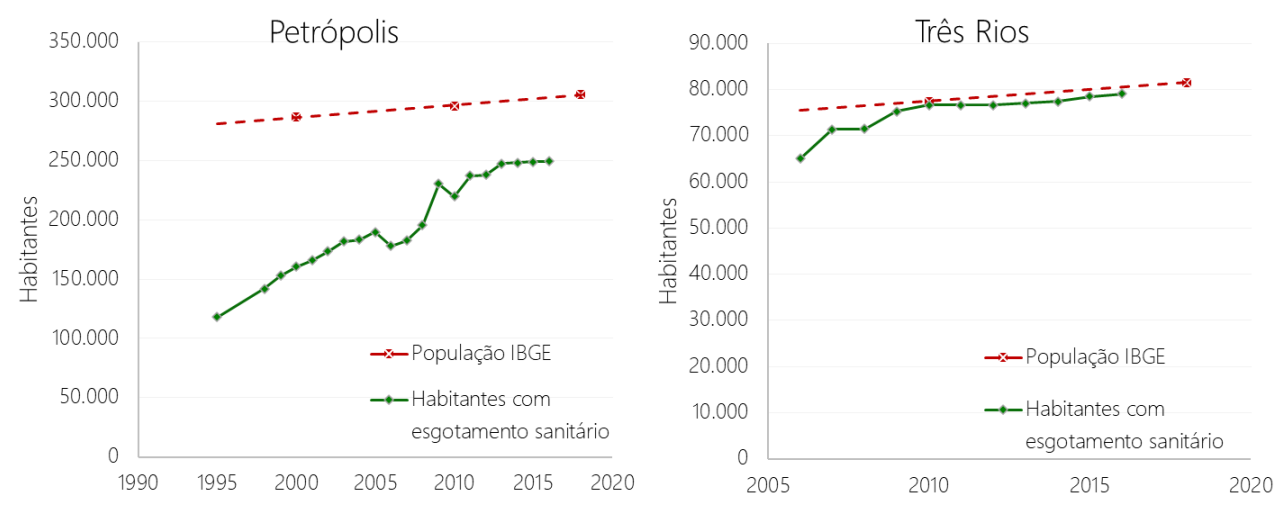

Figura 2 - Evolução histórica do saneamento nos municípios drenantes para o rio Piabanha Fontes: SNIS, 2019; IBGE, 2019.

De acordo com a classificação da ANA (2017), a distribuição da carga orgânica gerada pela população pode ser dividida em: com coleta e com tratamento, quando o efluente doméstico é encaminhado via rede coletora à uma ETE; com coleta e sem tratamento 
quando os moradores possuem cobertura de rede porém ainda não foi implementada uma ETE para o devido tratamento; sem coleta e sem tratamento, quando a população da região não tem acesso nem à rede; e por fim; a solução individual quando os cidadãos constroem seu próprio sistema de tratamento para os efluentes gerados, em geral, um sistema de fossas sépticas.

As informações de esgotamento sanitário consolidadas por município estão reunidas na Figura 3, contendo o destino do esgoto gerado em relação à população do município.

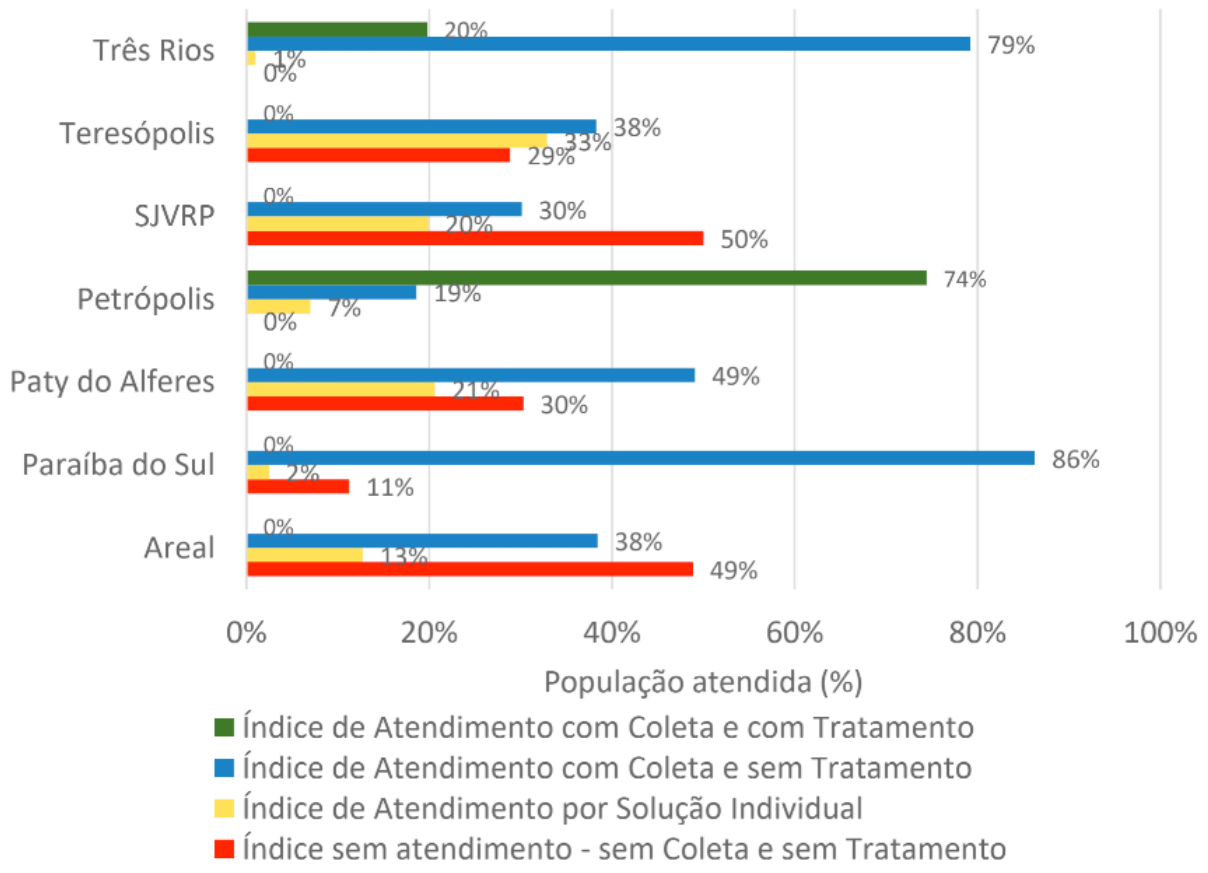

Figura 3 - Índices de atendimento considerando a distribuição de carga gerada Fonte: ANA, 2017.

Uma vez estabelecidos os índices de atendimento por cidade, obteve-se em ANA (2017) a carga orgânica lançada - COL (vazão x concentração) diariamente, expressos em kg DBO.dia-1 na Figura 4. De acordo com dados de estimativas populacionais do IBGE (2018), foi possível construir uma relação entre o número de habitantes por município e a carga orgânica lançada (Figura 5) 


\section{Carga Orgânica Lançada Total}

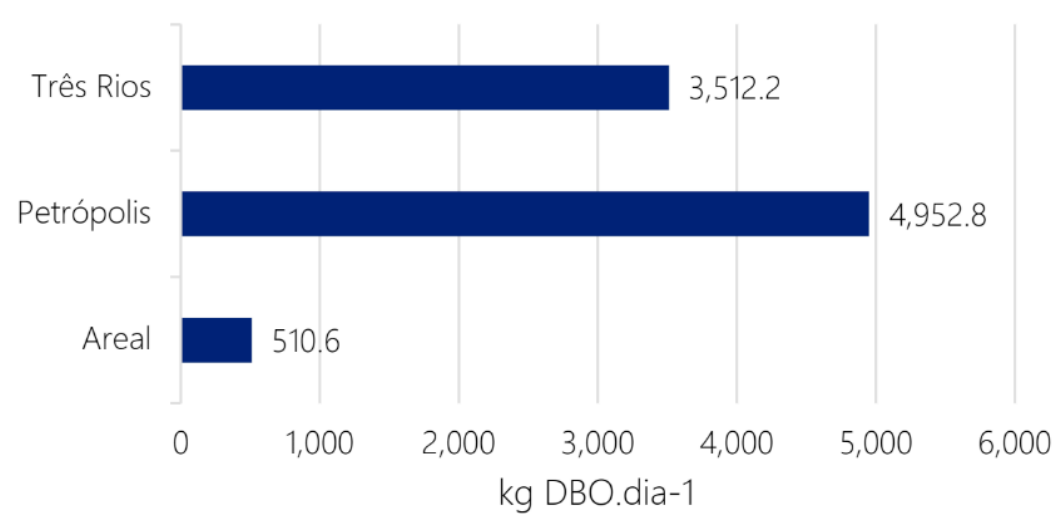

Figura 4 - Quantificação da carga orgânica lançada diariamente no ano 2013 Fonte: ANA, 2017.

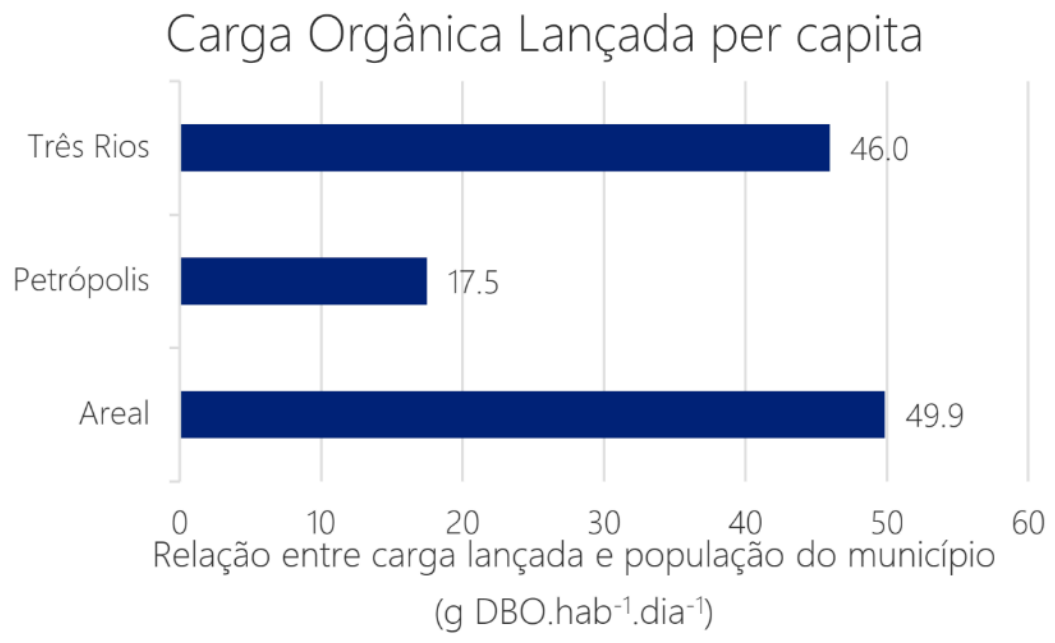

Figura 5 - Relação entre população dos municípios e lançamento de carga orgânica Fonte: ANA, 2017; IBGE, 2019.

Na Figura 5, é possível observar uma razão relativamente baixa na carga orgânica lançada per capita no município de Petrópolis, enquanto as outras cidades possuem relações mais elevadas, embora Petrópolis seja o maior responsável por lançamento de carga orgânica. Isso é explicado pelo fato de ser o município com maior cobertura de esgotamento sanitário com coleta e tratamento (74,4\%), representado na Figura 3, ou seja, a concentração de DBO dos efluentes domésticos de Petrópolis é reduzida pelas ETEs.

Considerando a carga gerada e a população dos municípios, foi possível chegar 
a uma média de carga orgânica gerada por habitante por dia de 53,6 g DBO.hab ${ }^{-1} \cdot$ dia $^{-1}$, coerente com o valor $54 \mathrm{~g} \mathrm{DBO} \cdot \mathrm{hab}^{-1}$. dia-1 sugerido por Von Sperling (2014). No entanto, quando se avalia a carga orgânica lançada per capita, o impacto dos níveis de tratamento se mostra relevante. No município de Petrópolis, a COL é de 17,5 g DBO.hab-1.dia-1; em Três Rios, 45,9 g DBO.hab-1.dia-1; e em Areal, 49,9 g DBO.hab-1.dia-1.

Na Figura 6, estão destacadas as cargas de lançamento por município, quantidade de lançamentos por munícipio, adensamento populacional e estações de monitoramento, classificadas de acordo as classes do IQA ${ }_{\mathrm{FAL}}$ provenientes das estações de monitoramento da rede HIDROECO (2018) (ano hidrológico de referência 2012/2013).

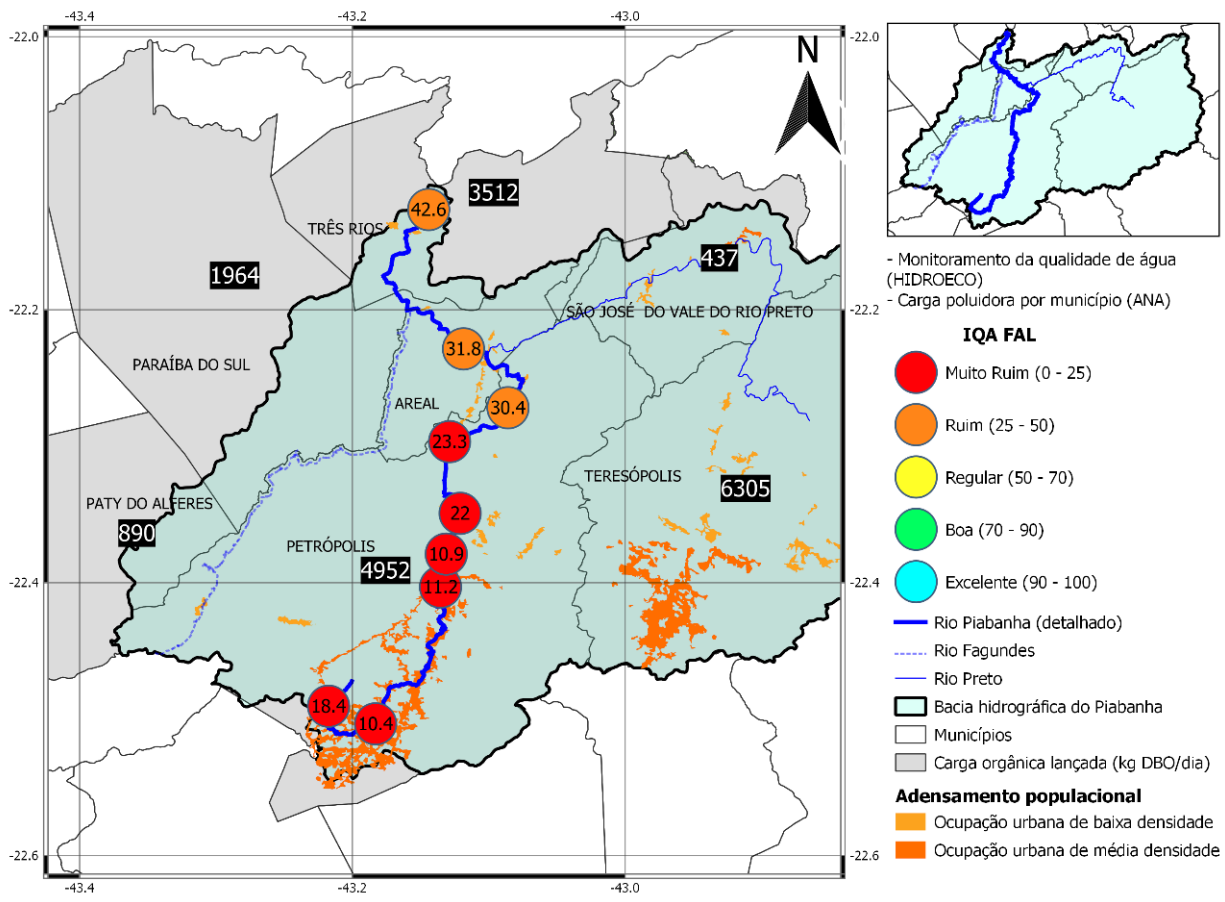

Figura 6 - Consolidação dos resultados de monitoramento da rede HIDROECO do IQAFAL médio do período entre 2012 e 2013 no Rio Piabanha

A Figura 6 permite identificar a correlação entre qualidade da água e o lançamento de carga orgânica, além de apresentar o adensamento populacional na bacia. Apesar de os trechos de montante corresponderem à região da bacia com os melhores índices de tratamento, estes possuem os piores valores de $I_{\mathrm{FAL}}$. Esse fato se explica por uma sequência de fatores, dentre eles, o nível de tratamento dos efluentes, as baixas vazões do corpo receptor e a capacidade de autodepuração do rio.

A alta densidade populacional na cabeceira do rio leva a uma maior concentração de 
DBO no esgoto a ser desaguado em um ponto de lançamento ou ainda em pontos próximos. Estes efluentes, mesmo devidamente tratados, continuam com uma carga remanescente e impactam os corpos hídricos.

Outro fator importante é a capacidade de diluição dos corpos receptores. Devido à menor área de drenagem dos trechos iniciais, suas vazões são baixas e possuem pouca capacidade de diluir os efluentes lançados, em contrapartida, trechos médios e inferiores possuem maiores áreas de contribuição, o que lhes garante maiores vazões, portanto maior capacidade de diluir efluentes.

Outro processo que contribui para o consumo de carga orgânica, outrossim da qualidade de água em rios é o mecanismo de autodepuração dos corpos d'água. Esse é um processo natural de restabelecimento do equilíbrio no corpo receptor após o lançamento de efluentes (VON SPERLING, 2014).

\section{I ANÁLISE DOS RESULTADOS}

Pelo exposto anteriormente, a divergência de dados presente nas bases de dados oficiais pode levar o usuário destas informações a conclusões equivocadas. No caso do município Três Rios, por exemplo, de acordo com o Atlas de Esgotos, apenas 20\% do esgoto é coletado com tratamento e $79 \%$ do esgoto é coletado sem tratamento. Entretanto, os dados provenientes do SNIS indicam que, em 2013 (mesmo ano de referência do Atlas Esgotos), o indicador correspodente à população total atendida com esgotamento sanitário corresponde a cerca de 95\% da população do município, indicando uma grande divergência nos dados das duas fontes oficiais utilizadas.

Essa divergência pode ser atribuida à metodologia empregada para obtenção dos dados. No SNIS, as informações são fornecidas pelos prestadores de serviços, dentre eles: companhias estaduais, empresas e autarquias municipais, empresas privadas ou, ainda, as próprias prefeituras. A metodologia adotada para definição do índice ES001 - População total atendida com esgotamento sanitário, apresentado na Figura 2 possui alta incerteza envolvida. Uma vez que este pode ser estimado a partir do número de residências ativas de esgotos com dados do IBGE e não a partir de levantamentos de campo (BRASIL, 2019).

Por outro lado, o Atlas Esgotos, elaborou um estudo que permitiu o refinamento de informações através de dados primários. Esses dados foram obtidos por meio de visitas de campo e reuniões técnicas para municípios com prestador de serviço institucionalizado e municípios sem prestador institucionalizado com população urbana acima de 50 mil habitantes, que é o caso dos municípios analisados no presente estudo. Essa metodologia garante uma visão mais realista da situação por se tratar de dados primários efetivamente quantificados pelo órgão responsável pela gestão dos recursos hídricos no Brasil (ANA, 2017).

Observou-se ainda a ausência de dados declarados de forma consistente no SNIS 
pelos prestadores de Areal, Paraíba do Sul, Paty dos Alferes, São José do Vale do Rio Preto e Teresópolis referente ao esgotamento sanitário no município. Essa falta de informação reforça a necessidade de maior transparência no exercício da atividade e desempenho do prestador de serviços de saneamento.

O mapa gerado permite observar a relação entre os indicadores de desempenho de serviços de esgotamento sanitário e alto adensamento urbano com a maior degradação da qualidade da água no corpo d’água em estudo, o Rio Piabanha.

A densa ocupação urbana no município de Petrópolis resulta na geração de elevadas vazões de esgoto. Apesar dos bons índices de coleta e tratamento (74,4\% da população), a cidade é responsável pelo despejo de, aproximadamente, 5 toneladas de DBO por dia no rio Piabanha e seus afluentes. Além de despejar alta carga orgânica, os corpos receptores dos efluentes estão localizados em trechos de cabeceira, o que implica em baixa capacidade de diluição, sendo então mais sensíveis ao lançamento de carga orgânica.

O inverso ocorre nos trechos mais a jusante, como no caso de Três Rios, mesmo possuindo baixos índices de coleta e tratamento (19,8\% da população) e lança mais de 3,5 toneladas de DBO por dia. O despejo de esgoto neste trecho não compromete tanto a qualidade de água no rio quanto em Petrópolis, pois Três Rios está situado no trecho final do rio Piabanha, que dispõe de elevada capacidade de diluição graças à vazão bem superior à da cabeceira e à autodepuração dos despejos de usuários à montante ao longo dos cerca de $80 \mathrm{~km}$ do rio e vários trechos encachoeirados.

\section{I CONCLUSÕES}

Constata-se que as divergências entres as fontes de dados sobre saneamento representam um fator preocupante, visto que se tratam de fontes oficiais e são as principais fontes de informação da população, projetistas e tomadores de decisão. É importante reavaliar as metodologias de coleta de informações das concessionárias, para evitar o repasse de dados que não representam adequadamente a realidade do saneamento de municípios.

As análises apresentadas neste trabalho, permitem concluir que a cidade de Petrópolis é a principal responsável pelo lançamento de efluentes domésticos no rio Piabanha, consequentemente pela degradação ambiental deste rio em seus trechos iniciais. Apesar dos avanços no serviço de esgotamento sanitário, ainda se encontra distante de alcançar níveis desejados de qualidade de água no corpo hídrico que dá nome à bacia.

É importante também destacar que apesar da melhor qualidade expressa no IQA FAL $_{\text {dos }}$ trechos a jusante, estes ainda são baixos na escala do índice. Assim sendo, tais municípios também merecem atenção na implementação de serviços de esgotamento sanitário com objetivo de melhoria da qualidade ambiental.

Cabe também destacar a importância da modelagem integrada das fontes pontuais, 
como indústrias, além de fontes difusas, a fim de proporcionar uma melhor representação das condições de qualidade da água ao longo do rio. A adoção de modelagem matemática permite construir cenários de implementação dos serviços de saneamento da região previstos pelos planos municipais de saneamento e pelo plano de bacia. Cabe destacar, novamente, a importância de informações consistentes sobre os serviços de esgotamento sanitário presentes nos municípios, bem como suas condições de operação e eficiência. De posse dessas informações, pode-se prever cenários mais eficientes de curto, médio e longo prazo para aumento da abrangência dos serviços levando em conta verbas disponíveis pelo munícipio.

Conclui-se que o presente trabalho se apresenta como uma importante etapa de levantamento de informações para fins de uma modelagem mais aprofundada em relação às que foram realizadas anteriormente. Dessa forma, permite-se a simulação de cenários mais próximos da realidade que auxiliam tomadores de decisão na escolha de priorização de investimentos.

\section{AGRADECIMENTOS}

O presente trabalho foi realizado com apoio da Coordenação de Aperfeiçoamento de Pessoal de Nível Superior - Brasil (CAPES) - Código de Financiamento 001 e do CNPq, Conselho Nacional de Desenvolvimento Científico e Tecnológico - Brasil.

\section{REFERÊNCIAS}

AGEVAP. Diagnóstico dos Recursos Hídricos. In: Plano de Recursos Hídricos da Bacia do Rio Paraíba do Sul. Elaboração Fundação COPPETEC e Laboratório de Hidrologia e Estudos do Meio Ambiente da COPPE/UFRJ. Rio de Janeiro, nov. 2006

ALBUQUERQUE, M. M.; DALTRO FILHO, J. Adaptação do indicador de salubridade ambiental (ISA) como ferramenta de análise da salubridade do ambiente da Comunidade Saramém-Brejo Grande/SE. Rev. Scientia Plena, Sergipe, v.11, n.11, p. 1-9, 2015.

AGÊNCIA NACIONAL DE ÁGUAS - ANA. Atlas Esgotos: Despoluição de bacias hidrográficas. Secretaria Nacional de Saneamento Ambiental. Brasília: ANA, 2017. 88 p.

BRASIL. Sistema Nacional de Informações sobre Saneamento: Diagnóstico dos serviços de água e esgotos - 2017. Brasília: SNS/MDR, 2019. 226 p.

CERHI. Resolução ${ }^{\circ} 140$ de 22 de maio de 2013. Aprova nova definição das regiões hidrográficas do Estado do Rio de Janeiro e revoga a resolução CERHI n 18 de 08 de novembro de 2006. Diário Oficial do Estado do Rio de Janeiro, Rio de Janeiro, RJ, 12 de junho de 2013.

COPPE/UFRJ, 2010, Projeto EIBEIX-I: Estudos Integrados de Bacias Experimentais -

Parametrização Hidrológica na Gestão de Recursos Hídricos das Bacias da Região Serrana do Rio de Janeiro. In: Relatório Técnico Parcial 2, Chamada Pública MCT/FINEP/CT-HIDRO - Bacias Representativas 04/2005. Elaborado conjuntamente pela fundação COPPETEC-COPPE-UFRJ com colaboração do IGEO-UFRJ-UERJCPRM-SERLA (INEA). 
HIDROECO. Relatório final do projeto HIDROECO no Rio Piabanha. Coordenação José Paulo Soares de Azevedo (COPPE/UFRJ). Contrato 01.11.0101.000 entre COPPETEC, UFRJ, UFSM, CPRM SEDE, UNESP, EESC, UFBA, CETEM, UFAL, INEA e FINEP, 2018.

IBGE - Instituto Brasileiro de Geografia e Estatística. Projeção da população do Brasil e das Unidades da Federação. Disponível em: <https://www.ibge.gov.br/apps/populacao/projecao/>. Acesso em: 25 mar. 2019.

INEA. Caracterização ambiental (R2-F). In: Elaboração do plano estadual de Recursos Hídricos do estado do Rio de Janeiro. Elaboração Fundação COPPETEC e Laboratório de Hidrologia e Estudos do Meio Ambiente da COPPE/UFRJ. Rio de Janeiro, mar. 2014.

MARCHI, C. M. D. F. Novas perspectivas na gestão do saneamento: apresentação de um modelo de destinação final de resíduos sólidos urbanos. URBE. Revista Brasileira de Gestão Urbana, v. 7, n. 1, p. 91-105, jan./abr. 2015.

SNIS - Sistema Nacional de Informações sobre Saneamento: Série Histórica. Disponível em: http://app3.cidades.gov.br/serieHistorica. Acesso em: 25 mar. 2019.

VON SPERLING, M. Introdução à qualidade das águas e ao tratamento de esgotos. 4. ed. Belo Horizonte: Editora UFMG, 2014.

WEINBERG, A. Metodologia para priorização do controle e monitoramento da qualidade das águas, como ferramenta para gestão de recursos hídricos. Rio de Janeiro: UFRJ/COPPE. Dissertação (mestrado), 2018. 


\section{PHYSICO-CHEMICAL DIAGNOSIS OF WATER QUALITY IN THE MIRASSOL STREAM, CITY OF SÃO PAULO, BRAZIL}

Data de aceite: 04/01/2021

Data de submissão: 01/12/2020

André Contri Dionizio

Municipal University of São Caetano do Sul

São Paulo/Brazil

http://lattes.cnpq.br/7354535984086636

Marta Ângela Marcondes

Municipal University of São Caetano do Sul

São Paulo/Brazil

http://lattes.cnpq.br/4139017884353855

Raul Neiva Bertulucci

Municipal University of São Caetano do Sul

São Paulo/Brazil

http://lattes.cnpq.br/8463796749575237

ABSTRACT: The Watershed of The Mirassol Stream is located in the city of São Paulo-Brazil, it suffers constant environmental degradation, due to the lack of involvement and interest from the local community and public management. The objective of this study is to provide a quality diagnosis of the stream waters. Water samples were collected in the months of August (dry season) and October (transition period) of 2018 and January (rainy season) of 2019, in three places called Points 1, 2 and 3. In order to understand the anthropic influences along the margins of the Mirassol Stream, Physicalchemical analyzes were carried out in situ and in laboratories to check the release of domestic effluents and their different concentrations in upstream and downstream areas. The results of the analyzes showed values above the parameters of domestic effluents: Total Ammonia, Total Sulphide, Total Phosphor and $\mathrm{pH}$, mainly at the downstream areas. Based on the results, it was possible to verify the high concentration of pollutants and classify Mirassol Stream as Class IV, the worst classification for freshwater rivers, according to the Brazilian National Resolution for surface water - CONAMA Nr 357/2005.

KEYWORDS: Monitoring, Water Quality, Watershed.

DIAGNÓSTICO FÍSICO-QUÍMICO DE QUALIDADE DA ÁGUA DO CÓRREGO MIRASSOL, CIDADE DE SÃO PAULO, BRASIL

RESUMO: A Microbacia do Córrego Mirassol, localizada na cidade de São Paulo- Brasil, sofre constante degradação ambiental, sendo um espaço pouco valorizado tanto pela comunidade local quanto pela gestão pública. Este estudo propôs fornecer um diagnóstico da qualidade das águas do córrego, onde foram coletadas amostras de água nos meses de agosto (período seco) e outubro (período de transição) de 2018 e janeiro (período chuvoso) de 2019, em três locais denominados de Pontos 1 a 3 , com análises físico-químicas realizadas in situ e laboratoriais para a verificação de parâmetros que demonstrassem lançamentos de efluentes domésticos e suas diferentes concentrações de montante à jusante, com o intuito de perceber as influências antrópicas ao longo das ocupações de margens do Córrego Mirassol. Os resultados das análises demonstraram valores fora dos estabelecidos para os parâmetros relacionados 
com efluentes domésticos: Amônia, Sulfetos, Fósforo e pH, sobretudo, nos pontos à jusante. Com base nos resultados, foi possível verificar a alta concentração de poluentes e enquadrar o Córrego Mirassol como Classe IV, pior classificação para os rios de água doce, de acordo com a resolução brasileira para águas superficiais - CONAMA Nr 357/2005.

PALAVRAS-CHAVE: Microbacia; Monitoramento; Qualidade da água.

\section{I INTRODUCTION}

Metropolis are specially concerned with the contamination of watercourses due to the need of providing potable water which is vital for the functioning of society. Therefore, the use of water from the countryside has been a solution, due to the poor state of urban streams, which require highly sophisticated technological equipment that increases the price of water treatment. (TUCCI, 2010)

In the field of urbanization and water resources in large cities, can be consider the following as negative aspects: floods; changes in the hydrological cycle and contamination of aquatic environments that is due to the release of domestic sewage and the lack of treatment of it. (TUCCl, 2010)

Water resource management is one of the most serious issues in the contemporary society. It is of utmost importance to know the quality of water resources and to determine the conditions of a watercourse. (MENDONÇA and LEITÃO, 2008).

The main instrument of water resource planning and management policy is the monitoring of it, since it functions as a tool for inspecting the use of water bodies. The monitoring is used in order to provide information that allows planning of environmental control, since it shows the effects on water resources and it gives a qualitative characteristic of the water. (GUEDES et al, 2012)

To set environmental sanitation goals it is necessary to carry out the evaluation and monitoring of the physiochemical characteristics and behavior during different climatic conditions. (BRAGA et al, 2006)

Due to these reasons, the objective of this research was to carry out an evaluation of the parameters of water quality in the Mirassol Stream, based on the physical-chemical assessment of its waters and on the established limits of the Brazilian legislation. (CONAMA, 2005)

To achieve this objective, were chosen three collection locations from the upstream and downstream areas, under different aspects, seasons and shore occupation with the objective of verifying the hypothesis of variation and the maintenance of the results under different circumstances. 


\section{I MATERIAL AND METHODS}

\subsection{Characteristics of the studied area}

São Paulo is the capital of the state of São Paulo, the most populous city in Brazil. Located at latitude $23^{\circ} 33^{\prime} 01^{\prime \prime} S$ and longitude $46^{\circ} 38^{\prime} 02^{\prime \prime} \mathrm{W}$. The total area of the city is 1.521 $\mathrm{km}^{2}$. (IBGE, 2010)

Mirassol Stream is a small urban watercourse that during the urbanization of the city of São Paulo underwent different transformation processes. It has an approximate length of 1932 meters and it is located at coordinates Latitude $23^{\circ} 38^{\prime} 09.5^{\prime \prime S}$ / Longitude 46³6'38.1"W. (SIURB, 2011)

It has a variable altimetry of 820 meters upstream and 740 meters downstream, its physical characteristics vary between underground galleries. rectangular open channels and a concrete streambed. It divides the western district of Cursino with the eastern district of Sacomã. In conjunction with the district of Ipiranga they are inserted in the borough of Ipiranga, which is responsible for public management of these three districts. (SIURB, 2011)

On August 30, 2018, there were 14,315 residences in the area of the study, of which 13,173 had sewage collection, totaling $92 \%$ of the residencies. However, there was no treatment to the generated sewage, which was being released into the Mirassol Stream. The entire watershed area is administrated by SABESP (a public company responsible for basic sanitation). (SABESP, 2018).

\subsection{Collection Points}

To analyze the waters of Mirassol Stream, samples were collected at three points, named Point 1, 2 and 3. It is observed that Point 1 (upstream) is in the transition between underground channelling and open channel flow, whose main objectives of analysis were: to compare the results with the samples from Points 2 and 3 (downstream); and to compare whether the population density in the margins can be an influencing factor in the results. The Figure 1 shows the Mirassol Stream watershed map and the location of the collection points. 


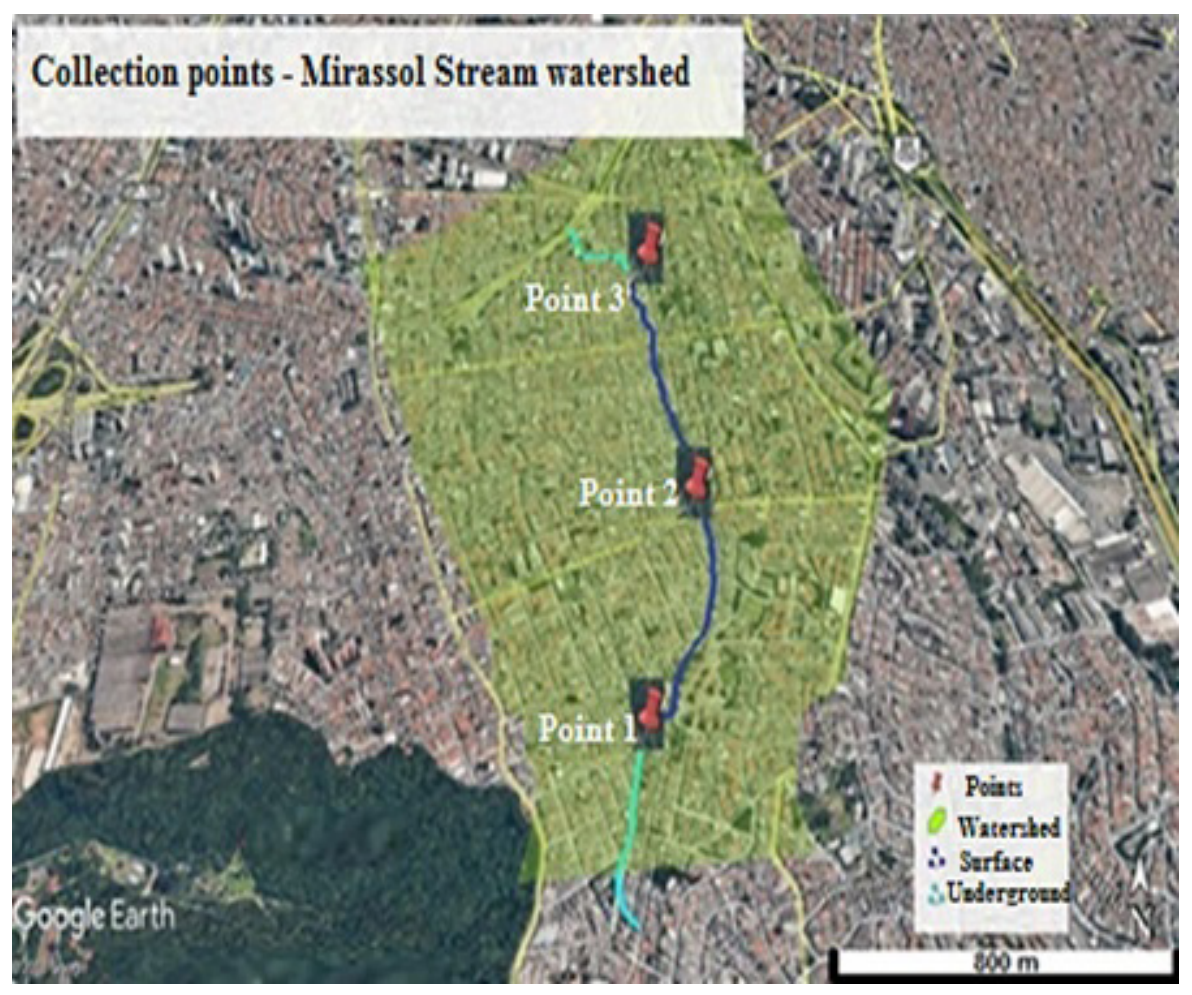

Figure 1 - Map of the sampling points of the Mirassol Stream watershed.

To locate the geographic coordinates of the analyzed points was used the Datum WGS 84, from Google Earth, being available according to Table 1.

\begin{tabular}{|c|c|c|}
\hline Samples & Latitude (South) & Longitude (West) \\
\hline Point 1 & $23^{\circ} 38^{\prime} 09.5^{\prime \prime}$ & $46^{\circ} 36^{\prime} 38.1^{\prime \prime}$ \\
\hline Point 2 & $23^{\circ} 37^{\prime} 54.1^{\prime \prime}$ & $46^{\circ} 36^{\prime} 33^{\prime \prime}$ \\
\hline Point 3 & $23^{\circ} 37^{\prime} 30.9^{\prime \prime}$ & $46^{\circ} 36^{\prime} 40.2^{\prime \prime}$ \\
\hline
\end{tabular}

Table 1: Geographic Coordinates of the Collection Points.

\subsection{Water collection and analysis}

For limnological analysis, it is important to check the rainfall and flow rates of the three analyzed points, as the concentration of pollution may vary according to the rainfall rate. The dilution of contaminants can occur in places with frequent rain. (BELLUTA et.al, 2011) 
To analyze the waters of the Mirassol Stream, samples were collected on three dates; corresponding to the driest month (31 Aug 2018), transition month (31 Oct 2018) and the wettest month (30 Jan 2019). (IAG-USP/2017)

The modus operandi used for collections, transport and analysis followed the determined procedures of fresh waters sampling. (APHA, 2005)

\subsection{Analytical Tools}

In the analysis, were used the equipment, references and parameters described in Table 2.

\begin{tabular}{|c|c|c|c|c|c|}
\hline Parameter & $\begin{array}{l}\text { Instruments Brand: } \\
\text { Lovibond }\end{array}$ & $\begin{array}{c}\text { Reagents } \\
\text { Brand: Vario }\end{array}$ & Analysis Location & $\begin{array}{l}\text { Standard Limit } \\
\text { (Class III) }\end{array}$ & Unit \\
\hline Turbidity & \multirow{4}{*}{$\begin{array}{l}\text { Multiparameter } \\
\text { Colorimeter } \\
\text { MD } 600\end{array}$} & $-x-$ & \multirow{4}{*}{$\begin{array}{c}\text { Municipal } \\
\text { University of São } \\
\text { Caetano do Sul }\end{array}$} & 100 & NTU \\
\hline Total Ammonia & & Limit 50 mg & & 13,3 & \multirow{4}{*}{$\mathrm{mg} / \mathrm{L}$} \\
\hline Total Sulphide & & Limit 3,5 mg & & 0,3 & \\
\hline Total Phosphor & & Limit 70 mg & & 0,075 & \\
\hline $\begin{array}{l}\text { Dissolved } \\
\text { Oxygen }\end{array}$ & \multirow{3}{*}{$\begin{array}{l}\text { Multiparameter Meter } \\
\text { SensoDirect } 150\end{array}$} & $-x-$ & \multirow{3}{*}{ In Situ } & $>4$ & \\
\hline $\mathrm{pH}$ & & $-x-$ & & 6 a 9 & $-x-$ \\
\hline Water/Air Temp. & & $-x-$ & & $-x-$ & ${ }^{\circ} \mathrm{C}$ \\
\hline
\end{tabular}

Table 2: Equipment, parameters and references for analysis.

\subsubsection{Flow Measurement}

To measure the flow, a plastic bottle (PET bottle filled with $3 / 4$ of water) was used, it was launched in the center of the stream, and its travelling time was measured. The test was performed three times to obtain the average time in each point. The size of the stream and the water depth were considered. (PALHARES et.al, 2007)

\section{I RESULTS AND DISCUSSION}

\subsection{Climate conditions}

As shown in Table 3, it is observed that the climatic conditions were different in each test. In addition, until three days after the tests, there was no rain. 


\begin{tabular}{|c|c|c|c|}
\hline Date & $\begin{array}{c}\text { Flow } \\
\left(\mathbf{m}^{3} / \mathbf{s}\right)\end{array}$ & $\begin{array}{c}\text { Accumulated } \\
\text { monthly } \\
\text { rainfall }(\mathbf{m m})\end{array}$ & $\begin{array}{c}\text { Air } \\
\text { Temp. } \\
\mathbf{(} \mathbf{~} \mathbf{~})\end{array}$ \\
\hline $8 / 31 / / 2018$ & 0,08 & 43,6 & 24,4 \\
\hline $10 / 31 / 2018$ & 0,12 & 152,2 & 26,4 \\
\hline $1 / 30 / 2019$ & 0,14 & 268,0 & 33,5 \\
\hline
\end{tabular}

Table 3: Climatic Conditions of Collections.

\subsection{Analysis of data collection}

\subsubsection{Flow}

Only the flow analysis of Total Sulphide, Total Phosphor, and Total Ammonia was not enough to explain the influence on the results; however, it is noticed that the results are better with lower flow and the points upstream, in comparison to those of downstream.

\subsubsection{Turbidity}

It can be noticed that, according to Graph 1, the highest turbidity values were registered in the downstream point in comparison with the upstream points, these values were also registered during the high flow period, which can result in a dilution of pollutants. This possibility has great influence in the sediments that are upturned and which, theoretically, would remain suspended in the water. However, this is not the case for the Mirassol Stream, since at the time the bottom of it was modified to the rectangular concrete galleries style, showing that the higher turbidity values can be explained, possibly, by an increase in the discharge of domestic effluents. (ANA, 2011).

\section{TURBIDITY ( NTU)}

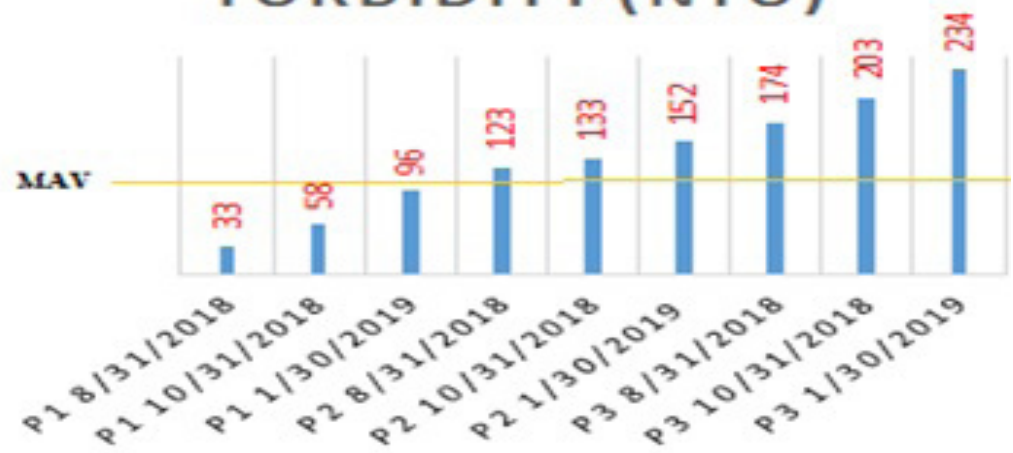

Graph 1: Turbidity Values. MAV (Max Allowable Value). 


\subsubsection{Total Sulphide}

In the case of Sulphide, it is common to find the presence of industrial and domestic effluents, originated from the anaerobic decomposition of organic matter, mostly in environments with low values of Dissolved Oxygen, like the sewers. The presence of Sulphide (H2S) is normally characterized by the detection of bad smell. It is an extremely toxic gas, which irritates the skin, eyes and mucosa. (ALABURDA, 1998).

As shown in Graph 2, the highest values for Total Sulphide were recorded in the periods of greater precipitation, flow and in the downstream points in comparison to the upstream points.

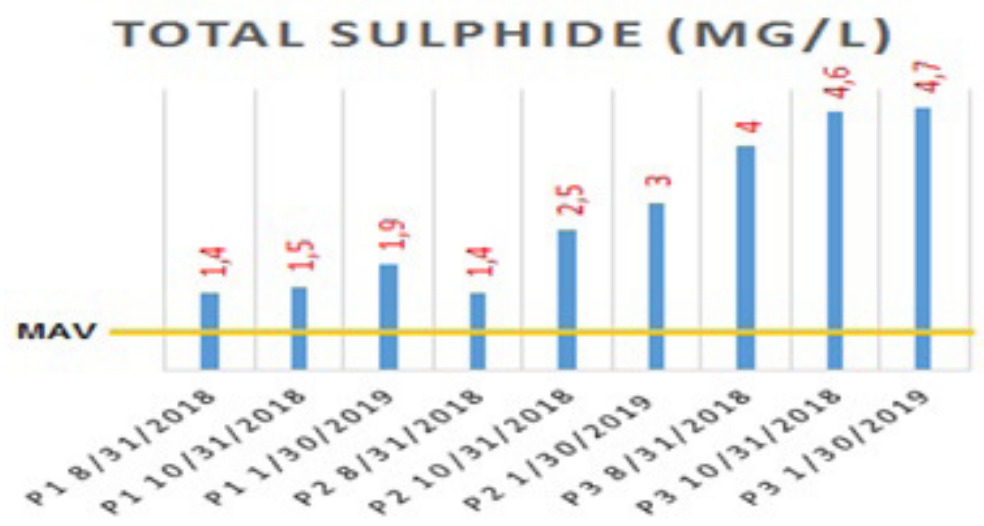

Graph 2: Total Sulphide Values. MAV (Max Allowable Value).

\subsubsection{Total Ammonia}

Ammonium in high concentrations may be the result of nearby sources of contamination, such as urine found in domestic effluents. (ALABURDA, 1998).

As shown in Graph 3, the highest values of Total Ammonia were recorded in the periods of greater precipitation, flow and in the downstream points in comparison to the upstream points. 


\section{TOTAL AMMONIA (MG/L)}

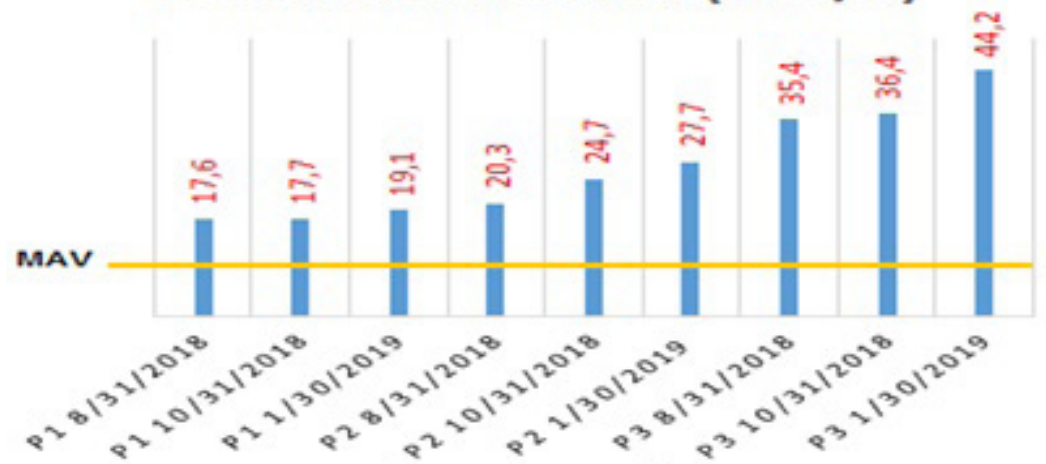

Graph 3: Total Ammonia Values. MAV (Max Allowable Value).

\subsubsection{Total Phosphor}

Among the phosphorus sources, domestic sewers stand out, due to the presence of phosphorous detergents and the fecal matter itself. Storm drainage from urban areas is also a significant source of phosphorus for water bodies (diffuse pollution). (ANA, 2011).

As shown in Graph 4, the highest values of Total Phosphorus were recorded in the periods of greater precipitation, flow and in the downstream points in comparison to the upstream points.

\section{TOTAL PHOSPHOR (MG/L)}

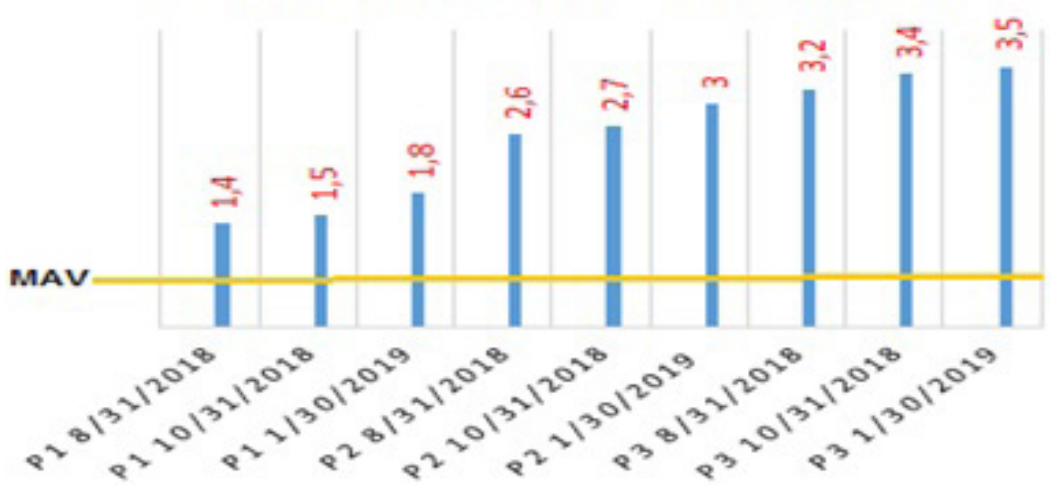

Graph 4: Total Phosphor Values. MAV (Max Allowable Value).

\subsubsection{Dissolved Oxygen}

Dissolved Oxygen is one of the main indicators of life possibility in streams; it influences several other indicators of water quality and temperature, which are essential 
factors for the comparison of the indicators and measurement of the parameters. This is due to the solubility of the gases and the oxygen, which decrease while water temperature rises, therefore, for the same water mass the concentration of dissolved oxygen will be lower than the temperature. (ANA, 2011).

As shown in Graph 5, the highest values of Dissolved Oxygen were recorded in the downstream points in comparison to the upstream points. These are factors that may have influenced the results: periods of greater precipitation and flow, as well as the aeration caused by the speed of the water, also generated by altitude difference. (ANA, 2011).

\section{DISSOLVED OXYGEN \\ ( MG/L)}

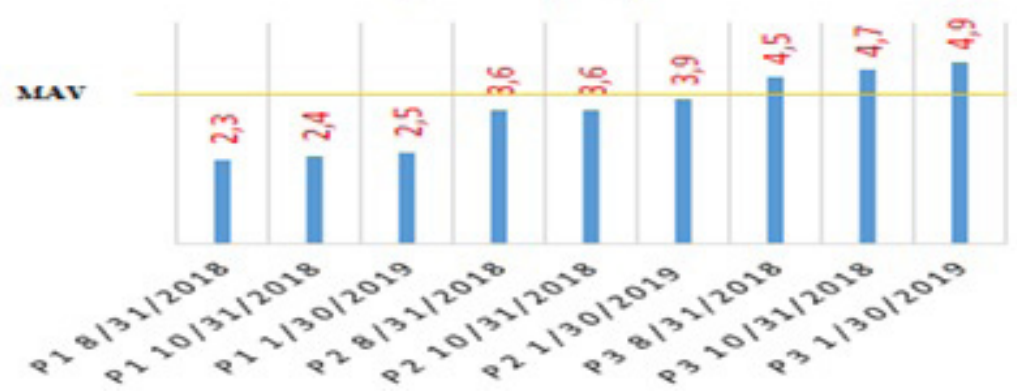

Graph 5: Dissolved Oxygen Values. MAV (Minimum Allowable Value).

\subsubsection{Water Temperature}

The importance of studying this parameter lies in the fact that temperature is a determinant of the availability of Dissolved Oxygen, but also that it interferes with the increase or decrease in metabolic activity of bacteria and other microorganisms. (VON SPERLING, 2011).

As shown in Graph 7, the highest values of Water Temperature were registered in the downstream points in relation to the upstream points, this is also due to different atmospheric conditions, as well as, the incidence of shadow in the collection points. It is noteworthy that there is no vegetation cover on the margins at any point. 


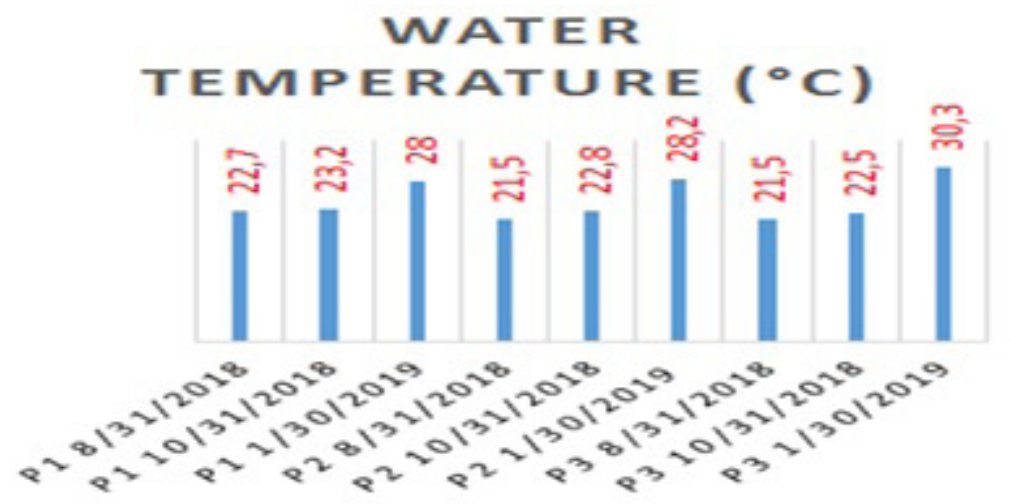

Graph 7: Water Temperature Values. MAV (Max Allowable Value).

\subsection{8 $\mathrm{pH}$}

The $\mathrm{pH}$ is highly influenced by the amount of organic matter that decomposes. The greater the amount of available matter, the lower the $\mathrm{pH}$, since the decomposition of this material produces acids. (ESTEVES, 1998).

In the samples, the $\mathrm{pH}$ was more acidic at lower flows and at the downstream points in comparison to the upstream points, as shown in Graph 8.

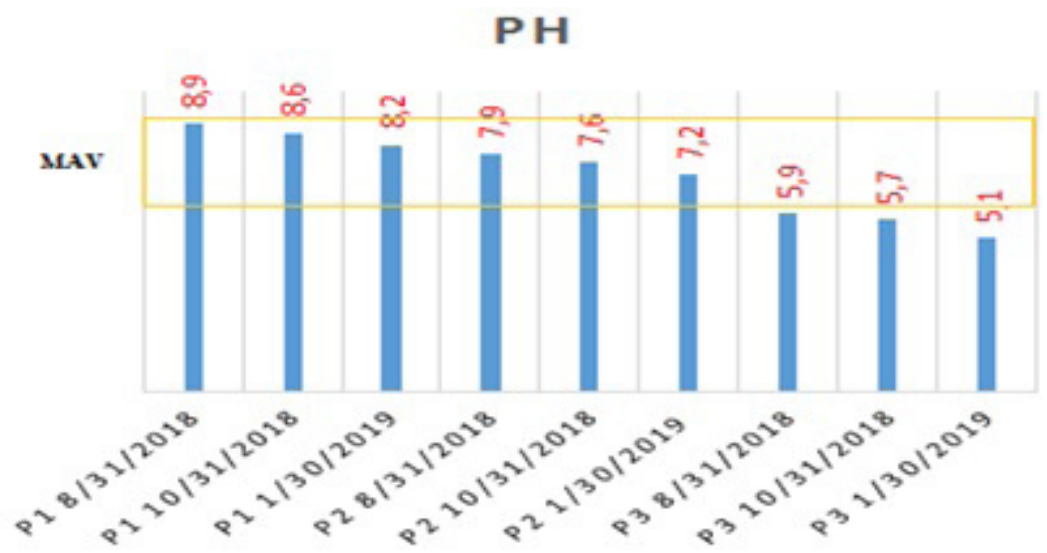

Graph 8: pH Values. MAV (Max Allowable Value).

\section{I CONCLUSION}

Based on the results, it is suggested to deepen the studies with a greater number of parameters and analyzes of different spectra. It is also suggested to initiate a historical series based initially on the results of this study with the objective of comparing and monitoring, since the competent institution did not do it until the conclusion of this study. 
It is important to highlight that, even though the physical chemical analyzes are fundamental for the measurement of the water quality, it was not possible to evaluate the contamination effects in the watershed ecosystem, since it requires specific studies on this field. In addition, the studies were carried out in a punctual way and measured instantly at the collection point, therefore, it is needed a greater number of metering to achieve more precise results.

It was noticed that the results obtained in different seasons had changed and might have influenced the final results. Also, the downstream points presented, in general, worse values than the upstream points, needing deeper studies on the hypotheses raised by this study.

Due to the diagnosis it was possible to verify that the Mirassol stream suffers environmental degradation daily, it is caused by the lack of collection and treatment of sewage, another factor that contributes to this is the discharge of domestic sewage. All these factors are drastically affecting the quality of the water in comparison to the established parameters.

In conclusion, to this study, it appears that the obtained results are not consistent with the Maximum Allowable Values for Class III Rivers, as recommended by Brazilian legislation - Resolution 357/2005 - CONAMA. Therefore, The Mirassol Stream water is not favorable for use other than those established by the Class IV.

\section{REFERENCES}

ALABURDA, J. NISHIHARA, L (1998). Presence of nitrogen compounds in well water. Rev. Saúde Pública [online]. n.2, vol.32, pp.160-165.

ANA (2011) National guide for the collection and preservation of samples: water, sediment, aquatic communities and liquid effluents. National Agency of Water [ANA]. $326 \mathrm{p}$ Brasilia-Brazil AMERICAN PUBLIC HEALTH ASSOCIATION [APHA], (2005) Standard Methods the Examination of Water and Wastewater. 21st ed. Parte 9000

BELLUTA, I .; NEVES, R. DE C. F .; ZAMPIERI, F.E. OF S .; SILVA, R.F.B. GIVES; SARTORI, A.A. OF C .; ZIMBACK, C.R.L. (2011). Application of geoprocessing technique in degraded areas of riparian forest and its correlation with water quality in a hydrographic sub-basin. Irrigates, Botucatu, v. 16, n. 2, p. 177-198.

BRAGA, B; PORTO, M and TUCCI, C. E. M (2006). Monitoring of water quantity and quality. [Monitoring of water quality and singing] In: Rebouças, A. C .; Braga, B .; Tundisi, J. G. (org.). Freshwater in Brazil: Ecological capital, use and conservation. 3a.ed., São Paulo: Editorial Scriptures. ch.5, p.145-160.

BRAZIL. National Environment Council [CONAMA] (2005) Resolution no. 357, of March 17, 2005. Provides for the classification of bodies of water and environmental guidelines for their classification, as well as establishing the conditions and standards for effluent discharge, and other measures. DOU Publication $n^{\circ} .053$ 03/18/2005 p. 56-68. Available at: <http://www.mma.gov.br/port/conama/legiabre. cfm?codlegi $=43$. $>$ 
Brazilian Institute of Geography and Statistics [IBGE] (2010). Demographic census - Brazil (2010) Available at: https://ww2.ibge.gov.br/home/ estatistica / populacao / censo 2000.

ESTEVES, F. A. (1998) Fundamentals of limnology. Interience: FINEP. Rio de Janeiro. 602p

GUEDES, S. A. H .; SILVA, D. D. da., ELESBON, A. A. A.; Ribeiro, C. B. M .; MATOS, A. T. de .; JOSÉ $\mathrm{H}$ and P. SOARES, J. H. P. (2012). Application of multivariate statistical analysis in the study of water quality in Rio Pomba, MG. Brazilian Journal of Agricultural and Environmental Engineering, 16 (5), p.558-563.

Institute of Astronomy and Geophysics of the University of São Paulo [IAG / USP] (2017) - Annual Climatological Bulletin of the Meteorological Station of IAG / USP. [IAG Meteorological Station Annual Climatological Report] Technical Section of Meteorological Services - Institute of Astronomy, Geophysics and Atmospheric Sciences, University of São Paulo, 20, São Paulo.

MENDONÇA, F. A. and LEITÃO, S. A. M. (2008). Urban socio-environmental risks and vulnerability: a perspective based on water resources. GeoTexts, 4 (1 and 2), pp. 145-163.

Municipal Secretariat of Urban Infrastructure and Works of São Paulo [SIURB] (2011) Executive Project of Mirassol Stream - Compec Galasso - Superintendence of Road Projects - PROJ 4. São Paulo.

PALHARES, J. C. P.; RAMOS, C.; KLEIN, J. B.; LIMA, J. C. M. M. DE; MULLER, S. (2007). Technical Communication 455. Flow measurement in rivers by the float method - [Electronic Version], Brazilian Agricultural Research Corporation [Embrapa] Concórdia, Santa Catarina. Available at: https://www. embrapa.br/busca-de-publicacoes/-/publicacao/443939/medicao-da-vazao-em-rios-pelo-metodo-doflutuador.

SABESP - Basic Sanitation Company of São Paulo - Map of Mirassol Stream - Sewerage Networks August / 2018. Obtained through consultation on Aug 302018 by the Access to Information Law.

TUCCI, C. E. M (2010) Urbanization and water resources. In: Bicudo, C. E. de M .; Tundisi, J. G .; Scheuenstuhl, M. C. B. Águas do Brasil: strategic analyzes. São Paulo: Institute of Botany.

VON SPERLING, Marcos. (2011) Introduction to water quality and sewage treatment, UFMG, Vol 1, $452 p$ 


\section{CAPÍTULO 15}

\section{ACTIVIDADES ANTRÓPICAS Y CONTAMINANTES EMERGENTES, PROPIEDADES FISICOQUIMMICAS Y MICROBIOLÓGICAS DEL RIO CHUMBAO, PERÚ}

Data de aceite: 04/01/2021

Data de submissão: 04/11/2020

\section{Carlos Alberto Ligarda Samanez}

Universidad Nacional José María Arguedas

Andahuaylas-Perú

\section{David Choque Quispe}

Universidad Nacional José María Arguedas

Andahuaylas-Perú

https://orcid.org/0000-0003-4002-7526

\section{Betsy Suri Ramos Pacheco}

Universidad Nacional José María Arguedas

Andahuaylas-Perú

https://orcid.org/0000-0002-0286-0632 https://orcid.org/0000-0001-7519-8355

actividades agropecuarias estudiadas, no se han detectado valores significativos de concentración de pesticidas. Algunas de las propiedades fisicoquímicas y microbiológicas están por encima de los estándares de calidad ambiental según la normativa actual, los cuales se incrementan en los puntos donde existe descarga de aguas residuales. Se determinó un deterioro progresivo de la calidad del agua del río Chumbao, lo cual es originado por las actividades antrópicas que se realizan en la cuenca; es posible que ésta sea la causa de la prevalencia de enfermedades infecciosas y parasitarias en la población del área de estudio.

PALABRAS CLAVE: Medio ambiente, salud pública, contaminación del agua.

\section{ANTHROPIC ACTIVITIES AND EMERGING POLLUTANTS, PHYSICOCHEMICAL AND MICROBIOLOGICAL PROPERTIES IN THE CHUMBAO RIVER, PERU}

\section{ubica en la Región Peruana de Apurímac, el} conglomerado urbano más importante está conformado por los distritos de San Jerónimo, Andahuaylas y Talavera, éste área poblada y el río Chumbao comparten el mismo espacio en la cuenca. El objetivo fue determinar la influencia de las actividades antrópicas sobre la concentración de pesticidas, características fisicoquímicas y microbiológicas del rio Chumbao, en la provincia de Andahuaylas, Perú. Se estudiaron las actividades antrópicas, 19 pesticidas organoclorados, 25 pesticidas organofosforados, 18 propiedades fisicoquímicas y 2 microbiológicas, en siete puntos de muestreo del rio Chumbao durante las épocas de lluvia y estiaje. Se identificó el uso de varios productos veterinarios y agrícolas en las
ABSTRACT: The province of Andahuaylas is located in Apurímac which is a Peruvian region in the Andes. Andahuaylas has three important districts: San Jerónimo, Andahuaylas and Talavera. These areas are very populated and their buildings are near the Chumbao river. The study aimed to determine the influence of anthropic activities in the concentration of pesticides, physicochemical and microbiological characteristics in the Chumbao river. The Anthropic activities studied were 19 organochlorine pesticides and 25 organophosphate pesticides. Also, it was studied 18 physicochemical and 2 microbiological properties at seven sampling 
points along the Chumbao river during the rainy and dry season. Veterinary and agricultural products were identified in the agricultural activities. However, it has not found significant values of pesticide concentration. About the physicochemical and microbiological properties some of them are above the environmental quality standards according to current regulations, which are increased at points where there is wastewater discharge. There is a progressive deterioration of the water quality in the Chumbao river, which is caused by the anthropic activities that are carried out in the basin. It is possible that this is the cause of infectious and parasitic diseases in the population.

KEYWORDS: Environment, Public Health, Water Contamination.

\section{I INTRODUCCIÓN}

Según la Universidad de Yale, Perú ocupó el puesto 64 en desempeño ambiental en 2019. Los municipios no realizan tratamiento de aguas residuales que provienen de actividades agrícolas, domésticas e industriales. El país tiene un índice de desempeño ambiental bajo de 61.92 en conservación de recursos hídricos y saneamiento básico (Yale University, 2019).

La provincia de Andahuaylas está ubicada en Apurímac, que es una región peruana. Su población ronda los 142,477 habitantes y el núcleo urbano más importante está conformado por tres distritos: Andahuaylas, San Jerónimo y Talavera. Estos tienen una población de 68,840 habitantes lo que corresponde al $48 \%$ de la población provincial que tiene una tasa de crecimiento anual del 1,94\%. Esta zona poblada y el río Chumbao comparten el mismo espacio en la cuenca. Sin embargo, la ciudad no ha podido establecer una dinámica positiva de convivencia con el río porque ha cortado sus fluidos naturales, está sellando sus afloramientos y talando sus bosques. La ciudad trata el río como un vertedero y lo está convirtiendo en un depósito de diversos desechos y residuos (INEI, 2020). La contaminación química provocada por acciones antrópicas genera efectos nocivos para la salud. Algunos plaguicidas como carbamatos, organoclorados y organofosforados, además de trazas de metales pesados e hidrocarburos, se han encontrado en cuerpos de agua para abastecimiento de redes de agua potable. Este problema ha tenido un impacto en los asentamientos humanos, actividades agrícolas y turísticas que utilizan las fuentes de agua. Estos componentes se encontraron en concentraciones superiores a las permitidas por la normativa vigente. La existencia de productos químicos se da principalmente en poblaciones con sistemas de abastecimiento de agua compleja, altamente influenciados por las actividades humanas que realizan. El análisis de peligros y riesgos es fundamental, controlando la salud de estas poblaciones (Barragán, Rivillas, Villegas y Medina, 2020). Los ríos están bastante contaminados por la evacuación directa de aguas residuales domésticas e industriales, que no son tratadas. Las actividades antrópicas influyen en las características fisicoquímicas y microbiológicas que están provocando un efecto adverso sobre la salud humana. Esto se observa en niños $>5$ años que padecen enfermedades 
infecciosas y parasitarias en su sistema digestivo (Díaz y Granada, 2018). Debido a los problemas ambientales que enfrenta el río, la ciudad debe priorizar proyectos de salud pública, lo que necesita del útil instrumento de diagnóstico que este estudio realizó y cuyo objetivo fue determinar la influencia de las actividades antrópicas en la concentración de contaminantes emergentes, características fisicoquímicas y microbiológicas en el río Chumbao, en la provincia de Andahuaylas, Perú.

\section{I MATERIALES Y MÉTODOS}

\subsection{Diseño de muestreo}

Se seleccionaron siete puntos de muestreo tanto para la época de lluvia (abril del 2019) y estiaje (octubre del 2019), el punto 1 (P1) se situó a 400 m arriba de la hidroeléctrica del Chumbao, donde no existen muchas actividades antrópicas, el punto 2 (P2) ubicado a $100 \mathrm{~m}$ debajo del puente del Colegio Solaris a $5.76 \mathrm{~km}$ del punto anterior, el punto 3 (P3) a la altura del Coliseo Cerrado de Andahuaylas a $3.03 \mathrm{~km}$ del P3, el punto 4 (P4) a la altura del Cuartel de Ingeniería del Ejército del Perú en el Barrio de Curibamba a 2.77 km del punto anterior, el punto 5 (P5) a $300 \mathrm{~m}$ abajo del puente de Talavera a la altura del colegio Gregorio Martinelly a $5.58 \mathrm{~km}$ del punto anterior, el punto 6 (P6) a $200 \mathrm{~m}$ arriba del puente Orcconmayo a $4.06 \mathrm{~km}$ del P5 y finalmente el punto 7 (P7) en Posoccoy a $6.51 \mathrm{~km}$ del penúltimo punto.

Para la elección de las estaciones de muestreo se observó que las actividades agropecuarias, comerciales, domesticas e industriales se incrementaban conforme se descendía por la cuenca del rio Chumbao, en un tramo de 27.70 km (Figura 1 y Tabla 1).

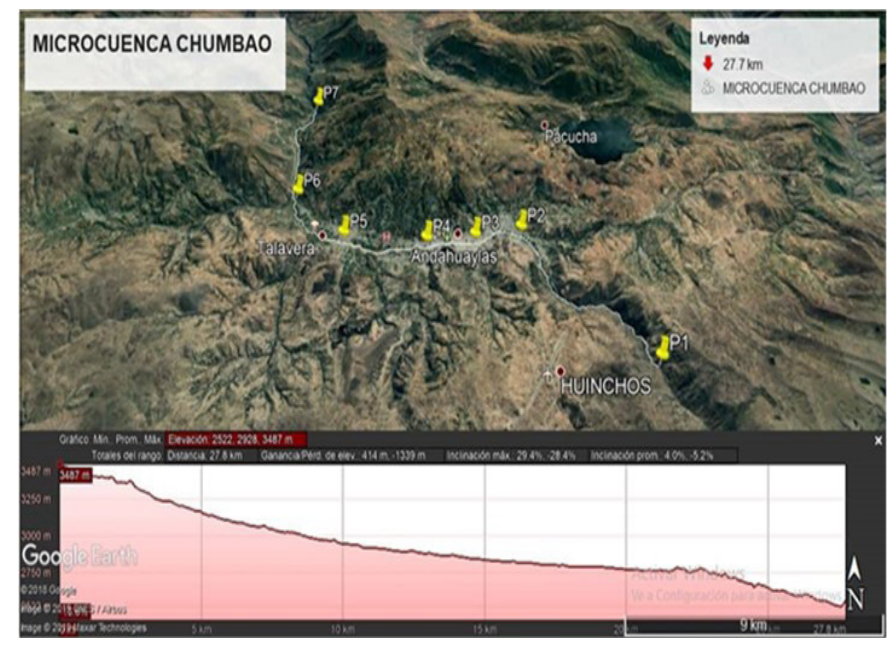

Figure 1: Sampling points in the Chumbao river basin.

Source: Document obtained during the study. 


\begin{tabular}{|c|c|c|c|c|}
\hline Code & Name & Altitude & Latitude & Longitude \\
\hline P1 & Above the hydroelectric plant of the Chumbao river & 3198 & $13^{\circ} 42^{\prime} 33.5^{\prime \prime}$ & $73^{\circ} 18^{\prime} 46.1^{\prime \prime}$ \\
\hline P2 & In front of the Solaris College & 2992 & $13^{\circ} 39^{\prime} 23.5^{\prime \prime}$ & $73^{\circ} 21^{\prime} 31.0^{\prime \prime}$ \\
\hline P3 & In front of the Chanka Nation Coliseum & 2922 & $13^{\circ} 39^{\prime} 33.1^{\prime \prime}$ & $73^{\circ} 22^{\prime} 38.4^{\prime \prime}$ \\
\hline P4 & In front of the Army Engineering Barracks & 2875 & $13^{\circ} 39^{\prime} 37.0^{\prime \prime}$ & $7^{\circ} 23^{\prime} 49.4^{\prime \prime}$ \\
\hline P5 & In front of the Gregorio Martinelly School & 2817 & $13^{\circ} 39^{\prime} 27.0^{\prime \prime}$ & $7^{\circ} 25^{\prime} 51.6^{\prime \prime}$ \\
\hline P6 & Above the Orcconmayo bridge & 2767 & $13^{\circ} 38^{\prime} 18.9^{\prime \prime}$ & $73^{\circ} 27^{\prime} 09.3^{\prime \prime}$ \\
\hline P7 & Km 6.51 on the way to Posoccoy & 2529 & $13^{\circ} 35^{\prime} 26.2^{\prime \prime}$ & $73^{\circ} 27^{\prime} 01.1^{\prime \prime}$ \\
\hline
\end{tabular}

Table 1: Geographical location of the sampling points in the Chumbao river. Andahuaylas, Peru

\subsection{Análisis de actividades antrópicas}

Mediante recorridos de campo y protocolos de observación, se identificaron aquellas actividades antrópicas del tipo doméstico, comercial e industrial, que influyen en la contaminación del agua del rio Chumbao; para ello se describió cada actividad; relacionándose los afluentes naturales y usuarios generadores de aguas residuales que alimentan y descargan al cauce principal, los cuales inciden en la presencia de pesticidas, características fisicoquímicas y microbiológicas. También se recogió información secundaria en las bases de datos de entidades estatales como el Instituto Nacional de Estadística e Informática (INEI).

Se realizaron encuestas a las personas que desarrollan actividades agropecuarias en el área de estudio, con la finalidad de conocer el uso de productos químicos. Para determinar el número de encuestas, se hizo un muestreo aleatorio estratificado (MAE) a partir de una población finita, que fue recabada de la Dirección de Información Agraria (DIA), perteneciente a la Dirección Sub Regional Agraria Andahuaylas (DSRAA), para lo cual se utilizó la siguiente fórmula:

$$
n=Z^{\wedge} 2^{*} p^{*} q^{*} N /\left(E \wedge 2^{*}(N-1)+Z^{\wedge} 2^{*} p^{*} q\right)
$$

Donde:

$$
\begin{aligned}
& \text { Z: } 1.96 \\
& \text { p: } 96 \% \\
& \text { q: } 4 \% \\
& \text { E: } 5 \% \\
& \text { N: Población } \\
& \text { n: Tamaño de muestra }
\end{aligned}
$$

Para determinar los valores de $p$ y q se hizo una pre encuesta a 50 personas ( $p$ a favor y q en contra). 


\subsection{Análisis de contaminantes emergentes, propiedades fisicoquímicas y microbiológicas}

La toma de muestras se realizó de acuerdo al Protocolo Nacional para el Monitoreo de la Calidad de los Recursos Hídricos Superficiales aprobado con Resolución Jefatural $N^{\circ}$ 010-2016-ANA (Autoridad Nacional del Agua, 2016), las que fueron recolectadas en dos temporadas (lluvia y estiaje), las fechas de muestreo fueron el 12 de abril y 10 de octubre del año 2019 respectivamente, en total fueron 7 puntos de muestreo distribuidos espacialmente en el tramo de estudio. Se realizó con el equipo de trabajo, conformado por Ingenieros (Ambiental, Agroindustrial y Alimentario). Para todos los puntos de muestreo se incluyó en el equipo un conductor y un vehículo, esto debido a las distancias que existen entre las estaciones. Las muestras se conservaron y transportaron refrigeradas en cajas de tecnopor con ice packs a $4^{\circ} \mathrm{C}$ y entregadas en el distrito de Talavera al Laboratorio de Investigación de Análisis y Control de Agua (LICAA) de la Universidad Nacional José María Arguedas (UNAJMA), en la cual se desarrolló la caracterización fisicoquímica, por otro lado se enviaron las muestras para el análisis de pesticidas al laboratorio de Certificaciones del Perú (CERPER), ubicado en la ciudad de Lima. Los métodos de análisis se resumen en la Tabla 2.

\begin{tabular}{|c|c|c|c|}
\hline Variable & $\begin{array}{c}\text { Unit of } \\
\text { measurement }\end{array}$ & Determination method & $\begin{array}{l}\text { Laboratory } \\
\text { name }\end{array}$ \\
\hline Organochlorine pesticides & $\mu \mathrm{g} / \mathrm{L}$ & EPA method 8081 B.2007 & CERPER \\
\hline Organophosphate pesticides & $\mu \mathrm{g} / \mathrm{L}$ & EPA method 8270 D.2014 & CERPER \\
\hline Nickel & $\mathrm{mg} \mathrm{Ni/L}$ & PAN method & LICAA \\
\hline Bromine & $\mathrm{mg} \mathrm{Br} / \mathrm{L}$ & DPD method & LICAA \\
\hline Iron & $\mathrm{mg} \mathrm{Fe} / \mathrm{L}$ & TPTZ method & LICAA \\
\hline Chrome & $\mu \mathrm{g} \mathrm{Cr} / \mathrm{L}$ & Diphenylcarbohydrazide method & LICAA \\
\hline Dissolved oxygen (DO) & $\mathrm{mg} \mathrm{O}_{2} / \mathrm{L}$ & User manual & LICAA \\
\hline $\mathrm{pH}$ & & User manual & LICAA \\
\hline $\begin{array}{l}\text { Biochemical oxygen demand } \\
\text { (BOD) }\end{array}$ & $\mathrm{mg} \mathrm{O}_{2} / \mathrm{L}$ & APHA method $4500-O \mathrm{C}, 5210 \mathrm{~B}$ & LICAA \\
\hline Nitrates & $\mathrm{mg} \mathrm{NO}_{3}^{-1 / \mathrm{L}}$ & APHA method $4500-\mathrm{NO}_{3} \mathrm{E}$ & LICAA \\
\hline Phosphates & $\mathrm{mg} \mathrm{PO}_{4}^{-2 / L}$ & APHA method 4500-P E & LICAA \\
\hline Temperature & ${ }^{\circ} \mathrm{C}$ & User manual & LICAA \\
\hline Turbidity & FTU & User manual & LICAA \\
\hline Color & Pt-Co & User manual & LICAA \\
\hline Dissolved Solids Totals & $\mathrm{mg} / \mathrm{L}$ & APHA method $2540 \mathrm{E}$ & LICAA \\
\hline Conductivity & uS/cm & User manual & LICAA \\
\hline Alkalinity & $\mathrm{mgCaCO}_{3} / \mathrm{L}$ & APHA method 2320-A, 2320-B & LICAA \\
\hline Hardness & $\mathrm{mg} \mathrm{CaCO}_{3} / \mathrm{L}$ & APHA method $2340-\mathrm{C}$ & LICAA \\
\hline
\end{tabular}




\begin{tabular}{|c|c|c|c|}
\hline Fecal Coliforms & CFU/mL & APHA method 9211 B & LICAA \\
\hline Total Coliforms & CFU & APHA method 9222 A, 9222 B & LICAA \\
\hline
\end{tabular}

Table 2: Analysis methods to determine the concentration of pesticides, physicochemical and microbiological characteristics

\subsection{Análisis estadístico}

Para el análisis de la información obtenida en las encuestas se hizo uso de estadística descriptiva, los resultados se compararon con los valores críticos normados por la legislación actual.

Para determinar la influencia que ejercen las actividades antrópicas sobre la calidad del recurso hídrico del río Chumbao, se empleó una prueba de análisis de componentes principales (PCA), la cual agrupó las variables con alto grado de asociación y estableció el gradiente ambiental de las estaciones de muestreo, gradiente con el cual se determinó el impacto que tiene cada actividad sobre la calidad del recurso hídrico.

Los datos se procesaron utilizando los paquetes estadísticos SPSS 25, Statgraphics Centurión XVIII, Statistica V8 y la hoja de cálculo Microsoft Excel 2013.

\section{I RESULTADOS Y DISCUSIONES}

Los resultados de concentración de pesticidas, características fisicoquímicas y microbiológicas en el río Chumbao se muestran en la Tabla 3 y 4.

\begin{tabular}{|c|c|c|c|c|c|c|c|}
\hline Variable & P1L & P2L & P3L & P4L & P5L & P6L & P7L \\
\hline $\mathrm{a}-\mathrm{BHC} \mu \mathrm{g} / \mathrm{L}^{*}$ & $<0,0032$ & $<0,0032$ & $<0,0032$ & $<0,0032$ & $<0,0032$ & $<0,0032$ & $<0,0032$ \\
\hline a-Clordano $\mu \mathrm{g} / \mathrm{L}^{*}$ & 0,0023 & 0,0023 & $<0,0023$ & $<0,0023$ & 0,0023 & $<0,0023$ & $<0,0023$ \\
\hline Aldrin $\mu \mathrm{g} / \mathrm{L}^{*}$ & $<0,0027$ & $<0,0027$ & $<0,0027$ & $<0,0027$ & $<0,0027$ & $<0,0027$ & $<0,0027$ \\
\hline $\mathrm{B}-\mathrm{BHC} \mu \mathrm{g} / \mathrm{L}^{*}$ & $<0,0047$ & $<0,0047$ & $<0,0047$ & $<0,0047$ & $<0,0047$ & $<0,0047$ & $<0,0047$ \\
\hline $\mathrm{D}-\mathrm{BHC} \mu \mathrm{g} / \mathrm{L}^{*}$ & $<0,0023$ & $<0,0023$ & $<0,0023$ & $<0,0023$ & $<0,0023$ & $<0,0023$ & $<0,0023$ \\
\hline Dieldrin $\mu \mathrm{g} / \mathrm{L}^{*}$ & $<0,0026$ & $<0,0026$ & $<0,0026$ & $<0,0026$ & $<0,0026$ & $<0,0026$ & $<0,0026$ \\
\hline Endosulfan I $\mu \mathrm{g} / \mathrm{L}^{*}$ & $<0,0022$ & 022 & $<0,0022$ & $<0,0022$ & $<0,0022$ & $<0,0022$ & $<0,0022$ \\
\hline Endosulfan II $\mu \mathrm{g} / \mathrm{L}^{*}$ & $<0,0023$ & $<0,0023$ & $<0,0023$ & $<0,0023$ & $<0,0023$ & $<0,0023$ & $<0,0023$ \\
\hline $\begin{array}{l}\text { Endosulfan sulfato } \\
\mu \mathrm{g} / \mathrm{L}^{*}\end{array}$ & $<0,0042$ & $<0,0042$ & $<0,0042$ & $<0,0042$ & $<0,0042$ & $<0,0042$ & $<0,0042$ \\
\hline Endrin $\mu \mathrm{g} / \mathrm{L}^{*}$ & $<0,0023$ & $<0,0023$ & $<0,0023$ & $<0,0023$ & $<0,0023$ & $<0,0023$ & $<0,0023$ \\
\hline Endrin Aldehído $\mu \mathrm{g} / \mathrm{L}^{*}$ & $<0,0115$ & $<0,0115$ & $<0,0115$ & $<0,0115$ & $<0,0115$ & $<0,0115$ & $<0,0115$ \\
\hline $\mathrm{g}-\mathrm{BHC} \mu \mathrm{g} / \mathrm{L}^{*}$ & $<0,0027$ & $<0,0027$ & $<0,0027$ & $<0,0027$ & $<0,0027$ & $<0,0027$ & $<0,0027$ \\
\hline g-Clordano $\mu \mathrm{g} / \mathrm{L}^{*}$ & $<0,0030$ & $<0,0030$ & $<0,0030$ & $<0,0030$ & $<0,0030$ & $<0,0030$ & $<0,0030$ \\
\hline Heptacloro $\mu \mathrm{g} / \mathrm{L}^{*}$ & $<0,0034$ & $<0,0034$ & $<0,0034$ & $<0,0034$ & $<0,0034$ & $<0,0034$ & $<0,0034$ \\
\hline
\end{tabular}




\begin{tabular}{|c|c|c|c|c|c|c|c|}
\hline $\begin{array}{l}\text { Heptacloro Hepoxido } \\
\mu \mathrm{g} / \mathrm{L}^{*}\end{array}$ & $<0,0016$ & $<0,0016$ & $<0,0016$ & $<0,0016$ & $<0,0016$ & $<0,0016$ & $<0,0016$ \\
\hline Metoxicloro $\mu \mathrm{g} / \mathrm{L}^{*}$ & 0,0138 & $<0,0138$ & $<0,0138$ & $<0,0138$ & $<0,0138$ & $<0,0138$ & $<0,0138$ \\
\hline $\mathrm{P}, \mathrm{P}^{\prime}-\mathrm{DDD} \mu \mathrm{g} / \mathrm{L}^{*}$ & 0,0030 & $<0,0030$ & $<0,0030$ & $<0,0030$ & $<0,0030$ & $<0,0030$ & $<0,0030$ \\
\hline $\mathrm{P}, \mathrm{P}^{\prime}-\mathrm{DDE} \mu \mathrm{g} / \mathrm{L}^{*}$ & $<0,0024$ & $<0,0024$ & $<0,0024$ & $<0,0024$ & $<0,0024$ & $<0,0024$ & $<0,0024$ \\
\hline P, P'DDT. $\mu \mathrm{g} / \mathrm{L}^{*}$ & $<0,0010$ & $<0,0010$ & $<0,0010$ & $<0,0010$ & $<0,0010$ & $<0,0010$ & $<0,0010$ \\
\hline Carbophenothion $\mu \mathrm{g} / \mathrm{L}^{* *}$ & $<0,094$ & $<0,094$ & $<0,094$ & $<0,094$ & $<0,094$ & $<0,094$ & $<0,094$ \\
\hline Chlorobenzilate $\mu \mathrm{g} / \mathrm{L}^{* *}$ & $<0,089$ & $<0,089$ & $<0,089$ & $<0,089$ & $<0,089$ & $<0,089$ & $<0,089$ \\
\hline Coumaphos $\mu \mathrm{g} / \mathrm{L}^{* *}$ & $<0,114$ & $<0,114$ & $<0,114$ & $<0,114$ & $<0,114$ & $<0,114$ & $<0,114$ \\
\hline Diallate $\mu \mathrm{g} / \mathrm{L}^{* *}$ & $<0,089$ & $<0,089$ & $<0,089$ & $<0,089$ & $<0,089$ & $<0,089$ & $<0,089$ \\
\hline Dimethoate $\mu \mathrm{g} / \mathrm{L}^{* *}$ & $<0,079$ & $<0,079$ & $<0,079$ & $<0,079$ & $<0,079$ & $<0,079$ & $<0,079$ \\
\hline Dinoseb $\mu \mathrm{g} / \mathrm{L}^{* *}$ & $<0,131$ & $<0,131$ & $<0,131$ & $<0,131$ & $<0,131$ & $<0,131$ & $<0,131$ \\
\hline Disulfoton $\mu \mathrm{g} / \mathrm{L}^{\star *}$ & $<0,082$ & $<0,082$ & $<0,082$ & $<0,082$ & $<0,082$ & $<0,082$ & $<0,082$ \\
\hline EPN $\mu \mathrm{g} / \mathrm{L}^{* *}$ & $<0,123$ & $<0,123$ & $<0,123$ & $<0,123$ & $<0,123$ & $<0,123$ & $<0,123$ \\
\hline Ethion $\mu \mathrm{g} / \mathrm{L}^{* *}$ & $<0,175$ & $<0,175$ & $<0,175$ & $<0,175$ & $<0,175$ & $<0,175$ & $<0,175$ \\
\hline Famphur $\mu \mathrm{g} / \mathrm{L}^{* *}$ & $<0,087$ & $<0,087$ & $<0,087$ & $<0,087$ & $<0,087$ & $<0,087$ & $<0,087$ \\
\hline Fensulfothion $\mu \mathrm{g} / \mathrm{L}^{* *}$ & $<0,090$ & $<0,090$ & $<0,090$ & $<0,090$ & $<0,090$ & $<0,090$ & $<0,090$ \\
\hline Fenthion $\mu \mathrm{g} / \mathrm{L}^{* *}$ & $<0,078$ & $<0,078$ & $<0,078$ & $<0,078$ & $<0,078$ & $<0,078$ & $<0,078$ \\
\hline Imidan $\mu \mathrm{g} / \mathrm{L}^{* *}$ & $<0,168$ & $<0,168$ & $<0,168$ & $<0,168$ & $<0,168$ & $<0,168$ & $<0,168$ \\
\hline Kepone $\mu \mathrm{g} / \mathrm{L}^{* *}$ & $<0,099$ & $<0,099$ & $<0,099$ & $<0,099$ & $<0,099$ & $<0,099$ & $<0,099$ \\
\hline Leptophos $\mu \mathrm{g} / \mathrm{L}^{* *}$ & $<0,070$ & $<0,070$ & $<0,070$ & $<0,070$ & $<0,070$ & $<0,070$ & $<0,070$ \\
\hline Malathion $\mu \mathrm{g} / \mathrm{L}^{* \star}$ & $<0,073$ & $<0,073$ & $<0,073$ & $<0,073$ & $<0,073$ & $<0,073$ & $<0,073$ \\
\hline Methyl parathion $\mu \mathrm{g} / \mathrm{L}^{* \star}$ & $<0,094$ & $<0,094$ & $<0,094$ & $<0,094$ & $<0,094$ & $<0,094$ & $<0,094$ \\
\hline Parathion $\mu \mathrm{g} / \mathrm{L}^{* *}$ & $<0,085$ & $<0,085$ & $<0,085$ & $<0,085$ & $<0,085$ & $<0,085$ & $<0,085$ \\
\hline Phorate $\mu \mathrm{g} / \mathrm{L}^{* *}$ & $<0,075$ & $<0,075$ & $<0,075$ & $<0,075$ & $<0,075$ & $<0,075$ & $<0,075$ \\
\hline Phosalone $\mu \mathrm{g} / \mathrm{L}^{* *}$ & $<0,115$ & $<0,115$ & $<0,115$ & $<0,115$ & $<0,115$ & $<0,115$ & $<0,115$ \\
\hline Silvex $\mu \mathrm{g} / \mathrm{L}^{* *}$ & $<0,159$ & $<0,159$ & $<0,159$ & $<0,159$ & $<0,159$ & $<0,159$ & $<0,159$ \\
\hline Sulfotep $\mu \mathrm{g} / \mathrm{L}^{* *}$ & 068 & 68 & $<$ & $<0,068$ & $<0$, & 88 & $<0,068$ \\
\hline Terbufos $\mu \mathrm{g} / \mathrm{L}^{* *}$ & $<0,075$ & $<0,075$ & $<0,075$ & $<0,075$ & $<0,075$ & $<0,075$ & $<0,075$ \\
\hline $\begin{array}{c}\text { Tetrachlorvinphos } \\
\mu \mathrm{g} / \mathrm{L}^{\star \star}\end{array}$ & $<0,120$ & $<0,120$ & $<0,120$ & $<0,120$ & $<0,120$ & $<0,120$ & $<0,120$ \\
\hline Thionazin $\mu \mathrm{g} / \mathrm{L}^{\star \star}$ & $<0,069$ & $<0,069$ & $<0,069$ & $<0,069$ & $<0,069$ & $<0,069$ & $<0,069$ \\
\hline Níckel & $<0.052$ & $<0.052$ & $<0.052$ & 52 & 52 & 052 & $<0.052$ \\
\hline Bromine $\mathrm{mg} \mathrm{Br} / \mathrm{L}$ & 0.15 & 0.08 & 0.05 & 0.07 & 0.05 & $0.10^{B}$ & 0.07 \\
\hline Iron mg Fe/L & 0.56 & 0.53 & 0.31 & 0.49 & 0.50 & $0.36^{c}$ & 0.61 \\
\hline Chrome ug $\mathrm{Cr} / \mathrm{L}$ & $<0.011$ & $<0.011$ & $<0.011$ & $<0.011$ & $<0.011$ & $<0.011$ & $<0.011$ \\
\hline $\begin{array}{c}\text { Dissolved oxygen mg } \\
\mathrm{O}_{2} / \mathrm{L}\end{array}$ & 4.79 & 4.87 & 4.82 & 4.90 & 4.57 & 6.40 & 4.86 \\
\hline $\mathrm{pH}$ & 8.46 & 9.33 & 7.98 & 8.44 & 7.51 & 7.60 & 8.61 \\
\hline $\mathrm{BDO} \mathrm{mg} \mathrm{O}_{2} / \mathrm{L}$ & 2.71 & 2.11 & 9.88 & 28.37 & 58.45 & 91.13 & 115.34 \\
\hline Nitrates $\mathrm{mg} \mathrm{mgNO}_{3}^{-} / \mathrm{L}$ & $<1.00$ & $<1.00$ & $<1.00$ & $<1.00$ & $<1.00$ & $<1.00$ & $<1.00$ \\
\hline Phosphates $\mathrm{mgPO}_{4}^{-2} / \mathrm{L}$ & 0.05 & 0.17 & 1.31 & 1.64 & 1.52 & 1.87 & 1.02 \\
\hline
\end{tabular}




\begin{tabular}{|c|c|c|c|c|c|c|c|}
\hline Temperature $^{\circ} \mathrm{C}$ & 10.86 & 19.22 & 22.28 & 21.24 & 22.95 & 20.58 & 19.13 \\
\hline Turbidity FTU & 0.20 & 17.57 & 28.77 & 15.40 & 62.40 & 37.97 & 24.33 \\
\hline Color Pt-Co & 36.00 & 16.33 & 56.00 & 40.00 & 57.33 & 94.67 & 48.00 \\
\hline $\begin{array}{c}\text { Dissolved Solids Totals } \\
\mathrm{mg} / \mathrm{L}\end{array}$ & 22.00 & 25.67 & 43.33 & 56.33 & 76.67 & 139.33 & 168.00 \\
\hline Conductivity uS/cm & 44.67 & 51.33 & 86.33 & 108.33 & 154.33 & 277.67 & 337.00 \\
\hline Alkalinity $\mathrm{mgCaCO}_{3} / \mathrm{L}$ & 3.13 & 20.27 & 26.70 & 33.47 & 36.00 & 43.73 & 58.23 \\
\hline Hardness mgCaCO $/ \mathrm{L}$ & 6.97 & 44.07 & 80.80 & 101.37 & 109.10 & 100.67 & 200.80 \\
\hline $\begin{array}{c}\text { Fecal Coliforms CFU/ } \\
\mathrm{mL}\end{array}$ & 25 & 150 & 2000 & 2000 & 2500 & 9500 & 3000 \\
\hline Total Coliforms CFU & 0 & 0 & 1000 & 500 & 0 & 5000 & 0 \\
\hline
\end{tabular}

Where: P: sampling points, E: dry season, *: organochlorine pesticides and ${ }^{* *}$ : organophosphate pesticides.

Table 3. Pesticide concentration, physicochemical and microbiological characteristics in the rainy season

\begin{tabular}{|c|c|c|c|c|c|c|c|}
\hline Variable & P1E & P2E & P3E & $\mathrm{P} 4 \mathrm{E}$ & P5E & P6E & P7E \\
\hline $\mathrm{a}-\mathrm{BHC} \mu \mathrm{g} / \mathrm{L}^{*}$ & $<0,0032$ & $<0,0032$ & $<0,0032$ & $<0,0032$ & $<0,0032$ & $<0,0032$ & $<0,0032$ \\
\hline a-Clordano $\mu \mathrm{g} / \mathrm{L}^{*}$ & $<0,0023$ & $<0,0023$ & $<0,0023$ & $<0,0023$ & $<0,0023$ & $<0,0023$ & $<0,0023$ \\
\hline Aldrin $\mu \mathrm{g} / \mathrm{L}^{*}$ & $<0,0027$ & $<0,0027$ & $<0,0027$ & $<0,0027$ & $<0,0027$ & $<0,0027$ & $<0,0027$ \\
\hline $\mathrm{B}-\mathrm{BHC} \mu \mathrm{g} / \mathrm{L}^{*}$ & $<0,0047$ & $<0,0047$ & $<0,0047$ & $<0,0047$ & $<0,0047$ & $<0,0047$ & $<0,0047$ \\
\hline $\mathrm{D}-\mathrm{BHC} \mu \mathrm{g} / \mathrm{L}^{*}$ & $<0,0023$ & $<0,0023$ & $<0,0023$ & $<0,0023$ & $<0,0023$ & $<0,0023$ & $<0,0023$ \\
\hline Dieldrin $\mu \mathrm{g} / \mathrm{L}^{*}$ & $<0,0026$ & $<0,0026$ & $<0,0026$ & $<0,0026$ & $<0,0026$ & $<0,0026$ & $<0,0026$ \\
\hline Endosulfan I $\mu \mathrm{g} / \mathrm{L}^{*}$ & $<0,0022$ & $<0,0022$ & $<0,0022$ & $<0,0022$ & $<0,0022$ & $<0,0022$ & $<0,0022$ \\
\hline Endosulfan II $\mu \mathrm{g} / \mathrm{L}^{*}$ & $<0,0023$ & $<0,0023$ & $<0,0023$ & $<0,0023$ & $<0,0023$ & $<0,0023$ & $<0,0023$ \\
\hline $\begin{array}{l}\text { Endosulfan sulfato } \\
\mu \mathrm{g} / \mathrm{L}^{*}\end{array}$ & $<0,0042$ & $<0,0042$ & $<0,0042$ & $<0,0042$ & $<0,0042$ & $<0,0042$ & $<0,0042$ \\
\hline Endrin $\mu \mathrm{g} / \mathrm{L}^{*}$ & $<0,0023$ & $<0,0023$ & $<0,0023$ & $<0,0023$ & $<0,0023$ & $<0,0023$ & $<0,0023$ \\
\hline Endrin Aldehído $\mu \mathrm{g} / \mathrm{L}^{*}$ & $<0,0115$ & $<0,0115$ & $<0,0115$ & $<0,0115$ & $<0,0115$ & $<0,0115$ & $<0,0115$ \\
\hline $\mathrm{g}-\mathrm{BHC} \mu \mathrm{g} / \mathrm{L}^{*}$ & $<0,0027$ & $<0,0027$ & $<0,0027$ & $<0,0027$ & $<0,0027$ & $<0,0027$ & $<0,0027$ \\
\hline g-Clordano $\mu \mathrm{g} / \mathrm{L}^{*}$ & $<0,0030$ & $<0,0030$ & $<0,0030$ & $<0,0030$ & $<0,0030$ & $<0,0030$ & $<0,0030$ \\
\hline Heptacloro $\mu \mathrm{g} / \mathrm{L}^{*}$ & $<0,0034$ & $<0,0034$ & $<0,0034$ & $<0,0034$ & $<0,0034$ & $<0,0034$ & $<0,0034$ \\
\hline $\begin{array}{l}\text { Heptacloro Hepoxido } \\
\mu \mathrm{g} / \mathrm{L}^{*}\end{array}$ & $<0,0016$ & $<0,0016$ & $<0,0016$ & $<0,0016$ & $<0,0016$ & $<0,0016$ & $<0,0016$ \\
\hline Metoxicloro $\mu \mathrm{g} / \mathrm{L}^{*}$ & $<0,0138$ & $<0,0138$ & $<0,0138$ & $<0,0138$ & $<0,0138$ & $<0,0138$ & $<0,0138$ \\
\hline $\mathrm{P}, \mathrm{P}^{\prime}-\mathrm{DDD} \mu \mathrm{g} / \mathrm{L}^{*}$ & $<0,0030$ & $<0,0030$ & $<0,0030$ & $<0,0030$ & $<0,0030$ & $<0,0030$ & $<0,0030$ \\
\hline $\mathrm{P}, \mathrm{P}^{\prime}-\mathrm{DDE} \mu \mathrm{g} / \mathrm{L}^{*}$ & $<0,0024$ & $<0,0024$ & $<0,0024$ & $<0,0024$ & $<0,0024$ & $<0,0024$ & $<0,0024$ \\
\hline P, P'DDT. $\mu \mathrm{g} / \mathrm{L}^{*}$ & $<0,0010$ & $<0,0010$ & $<0,0010$ & $<0,0010$ & $<0,0010$ & $<0,0010$ & $<0,0010$ \\
\hline $\begin{array}{c}\text { Carbophenothion } \\
\mu \mathrm{g} / \mathrm{L}^{* *}\end{array}$ & $<0,094$ & $<0,094$ & $<0,094$ & $<0,094$ & $<0,094$ & $<0,094$ & $<0,094$ \\
\hline Chlorobenzilate $\mu \mathrm{g} / \mathrm{L}^{\star *}$ & $<0,089$ & $<0,089$ & $<0,089$ & $<0,089$ & $<0,089$ & $<0,089$ & $<0,089$ \\
\hline Coumaphos $\mu \mathrm{g} / \mathrm{L}^{* *}$ & $<0,114$ & $<0,114$ & $<0,114$ & $<0,114$ & $<0,114$ & $<0,114$ & $<0,114$ \\
\hline
\end{tabular}




\begin{tabular}{|c|c|c|c|c|c|c|c|}
\hline Diallate $\mu \mathrm{g} / \mathrm{L}^{* *}$ & $<0,089$ & $<0,089$ & $<0,089$ & $<0,089$ & $<0,089$ & $<0,089$ & $<0,089$ \\
\hline Dimethoate $\mu \mathrm{g} / \mathrm{L}^{* *}$ & $<0,079$ & $<0,079$ & $<0,079$ & $<0,079$ & $<0,079$ & $<0,079$ & $<0,079$ \\
\hline Dinoseb $\mu \mathrm{g} / \mathrm{L}^{* *}$ & $<0,131$ & $<0,131$ & $<0,131$ & $<0,131$ & $<0,131$ & $<0,131$ & $<0,131$ \\
\hline Disulfoton $\mu \mathrm{g} / \mathrm{L}^{* *}$ & $<0,082$ & $<0,082$ & $<0,082$ & $<0,082$ & $<0,082$ & $<0,082$ & $<0,082$ \\
\hline $\mathrm{EPN} \mu \mathrm{g} / \mathrm{L}^{* *}$ & $<0,123$ & $<0,123$ & $<0,123$ & $<0,123$ & $<0,123$ & $<0,123$ & $<0,123$ \\
\hline Ethion $\mu \mathrm{g} / \mathrm{L}^{* *}$ & $<0,175$ & $<0,175$ & $<0,175$ & $<0,175$ & $<0,175$ & $<0,175$ & $<0,175$ \\
\hline Famphur $\mu \mathrm{g} / \mathrm{L}^{\star *}$ & $<0,087$ & $<0,087$ & $<0,087$ & $<0,087$ & $<0,087$ & $<0,087$ & $<0,087$ \\
\hline Fensulfothion $\mu \mathrm{g} / \mathrm{L}^{* *}$ & $<0,090$ & $<0,090$ & $<0,090$ & $<0,090$ & $<0,090$ & $<0,090$ & $<0,090$ \\
\hline Fenthion $\mu \mathrm{g} / \mathrm{L}^{* *}$ & $<0,078$ & $<0,078$ & $<0,078$ & $<0,078$ & $<0,078$ & $<0,078$ & $<0,078$ \\
\hline Imidan $\mu \mathrm{g} / \mathrm{L}^{* *}$ & $<0,168$ & $<0,168$ & $<0,168$ & $<0,168$ & $<0,168$ & $<0,168$ & $<0,168$ \\
\hline Kepone $\mu \mathrm{g} / \mathrm{L}^{* *}$ & $<0,099$ & $<0,099$ & $<0,099$ & $<0,099$ & $<0,099$ & $<0,099$ & $<0,099$ \\
\hline Leptophos $\mu \mathrm{g} / \mathrm{L}^{* *}$ & $<0,070$ & $<0,070$ & $<0,070$ & $<0,070$ & $<0,070$ & $<0,070$ & $<0,070$ \\
\hline Malathion $\mu \mathrm{g} / \mathrm{L}^{\star *}$ & $<0,073$ & $<0,073$ & $<0,073$ & $<0,073$ & $<0,073$ & $<0,073$ & $<0,073$ \\
\hline $\begin{array}{l}\text { Methyl parathion } \\
\mu \mathrm{g} / \mathrm{L}^{* *}\end{array}$ & $<0,094$ & $<0,094$ & $<0,094$ & $<0,094$ & $<0,094$ & $<0,094$ & $<0,094$ \\
\hline Parathion $\mu \mathrm{g} / \mathrm{L}^{* *}$ & $<0,085$ & $<0,085$ & $<0,085$ & $<0,085$ & $<0,085$ & $<0,085$ & $<0,085$ \\
\hline Phorate $\mu \mathrm{g} / \mathrm{L}^{* *}$ & $<0,075$ & $<0,075$ & $<0,075$ & $<0,075$ & $<0,075$ & $<0,075$ & $<0,075$ \\
\hline Phosalone $\mu \mathrm{g} / \mathrm{L}^{\star *}$ & $<0,115$ & $<0,115$ & $<0,115$ & $<0,115$ & $<0,115$ & $<0,115$ & $<0,115$ \\
\hline Silvex $\mu \mathrm{g} / \mathrm{L}^{* *}$ & $<0,159$ & $<0,159$ & $<0,159$ & $<0,159$ & $<0,159$ & $<0,159$ & $<0,159$ \\
\hline Sulfotep $\mu \mathrm{g} / \mathrm{L}^{* *}$ & $<0,068$ & $<0,068$ & $<0,068$ & $<0,068$ & $<0,068$ & $<0,068$ & $<0,068$ \\
\hline Terbufos $\mu \mathrm{g} / \mathrm{L}^{* *}$ & 75 & 75 & 75 & $<0,075$ & $<0,075$ & $<0,075$ & $<0,075$ \\
\hline $\begin{array}{c}\text { Tetrachlorvinphos } \\
\mu \mathrm{g} / \mathrm{L}^{\star \star}\end{array}$ & $<0,120$ & $<0,120$ & $<0,120$ & $<0,120$ & $<0,120$ & $<0,120$ & $<0,120$ \\
\hline Thionazin $\mu \mathrm{g} / \mathrm{L}^{\star *}$ & $<0,069$ & $<0,069$ & $<0,069$ & $<0,069$ & $<0,069$ & $<0,069$ & $<0,069$ \\
\hline Níckel mg Ni/L & $<0.052$ & $<0.052$ & $<0.052$ & $<0.052$ & $<0.052$ & $<0.052$ & $<0.052$ \\
\hline Bromine $\mathrm{mg} \mathrm{Br} / \mathrm{L}$ & 0.20 & 0.10 & 0.09 & 0.11 & 0.09 & 0.13 & 0.10 \\
\hline Iron mg Fe/L & 0.60 & 0.59 & 0.37 & 0.53 & 0.58 & 0.39 & 0.69 \\
\hline Chrome ug $\mathrm{Cr} / \mathrm{L}$ & $<0.011$ & $<0.011$ & $<0.011$ & $<0.011$ & $<0.011$ & $<0.011$ & $<0.011$ \\
\hline $\begin{array}{l}\text { Dissolved oxygen mg } \\
\mathrm{O}_{2} / \mathrm{L}\end{array}$ & 7.75 & 8.54 & 5.18 & 8.03 & 2.21 & 5.11 & 7.91 \\
\hline $\mathrm{pH}$ & 7.65 & 7.76 & 8.10 & 8.10 & 7.87 & 8.02 & 8.53 \\
\hline $\mathrm{BOD} \mathrm{mg} \mathrm{O} / \mathrm{L}$ & 0.00 & 39.67 & 185.67 & 51.00 & 145.33 & 47.33 & 6.67 \\
\hline Nitrates $\mathrm{mg} \mathrm{mgNO}_{3} / \mathrm{L}$ & $<1.00$ & $<1.00$ & $<1.00$ & $<1.00$ & $<1.00$ & $<1.00$ & $<1.00$ \\
\hline Phosphates $\mathrm{mgPO}_{4}^{-2 / L}$ & 0.05 & 1.49 & 0.91 & 1.69 & 1 & 2.07 & 0.62 \\
\hline Temperature ${ }^{\circ} \mathrm{C}$ & 10.17 & 11.41 & 12.92 & 14.08 & 15.57 & 15.75 & 16.60 \\
\hline Turbidity FTU & 4.27 & 11.43 & 23.70 & 29.43 & 66.07 & 99.90 & 143.53 \\
\hline Color Pt-Co & 39.33 & 23.00 & 135.33 & 50.67 & 171.00 & 40.00 & 16.33 \\
\hline $\begin{array}{c}\text { Dissolved Solids Totals } \\
\mathrm{mg} / \mathrm{L}\end{array}$ & 52.67 & 107.00 & 217.00 & 234.00 & 402.00 & 434.00 & 453.00 \\
\hline Conductivity uS/cm & 105.33 & 214.00 & 434.33 & 468.00 & 803.67 & 868.67 & 905.67 \\
\hline Alkalinity $\mathrm{mgCaCO}_{3} / \mathrm{L}$ & 9.40 & 19.47 & 24.47 & 28.07 & 35.53 & 48.27 & 49.33 \\
\hline Hardness $\mathrm{mgCaCO}_{3} / \mathrm{L}$ & 20.33 & 42.30 & 74.17 & 85.73 & 107.63 & 112.60 & 170.13 \\
\hline
\end{tabular}




\begin{tabular}{|c|c|c|c|c|c|c|c|}
\hline $\begin{array}{c}\text { Fecal Coliforms CFU/ } \\
\mathrm{mL}\end{array}$ & 14 & 325 & 25500 & 1100 & 54000 & 25500 & 400 \\
\hline Total Coliforms CFU & 0.5 & $0 \mathrm{l}$ & 7000 & 250 & 20000 & 11500 & 70 \\
\hline
\end{tabular}

Where: P: sampling points, E: dry season, *: organochlorine pesticides and ${ }^{* *}$ : organophosphate pesticides.

Table 4. Pesticide concentration, physicochemical and microbiological characteristics in the dry season

\subsection{Influencia de las actividades antrópicas en la calidad del agua del rio Chumbao}

Se realizó una correlación múltiple de las variables, observándose un comportamiento positivo entre ellas. Por lo que se procedió a realizar el análisis de componentes principales $(\mathrm{PCA})$, en el que se retuvieron los 2 primeros componentes según el criterio de Kaiser (autovalores mayores a 1), con estos se logró explicar el $96.55 \%$ de la variabilidad de los datos originales.

El análisis de componentes principales muestra con claridad el proceso de degradación del recurso hídrico del rio Chumbao, por efecto de los vertimientos de las aguas residuales de las actividades agropecuarias, comerciales, domésticas e industriales. En la parte izquierda de la Figura 2, en color verde, se localizan las estaciones que se encuentran en la parte alta del valle del rio Chumbao, antes del casco urbano del distrito de San Jerónimo, estaciones en las cuales no se presenta contaminación importante; la primera estación P1 en época de lluvia y estiaje está por debajo del valor de restricción del color verdadero (36.00 y 39.33 Unid Pt-Co respectivamente), en el mismo punto de muestreo la turbiedad está por debajo del límite máximo permisible para aguas que pueden ser potabilizadas con desinfección (Ministerio del Ambiente, 2017). Tanto en la época de estiaje como en lluvias no se observan niveles de contaminación altos para las características estudiadas, debido a que en los alrededores de la hidroeléctrica del rio Chumbao no se observan aún actividades antrópicas contaminantes, salvo aquellas actividades de tipo agrícola como son el cultivo de papa, maíz, quinua, etc. Además de actividades pecuarias como la crianza de ganado vacuno, cuyes y otros.

En la estación P2 distanciada a $5.56 \mathrm{~km}$ del primer punto de muestreo (color amarillo en la Figura 2), el rio ingresa a la zona más poblada del distrito de San Jerónimo, tanto para la época de lluvia y estiaje, ésta ocupa una posición intermedia en contaminación por actividades agropecuarias y aguas residuales domésticas. Esta estación tiene un grado importante de contaminación (elevados niveles de DBO y color verdadero) y comparte algunas características con el punto de muestreo P7E afectado por el vertimiento de aguas residuales domésticas.

El punto de muestreo P4E de color negro, presenta los mayores niveles de 
contaminación, este punto está ubicado a la altura del Cuartel de Ingeniería en Curibamba, Andahuaylas. En el cual se observan las actividades domésticas, comerciales e industriales mayores. Notándose en la parte superior a dicha estación, comercios diversos y el camal Municipal de Andahuaylas, además de ser una zona densamente poblada.

En la Figura 2 en color rojo, se encuentran las estaciones con mayor degradación del recurso hídrico, pero inferiores al P4E; estos puntos de muestreo presentan bajas concentraciones de OD y valores altos de las demás variables fisicoquímicas asociadas al componente 1. Ocasionado por la alteración del río con aguas residuales domésticas, comerciales e industriales, que originan el incremento del $\mathrm{pH}$, alcalinidad, temperatura y Coliformes fecales.

Los valores altos de color verdadero, sólidos totales disueltos, conductividad, dureza y coliformes totales en las estaciones del casco urbano asociados al componente 2 , son producto del alto contenido de materia orgánica de las aguas residuales domésticas, vertidas en los distritos de Andahuaylas y Talavera.

Es preocupante la presencia de Coliformes totales y fecales en las estaciones estudiadas, con valores por encima del nivel saludable, ya que el agua del río es utilizada para el riego de los cultivos de quinua, papa, maíz, hortalizas y otros a lo largo de los distritos de San Jerónimo, Andahuaylas y Talavera. Esta preocupación surge porque en Andahuaylas el año 2019, se presentaron 4882 casos en personas mayores de 5 años y 4401 casos en niños menores de 5 años, de enfermedades diarreicas agudas (EDAs). El agua se contamina con heces humanas procedentes, por ejemplo, de aguas residuales, fosas sépticas o letrinas, que son particularmente peligrosas. Las heces de animales también contienen microorganismos capaces de ocasionar enfermedades diarreicas (Dirección Regional de Salud Apurímac, 2020). Según la OMS cada año mueren cerca de 1.87 millones de niños por causas asociadas a la enfermedad diarreica y cerca del $88 \%$ de estas muertes están asociadas con el abastecimiento de agua insalubre y el saneamiento e higiene deficientes (Boschi, Velebit y Shibuya, 2008).

En el diagnóstico del sector agua y saneamiento al 2017, se observó que 3.4 millones de peruanos no tienen acceso a agua potable y 8.1 millones no tienen alcantarillado. Solo el $47 \%$ de hogares accede a agua segura en el área urbana y $1.7 \%$ en el área rural, entre las causas que originan estos problemas están, los operadores con escaso apoyo y con graves problemas económicos, inversiones insuficientes e insostenibles (Encuesta Nacional de Programas Presupuestales, 2017).

El estado del río Chumbao en el tramo estudiado conformado por los distritos de San Jerónimo, Andahuaylas y Talavera viola los derechos de los habitantes de estos municipios. ya que la ley No. 30588 de reforma constitucional reconoce el derecho de acceso al agua como derecho constitucional en su artículo $7^{\circ}-\mathrm{A}$, en el cual el Estado reconoce el derecho de toda persona a tener acceso progresivo y universal al agua potable. El Estado garantiza este derecho priorizando el consumo humano frente a otros usos. El Estado promueve el 
manejo sustentable del agua, la cual es reconocida como un recurso natural esencial y como tal, constituye un bien público y patrimonio de la Nación. Su dominio es inalienable e imprescriptible (Congreso de la República del Perú, 2017).

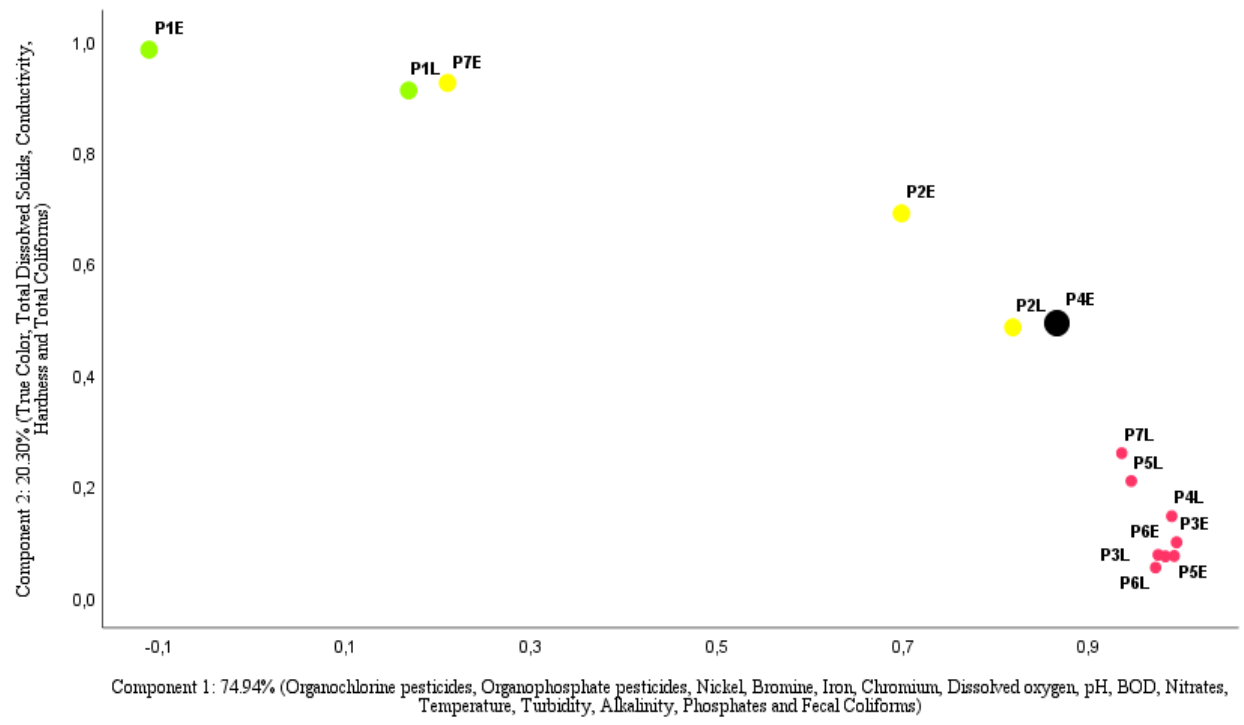

Figure 2: Spatial distribution of the stations in the pollution gradient of components 1 and 2. Rio Chumbao, Peru.

\section{I CONCLUSIONES}

Se determinó la influencia de las actividades antrópicas y la concentración de pesticidas, características fisicoquímicas y microbiológicas en el rio Chumbao, perteneciente a la provincia de Andahuaylas, región Apurímac, durante el año 2019.

Se identificaron las principales actividades antrópicas, con énfasis en las de tipo agropecuario (crianza de ganado vacuno, crianza de cuyes, cultivo de quinua, papa y maíz), que son las de mayor prevalencia en el área de estudio y que tienen estrecha relación con las propiedades estudiadas.

No se han detectado valores significativos de concentración de pesticidas organoclorados y organofosforados, para los límites de detección de las metodologías empleadas, sin embargo a nivel descriptivo se han identificado varios productos de uso veterinario y agrícola presentes en la microcuenca del rio Chumbao. En el caso de la actividad pecuaria se observa el uso frecuente de albendazol, mebendazol e ivermectina cómo antihelmínticos, para el control de moscas y otros ectoparásitos utilizan insecticidas 
organofosforados y piretroides. En el caso de los cultivos de quinua, papa y maíz se ha identificado diversos pesticidas y plaguicidas. No se han encontrado productos para el control de malezas.

Se logró determinar el nivel de las características fisicoquímicas y microbiológicas en las temporadas de lluvia y estiaje en el rio Chumbao, observándose que muchas de las propiedades estudiadas están por encima de los estándares de calidad ambiental formulados por la autoridad competente.

\section{AGRADECIMIENTOS}

A la Universidad Nacional José María Arguedas.

\section{REFERENCIAS}

AUTORIDAD NACIONAL DEL AGUA. Perú. Resolución Jefatural Nº10-2016-ANA (enero 11). Por el cual se reglamenta el Protocolo nacional para el monitoreo de la calidad de los recursos hídricos superficiales [cited 2020 May 25]. Disponible en: https://www.ana.gob.pe/sites/default/files/ normatividad/files/r.j._010-2016-ana_0.pdf.

BARRAGÁN B.; RIVILLAS M.; VILLEGAS M.; MEDINA J. Presence of pesticides, mercury and trihalomethanes in the water supply systems of Ibagué, Colombia: threats to human health. Rev. Ambient. Água [Internet]. 2020 [cited 2020 Aug 11] ; 15( 2 ): e2477. Available from: http://www.scielo. br/scielo.php?script=sci_arttext\&pid=S1980-993X2020000200313\&Ing=en. Epub Apr 27, 2020. https:// doi.org/10.4136/ambi-agua.2477.

BOSCHI-PINTO C.; VELEBIT L.; SHIBUYA K. Estimating child mortality due to diarrhoea in developing countries. Bull World Health Organ. 2008;86(9):710-717. http://doi.org/fr684z.

CONGRESO DE LA REPÚBLICA DEL PERÚ. Ley № 30588 reforma constitucional, reconoce el derecho de acceso al agua como derecho constitucional 2017 [cited 2020 May 25].

DÍAZ J.A.; GRANADA C.A. Efecto de las actividades antrópicas sobre las características fisicoquímicas y microbiológicas del río Bogotá a lo largo del municipio de Villapinzón, Colombia. rev.fac.med. [Internet]. 2018 Mar [cited 2020 Aug 11] ; 66 (1): 45-52. Available from: http://www.scielo.org.co/scielo.php?script=sci_arttext\&pid=S0120-00112018000100045\&lng=en. http:// dx.doi.org/10.15446/revfacmed.v66n1.59728.

DIRECCIÓN REGIONAL DE SALUD APURÍMAC. Perú. Dirección Ejecutiva de Inteligencia Sanitaria. Dirección de Epidemiologia. Sala Situacional [cited 2020 May 25].

ENCUESTA NACIONAL DE PROGRAMAS PRESUPUESTALES Perú. (ENAPRES) 2017 [cited 2020 May 25].

INSTITUTO NACIONAL DE ESTADÍSTICA E INFORMÁTICA INEI. Perú. Sistema de Información Regional para la Toma de Decisiones [cited 2020 May 25]. Disponible en: http://systems.inei.gob. pe:8080/SIRTOD/.

MINISTERIO DEL AMBIENTE. Perú. Decreto Supremo Nº04-2017-MINAM. Estándares de Calidad Ambiental (ECA) para aguas. Diario Oficial El Peruano, Lima, Perú, 07 de junio de 2017 [cited 2020 May 25].

YALE UNIVERSITY. Global Metrics for the Environment. New Haven: Enviromental Performance Index; 2019 [cited 2020 May 25]. Available from: https://goo.gl/u161bs. 


\section{SISTEMA EM PLATAFORMA WEB PARA IMPLANTAÇÃO DE PLANO DE SEGURANÇA DA ÁGUA (PSA) ÉM SISTEMAS DE ABASTECIMENTO DE ÁGUA}

Data de aceite: 04/01/2021

Data de submissão: 16/11/2020

\section{Nolan Ribeiro Bezerra}

Instituto Federal de Educação, Ciência e

Tecnologia de Goiás - câmpus Goiânia

Goiânia - Goiás

http://lattes.cnpq.br/7805750900666580

\section{Isabela Moura Chagas}

Instituto Federal de Educação, Ciência e

Tecnologia de Goiás - câmpus Goiânia

Goiânia - Goiás

http://lattes.cnpq.br/1065015271596149

Geraldo Alves Pereira Júnior

Instituto Federal de Educação, Ciência e Tecnologia de Goiás - IFG - câmpus Formosa

Formosa - Goiás

http://lattes.cnpq.br/1695001176543208

RESUMO: É indispensável que as agências prestadoras de serviços de saneamento básico forneçam água potável sem oferecer risco à saúde humana, para isso, deve-se implantar Plano de Segurança da Água (PSA) recomendados pela Organização Mundial de Saúde (OMS). O PSA é um instrumento de identificação de perigos e caracterização de riscos em sistemas e soluções coletivas de abastecimento de água, desde o manancial de captação de água até o consumidor. Sua finalidade é estabelecer medidas de controle para eliminar ou reduzir os perigos e riscos para níveis aceitáveis. Sua elaboração necessita de várias etapas, procedimentos e produção de protocolos e relatórios. Além disso, requer análise de inúmeros documentos, relatórios e dados de monitoramento da qualidade da água. Nesse sentido, faz-se, portanto, necessário o uso de ferramentas computacionais capazes de realizar estes procedimentos em tempo hábil, avaliando os parâmetros coletados e fazendo as comparações necessárias em todas as etapas pertinentes ao processo de tratamento da água para consumo humano. Com objetivo de suprir essas lacunas e otimizar a implantação do PSA, foi desenvolvido um Sistema de Informação para Implantação de Plano de Segurança da Água - SIPSA, sobre a plataforma web, utilizando ferramentas gratuitas. Devido à grande variedade de dispositivos, optou-se por usar apenas HTML, CSS e JAVASCRIPT no "desenho" e apresentação gráfica das páginas da plataforma no navegador. Cabe destacar, que o desenho gráfico do SIPSA foi concebido para esta primeira versão de forma bem simplificada, desta forma, recomenda-se que posteriormente, o sistema seja atualizado por um designer profissional. Para validar o SIPSA foi realizado um teste com os dados obtidos no desenvolvimento do PSA no sistema de abastecimento de água para consumo humano do Município de Formosa Goiás operado pela Saneamento de Goiás S/A (Saneago).

PALAVRAS-CHAVE: Avaliação de risco; Dispositivos móveis; Web Service; Software livre; água potável. 


\section{SYSTEM ON WEB PLATFORM FOR IMPLEMENTATION OF WATER SAFETY PLAN (WSP) IN WATER SUPPLY SYSTEMS}

ABSTRACT: It is indispensable that the sanitation companies supply potable water without posing any risk to human health, and for this as recommended by the World Health Organization (WHO), a Water Safety Plan (WSP), must be implemented. WSP is an instrument for hazard identification and risk characterization in collective water supply systems and solutions, ranging from the source of supply to the consumer. Its purpose is establishing mitigation measures to eliminate or reduce the hazards and risks to acceptable levels. Its elaboration requires several steps, procedures and the production of protocols and reports. In addition, it requires analysis of numerous documents, reports and monitoring data on water quality. Therefore, it is necessary to use computational tools able to perform these procedures in a proper time, evaluating the collected parameters and making the necessary comparisons in all the relevant steps of the drinking water treatment process. In order to fill these gaps and optimize the WSP implementation, an Information System for the Implementation of Water Security Plan (SIWSP) was developed over a web platform, using free tools. Due to the wide diversity of devices, it was chosen to use only HTML, CSS and JAVASCRIPT in the design, so that the graphical platform can be presented in the web browser. It should be noted that the SIWSP was designed for this first version in a very simplified way, so it is recommended that later the system be updated by a professional designer. To validate the SIWSP was performed a test with the data obtained from the development of the WSP in the drinking water supply system of the city of Formosa - Goiás operated by Saneamento de Goiás S/A (Saneago).

KEYWORDS: Risk assessment; Mobile devices; Web Service; Free software; Drinking water.

\section{I INTRODUÇÃO}

A água potável, destinada ao consumo humano, seja para a ingestão, preparação e produção de alimentos e à higiene pessoal, independentemente da sua origem, deve atender ao padrão de potabilidade e não oferecer riscos à saúde conforme estabelecido na Portaria de Consolidação n 5, de 03 de outubro de 2017 (BRASIL, 2017).

O fornecimento de água potável, que não ofereça risco à saúde, requer um controle da qualidade da água para consumo humano, desde a bacia hidrográfica até a distribuição sob a perspectiva de riscos à saúde. Cabe ao responsável pelo sistema de abastecimento de água (SAA) ou solução alternativa coletiva (SAC) realizar uma avaliação sistemática do sistema ou solução alternativa coletiva de abastecimento de água, sob a perspectiva dos riscos à saúde com base na qualidade da água distribuída, conforme os princípios dos Planos de Segurança da Água (PSA) recomendados pela Organização Mundial de Saúde (OMS) ou definidos em diretrizes vigentes no País (BRASIL, 2012, 2017).

O PSA é um instrumento de identificação dos perigos e caracterização dos riscos em SAA e SAC que contempla, desde o manancial de captação de água até o consumidor, com a finalidade de estabelecer medidas de controle para eliminar ou reduzir os perigos e riscos para níveis aceitáveis (WHO, 2011). O plano privilegia-se uma abordagem preventiva em 
detrimento da metodologia clássica de monitoramento de "fim-de-linha", integrando todo o processo de produção de água.

A elaboração do PSA necessita de várias etapas, procedimentos e elaboração de protocolos e relatórios, os quais envolvem o relacionamento e interpretação de grandes quantidades de dados obtidos por meio de variáveis e parâmetros, coletados nos períodos de tempo diário, mensal e semestral, que juntos formam um complexo sistema de tomada de decisões.

A grande quantidade de dados que são obtidos e armazenados deve passar por uma avaliação rigorosa e sistemática, onde são comparados com os valores aceitáveis definidos pelo Ministério da Saúde na Portaria $n^{\circ}$ 5/2017, sendo que as inconformidades entre estes devem gerar possíveis soluções para correção dos problemas e adequação dos valores.

A implantação do PSA envolve a atuação de uma equipe técnica com experiência e conhecimento prévio dos procedimentos e etapas a serem seguidas, além de exigir tempo suficiente para que todos estes procedimentos sejam satisfeitos de forma correta e precisa. Nesse sentido, faz-se, portanto, necessário o uso de ferramentas computacionais capazes de realizar estes procedimentos em tempo hábil, avaliando os parâmetros coletados e fazendo as comparações necessárias em todas as etapas pertinentes ao processo de tratamento da água para consumo humano.

Para suprir essas lacunas, surgiu a necessidade de desenvolver o Sistema de Informação para elaboração de Plano de Segurança da Água (SISPSA), sobre a plataforma web, utilizando ferramentas gratuitas.

\section{I PROCEDIMENTOS METODOLÓGICOS UTILIZADOS}

Em síntese, as etapas utilizadas para o desenvolvimento do sistema em plataforma web foram: i) seleção e adequação dos métodos inerentes ao PSA: o método selecionado foi baseado nos pilares de concepção do PSA, como também a metodologia proposta pela OMS (WHO, 2011), norma ISO 31000, as diretrizes do Ministério da Saúde (ABNT, 2012). Para este sistema foi utilizada o método da "Matriz de Priorização Qualitativa de Riscos" validado por Bezerra (2018) e ii) desenvolvimento do software em plataforma web para elaboração do PSA.

A proposição do software para implantação de PSA levou em consideração o levantamento de requisitos funcionais e não funcionais, que segundo Debastiani (2015), começa sempre pela seleção das fontes de informação, que foram utilizadas para montar a matriz de requisitos, sendo a matéria-prima usada para definição do escopo do projeto.

Os requisitos funcionais utilizados para conceber o SISPSA, trata da própria metodologia do PSA, obtida de um esforço conjunto entre colaboradores da prestadora de serviços Saneamento de Goiás S/A (SANEAGO), discentes e docentes do Instituto Federal de Goiás. Para a obtenção dos requisitos não funcionais foi realizada uma revisão 
bibliográfica, a qual buscou definir quais as tecnologias utilizadas para o desenvolvimento do sistema, com base na filosofia do software livre.

O passo seguinte realizou-se a prototipação do sistema, que foi construída segundo as recomendações presentes na literatura e foi adotado uma ferramenta que facilita o entendimento e a escrita dos códigos AJAX (Asynchronous JavaScript And XML), ferramenta indispensável para a usabilidade de páginas web;c) definição da modelagem do projeto utilizou-se a ferramenta SQL Power Architect, já para a modelagem dos diagramas estruturais do sistema foi contemplada a ferramenta Astah.

Para a implantação do sistema informatizado, seguiu as especificações do paradigma de software livre e selecionando uma das tecnologias emergentes e altamente difundidas no tocante ao desenvolvimento Back-End. Nesse sentido foi escolhido o framework Laravel da linguagem de programação PHP, baseado no padrão de projetos MVC (Modelos, Visões e Controladores). Para o Sistema Gerenciador de Banco de Dados (SGBD), optou-se por utilizar o Maria DB, uma ferramenta livre advinda do esforço coletivo de desenvolvedores ao redor do mundo que, segundo Elmasri (2014), pode ser entendida como uma versão livre do SGBD MySQL, que conta com uma série de melhorias de performance e execução de consultas que fazem seu diferencial. Como ferramenta para auxílio da programação Front-End, utilizou-se a biblioteca JQuery da linguagem JavaScript, por ser compatível com os propósitos gerais da aplicação, tais como a requisição assíncrona de conteúdos e manipulação do DOM (Modelo de Objeto de Documentos).

Para a estilização das páginas de forma padronizada e consistente, optou-se por utilizar a biblioteca de folhas de estilo em cascata Bootstrap, uma vez que esta disponibiliza uma gama de elementos já estilizados, fontes, recursos e orientação de elementos do HTML, permitindo o desenvolvimento rápido de layouts e conteúdos por permitir um alto reaproveitamento de códigos e vasta documentação.

Baseado no conceito de Software Livre o desenvolvimento do sistema se deu do uso majoritário de ferramentas e tecnologias de caráter livre em cada etapa ou fase de seu processo de desenvolvimento. Para o desenvolvimento do Back-End (Programação do lado do Servidor) foi utilizado o Framework Laravel da linguagem de programação PHP em conjunto com o SGBD (Sistema Gerenciador de Banco de Dados), já do lado do cliente, seu Front-End foi desenvolvido com a linguagem de marcação de hipertextos HTML, com o auxílio do Framework de estilização Bootstrap e da linguagem de scripts JavaScript com o Framework JQuery.

\section{I DESENVOLVIMENTO, CARACTERIZAÇÃO E FUNCIONALIDADES DO SISPSA}

O SISPSA é um sistema Web cujo objetivo principal é auxiliar as prestadoras de serviço de controle da qualidade e distribuição de água para o consumo humano no 
processo de implantação do Plano de Segurança da Água, regulamentado e recomendado pela Organização Mundial de Saúde (OMS).

As funcionalidades do SISPSA são subdivididas em módulos de usuários com diferenciação de responsabilidades, papéis e restrições de acesso, disponibilizando uma gama de tarefas e procedimentos, tais como o preenchimento de formulários pertinentes às etapas de execução do PSA, a definição de cronograma de atividades, a distribuição de responsabilidades para os integrantes da equipe constituinte, o gerenciamento de envio e recebimento de mensagens, a identificação de eventos perigosos e caracterização de riscos, bem como a proposição de medidas de controle, monitoramento operacional e a geração automática de relatórios.

O SISPSA possui uma resolução máxima horizontal de 1024*768 pixels e apresenta um disposição e navegação nos menus e botões de funcionalidades de forma bem simplificado, conforme descrito na Tabela 1. A plataforma apresenta os seguintes elementos de navegação: i) Menu principal; ii) Menus secundários; ii) Botões funcionalidades especiais; e, v) Botões de navegação nos formulários.

\begin{tabular}{c|l}
\hline Título & \multicolumn{1}{c}{ Funcionalidade } \\
\hline Início & Acesso ao conteúdo principal de apresentação do sistema. \\
\hline Tabelas Básicas & Acesso ao conteúdo explicativo sobre as Tabelas Básicas \\
\hline Cadastro do SAA & $\begin{array}{l}\text { Acesso ao conteúdo explicativo sobre o Cadastro do Sistema de } \\
\text { Abastecimento de Água }\end{array}$ \\
\hline Etapas do PSA & $\begin{array}{l}\text { Acesso ao conteúdo explicativo sobre as Etapas do Plano de } \\
\text { Segurança da Água }\end{array}$ \\
\hline Relatórios & Acesso ao conteúdo explicativo sobre os relatórios do sistema. \\
\hline Fazer Login & Acesso à página de Login. \\
\hline Contato & Acesso à página com informações para contato. \\
\hline Ajuda & Acesso à documentação de Ajuda.
\end{tabular}

Tabela 1: Funcionalidades do SISPSA.

Fonte: Autores.

A Figura 1 mostra o layout básico de navegação e conteúdo presente em cada um dos módulos, separando em sessões seus elementos principais e mais relevantes através das linhas vertical e horizontal. 


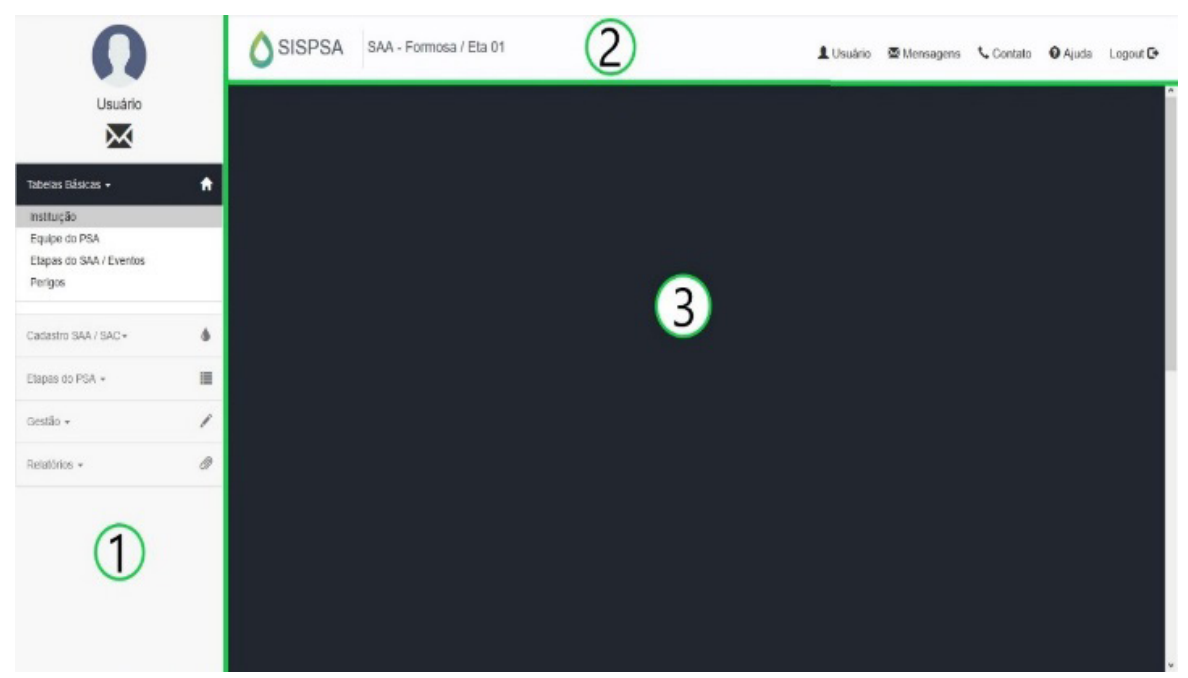

Figura 1: Layout básico de navegação e conteúdo do SISPSA.

Fonte: Autores.

A sessão 1 refere-se ao menu principal localizado lateralmente no canto esquerdo, através do qual é possível acessar as demais páginas e funcionalidades disponíveis para o perfil do usuário em questão. A sessão 2 identifica o cabeçalho situado na parte superior da página onde ficam disponíveis as opções de administração da conta, gerenciamento de envio e leitura de mensagens, acesso à documentação de ajuda e realização de logout do sistema. A sessão 3 identifica a área responsável por exibir formulários e funcionalidades, cujo conteúdo é alterado apenas quando solicitado pelo usuário através do menu principal, que dá acesso à página seguinte e pode sofrer alterações a partir da resposta de alguma ação ou comando.

O SISPSA exige a realização do cadastramento somente da equipe técnica instituída no PSA. A seleção da equipe técnica consiste na identificação de um grupo multidisciplinar com a finalidade de elaboração, implantação e avaliação do PSA. A seleção da equipe pode ser dividida conforme o cargo e responsabilidade de cada integrante, a hierarquia dos cargos segue a ordem: coordenador geral, diretor, técnico e colaborador.

O SISPSA foi concebido aos usuários com as seguintes responsabilidades: i) Coordenador (Permissão de alteração e cadastramento das Tabelas Básicas); ii) Diretor e técnico (Acesso a solicitação de inclusão de alteração da Tabela Básica) e iii) Colaborador (Somente leitura sem alteração).

As Tabelas Básicas (Tabela 1) tem como objetivo cadastrar armazenar informações técnicos para o desenvolvimento do PSA, como as instituições responsáveis pelo Sistema de Abastecimento de Água (SAA) e Solução Alternativa Coletiva (SAC), a equipe técnica responsável pela elaboração do PSA com suas respectivas responsabilidades, as etapas/ 
partes constituintes do SAA, (tipos de tecnologias), e eventos perigosos e os perigos. Para cada parte constituinte cadastrada deve-se incluir os seus respectivos "Eventos Perigosos", que se refere à determinada situação, ou incidente, que pode levar à presença de perigo (o que pode ocorrer e como). Essas tabelas são de preenchimento obrigatório e devem ser preenchida antes do cadastro do SAA que será implantado o PSA.

A Figura 2 apresenta as telas de Cadastro do Sistema de Abastecimento de Água no SISPSA, que tem como finalidade cadastrar o tipo de modalidade do sistema (SAA ou SAC), as localidades abastecidas, ou seja, os nomes das áreas do município abastecidas pelo SAA, os tipos de mananciais de captação (superficial ou subterrâneo), bem como o quantitativo de Estação de Tratamento de Água - ETA.

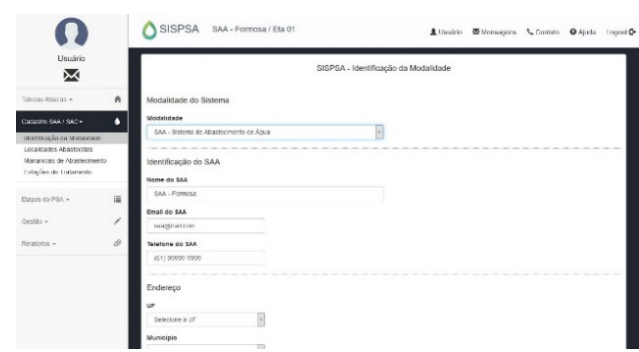

a) Cadastro da modalidade do SAA ou SAC

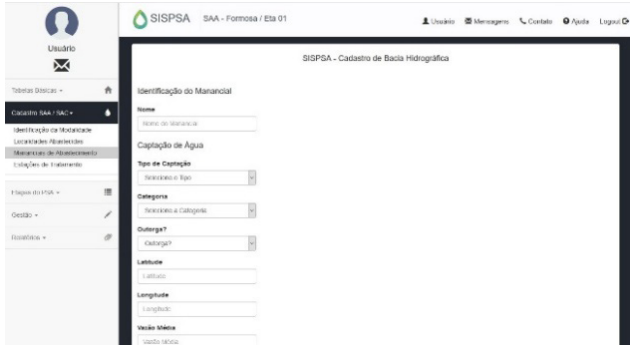

d) Tipos de mananciais abastecidos pelo SAA ou SAC e as informações

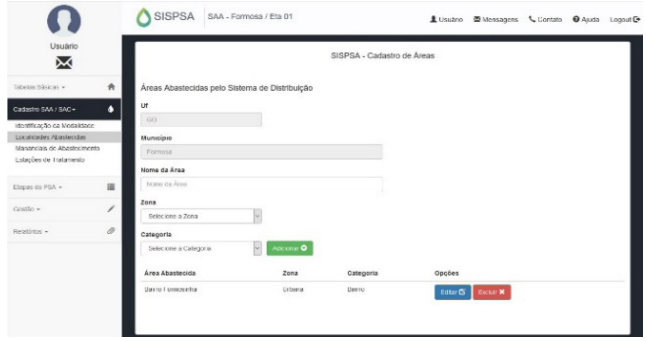

b) Localidade do SAA ou SAC

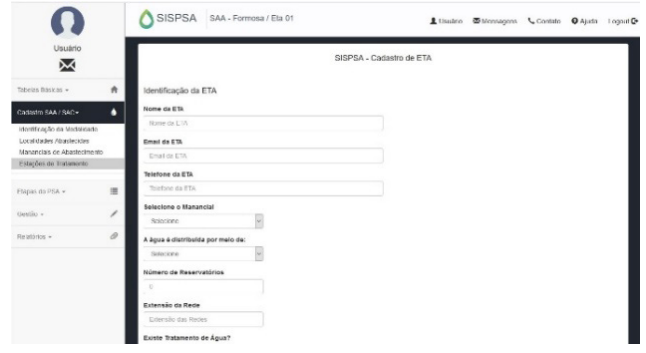

e) Quantitativo e as informações sobre as características da ETA

Figura 2: Telas de cadastro do sistema de abastecimento de água no SISPSA.

Fonte: Autores.

A próxima etapa, trata das etapas necessárias para elaboração do PSA, que foram concebidas em consonância com as diretrizes da OMS, MS e a utilização da Matriz de Priorização de Riscos validada por Bezerra (2018), conforme apresentada no Quadro 2. 


\begin{tabular}{|c|c|c|c|c|c|c|}
\cline { 3 - 7 } \multicolumn{2}{c|}{} & \multicolumn{5}{c|}{ Severidade } \\
\hline \multirow{2}{*}{$\begin{array}{c}\text { Frequência } \\
\text { Muito Baixa }\end{array}$} & 1 & 2 & 4 & 8 & 16 \\
\cline { 3 - 7 } & Baixa & Moderada & Elevada & Crítica & \\
\hline 4 & $\begin{array}{c}\text { Diária a } \\
\text { semanalmente }\end{array}$ & $\begin{array}{c}\text { Baixo } \\
(5)\end{array}$ & $\begin{array}{c}\text { Moderado } \\
(10)\end{array}$ & $\begin{array}{c}\text { Alto } \\
(20)\end{array}$ & $\begin{array}{c}\text { Alto } \\
(40)\end{array}$ & $\begin{array}{c}\text { Extremo } \\
\text { Plano de } \\
\text { Emenergência }\end{array}$ \\
\hline 3 & $\begin{array}{c}\text { Semestral a } \\
\text { anual }\end{array}$ & $\begin{array}{c}\text { Baixo } \\
(4)\end{array}$ & $\begin{array}{c}\text { Moderado } \\
(8)\end{array}$ & $\begin{array}{c}\text { Alto } \\
(16)\end{array}$ & $\begin{array}{c}\text { Alto } \\
(32)\end{array}$ & $\begin{array}{c}\text { Extremo } \\
\text { Plano de } \\
\text { Emergência }\end{array}$ \\
\hline 2 & $\begin{array}{c}\text { Acima de um } \\
\text { ano ate 5 anos }\end{array}$ & $\begin{array}{c}\text { Baixo } \\
(2)\end{array}$ & $\begin{array}{c}\text { Moderado } \\
(6)\end{array}$ & $\begin{array}{c}\text { Moderado } \\
(12)\end{array}$ & $\begin{array}{c}\text { Alto } \\
(24)\end{array}$ & $\begin{array}{c}\text { Extremo } \\
\text { Plano de } \\
\text { Emergência }\end{array}$ \\
\hline 1 & $\begin{array}{c}\text { Acima de 5 } \\
\text { anos }\end{array}$ & $\begin{array}{c}\text { Baixo } \\
(1)\end{array}$ & $\begin{array}{c}\text { Moderado } \\
(8)\end{array}$ & $\begin{array}{c}\text { Alto } \\
(16)\end{array}$ & $\begin{array}{c}\text { Extremo } \\
\text { Plano de } \\
\text { Emergência }\end{array}$ \\
\hline & $(2)$ & $\begin{array}{c}\text { Baixo } \\
(4)\end{array}$ & $\begin{array}{c}\text { Moderado } \\
(8)\end{array}$ & $\begin{array}{c}\text { Extremo } \\
\text { Plano de } \\
\text { Emergência }\end{array}$ \\
\hline
\end{tabular}

Legenda:

\begin{tabular}{|c|c|c|}
\hline \multicolumn{2}{|c|}{ Nível Descritor } & Significado da Severidade \\
\hline 1 & $\begin{array}{l}\text { Muito } \\
\text { Baixa }\end{array}$ & Sem impacto detectável. \\
\hline 2 & Baixa & $\begin{array}{l}\text { Impacto sobre a qualidade estética ou organoléptica da água, sem } \\
\text { causar rejeição da água, podendo ser mitigado em etapa seguinte do } \\
\text { sistema de abastecimento de água. }\end{array}$ \\
\hline 3 & Moderada & $\begin{array}{l}\text { Impactos com risco moderado à saúde, abaixo do padrão de } \\
\text { potabilidade, podendo ser mitigado em etapa(s) seguinte(s) do sistema } \\
\text { de abastecimento de água. }\end{array}$ \\
\hline 4 & Elevada & $\begin{array}{l}\text { Impactos com risco elevado à saúde, acima do padrão de potabilidade, } \\
\text { que não podem ser mitigados em etapa(s) seguinte(s) do sistema de } \\
\text { abastecimento. }\end{array}$ \\
\hline 5 & Crítica & $\begin{array}{l}\text { Impactos com risco extremo à saúde, acima do padrão de potabilidade, } \\
\text { com interrupção do fornecimento de água e necessidade de execução } \\
\text { de plano de contingência. }\end{array}$ \\
\hline \multicolumn{3}{|c|}{ Análise do Risco: } \\
\hline \multicolumn{3}{|c|}{$\begin{array}{l}\text { Risco Baixo } 5 \text { : Risco baixo } \\
\text { Risco Moderado } 6 \text { a 12: Risco tolerável } \\
\text { Risco Alto } 16 \text { a } 40 \text { : Risco não tolerável } \\
\text { Risco Extremo: Risco não tolerável, necessidade de adoção imediata de plano de } \\
\text { emergência. }\end{array}$} \\
\hline
\end{tabular}

Quadro 2: Matriz Semiquantitativa de Priorização de Risco validada.

Fonte: Autores.

As etapas adotadas contemplam a definição do cronograma de trabalho, a constituição da equipe técnica, a descrição do SAA ou SAC, a definição do diagrama de fluxo, a identificação de eventos, a caracterização de riscos, o monitoramento operacional e os planos de gestão. 
O cronograma de execução das principais atividades para implantação do PSA diz respeito à organização cronológica das atividades a serem desempenhadas pela equipe de implantação ao longo dos meses. Esse cronograma deve ser elaborado conforme a situação de cada SAA ou SAC. A Figura 3a e 3b apresenta um exemplo de cronograma gerado pelo SISPSA.

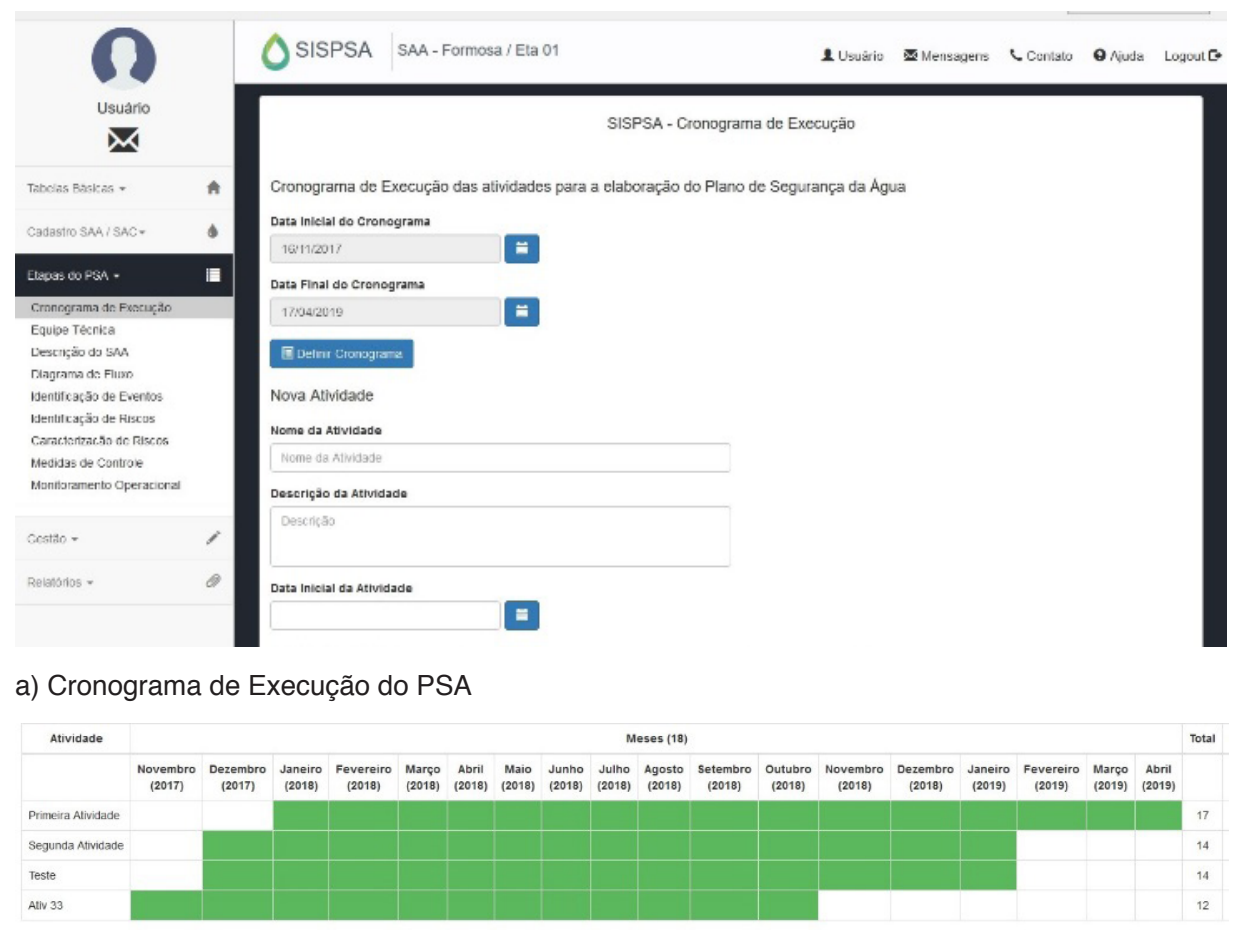

b) Modelo gerado de cronograma do SISPSA

Figura 3: Cronograma de Execução do PSA (a) e modelo de cronograma gerado no SISPSA (b).

Fonte: Autores.

A próxima etapa de elaboração do PSA, trata da constituição da equipe técnica. Na página do SISPSA fica à disposição do usuário a lista dos participantes da equipe técnica, permitindo a delegação das responsabilidades de cada usuário de forma individual. Clicando no link "Responsabilidades" é aberta uma caixa de texto para definição textual da responsabilidade do participante selecionado. A etapa de descrição e avaliação do sistema tem a finalidade de realizar avaliação sistemática do sistema de abastecimento de água, sob a perspectiva dos riscos à saúde humana, com base na ocupação da bacia contribuinte a zona de captação, no histórico das características de suas águas, nas características 
físicas do sistema, nas práticas operacionais e na qualidade da água distribuída. No SISPSA o usuário deve descrever textualmente cada uma das etapas vinculadas à ETA e ao SAA como um todo. Selecionando a etapa no campo de seleção e digitando o texto no campo específico. A definição do diagrama de fluxo do SAA ou SAC prevê a construção simples das etapas do fluxo do sistema, desde a bacia hidrográfica até a distribuição final. O fluxograma do sistema de abastecimento de água deve ser elaborado de uma forma fiel ao estado que se encontra o sistema, além de contemplar todos os itens da infraestrutura física. A validação do fluxo foi realizada por meio de: i) verificação da abrangência das etapas, ii) correção dos elementos constantes no diagrama e iii) confirmação do diagrama in-loco.

A etapa seguinte tem como objetivo identificar os eventos perigosos, ou seja, as possíveis causas de contaminação, onde e quando? Como pode acontecer em cada etapa do sistema de abastecimento (bacia hidrografia contribuinte a captação, zona de captação, estação de tratamento de água sistema de distribuição) e associá-las aos respectivos perigos (Figura 4).

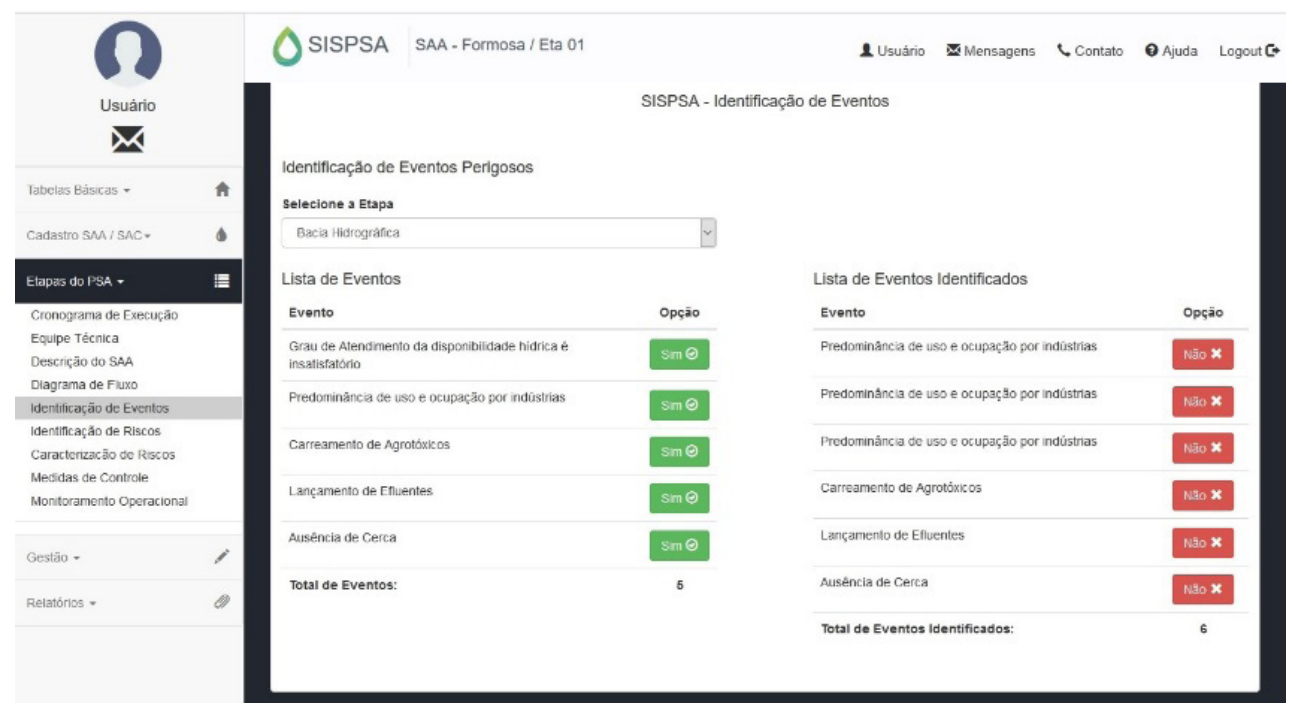

Figura 4: Identificação dos eventos perigosos do sistema de abastecimento de água.

Fonte: Autores.

Após a identificação dos eventos perigosos e seus respectivos perigos, em cada etapa do sistema de abastecimento de água para consumo humano, os mesmos devem ser avaliados e caracterizados os riscos, conforme a metodologia de caracterização de riscos. O risco é calculado no SISPSA (Figura 5) por meio da multiplicação da frequência do evento/perigo (valores variam entre 1: Acima de 5 anos, 2: Acima de um até 5 anos, 
3: Semestral a Anual, 4: Quinzenal a Mensal e 5: Diária a semanalmente) e função da severidade (valores variam entre 1: Muito Baixa, 2: Baixa, 4: Moderada, 8: Elevada, 16: Crítica). Esse cálculo é realizado para todos os eventos identificados em cada etapa do SAA ou SAC e o nível de risco varia de baixo, moderado, alto e extremo, conforme descrito no Quadro 3. Cada risco deve ser fundamentado com base na avaliação do risco.

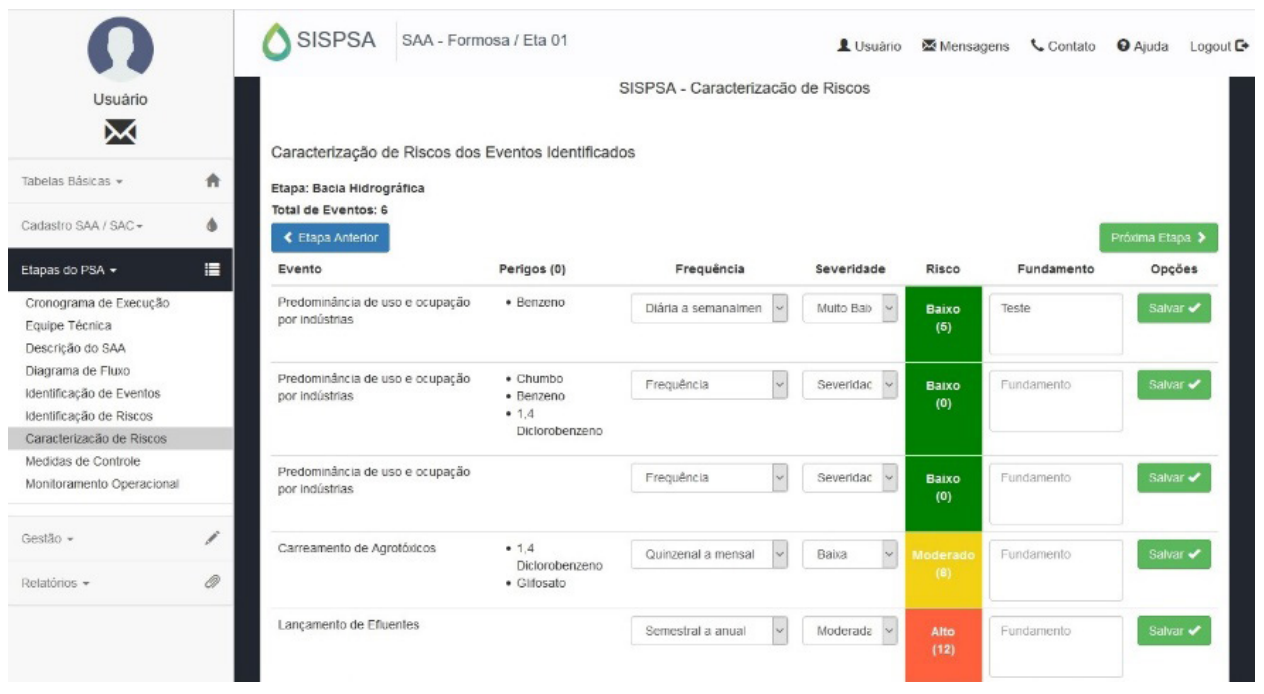

Figura 5: Caracterização dos riscos no SAA.

Fonte: Autores.

\begin{tabular}{|c|c|l|c|}
\hline Condição & Descritor & Tolerância & Cor \\
\hline Se $\mathrm{R} \leq 5$ & Risco Baixo & Tolerável & Amarelo \\
\hline Se $R \geq 6$ e $\mathrm{R} \leq 12$ & Risco Moderado & $\begin{array}{l}\text { Tolerável necessita de } \\
\text { medidas de controle }\end{array}$ & Laranja \\
\hline Se $\mathrm{R} \geq 16$ e $\mathrm{R} \leq 40$ & Risco Alto & Não Tolerável & Vermelho \\
\hline Se $\mathrm{R}>40$ & Risco Extremo & $\begin{array}{l}\text { Não Tolerável, necessidade de } \\
\text { adoção imediata de plano de } \\
\text { contingência }\end{array}$ \\
\hline
\end{tabular}

Quadro 3: Nível de risco.

Fonte: Autores.

Para cada risco classificado como moderado a alto deve-se propor medidas de controle. O monitoramento operacional tem a finalidade de monitorar os perigos identificados como significativos e eliminá-los em nível aceitáveis ou reduzi-los por meio de uma ou mais ações preventivas. Essa etapa consta de dois passos: i) estabelecimentos dos limites críticos e ii) estabelecimentos das medidas corretivas (Figura 6). 
A Etapa de Gestão do Sistema tem a finalidade de documentar todas as etapas anteriores, além de prever a verificação periódica de adesão ao PSA e de sua eficácia, além de estratégias de comunicação, que vai desde os procedimentos de rotina e emergências.

Os relatórios têm como finalidade extrair as informações necessárias para avaliação geral da implantação e funcionamento do PSA. O sistema permite extrair os Relatório de Riscos, Relatório do Protocolos e Relatório de Procedimento Operacional e Relatório do PSA.

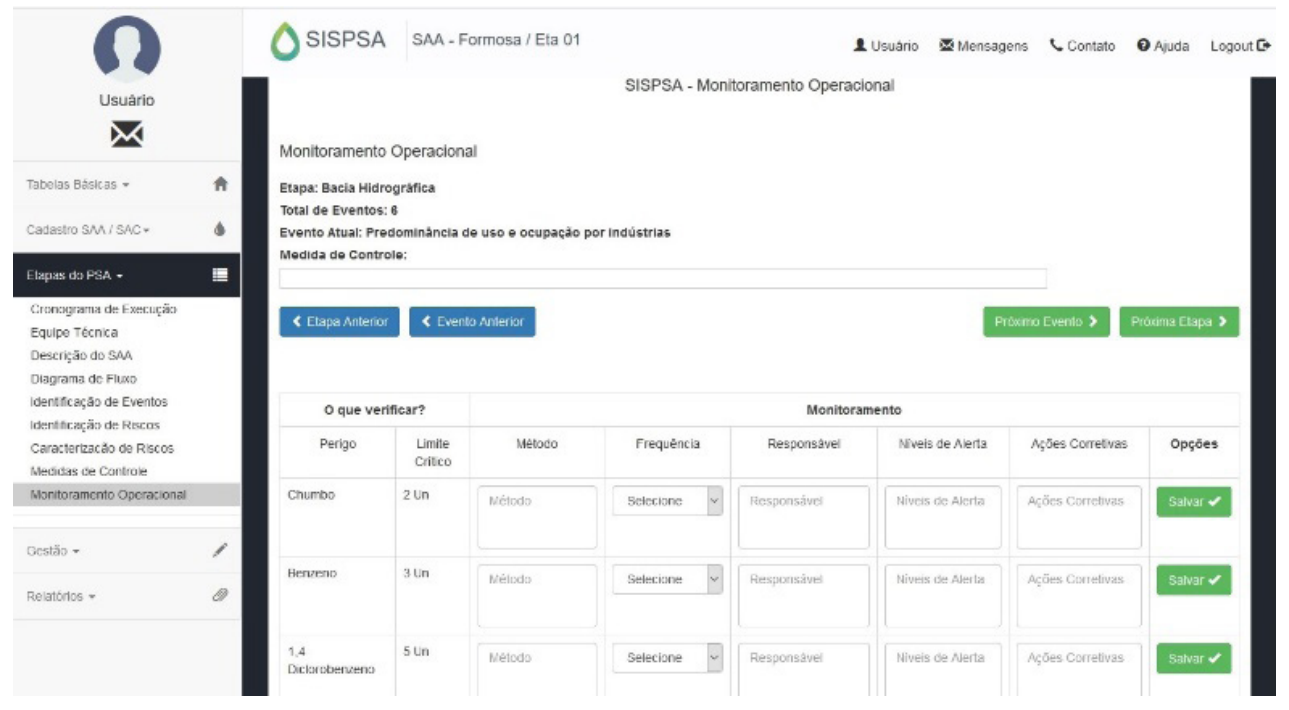

Figura 6: Monitoramento operacional.

Fonte: Autores.

\section{I CONSIDERAÇÕES FINAIS}

Cabe destacar, que o desenho gráfico do SISPSA foi concebido para esta primeira versão de forma bem simplificada, desta forma, recomenda-se que posteriormente, o mesmo seja atualizado por um profissional gráfico. Devido à grande variedade de dispositivos, optou-se por usar apenas HTML, CSS e JAVASCRIPT no "desenho" e apresentação gráfica das páginas da plataforma no navegador. O desenvolvimento de uma solução tecnológica completa para implantação do PSA envolve o desenvolvimento de uma ferramenta capaz de executar a computação necessária para a metodologia escolhida. Como resultado parcial foi obtido um protótipo prático de implantação do PSA, face às disposições da Portaria de Potabilidade e diretrizes da Organização Mundial de Saúde. 


\section{REFERÊNCIAS}

ABNT - ASSOCIAÇÃO BRASILEIRA DE NORMAS TÉCNICAS. ABNT NBR ISO; IEC:31010, Gestão de riscos - Técnicas para o processo de avaliação de riscos. 1. ed. Rio de Janeiro: ABNT, 2012. $96 \mathrm{p}$.

Bezerra, N. R. Aplicação da técnica Delphi para validação dos métodos a serem utilizados no sistema em plataforma web para implantação de Plano de Segurança da Água. Revista Eletrônica de Gestão e Tecnologias Ambientais, v. 6, n. 1, p. 29-40, 2018. doi:http://dx.doi.org/10.9771/gesta.v6i1.21957

BRASIL. Portaria de Consolidação $n^{\circ}$ 05, de 03 de outubro de 2017. Estabelece os procedimentos e responsabilidades relativos ao controle e vigilância da qualidade da água para consumo humano e seu padrão de potabilidade. Ministério da Saúde, Brasília, série E, 2017. Publicação № 190 - DOU de 03/10/17 - Seção 1 - Suplemento. p.360.

BRASIL. Ministério da Saúde. Secretaria de Vigilância em Saúde. Departamento de Vigilância em Saúde Ambiental e Saúde do Trabalhador. Plano de segurança da água: garantindo a qualidade e promovendo a saúde: um olhar do SUS. Ministério da Saúde, Secretaria de Vigilância em Saúde, Departamento de Vigilância em Saúde Ambiental e Saúde do Trabalhador. - Brasília: Ministério da Saúde, 2012. 60 p.

DEBASTIANI, C. A. Definindo Escopo em Projetos de Software. São Paulo: Novatec, 2015.

ELMASRI, R.; NAVATHE, S. B. Fundamentals of database systems. 7. Ed. [S.I.]: Pearson Addison Wesley, 2016. $1272 \mathrm{p}$.

WORLD HEALTH ORGANIZATION (WHO). Guidelines for drinking-water quality. 4. ed. WHO chronicle, v. 38, p. 104-108, 2011. 


\section{CAPÍTULO 17 \\ SISTEMA WEB PARA ESTIMATIVA DE EVAPOTRANSPIRAÇÃO POTENCIAL POR DIFERENTES MÉTODOS}

Data de aceite: 04/01/2021

\section{Lucas Moraes dos Santos}

Universidade de Caxias do Sul Caxias do Sul, Brasil http://lattes.cnpq.br/6515220284220218 https://orcid.org/0000-0003-4214-1576

Taison Anderson Bortolin

Universidade de Caxias do Sul

Caxias do Sul, Brasil http://lattes.cnpq.br/4843516980586649 https://orcid.org/0000-0003-0905-5684

Adriano Gomes da Silva Universidade de Caxias do Sul Caxias do Sul, Brasil http://lattes.cnpq.br/9796517738655066 https://orcid.org/0000-0003-1548-9104

Vania Elisabete Schneider Universidade de Caxias do Sul Caxias do Sul, Brasil http://lattes.cnpq.br/9940289333509769 https://orcid.org/0000-0001-8217-3607

RESUMO: Um dos parâmetros do ciclo hidrológico que possui grande influência na gestão da água e na produção agrícola é a evapotranspiração. Encontrar formas de repor essa quantidade de água perdida, ao solo, é essencial, seja a partir das chuvas ou das técnicas de irrigação. Em geral, para determinar a evapotranspiração são utilizados métodos indiretos, destacando-se o de Penman-Monteith. No entanto, o método necessita de um grande número de variáveis sendo necessária a utilização de outros métodos indiretos, menos exigentes em relação aos dados requeridos. Devido a uma grande quantidade de métodos para serem comparados é interessante fazer o uso de ferramentas computacionais que permitam automatizar estes cálculos. Diante do problema, vislumbrou-se o desenvolvimento de uma aplicação web que efetua o cálculo da evapotranspiração de referência (ETo) de forma automatizada, a partir de diversos métodos matemáticos encontrados na literatura. O sistema dispõe ao usuário, resultados da ETo diária $(\mathrm{mm} / \mathrm{mes})$ para um determinado período de tempo, bem como a média diária $(\mathrm{mm} /$ mes), para o mês, e mensal $(\mathrm{mm} / \mathrm{mes})$, para determinado mês durante o período de alguns anos, utilizando dados atualizados oriundos de estações meteorológicas operadas pelo INMET. A aplicação facilita o processo de cálculo minimizando o tempo de estimativa e contribuindo à análise dos resultados pelo usuário.

PALAVRAS-CHAVE:

Evapotranspiração.

Automatização. Web.

\section{WEB SYSTEM FOR ESTIMATION OF EVAPOTRANSPIRATION POTENTIAL BY DIFFERENT METHODS}

ABSTRACT: One of the parameters of the hydrological cycle that has great influence in water management and agricultural production is evapotranspiration. Finding ways to restore this amount of lost water to the ground is essential, whether from rain or irrigation techniques. In general, indirect methods are used to determine evapotranspiration, especially Penman-Monteith. However, the method requires a large number 
of variables, requiring the use of other indirect methods, less demanding in relation to the required data. Due to a great number of methods to be compared it is interesting to make use of computational tools that allow to automate these calculations. In the face of the problem, the development of a web application that calculates the reference evapotranspiration (ETo) in an automated way, from the several mathematical methods found in the literature, was glimpsed. The system provides the user with daily ETo results ( $\mathrm{mm} / \mathrm{month}$ ) for a given period of time, as well as the daily average ( $\mathrm{mm} /$ month), for the month, and monthly ( $\mathrm{mm} / \mathrm{month}$ ) for a given month during the period, using up-to-date data from INMET-operated weather stations. The application facilitates the calculation process minimizing the estimation time and contributing to the analysis of the results by the user.

KEYWORDS: Evapotranspiration. Automation. Web.

\section{I INTRODUÇÃO}

A evapotranspiração (ET) é um elemento importante do ciclo hidrológico e as possíveis tendências neste processo, entre outras coisas, podem influenciar a gestão da água e a produção agrícola (MAČEK et al, 2018). A evapotranspiração pode ser considerada como um dos fatores mais importantes para indicar a mudança climática em bacias hidrográficas, uma vez que influencia tanto no escoamento superficial quanto no armazenamento de água na bacia (CANNAROZZO et al., 2006; LIU et al., 2008).

A ET é controlada e influenciada por diferentes fatores: temperatura média diária, velocidade dos ventos, umidade relativa, balanço de energia, demanda atmosférica, suprimento de água do solo às plantas e pelas características fisiológicas das plantas (MENDONÇA et al., 2003; PEREIRA et al., 2009, YANG et al., 2011, WANG et al., 2014). Em geral, é mais comum trabalhar com a evapotranspiração potencial (EPT), a qual pode ser definida como a taxa na qual a evapotranspiração (ET) ocorreria em uma grande área coberta completa e uniformemente com vegetação em crescimento, com acesso ilimitado a água, sem efeitos de advecção ou aquecimento (MCVICAR et al., 2012; MCMAHON et al., 2013).

Em função da dificuldade para realizar as medições diretas, a aplicação dos métodos indiretos tem se tornado uma ferramenta em potencial para a determinação da evapotranspiração (SULEIMAN e HOOGENBOOM, 2007, MOURA et al. 2013, PAIVA et al., 2016). Os métodos indiretos são utilizados para estimar a transferência de vapor d'água para a atmosfera em condições climáticas específicas, no entanto, poucos têm sido adaptados para situações climáticas distintas daquelas que Ihes deram origem.

Existem diversos métodos para estimar a evapotranspiração, entre eles alguns baseados somente na temperatura, como o de Thornthwaite e outros baseados também na radiação solar, como o de Makkink e Jensen-Haise. Destaca-se ainda o método de Penman-Monteith, recomendado pela FAO (Food and Agriculture Organization of the United Nations) e utilizado para a calibração de outros métodos (ALLEN et al., 1998). No entanto, em alguns casos, o uso do método de Penman-Monteith é restrito pela falta de 
algumas variáveis de entrada, sendo necessária a utilização de outros métodos indiretos, menos exigentes em relação aos dados requeridos (GONÇALVES et al., 2009; PALARETTI et al., 2014; CRUZ, 2016; JÚNIOR et al., 2017). Diferentes autores recomendam que antes de aplicar um método para determinada região, é necessário verificar o desempenho deste e, se necessário, fazer calibrações com o objetivo de minimizar os erros de estimativa (LEITÃO et al., 2007; PEREIRA et al., 2009; PILAU et al., 2012).

Entretanto, considerando as dificuldades de processamento de dados e uma gama muito grande de métodos para serem comparados é interessante utilizar ferramentas computacionais que permitam automatizar estes cálculos contribuindo para uma análise mais eficaz da evapotranspiração em determinada região. Diferentes softwares podem ser encontrados na literatura, geralmente utilizando apenas o método de Penman-Montheit para estimativa de evapotranspiração (GOCIC e TRAKKOVIC, 2010; FEITOSA et al., 2014; DANLU et al., 2017).

Com base no exposto, este trabalho tem por objetivo apresentar o desenvolvimento de uma aplicação web que visa automatizar o processo do cálculo de evapotranspiração potencial.

\section{I MATERIAIS E MÉTODOS}

O presente trabalho utilizou uma versão modificada da metodologia de desenvolvimento conhecida por Processo Unificado (PU), que sugere uma abordagem para modelagem e construção de software através de iterações curtas com resultados testáveis (LARMAN, 2007). Para modelar a aplicação, empregou-se o conceito de representação abstrata de processos que tem por objetivo descrever de forma abstrata os processos que compõem o sistema (SOMMERVILLE, 2007). A aplicação está baseada no paradigma cliente/servidor no qual um processo no host local, denominado cliente, solicita serviços a outro processo, normalmente localizado em um host remoto, denominado servidor (FOROUZAN, 2008). O servidor, por sua vez, retorna os serviços requisitados ao cliente, no momento que o usuário interage com a aplicação (SOMMERVILLE, 2007).

Para desenvolvimento da aplicação web foi empregado o padrão de arquitetura de software MVC (Model-View-Controller) que utiliza o paradigma de programação orientada a objetos (POO), um padrão de desenvolvimento que subdivide o software em componentes dispostos como modelo, visão e controlador, permitindo melhor controle da qualidade do software, no que tange ao processamento dos dados e design de interface (HASAN e ISAAC, 2011).

Para o desenvolvimento programático do lado servidor (back-end) foi usada a linguagem de programação PHP (acrônimo recursivo para Hipertext Preprocessor), versão 7.0. O PHP caracteriza-se por ser uma linguagem de domínio específico (abrangendo o desenvolvimento web), cujo código é interpretado por um módulo PHP presente no lado 
servidor (PHP, 1995). No servidor, também é utilizada a linguagem de programação do préprocessador de texto Smarty Template Engine ${ }^{T m}$, para a geração e montagem dos templates dinâmicos (SMARTY TEMPLATE ENGINE, 2010).

No lado cliente (front-end) as interfaces de usuário da aplicação foram desenvolvidas utilizando a linguagem de marcação HTML5 (do Inglês Hypertext Markup Language, versão 5), de estilos CSS3 (do Inglês Cascading Style Sheets, versão 3) e de scripting JavaScript (JS), empregando componentes do framework web, de código-fonte aberto, Bootstrap para desenvolvimento do design das páginas (BOOTSTRAP, 2013). O CSS e o JavaScript foram utilizados para estilizar e aprimorar a navegação do usuário no site.

Algumas bibliotecas externas foram empregadas, dentre elas a OpenLayers para disponibilização do WebMapa interativo. A OpenLayers caracteriza-se por uma biblioteca modular javascript de alto desempenho e código aberto, com recursos para exibição e interação com mapas, além de permitir a manipulação de dados geoespaciais (OPENLAYERS, 2006). Outro fator que contribuiu à escolha da biblioteca foi devido a sua licença livre.

$\mathrm{Na}$ estruturação do banco de dados, foram desenvolvidos os Modelos Entidade Relacionamento (MER) e Diagramas Entidade - Relacionamento (DER) da aplicação, por meio do plugin ER Master de construção de DERs, disponível para o ambiente integrado de desenvolvimento Eclipse (ERMASTER, 2013). Para armazenar os dados meteorológicos oriundos das estações, foi empregado o gerenciador de banco de dados PostgreSQL.

O trabalho, por utilizar do PU e suas Fases, foi desenvolvido em quatro etapas: concepção, elaboração, construção e transição. A etapa de concepção abrangeu o levantamento bibliográfico e pesquisa sobre sistemas que possuem funcionalidades semelhantes aos do projeto proposto. A elaboração consistiu na especificação do sistema, com base nos requisitos levantados, bem como na modelagem dos dados. Na construção foi realizada a implementação do sistema, ou seja, a conversão dos modelos ER para um banco de dados, o emprego de linguagens de programação usadas para definição de estruturas de dados, geração de código e o desenvolvimento das interfaces de funcionalidade do sistema, empregando linguagens de programação usadas em desenvolvimento web. Por fim, na transição, houve a disponibilização do sistema ao usuário e avaliação dos resultados (SCHACH, 2010).

\subsection{Modelagem dos dados}

Modelos de dados são ferramentas que permitem demonstrar como serão construídas as estruturas de dados que darão suporte aos processos do sistema, como esses dados estarão organizados e quais relacionamentos pretende-se estabelecer entre eles (DEBASTIANI, 2015). Para obter os dados meteorológicos optou-se por utilizar o Sistema de Monitoramento Agrometeorológico (Agritempo), que tem como mantenedores a Embrapa Informática Agropecuária e o Centro de Pesquisas Meteorológicas e Climáticas 
Aplicadas à Agricultura, da Universidade Estadual de Campinas (Unicamp) (AGRITEMPO, 2002). A escolha do Agritempo foi motivada pelo fato do sistema conter mais parâmetros meteorológicos.

Cada conjunto de dados é formado por parâmetros meteorológicos medidos diariamente nas estações meteorológicas e assim discriminados: temperatura, umidade relativa do ar, precipitação, radiação solar, pressão atmosférica, direção e velocidade do vento, pontos de orvalho e disponibilidade de água do solo. Na conversão do DER em Linguagem de definição de dados (DDL - do inglês, Data Definition Language), as entidades passaram a ser representadas por tabelas e os atributos, por colunas. Estes dados foram diferenciados pelo identificador da estação correspondente em banco de dados. Se não existirem informações armazenadas em banco, para o período consultado pelo usuário, uma nova consulta ao Agritempo é realizada usando a data do último registro de dados armazenado em banco e a data solicitada como chave de busca. Assim o banco de dados estará atualizado.

\subsection{Modelagem da aplicação}

$\mathrm{Na}$ modelagem da aplicação foram desenvolvidas as estruturas base do padrão MVC (responsáveis pelo armazenamento e consulta dos dados), o controle das interações usuário-sistema, a renderização da página inicial e o núcleo de funcionalidades base do sistema. A partir destas estruturas, os dados meteorológicos puderam ser processados e armazenados em banco de dados, estando disponíveis ao usuário para posterior análise. Também foi realizado o desenvolvimento programático dos métodos matemáticos, empregados na estimativa de ETo.

Após a aplicação dos métodos matemáticos sobre os dados de estações meteorológicas consultados, são obtidos os resultados de ETo. Com vistas a possibilitar uma melhor exibição dos pontos das estações meteorológicas e interação com o mapa, empregou-se um WebMapa. Por fim, desenvolveu-se a gerência de usuários, responsável pelo cadastro de novos usuários ao sistema e controle de acesso a aplicação através de uma política de níveis de usuários.

\subsection{Construção}

Após a modelagem dos dados, desenvolveu-se a lógica responsável pelo controle das interações entre usuário e sistema, bem como o desenvolvimento programático dos métodos matemáticos. Conforme o uso do desenvolvimento iterativo proveniente do PU, optou-se por armazenar previamente uma faixa de dados meteorológicos em banco de dados e delegar à Controladora o gerenciamento da consulta ao Agritempo. Essa abordagem foi estabelecida após as consultas ao servidor externo tornarem-se demasiadamente lentas para longos períodos de tempo.

Inicialmente, a Controladora cria uma instância do Modelo, responsável pela 
conexão com o banco de dados, e do Visualizador que se encarrega de construir e apresentar a página inicial. A página inicial é composta por um formulário onde o usuário deverá inserir as informações necessárias de acesso ao sistema. Os elementos da página inicial são processados pelo componente Smarty. Este componente é utilizado no sistema por meio do Visualizador, que coleta os dados e ações em nível de execução do código PHP e, antes do retorno ao cliente da página .html, processa o .tpl e gera o arquivo .html. A Controladora, por sua vez, envia uma solicitação ao Modelo, contendo as informações do usuário encapsuladas junto à requisição ao servidor.

Cabe a Controladora também o gerenciamento do processo de consulta aos dados meteorológicos das estações, realizada por meio de um método POST. Cada consulta contém as informações do formulário (código identificador da estação e período da pesquisa) encapsuladas junto à requisição ao servidor externo. Com o retorno dos dados meteorológicos, a Controladora envia-os ao Visualizador que os apresenta ao usuário. Em seguida, o usuário deverá optar por um dos métodos matemáticos para estimar a ETo sobre os dados consultados. Atualmente, existe um total de 14 métodos matemáticos implementados para estimativa da ETo os quais são apresentados na Tabela 1.

\begin{tabular}{|c|c|}
\hline Método & Equação \\
\hline $\begin{array}{l}\text { Thornthwaite } \\
\text { (1948) }\end{array}$ & $\begin{array}{l}\text { ETo }=16 *\left(10 * \frac{T_{i}}{I}\right)^{a}, 0{ }^{\circ} \mathrm{C} \leq T_{i} \leq 26{ }^{\circ} \mathrm{C} \\
\text { ETo }=-415,85+32,24 T_{i}-0,43 T_{i}^{2}, T_{i}>26^{\circ} \mathrm{C} \\
I=\sum_{i=1}^{12}\left(0,2 T_{i}\right)^{1,514}, T_{i} \geq 0{ }^{\circ} \mathrm{C} \\
a=6,75 * 10^{-7} I^{3}-7,71 * 10^{-5} I^{2}+1,7912 * 10^{-2} I+0,49239 \\
C=\frac{N}{12} * \frac{1}{30} \quad N=\frac{2}{12} * \omega_{s} \\
\left.\cdot \text { ETo }=\text { Evapotranspiração de referência (mm mês }{ }^{-1}\right) ; \\
\cdot T_{\mathrm{i}}=\text { Temperátura do ar média mensal }\left({ }^{\circ} \mathrm{C}\right) ; \\
\cdot \mathrm{I}=\text { Índice térmico imposto pelo regime climático local; } \\
\cdot \mathrm{i}=\text { Representa o mês do ano (i=1, janeiro; } \ldots . . \mathrm{i}=12, \text { dezembro); } \\
\cdot \mathrm{N}=\text { Fotoperíodo (h) de determinado dia; }\end{array}$ \\
\hline $\begin{array}{l}\text { Thornthwaite } \\
\text { (1948) - } \\
\text { Modificado }\end{array}$ & $\begin{array}{l}T_{\theta f}=K *\left(T_{i}+A\right) \quad T_{e f}=0,5 k *\left(3 T_{\max }-T_{\min }\right) \\
T=\left(\frac{T_{\max }+T_{\min }}{2}\right) \quad A=T_{\max }-T_{\min } \\
\cdot{ }^{\mathrm{A}}=\text { Amplitude térmica diária; } \\
\cdot \mathrm{T}_{\text {max }}=\text { Temperatura máxima }\left({ }^{\circ} \mathrm{C}\right) ; \\
\cdot \mathrm{T}_{\min }=\text { Temperatura mínima }\left({ }^{\circ} \mathrm{C}\right) ; \\
\cdot \mathrm{k}=0,72 \text { e } \mathrm{k}=0,69\end{array}$ \\
\hline
\end{tabular}




\begin{tabular}{|c|c|}
\hline Método & Equação \\
\hline $\begin{array}{l}\text { Hargreave } \\
\text { Samani }\end{array}$ & 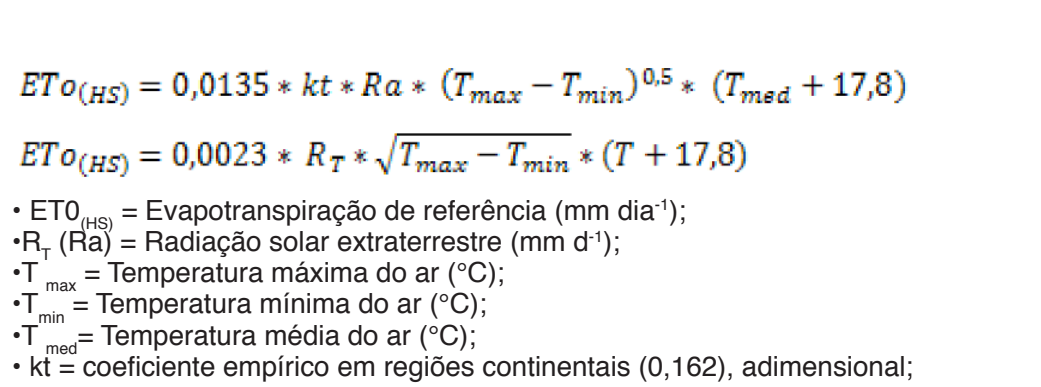 \\
\hline $\begin{array}{l}\text { Blaney - } \\
\text { Criddle }\end{array}$ & $\begin{array}{l}E T o_{(B C)}=a+b * f \\
f=p *(0,46 * T+8,13) \\
a=0,0043 * U R_{\min }-\frac{n}{N}-1,41 \\
b=a_{0}+a_{1} * U R_{\min }+a_{2} * \frac{n}{N}+a_{3} * u_{2}+a_{4} * U R_{\min } * \frac{n}{N}+a_{5} * U R_{\min } * u_{2} \\
\cdot \text { ETo } \\
\cdot \text { UR mín = Evapotranspiração de referência }\left(\mathrm{mm} \mathrm{d}^{-1}\right) ; \\
\cdot \mathrm{n}=\text { Insolação (h); } \\
\cdot \mathrm{N}=\text { Fotoperíodo }(\mathrm{h}) ; \\
\cdot \mathrm{p}=\text { Percentagem diária de horas de luz e varia em função da latitude e época do } \\
\text { ano; } \\
\cdot \mathrm{a}_{0}=0,8192 ; \mathrm{a}_{1}=-0,004092 ; \mathrm{a}_{2}=1,0705 ; \mathrm{a}_{3}=0,06565 ; \mathrm{a}_{4}=-0,005968 ; \mathrm{a}_{5}= \\
-0,000597 ;\end{array}$ \\
\hline Camargo & $\begin{array}{l}E T o_{(C A)}=R_{T} * T * K_{f} * N D \\
\cdot \text { ETo }_{(C A)}=\text { Evapotranspiração de referência }\left(\mathrm{mm} \mathrm{d}^{-1}\right) ; \\
\cdot \mathrm{R}^{\mathrm{T}}=\text { Radiação solar extraterrestre }\left(\mathrm{mm} \mathrm{d}^{-1} \text { de evapotranspiração equivalente); }\right. \\
\cdot \text { ND = Número de dias do período analisado; } \\
\cdot \mathrm{T}=\text { Temperatura do ar média }\left({ }^{\circ} \mathrm{C}\right) ; \\
\cdot \mathrm{k}_{f}=\dot{E} \text { um fator de ajuste que varia com a temperatura do ar média anual do local: } \\
\mathrm{k}_{f}=0,01 \text { para } \mathrm{T}<23^{\circ} \mathrm{C} ; \mathrm{k}_{f}=0,0105 \text { para } \mathrm{T}=24^{\circ} \mathrm{C} ; \mathrm{k}_{f}=0,011 \text { para } \mathrm{T}=25^{\circ} \mathrm{C} ; \\
\mathrm{k}_{f}=0,0115 \text { para } \mathrm{T}=26^{\circ} \mathrm{C} ; \mathrm{k}_{f}=0,012 \text { para } \mathrm{T}>26^{\circ} \mathrm{C} ;\end{array}$ \\
\hline $\begin{array}{l}\text { Jensen - } \\
\text { Haise }\end{array}$ & $\begin{array}{l}E T o_{(J H)}=R_{s} *(0,0252 * T+0,078) \\
E T o_{\circlearrowleft J H)}=R_{s} *\left(0,025 * T_{m e d}+0,08\right) \\
\cdot \mathrm{ETo}_{(J \mathrm{H})}=\text { Evapotranspiração de referência }\left(\mathrm{mm} \mathrm{d}^{-1}\right) ; \\
\cdot \mathrm{R}_{S}=\text { Radiação solar global convertida em unidades de água evaporada (mm dia } \\
\left.\cdot{ }^{-1}\right) ; \\
\mathrm{T}_{\text {med }}=\text { Temperatura diária média do } \operatorname{ar}\left({ }^{\circ} \mathrm{C}\right) ;\end{array}$ \\
\hline Makkink & $\begin{array}{l}\text { ETo }_{(M K)}=0,61 * W * R_{T}-0,12 \\
\cdot \mathrm{ETo}_{(\mathrm{MK})}=\text { Evapotranspiração de referência }\left(\mathrm{mm} \mathrm{d}^{-1}\right) \\
\cdot \mathrm{W}=\text { Fator de ponderação }\end{array}$ \\
\hline
\end{tabular}




\begin{tabular}{|c|c|}
\hline Método & Equação \\
\hline $\begin{array}{l}\text { Benavides - } \\
\text { Lopez (BL) }\end{array}$ & $\begin{array}{l}E T o_{(B L)}=1,21 * 10 *\left(\frac{7,45 * T_{\text {med }}}{234,7+T_{\text {med }}}\right) *(1-0,01 * U R)+0,21 * T_{\text {med }}-2,30 \\
\cdot \mathrm{ETo}_{(\mathrm{BL})}=\text { Evapotranspiração de referência }\left(\mathrm{mm} \mathrm{d}^{-1}\right) ; \\
\cdot \mathrm{T}_{\text {med }}=\text { Temperatura média do } \operatorname{ar}\left({ }^{\circ} \mathrm{C}\right) ; \\
\cdot \mathrm{UR}=\text { Umidade relativa do ar }(\%) ;\end{array}$ \\
\hline Hamon (HA) & $\begin{array}{l}E T O_{(H A)}=0,55 *\left(\frac{N}{12}\right)^{2} *\left(\frac{4,93 e^{\left(0,062 T_{\text {medi }}\right)}}{100}\right) * 25,4 \\
\cdot \mathrm{ETo}_{(\text {HA }}=\text { Evapotranspiração de referência }\left(\mathrm{mm} \mathrm{d}^{-1}\right) ; \\
\cdot \mathrm{N}=\text { Numero de horas de brilho solar possiveis (fotoperíodo); } \\
\cdot \mathrm{T}_{\text {med }}=\text { Temperatura média do ar }\left({ }^{\circ} \mathrm{C}\right) ;\end{array}$ \\
\hline $\begin{array}{l}\text { Priestley \& } \\
\text { Taylor (PT) }\end{array}$ & 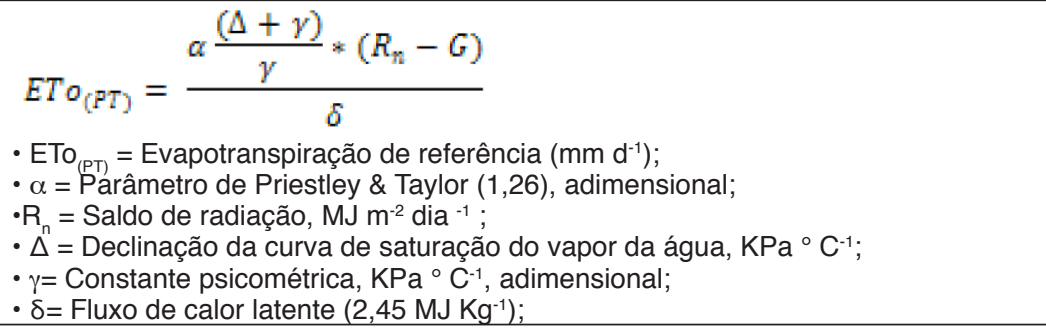 \\
\hline Turc (TU) & 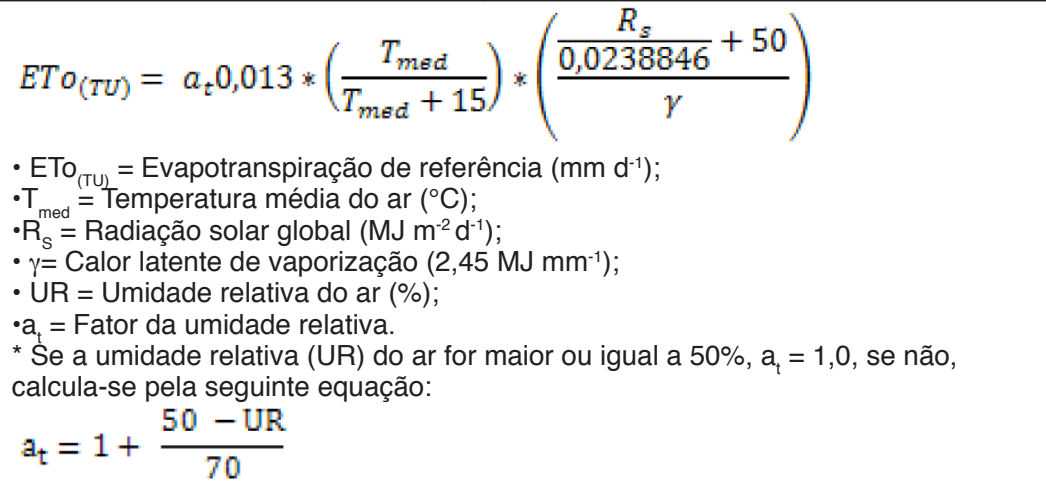 \\
\hline Linacre & $\begin{array}{l}E T o=\frac{500 *\left(\frac{T_{\text {med }}+0,006 * h}{100-\varphi}\right)+15 *\left(T_{\text {med }}-T_{p o}\right)}{80-T_{\text {med }}} \\
E T o=\frac{J *\left(\frac{T_{a}-0,006 * z}{100-\emptyset}\right)+15 *\left(T_{a}-T_{o}\right)}{80-T_{a}} \\
T_{p o}=\frac{237,3 * \log \left(e_{a}\right)-156,8}{8,16-\log \left(e_{a}\right)} \\
\cdot \mathrm{h}=\text { Altitude local (metros); } \\
\cdot \varphi=\text { Altitude em módulo (graus) } \\
\cdot \mathrm{T}_{\text {po }}=\text { Temperatura média do ponto de orvalho }\left({ }^{\circ} \mathrm{C}\right) ; \\
\cdot \mathrm{e}_{\mathrm{a}}=\text { Pressão do valor atual; } \\
\cdot \mathrm{z}=\text { Altitude (metros); } \\
\cdot \mathrm{T}_{\mathrm{a}}=\text { Temperatura média do ar }\left({ }^{\circ} \mathrm{C}\right) ; \\
\cdot \varnothing=\text { A latitude local (graus) } \\
\cdot \mathrm{T}_{0}=\text { Temperatura em ponto de orvalho }\left({ }^{\circ} \mathrm{C}\right) ; \\
\cdot J=\text { Constante igual a } 500 \text { para uma vegetação e } 700 \text { para uma superfície com } \\
\text { água livre, como um lago ou uma represa; }\end{array}$ \\
\hline
\end{tabular}




\begin{tabular}{|c|c|}
\hline Método & Equação \\
\hline Kharrufa & $\begin{array}{l}\text { ETo }=0,34 * p * T_{\text {med }}^{1,3} \\
\cdot p=\text { porcentagem do total do fotoperíodo e a temperatura do ar. } \\
\cdot \text { Tmed = temperatura média do ar }\end{array}$ \\
\hline $\begin{array}{l}\text { Penman- } \\
\text { Monteith }\end{array}$ & $\begin{array}{l}E T o=\frac{0,408 \Delta\left(R_{n}-G\right)+\gamma\left(\frac{900}{T+273}\right) \mu_{2}\left(e_{s}-e_{a}\right)}{\Delta+\gamma\left(1+0,34 \mu_{2}\right)} \\
\cdot E T_{o}=\text { evapotranspiração de referência (mm/dia); } \\
\cdot \mathrm{R}_{\mathrm{n}}=>\text { saldo de radiação }\left(\mathrm{MJ} / \mathrm{m}^{-2} \mathrm{dia}^{-1}\right) ; \\
\cdot \mathrm{G}^{-1} \Rightarrow>\text { fluxo de calor no solo }\left(\mathrm{MJ} \mathrm{m}^{-2} \mathrm{dia}^{-1}\right) ; \\
\cdot \mathrm{T}=>\text { temperatura média diária do ar }\left({ }^{\circ} \mathrm{C}\right) ; \\
\cdot \mu_{2}=>\text { velocidade média diária do vento a } 2 \mathrm{~m} \text { de altura }\left(\mathrm{m} \mathrm{s}^{-1}\right) ; \\
\cdot \mathrm{e}_{\mathrm{s}}=>\text { pressão de saturação do vapor média diária }(\mathrm{KPa}) ; \\
\cdot \mathrm{e}_{\mathrm{a}} \Rightarrow \text { pressão atual de vapor média diária }(\mathrm{KPa}) ; \\
\cdot \Delta \Rightarrow \text { declividade da curva de pressão de vapor }\left(\mathrm{kPa}{ }^{\circ} \mathrm{C} 1\right) ; \mathrm{e}, \\
\cdot \gamma \Rightarrow \text { constante psicométrica }\left(\mathrm{KPa}^{\circ} \mathrm{C}^{-1}\right) .\end{array}$ \\
\hline
\end{tabular}

Tabela 1 - Métodos para cálculo de evapotranspiração potencial

Fonte: Adaptado de Embrapa (2010)

AControladora envia uma instrução ao Modelo indicando quais métodos matemáticos devem ser executados. Cada método foi implementado programaticamente no Modelo que também se encarrega da consulta dos dados meteorológicos em banco de dados. Estes dados correspondem aos parâmetros meteorológicos específicos à execução de método selecionado. Sobre cada conjunto de dados estima-se a ETo e, posteriormente, os resultados obtidos são enviados à Controladora. Esta, por sua vez, envia-os ao Visualizador, para que este exiba as informações resultantes ao usuário.

Com vistas a obter parâmetros intermediários para estimativa da ETo, os quais não estão presentes no conjunto de dados advindos das estações meteorológicas, foram implementados métodos auxiliares para obtenção desses parâmetros. Dessa forma, reduz-se o problema da redundância de código pertinente a diversos métodos utilizando as mesmas variáveis, criando classes com domínios mais específicos. O diagrama de sequência de execução para o método matemático de Hargreaves-Samani (1985) é apresentado na Figura 1. 


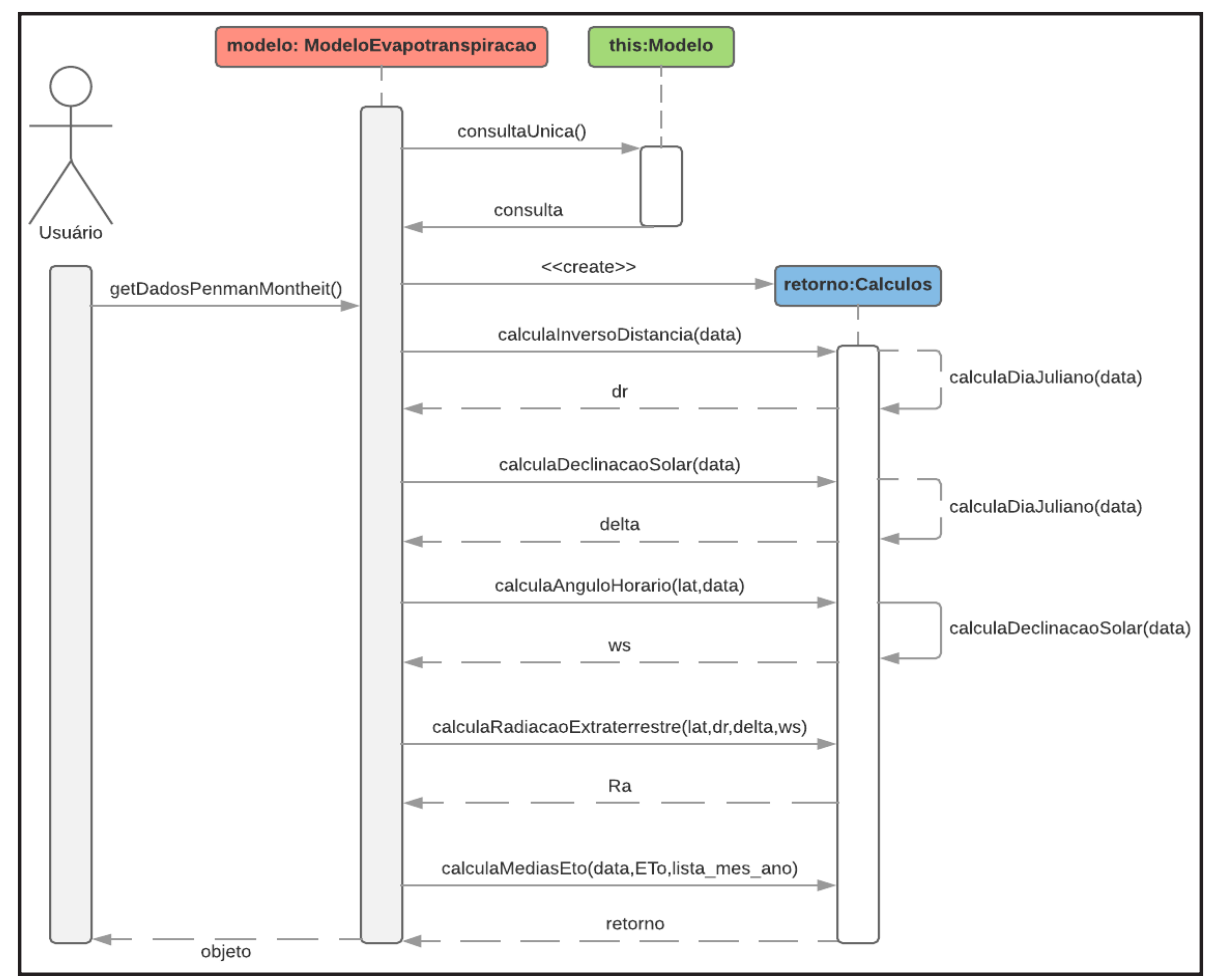

Figura 1 - Diagrama de sequência para o método de Hargreaves e Samani (1985)

Fonte: Elaborado pelo autor.

A gerência de usuários foi implementada com o intuito de manter o controle de quem acessa o sistema, bem como informações sobre qual instituição está utilizando a aplicação. O gerenciamento de usuários opera baseado em uma política de níveis de usuário onde o nível de usuário logado é o nível com menor acesso e o de administrador maior. O maior nível herda as funções do menor. $\mathrm{O}$ administrador tem a função de manter o controle dos usuários, podendo restringir o acesso, excluir contas, se necessário, etc. $\mathrm{O}$ usuário logado poderá consultar os dados meteorológicos, além de aplicar os métodos matemáticos sobre os dados consultados, obtendo as estimativas de ETo para o período consultado. A leitura das coordenadas do banco de dados e inserção dos pontos no mapa são realizadas utilizando javascript.

\section{I RESULTADOS E DISCUSSÕES}

Para acessar a aplicação, é necessária a realização de um cadastro prévio que conterá algumas informações tais como nome, usuário, endereço eletrônico, senha e instituição, necessárias ao registro do usuário a aplicação. $O$ acesso a aplicação pode ser realizado através do link https://siambiental.ucs.br/intermediador/. As informações para 
cadastro de usuário podem ser visualizadas na Figura 2.

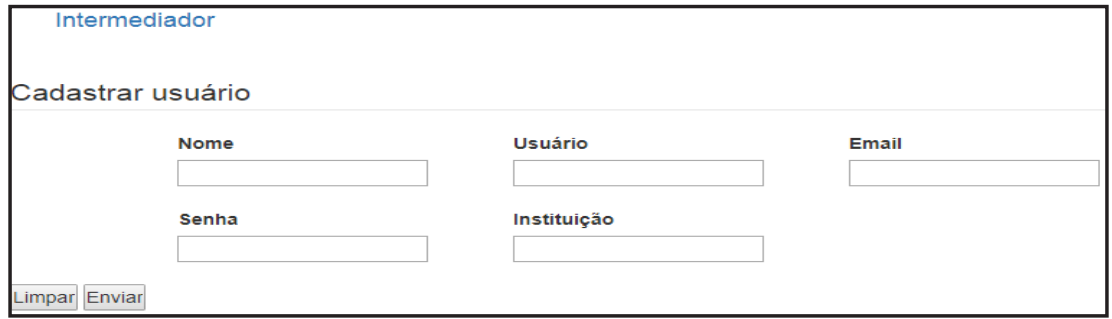

Figura 2 - Formulário de cadastro ao sistema

Fonte : Elaborado pelo autor.

A página de acesso à aplicação pode ser visualizada na Figura 3, onde o usuário deverá inserir suas informações de usuário e senha caso deseje utilizar do sistema.

\begin{tabular}{|l|l|}
\hline \multicolumn{1}{|c|}{ Intermediador } \\
Entrar no sistema \\
Usuário $\square$ Senha & Login \\
\hline
\end{tabular}

Figura 3 - Formulário de acesso ao sistema

Fonte: Elaborado pelo autor.

Os dados das estações meteorológicas podem ser consultados através de um WebMapa, ilustrado na Figura 4, onde as estações são representadas por meio de pontos. 


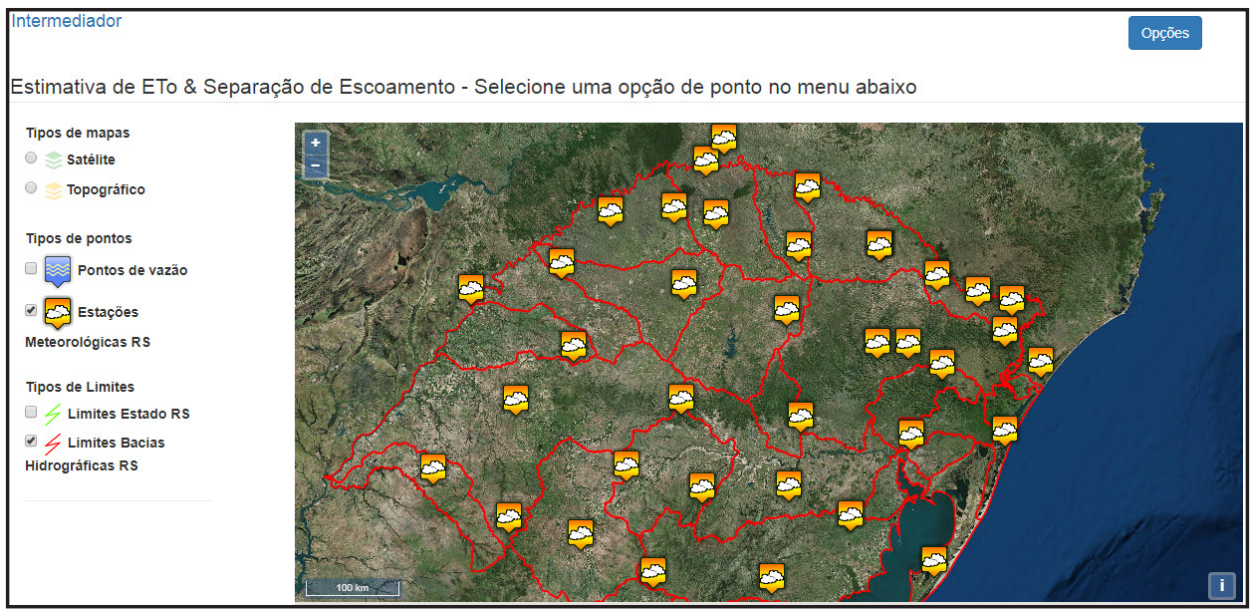

Figura 4 - WebMapa dispondo as estações meteorológicas do Estado do Rio Grande do Sul Fonte: Elaborado pelo autor.

Ao selecionar uma estação meteorológica (Figura 5), o usuário deverá inserir o período que deseja efetuar a pesquisa. Caso não existam dados armazenados no banco de dados para determinado período, uma consulta ao servidor remoto com parâmetros de requisição é realizada e o retorno é utilizado para atualizar os dados da estação meteorológica em banco.

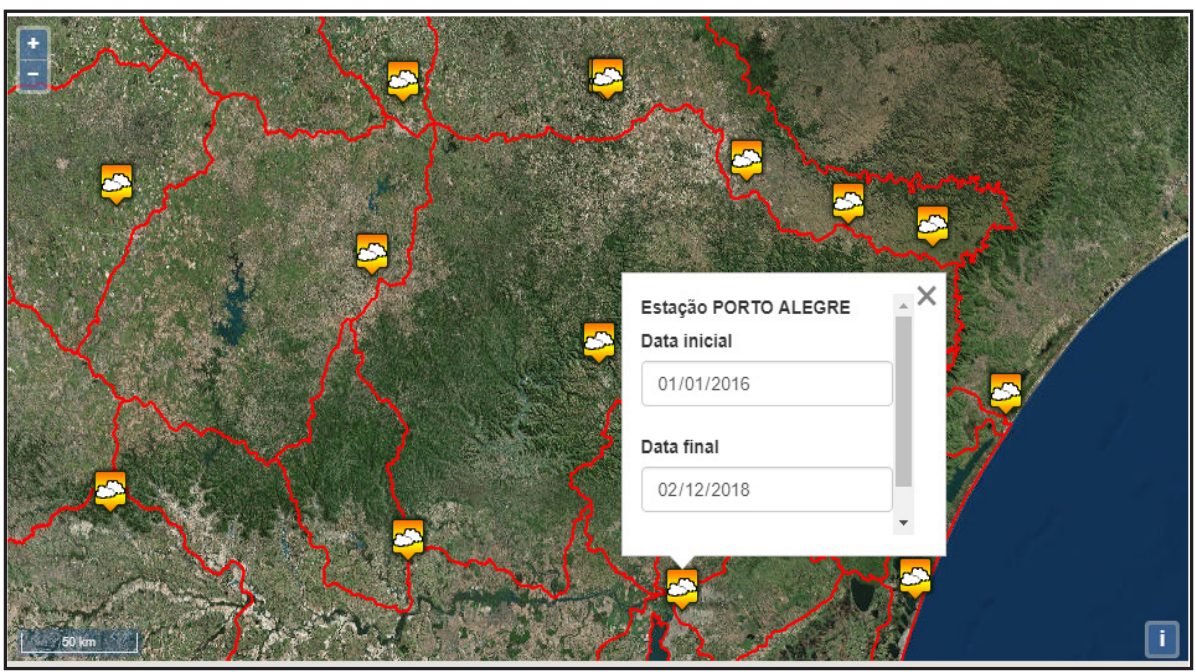

Figura 5 - Seleção do ponto correspondente a estação meteorológica do município de Porto Alegre - RS - período de análise: 01/01/2016 a 02/12/2018.

Fonte: Elaborado pelo autor. 
Os dados meteorológicos, resultantes da consulta, são apresentados ao usuário, conforme ilustra a Figura 6. O usuário tem a opção de baixá-los no formato .csv, para posterior análise.

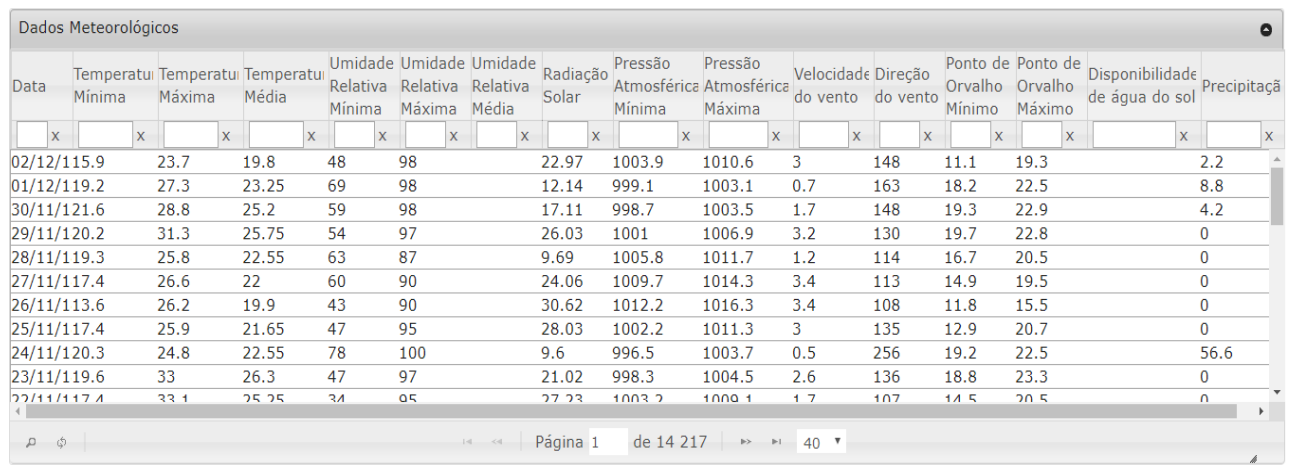

Figura 6 - Dados meteorológicos consultados para a estação meteorológica do município de Porto Alegre - RS - período de análise: 01/01/2016 a 02/12/2018.

Fonte: Elaborado pelo autor.

A partir da consulta aos dados meteorológicos, o usuário deverá escolher, dentre os métodos matemáticos (Tabela 1), quais pretende executar para estimar a ETo. Caso o usuário selecione mais de um método matemático para estimar a ETo, o sistema insere os resultados em um arquivo .csv e este é disponibilizado para o usuário. No entanto, se apenas um método é selecionado, o sistema disponibiliza os resultados em uma tabela, conforme ilustrado na Figura 7.

\begin{tabular}{|l|l|l|l|l|l|}
\hline \multicolumn{1}{|c|}{ Periodo analisado } & \multicolumn{1}{|c|}{ Evapotranspiraçāo (mm/dia) } & \multicolumn{1}{|c|}{ Mês/Ano } & \multicolumn{1}{|c|}{ Média diária mensal (mm/dia) } & \multicolumn{1}{|c|}{ Meses } & \multicolumn{1}{c|}{ Média mensal (mm/mês) } \\
\hline $02 / 12 / 18$ & 5.55 & Dezembro/2018 & 5.26 & Dezembro & 127.86 \\
\hline $01 / 12 / 18$ & 4.98 & Novembro/2018 & 6.2 & Novembro & 162.84 \\
\hline $30 / 11 / 18$ & 5.47 & Outubro/2018 & 5.13 & Outubro & 146.09 \\
\hline $29 / 11 / 18$ & 6.56 & Setembro/2018 & 3.99 & Setembro & 116.66 \\
\hline $28 / 11 / 18$ & 5.36 & Agosto/2018 & 3.18 & Agosto & 78.05 \\
\hline $27 / 11 / 18$ & 5.61 & Julho/2018 & 2.52 & Julho & 75.18 \\
\hline $26 / 11 / 18$ & 6.39 & Junho/2018 & 2.24 & Junho & 60.77 \\
\hline
\end{tabular}

Figura 7 - Resultados de ETo para a estação meteorológica do município de Porto Alegre - RS período de análise: 01/01/2016 a 02/12/2018.

Fonte: Elaborado pelo autor.

Após aplicar os métodos matemáticos sobre os dados consultados, são obtidos os 
resultados para a ETo diária, ETo média diária mensal em milímetros por dia ( $\mathrm{mm} / \mathrm{dia})$, e a Eto média mensal em milímetros por mês ( $\mathrm{mm} / \mathrm{mês})$. A título de exemplo, a Figura 6 apresenta os resultados do cálculo da ETo diária, média diária mensal e média mensal, a partir do método de Penman-Monteith-FAO, para um período compreendido entre 01/01/2016 a 02/12/2018 tendo por base os dados da estação meteorológica do município de Porto Alegre - RS (dados disponíveis de 01/01/1965 a 03/12/2018).

O administrador poderá gerenciar os usuários através de uma tabela (Figura 8) contendo as informações cadastradas.

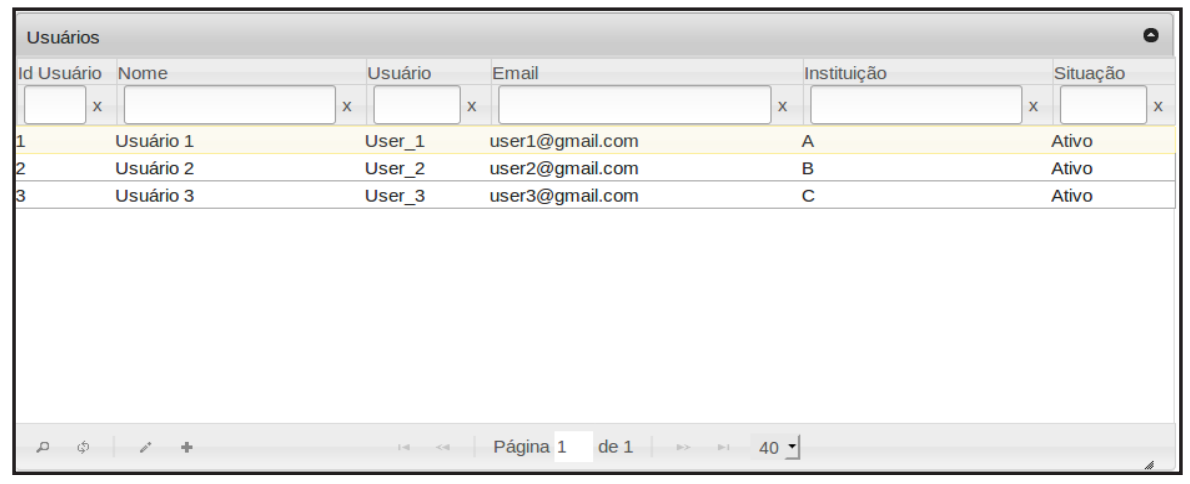

Figura 8 - Tabela de controle dos usuários cadastrados no sistema

Fonte: Elaborado pelo autor.

Para controlar o acesso de determinado usuário a aplicação, o administrador poderá alterar a situação deste, a partir da tela de edição de informações do usuário, apresentada na Figura 9.

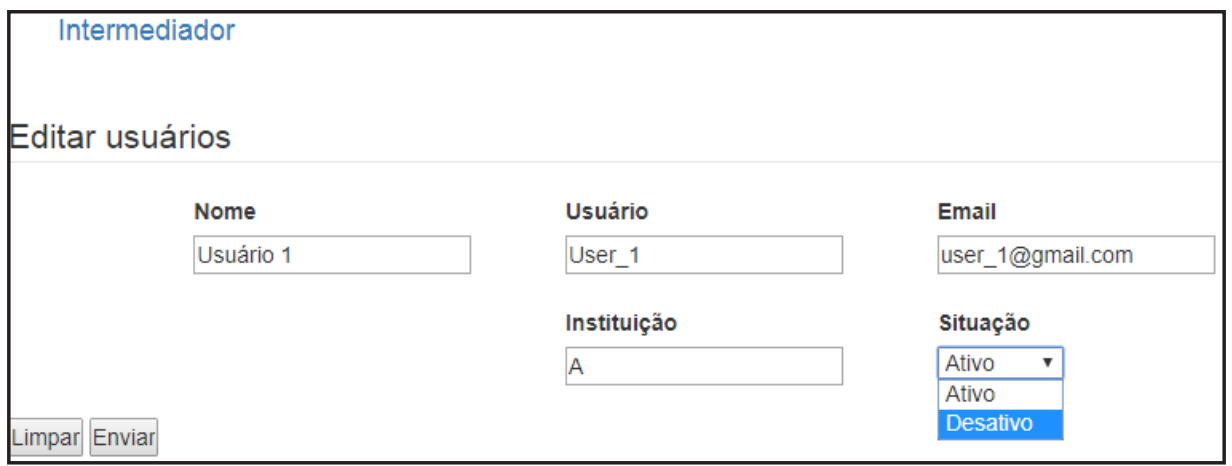

Figura 9 - Formulário para edição de informações de usuários Fonte: Elaborado pelo autor. 
A possibilidade de aplicação de diversos modelos matemáticos para cálculo de evapotranspiração utilizando dados meteorológicos e sua disponibilização como um sistema web auxilia os pesquisadores evitando a necessidade de implementação de novos algoritmos para resolução de um método em específico. Assim, viabiliza a alocação do tempo anteriormente direcionado ao desenvolvimento de ferramentas computacionais específicas para diferentes métodos, para análises sobre os resultados fornecidos pelo sistema (GONÇALVES et al., 2009; PALARETTI et al., 2014; CRUZ, 2016; JÚNIOR et al.,2017).

O arquivo resultante do cálculo (arquivo em formato .csv) gerado com a utilização de mais de um método para estimativa de ETP permite, além disso, uma análise comparativa de diversos modelos, cuja relação e análise dos resultados gerados fica a critério do usuário. A disponibilização dos dados brutos e compilados em planilha eletrônica é um modo de aprimorar a aplicação de modelos desenvolvida, sendo pertinente a diversos trabalhos já desenvolvidos, nos quais foram aplicados múltiplos métodos de comparação (GONÇALVES et al., 2009; OLIVEIRA et al., 2010; JÚNIOR et al., 2012; CHAGAS et al., 2013).

Entretanto, os usuários devem estar cientes das suposições e limitações completas antes de usar qualquer modelo ET nesta aplicação web. Quase todo modelo de ET contém suposições relacionadas às condições climáticas específicas sob as quais os modelos se aplicam. Por exemplo, alguns modelos assumem que os subprocessos relacionados a ET são insignificantes, enquanto outros modelos são apenas calibrados para o clima de uma região específica (ROSENBERRY et al., 2007; TABARI et al., 2013; GUO et al., 2016).

\section{I CONCLUSÃO}

O sistema proporcionou uma forma automatizada de efetuar o cálculo de ETo, a partir de diversos métodos matemáticos e para longos períodos de tempo. Devido ao nível de complexidade matemática de alguns métodos, o processo de estimativa de evapotranspiração tornar-se-ia inviável, em especial, quando os períodos de análise compreendem muitos anos ou ainda, quando não estão disponíveis alguns parâmetros. Como salienta Oliveira et al. (2010), devido a característica empírica presente em alguns métodos usados no cálculo de ETo, a obtenção dos resultados, por vezes, fica comprometida devido a indisponibilidade de determinados parâmetros meteorológicos a uma região. Com vistas a contornar esse problema, a aplicação dispõe de um número considerável de técnicas alternativas que se utilizam de diferentes parâmetros para calcular a ETo, tendo o usuário a opção de escolher qual técnica é mais adequada para seu estudo. Além disso, o sistema possui a opção de executar mais de um método concomitantemente, proporcionando uma forma prática ao usuário que deseja realizar análises.

O emprego do WebMapa possibilitou ao usuário maior facilidade no processo de 
consulta dos dados meteorológicos. A partir de uma representação visual dos pontos climatológicos disponíveis, o usuário pode selecionar a estação meteorológica desejada e realizar a consulta pretendida. No tocante a gerência dos usuários, o sistema provê uma forma hierárquica de acesso aos recursos da aplicação. O administrador poderá excluir usuários de forma prática, bem como editar algumas informações cadastradas. O usuário, por sua vez, poderá efetuar diversas análises sobre os dados consultados, de acordo com sua necessidade.

A validação dos resultados vem sendo constantemente realizada, bem como a correção de possíveis erros. Além disso, vem sendo desenvolvido o estudo de técnicas atuais que proporcionem as melhorias à aplicação, tanto na usabilidade, quanto na disponibilização de novas funcionalidades, dentre elas a elaboração de gráficos e análises estatísticas e de desempenho dos métodos.

\section{REFERÊNCIAS}

ALLEN, R.G. et al. Crop evapotranspiration. Guidelines for computing crop water requirements. Rome: FAO, 1998. 299p.

AGRITEMPO. Agritempo: Sistema de Monitoramento Agrometeorológico. Disponível em: <http://www. agritempo.gov.br>.

BOOTSTRAP, T. Twitter bootstrap. 2013. Disponível em: <http://getbootstrap.com>.

BORGES JÚNIOR, João C. F. et al. Métodos de estimativa da evapotranspiração de referência diária para a microrregião de Garanhuns, PE. Revista Brasileira de Engenharia Agrícola e Ambiental, Campina Grande, v. 16, n. 4, p.380-390, jan. 2012.

CANNAROZZO, L.V. Noto, F. Viola. Spatial distribution of rainfall trends in Sicily (1921-2000) Phys. Chem. Earth, 31 (18) (2006), pp. 1201-1211

SMARTY TEMPLATE ENGINE. Chapter 1. What is Smaty? Part I. Getting Started. Disponível em: <https://www.smarty.net/docs/en/what.is.smarty.tpl>. Acesso em: 03 de Fev. de 2019.

DEBASTIANI, Carlos Alberto. Definindo Escopo em Projetos de Software. São Paulo: Novatec, 2015. $144 \mathrm{p}$.

ECLIPSE FOUNDATION. Eclipse Process Framework. Disponível em:<https://www.eclipse.org/>. Acesso em: 03 de Fev. de 2019.

EMBRAPA. Documentos 263 - Evapotranspiração-Uma Revisão sobre os Métodos Empíricos. Empresa Brasileira de Pesquisa Agropecuária Embrapa Arroz e Feijão Ministério da Agricultura, Pecuária e Abastecimento, 2010.

ERMASTER. What is ERMaster?. Disponivel em: <http://ermaster.sourceforge.net/>. Acesso em: 03 de Fev. de 2019. 
EVAPOTRANSPIRATION: MODELLING ACTUAL, POTENTIAL AND REFERENCE CROP

EVAPOTRANSPIRATION. Disponível em: <https://cran.r-project.org/web/packages/Evapotranspiration/ index.html >. Acesso em: 03 de Fev. de 2019.

FANAYA JÚNIOR, Eder Duarte et al. MÉTODOS EMPÍRICOS PARA ESTIMATIVA DA EVAPOTRANSPIRAÇÃO DE REFERÊNCIA PARA AQUIDAUANA, MS. Irriga, Botucatu, Sp, v. 17, n. 4, p.418-434, 02 out. 2012.

FEITOSA, D. G. et al. ARTIGO TÉCNICO SOFTWARE SMAI 2.0 PARA ESTIMATIVA DA EVAPOTRANSPIRAÇÃO DE REFERÊNCIA DIÁRIA E HORÁRIA 1. [s. I.], [s.d.]. Disponível em: http:// clima.feis.unesp.br/smai.

FOROUZAN B. A. Comunicação de Dados e Redes de Computadores. 4. ed. São Paulo: McGraw-Hill, 2008.

GONÇALVES, Fabrício Mota et al. COMPARAÇÃO DE MÉTODOS DA ESTIMATIVA DA EVAPOTRANSPIRAÇÃO DE REFERÊNCIA PARA O MUNICÍPIO DE SOBRAL-CE. Revista Brasileira de Agricultura Irrigada, Fortaleza, Ce, p.1-8, 12 ago. 2009.

GOCIC, Milan; TRAJKOVIC, Slavisa. Software for estimating reference evapotranspiration using limited weather data. Computers and Electronics in Agriculture, [s. I.], v. 71, n. 2, p. 158-162, 2010.

GUO, D., S. WESTRA, AND H. R. MAIER, An R package for modelling actual, potential and reference evapotranspiration, Environ. Model. Software, 78, 216-224, 2016.

HASAN, S.s.; ISAAC, R.k.. An integrated approach of MAS-CommonKADS, Model-View-Controller and web application optimization strategies for web-based expert system development. Expert Systems With Applications, [s.I.], v. 38, n. 1, p.417-428, jan. 2011. Elsevier BV.

JÚNIOR, Aderson Soares de Andrade. AVALIAÇÃo DE MÉTOdOS PARA ESTIMATIVA DA EVAPOTRANSPIRAÇÃO DE REFERêNCIA NO ESTADO DO PIAUÍ. Teresina- Pi: Revista da Sociedade Brasileira de Agrometeorologia, v. 11, n. 4, 10 ago. 2017. Issn 2526-7043.

LARMAN C. Utilizando UML e padrões: uma introdução à análise e ao projeto orientados a objetos e ao desenvolvimento iterativo. 3. ed. Porto Alegre: Bookman, 2007.

LEITÃO, M. DE M. V. B. R.; OLIVEIRA, G. M. DE; LEITÃO, T. J. V. Avaliação do desempenho de diferentes métodos de estimativa da evaporação para duas regiões da Paraíba. Revista Brasileira de Engenharia Agrícola e Ambiental, 2007.

LIU, Z.F. YANG, B.S. CUI. Spatial and temporal variability of annual precipittion during 1961-2006 in Yellow River Basin China. J. Hydrol., 361 (2008), pp. 330-338.

MAČEK, Urška; BEZAK, Nejc; ŠRAJ, Mojca. Reference evapotranspiration changes in Slovenia, Europe. Agricultural and Forest Meteorology, [s. I.], v. 260-261, p. 183-192, 2018.

M. CANNAROZZO, L.V. Noto, F. Viola. Spatial distribution of rainfall trends in Sicily (1921-2000) Phys. Chem. Earth, 31 (18) (2006), pp. 1201-1211 
MCMAHON, T.A., PEEL, M.C., LOWE, L., SRIKANTHAN, R., MCVICAR, T.R.. Estimating actual, potential, reference crop and pan evaporation using standard meteorological data: a pragmatic synthesis. Hydrol. Earth Syst. Sc. 17 (4), 1331-1363, 2013.

MCVICAR, T.R., KÖRNER, C. On the use of elevation, altitude, and height in the ecological and climatological literature. Oecologia 171 (2), 335-337, 2013.

MENDONÇA, J.C. et al. Comparação entre métodos de estimativa da evapotranspiração de referência (ETo) na região Norte Fluminense, RJ. Revista Brasileira de Engenharia Agrícola e Ambiental, Campina Grande, v.7, n.2, p.275-279, 2003.

MOURA, Ada Ravana Costa et al. Evapotranspiração de referência baseada em métodos empíricos em bacia experimental no Estado de Pernambuco - Brasil. Revista Brasileira de Meteorologia, [s. I.], 2013.

OLIVEIRA, Gertrudes Macario de et al. COMPARAÇÃO ENTRE MÉTODOS DE ESTIMATIVA DA EVAPOTRANSPIRAÇÃO DE REFERÊNCIA NA REGIÃO NORTE DA BAHIA. Revista Brasileira de Agricultura Irrigada, Fortaleza, Ce, v. 4, n. 2, p.104-109, 12 jun. 2010.

OPENLAYERS. Basic Concepts. Disponível em: < https://openlayers.org/en/latest/doc/tutorials/ concepts.html>. Acesso em: 03 de Fev. de 2019.

PAIVA, C. M. de S.; PINHEIRO, A. da S. Avaliação de métodos de estimativa da evapotranspiração de referência para fins de manejo da irrigação. Anuário do Instituto de Geociências, v. 39, n. 1, p. 42-51, 2016.

PALARETTI, Luiz F.; MANTOVANI, Everardo C.; SEDIYAMA, Gilberto C.. Comparação entre métodos de estimativa da evapotranspiração de referência (ETo) em regiões citrícolas paulistas. Engenharia Agrícola, [s.I.], v. 34, n. 1, p.38-47, fev. 2014. FapUNIFESP (SciELO).

PEREIRA, D. dos R. et al. Desempenho de métodos de estimativa da evapotranspiração de referência para a região da Serra da Mantiqueira, MG. Ciência Rural, Santa Maria, v. 39, n. 9, p. 2488-2493, dez. 2009.

PILAU et al. Desempenho de métodos de estimativa da evapotranspiração de referência nas localidades de Frederico Westphalen e Palmeira das Missões, RS. Ciência Rural, Santa Maria, v. 42, n.2, p.283-290, fev. 2012.

PHP: Hypertext Preprocessor. 1995. Disponível em: <http://php.net/>.

PHP: What is PHP ?. Disponível em: <https://secure.php.net/manual/pt_BR/intro-whatis.php>. Acesso em: 03 de Fev. de 2019.

PHP: What can PHP do ?. Disponível em: <https://secure.php.net/manual/pt_BR/intro-whatcando.php>. Acesso em: 03 de Fev. de 2019.

POSTGRESQL. What is PostgreSQL ?. Disponível em: <https://www.postgresql.org/about/>. Acesso em: 03 de Fev. de 2019. 
ROSENBERRY, D.O., WINTER, T.C., BUSO, D.C.LIKENS, G.E. 2007, Comparison of 15 evaporation methods applied to a small mountain lake in the northeastern USA, Journal of Hydrology, vol. 340, no. 3, pp. 149-166.

SCHACH S. R. Engenharia de Software: Os Paradigmas Clássico e Orientado a Objetos. 7. ed. São Paulo: McGraw Hill, 2009.

SOMMERVILLE I. Engenharia de Software. 8. ed. São Paulo: Pearson Addison Wesley, 2007.

SOMMERVILLE I. Engenharia de Software. 9. ed. São Paulo: Pearson Addison Wesley, 2011.

SULEIMAN, A. A.; HOOGENBOOM, G. Comparison of Priestley-Taylor and FAO-56 Penman-Monteith for daily reference evapotranspiration estimation in Georgia. Journal of Irrigation and Drainage Engineering, v.33, n.2, 175-182. 2007.

TABARI, H., GRISMER, M.E.TRAJKOVIC, S., Comparative analysis of 31 reference evapotranspiration methods under humid conditions, Irrigation Science, vol. 31, no. 2, pp. 107-117., 2013.

WANG, H. LIU, L. ZHANG, R. ZHANG Climate change trend and its effects on reference evapotranspiration at Linhe Station, Hetao Irrigation District Water Sci. Eng., 7 (3) (2014), pp. 250266.

YANG, Q. LIU, B. CuiSpatial distribution and temporal variation of reference evapotranspiration during 1961-2006 in the Yellow River Basin China. Hydrol. Sci. J., 56 (6) (2011), pp. 1015-1026 


\section{UM CENÁRIO DA EDUCAÇÃO AMBIENTAL EM RESÍDUOS SÓLIDOS NO MUNICÍPIO SANTARÉM - PA: ESTUDO DE CASO - RESIDENCIAL SALVAÇÃO}

Data de aceite: 04/01/2021

\section{Jarlison Sarmento Lopes}

Universidade Federal do Oeste do Pará- UFOPA Santarém - PA

http://lattes.cnpq.br/5804450976807210

\section{Andressa Rodrigues de Sousa}

Universidade Federal do Oeste do Pará- UFOPA

Santarém - PA

http://lattes.cnpq.br/7579027145564161

Antônia Liliane Ferreira de Oliveira

Universidade Federal do Oeste do Pará- UFOPA

Santarém - PA

http://lattes.cnpq.br/8513807554674177

\section{Claudiane da Silva Rosa}

Santarém - PA

http://lattes.cnpq.br/106906919449021

Ewellyn Cristina Santos de Sousa

Universidade Federal do Oeste do Pará- UFOPA

Santarém - PA.

http://lattes.cnpq.br/9282145308173973

\section{Kairo Silva de Oliveira}

Universidade Federal do Oeste do Pará- UFOPA

Santarém - PA

http://lattes.cnpq.br/0422464611298665

Elton Raniere da Silva Moura

Universidade Federal do Oeste do Pará- UFOPA

Santarém - PA

http://lattes.cnpq.br/3955051826107598

Maria Francisca de Miranda Adad

Universidade Federal do Oeste do Pará- UFOPA

Santarém - PA

http://lattes.cnpq.br/562474419728196
RESUMO: O Residencial Salvação é uma obra inclusa no projeto "Minha Casa, Minha Vida", finalizada no ano de 2016, no município de Santarém, com o total de 3.081 unidades habitacionais. Como toda área urbana do município de Santarém, conta com o serviço público de limpeza que se encarrega de executar a coleta dos resíduos que são gerados pela população. O lixo geralmente é posto pelos moradores, acondicionado em sacos plásticos, em lixeiras em frente às residências e, em dia e horário predeterminados, o caminhão coletor faz o processo de recolhimento do mesmo, o qual é destinado ao Aterro Controlado do Perema. Partindo desses pontos, procurou-se analisar a obra Residencial Salvação no município de Santarém - PA e a sensibilização dos moradores quanto as questões ambientais. Este trabalho consistiu, principalmente, avaliar a área de estudo, bem como o grau de conhecimento dos residentes, através de do estudo bibliográfico, visita e intervenção, buscando meios de interação com a população, estimulando a prática da Educação Ambiental em Resíduos Sólidos. A metodologia adotada pelos pesquisadores foi dividida em três etapas. A etapa inicial consistiu no embasamento teórico sobre o tema proposto. A segunda fase foi direcionada a efetivação da visita técnica à área de estudo. A etapa final, também chamada de intervenção, teve como intuito realizar práticas de educação ambiental por meio de uma palestra dinâmica. A utilização da educação ambiental foi primordial, pois mostrou eficiência como uma ferramenta eficaz para compartilhar conhecimentos obtidos no meio acadêmico com a comunidade em estudo. 
PALAVRAS-CHAVE: Meio Ambiente; Residencial Salvação; Educação Ambiental.

\title{
THE CURRENT SCENARIO OF ENVIRONMENTAL EDUCATION IN SOLID WASTE IN THE MINICIPALITY OF SANTARÉM - PA: A CASE STUDY OF THE RESIDENTIAL SALVATION
}

\begin{abstract}
Residencial Salvação is a work included in the project "Minha Casa, Minha Vida", completed in 2016, in the municipality of Santarém, in a total of 3,081 housing units. Like all urban areas in the municipality of Santarém, the public cleaning service is responsible for carrying out the collection of waste that is generated by the population. Trash is usually put by the residents, put in plastic bags, in garbage cans in front of the residences, and, by day and at predetermined times, the pickup truck collects the same, which is destined for Perema's Controlled Landfill. Based on these points, we tried to analyze the work Residencial Salvação in the municipality of Santarém - PA and the sensitization of the residents on environmental issues. This work consisted mainly of evaluating the study area, as well as the degree of knowledge of the residents, through the bibliographic study, visit and intervention, seeking means of interaction with the population, stimulating the practice of Environmental Education in Solid Waste. The methodology adopted by the researchers was divided into three stages. The initial stage consisted of the theoretical basis on the proposed theme. The second phase was directed to the accomplishment of the technical visit to the study area. The final stage, also called intervention, aimed to carry out environmental education practices through a dynamic lecture. The use of environmental education was paramount, since it showed efficiency as an effective tool to share knowledge obtained in the academic environment with the community under study.
\end{abstract}

KEYWORDS: Environment; Residential Salvation; Environmental Education.

\section{INTRODUÇÃO}

O desenvolvimento da sociedade é necessário para a humanidade, porém é importante destacar a forma de realização do mesmo, o qual tem que ser em consonância com o meio ambiente. Em contrapartida, o que vemos no cenário atual são os grandes impactos negativos que o ser humano vem causando na natureza. Os resíduos urbanos é uma questão de saúde pública comumente negligenciados pela maior parte das pessoas. A educação ambiental em relação ao descarte adequado, tanto em casa quanto em ambientes de trabalho, se mostra insuficiente ou até mesmo nulo quando se observa o desmazelo da população com seu lixo

"O Programa Minha Casa Minha Vida foi anunciado em 2009 com o objetivo principal de reduzir o déficit habitacional, garantindo o acesso à casa própria e melhorando a qualidade de vida da população brasileira." (FORAGI, 2012, p. 15). Sendo este, uma iniciativa do Governo, por meio do Ministério das Cidades e a Caixa Econômica Federal, o programa contemplou diversas famílias de 5 estados da federação. Foram entregues cerca de 6.597 imóveis, sendo no total de 26,5 mil famílias contempladas, dispondo de imóveis de qualidade, com abastecimento de água, esgotamento sanitário, drenagem, energia 
elétrica, iluminação pública, pavimentação e urbanização. O Residencial Salvação é uma obra inclusa no projeto "Minha Casa, Minha Vida", finalizada no ano de 2016, no município de Santarém, no total de 3.081 unidades habitacionais. (BRASIL, 2016)

Como toda área urbana do município de Santarém, conta com o serviço público de limpeza que se encarrega de executar a coleta dos resíduos que são gerados pela população. O lixo geralmente é posto pelos moradores, acondicionado em sacos plásticos, em lixeiras em frente as residências e, em dia e horário predeterminados, o caminhão coletor faz o processo de recolhimento do mesmo, o qual é destinado ao Aterro Controlado do Perema. Partindo desses pontos, procurou-se analisar a obra Residencial Salvação no município de Santarém - PA e a sensibilização dos moradores quanto as questões ambientais. Este trabalho consistiu, principalmente, avaliar a área de estudo, bem como o grau de conhecimento dos residentes, através de do estudo bibliográfico, visita e intervenção, buscando meios de interação com a população, estimulando a prática da Educação Ambiental em Resíduos Sólidos.

\section{A EDUCAÇÃO AMBIENTAL E A GESTÃO DE RESÍDUOS URBANOS}

\section{Discussões Voltadas para a Educação Ambiental:}

O modelo de gestão associado aos resíduos sólidos levanta inúmeras questões a serem discutidas a respeito de uma sociedade que gera, de forma desenfreada, uma grande quantidade de lixo oriundo da cultura consumista e necessidades supérfluas da população, causando efeitos que podem se tornar irreversíveis se não forem tomadas medidas preventivas para minimizar os danos causados ao meio ambiente. As consequências decorrentes desse comportamento são prejudiciais aos seres humanos, além de contribuírem, diretamente, na perda acelerada dos recursos naturais.

Segundo Dias, Marques e Dias (2016, p.12) “A Educação Ambiental está intimamente ligada ao indivíduo como ser social, portanto, é importante a percepção individual como elemento da prática ou disseminação da Educação Ambiental sob os olhares de cada ator do espaço social”. Portanto, é notório a necessidade de informação que precisa ser repassada para a sociedade de diferentes maneiras, para que cada indivíduo possa ter uma percepção individual sobre seu papel na mudança de comportamento de todos.

A Educação Ambiental surgiu da necessidade de formar uma nova postura na sociedade em decorrência da crise em âmbito mundial, que passou a afetar todos os grupos sociais nas mais diversas escalas de abrangência, como uma ferramenta de combate ao descaso das pessoas, pois é necessário sensibilizar a população para a possibilidade de percorrer caminhos mais sustentáveis e ecologicamente equilibrados. (SORRENTINO, TRAJBER E FERRARO JÚNIOR, 2005)

Após a Segunda Revolução Industrial, os impactos ambientais expandiram-se de 
maneira que se tornou visível a crise ambiental. Surgem, então, as primeiras discussões como a Conferência de Estocolmo, em 1972, realizada pela Organização das Nações Unidas - ONU, em que foi criado o Programa das Nações Unidas para o Meio Ambiente PNUMA. Também na Conferência de Belgrado, em 1975, foram definidas as orientações para o Programa de Educação Ambiental. Em 1977, na Conferência Intergovernamental de Tbilisi, foram definidos objetivos e estratégias para a Educação Ambiental. (MARCATTO, 2002). Além dessas, ressalta-se também a RIO 92, realizada na cidade do Rio de Janeiro, em junho de 1992, marcada pela criação da Agenda 21, que abordava os problemas ambientais contidos no meio urbano da atualidade. (CARDOSO, 2002)

No Brasil, a Lei 9. 795 de 27 de abril de 1999, institui a Política Nacional de Educação Ambiental - PNEA, que ressalta a importância da Educação Ambiental para o desenvolvimento educacional da sociedade como um todo, devendo está presente em todos os níveis de ensino. Destaca-se o seu artigo $1^{\circ}$ :

Entendem-se por educação ambiental os processos por meio dos quais o indivíduo e a coletividade constroem valores sociais, conhecimentos, habilidades, atitudes e competências voltadas para a conservação do meio ambiente, bem de uso comum do povo, essencial à sadia qualidade de vida e sua sustentabilidade. (BRASIL, 1999, art. $1^{\circ}$ )

A PNEA foi um marco essencial para o desenvolvimento da educação ambiental do país, uma vez que sua proposta educacional visa à conservação do meio ambiente de forma bastante expressiva, tornando viável a integração da sociedade com o meio que está inserida, sendo necessário a disposição da população para exercer a sua prática.

\section{A problemática dos Resíduos Sólidos Urbanos - RSU}

A gestão dos resíduos sólidos urbanos apresenta-se hoje como uma prática em constante aprimoramento, o que passa a ser motivo de discussões em torno da geração dos materiais, descarte e possíveis impactos causados ao meio ambiente e à saúde do homem. Para Amorim et al (2010) a produção de resíduos está diretamente ligada ao estilo de vida, cultura, trabalho, nutrição, higiene e consumo humano.

O autor destaca que o acelerado processo de urbanização aliado ao consumo excessivo de produtos com ciclo de vida menores, ou descartáveis, provocam mudanças no volume do resíduo gerado, causando assim, o aumento de sua concentração. Desse modo, a tarefa de gerenciar os Resíduos Sólidos Urbanos - RSU, torna-se indispensável para a municipalidade e tem como objetivo demandar ações articuladas para promover medidas que possibilitem a diminuição de danos ambientais.

De acordo com Muniz (2013), os resíduos lançados em locais impróprios também podem ocasionar problemas à saúde pública como a proliferação de vetores de doenças, como moscas, mosquitos, baratas e ratos, geração de maus odores e, sobretudo, poluição do solo e das águas superficiais por meio da lixiviação que compromete os solos e os corpos hídricos. Segundo Roth e Garcias (2009), esses são efeitos diretos. Além desses, 
existem os indiretos, tais como a extinção da matéria-prima e a escassez de locais onde se possam criar mais aterros sanitários. Por isso, enfatiza-se a importância do tratamento para cada tipo de resíduo produzido.

É importante destacar que os avanços referentes a gestão de RSU no país estão ocorrendo de forma morosa e obteve progressos com a criação da Lei Federal n 12.305 de agosto de 2010, que institui a Política Nacional dos Resíduos Sólidos - PNRS, apresentando de forma ampla a importância da implantação da Gestão Integrada dos Resíduos Sólidos Urbanos - GIRSU e o gerenciamento ambientalmente adequado, propondo metas e práticas, a fim de propiciar soluções relacionadas aos resíduos.

\subsection{Política Nacional de Resíduos Sólidos - PNRS}

Morais (2015) afirma que, até 1989, no Brasil, a destinação final dos resíduos se resumia, principalmente, aos lixões a céu aberto, não havendo uma lei específica que delimitasse a responsabilidade do gerador quanto aos resíduos gerados.

Nessa época, conforme a mesma autora, foi apresentado no Senado Federal, o projeto de lei $n^{\circ} 354$, no qual constava alguns elementos relacionados ao Gerenciamento dos Resíduos de Serviços de Saúde - GRSS, sofrendo diversas alterações até a sua aprovação, sendo promulgada, oficialmente, como Projeto de Lei n²03, de 1991, o qual foi considerado o principal reflexo para a formulação da PNRS. Após 19 anos de desavenças entre os representantes legais quanto a regularização de alguns artigos no projeto de lei, assim como à inclusão de outros projetos de lei com afinidade nessa temática, foi, finalmente, validada a Lei $n^{\circ} 12.305$ em 2 agosto de 2010.

A Lei 12.305 estabelece a Política Nacional de Resíduos Sólidos - PNRS, além fornecer os princípios, objetivos, instrumentos e diretrizes voltados a regulamentação do gerenciamento e da Gestão Integrada de Resíduos Sólidos - GIRS no país sendo certificado e reforçado no artigo $1^{\circ}$ da referida lei. (BRASIL,2010)

Dentre os diversos objetivos encontrados na lei, destaca-se a "não geração, redução, reutilização, reciclagem e tratamento dos resíduos sólidos, bem como disposição final ambientalmente adequada dos rejeitos”, o qual demonstra o grau de prioridade a ser adotado no procedimento da gestão e gerenciamento dos resíduos sólidos. (BRASIL, 2010, art. $7^{\circ}$, II)

Segundo Movieco (2013), a PNRS condena as ações que ferem ou desrespeitam o meio ambiente, buscando alternativas para a melhoria da qualidade ambiental nos processos produtivos do meio empresarial, motivando a inclusão de Sistemas de Gestão Ambiental - SGA, assim como o Plano de Gerenciamento de Resíduos Sólidos - PGRS.

A PNRS foi um grande marco para a GIRS do país, pois delimitou a inteira responsabilidade de geração dos resíduos ao seu gerador, bem como elaborou a destinação e disposição ambientalmente correta dos mesmos. Além disso, definiu diversos conceitos e instrumentos inovadores que se interligam diretamente com o tema, dentre eles, a logística 
reversa, a qual remete aos fabricantes o processo de retirada, a destinação e a disposição do lixo produzido. (KONRAD e CALDERAN, 2011)

\subsection{A Coleta Seletiva e seus benefícios para a sociedade}

Uma maneira de fazer a separação apropriada dos resíduos acontece por meio da coleta seletiva, a qual leva em consideração a destinação adequada dos objetos recicláveis. Ela surge como uma maneira de diminuir os impactos que o despejo incorreto dos mesmos pode ocasionar.

Para Moraes, Silva e Leal (2006, p. 2), entende-se por coleta seletiva como "um sistema de recolhimento de resíduos recicláveis previamente separados na fonte geradora compreendendo papéis, plásticos, vidros e metais", ou seja, de uma forma geral, é a separação dos resíduos que tenham um potencial de reciclagem ou reutilização, evitando que os mesmos sejam enviados para os aterros sanitários ou lixões.

No entanto, é válido ressaltar que essa atitude de fazer a separação correta de materiais deve se limitar aos objetos que estão inteiramente limpos, isentos de qualquer substância que venha a contaminá-los, ou seja, é necessário fazer a higienização dos mesmos, pois, se não ocorrer dessa forma, a lógica da coleta seletiva é quebrada.

Conforme Peixoto, Campos e Agosto (2005), existem algumas formas de operação da coleta seletiva, as quais se resumem principalmente, na coleta de porta em porta e a coleta em ponto de entregas voluntárias - PEV's. A coleta de Porta em Porta, refere-se ao recolhimento dos materiais recicláveis, em dias específicos, segregados nos domicílios ou estabelecimentos comerciais, a qual é de inteira responsabilidade do poder público. Os PEV's são pontos devidamente alocados em locais estratégicos, onde a população seja capaz de, voluntariamente, descartar os seus resíduos corretamente, já separados em suas residências.

Também, existe um padrão de cores que auxiliam o descarte correto dos resíduos, tais cores são asseguradas pela Resolução CONAMA n 275 de 2001, são elas: Azul, que se encarrega do resíduo relativo ao papel; Vermelho, referente ao plástico; Verde, relacionados ao vidro; Amarelo, pertencente ao Metal; Preto, madeira; Laranja, resíduos perigosos; Branco, ambulatoriais e de serviço de saúde; Roxo, resíduos radioativo; Marrom, material de origem orgânica; Cinza, resíduos diversos que são descartados por estarem sujeitos a contaminantes que podem prejudicar os demais. (BRASIL, 2001)

Desta forma, com o auxílio da coleta seletiva é possível minimizar os impactos que os resíduos podem causar, visto o descarte correto dos mesmos e a possibilidade de geração de trabalho e renda para uma camada da população excluída, os catadores de materiais recicláveis.

\section{Os R's da Sustentabilidade}

A sustentabilidade é marcada pela consonância entre o meio ambiente, a sociedade 
e a economia. Para a ocorrência de tal, é necessário adotar medidas que diminuam os problemas relacionados ao meio ambiente, gerando renda e inclusão social.

Levando em consideração aos resíduos sólidos, é importante destacar a existência de tais mecanismos que colaboram para o fortalecimento dos pilares da sustentabilidade, seguindo a lógica dos 3R's: redução, reutilização e reciclagem. A redução é o primeiro "R" a ser levado em consideração quando se fala em sustentabilidade.

De acordo Quadros (2015), reduzir é minimizar qualquer ação que reflete na produção de resíduos, sendo visto como o método mais importante e vantajoso, pois não é necessária qualquer interação negativa com a natureza.

A redução visa, principalmente, a mitigação das fontes geradoras. $O$ fato de diminuir a grande demanda de lixo produzido, reflete diretamente na minimização dos possíveis impactos que os mesmos podem ocasionar. Reduzir requer a mudança de vários hábitos que a própria sociedade nos impõe, tal como a compra de objetos inúteis e com baixa durabilidade entre outros. Os recursos se tornam uma arma impactante quando não utilizados de forma adequada.

Quando não há mais formas de reduzir o consumo, outro "R" entra em ação, representado pela reutilização. A reutilização é o "processo de aproveitamento dos resíduos sólidos sem sua transformação biológica, física ou físico-química", ou seja, é uma forma de destinação final ambientalmente adequada, para os materiais que iriam ser descartados no meio ambiente. (BRASIL, 2010, Art $3^{\circ}$, XVIII)

Reutilizar parte do fato de aproveitar novamente algum utensílio que seria, posteriormente, descartado, como caixas de sapatos, garrafas pet, sacolas, dentre outros. Além do mais, outras ações podem contribuir significativamente para a desenvoltura da reutilização, tais como a preferência por produtos reutilizáveis, ou mesmo a doação de objetos que não tem mais serventia. (QUADROS, 2015)

A reciclagem, por sua vez, sendo o elemento final da cultura dos 3 R's, é tão essencial quanto os demais, pois ela consiste em fazer com que os produtos retornem ao mercado, evitando à extração de sua matéria-prima novamente. Adad (2018, p. 14) sustenta essa afirmação declarando que a reciclagem surge "como mecanismo desacelerador do uso e do desgaste de estoques naturais, reduzindo o ritmo do consumo de entropia pelos processos industriais".

Reciclagem, conforme a PNRS, é definida como "processo de transformação dos resíduos sólidos" (BRASIL, 2010, Art. 3, XIV), alterando diretamente a sua natureza física, físico-química ou biológicas, com o objetivo de criar um produto que possua ou não a mesma finalidade do anterior. Calderoni (2003, p. 52) contribui dizendo que "reciclar é 'ressuscitar' materiais, permitir que outra vez sejam aproveitados", fazendo com que haja benefícios ao meio ambiente, com a renovação dessa "matéria", evitando o desperdício e seu descarte incorreto.

Pode-se afirmar que a cultura dos 3R's é uma grande aliada na era consumista 
que perdura na atualidade, pois, a mesma, contribui grandemente para a desenvoltura de um ambiente saudável, além de ser fonte geradora renda para a sociedade, visto que há várias formas de aplicabilidade dessa técnica. Exemplo disso, são as cooperativas e associações de catadores, que se apropriam desses métodos para brigarem no amplo mercado, contribuindo grandemente para a movimentação do setor econômico. Neste sentido, fortalece essa alegação Adad (2018) ao enfatizar que:

Cooperativas e associações de catadores representam, assim, um importante papel socioeconômico pois significam a busca pela transformação do seu modo de produzir e viver em comunidade, uma vez que thes oferece perspectiva de obter protagonismo social ao se sentirem partícipes do processo produtivo e na luta por condições mais seguras no exercício da atividade. (ADAD, 2018, p. 28)

Discussões recentes incluem Repensar e Recusar na lógica dos R's da sustentabilidade. De acordo com Massir, Massi e Ramos (2017), o primeiro surge da necessidade de rever os hábitos que podem colaborar para a degradação do meio ambiente, estimulando a criação de técnicas de produção mais sustentáveis. O segundo refere-se à rejeição de produtos que implicam na geração desnecessária de resíduos, como mercadorias de dupla embalagem ou acessórios insignificantes, aderindo materiais com tecidos mais firmes, e negando os descartáveis.

Com o auxílio dessas técnicas, baseada no princípio dos 5R's, pode-se contribuir de maneira expressiva para a melhoria do meio ambiente, visto a grande dificuldade em reduzir o consumo exagerado, pois, isso implica não somente em mudanças de hábitos, mas também necessita de uma reflexão da sociedade quanto aos seus valores culturais.

\section{METODOLOGIA}

Para este estudo, foi realizado uma pesquisa bibliográfica e estudo de caso com abordagem qualitativa, tendo caráter descritivo-exploratório.

A pesquisa é classificada por ter caráter exploratório e descritivo, a qual aprecia a utilização da abordagem qualitativa. De acordo com Trigueiro (2014) a pesquisa exploratória tem o intuito de promover familiaridade com o objeto de pesquisa, através da elaboração de problemas específicos, proporcionando mais informações da área de estudo, tendo necessidade de realizar o estudo documental e bibliográfico do assunto em pauta.

Segundo Prodanov e Freitas (2013) a pesquisa descritiva é caracterizada pela descrição de fatos observados, visando relatar as peculiaridades de um determinado objeto de estudo, quer seja uma população ou fenômeno, através de parâmetros préestabelecidos, sem haver interferência do pesquisador.

Quanto ao tipo de abordagem Godoy (1995) afirma que a pesquisa qualitativa busca estudar os fenômenos relacionados ao homem e o meio que está inserido. Parte 
de perguntas frequentemente amplas, mas que no decorrer da pesquisa, vão se tornando mais compreensivas. Para garantir tais conhecimentos, o procedimento utilizado foi o levantamento bibliográfico e estudo de caso.

Em consonância com Marconi e Lakatos (2007, p. 43-44) a pesquisa bibliográfica "trata-se de levantamento de toda a bibliografia já publicada, em forma de livros, revistas, publicações avulsas e imprensa escrita". Enquanto Gil (2008) categoriza o estudo de caso como base na pesquisa aprofundada, e visa buscar o detalhamento de determinado objeto de estudo.

\section{Caracterização da área de estudo}

O local de estudo da pesquisa, foi o Residencial Salvação (Figura 1), empreendimento integrado ao programa "minha casa, minha vida". A área está localizada no município de Santarém, no estado do Pará, situa-se a margem esquerda da rodovia Engenheiro Fernando Guilhon, no sentido centro -aeroporto, com área total de aproximadamente 79,5 hectares. É um conjunto habitacional formado por 3.081 casas, e possui cerca de 12.000 moradores (SANTOS, 2017).

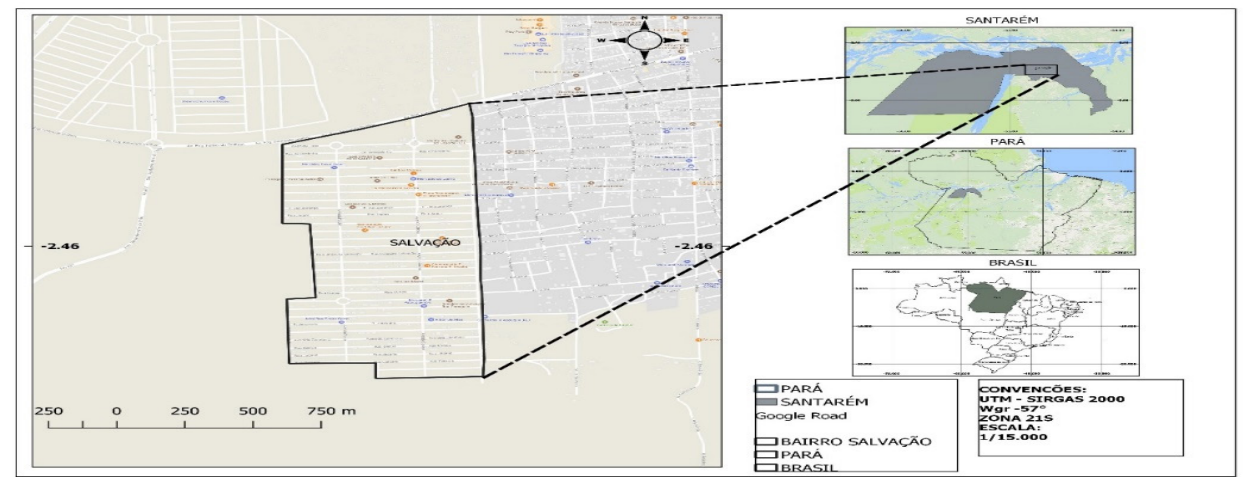

Figura 1- Localização do Residencial Salvação

Fonte: a pesquisa (2019)

O estudo foi realizado por membros do projeto de pesquisa "Um modelo de gestão eficiente de resíduos sólidos em Santarém, Pará", da Universidade Federal do Oeste do Pará - UFOPA. A atuação do grupo intencionou promover ações de educação ambiental, visando a sensibilização dos moradores para as questões acerca da preservação do meio ambiente e de uma melhor qualidade de vida para as pessoas que nele residem.

A metodologia adotada pelos pesquisadores foi dividida em três etapas. A etapa inicial consistiu no embasamento teórico sobre o tema proposto, o que auxiliou a realização da pesquisa, através da literatura especializada. A segunda fase, foi direcionada a efetivação 
da visita técnica à área de estudo. A etapa final, também chamada de intervenção, teve como intuito realizar práticas de educação ambiental por meio de uma palestra dinâmica.

\section{RESULTADOS E DISCUSSÕES}

\section{Visita técnica à área de estudo}

A visita técnica à área de estudo teve como objetivo proporcionar aos pesquisadores uma percepção sobre os impactos que a destinação causa ao Residencial. O registro fotográfico feito durante este momento, possibilitou apresentar, intencionalmente, tais situações aos moradores durante a palestra para produzir uma reflexão sobre esses acontecimentos.

Apesar do Residencial Salvação ser uma construção recente, é notável o acúmulo excessivo de lixo nas ruas, em terrenos abandonados, em frente aos estabelecimentos comerciais e até atrás de algumas residências. Os tipos de resíduos encontrados são diversos, sendo classificados desde resíduos domiciliares, de estabelecimentos comerciais e prestadores de serviços, de serviços de saúde, além de resíduos de construção civil.

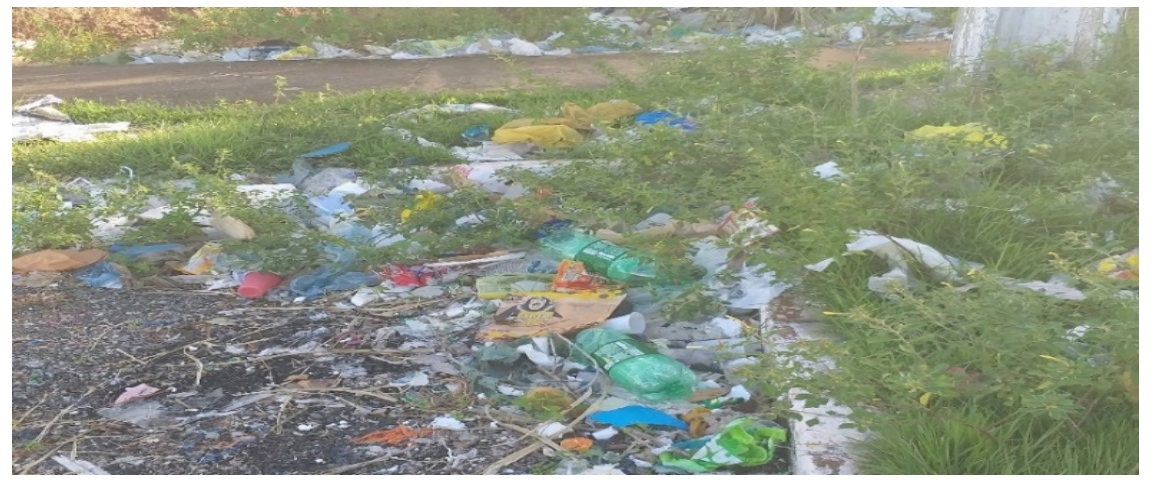

Imagem 1 - Acúmulo de resíduos diversos

Fonte: a pesquisa (2019)

Em um dos pontos observados, notou-se uma grande quantidade de resíduos orgânicos de caroço de açaí (Imagem 2), e este, segundo Teixeira et al (2006), por apresentar em sua composição um teor considerável de lignina, é um elemento de difícil decomposição e com significativo potencial causador de impactos por seu despejo no solo, representa um sério problema ambiental. 


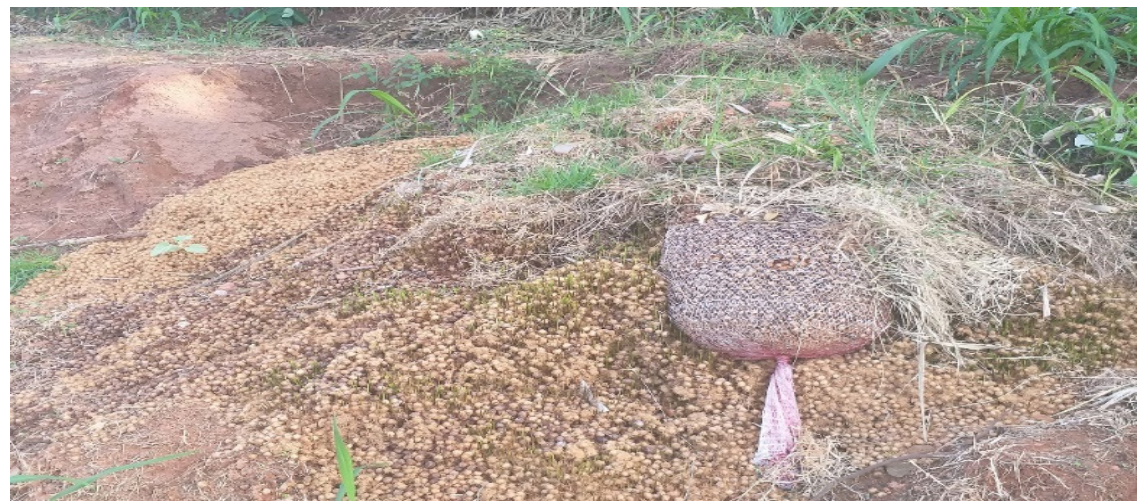

Imagem 2 - Resíduos orgânicos de Caroços de açaí (Rua Cauré com Área Verde)

Fonte: a pesquisa (2019)

Salienta-se também que resíduos de origem eletrônica foram encontrados no local (Imagem 3). Estes, por sua vez, possuem um alto teor tóxico em sua constituição, provocando grandes riscos a salubridade do meio ambiente, afetando seriamente o solo e os lençóis freáticos e, por consequência, a saúde humana. Reforçam esta afirmação, Mattos, Mattos e Perales (2008) ao atestarem que:

Ao serem jogados no lixo comum, as substâncias químicas presentes nos componentes eletrônicos, como mercúrio, cádmio, arsênio, cobre, chumbo e alumínio, penetram no solo e nos lençóis freáticos contaminando plantas e animais por meio da água, podendo provocar a contaminação da população através da ingestão desses produtos. (MATTOS, MATTOS e PERALES, 2008, p. 01)

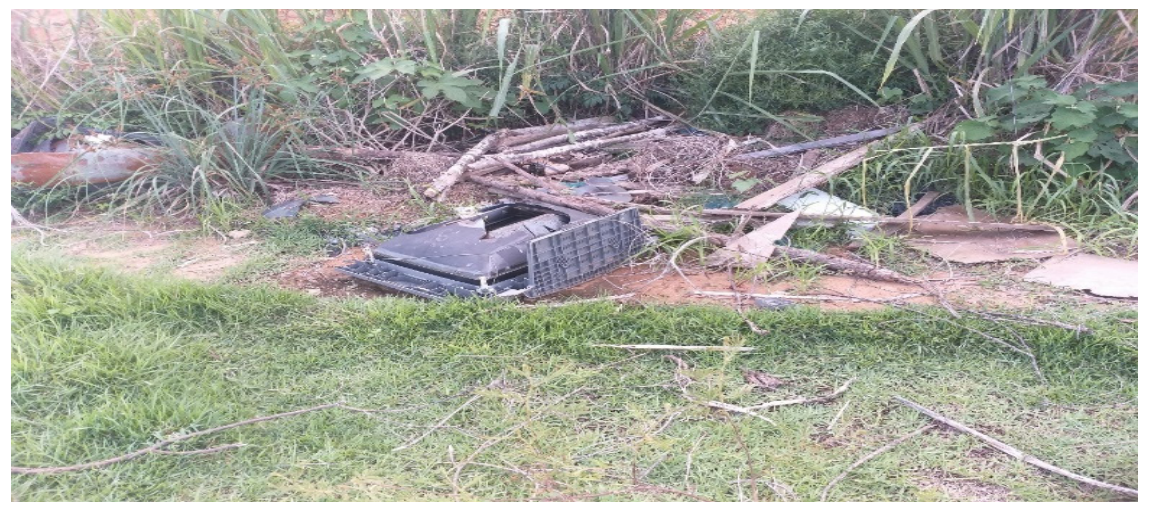

Imagem 3 - Resíduo eletrônico

Fonte: a pesquisa (2019) 
Após as devidas observações e registros fotográficos, foi realizado um pré-teste com alguns residentes da região. $O$ intuito do mesmo era fazer o levantamento de algumas questões ali constadas, e sua eficiência para a futura implantação, na continuidade deste estudo, de um programa piloto de coleta seletiva no Residencial Salvação.

\section{Intervenção}

Durante a realização da intervenção, estavam presentes 32 comunitários do residencial. A dinâmica, "Reciclando Ideias", utilizada na palestra consistiu com a interação dos moradores, onde os mesmos apresentavam um problema sobre resíduos sólidos no local e as suas respectivas soluções. Os problemas foram escritos em uma figura com formato de folha e as possíveis soluções foram escritas em uma figura com formato de um fruto. Desta forma, as folhas e os frutos foram sendo fixados em uma representação de árvore, conforme a imagem a seguir:

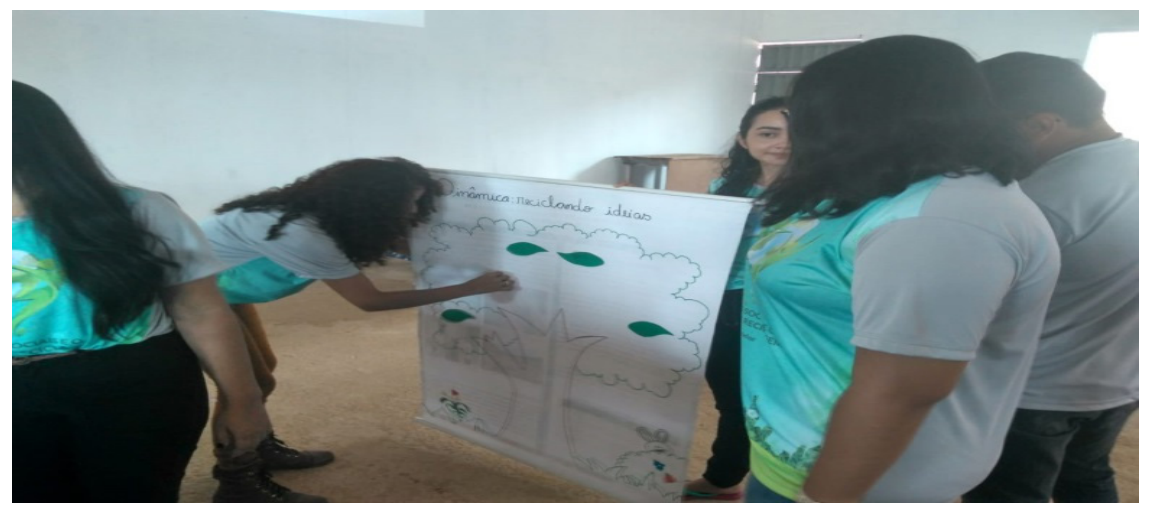

Imagem 4- Dinâmica "Reciclando Ideias"

Fonte: a pesquisa

O objetivo da dinâmica foi fazer com que os moradores daquela localidade, refletissem sobre os problemas ocasionados pelo descarte incorreto dos resíduos no meio ambiente, assim, servindo como um elemento catalisador para reforçar a reponsabilidade dos mesmos para com os problemas ambientais, a fim de serem propostas soluções para que essas problemáticas sejam minimizadas.

Em seguida à dinâmica, foram apresentados em slides algumas fotos do local de estudo, registradas pelos pesquisadores do projeto uma semana antes desta atividade, para fortalecer as discussões e prepara-los para o próximo momento da intervenção. Essas imagens eram parte da visita realizada pelo grupo de pesquisa, as quais apresentavam a situação de descarte de resíduos em locais inapropriados, realizados pelos próprios comunitários, no intuito de chamar à atenção dos mesmos para com os problemas do 
descarte inadequado dos RSU e fazer com que se sentissem parte da solução.

Após à ocorrência da dinâmica, aconteceu a palestra sobre educação ambiental em resíduos sólidos. A palestra teve início, aproximadamente. A finalidade do encontro foi repassar conhecimentos sobre as consequências que o descarte inadequado dos resíduos pode causar, a fim de estimular os moradores a terem o hábito de separar corretamente os materiais, levando em consideração os resíduos recicláveis e os resíduos não recicláveis (Imagem 5).

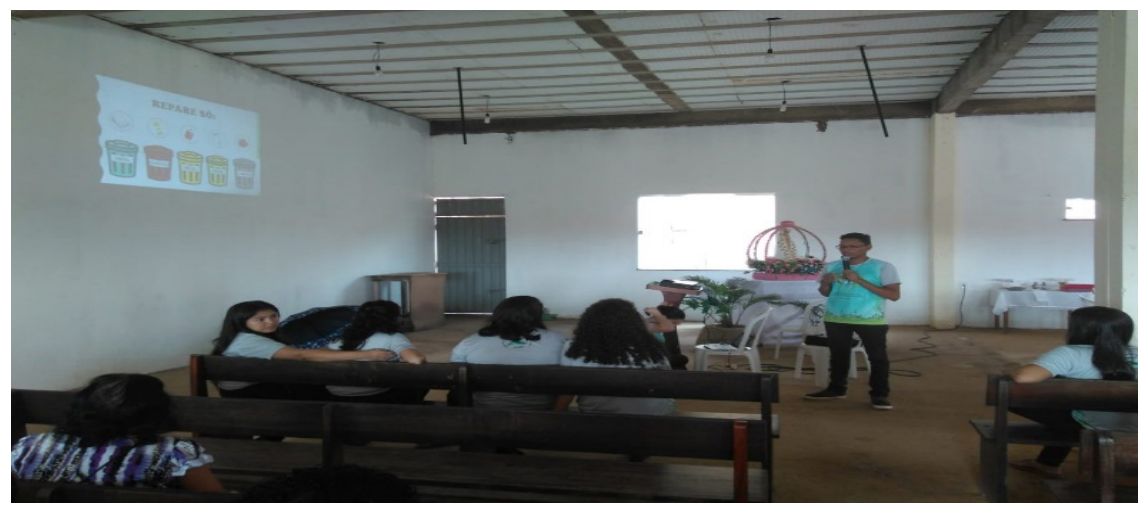

Imagem 5- Palestra "Educação Ambiental em Resíduos Sólidos"

Fonte: a pesquisa

Durante esse momento os moradores demonstraram interesse acerca do assunto explorado, sendo participativos e respondendo às perguntas feitas pelos palestrantes, tais como: O que é lixo? O que pode ir para a reciclagem? O que é resíduo? e outros. Além disso, contribuíram significativamente com a pesquisa quando citavam situações diárias envolvendo a temática.

\section{CONCLUSÃO}

Tendo em vista o crescimento da sociedade, e consequentemente dos resíduos sólidos, a necessidade de implantar um modelo educacional que vise, principalmente, a conservação do meio ambiente, tem se tornado um grande desafio. A busca por tal modelo, baseado na educação ambiental, é bastante compreensível, pois os valores culturais do ser humano vem sendo corrompidos, gradativamente, pelo conforto que o mercado oferece, e que na maioria das vezes, agride de forma expressiva o meio ambiente.

Nota-se que a prática de jogar lixo pelas ruas está cada vez mais comum nos dias atuais, apesar de ser proibida e causar transtornos aos moradores, representa atualmente um sério problema ambiental. Conforme as observações obtidas, verificou-se a grande quantidade de resíduos sólidos jogados em diversos pontos do Residencial Salvação. 
Em geral, o que se percebeu durante as visitas, é que a maioria da população residente naquela região, aparenta acreditar que os problemas relacionados ao "lixo" devem ser resolvidos unicamente pelos representantes do poder público e esquecem-se de que sua participação é indispensável. Por isso, é de suma importância informar aos moradores sobre as consequências que a destinação inadequada dos resíduos ocasiona a qualidade de vida do homem e do meio ambiente.

Verificou-se também que a comunidade possui a conscientização necessária para entender tanto a magnitude do problema que está em sua volta, como também suas soluções. Entretanto, as atitudes da população não correspondem aos discursos que são retratados por eles.

A utilização da educação ambiental foi primordial, pois mostrou eficiência como uma ferramenta eficaz para compartilhar conhecimentos obtidos no meio acadêmico com a comunidade em estudo. O estudo buscou ajudar a população envolvida a se organizar melhor para o descarte correto dos resíduos no meio em que está inserida, sensibilizando-a e propagando a cultura da conservação do meio ambiente, chamando a atenção para a importância de que a comunidade se torne elemento catalizador para a propagação da Educação Ambiental em Resíduos Sólidos, pois, dessa forma, é provável que a problemática relacionada ao descarte incorreto dos Resíduos Sólidos, seja atenuada.

\section{AGRADECIMENTOS}

Os autores agradecem a disponibilidade e o carinho dos comunitários do Residencial Salvação na participação das intervenções realizadas pelos pesquisadores do grupo de Estudos, Pesquisa e Extensão em Educação Ambiental - GEPEEA da Universidade Federal do Oeste do Pará.

\section{REFERÊNCIAS}

ADAD, Maria Francisca de Miranda. O Papel dos Atores Sociais do Mercado de Reciclagem em Santarém: Uma Análise Socioeconômica À Luz do Indicador Força Motriz-Estado-Resposta. 2108. Tese de Mestrado. Universidade Federal do Oeste do Pará. Programa de Pós-Graduação Doutorado Sociedade, Natureza E Desenvolvimento. Santarém: 2018.

AMORIM, A.P.; ALBUQUERQUE, B. M.; GAUTÉRIO, D. T.; JARDIM, D. B.; MARRONE, E. C.; SOUZA, R. M. Lixão Municipal: Abordagem de uma Problemática Ambiental na Cidade do Rio Grande RS. Ambiente \& Educação, v. 15, n. 1, p. 159-178, 2010.

BRASIL. (1989.) Projeto de Lei n. 354 de 27 de outubro de 1989. Dispõe sobre o acondicionamento, a coleta, o transporte, e a destinação final dos resíduos de serviços de saúde. Diário Oficial da República Federativa do Brasil, Brasília, DF, 2, abr. 1991. Disponível em: <http://rla.org/upload/ regulatory/national-solid-waste.pdf>. Acesso em: fevereiro de 2018.

BRASIL. (1991). Projeto de Lei n. 203 de 01 de abril de 1991. Dispõe sobre o acondicionamento, a coleta, o transporte, e a destinação final dos resíduos de serviços de saúde. Diário Oficial da República Federativa do Brasil, Brasília, DF, 2, abr. 1991. 
BRASIL. (1999). Lei ${ }^{\circ} 9.795$ de 27 de abril de 1999. Dispõe sobre a educação ambiental, institui a Política Nacional de Educação Ambiental e dá outras providências. Diário Oficial da Republica do Brasil, Brasília, DF, 28 de abr. 1999.

BRASIL. (2001). Ministério do Meio Ambiente. Conselho Nacional do Meio Ambiente. Resolução $\mathbf{n}^{\circ}$ 275, de 25 de abril de 2001 - CONAMA - Brasília, DF - D.O.U nº 117 de 19/06/2001 Seção 01, página 80.

BRASIL. (2010). Lei $n^{\circ}$ 12.305, de 02 de agosto de 2010. Política Nacional de Resíduos Sólidos - PNRS. Presidência da República Federativa do Brasil. Disponível em: <http://www.planalto.gov.br/ ccivil_03/_ato20072010/2010/lei//12305.htm>. Acesso em Out 2018.

BRASIL. (2016). Mais de26,5 Mil Pessoas Recebem as Chaves da Casa Própria do Minha Casa, Minha Vida. Ministério do Desenvolvimento Regional. Disponível em: <http://www.cidades.gov.br/ ultimas-noticias/4279-mais-de-26-5-mil-pessoas-recebem-as-chaves-da-casa-propria-do-minha-casaminha-vida>. Acesso em: março de 2019.

CALDERONI, S. Os Bilhões Perdidos no Lixo. 4a ed. São Paulo: Humanitas/FFLCH-USP, 2003.

CARDOSO, A. L. Trajetórias da Questão Ambiental Urbana: da rio 92 às agendas 21 locais. Revista Paranaense de Desenvolvimento - RPD. Curitiba, n. 102, p. 51-69, jan./jun. 2002.

DIAS, L. S.; MARQUES, M. D. DIAS, L. S. Educação, Educação Ambiental, Percepção Ambiental e Educomunicação. In: DIAS, L. S.; LEAL, A. C.; CARPI JUNIOR, S. Educação Ambiental: conceitos, metodologia e práticas. $1^{a}$ ed. Tupã, São Paulo: Editora ANAP, 2016. p. 12-44.

FORAGI, R. Uma Análise do Programa Minha Casa Minha Vida. Porto Alegre, RS, 2012. Trabalho de conclusão de curso. Universidade Federal do Rio Grande do Sul - Departamento de Ciências Econômicas.

GIL, A. C. Métodos e Técnicas de Pesquisa Social. 6ª ed. São Paulo: Editora Atlas, 2008.

GODOY, A. S. Pesquisa Qualitativa: tipos fundamentais. Revista de administração de Empresas ERA. São Paulo, v. 35, n.3, p, 20-29 mai./jun. 1995.

KORAND, O.; CALDERAN, T. B. A Preservação Ambiental na Visão da Política Nacional dos

Resíduos Sólidos. In: Âmbito Jurídico., Rio Grande XVI, n. 89, jun. 2011. Disponível em: <http://www. ambitojuridico.com.br/site/?n_link=revista_\%20artigos_leitura\&artigo_id=9750>. Acesso em: fevereiro 2019.

MARCATTO, C. Educação Ambiental: conceitos e princípios. $1^{\text {a }}$ ed. Belo Horizonte: Fundação Estadual do Meio Ambiente - FEAM, 2002.

MARCONI, Marina de Andrade; LAKATOS, Eva Maria. Metodologia do Trabalho Cientifico. $7^{\mathrm{a}}$ ed. São Paulo: Editora Atlas, 2007

MASSIR, C. G.; MASSI, E. H.; RAMOS, D. J. Educação Ambiental Crítica como Ferramenta na Política dos 5R's. $8^{\circ}$ Fórum Internacional de Resíduos Sólidos. Curitiba, Brasil. 2017.

MATTOS, K. M. C.; MATTOS, M. C.; PERALES, W. J. S. Os Impactos Ambientais Causados pelo Lixo Eletrônico e o Uso da Logística Reversa para Minimizar os Efeitos Causados ao Meio Ambiente. XXVIII. Encontro Nacional de Engenharia de Produção-ENEGEP. A integração de cadeias produtivas com a abordagem da manufatura sustentável. Rio de Janeiro, 2008. 
MORAIS, Karine Tavares. Conflitos Socioambientais no Contexto da Política Nacional de

Resíduos Sólidos: implantação da logística reversa do plástico. 2015. Tese de Mestrado. Universidade

Federal de Alagoas. Programa de Pós-Graduação em Sociologia. Maceió: 2015.

MORAES, F. G.; SILVA, K. M. D.; LEAL, A. C. Coleta Seletiva no Município de Martinópolis - Sp.

Departamento de Geografia, VI Seminário Latino Americano e II Seminário Ibero Americano de

Geografia Física. Martinópolis: IGCE/UNESP, 2006.

MOVIECO - Econotcias, Informativo Ecológio. PNRS - Nosso Problema, Nossa Solução!. (Cartilha). 2013, 28 páginas

MUNIZ, C. A. L. Análise Comparativa dos Métodos de Fatores Ponderados na Seleção de Áreas para Aterro Sanitário. Universidade Federal do Rio Grande do Norte, Natal, 2013.

PEIXOTO, K.; CAMPOS, V. G.; AGOSTO, M. A. A Coleta Seletiva e a Redução dos Resíduos

Sólidos. Instituto Militar de Engenharia. Rio de Janeiro. 2005, 21 páginas.

PRODANOV, C. C.; FREITAS, E. C. Metodologia do Trabalho Científico: métodos e técnicas da pesquisa e do trabalho acadêmico. 2 ed. Novo Hamburgo, RS: Feevale, 2013.

QUADROS, Michele Soares. Separação de Resíduos Domiciliares: Diagnóstico com Alguns Moradores no Bairro Nossa Senhora de Lourdes em Santa. 2015. Monografia (especialização em Educação Ambiental). Universidade Federal de Santa Maria. Santa Maria: 2015.

ROTH, C. G.; GARCIAS, C. M. Construção Civil e a Degradação Ambiental. Desenvolvimento em Questão. Unijuí. V 7. n. 13, p. 111-123. 2009.

SANTOS, B. A. As Políticas de Habitação e Urbanização Diante da Mudança do Clima: estado da vulnerabilidade e da adaptação em Santarém - Pará. 2017. Tese de mestrado, Universidade Federal de Brasília. Programa de Pós-Graduação em Desenvolvimento Sustentável, Brasília, 2017.

SORRENTINO, M.; TRAJBER, R.; FERRARO JUNIOR. Educação Ambiental como Política Pública. Revista Educação e Pesquisa, São Paulo, v. 31, n. 2, p. 285-299, mai./ago. 2005.

TEIXEIRA, B. L.; OLIVEIRA, R. F.; FURLAN JÚNIOR, J.; CAMPOS, P. I. F.; GERMANO, V. L. C. Compostagem: lixo orgânico urbano e resíduo da agroindústria do açaí. Belém: Embrapa Amazônia Oriental: Albrás, 2006.

TRIGUEIRO, R. M. Metodologia Científica. Londrina: Editora e Distribuidora Educacional S.A, 2014.

VILHENA, A. Guia da Coleta Seletiva de Lixo/ texto e coordenação André Vilhena; ilustrações Sandro Falsetti - São Paulo: CEMPRE - Compromisso Empresarial para Reciclagem. $2^{\mathrm{a}}$ ed. São Paulo, 2013. 


\section{EDUCAÇ̃̃O AMBIENTAL COM ESTUDANTES DO ENSINO MÉDIO DURANTE A PANDEMIA DO CORONAVÍRUS EM ESCOLAS RURAIS DE LAGES-SC}

Data de aceite: 04/01/2021

\section{Daniely Neckel Rosini}

Universidade do Estado de Santa Catarina (UDESC)

Lages - SC

http://lattes.cnpq.br/1290138248832119

\section{Débora Cristina Correia Cardoso}

Universidade do Estado de Santa Catarina

(UDESC)

Lages - SC

http://lattes.cnpq.br/2767570871721905

Jordana dos Anjos Xavier

Universidade do Estado de Santa Catarina

(UDESC)

Lages - SC

http://lattes.cnpq.br/1562975042294996

Valter Antonio Becegato

Universidade do Estado de Santa Catarina

(UDESC)

Lages - SC

http://lattes.cnpq.br/3196823526572670

Vitor Rodolfo Becegato

Universidade do Estado de Santa Catarina

(UDESC)

Lages - SC

http://lattes.cnpq.br/7642634231071974

Alexandre Tadeu Paulino

Universidade do Estado de Santa Catarina

(UDESC)

Pinhalzinho - SC

http://lattes.cnpq.br/8957379372810063
RESUMO: A educação básica no Brasil conta com normas direcionadas as redes de ensino que elencam diversos temas relacionados à educação ambiental. O art. 28 da Lei de Diretrizes e Bases da Educação Nacional ainda assegura a oferta de educação básica a população rural, adaptada as especificidades da vida rural. Com isso, a educação ambiental é considerada um elemento fundamental na base da educação nacional, que deve estar presente em todos os níveis do processo educativo. No entanto, além das adaptações necessárias na educação da população rural, no ano de 2020 foi inevitável um ajuste nas práticas pedagógicas em função da pandemia do coronavírus, juntamente com a carência em tecnologias, conexão, estrutura e amparo familiar de alguns estudantes. Diante do exposto, o presente trabalho objetivou relatar um estudo realizado com alunos do ensino médio de escolas na área rural do município de LagesSC durante a pandemia do coronavírus, com o intuito de fomentar a importância da educação ambiental nas escolas do campo. Os estudantes do $2^{\circ}$ e $3^{\circ}$ ano do ensino médio, de escolas da rede municipal localizadas em localidades da Coxilha Rica, interior do município de Lages, desenvolveram atividades de biologia por meio do conhecimento da biota nativa e das relações ecológicas presentes no ambiente, que os proporcionou uma reflexão crítica sobre os impactos ambientais causados pelas atividades antrópicas. Pode-se concluir que a educação ambiental é fundamental em todos os níveis de ensino, principalmente nas escolas rurais, porém há uma lacuna no que diz respeito às práticas desenvolvidas nesse contexto. 
PALAVRAS-CHAVE: Educação ambiental. Escolas rurais. Coronavírus. Animais vertebrados. Relações ecológicas.

\title{
ENVIRONMENTAL EDUCATION WITH HIGH SCHOOL STUDENTS DURING THE CORONAVIRUS PANDEMIC IN RURAL SCHOOLS OF LAGES-SC
}

\begin{abstract}
Basic education in Brazil has norms directed to education networks that list several themes related to environmental education. Art. 28 of the Law of Guidelines and Bases of National Education also ensures the provision of basic education to the rural population, adapted to the specificities of rural life. As a result, environmental education is considered a fundamental element at the base of national education, which must be present at all levels of the educational process. However, in addition to the necessary adaptations in the education of rural population, adjustments in pedagogical practices due to the coronavirus pandemic were inevitable in 2020 , along with the lack of technologies, connection, structure and family support of some students. In view of the exposed, the present study aimed to report a study carried out with high school students from schools in the rural area of the city of LagesSC during the coronavirus pandemic, in order to promote the importance of environmental education in rural schools. The 2 nd and 3 rd year high school students, from municipal schools located in the Coxilha Rica region, outskirts of Lages, developed biology activities utilizing the knowledge of native biota and the ecological relationships present in the environment, which provided a critical reflection on the environmental impacts caused by human activities. It can be concluded that environmental education is fundamental at all levels of education, especially in rural schools, but there is a gap with regard to the practices developed in this context.
\end{abstract}

KEYWORDS: Environmental education. Rural schools. Coronavirus. Vertebrate animals. Ecological relations.

\section{I INTRODUÇÃO}

A legislação ambiental foi implementada no Brasil a partir da Política Nacional do Meio Ambiente (BRASIL, 1981). Um dos princípios dessa lei, é promover a educação ambiental a todos os níveis de ensino com o objetivo de proporcionar a participação ativa dos cidadãos na defesa do meio ambiente.

Com isso, em 1988 foi instituída a constituição federal no Brasil, que prevê, em seu artigo 255, que todo cidadão tem direito a um meio ambiente ecologicamente equilibrado, bem de uso comum e essencial à qualidade de vida. Além disso, frisa também que a educação ambiental deve estar presente em todos os níveis de ensino com o objetivo de conscientizar a população sobre a preservação do meio ambiente (BRASIL, 1988).

As preocupações em torno das políticas educacionais foram descritas pela Política Nacional de Educação Ambiental, aprovada em 1999 e regulamentada em 2002, a qual afirma que "a educação ambiental é um componente essencial e permanente da educação nacional, devendo estar presente, de forma articulada, em todos os níveis e modalidades 
do processo educativo, em caráter formal e não-formal” (BRASIL, 1999).

A Lei das Diretrizes e Bases da Educação Nacional (BRASIL, 1996), não especifica sobre a educação ambiental nos níveis de ensino. Porém, no art. $28^{\circ}$, destaca sobre a oferta de educação básica para a população rural, em que os sistemas de ensino precisam promover as adaptações de acordo com as especificidades da vida rural. A Base Nacional Comum Curricular (BRASIL, 2018) é um documento que instituiu referências obrigatórias para a elaboração dos currículos escolares, elencando normas para as redes de ensino básico no Brasil e este documento descreve vários temas relacionados à educação ambiental nos diferentes componentes curriculares e níveis de ensino.

$O$ ano de 2020 se caracterizou por ser um ano desafiador em todos os setores, principalmente na educação. O coronavírus mudou a vida das pessoas (SABINO-SILVA; JARDIM; SIQUEIRA, 2020). A dinâmica de sala de aula e as relações construídas precisaram ser adaptadas. Todos os professores foram desafiados a propor novas práticas pedagógicas para construir o conhecimento com o maior número de alunos possível. Professores da rede pública de ensino lidam ainda com a falta de tecnologias, de conexão, de estrutura e amparo familiar de muitos estudantes.

É dever de todos defender e preservar o meio ambiente para as presentes e futuras gerações (BRASIL, 1988). Porém, não se preserva aquilo que não se conhece. Por isso, as políticas educacionais são essenciais para que a população desenvolva a consciência crítica sobre o tema.

O município de Lages-SC está inserido no bioma Mata Atlântica, caracterizado por possuir uma grande biodiversidade (ZANINI, et al., 2020), porém, muitas pessoas não conhecem isso. Com base nesses conceitos, o objetivo desse trabalho foi relatar um estudo realizado com os alunos de quatro turmas do ensino médio de duas escolas na área rural do município de Lages-SC, durante a pandemia do coronavírus, sobre os conceitos de animais vertebrados e relações ecológicas, valorizando a biota nativa e contribuir para fomentar a importância da educação ambiental nas escolas do campo.

\section{I MATERIAIS E MÉTODOS}

O estudo foi realizado em duas escolas públicas municipais, localizadas na área do município de Lages-SC. Lages foi fundada pelos tropeiros e se destaca pela criação de gado, pelas madeireiras, lavouras e turismo rural. O município está inserido no bioma Mata Atlântica, na formação da Floresta Ombrófila Mista, na régio Sul do Brasil. É o município que apresenta maior extensão territorial de Santa Catarina. A população estimada é de 157.743 habitantes. O planalto de Lages foi coberto por floresta de araucária e tem altitude média de 900 m (IBGE, 2018). As massas de ar que atuam no em Lages são a tropical atlântica, polar atlântica, tropical continental e equatorial continental. O município está inserido em área de interferência do clima mesotérmico úmido, com verão fresco, sem estação seca, 
com amplitude térmica entre inverno e verão (OMETTO,1981).

A Secretaria Municipal da Educação do Município de Lages dispõe de 127 unidades de ensino, sendo 15 escolas no campo. A rede municipal possui 15.546 estudantes matriculados em 2020, destes, 69 no ensino médio, todos nas escolas do campo (SECRETARIA MUNICIPAL DA EDUCAÇÃO DE LAGES, 2020).

Este trabalho analisou as atividades de Biologia realizadas pelos estudantes dos $2^{\circ \mathrm{s}}$ e $3^{\text {os }}$ anos do Ensino Médio das localidades de Fazenda do Baú e Morrinhos, localizados na Coxilha Rica, no município de Lages-SC, no período do mês de novembro de 2020. Os alunos tinham entre 15 e 18 anos. Estas atividades foram desenvolvidas por meio da compreensão da biota nativa para conhecimento dos vertebrados e das relações ecológicas presentes no ambiente, possibilitando uma reflexão crítica dos estudantes sobre os principais impactos ambientais causados pelas atividades humanas.

A Secretaria Municipal de Educação de Lages disponibilizou a plataforma do Google Scholar para a comunidade escolar, mas o acesso à internet dos alunos é muito limitado. Como alternativa, foi criado um grupo no Whatsapp, um aplicativo de troca de mensagens que tem acesso mais fácil, se manteve ativo durante todo o ano letivo e os alunos receberam sugestões de materiais escolares e compartilharam informações. Além disso, foram realizadas reuniões online, com apresentação, elaboração de conceitos através das plataformas Google Meet, Mentimeter e Google Formulários.

As atividades foram elaboradas por todos os alunos do Ensino Médio da área do estudo. As atividades do $2^{\circ}$ ano foram encaminhadas para três alunos em Morrinhos e três alunos da Fazenda do Baú. Já as do $3^{\circ}$ ano, foram enviadas para uma aluna em Fazendo do Baú e três alunos em Morrinhos.

\section{I RESULTADOS E DISCUSSÃO}

\subsection{A importância da educação ambiental na escola rural}

A educação do campo é uma modalidade extremamente importante, que teve início no Brasil com os jesuítas. Atualmente, o êxodo rural é muito intenso e levar oportunidades de estudo para a área rural é uma forma de respeito à diversidade e valores da população. $A$ educação ambiental nessas áreas rurais faz com que os estudantes se sintam pertencentes ao meio em que vivem e repensem as práticas que agridem o meio ambiente, buscando o equilíbrio socioambiental (FERNANDES, 2019).

O cenário em que vivemos, exige que sejam feitas mudanças bruscas no modo de produção, desafiando a sociedade a encontrar novos caminhos para a construção do presente e, consequentemente, do futuro. Os principais impactos ambientais ocasionados pelas atividades rurais estão relacionados com o desmatamento, compactação e erosão do solo, contaminação dos corpos hídricos e extinção de espécies (BERNARDES; MATOS; NEHME, 2013). A escola é um ambiente plural e a educação precisa ser próxima da 
realidade, servindo como uma reflexão da condição humana para que os jovens entendam o seu entorno (MENEZES, 2017).

Os diversos problemas ambientais observados no mundo contemporâneo fazem com que as pessoas repensem às questões, refletindo sobre o mundo em que se vive, para que aconteça o respeito aos limites biológicos, químicos e físicos da natureza. A educação tem papel essencial nesse processo, com o objetivo de formar cidadãos com consciência e com respeito, proporcionando a mudança de atitudes. A educação ambiental é mediadora nas ações transformadoras em que os seres humanos se sentem realmente responsáveis diante do local em que vivem, contribuindo para a formação humana integral (RAMADHAN; SUKMA; INDRIYANI, 2019).

\subsection{Animais vertebrados}

A Mata Atlântica é um dos seis biomas brasileiros que é rico em biodiversidade. Ocupa 15\% do território nacional em 17 estados diferentes. A Mata Atlântica abriga mais de 15.700 espécies de plantas, mais de 2.208 espécies de vertebrados, destes 298 são mamíferos, 992 espécies de aves, 200 de répteis, 370 de anfíbios e 350 de peixes. Na Mata Atlântica estão mais de $5 \%$ de todas as espécies de vertebrados do mundo. Os impactos ambientais ocasionados a esse bioma estão relacionados principalmente à ocupação populacional e colonização no Brasil, desmatamentos sucessivos, atividades agropecuárias, exploração predatória, industrialização, expansão urbana e consumo excessivo (ALMEIDA, 2016).

$O$ estudo dos animais vertebrados na rede municipal de Lages acontece no $2^{\circ}$ ano do Ensino Médio. A atividade enviada para os alunos teve como objetivo fazer com que eles entendessem o funcionamento e a importância dos vertebrados para o equilíbrio do meio ambiente, compreendessem o modo de vida dos vertebrados e sua relação com os seres humanos, conhecessem e valorizassem a fauna nativa da região serrana de Santa Catarina e comentassem situações problemas, indicando soluções para as mesmas.

Nas duas atividades anteriores dos $2^{\text {os }}$ anos, os animais invertebrados foram estudados. Na atividade do mês de novembro, os alunos deveriam ler o texto sobre os cinco grupos dos animais vertebrados: peixes, anfíbios, répteis, aves e mamíferos, sublinhar o que achassem mais importante e responder às atividades sobre o modo de vida, a fisiologia e a importância ecológica de diversas espécies. Além disso, os alunos precisavam escolher um animal vertebrado que é nativo da nossa região e fazer a classificação dele. Sobre esse animal, foram desafiados a encontrar, filmar e observar. Depois, os alunos precisavam fazer um vídeo ou um texto, descrevendo a importância do animal para o ambiente, qual classificação taxonômica ele pertence, quantos anos vive, seu corpo funciona, esqueleto, respiração, circulação, excreção, alimentação, sistema nervoso, reprodução, novidades evolutivas e curiosidades sobre ele.

Um dado que chamou muita atenção, foi o fato de que os alunos citaram primeiramente durante as aulas, bovinos, suínos e galináceos como animais nativos. Isso demonstrou que 
muitos estudantes não entendem as relações que acontecem no ambiente e a importância da preservação dos animais nativos. Percebeu-se que era necessário retomar os conceitos de animais nativos, que ocorrem naturalmente em uma região; animais exóticos, quando a espécie foi introduzida pelo ser humano em um local, não habitando seu ambiente natural; e animais domésticos, que são aqueles que servem de propósito para o trabalho ou são de estimação (LOCKWOOD et al., 2019). Todos os alunos tiveram resultado satisfatório na atividade.

$\mathrm{Na}$ sequência os alunos foram desafiados a encontrarem animais vertebrados presentes na região da Coxilha Rica em Lages-SC. O resultado foi bem interessante. Os acadêmicos produziram vídeos muito criativos e conseguiram localizar diversos animais em seus ambientes naturais, descrevendo o modo de vida deles. Os animais vertebrados são organizados em cinco principais classificações: peixes, anfíbios, répteis, aves e mamíferos. Os animais ectotérmicos são aqueles em que a temperatura do corpo não é estável e varia conforme a temperatura do ambiente (RUBALCABA; GOUVEIA; OLALLA-TÁRRAGA, 2019). A figura 1, mostra os animais ectotérmicos citados pelos alunos que são da fauna nativa.

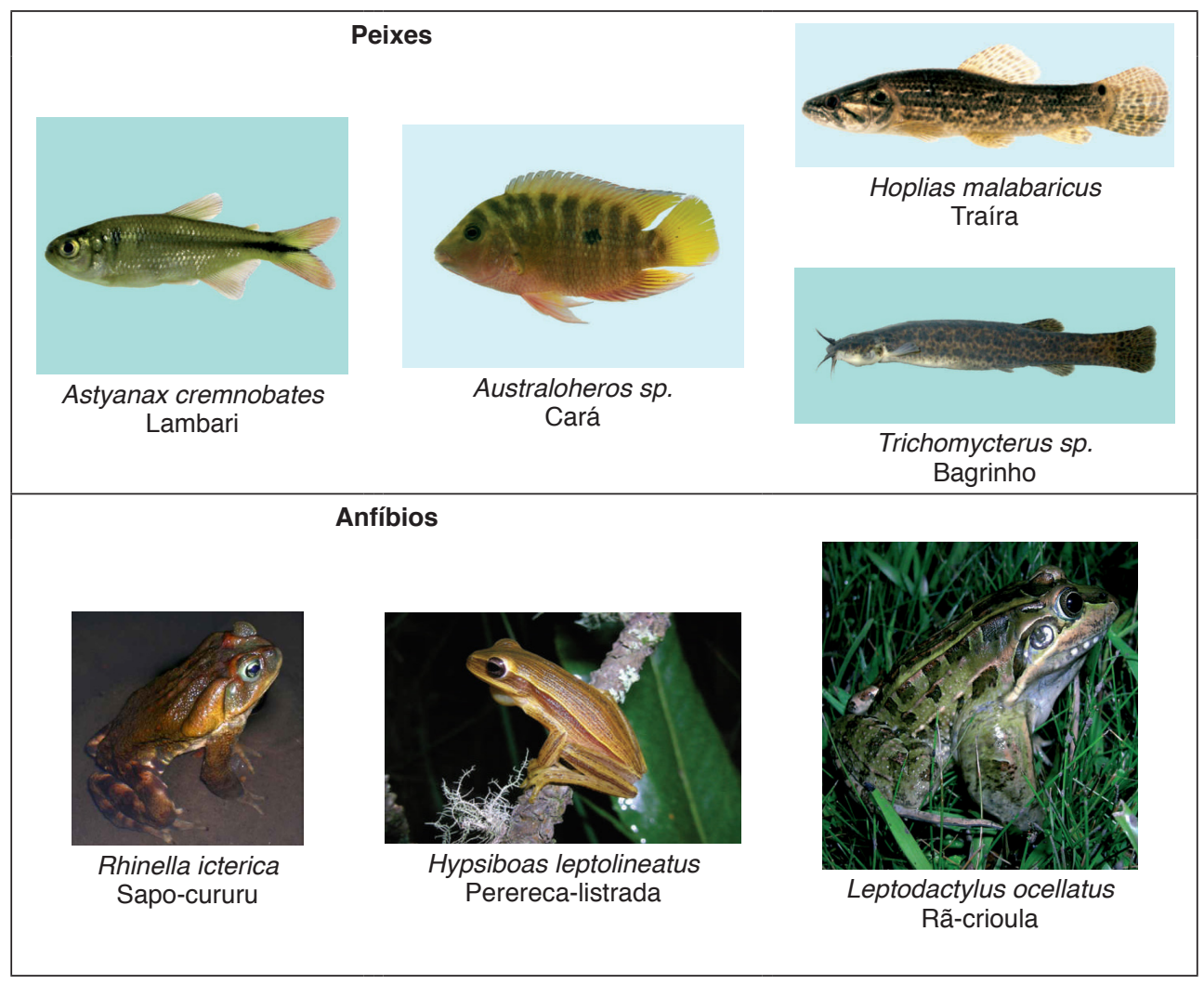




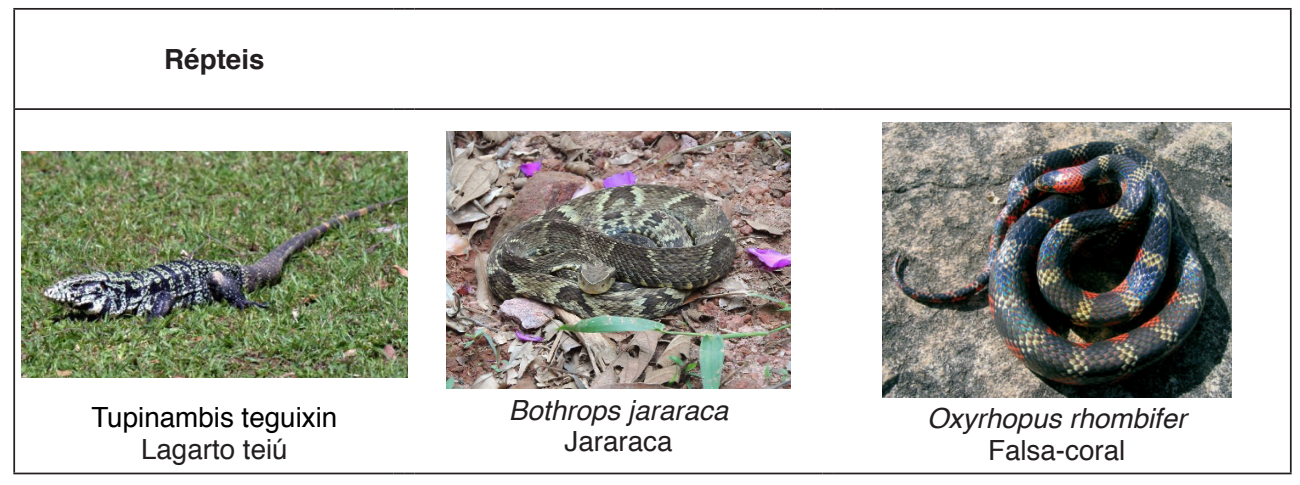

Figura 1 - Animais ectotérmicos nativos citados pelos alunos que ocorrem na região serrana de Santa Catarina, com base em Buckup (2016).

Os animais vertebrados endotérmicos são aqueles que mantém a temperatura do corpo independente da temperatura do ambiente. As aves conseguem manter a temperatura de seu corpo em torno de 40 a $42^{\circ} \mathrm{C}$ por causa de um centro termorregulador, localizado no sistema nervoso central, e as penas auxiliam nesse processo. Já os mamíferos, possuem os pelos e tem uma alta taxa metabólica em que o metabolismo faz trocas de calor com o ambiente (VERBECK, 2020).

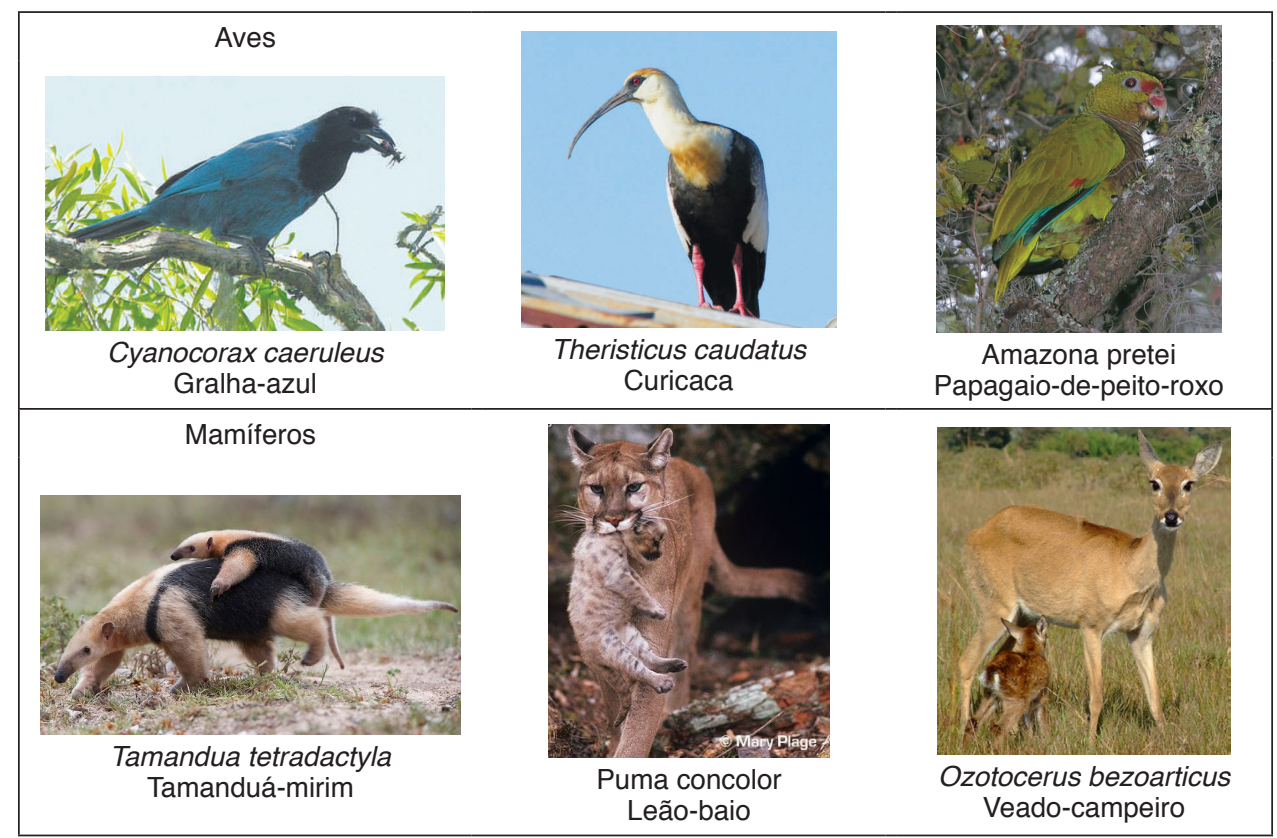

Figura 2 - Animais endotérmicos nativos, citados pelos alunos, que ocorrem na região serrana de Santa Catarina, com base em Buckup (2016). 
Apesar de a maioria das fotos e vídeos não terem ficado com boa qualidade, o que é normal devido à complexidade para se tirar fotos de animais no seu ambiente natural, todos os alunos conseguiram alcançar os objetivos propostos. A Figura 3 mostra a foto tirada e utilizada por uma aluna para a elaboração do vídeo.

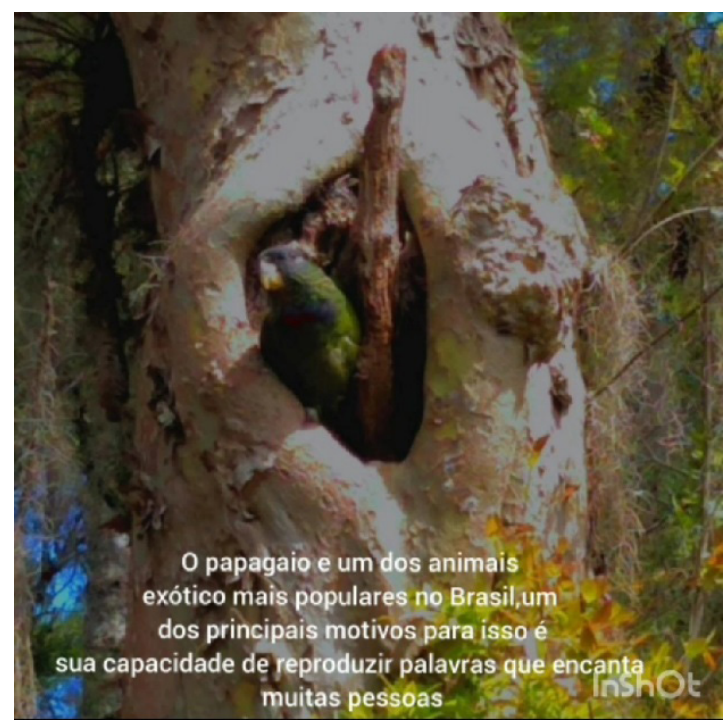

Figura 3 - Parte do vídeo do papagaio elaborado por uma estudante do $2^{\circ}$ ano

\subsection{Relações ecológicas}

As relações ecológicas são as relações que acontecem entre os seres vivos no meio ambiente. Elas podem ser classificadas segundo o nível de interdependência em intraespecíficas (entre seres da mesma espécie) e interespecíficas (entre seres de espécies diferentes). Além disso, as relações ecológicas podem ser harmônicas ou desarmônicas. O tema Ecologia é trabalhado com os alunos do terceiro ano do Ensino Médio nas escolas do município de Lages-SC. As principais relações estudadas estão descritas na Figura 4 (MORAN, 2017). 


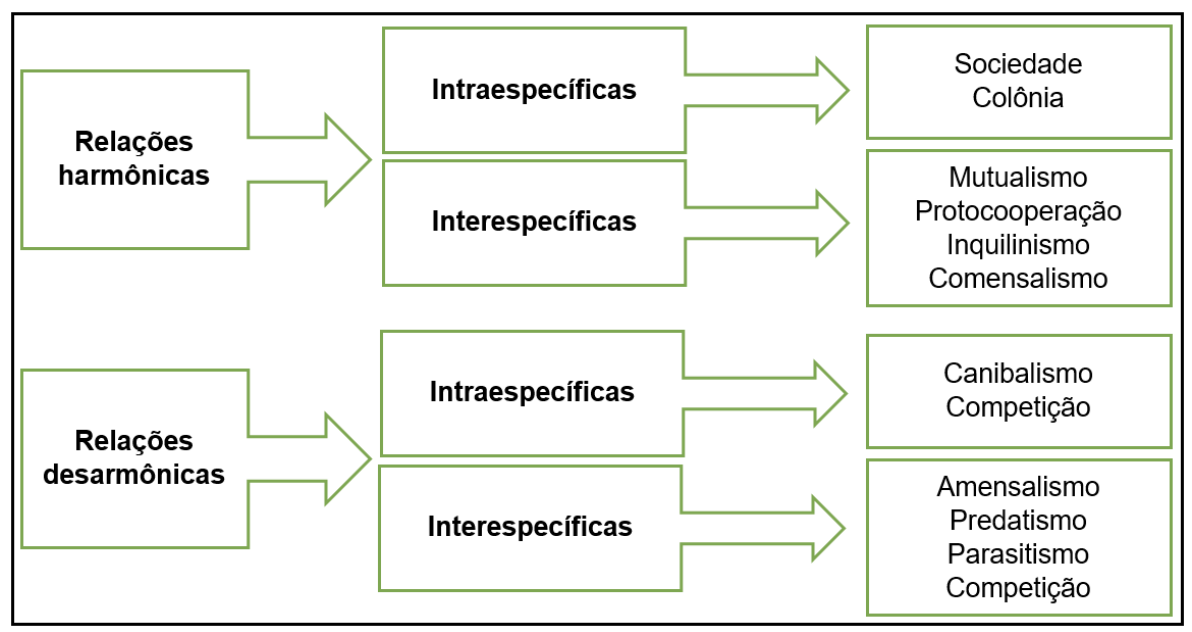

Figura 4 - Principais relações ecológicas que ocorrem no ambiente.

As atividades encaminhadas para os alunos do terceiro ano do Ensino Médio, tiveram como objetivo fazer com que os alunos entendessem a dinâmica do meio ambiente, observassem o mundo em sua volta, conhecessem as diferentes formas de vida que habitam a região em que vivem, comparassem os modos de vidas e as relações que ocorrem entre os seres vivos, valorizassem a fauna e a flora nativas e analisassem a forma em que o ser humano interfere na vida dos seres vivos.

Os alunos recebiam duas atividades impressas mensalmente, que eram levadas até suas residências por meio do transporte escolar e no final do mês eram recolhidas. Nas atividades encaminhadas no mês de novembro, sobre as relações ecológicas, os alunos precisaram ler o texto, sublinhar o que achassem mais importante e responder às atividades sobre as relações.

Os alunos conseguiram desenvolver muito bem as atividades propostas. A Figura 5 mostra algumas atividades desenvolvidas pelos estudantes.

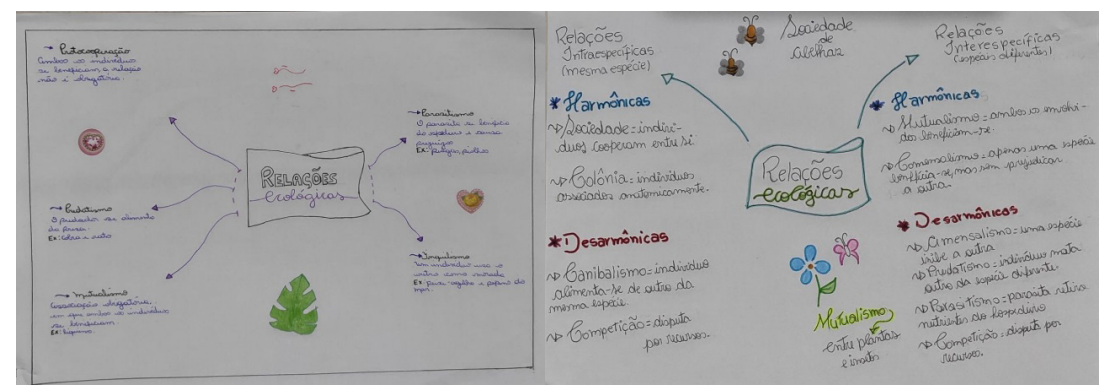

Figura 5 - Parte das atividades sobre as relações ecológicas desenvolvidas pelos estudantes. 
$\mathrm{Na}$ outra atividade, os alunos precisaram escolher cinco relações ecológicas e observá-las ocorrendo no ambiente. Depois, produzir um vídeo filmando, nomeando e explicando cada uma das relações ecológicas que observaram. Caso os alunos não conseguissem fazer a gravação, eles poderiam fazer desenhos e textos exemplificando e explicando cada uma das relações ecológicas que conseguiram observar no ambiente. Vale ressaltar, que os conceitos de animais nativos, exóticos e domésticos também precisaram ser esclarecidos para estes alunos.

Os alunos conseguiram relatar muito bem todas as relações que eles observaram no ambiente, diferenciando-as em harmônicas ou desarmônicas e, também, em intraespecíficas (entre seres da mesma espécie) ou interespecíficas (seres de espécies diferentes). Na Figura 6 observa-se as relações ecológicas mais observadas pelos estudantes. Todos os alunos citaram a relação de parasitismo que ocorre entre a pulga e o cachorro. Quatro alunos descreveram o predatismo, dois falando da relação do leão com o veado-campeiro e dois do leão com a capivara. Três alunos afirmaram observar a relação de inquilinismo entre a bromélia e a árvore; três alunos citaram a sociedade das abelhas e um citou a de formigas; dois citaram a competição interespecífica entre o grilo e a formiga e entre a cutia e a gralha-azul; um aluno falou do comensalismo do urubu e uma aluna do mutualismo das flores e abelhas.

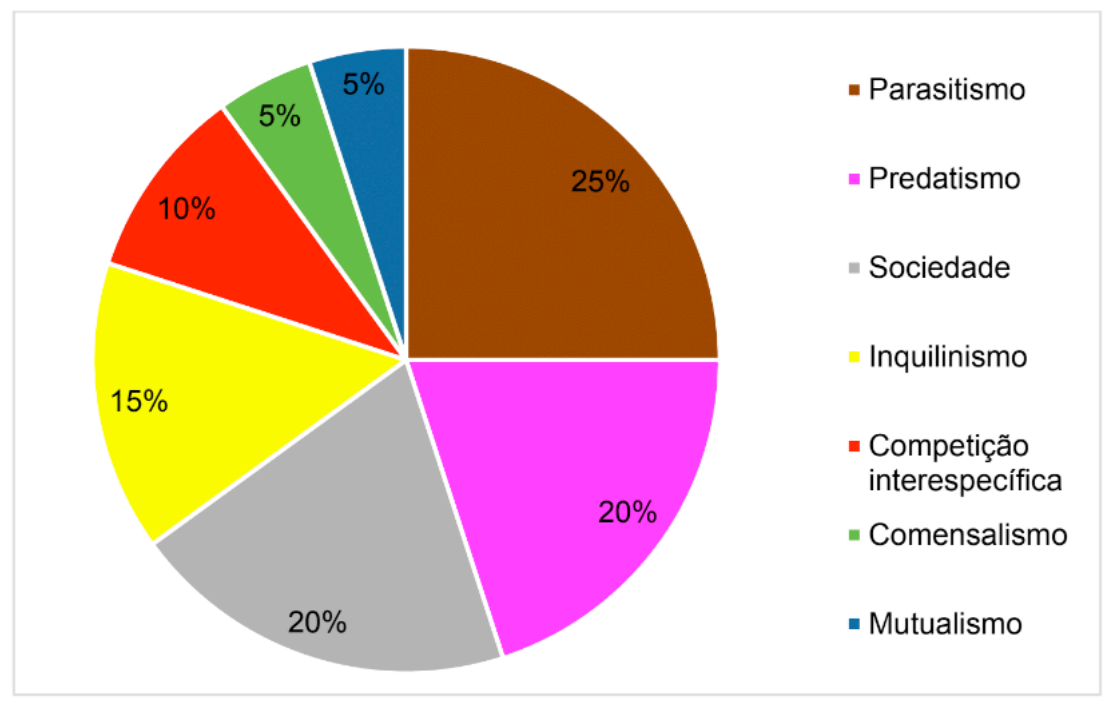

Figura 6 - Relações ecológicas citadas pelos estudantes

\section{I CONCLUSÃO}

O coronavírus modificou o modo de vida das populações, o processo de ensino- 
aprendizagem foi um enorme desafio para toda a comunidade escolar. Com este trabalho, foi possível concluir que a educação ambiental tem papel fundamental em todos os níveis de ensino, principalmente nas escolas rurais, em que os alunos têm contato intenso com o meio ambiente. Os alunos conseguiram desenvolver as atividades, mas tudo se tornou mais complexo pelo fato do isolamento social. Mais práticas precisam ser desenvolvidas no ambiente escolar. É preciso valorizar as espécies nativas, pois apenas o conhecimento pode levar à reflexão dos estudantes. Ninguém protege aquilo que não conhece!

\section{AGRADECIMENTOS}

À UNIEDU (Programa de Bolsas Universitárias de Santa Catarina) e à CAPES (Coordenação de Aperfeiçoamento de Pessoal de Nível Superior) pela concessão das bolsas de estudos.

\section{REFERÊNCIAS}

ALMEIDA, Danilo Sette de. Recuperação ambiental da Mata Atlântica. Editus, 2016.

BERNARDES, Maria Beatriz; MATOS, Patrícia Francisca; NEHME, Valéria Guimarães. Educação Ambiental e Agroecologia nas Escolas do Campo. Brazilian Geographical Journal: Geosciences and Humanities research medium, v. 4, n. 2 S, 2013.

BRASIL. Lei 6.938, de 31 de agosto de 1981. Dispõe sobre a Política Nacional do Meio Ambiente, seus fins e mecanismos de formulação e aplicação, e dá outras providências. Diário Oficial [da]União, de 02 de setembro de 1981.

BRASIL. Constituição de 1988. Constituição da República Federativa do Brasil de 1988. Diário Oficial [da] União, de 05 de outubro de 1988, Seção 1.

BRASIL. Lei 9.795, de 27 de abril de 1999. Dispõe sobre a educação ambiental, institui a Política Nacional de Educação Ambiental e dá outras providências. Diário Oficial [da] União, de 28 de abril de 1999.

BRASIL. Lei 9.394, de 20 de dezembro de 1996. Estabelece diretrizes e bases da educação nacional. Diário Oficial [da] União, de 23 de dezembro de 1996, Seção 1.

BRASIL. Ministério da Educação. Base Nacional Comum Curricular. Brasília, 2018.

BUCKUP, Georgina Bond (organizadora). Biodiversidade dos Campos de Cima da Serra. Porto Alegre: Libretos, 2010. 196 p.

FERNANDES, Milena da Silva. Educação do Campo. Revista Panorâmica online, v. 1, 2019.

IBGE - INSTITUTO BRASILEIRO DE GEOGRAFIA E ESTATÍSTICA, IBGE Cidades. 2018. 
LOCKWOOD, Julie L. et al. When pets become pests: the role of the exotic pet trade in producing invasive vertebrate animals. Frontiers in Ecology and the Environment, v. 17, n. 6, p. 323-330, 2019.

MENEZES, Priscylla Karoline. O ENSINO DE GEOGRAFIA EM DIFERENTES CONTEXTOS: os desafios da atuação docente na Educação do Campo. Revista Brasileira de Educação em Geografia, v. 7, n. 13, p. 456-470, 2017.

MORAN, Erin K.; CULBRETH, Adam J.; BARCH, Deanna M. Ecological momentary assessment of negative symptoms in schizophrenia: Relationships to effort-based decision making and reinforcement learning. Journal of abnormal psychology, v. 126, n. 1, p. 96, 2017.

OMETTO, José C. Bioclimatologia vegetal. São Paulo: Agronômica Ceres 1981. 440p.

RAMADHAN, Syahrul; SUKMA, Elfia; INDRIYANI, Vivi. Environmental education and disaster mitigation through language learning. In: IOP Conference Series: Earth and Environmental Science. IOP Publishing, 2019. p. 012054.

RUBALCABA, Juan G.; GOUVEIA, Sidney F.; OLALLA-TÁRRAGA, Miguel A. A mechanistic model to scale up biophysical processes into geographical size gradients in ectotherms. Global Ecology and Biogeography, v. 28, n. 6, p. 793-803, 2019.

SABINO-SILVA, Robinson; JARDIM, Ana Carolina Gomes; SIQUEIRA, Walter L. Coronavirus COVID-19 impacts to dentistry and potential salivary diagnosis. Clinical Oral Investigations, v. 24, n. 4, p. 16191621, 2020.

Secretaria de Educação do Município de Lages, 2020. Dados das escolas. Disponível em: <https:// www.educacaolages.sc.gov.br/sobre>. Acesso em 20 nov. 20.

VERBERK, Wilco et al. Universal metabolic constraints shape the evolutionary ecology of diving in animals. Proceedings of the Royal Society B, v. 287, n. 1927, 2020.

ZANINI, Alanza Mara et al. PERCEPÇÕES DE ESTUDANTES DO SUL DO BRASIL SOBRE A BIODIVERSIDADE DA MATA ATLÂNTICA. Interciencia, v. 45, n. 1, p. 15-22, 2020. 


\section{SOBRE O ORGANIZADOR}

DANIEL SANT'ANA - Possui doutorado em Uso e Conservação de Água pela Oxford Brookes University - Inglaterra (2010), mestrado em Eficiência Energética e Sustentabilidade em Edificações pela Oxford Brookes University - Inglaterra (2005) e graduação em Arquitetura e Urbanismo pela Pontifícia Universidade Católica de Campinas (2002). Atualmente, é Professor Associado na Universidade de Brasília (UnB), líder do grupo de pesquisa Água \& Ambiente Construído e coordenador do curso de extensão Aproveitamento de Água Pluvial e Reúso de Água. Atua em processos de editoração como Editor Associado no periódico Paranoá, como avaliador ad hoc em periódicos nacionais e periódicos internacionais e é membro do Conselho Editorial da Atena Editora. Foi membro de comitê de assessoramento ad hoc para o Conselho Nacional de Desenvolvimento Científico e Tecnológico (CNPq), Fundação de Apoio a Pesquisa do Distrito Federal (FAPDF) e Programa de Iniciação Científica (ProlC/UnB). Foi membro da comissão de estudo especial da Associação Brasileira de Normas Técnicas (ABNT) participando da elaboração das Normas Técnicas NBR 16782 (Conservação de Água em Edificações) e NBR 16783 (Uso de Fontes Alternativas de Água Não Potável em Edificações), e na revisão da Norma Técnica NBR 15527 (Aproveitamento de Água de Chuva). Tem experiência na área de Sustentabilidade com ênfase em Conservação de Água, atuando principalmente nos seguintes temas: Planejamento, Gestão e Governança da Água; Demanda Urbana e Usos-Finais de Água; Uso Racional de Água; e Sistemas Prediais de Água Não Potável. 


\section{ÍNDICE REMISSIVO}

\section{A}

Água $9,11,12,19,21,22,23,30,47,48,49,50,51,52,53,54,55,56,57,58,59,60$, $61,65,67,68,69,70,71,75,77,86,87,88,89,90,91,92,93,94,95,96,97,98,99,100$, $101,102,103,104,105,106,107,108,117,118,126,127,128,129,132,133,134,135$, $136,138,139,140,141,142,144,146,148,151,152,155,156,157,158,159,160,161$, 184, 185, 186, 187, 188, 189, 190, 191, 192, 193, 194, 197, 198, 199, 202, 204, 205, 218, 227, 245

Água pluvial 52, 55, 58, 98, 102, 103, 107, 245

Água potável 9, 52, 53, 55, 89, 91, 98, 99, 103, 107, 185, 186

Água residual artificial 118

Águas subterrâneas 99, 126, 128, 129, 131, 136, 137, 138, 144, 145, 146

Água subterrânea 126, 127, 128, 135, 136, 139, 140, 142, 146

Aproveitamento de água de chuva 56, 59, 60, 98, 99, 101, 108, 245

Atividade floculante 117,118

Automatização 198

Avaliação de risco 185

B

Bacia hidrográfica $1,2,3,5,8,9,11,12,17,18,23,148,150,186,194$

Bacteriología 109

C

Captação pluvial 48, 50, 55, 56, 57

Carga orgânica 148, 151, 152, 153, 154, 155, 156, 157

Contaminación del agua 172, 175

Coronavírus 233, 234, 235, 242

D

Desempenho 18, 61, 72, 96, 157, 200, 201, 213, 214, 215

Desenvolvimento urbano $3,6,31,35,37,38,39,41,44,51$

Distribuição de água 9, 75, 86, 88, 89, 91, 129, 188

Drenagem urbana $19,47,48,49,53,57,58,60$

E

Educação ambiental 54, 217, 218, 219, 220, 225, 226, 229, 230, 231, 232, 233, 234, 235, 
236, 237, 243

Esgotamento sanitário 9, 12, 61, 65, 148, 151, 152, 153, 154, 156, 157, 158, 218

Evapotranspiração 198, 199, 200, 203, 204, 205, 206, 212, 213, 214, 215

I

Indicador de revisão tarifária 61

Infraestrutura $1,2,3,4,6,7,9,10,12,13,14,15,16,96,148,150,194$

Inundações 12, 16, 47, 48, 49, 50, 52, 53, 54, 56

$\mathbf{L}$

Legislação 3, 4, 6, 10, 21, 22, 30, 31, 38, 48, 54, 55, 56, 57, 63, 127, 234

M

Medio ambiente 116, 172

Método GOD 126, 128, 130, 132, 133, 135, 136

Microbacia 160, 161

Modelagem computacional 137, 138, 140, 145

Monitoramento $17,35,37,41,43,44,58,70,128,140,148,151,155,159,161,185,187$, $189,192,195,196,201,213$

$\mathbf{P}$

Perdas de água 88, 91, 92, 94, 96, 97

Porcentagem de remoção 117, 118

Q

Qualidade de água 148, 151, 156, 157

R

Recursos hídricos 3, 17, 22, 30, 40, 51, 57, 58, 59, 73, 88, 89, 90, 91, 92, 96, 97, 98, 99, 126, 127, 135, 136, 145, 149, 150, 156, 158, 159, 173, 176, 184

Regulação econômica financeira 61

Relações ecológicas 233, 234, 235, 236, 240, 241, 242

S

Salud pública 109, 116, 172, 174

Saneamento $1,2,3,4,9,10,11,12,13,14,15,16,17,18,19,32,39,61,62,63,66,69$, $70,72,73,92,96,97,126,128,148,150,151,152,157,158,159,185,186,187$

Software livre 185, 188

Sustentabilidade 19, 26, 31, 33, 34, 37, 38, 39, 43, 44, 60, 61, 62, 63, 64, 69, 72, 96, 97, $98,108,220,222,223,224,245$ 


\section{U}

Urbanização 1, 3, 4, 6, 7, 12, 17, 18, 23, 48, 49, 57, 59, 219, 220, 232

Uso e ocupação do solo $3,6,17,21,31,34,35,37,39,40,42,43,45,46,126$

V

Vulnerabilidade ambiental 126,127

W

Web service 185,186 


\section{Base dle Conhecimentos}

Gerados na Engenharia Ambiental e Sanitária 


\section{Base dle Conhecimentos}

Gerados na Engenharia Ambiental e Sanitária

www.atenaeditora.com.br contato@atenaeditora.com.br @atenaeditora 우 www.facebook.com/atenaeditora.com.br 